\title{
European private international law on legal parentage? Thoughts on a European instrument implementing the principle of mutual recognition in legal parentage
}

Citation for published version (APA):

Saarloos, K. (2010). European private international law on legal parentage? Thoughts on a European instrument implementing the principle of mutual recognition in legal parentage. [Doctoral Thesis, Maastricht University]. Océ Business Services. https://doi.org/10.26481/dis.20100701ks

Document status and date:

Published: 01/01/2010

DOI:

10.26481/dis.20100701ks

Document Version:

Publisher's PDF, also known as Version of record

Please check the document version of this publication:

- A submitted manuscript is the version of the article upon submission and before peer-review. There can be important differences between the submitted version and the official published version of record.

People interested in the research are advised to contact the author for the final version of the publication, or visit the DOI to the publisher's website.

- The final author version and the galley proof are versions of the publication after peer review.

- The final published version features the final layout of the paper including the volume, issue and page numbers.

Link to publication

\footnotetext{
General rights rights.

- You may freely distribute the URL identifying the publication in the public portal. please follow below link for the End User Agreement:

www.umlib.nl/taverne-license

Take down policy

If you believe that this document breaches copyright please contact us at:

repository@maastrichtuniversity.nl

providing details and we will investigate your claim.
}

Copyright and moral rights for the publications made accessible in the public portal are retained by the authors and/or other copyright owners and it is a condition of accessing publications that users recognise and abide by the legal requirements associated with these

- Users may download and print one copy of any publication from the public portal for the purpose of private study or research.

- You may not further distribute the material or use it for any profit-making activity or commercial gain

If the publication is distributed under the terms of Article 25fa of the Dutch Copyright Act, indicated by the "Taverne" license above, 


\section{European private international law on legal parentage?}

Thoughts on a European instrument implementing the principle of mutual recognition in legal parentage 



\title{
European private international law on legal parentage?
}

Thoughts on a European instrument implementing the principle of mutual recognition in legal parentage

\author{
DISSERTATION \\ To obtain the degree of Doctor \\ at the Maastricht University, \\ on the authority of the Rector Magnificus \\ Prof. dr. G.P.M.F. Mols \\ in accordance with the decision of the Board of Deans \\ to be defended in public \\ on Thursday the 1st of July 2010, at 12:00 hours \\ by
}

Kees Jan Saarloos 
Supervisor:

Prof. dr. G.R. de Groot

Assessment Committee:

Prof. dr. C. J. Forder (chair)

Prof. dr. M. Bogdan (Lund University, Sweden)

Dr. J. Israël

Dr. S. W. E. Rutten

Dr. L. Strikwerda (Advocate General at the Hoge Raad der Nederlanden)

Print: Océ Business Services, Maastricht I OBS 6022

Cover design: Hajo

ISBN: 978-90-9025425-8

(C) Kees Jan Saarloos (2010)

All rights reserved. 
Voor mijn ouders 



\section{Voorwoord}

Ik ben rechten gaan studeren om advocaat te worden. Het idee was om zo snel mogelijk af te studeren en daarna 'aan de slag te gaan'. Snel afstuderen lukte, maar de beëdiging tot advocaat heeft sinds de aanvang van de studie ruim tien jaar op zich laten wachten.

Voor $\mathrm{u}$ ligt het resultaat van een vijf jaar durende omweg die leerzamer en verrijkender is gebleken dan ik aan het begin had kunnen vermoeden. Het idee voor het schrijven van dit proefschrift kwam van mijn promotor, professor G.R. de Groot. Zowel binnen als buiten de faculteit heeft hij kansen en mogelijkheden voor mij gecreëerd waarmee ik mijn promotietijd tot een succes en een genoegen heb kunnen maken. Ik ben hem daar zeer dankbaar voor.

Het doen van onderzoek naar regels, akten en bureaucratie kan alleen maar boeien, als men de maatschappelijke problematiek begrijpt waar het recht een oplossing voor probeert te vinden. De kennismaking met de praktijk van de internationale burgerlijke stand was daarom een onmisbare ervaring voor het schrijven van dit proefschrift. Verschillende mensen hebben daaraan een belangrijke bijdrage geleverd.

Via de IPR-commissie van de Nederlandse Vereniging van Burgerzaken onder voorzitterschap van mr. Otten werd ik geïntroduceerd in de praktijk van de internationale burgerlijke stand. Ik ben de leden van de commissie erkentelijk voor hun geduld en hun bereidheid mij de regels van de burgerlijke stand te leren.

Later was het de praktijk van de Dienst Persoonsgegevens Amsterdam die hielp bij het verwerven van inzicht in de zin (en onzin) van het internationale afstammingsrecht. Met name de discussies met mr. Gubbels heb ik als zeer leerzaam en aangenaam ervaren. In het buitenland waren het vooral de heer Tegenfeldt (afdeling bevolkingsregistratie van de Zweedse belastingdienst) en de medewerkers van de General Register Office in Engeland die hebben geholpen bij het verkrijgen van inzicht in het functioneren van het internationale afstammingsrecht.

De kennismaking met de praktijk van Everaert Advocaten te Amsterdam heeft ook in belangrijke mate mijn visie op het internationale afstammingsrecht gevormd. De hartelijke samenwerking met mr. Kidjan, mr. De Voer en mr. Groen bood mij de mogelijkheid ideeën te testen in de praktijk en aan te passen aan de realiteit. Ik ben hun zeer dankbaar voor deze samenwerking.

De samenwerking met de praktijk is onmisbaar geweest voor het schrijven van dit proefschift, maar was niet voldoende. Onderzoek doen leert men door met ervaren onderzoekers te discussiëren over het onderwerp, waardoor men wordt gedwongen stellingen secuur te formuleren en goed te onderbouwen. Uiteraard is het daarvoor van belang dat er ervaren onderzoekers zijn die tijd willen maken om te discussiëren en bereid zijn de stellingen van de jonge onderzoeker aan meer dan een marginale toetsing te onderwerpen.

Naast mijn promotor heeft dr. Rutten daarin een waardevolle rol vervuld door bijna altijd spontaan tijd te maken voor korte en lange discussies over familierecht en internationaal privaatrecht. Professor Forder leerde mij vanaf het begin dat bij wijze van spreken achter elke zin een voetnoot hoort. Verder was haar uitnodiging om mee te schrijven aan een artikel over afstammingsrecht en mensenrechten een belangrijke impuls voor de gedachtevorming voor het eerste deel van dit boek. Discussies met dr. Israël hebben een belangrijke bijdrage geleverd aan de inhoud van het derde deel van dit boek. 
Geen proefschrift zonder leescommissie. Daarom dank ik professor Forder, professor Bogdan, dr. Israël, dr. Rutten, en dr. Strikwerda voor de tijd die zij hebben genomen om mijn proefschrift te beoordelen.

Ten slotte dank ik Peter, die twee jaar moest horen dat het allemaal bijna af was, voor zijn geduld.

Utrecht, april 2010 



\section{TABLE OF CONTENTS}

\section{Voorwoord}

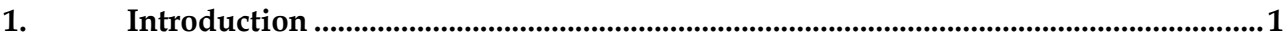

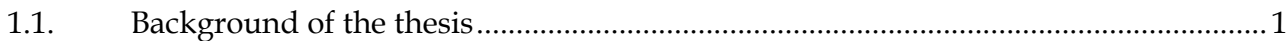

1.1.1. Aren't the biological parents the child's legal parents? .............................................. 1

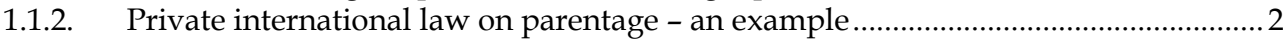

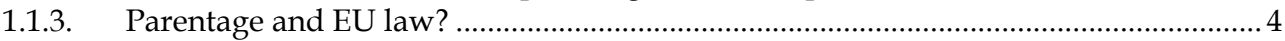

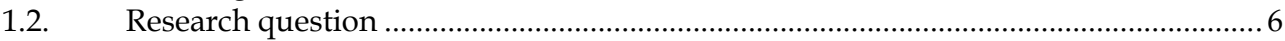

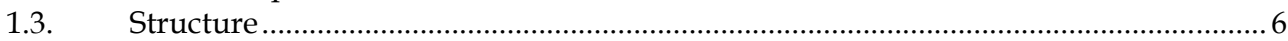

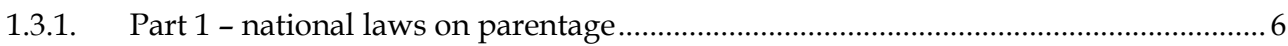

1.3.2. Part 2 - private international law on parentage ......................................................

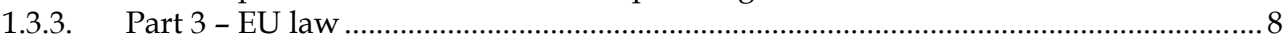

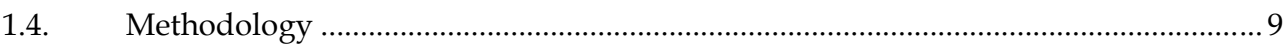

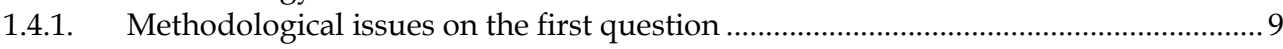

1.4.2. Methodological issues on the second question ........................................................ 11

Part 1 Legal parentage from a comparative perspective ...........................................................13

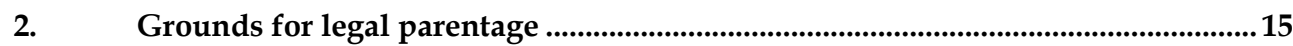

2.1. Grounds for legal maternity .................................................................................. 15

2.2. Grounds for legal parenthood of the second parent .............................................17

2.2.1. Grounds for legal parenthood of the second parent under Dutch law......................18

2.2.2. Grounds for legal parenthood of the second parent under English law .................. 20

2.2.3. Grounds for legal parenthood of the second parent under French law .................... 24

2.2.4. Grounds for legal parenthood of the second parent under German law .................. 25

2.2.5. Grounds for legal parenthood of the second parent under Swedish law..................26

2.3. Conclusion on the grounds for legal parentage ..........................................................2 29

3. Establishment and annulment of legal parentage ........................................................ 31

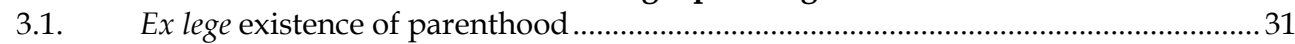

3.1.1. Ex lege existence of legal parentage under English law ............................................... 32

3.1.2. Ex lege existence of legal maternity .................................................................................. 34

3.1.3. Ex lege existence of the legal paternity of the husband under Dutch, French,

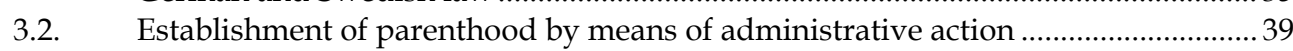

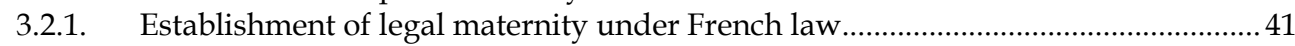

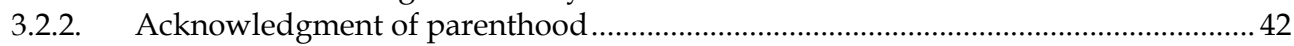

3.2.2.1. The legal nature of the acknowledgment of parenthood ............................................. 43

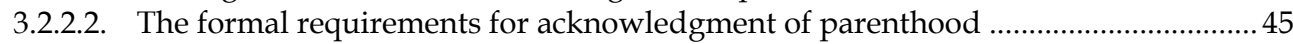

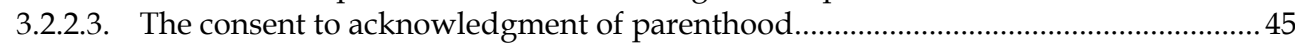

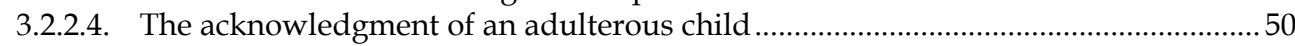

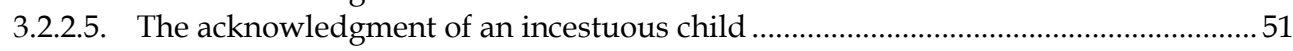

3.3. Establishment of parenthood by apparent status ...................................................... 52 
3.4. Establishment of parenthood by judicial decision...................................................57

3.4.1. The ground for judicial establishment of legal parentage ..........................................58

3.4.2. Locus standi for judicial establishment of legal parentage...........................................59

3.4.3. Periods of limitation for judicial establishment of legal parentage ............................ 61

3.4.4. Evidence in case of judicial establishment of legal parentage.....................................62

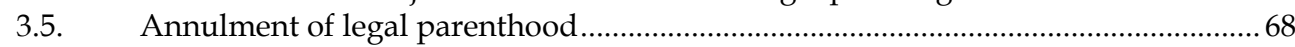

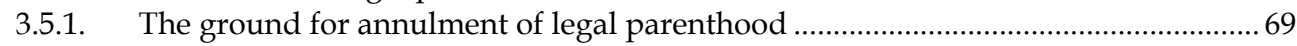

3.5.2. Restrictions on judicial annulment of paternity under Dutch law ............................. 70

3.5.3. Annulment of legal parenthood and apparent status under French law .................. 72

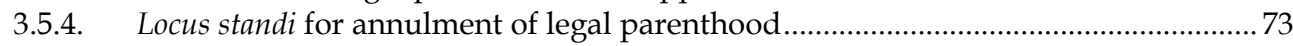

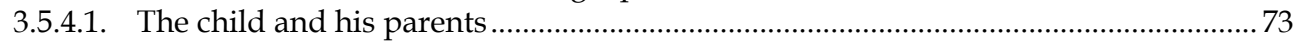

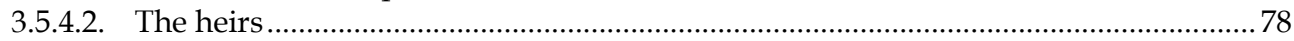

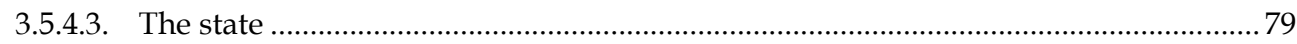

3.5.5. Periods of limitation for annulment of legal parenthood ......................................... 82

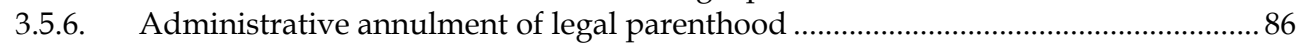

3.6. Conclusion on the establishment and annulment of legal parentage ......................... 88

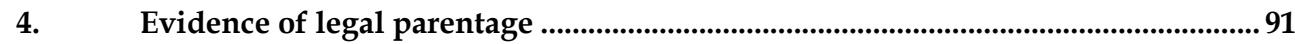

4.1. Evidence of legal parentage under English law ...................................................... 91

4.2. Evidence of legal parentage under Dutch, French and German law ......................... 95

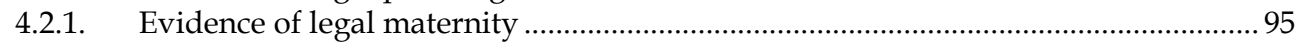

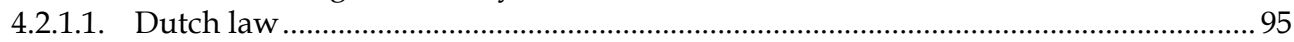

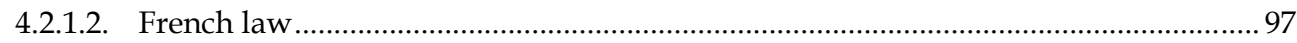

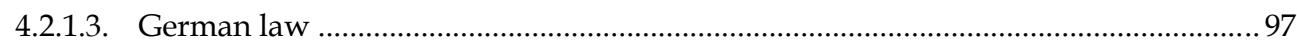

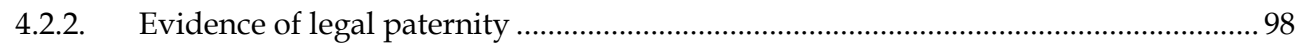

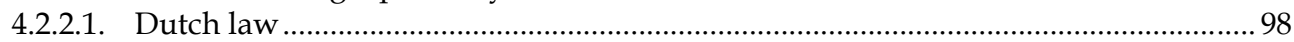

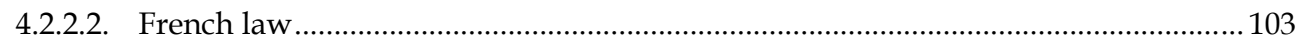

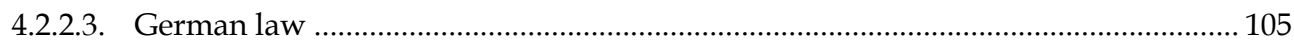

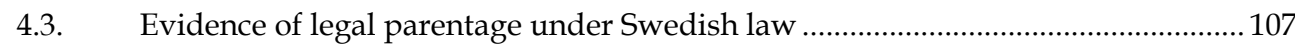

4.4. Conclusion on the evidence of legal parentage....................................................... 110

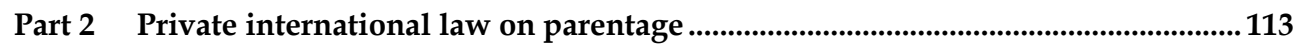

5. International jurisdiction to establish and annul legal parentage ........................115

5.1. International jurisdiction of registrars in matters concerning parentage ................ 115

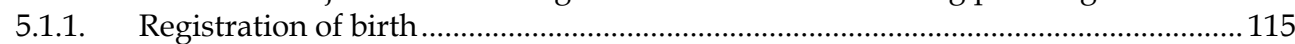

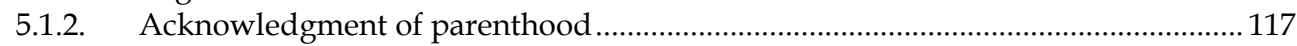

5.2. International jurisdiction of courts in matters concerning parentage ....................... 119

5.2.1. International jurisdiction of courts under Dutch law.............................................. 120

5.2.2. International jurisdiction of courts under English law .......................................... 121

5.2.3. International jurisdiction of courts under French law .............................................. 123

5.2.4. International jurisdiction of courts under German law ............................................ 125

5.2.5. International jurisdiction of courts under Swedish law ........................................... 125

5.3. Conclusions on international jurisdiction in matters concerning parentage............126

6. Applicable law to legal parentage...................................................................................129

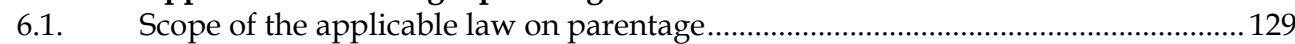




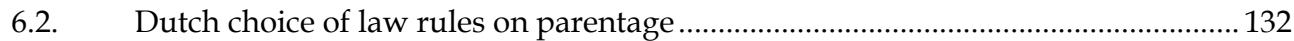

6.2.1. Applicable law to legal parentage based on marriage under Dutch PIL................. 133

6.2.2. Applicable law to annulment of marital paternity under Dutch PIL....................... 134

6.2.3. Applicable law to the legal parentage between the woman and the child born out of wedlock under Dutch PIL

6.2.4. Applicable law to acknowledgment of paternity under Dutch PIL ......................... 138

6.2.5. Applicable law to annulment of acknowledgment of paternity under Dutch PIL. 142

6.2.6. Applicable law to judicial establishment of legal paternity under Dutch PIL ........ 142

6.2.7. Applicable law to legitimation under Dutch PIL.................................................... 143

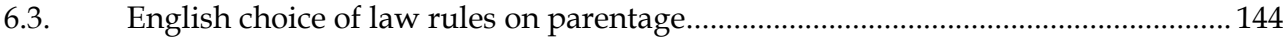

6.3.1. Applicable law to legitimacy under English PIL ..................................................... 145

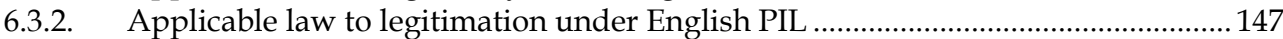

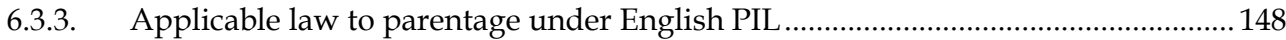

6.3.3.1. Section 30 Human Fertilisation and Embryology Act 1990 ....................................... 149

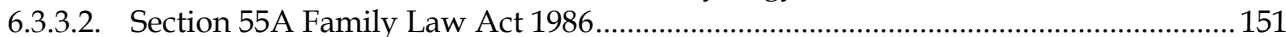

6.3.3.3. Section 50 (9), (9A) British Nationality Act 1981 …...................................................... 153

6.3.3.4. The law applicable to the evidence of parentage ....................................................... 154

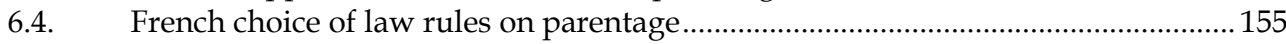

6.4.1. Applicable law to parentage under French PIL ...................................................... 156

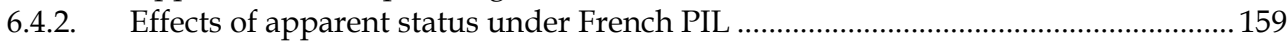

6.4.3. Applicable law to acknowledgment of parenthood under French PIL ...................161

6.4.4. Relationship between articles 311-14 and 311-17 Code civil .....................................162

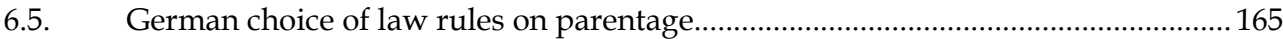

6.5.1. Applicable law to the establishment of parentage under German PIL..................... 165

6.5.1.1. The hierarchy among the connecting factors and conflicting results in German PIL167

6.5.1.2. Conflit mobile under article 19 EGBGB ...................................................................... 172

6.5.2. Applicable law to the consents to acknowledgment under German PIL .................173

6.5.3. Applicable law to contest legal parentage under German PIL ................................174

6.6. Swedish choice of law rules on parentage ............................................................... 176

6.6.1. Applicable law to legal parentage based on marriage under Swedish PIL............. 176

6.6.2. Applicable law to acknowledgment of parenthood under Swedish PIL.................178

6.6.3. Applicable law to judicial establishment of legal parenthood under Swedish PIL 179

6.6.4. Applicable law to contest legal parenthood ........................................................... 180

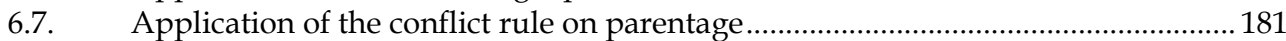

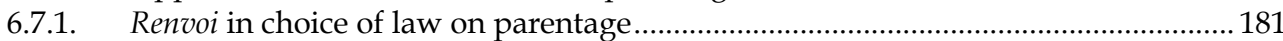

6.7.2. Public policy exception in choice of law on parentage ............................................... 184

6.7.3. Application of English law pursuant to continental private international law .......191

6.8. Conclusion on applicable law in matters concerning parentage .............................. 195

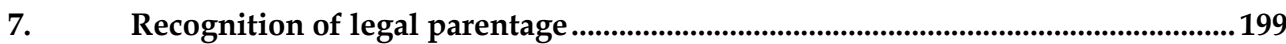

7.1. Recognition of legal parentage in foreign judgments ............................................. 199

7.1.1. Recognition of foreign judgments on parentage under Dutch law ..........................199

7.1.2. Recognition of foreign judgments on parentage under English law ......................... 200

7.1.2.1. Foreign judgments on parentage as evidence of paternity....................................... 201

7.1.2.2. Recognition of judicial establishment of paternity in relation with foreign decrees

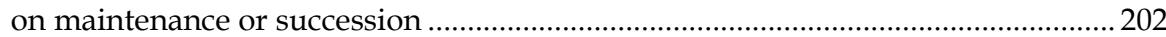

7.1.3. Recognition of foreign judgments on parentage under French law ......................... 203

7.1.4. Recognition of foreign judgments on parentage under German law....................... 206

7.1.5. Recognition of foreign judgments on parentage under Swedish law ..................... 207 
7.2. Recognition of legal parentage in foreign documents............................................. 209

7.2.1. Recognition of legal parentage under Dutch private international law .................. 210

7.2.1.1. Background of the Dutch recognition rules on legal parentage ............................... 210

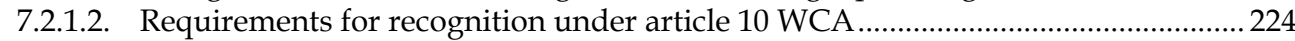

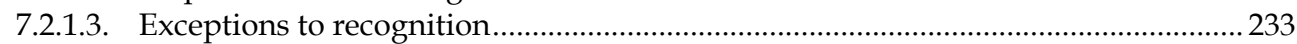

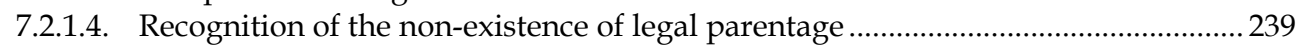

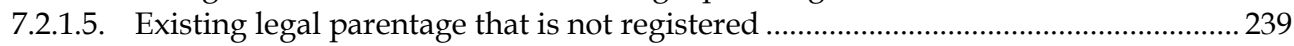

7.2.2. Recognition of foreign instruments of civil status under Dutch law ....................... 240

7.2.3. Recognition of legal parentage under English private international law ................ 241

7.2.4. Recognition of foreign instruments of civil status under English law .................... 242

7.2.5. Recognition of legal parentage under French private international law ................. 244

7.2.6. Recognition of foreign instruments of civil status under French law ...................... 245

7.2.7. Recognition of legal parentage under German private international law ............... 248

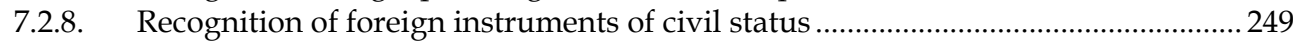

7.2.9. Recognition of legal parentage under Swedish private international law .............. 250

7.2.10. Recognition of foreign instruments of civil status under Swedish law ................... 254

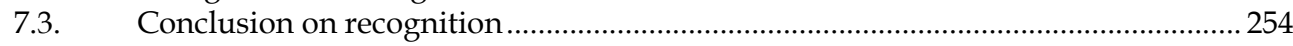

Part 3 European private international law on personal status ......................................... 259

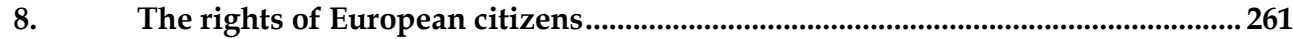

8.1. The free movement of persons before the Treaty of Maastricht .............................. 261

8.2. Free movement and equal treatment of EU citizens after the Treaty of Maastricht262

8.2.1. The right to reside on the territory of the Member States........................................ 262

8.2.2. EU citizens' right to equal treatment and beyond .................................................... 264

8.2.2.1. The right not to suffer discrimination ........................................................................ 264

8.2.2.2. The right not to be hindered in the exercise of the right to free movement and

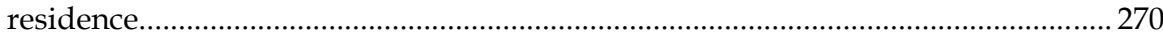

8.2.2.3. Objective justifications for discrimination and hindrances to free movement ....... 273

8.2.2.4. Disparate treatment does not constitute discrimination or a restriction (Schempp) 283

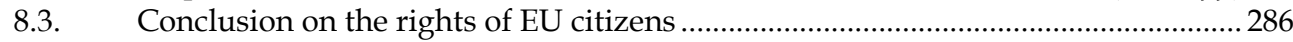

9. The application of Garcia Avello and Grunkin and Paul to civil status ................289

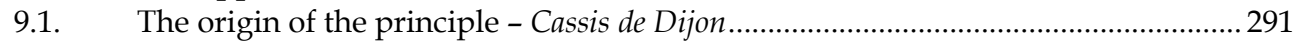

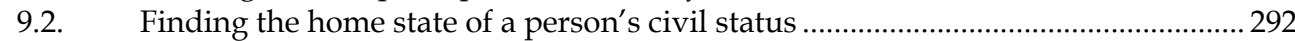

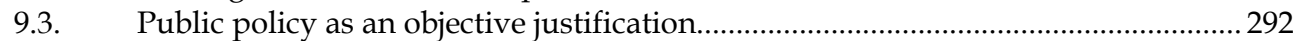

9.4. The relevance of a concrete conflict of interest between the persons involved ...... 293

9.5. The role of choice of law rules - nationality as a connecting factor ............................294

10. Implementation of Garcia Avello and Grunkin and Paul .......................................299

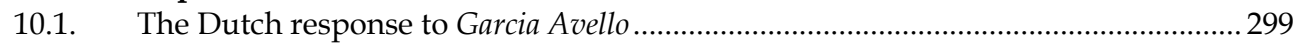

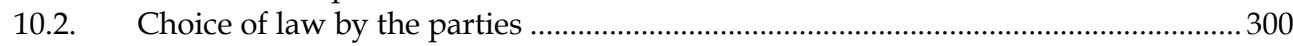

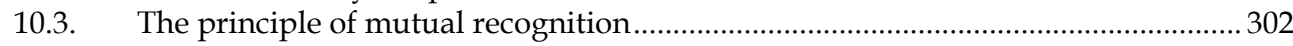

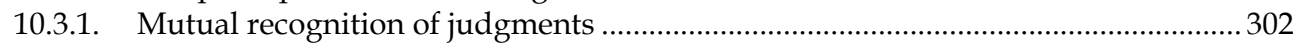

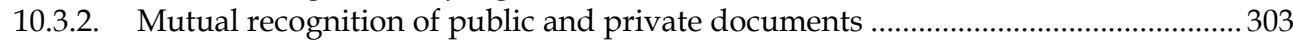


11. Conclusion - Thoughts on a European instrument implementing the principle of mutual recognition in legal parentage

11.1. The legal basis for European legislation on private international law on legal parentage.

11.2. Working out the principle of mutual recognition in legal parentage .......................313

11.2.1. Applicable law to legal parentage at the registration of birth...................................... 316

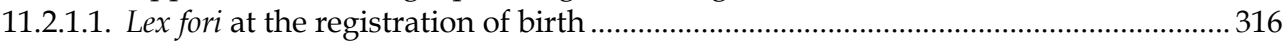

11.2.1.2. Habitual residence of the child at the moment of birth ............................................. 318

11.2.2. Recognition of parentage that has been recorded abroad .......................................... 318

11.2.3. Applicable law to change the legal parentage that has been established abroad... 320

11.2.3.1. Judicial declaration on the child's parentage without status effect...........................320

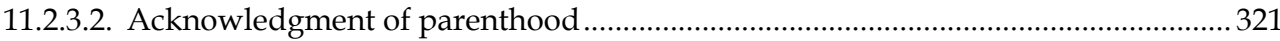

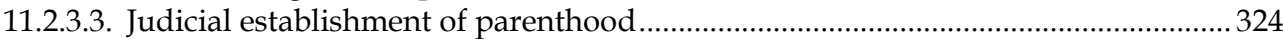

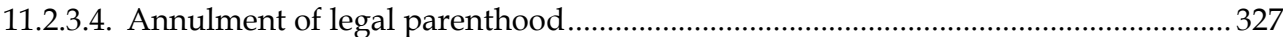

11.2.4. Exceptions to recognition - the public policy exception...........................................329

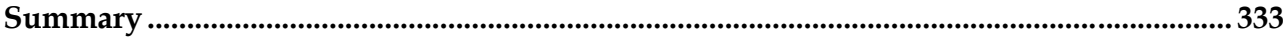

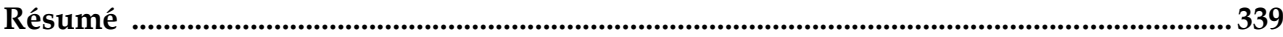

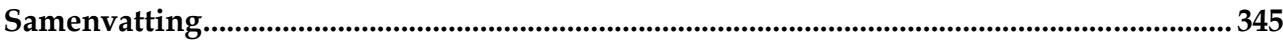

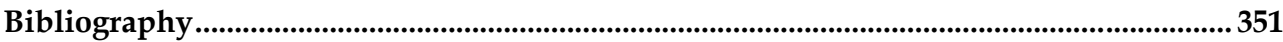

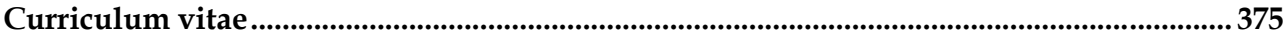






\section{Introduction}

\subsection{Background of the thesis}

This thesis is about the determination of the legal parents of a child in an international case. In this introduction first the legal background of this thesis and the social issues it deals with will be discussed.

\subsubsection{Aren't the biological parents the child's legal parents?}

Although the question of legal parentage may seem straightforward at first sight - 'aren't the biological parents the legal parents of the child?' - a closer look raises various points of discussion. Three will be explained by way of an example.

The first issue in contemporary legal systems is the protection of the mother and her child. Here the question is whether the law should recognise the biological father as the legal father of the child even if that would endanger the welfare of the mother and/or her child. Imagine a case where the child is born as a result of rape or where the man has abused or assaulted the mother. Although in such cases it cannot be denied that the man is the biological father of the child, it is not self evident that the man should play a role in the upbringing and education of the child. Why then should the law recognise him as the father, as a result of which all kinds of rights and duties arise?

The second issue relates to the first and concerns the protection of existing family life. Imagine the case where a woman gives birth to a child who is not begotten by her husband. Nine months earlier the marriage was in difficulties, both spouses challenged the monogamy principle and at a certain moment the woman falls pregnant. Both spouses realise that there is a chance that the husband is not the father of the child, but they do not want to divorce: they have two other children and the man and the woman operate a business together. A divorce will not only destroy their family, but also their career and they manage to get their relationship back on track. The first child is born, no further questions are asked and he is raised as a child of the spouses. Forty years later the father dies. In the meantime one of the children has found out that the first child is not a 'real' child of his deceased father. Should the second child be allowed to contest the parentage of the first child, as a result of which the second child will get a bigger share in the succession or are the social familial ties that developed over the past forty years more important?

The third issue in the modern law on parentage is assisted reproduction. Should the biological father of the child be recognised in law as the father, if the biological father is only a sperm donor? What about surrogate motherhood? And does it matter whether the intended parents are of the same sex? These questions will be discussed in more detail below.

These three issues of the law on parentage relate to rather different fact patterns but they have one thing in common. In all three cases the central question is whether the biological father (or mother) should be recognised as the legal parent of the child or someone else should be. Legal systems answer these questions differently depending on their view on the interest of the child, the 'rights' of the persons involved and other moral and ethical values.

What is important for this thesis is that as a result of the different answers to these questions, legal systems may come to different solutions in the same case. Thus, for example, in a case where a child is conceived with donor sperm, German law provides that the legal paternity of the sperm donor can be established while this is not possible under Dutch law. 


\subsubsection{Private international law on parentage - an example}

The objective of this research is not to find the best solution for all the different problems that can come up in determining the legal parentage of the child. This thesis deals with the rules on parentage in different legal systems in order to answer a different question: how do the legal systems solve a case where the persons have connections with more than one country, or rather more than one legal system?

This problem is stated in a case which led to the decision of the district court of The Hague on the 10th of December 2007. ${ }^{1}$ Facts that may identify the persons involved have been changed in order to protect their privacy.

Bas and Judith van Rijswijk are married and live in the Netherlands. Mrs Van Rijswijk suffers from Mayer-Rokitansky-Küster-Hauser syndrome. That means that she does not have a uterus and her vagina is malformed as a result of which she cannot carry a child. However, she has good functioning ovaries and therefore with the help of a surrogate mother she and her husband could have a child of their own. In 2003 the Dutch couple gets into contact with an English woman called Jennet McCarry who is married to Rob McCarry. Mrs McCarry is willing to act as a surrogate mother for the child of Mr and Mrs Van Rijswijk.

The contact between the two couples has been arranged through Childlessness Overcome Through Surrogacy, an English non-profit organisation run by volunteers. Their aim is to pass on their 'experience to surrogates and would-be parents, helping them to understand the implications of surrogacy before they enter into an arrangement and to deal with any problems that may arise during it.' 2 Through its splinter group Triangle, it puts surrogates and intended parents into contact with each other.

Mrs McCarry and Mr and Mrs van Rijswijk agree that Mrs McCarry shall undergo an IVF treatment. The embryo which is created with the genetic material of Mr and Mrs van Rijswijk is placed in the uterus of Mrs McCarry. Nine months later she gives birth in England to a girl, Lisa. The girl is immediately handed over to Mr and Mrs van Rijswijk who take Lisa to their home in the Netherlands.

Lisa's birth is reported to the civil status registrar in England. On the birth certificate, Mrs McCarry and Mr van Rijswijk are mentioned as the (legal) parents of Lisa. Mrs McCarry is not Lisa's genetic mother, but she is mentioned as the legal mother because she gave birth to the child. Mr van Rijswijk is mentioned as the legal father, because Mr McCarry made a formal declaration that he did not consent to the treatment of his wife. Therefore, in this case English law treats the biological father, Mr van Rijswijk, as the legal father.

Although with the handing over of Lisa Mr and Mrs van Rijswijk have in fact overcome their childlessness, the legal problems begin. They have to make sure that the Dutch register of civil status (burgerlijke stand) and the population register (gemeentelijke basisadministratie) state them as the legal parents of Lisa. That is problematic because according to Dutch law $\mathrm{Mr}$ and Mrs McCarry would be the legal parents of Lisa. After all, Dutch law provides that the husband of the woman who carried the child shall be the legal father.

In June 2005 the Dutch Child Protection Agency applied to the district court of The Hague to terminate Mrs McCarry's parental responsibility. Under Dutch law, only the Child Protection Agency can make this application and the application is necessary with a view to the adoption of Lisa by Mrs van Rijswijk.

During the procedure, the court also has to determine whether Mr van Rijswijk is the legal father of Lisa. This is a difficult question. According to English law he is the legal father and he is mentioned as the father on the birth certificate, but according to Dutch law he is not the legal father.

\footnotetext{
${ }_{1}^{1}$ Rechtbank Den Haag, 10 December 2007, LJN BC5651.

2 http:/ / www.surrogacy.org.uk.
} 
The case presents a conflict of laws. There is a conflict because the case has ties with both English law (place of birth, residence and nationality of the surrogate) as well as with Dutch law (residence and nationality of the intended parents, residence of the child). The conflict is problematic because the two legal systems involved appoint different men as the legal father of the child. Which law is applicable?

The initial reaction of most people is that the Dutch court should apply Dutch law. Although such a solution is not completely without merit, it implies that the English authorities apply English law. That would be problematic because it would lead to a limping personal status of the child: in England one man is the father of the child while in the Netherlands another man is the father. The problems that can arise from such a limping situation are easily imaginable.

The problem of a conflict of laws has already been recognised for centuries. Since Von Savigny published his famous treatise on the conflict of laws in $1849,{ }^{3}$ the traditional European way to solve the conflict is by selecting one of the legal systems involved to govern the case. Thus, for example, in Dutch law one will find the rule that the legal parentage of a child who is born to a married woman is governed by the law of the common nationality of the mother and her husband. This is called a 'conflict rule' and the operative part of the rule that connects the case with a certain legal system (in the example the common nationality of the mother and her husband) is called a 'connecting factor'.

One of the functions of a conflict rule is to solve a conflict of systems of private law; thereby the conflict rule aims at avoiding limping legal relations and to create international harmony of decisions or decisional harmony in cases with a foreign element. A limping legal relation is a legal relationship that exists in one legal system, but not in the other. Thus the case of Mr van Rijswijk presents a limping parental status because Van Rijswijk is the legal father of the child under English law, but not under Dutch law.

It is difficult to create decisional harmony with the variety of conflict rules that are enacted at the national level because all the national legal systems have their own view on the best way to solve conflicts of laws. Since there is no worldwide consensus on the best connecting factor for, in this case, legal parentage, each legal system has its own conflict rules, often with different connecting factors. It is like a symphony orchestra trying to play a symphony without a conductor, with all the members of the orchestra being sovereign in their interpretation of the piece.

Thus depending on the law that is appointed by the different national conflict rules, the case might still be solved differently in the countries involved despite the effort of national conflict rules to avoid that. That means that that at least in theory the limping status subsists.

The lack of consensus on the appropriate connecting factor is only one part of the problem why national conflict rules do not always solve the conflict of laws properly. Even if the national conflict rules appoint the same legal system or different legal systems with the same rules, it is still possible that the foreign law is not applied if the result of its application is considered unacceptable. In that case the foreign law violates the public policy of the state involved which also leads to a limping relationship.

It is hard to say in the abstract how problematic a limping legal relationship is. In the case of van Rijswijk it is bad, because the paternity of Mr van Rijswijk does not exist in the country where he lives. However in the opposite case, where he would be the father under Dutch law and not under English law, Mr van Rijswijk would probably not experience any problems as long as he or the child does not settle in England or for some reason have to prove the parentage of the child in England. This brings us to the actual point of this thesis.

\footnotetext{
${ }^{3}$ Savigny 1849.
} 


\subsubsection{Parentage and EU law?}

If it has been established that the national conflict rules have not solved the conflict of laws, the question is how to proceed. In a world with only individual nation states the persons involved simply have to live with it. However, for centuries it has been recognised that limping relations, especially when it concerns the personal status of individuals should be avoided. Therefore, at the international level various initiatives have been developed to come up with solutions in the form of conventions and treaties that regulate conflicts of private law. At a global level, the Hague Conference on Private International Law has been established with the aim 'to work for the progressive unification of the rules on private international law.' ${ }^{4}$ But also at regional levels, different organisations are concerned with this issue. In Europe, notably the International Commission on Civil Status (CIEC) is concerned with the international co-operation in civil status matters and also the European Union is slowly but steadily entering the field of international family law.

On the basis of European Union law citizens of the EU have the right to move and reside freely within the territories of the Member States. Obstacles to the free movement are not allowed unless they can be justified. Thus Mr van Rijswijk has the freedom to go to England, to receive services there, perhaps to live there for a while and become the father of Lisa and than to go back to the Netherlands. Could it be possible that the Dutch rule as a result of which his 'English' paternity does not exist in the Netherlands is somehow incompatible with Van Rijswijk's rights under EU law? In more general terms, the question is whether the decisional disharmony between Dutch and English law violates primary EU law.

The case of $\mathrm{Mr}$ and Mrs van Rijswijk has a problem structure that is not unique and appears in different areas of the law. The structure of the problem is that citizens from one Member State want to benefit from the legal possibilities in another Member State. Thus a German/Swedish lesbian couple goes to Sweden for fertility treatment and to give birth, in order to benefit from the rules on same sex parenthood: is their parenthood recognised in Germany? A French/Dutch same sex couple goes to the Netherlands to get married: is the marriage recognised in France? And the problem does not only exist for natural persons, but also for legal entities: a Dutch entrepreneur incorporates his business in England, but exercises his main activities in the Netherlands: is the legal entity of the English corporation recognised in the Netherlands?

If the answer to these questions is no, the next question in all these situations is whether the refusal to recognise the legal relationship that has been established abroad amounts to a violation of the free movement rights of the persons involved.

Hypothetically, it is also possible that national choice of law rules violate EU law by themselves. This could be the case for example if they use nationality as a connecting factor while article 18 TFEU prohibits the discrimination on the basis of nationality.

For example, under French law, the acknowledgment of paternity establishes the legal paternity of the acknowledger even if the mother of the child does not consent to the acknowledgment. Under Dutch law the acknowledgment is only valid if the mother of the child consents. French law provides that the acknowledgment of paternity is governed by the national law of the acknowledger. That means that the man who wants to acknowledge his paternity shall be treated differently according to whether he is French or, let's say, Dutch.

Article 18 TFEU provides that within the scope of application of EU law any discrimination on the basis of nationality shall be prohibited. If the French authorities refuse to recognise a Dutch man as the father of the child because the mother of the child did not

\footnotetext{
${ }^{4}$ Article 1 Statute of the Hague Conference on Private International Law (1955).
} 
consent to his acknowledgment of paternity, the question is whether the Dutch man can invoke article 18 TFEU arguing that if he were a French national he would have been recognised as the legal father of the child despite the refusal of the mother to consent to his acknowledgment of paternity.

The answers to these questions are far from easy, because it is not clear what influence EU law has on national private international law. Although there have always been cases where questions of family law were incidental to the determination of rights under EU law, the Community did not assert legislative competence in the field of (international) family law until the Treaty of Amsterdam. ${ }^{5}$ Moreover, in 1999 the European Court of Justice still ruled that 'neither the national provisions of private international law determining the substantive law applicable to the effects of a divorce nor the national provisions of civil law substantively regulating those effects fall within the scope of the Treaty.' 6

The attitude of the Court towards international family law changed drastically in Garcia Avello (2003) $)^{7}$ and Grunkin and Paul (2008). ${ }^{8}$ Both cases deal with the surnames of children. In Garcia Avello the Court held that the Belgian authorities were obliged under EU law to change the name of the Belgian/Spanish children in accordance with Spanish law; in Grunkin and Paul the German authorities had to recognise the name of a German child established in accordance with Danish law. In both cases, the effects of the Court's rulings were that the result of national choice of law rules was in violation of EU law. It is these cases, which will be analysed extensively, that lead to the hypothesis that primary EU law indeed may affect the international family law of the Member States.

Since the Treaty of Amsterdam, not only the Court but also the European legislator moved into the area of international family law. Its objective is to create an area of freedom, security and justice for the citizens of the European Union on the basis of the principle of mutual recognition. The most notable achievement in international family law is the enactment of Council Regulation No 1347/2000 of 29 May 2000 on jurisdiction and the recognition and enforcement of judgments in matrimonial matters and in matters of parental responsibility for children of both spouses, later replaced by Council Regulation No 2201/2003 of 27 November 2003 concerning jurisdiction and the recognition and enforcement of judgments in matrimonial matters and the matters of parental responsibility.

If it appears that national private international law on parentage under certain circumstances violates primary EU law, the question arises whether the Community

\footnotetext{
${ }^{5} \mathrm{~A}$ nice example that shows the deference of the Court of First Instance to the exclusive competence of the Member States in international family law is Díaz García v. European Parliament (CFI 18 December 1992, case T-43/90). In that case it had to be determined whether the applicant, Mr Díaz García, was legally responsible to maintain the children of his female partner with whom he was living. He was neither the legal nor the biological father of the children and he was not married to the mother. The Court of First Instance held that the legal responsibility of the applicant had to be determined on the basis of the national legal system(s) to which the applicant is subject (§ 37-41). In this case, the Belgian and Spanish legal systems involved both came to the result that the applicant was under no legal obligation to maintain the children of his partner. If the legal systems would have come to different results, it would be much harder for the Court to maintain its deference to the national legal systems. Other well-known examples of decisions involving family matters relate to the interpretation of definition of spouse and the interpretation of marriage in community law and staff regulations: ECJ 7 January 2004, case C-117/01 (K.B.v National Health Service Pensions Agency) Rec. p. I-541; ECJ 31 May 2001, case C-122/99P and C-125/99P (D and Kingdom of Sweden $v$ Council of the European Union) Rec. 2001, p. I-4319; ECJ 17 February 1998, case C-249/96 (Grant v South-West Trains Ltd) Rec 1998, p. I-621; ECJ 17 April 1986, case 59/85 (Netherlands $v$ Reed) Rec. 1986, p. I-1283. In these cases it was not so much family law (marriage law) itself that was at stake, but the question whether unmarried couples could benefit from rights granted to married couples or whether same sex couples could benefit from rights granted to couples of the opposite sex.

${ }^{6}$ ECJ 10 June 1999, case C-430/97 (Johannes v Johannes) Rec.1999, p. 3475.

7 ECJ 2 October 2003, case C-148/02 (Garcia Avello) Rec. 2003, p. I-11613.

8 ECJ 14 October 2008, case C-353/06 (Grunkin and Paul) Rec. 2008, p. I-7639.
} 
legislator should come up with a European private international law on parentage and what such private international law should look like.

\subsection{Research question}

The objective of this thesis is to provide a basis for a European instrument on the recognition of legal parentage in one Member State that has been established in another Member State, if the European Union decides to become active in this field. This basis is established through answering two questions.

The first question is in what kind of cases, if any, the national systems of private international law violate rules of primary EU law, more in particular the prohibition of discrimination on the basis of nationality (art. 18 TFEU) and the right to free movement of EU citizens (art. 21 TFEU). In order to answer this question, Part 1 will explain the differences between the rules on parentage and the underlying policy of these rules in five legal systems of the European Union, namely the Dutch, English, French, German and Swedish legal systems. Part 2 examines the systems of private international law on parentage in these legal systems. In part 3 the case law of the European Court of Justice and the policy of the European legislator on international family law will be studied in order to establish what European law demands from national systems on private international law on parentage.

If it is established that in certain cases the outcome of national rules on private international law violate primary EU law, the second question is how this violation can be remedied. In the conclusion one solution will be examined in particular, namely the unification of private international law on parentage. The unification of private international law is proposed by the Treaty on the Functioning of the European Union in article 81 TFEU.

\subsection{Structure}

\subsubsection{Part 1 - national laws on parentage}

The first part of this thesis describes the national law on parentage in England and Wales, France, Germany, the Netherlands and Sweden. Although the subject of this thesis is mainly private international law, there are different reasons to start with a description of the substantive law on parentage.

First of all, private international law on parentage is only relevant to the extent that national legal systems on parentage are different. If the legal systems involved in a particular case all come up with the same solution there is no need to make a choice of law. Thus in order to appreciate the relevance of private international law on parentage, how the legal systems differ must be examined.

Secondly, although national private international law is meant to deal with international cases and foreign law, it is often written with the own national system of substantive law in mind. For example, French private international law on parentage has a special rule on the effects of apparent status in an international context. One can only appreciate the meaning of this rule, if one knows what apparent status is and how it works in the French law on parentage.

Although the bias in favour of the own national legal system (the lex fori) probably exists with regard to choice of law rules in general, it is even stronger in matters concerning parentage because of the public policy concerns involved. The application of foreign law cannot jeopardize the national public policy on parentage. These public policy concerns refer inter alia to the protection of the family life of the mother and her child (the 
Netherlands), the social family life of the established legal family (France, the Netherlands, Germany), the interest of the child to know his biological affiliation (England, Sweden, Germany) and certain choices regarding the legal effects of (medically) assisted reproduction (all legal systems). Moreover, in all legal systems the parentage of a child can be relevant to determine the child's nationality.

It is only natural that the national legislator does not ignore these high profile interests in an international case. If, for example, the protection of the family life of the mother and her child is an important concern in purely internal cases, it can hardly be expected from judges and other legal practitioners that they disregard these issues in a case with a foreign element. The idea that choice of law rules are neutral in the sense that they should not be concerned with the outcome of the case is, also in matters concerning parentage, outdated. ${ }^{9}$

Given the fact that national private international law on parentage is not neutral, but tailored to protect the national policy on parentage, it can only be understood by understanding the national law on parentage on which it is based.

Also with a view to the development of European private international law on parentage it is important to appreciate the interaction between substantive law and private international law. After all, if two Member States advance conflicting policies through their national systems of private international law on parentage, it will not be easy to get them to agree on a unified system of private international law. Given that under EU law the unification of international family law still requires unanimity among the Member States, this interaction is a relevant aspect to keep in mind. ${ }^{10}$

The third reason why it is important to study the substantive law on parentage is that unified rules on private international law, more in particular choice of law rules, can only work if they use a vocabulary that is understood by the different legal systems in which they have to be applied. Thus if it would be concluded that European choice of law rules on parentage are necessary, they must be formulated in terms that make sense in all the legal systems involved. That is only possible if it is clear what the national systems on parentage are about.

\subsubsection{Part 2 - private international law on parentage}

In the second part the national systems of private international law on parentage in the five Member States under consideration will be described. The focus in this part shall be on the national choice of law rules on parentage. The reason for this is that in matters concerning parentage, judicial pronunciations only play a limited role. For most persons, parentage shall never be established by a court, but only by a civil status registrar and other administrative authorities like the population register. Nonetheless, also the rules on jurisdiction of courts and the recognition of foreign judgments on parentage shall be discussed briefly in order to get a complete picture of the system of private international law on parentage. The description of the national systems of private international law on parentage serves two purposes.

Firstly, it must be revealed to what extent the national systems of private international establish decisional harmony in matters concerning a child's parentage. The problem of decisional harmony can be explained by the following oversimplified example: if Sweden

\footnotetext{
9 In general: Strikwerda 1986; Jessurun d'Oliveira 1985; Jaffey 1982; Neuhaus 1963. With regard to parentage in particular: Th.M. de Boer \& Kotting 1989, p. 75.

10 According to Basedow, the communitarisation of private international law means that the interest based conflicts systems that have been developed in the Member States will be replaced by a more neutral Savignian choice of law system (Basedow 2009, p. 458). The Dutch Advocate-General for private international law at the Hoge Raad, Strikwerda stated in an interview that because of the national interests that are protected by choice of law rules in family law the unification of choice of law rules is not self evident (T.M.C. Asser Instituut report on non-harmonisation of choice of law rules in divorce matters 2002, p. 21). See also Th.M. de Boer 2008.
} 
applies the law of the domicile of the child to determine the parentage of the child and if France applies the national law of the child to determine the same issue, there is no decisional harmony if according to the law of the domicile $X$ is the father, while according to the national law $\mathrm{Y}$ is the father. If, in a particular case, the child has ties with both France and Sweden it may find himself in difficulties because he has a different father in France and in Sweden.

In practice this kind of 'short circuit' does not happen very often, because the law is much more complex or refined than the example suggests. Thus the first aim is to examine how the complexity works and where 'short circuits' in the decisional harmony, and for that matter possible violations of EU law, may arise.

The second reason to examine the national systems of private international law is that they may serve as a source of inspiration for future European private international law on parentage. The legal systems involved use different techniques to deal with choice of law problems. It is useful to understand these techniques and to appreciate their merits in drafting European private international law.

\subsubsection{Part 3 - EU law}

The third part of this thesis describes the possible influence of EU law on private international law on parentage. It is a 'possible' influence, because so far the European Court of Justice has not ruled on cases involving legal parentage and the European legislator has also not touched this subject. However, there is case law of the European Court of Justice on other parts of personal status: the surname of a person and his marital status. Thus the objective is to analyse the case law of the European Court of Justice and to determine what the Court demands from national systems of private international law. In the conclusion it shall be examined how the requirements that have been formulated by the Court can be worked out in legislation, taking into account the national legal provisions on parentage.

Another question, which falls outside the scope of this thesis, is whether the EU is the best level to deal with problems that arise out of a divergence of national systems of national systems of private international law. Is it not better to deal with these issues at a global level? After all, some important practical problems concerning personal status in private international law in European Member States exist especially with regard to immigrants from non-European countries. Moreover, given that the EU of 27 Member States acts on the basis of unanimity in family matters, the chances of success in Brussels are not necessarily higher than at a global level. ${ }^{11}$ Another factor that according to some pleads in favour of another level of governance to regulate private international law on parentage is that the quality of EU private international law is perceived to be nothing short of inferior. They argue that the proper forum for unification of private international law is the Hague Conference on Private International Law. ${ }^{12}$

This thesis is not meant to express any preference for regulation at EU level or at a global level. If it appears that primary EU law mandates the unification of private international law on parentage, the question is simply what this private international law should look like. Whether it should be enacted at a European or a global level is a different question that falls outside the scope of this thesis.

This thesis also does not examine other pertinent problem areas such as the determination of the contents of the foreign law and the appreciation of the authenticity of

\footnotetext{
11 Beaumont 2009, p. 511.

12 See inter alia Schmidt 2006; Th.M. de Boer 2005; Jänterä-Jareborg 2003.
} 
foreign documents. In fact, determining the applicable law is in most legal systems and in most cases relatively easy. The real problem is finding out what foreign law says. ${ }^{13}$

For example, the application of Finnish law to determine the parentage of a child by a Dutch civil status registrar in Ooststellingwerf, or any other small municipality, is a real problem. The registrar does not deal with this kind of cases on a regular basis, he or she is obviously not trained in Finnish law and he or she does not have access to Finnish law. The result is that the application of Finnish law is frequently nothing more than a Dutch interpretation of - for example - a German translation of Finnish law as it appears in Bergmann/Ferid. ${ }^{14}$ Thus legal practitioners reading this thesis should not expect a magic formula to solve private international law cases. This thesis only deals with a small element of a rare type of case.

\subsection{Methodology}

In examining the influence of primary EU law on private international law on parentage two questions arise. The first question examines in what kind of cases, if any, the current systems of private international law violate EU law. The second question is what a unified European private international law on parentage should look like.

\subsubsection{Methodological issues on the first question}

In general, the method to find out whether a legal problem exists is relatively straightforward. The first step is to find out what the rules on the topic are by consulting the law, explanatory reports, case law and commentaries of the legal systems involved. The second step is to formulate the result that has to follow from the rules in a particular case. If the rules indeed lead to the desired result there is no problem. If, however, the rules lead to a different result there is a problem.

With regard to this thesis the first step means that the rules that deal with the determination of parentage in an international case in the legal systems under consideration have to be identified. These rules will be refered to as the private international law of the legal systems involved. Above, it has been indicated that the study of private international law is not complete without a study of the underlying substantive law. Thus the question is how the substantive law and the private international law on parentage has to be studied in order to determine whether or not there is a problem with primary EU law. This question raises different methodological questions.

The first issue is the legal systems that have to be examined. Currently, the European Union consists of more than 27 legal systems. ${ }^{15}$ Theoretically, in order to examine whether there is a European wide problem one would have to examine all these legal systems. For more than one reason (language, time) that is not possible.

Therefore, five legal systems mentioned before have been selected, since it appeared from preliminary research that these legal systems have different approaches to legal parentage and private international law on parentage. If a problem among these legal systems has been found, the chance is considerable that the problem also exists in other legal

\footnotetext{
${ }^{13}$ See also the Dutch advocate general for private international law at the Hoge Raad (Practical problems resulting from the non-harmonisation of choice of law rules in divorce matters, Report by the T.M.C. Asser Instituut, Den Haag (2002) (JAI/A3/2001/04), p. 29).

${ }^{14}$ A. Bergmann, M. Ferid \& D. Henrich, Internationales Ehe- und Kindschaftsrecht, Frankfurt am Main: Verlag für Standesamtwesen (loose leaf commentary on foreign law).

${ }^{15}$ At this moment there are 27 Member States. Some Member States like the United Kingdom have more than one legal system.
} 
systems. At the same time, the conclusion that there is no problem amongst these five legal systems obviously does not guarantee that there is no problem elsewhere.

The second issue is how to present the different legal systems in order to find the information needed. The aim of the description of substantive law on parentage is to find out what the structure and the policy of the law on parentage is. Therefore, part 1 presents a basic structure that is common to the legal systems under consideration to indicate at the different parts of the structure how and why the legal systems differ. To make this more concrete, let us explain the structure that has been found to describe the substantive law on parentage.

Every legal system under consideration has to assign parents to children because the legal systems attach legal consequences to the status of being a parent or child of a certain person. These legal consequences are very diverse: in nationality law the child may obtain the nationality of his parents, in immigration law parents and children may be entitled to family reunification, the parents may be under an obligation to maintain their child, the parents usually have parental responsibility or custody over the child, children may be entitled to inherit from their parents, parents may be entitled to child allowances from the state or their employer and so on. In all these cases it must be determined who the parents of the child are for legal purposes. These persons are referred to as the legal parents.

In order to assign parents to children the legislator in a particular legal system has to go through three steps. The first step is that it has to determine who, in general has to be considered the parents of a child. There is some discussion possible, but in most cases the biological parents of the child are considered the child's parents.

The second step is to determine how to bestow legal parenthood upon the biological parents. A straightforward and simple rule to bestow the biological parents with legal parenthood is the rule that the child's biological parents are his or her legal parents. A more complicated rule provides that the husband of the mother at the moment of birth or the man who validly acknowledged his paternity is the legal father of the child. Here the question is how these rules on the establishment and annulment of legal parenthood work and why legal systems have chosen these specific rules.

At the third step it must be determined how the existence of legal parenthood is proven. Here, legal systems differ because at the second step it appeared that the object of proof is different. Depending on the legal system involved, one has to prove the existence of biological affiliation, of a marriage or of a valid acknowledgement. Since the legal parentage of a child is such a basic element of his personal status some legal systems have specific rules of evidence to prove legal parentage.

The three steps are the three parts of the structure of the law on parentage which in the author's view constitute the structure of the law on parentage which is common to the legal systems under consideration. On the basis of this common functional three-step structure the steps can be examined by reference to on which legal systems agree and where they differ. It will provide the reader with a structured overview of the similarities and differences and the national policies involved in the legal systems under consideration.

The second step to consider whether there is a problem is to determine what European law demands from the national legal systems of the Member States when it comes to the determination of parentage in an international case. It consists of an interpretation of primary EU law on the basis of case law of the European Court of Justice. In this respect, there are no specific issues of methodology to be addressed.

The third step is to evaluate the kind of cases where the national legal systems cannot stand the test of European law if applicable. It is for others to determine whether these cases are 
problems requiring concrete action. The analysis made in this part may also be useful for practitioners who are not yet aware of the relationship between national private international law and EU law. After all, if they do not raise the issue before courts and administrative authorities, dormant problems may never come to the surface.

\subsubsection{Methodological issues on the second question}

The author is not aware of any particular scientific legal method to draft EU law. In particular the idea that the common core in national systems of private international law will lead to the European solution must be rejected. After all, unification of private international law on parentage is only necessary if the national legal systems fail to meet the requirements of primary EU law. If that is the case, the common core in national private international law is apparently not very well equipped to deal with the requirements of EU law.

A unified private international law on parentage is the result of a balancing exercise between EU law (non-discrimination and free movement rights) on the one hand and the different public policies of Member States on the other. Thus, the European legislator is well advised to study in detail the specific problems that come up with the determination of parentage in an international case. For that purpose, it is very useful to study the national systems of private international law and their application because it shows the specific problems that have to be solved by the unified rules. It also gives the European legislator an opportunity to explain in an explanatory report how the unified private international law must be applied with regard to certain national specificities. Such an explanation is absolutely necessary to avoid time consuming procedures for the reference of preliminary questions to the ECJ.

This dissertation takes into account the development of case law, legislation and doctrine up to January 2010. 


\section{Part 1 Legal parentage from a comparative perspective}

Differences in private law are the raison d'etre of private international law. There is no point in making a choice between the application of the law of legal systems A and B if the laws of both legal systems are the same. The aim of this chapter is to find out the differences between the national systems on parentage and their underlying policies. This part, and the thesis in general, is not concerned with the law on the adoption of children.

The national legal systems on parentage shall be studied at three levels. In chapter two the basis for legal parentage will be studied. In chapter three the rules on establishment and annulment of legal parentage will be examined and in chapter four the rules of evidence in legal parentage will be studied. 


\section{Grounds for legal parentage}

The objective of the law on parentage is to determine who the child's parents are for the purpose of the effects which the law attaches to the parent-child relationship. The answer to this question used to be quite straightforward: the child's genetic/biological parents are the legal parents of the child. The original challenge for the law on parentage was not to determine the basis of legal parenthood, but to provide for rules to prove genetic parenthood (especially paternity) and to determine whether the child was legitimate, legitimated or illegitimate. However, technical developments in the field of assisted reproduction and changes in the social perception of fertility treatment, surrogacy and unwanted childlessness have put the very basis of the law on parentage to the question.

The objective of this chapter is to describe the grounds for legal parenthood in the five legal systems at hand. Sometimes the grounds are stated expressly in the law as in England and Wales and Sweden for cases involving assisted reproduction. Sometimes the grounds have to be derived from the provisions on judicial establishment and annulment of legal parenthood, as in France, Germany and the Netherlands. For those legal systems, it is submitted that the fact that has to be proven (e.g. genetic affiliation or consent to fertility treatment) in order to establish or annul legal parenthood is the ground for legal parenthood.

\subsection{Grounds for legal maternity}

Childbirth is the ground for legal maternity in the case of natural reproduction and assisted reproduction in all legal systems considered. Under Dutch and German law this ground follows directly from the civil codes themselves, which state that the woman who gives birth to the child shall be the child's legal mother. ${ }^{16}$

Under English common law the opinion of Lord Simon of Glaisdale in the The Ampthill Peerage case is often cited as the leading case on legal maternity:

Motherhood, although also a legal relationship, is based on a fact, being proved demonstrably by parturition. Fatherhood, by contrast, is a presumption. ${ }^{17}$

In parallel with the common law position, section 33 (1) of the Human Fertilisation and Embryology Act 2008 provides that the woman who is carrying or has carried a child as a result of the placing in her of an embryo or of sperm and eggs, and no other woman is to be treated as the mother of the child. Pursuant to paragraph 3, the provision applies irrespective of the place where the woman received treatment.

Swedish law has no specific provisions on legal maternity in case of natural reproduction. It was considered self-evident that the woman who gives birth to the child is the child's mother. ${ }^{18}$ In case of artificial reproduction $\S 1: 7$ of the Föräldrabalk (1949:381) provides that if a woman gives birth to a child who has been created with the ovum of another woman, the woman who gives birth to the child shall be considered to be the child's mother.

The French Code civil only provides how legal maternity can be established and annulled; just like English and Swedish law it does not state explicitly who the legal mother

\footnotetext{
${ }^{16}$ Netherlands: article 1:198 Burgerlijk Wetboek. Germany: §1591 Bürgerliches Gesetzbuch.

17 The Ampthill Peerage [1977] A.C. 457, at 577. Also e.g. Masson, Bailey-Harris \& Probert 2008, nr. 17-003.

18 Socialstyrelsen 2005, p. 105; Karnov/Saldeen 2007, Föräldrabalk, note 27. See also Högsta Domstolen, 7 July 2006 , case number Ö5151-04, NJA 2006, 505.
} 
of the child is. However, it is apparent from the provisions of the civil code that the legislative aim is to establish the legal maternity of the woman who gave birth to the child. Firstly, article 332 French Civil code states that legal maternity can be annulled if it is proved that the legal mother did not give birth to the child. Secondly, article 55 French Civil code states that the birth has to be declared within three days after the birth of the child, which indicates that the woman who gives birth to the child should be mentioned in the birth register as the child's mother. However, unlike under the other legal systems, under French law the legal maternity of the birthmother is not established automatically.

The choice for the birthmother as the legal mother of the child is no longer self-evident. Medically assisted reproduction techniques make it possible that one woman carries the child that has been created with the egg of another woman. As a result of this development legislators have had to make a choice between the birthmother and the genetic mother of the child. Another development that has put the maxim mater semper certa est to the test, is the growing social acceptance of surrogacy. Surrogacy is the phenomenon whereby a woman gets pregnant with the intention of handing over the child to commissioning parents. Often, but not always, the surrogate mother carries a child that has been created with the ovum of another woman.

We have seen that the different legislators recognised that maternity is not as selfevident as it used to be: the Dutch, English, German and Swedish legislators created specific provision to deal with legal maternity. All four legislators have chosen the birthmother as the legal mother of the child. Why?

The first reason is that maternity remains more associated with giving birth than with genetic affiliation. ${ }^{19}$ The Dutch legislator stated in this respect that the choice for the birthmother as the legal mother in case of egg donation was justified by the choice of the birthmother to fall pregnant with the ovum of another woman, by her pregnancy as such and by the fact that she gave birth. ${ }^{20}$ Also, the German legislator based its choice for the birthmother on the 'physical, psychological and sociological bond' between the birthmother and the child during the pregnancy and directly after the birth. ${ }^{21}$

Notwithstanding this strong association of giving birth with maternity, the legal maternity of the birthmother is not sacrosanct under the legal systems considered. Under English law the birthmother is always the legal mother at first instance. However, in case of surrogacy it is possible that by means of a parental order the commissioning parents obtain all parental rights. ${ }^{22}$ Under Dutch law, the choice for the birthmother as the legal mother of the child is to discourage surrogacy. ${ }^{23}$ However, surrogacy itself is not prohibited, medically assisted reproduction techniques with a view to surrogacy are allowed and the commissioning parents can become the legal parents of the child by adopting the child. ${ }^{24}$

Also under German law, the choice for the birthmother as the legal mother of the child is meant to discourage surrogacy. ${ }^{25}$ According to the Swedish legislator, surrogacy can lead to grave problems if the surrogate mother changes her mind during the pregnancy and refuses to hand over the child. Moreover, it was deemed unethical that the infertility of a

\footnotetext{
19 See also Sheldon 2005, p. 540.

${ }^{20}$ Kamerstukken II 1995-1996, 24649, nr. 3, p. 7.

21 BR Drucks. 180/96, p. 92 and BT Drucks. 13/4899, p. 82

22 Section 30 Human Fertilisation and Embryology Act 1990.

${ }^{23}$ Kamerstukken II 1991-1992, 21968, nr. 5, p. 8; Kamerstukken II, 1996-1997, 25000 XVI, nr. 62, p. 13.

${ }^{24}$ On the establishment of legal parentage in case of surrogacy under Dutch law see inter alia Schoots, Van Arkel \& Dermout 2004; Bergen \& Buijssen 2004; Vlaardingerbroek 2003; Broekhuijsen-Molenaar 1991

25 BR Drucks. 180/96, p. 92 and BT Drucks. 13/4899, p. 82.
} 
couple be solved by using the womb of another woman.26 Both under German and Swedish law medically assisted reproduction techniques with a view to surrogacy are not allowed.27

In Sweden there are no statutory rules on the adoption of children in case of surrogacy. In 2006, the Högsta Domstol ruled on the application for adoption by the commissioning woman of a child who was born to a surrogate mother. ${ }^{28}$ An embryo created with the gametes of the commissioning parents was placed in the womb of the sister of the man in a hospital in Finland. The surrogate gave birth to the child in Sweden and handed over the child to the commissioning parents. The legal paternity of the commissioning father was established by his acknowledgment of paternity. After more than one year, the commissioning mother applies for the adoption of the child. At first instance her husband consents to the adoption but he changed his mind and withdrew his consent. The majority of the judges of the Högsta Domstol ruled that the mother cannot adopt the child if the legal father of the child does not consent, even if she is the genetic mother of the child. Although the Swedish legislator disapproves of surrogacy, Sweden's highest court did not rule that adoption in case of surrogacy is not allowed because of the surrogacy arrangement.

In France, the civil code explicitly provides that surrogacy violates French public policy. ${ }^{29}$ The current attitude in French law towards surrogacy does not only mean that medically assisted reproduction techniques with a view to surrogacy are not allowed; ${ }^{30}$ at various occasions the Cour de Cassation has even held that the adoption of the child by the commissioning mother is not allowed, since surrogacy violates French public policy. ${ }^{31}$ Although surrogacy is not allowed under French law, the birthmother has the right to give birth anonymously. ${ }^{32}$ If the birthmother gave birth anonymously, her legal maternity cannot be judicially established.

In this paragraph it has been shown that in all legal systems under consideration childbirth is the basis for legal maternity. In cases where the genetic mother and the birthmother are not the same woman, all legal systems provide that the birthmother shall be the legal mother of the child. The legal maternity of another woman cannot be established on account of the law on parentage. Only under English law it is possible that in case of surrogacy the commissioning parents acquire parental status by means of a special judicial order, the parental order.

\subsection{Grounds for legal parenthood of the second parent}

Under all five legal systems under consideration a child can only have two legal parents. The first parent is the legal mother of the child and the basis for her legal maternity has been

\footnotetext{
26 Prop. 2001/02:89, p. 55.

${ }^{27}$ Germany: 11 Gesetz zum Schutz von Embryonen (Embryonenschutzgesetz). Sweden: Lag (2006:351) om genetisk integritet m.m.

${ }^{28}$ Högsta Domstolen, 7 July 2006, case number Ö5151-04, NJA 2006, 505. For a description of the facts and a legal analysis of the case see Singer 2006.

${ }^{29}$ Article 16-7 and 16-9 Code civil. There are however signs that the attitude towards surrogacy in France is changing: Sénat 2007-2008, Rapport d'information sur la maternité pour autrui (28 June 2008), nr. 421.

${ }^{30}$ Art. L2141-3 (1) Code de la santé public, which provides that an embryo shall only be created in vitro to remedy the infertility of a couple and that the gametes must come from at least one person of that couple.

31 Cass. Civ. ass. plén., 31 May 1991, Bull civ. no. 4; Cass. Civ. 1er, 9 December 2003, D. 2004, p. 1998 (note PoissonDrocourt). For references to more case law and literature see in French Granet-Lambrechts 2008, Labbée 2007 and in Dutch Braat 2008. The legal parenthood of French commissioning parents that has been established abroad in case of surrogacy violates French public policy (Cour d'appel de Rennes, 4 July 2002, D. 2002, 2902; Cour d'appel de Paris, 26 February 2009, La semaine juridique 2009, 83(26), p. 16 (note Mirkovic)).

32 Art. 326 Code civil.
} 
explained in the previous paragraph. In this paragraph the basis for the legal parenthood of the second parent shall be examined.

Under Dutch, French and German law the second parent can only establish his legal parenthood on account of the rules on parentage if he is male. The female partner of the legal mother of the child either cannot establish her legal maternity or she can only establish her legal maternity on account of the rules of adoption. Under English and Swedish law however, the legal parenthood of the female partner of the legal mother of the child can be established by virtue of the rules of parentage. ${ }^{33}$ That is why this thesis refers to the ground for the legal parenthood of the second parent instead of the ground for legal paternity.

The basis for the legal parenthood of the second parent used to be quite straight forward. Legal paternity used to be based on genetic paternity. ${ }^{34}$ The question was not so much who should be the legal father of the child but how legal paternity could be proven and established. However, the rise of medical technology in the field of parentage and society's acceptance of the use of artificial reproduction techniques to remedy infertility of couples has forced legislators to rethink the basis for the legal parenthood of the second parent.

Within the five legal systems under consideration the two main ideas on which the legal parenthood of the second parent is based are either genetic paternity or consent to or responsibility for fertility treatment. Consent to fertility treatment as a basis for legal parenthood is an exception to the starting point that legal parentage is based on genetic parentage. The objective of this paragraph is to describe the boundaries of the exception: when is legal parenthood based on consent and becomes genetic parentage irrelevant? Consent to fertility treatment is only a basis for legal parentage if certain conditions are fulfilled. The requirements for the relationship between the mother and the consenting person, the object to which the person has to consent, the formal requirements for a valid consent, the possibility to withdraw one's consent to fertility treatment and the position of the biological father (the sperm donor) of the child will be looked at.

\subsubsection{Grounds for legal parenthood of the second parent under Dutch law}

Under Dutch law, legal paternity is primarily based on genetic paternity. ${ }^{35}$ That means that the law is based on the assumption that the biological father of the child should be his legal father. This assumption is not made explicit, but it follows from provisions such as article 1:200 (1) Burgerlijk Wetboek, which provides that the legal paternity of the husband shall be annulled if it is proven that he is not the biological father of the child.

Additionally in 1970 a provision was introduced in the Dutch law on legal parentage to deal with legal paternity in case of artificial reproduction with donor semen. The provision is now contained in article 1:200 (3) Burgerlijk Wetboek and it provides that the mother and the husband cannot apply for the annulment of the legal paternity of the husband on the ground that he is not the biological father of the child, if the husband consented to an act that could have resulted in the procreation of the child. It was acknowledged that if the husband consented to a certain fertility treatment of his wife with donor sperm, it would be

\footnotetext{
${ }^{33}$ England: sections 42 to 47 Human Fertilisation and Embryology Act 2008. These provisions entered into force on 6 April 2009 (section 6 (1) under a Human Fertilisation and Embryology Act 2008 (Commencement No.1 and Transitional Provisions) Order 2009 (SI 2009/479). Sweden: § 1:9 Föräldrabalk (1949:381). The possibility for the lesbian partner of the mother to become the child's legal mother has been inserted by Act SFS 2005:434 and entered into force on the 1st of July 2005. On the Swedish law see inter alia Jänterä-Jareborg 2006a; Jänterä-Jareborg 2006b.

${ }^{34}$ Especially French lawyers will not readily agree with this proposition. Under French law, the basis for legal paternity is considered to be a mixture of biological paternity and social reality (Dekeuwer-Defossez 1999, p. 25). In this thesis the balancing between biological and social reality as a basis for legal parentage shall be discussed in chapter 3. Establishment and annulment of legal parentage.

35 See also e.g. Kamerstukken II, 1999-2000, 26 673, nr. 5, p. 3.
} 
unreasonable if the husband or the mother would be allowed to reconsider that decision. The consent of the husband to the treatment of his wife creates a responsibility for the man and the woman to raise the child that is born from that treatment as their own. ${ }^{36}$ However, the child is in such a case still allowed to contest the legal paternity of his mother's husband. Therefore, it is not entirely correct to say that consent is a basis for legal parentage. The consent of the husband and the mother only bars the husband and the mother from contesting the husband's legal paternity.

In 1998 the effect of the consent of a man to the fertility treatment of his partner with donor semen was extended. The legislator introduced article 1:207 Burgerlijk Wetboek allowing the judicial establishment of legal paternity. Before 1998, Dutch law did not have a possibility to judicially establish legal paternity. On the basis of article 1:207 (1) Burgerlijk Wetboek, the legal paternity of the begetter of the child or of the man who, as a life companion, consented to the act that could have resulted in the procreation of the child can be judicially established. The begetter of the child is the biological father who has begotten the child in a natural way. The man who consented to the act that could have resulted in the procreation of the child is for example the man who consented to the artificial insemination with donor semen of his partner. Article 1:207 (1) Burgerlijk Wetboek implies that the legal paternity of the sperm donor who is not the life companion of the mother cannot be judicially established.

Consent to the act that could have resulted in the procreation of the child is only relevant for legal parentage if the consenting person is the husband of the mother or if he is her life companion. The concept of life companion has not been defined by law or in the parliamentary documents nor has it led to problems in case law.

Articles 1:200 (3) and 207 (1) Burgerlijk Wetboek attach a certain effect to the consent of the mother's husband or life companion to the act that could have resulted in the procreation of the child'. This phrase refers especially to fertility treatment with donor semen. The husband or life companion who consents to such treatment cannot contest his legal paternity and the legal paternity of the life companion can be judicially established if he does not acknowledge his paternity. ${ }^{37}$ However, the provisions are not confined to artificial reproduction. In fact, in 2003 the Hoge Raad held that that the husband who consented to and encouraged his wife to commit acts of prostitution could not contest his legal paternity concerning the child who was born to his wife as a result of the prostitution. ${ }^{38}$ According to the Hoge Raad, the husband consented to an act which could have resulted in the conception of the child.

Articles 1:200 (3) and 207 (1) Burgerlijk Wetboek only require that the husband or the life companion consented to an act that could have resulted in the procreation of the child. The Dutch legislator considered that it would be virtually impossible to prove, for example, that the child could have been conceived as a result of adultery with consent of the husband or donor insemination. Therefore, only the consent of the husband or the partner to an act in the conception period that could have resulted in the procreation of the child has to be proven. 39

However, the man is allowed to prove that the child is not born as a result of the act to which he consented. If the husband consented to the sexual intercourse of his spouse or partner with another man, the man has to bear the consequences of that consent even if he consented under the condition that no children would be begotten: he cannot annul his

\footnotetext{
36 Parlementaire Geschiedenis/Boek 1 Invoeringswet 1969, p. 1297, 1303; Commissie kunstmatige inseminatie bij de mens, Report 1965, p. 23.

${ }^{37}$ See for example Kamerstukken II 1995-1996, 24649, nr 3, p. 7, 9, 21.

${ }^{38}$ Hoge Raad, 7 February 2003, NJ 2003/358. See also already Parlementaire Geschiedenis/Boek 1 Invoeringswet 1969, p. $1301,1303,1309$.

39 Parlementaire Geschiedenis/Boek 1 Invoeringswet 1969, p. 1301.
} 
paternity. 40 On the other hand, if the husband consented to the fact that his wife travels with another man, he does not consent to the wife having sexual intercourse. In such a case he is allowed to contest his legal paternity if a child is born to his wife from her travel partner. ${ }^{41}$ Also, if the husband consented to fertility treatment with donor semen, but if the child is begotten by a friend of the mother the husband is allowed to contest his legal paternity. The same applies if the husband allowed sexual intercourse with one specific person and the child is begotten by another person. ${ }^{42}$ Thus, the formulation that the act could have resulted in the procreation of the child merely shifts the burden of proof: if it has been established that a man consented to an act that could have resulted in the conception of the child, it is up to him to prove that the child is not born as a result of that act. If the man cannot prove that, the child is presumed to be the result of the act to which the man consented.

The law does not require the consent of the husband or the life companion to be in a certain form. The law does also not specify anything with regard to the possibility to withdraw one's consent.

The position of the sperm donor is not explicitly regulated under Dutch law. It is clear that if the mother and her partner use the sperm of an unknown sperm donor, the law does not aim at the establishment of his legal paternity. It has bee shown that in such a case the law aims at the establishment of the legal paternity of the consenting partner (art. 1:207 (1) Burgerlijk Wetboek). However, if the couple has used the sperm of a known donor, Dutch law is not clear as to what the basis of the child's legal parentage should be: should legal parenthood in such a case be established on the basis of genetic parentage or should it be based on the basis of the consent of the partner of the mother? This question has arisen in situations where two women used the sperm of a friend to create a child. Problems arise if both the female partner of the mother and the sperm donor want to be recognised as the parent of the child. In such a case it can happen that the mother of the child blocks the donor's acknowledgment of paternity ${ }^{43}$ and the donor blocks the attempt of the female partner of the mother to adopt the child. ${ }^{44}$ In such a case, the child remains without a second legal parent.

\subsubsection{Grounds for legal parenthood of the second parent under English law}

Under English law, the basis for the legal parenthood of the second parent depends on whether the child has been conceived through intercourse or assisted reproduction techniques. In cases of natural reproduction, the law on parenthood is not codified but part of the common law. At common law, in cases of natural reproduction the biological father is the legal father of the child. 45

In cases of assisted reproduction, the basis for legal parenthood is the responsibility of the mother's partner (male or female) for the creation of the child with artificial reproduction techniques. In the debates preceding the enactment of the Human Fertilisation and Embryology Act 1990, Lord Mackay of Clashfern formulated it as follows:

The conclusion I have reached is that if it is to remain possible for unmarried couples to receive the benefit of treatment to bring a child into being, both should have imposed upon them the responsibility for the child. I was most concerned that this proposal

\footnotetext{
40 Parlementaire Geschiedenis/Boek 1 Invoeringswet 1969, p. 1307, 1309.

41 Parlementaire Geschiedenis/Boek 1 Invoeringswet 1969, p. 1310.

42 Kamerstukken I 1997-1998, 24649, nr. 11a, p. 4; nr. 11d, p. 5.

${ }^{43}$ Hoge Raad, 24 January 2003, LJN AF0205, NJ 2003/386.

${ }^{44}$ Hoge Raad, 21 April 2006, LJN AU9726, NJ 2006/584.

${ }^{45}$ Masson, Bailey-Harris \& Probert 2008, nr. 17-004; Lowe \& Douglas 2007, p. 305; Mackay of Clashfern 2008 , par. 93.
} 
should not be seen as encouraging unmarried people to use infertility treatments, thus perhaps undermining marriage, or leading to children having unsuitable social fathers because of the difficulty in distinguishing partners to stable relationships from more transitory ones. On reflection, having regard to the other provisions of the Bill, these considerations should not deter us from inserting this amendment. ${ }^{46}$

Legal parenthood in the case of assisted reproduction was formally determined by the Human Fertilisation and Embryology Act 1990. However, since 6 April 2009, the provisions on parenthood in the Human Fertilisation and Embryology Act 2008 apply to children conceived after that date. ${ }^{47}$ It has already been pointed out that the rule on legal maternity under both the 1990 Act and the 2008 is straightforward. Both under section 27 of the 1990 Act and section 33 of the 2008 Act the legal mother of the child is the woman who gave birth to the child even if the child has been created with the ovum of another woman.

The definition for the legal parenthood of the mother's partner is a lot more complicated. Sections 35 to 47 Human Fertilisation and Embryology Act 2008 distinguish three situations.

The first situation is where the mother is married with a man (section 35) or in a civil partnership with a woman (section 42) at the moment of the fertility treatment. In such a case, the husband or the partner shall be the legal parent of the child unless it is shown that he or she did not consent to the treatment. The consent of the husband or the partner does not need to be in a special form in order to be valid. ${ }^{8}$ In case of a marriage or a partnership, the law also does not regulate the withdrawal of consent.

The second situation is the case where the mother is not married or in a registered civil partnership at the moment of the fertility treatment. In either case her male or female partner shall be treated as the legal parent of the child if the requirements of sections 36 and 37 for male partners and sections 43 and 44 for female partners are fulfilled. The requirements for male and female partners are the same.

The first requirement under the 2008 Act in order for the male or female partner of the mother to be considered the legal parent of the child is that the fertility treatment has taken place in a licensed clinic. ${ }^{49}$ If the treatment of the mother did not take place in a licensed clinic but, for example, at home (do-it-yourself insemination) or abroad, the partner is not the legal parent of the child. ${ }^{50} \mathrm{In} U . v W$. (Attorney-General intervening) it is explained that in this case the legislator wanted to make sure that the partner shall be fully aware of the 'important and probably expensive consequences of his joining with the woman in seeking treatment with the donor sperm.' ${ }^{\prime 1}$ After all, a clinic operating under a licence is obliged to inform the mother and her partner of the consequences of their actions. If the persons involved seek treatment with a person without a licence, it cannot be guaranteed that the partner of the mother will be informed of the consequences of his or her consent to the treatment.

The requirement that the couple must be treated by a person to whom a licence applies does not exist if the mother and her partner are married or in a civil partnership. The difference in treatment of married and unmarried couples (and of the children born to them), is justified under the 1990 Act by the fact that 'it is a natural assumption that, if a wife is seeking treatment with donor sperm, the husband should be the legal father of any resultant

\footnotetext{
${ }^{46}$ Hansard, 20 March 1990 (517 HL Official Report (5 $5^{\text {th }}$ series), cols. 209-210) (cited by Lord Hope of Craighead in In re $D$ (a child appearing by her guardian ad litem) [2005] UKHL 33, [2005] 2 AC 621.

47 Transitional provisions: section 57 Human Fertilisation and Embryology Act 2008. For a brief and practical summery on the provisions on parenthood in the 2008 Act see Gamble \& Ghevaert 2009.

${ }^{48}$ Masson, Bailey-Harris \& Probert 2008, nr. 17-004.

49 Sections 36 under a and 43 under a Human Fertilisation and Embryology Act 2008.

50 See for example U $v$ W (HM Attorney General Intervening), [1998] Fam 29.

51 U. v W. (Attorney-General intervening) [1998] Fam 29.
} 
child unless he shows he shows that he did not consent to the treatment.'52 Apparently, the legal parenthood for the partner who is not married to or in a partnership with the mother nor genetically affiliated with the child is such an unexpected exception that it must be guaranteed that the partner is properly informed. For the $2008 \mathrm{Act}$, the legislator explained that treatment in a licensed clinic is important in order to ensure the proper administration of the parties' intentions. ${ }^{53}$

The second requirement is that the agreed fatherhood conditions (for a male partner) or female parenthood conditions (for a female partner) are satisfied. ${ }^{54}$ These conditions are listed in sections 37 and 44 of the 2008 Act. They are met, first of all, if the partner informed the responsible person at the clinic of his or her consent to the fertility treatment and if the mother agreed that her partner shall be treated as the legal parent of the child. Second, the consent should not have been withdrawn before the treatment of the mother has taken place. Consent and withdrawal of consent are only effective if in writing and signed by the person who consents or withdraws consent and if the responsible person at the clinic has been informed of the consent or the withdrawal of the consent. Third of all, the mother should not have notified the responsible person at the clinic that she consents to another man or woman being treated as the legal parent of the child. Finally, the mother and her partner should not be within the prohibited degrees of relationship to each other.

The rather complicated second requirement intends to remedy the legal uncertainty with regard to parenthood after assisted reproduction for unmarried couples that existed under the Human Fertilisation and Embryology Act 1990. Section 28 (3) of the 1990 Act provided that the male partner of the mother would be considered the legal father of the child who was created with donor sperm, if the man and the mother of the child received treatment together by a person to whom a licence applied. As identified by case law, problems arose on the interpretation of the phrase 'receiving treatment together' in situations where a couple started treatment together, but split up before the actual insemination of the mother or the placing in her of the embryo. In such a case, it was uncertain whether the couple received treatment together as a result of which the ex-partner should be considered the legal father of the child. ${ }^{55}$ This uncertainty is resolved by the Human Fertilisation and Embryology Act 2008.

The third situation that is distinguished by the provisions on legal parenthood in the Human Fertilisation and Embryology Act 2008 is the case where the mother is married to another person at the moment of birth. The rules on parenthood in the two situations described above: thus either 1, the mother is married or in a civil partnership or 2, the mother is in an informal relationship, are subject to the common law presumption of legitimacy. ${ }^{56}$ That means that these rules on parenthood do not apply if another person is presumed to be the father of the child under the presumption of legitimacy. At common law, the husband of the mother at the moment of birth (not conception) is presumed to be the father of the child. ${ }^{57}$ Thus, if a woman was married or in a civil partnership at the moment of her fertility treatment but at the moment of the child's birth she is married to another man, that man shall be presumed the child's legal father until it has been proven that he is not the

\footnotetext{
52 U. v W. (Attorney-General intervening) [1998] Fam 29.

${ }^{53}$ Explanatory Notes to Human Fertilisation and Embryology Act 2008, par. 165.

54 Sections 36 under b and 43 under b Human Fertilisation and Embryology Act 2008.

${ }_{55}$ E.g. In re D (a child appearing by her guardian ad litem) [2005] UKHL 33, [2005] 2 AC 621, [2005] 4 All ER 433, [2005] 2 FCR 223; Re R (a child) [2005] UKHL 33, [2005] 2 AC 621, [2005] 4 All ER 433, [2005] 2 FCR 223. On the concept of receiving treatment together under the 1990 Act see also Lowe \& Douglas 2007, p. 313; Vonk 2007, p. 159-162.

56 Sections 38 (2) and 45 (2) Human Fertilisation and Embryology Act 2008.

${ }^{57}$ Lowe \& Douglas 2007, p. 321.
} 
child's biological father. If the presumption of legitimacy has been rebutted, the application of the rules described above revives. ${ }^{58}$

Under the 1990 Act, section 28 (6) subsection 6 provided that if the sperm of the mother's husband or partner was used after his death he was not to be treated in law as the father of the child. In 2003 the High Court declared that the impossibility of a woman to register her deceased husband or partner as the father of the child violated the mother's rights under article 8 of the European Convention on Human Rights. ${ }^{59}$ Therefore, the Human Fertilisation and Embryology (Deceased Fathers) Act 2003 inserted subsections 5A to 5D in section 28 of the Human Fertilisation and Embryology Act 1990. These provisions have been taken over in sections 39, 40 and 46 of the Human Fertilisation and Embryology Act 2008.

Sections 39, 40 and 46 of the Human Fertilisation and Embryology Act 2008 describe the situations in which a deceased is treated as the parent of the child solely for the purpose of being mentioned as the parent on the child's birth record. The child does not acquire any kind of status or rights with regard to the deceased. 60

In essence, section 39 provides that if the child is created with the sperm of a man who consented in writing to both the treatment of the woman with his sperm and him being mentioned as father on the child's birth record and if no other man is treated as the father of the child, that man shall be mentioned as the father on the child's birth record.

If the child has been carried by the mother as a result of the placing in her of an embryo which is created with donor sperm, the deceased husband of the mother (section 40 (1)), the deceased woman with whom she is in a civil partnership (section 46 (1)) or her deceased male or female partner (sections 40 (2) and 46 (2) respectively) can only be mentioned as the parent if, in addition to the requirements explained above, the embryo was created during the lifetime of the deceased, but placed in the mother after his or her death. In these situations the mother's husband or partner is not genetically affiliated with the child. Therefore, he or she can only be named as the father if he or she was alive when the embryo was created. Otherwise, his or her connection with the child is deemed too insignificant to be mentioned as parent on the birth record. The partner with whom the mother does not have a marriage or a civil partnership can only be mentioned as the parent, if the treatment was provided in a licensed clinic.

The position of the sperm donor is determined by sections 38 (1), 41 and 45 (1) Human Fertilisation and Embryology Act 2008. Sections 38 (1) and 45 (1) provide that where a person is treated as the parent of the child by virtue of sections $35,36,42$ or 43 no other person is treated as the parent of the child. Thus, if the husband or partner of the mother is treated as the legal parent under sections $35,36,42$ or 43 , the sperm donor shall not be treated as the father.

However, if no person is treated as the parent of the child under sections 35, 36, 42 or 43, it does not automatically mean that the sperm donor is the child's legal father. Section 41 provides that where the sperm of a man who had given such consent as required by paragraph 5 of schedule 3 to the 1990 Act was used for a purpose for which such consent was required he is not to be treated as the father of the child. The consent which is meant is the consent to 'treatment services', which is defined as 'medical, surgical or obstetric

\footnotetext{
58 See also Explanatory Notes to Human Fertilisation and Embryology Act 2008, par. 168 and 174. For a slightly different interpretation under the 1990 Act see Lowe \& Douglas 2007, p. 312; Lee \& Morgan 2001, p. 221; Douglas \& Barton 1995, p. 65.

${ }^{59}$ Explanatory Notes to Human Fertilisation and Embryology (Deceased Fathers) Act 2003 (c. 24), par. 3.

${ }^{60}$ Explanatory Notes to Human Fertilisation and Embryology (Deceased Fathers) Act 2003 (c. 24), par. 4.
} 
services provided to the public or a section of the public for the purpose of assisting women to carry children.' 61

If the donor's sperm has not been used in the course of treatment services but for the purpose of self-insemination, the donor is the legal father of the child if no person is the parent on the basis of sections 35, 36, 42 and 43.62 If his sperm has been used in the course of treatment services, but if no man consented to the treatment, for example because the woman does not have a partner, it follows that the child does not have a legal father. ${ }^{63}$

Being legally fatherless under English law means something else than being legally fatherless under continental law. Under continental law, it means that legal paternity has not been established, but it can still be established. Under English law it means that no man shall be recognised in law as the legal father of the child, unless the child is adopted.

\subsubsection{Grounds for legal parenthood of the second parent under French law}

Under French law, the basis for legal paternity is almost always biological paternity. However, that does not mean that the legal paternity of the biological father is always established. In the chapter on the establishment of legal parentage it will be shown that the French legislator developed a system that on the one hand aims at the establishment of the legal paternity of the biological father: the husband is not the legal father if the child is born during the divorce proceeding and if the person who acknowledged his paternity is not the biological father of the child, his legal paternity can in principle be contested. On the other hand French law also takes account of existing social relations by limiting the possibility to contest existing legal paternity.

Only in the case of fertility treatment with donor sperm is legal paternity not based on biological paternity, but on the man's consent to the treatment. Just like under English law, French law takes the view that if the partner of the mother consents to the creation of a child with donor sperm, it is the partner and not the sperm donor who is responsible for the upbringing of the child. ${ }^{64}$ The idea has been laid down in articles 311-19 Code civil, which determines the status of the donor and 311-20 Code civil, which determines the status of the mother and her partner.

Per article 311-20 Code civil the husband of the mother who consented to the medically assisted procreation with donor semen (procréation médicalement assistée avec tiers donneur) cannot contest his legal paternity on the ground that he is not the biological father of the child. The husband is allowed to prove that the child is not born from the fertility treatment to which he consented. If the child is born to an unmarried mother the man who consented to the medically assisted procreation is obliged to acknowledge his paternity. If the man does not acknowledge his paternity, his legal paternity can be judicially established.

Article 311-20 Code civil only applies to a married couple or to a man and a woman who are cohabiting. Cohabition is defined in article 151-8 Code civil as a factual union, characterised by a stable and continuous living together as a couple of two persons of opposite sex or the same sex. ${ }^{65}$ Article 311-20 Code civil also requires the child to be born as a result of medically assisted reproduction with donor sperm (assistance médicale nécessitant l'intervention d'un tiers donneur). The term 'medically assisted reproduction' is defined in article L2141-1 Code de la santé public (Public Health Act):

\footnotetext{
${ }^{61}$ Section 2 Human Fertilisation and Embryology Act 1990.

62 Lee \& Morgan 2001, p. 224; Douglas \& Barton 1995, p. 66.

63 Sheldon 2005, p. 541; Lee \& Morgan 2001, p. 224; Douglas \& Barton 1995, p. 67.

${ }^{64}$ Dekeuwer-Defossez 1999, p. 37.

${ }^{65}$ Article 151-8 Code civil: Le concubinage est une union de fait, caractérisée par une vie commune présentant un caractère de stabilité et de continuité, entre deux personnes, de sexe différent ou de même sexe, qui vivent en couple. For an explanation of the different elements of the definition see Malaurie \& Fulchiron 2006, nr. 311-317.
} 
L'assistance médicale à la procréation s'entend des pratiques cliniques et biologiques permettant la conception in vitro, le transfert d'embryons et l'insémination artificielle, ainsi que toute technique d'effet équivalent permettant la procréation en dehors du processus naturel, dont la liste est fixée par arrêté du ministre chargé de la santé, après avis de l'Agence de la biomédecine.

It follows that the provisions of article 311-20 Code civil on the legal paternity of the consenting partner do not necessarily apply in case of do-it-yourself insemination. In such a case, the legal paternity of the consenting partner can be established on the basis of his marriage to the mother or by his acknowledgement, but it could also be annulled on the basis that he is not the biological father of the child. 66

Article 311-20 Code civil provides for serious formal requirements for the consent of the mother's partner. According to article 311-20 Code civil the consent has to be given before a judge or a civil law notary who has to inform the couple of the legal consequences of the consent. The judge or the civil law notary has to inform the couple of the impossibility to establish the legal paternity of the sperm donor, of the prohibition to contest legal paternity, of the situation in which the consent is cancelled by operation of the law and of the possibility to apply for the judicial establishment of the legal paternity of the consenting partner if he does not voluntarily acknowledge his paternity. ${ }^{67}$ The consent of the mother's husband or partner shall be laid down in an authentic instrument (acte authentique). ${ }^{68}$

Unlike Dutch and English law, French law explicitly describes the cases in which the consent of the husband or the partner of the mother is cancelled by operation of the law. The consent to the fertility treatment shall be ineffective in case of death, divorce or legal separation or the ending of the cohabitation before the fertility treatment took place. Just like under English law, the consent is also ineffective if the doctor who treats the couple is informed in writing of the withdrawal of the consent. ${ }^{69}$ In that case not only is the consent of the husband or the partner of the woman ineffective, but the fertility treatment shall also be stopped. Under French law, only heterosexual couples can benefit from medically assisted fertility treatment. ${ }^{70}$

The position of the sperm donor is determined by article 311-19 Code civil. The article provides that in case of medically assisted procreation with donor sperm, the legal paternity of the donor cannot be established. The donor can also not be held liable to maintain the child that has been born as a result of the medically assisted procreation. Article 311-19 Code civil only applies in the case of medically assisted reproduction as has been explained above. Hence, the legal paternity of the sperm donor who helps the lesbian couple with their 'do-ityourself' insemination can be judicially established.

\subsubsection{Grounds for legal parenthood of the second parent under German law}

From the five legal systems under consideration, the German legal system still adheres the most to biological affiliation as the basis for legal parentage. It was only in 2002 that the

\footnotetext{
${ }^{66}$ On the possibility to annul legal paternity see § 3.5. Annulment of legal parenthood.

67 Article 1157-3 Code de procédure civil.

68 Article 1157-2 Code de procédure civil.

69 Article 311-20 Code civil.

${ }^{70}$ Article L2141-2 (3) Code de la santé publique formulates the requirements in order to be eligible for medically assisted reproduction: L'homme et la femme formant le couple doivent être vivants, en âge de procréer, mariés ou en mesure d'apporter la preuve d'une vie commune d'au moins deux ans et consentant préalablement au transfert des embryons ou à l'insémination. Font obstacle à l'insémination ou au transfert des embryons le décès d'un des membres du couple, le dépôt d'une requête en divorce ou en séparation de corps ou la cessation de la communauté de vie, ainsi que la révocation par écrit du consentement par l'homme ou la femme auprès du médecin chargé de mettre en œuvre l'assistance médicale à la procréation. See also Demay de Goustine 1996.
} 
German legislator recognised that the man who consented to the fertility treatment of his wife or partner is responsible for the upbringing of the child. ${ }^{71}$ On the 12th of April 2002 the Gesetz zur weiteren Verbesserung von Kinderrechten entered into force and added a subparagraph to § 1600 Bürgerliches Gesetzbuch. § 1600 (5) BGB now provides that if the child is born as a result of artificial procreation with donor semen with the consent of the man and the mother, the man and the mother cannot contest the legal paternity of the man. In contrast to English and French law, the provision does not specify the relationship between the mother and 'the man'. According to the explanatory notes, 'the man' refers to the man who is the legal father either on the basis of his marriage to the mother or his acknowledgment of paternity. ${ }^{72}$

The provision resembles the Dutch article 1:200 (3) Burgerlijk Wetboek. Also under German law, the child is still allowed to contest the legal paternity of the man who consented to the fertility treatment as a result of which he or she is born.

Compared with the other legal systems, the German regulation on the effects on consent to fertility treatment with donor sperm is brief. § 1600 (5) Bürgerliches Gesetzbuch only bars the possibility to contest existing paternity. Thus, legal paternity must first be established either automatically or voluntarily before the consent to the fertility treat has any legal effect in the law on parentage. The paternity of the mother's husband at the moment of birth exists automatically. ${ }^{73}$ If the mother is not married, the consenting partner first has to acknowledge his paternity voluntarily. However, if he does not acknowledge his paternity voluntarily, his legal paternity cannot be judicially established. ${ }^{74}$

Neither the law nor the explanatory report to $\S 1600$ (5) Bürgerliches Gesetzbuch specifies the kind of treatment that bars the possibility for the mother and the legal father to contest his legal paternity. The only thing the law provides is that the child must be born as a result of artificial procreation with donor semen (künstliche Befruchtung mittels Samenspende eines Dritten).

With regard to the form of the consent the law does not specify anything. Therefore the prevailing view is that the consent of the man to the fertility treatment does not need to be in a specific form in order to be effective. ${ }^{75}$ Neither the law nor the explanatory report addresses the possibility for the husband or the partner to withdraw consent to the fertility treatment. ${ }^{76}$

The Gesetz zur weiteren Verbesserung von Kinderrechten of 2002 does not affect the status of the sperm donor under German law. As long as the legal paternity of another man exists his legal paternity cannot be established. However, if the child discovers who the sperm donor is, he or she can contest the legal paternity of the legal father and apply for judicial establishment of the legal paternity of the biological father; ${ }^{77}$ the anonymity of the donor is not protected.78

\subsubsection{Grounds for legal parenthood of the second parent under Swedish law}

Also under Swedish law the starting point is that the legal parenthood of the second parent is based on his genetic affiliation with the child. It will be shown that the Swedish legal

\footnotetext{
71 BR Drucks. 369/99, p. 8; BT Drucks. 14/2096, p. 10.

72 BR Drucks. 369/99, p. 6, 8; BT Drucks. 14/2096, p. 6, 10.

$73 \S 1592$ (1) Bürgerliches Gesetzbuch.

$74 \S 1600 d$ Bürgerliches Gesetzbuch.

75 Gernhuber \& Coester-Waltjen 2006, p. 628; Staudinger/Rauscher 2004, §1600, nr. 78.

${ }^{76}$ Cf. Janzen 2002, p. 786.

77 MünchKomm/Wellenhofer 2008, § 1592, nr. 35; §1600d, nr. 30; Staudinger/Rauscher 2004, § 1600, nr. 99; §1600d, nr. 15 .

${ }^{78}$ BT Drucks. 12/2091, in which the government answers the question to what extent the anonymity of the sperm donor is protected. See also MünchKomm/Wellenhofer 2008, § 1592, nr. 37.
} 
system goes to great lengths to make sure that in case of natural reproduction the legal paternity of the biological father shall be established. However, Swedish law also provides for interesting exceptions to genetic affiliation as the basis for the legal parenthood of the second parent in cases of fertility treatment. Not only the consenting male partner of the mother but also the consent of the mother's female partner can serve as a basis for the establishment of her legal parenthood on account of the rules on parentage. Just as under the other legal systems considered, the consent of the mother's partner to the fertility treatment is a basis for the establishment of legal parenthood, because the consent to the fertility treatment has made the mother's partner responsible for the upbringing of the child who is born as a result of the treatment. ${ }^{79}$

$\S 6$ of the first chapter of the Föräldrabalk (Children and parents' code) provides that if the mother has been inseminated with the consent of her husband or the man with whom she is living together (her partner) and if it is likely that the child is begotten as a result of the insemination, the husband or the partner is considered the father of the child. $\S 1: 8$ Föräldrabalk provides the same for the case where the child is born as a result of in vitro fertilisation.

The first requirement in order for the consent of a man to be the basis for his legal paternity is that the man is married to the mother or that he is her cohabiting partner (sambo). The concept of cohabiting partner is governed by the Sambolag (2003:376), which in $\S 1$ provides that cohabitees (sambor) are two people who live together on a permanent basis as a couple and who have a joint household.

The legal paternity of the husband or the cohabiting partner of the mother is based on his consent to the insemination of the mother ( $\$ 1: 6$ Föräldrabalk) or to the fertilisation of her egg cell outside her body ( $\$ 1: 8$ Föräldrabalk). Both types of fertility treatment are since 1 July 2006 governed by the Lag (2006:351) om genetisk integritet m.m. For his paternity the consent of the husband or the cohabiting partner of the mother to the mother's treatment is not subject to formal requirements. ${ }^{80}$ However, the Lag (2006:351) om genetisk integritet m.m. requires the written consent of the husband or the cohabiting partner of the mother before she can be treated. 81 Thus if the treatment takes place in Sweden, there shall usually be a written consent of the man to the treatment of the mother.

§§ 1:6 and 1:8 Föräldrabalk provide that it must be sannolikt that the mother's child is created as a result of the fertility treatment to which the man consented. Sannolikt means more or less 'likely'. The adjective indicates the second highest burden of proof in Swedish law. ${ }^{82}$ Thus, it does not need to be proven with absolute certainty that the child is born as a result of the act or the treatment. Under Swedish law it is allowed though to prove that the child is not born from the insemination or the fertility treatment or that the husband did not consent. ${ }^{83}$ Thus under Swedish law, the formulation 'must be likely' merely shifts the burden of proof: as soon as it has been established that it is likely that the child is born from insemination or fertility treatment it is up to the other party (the alleged father) to prove that the child is not born as a result of such actions or to prove that he did not consent.

The Swedish legislator explicitly addressed the withdrawal of consent to fertility treatment in the explanatory report to § 1:6 Föräldrabalk. Unlike under French law, there is no provision in Swedish law that automatically cancels the consent of the husband or cohabiting partner of the mother. The consent of the husband or the cohabiting partner can be withdrawn in order to render it ineffective. However, the man who withdraws his

\footnotetext{
${ }^{79}$ SOU 1983:42, p. 67, 74.

80 Prop. 1984/85:2, p. 20. Walin, G., Föräldrabalken och internationell föräldrarätt, Norstedt, Stockholm, 1996, p. 81.

81 § 6:1 and § 7:3 Lag (2006:351) om genetisk integritet m.m.

82 On the different burdens of proof in Swedish law on legal affiliation see Saldeen 1980, p. 55.

83 Prop. 1984/85:2, p. 14, 19. Singer 2000, p. 341, 342.
} 
consent has to make sure that not only his (ex) partner is informed but also the doctor who treats his (ex) partner. If the doctor has not been informed about the withdrawal of the consent before the insemination has taken place, the man shall still be considered the father of the child. 84

Not only the male partner of the mother but also her female partner acquires the status of legal parent if she consents to the fertility treatment of the mother. § 1:9 Föräldrabalk was introduced on the first of July 2005 and amended in 2009. It provides that if the fertility treatment of the mother has taken place within the framework of chapter 6 or 7 of the Lag (2006:351) om genetisk integritet m.m. with the consent of a woman who is the mother's female spouse, her registered partner or her cohabiting partner and if, with a view to the circumstances of the case, it is likely that the child is born as a result of the treatment, the woman shall be the legal parent of the child.

§ 1:9 Föräldrabalk was inserted in the best interest of the child. The idea is that if a woman is treated under the Lag (2006:351) om genetisk integritet m.m, the sperm donor is unknown. In such a case, it is considered to be in the best interest of the child if the person who in reality fulfils the parental role is also recognised in law as the legal parent of the child. 85

The requirements for the lesbian partner of the mother to be treated as the legal parent of the child are more demanding than the requirements that have to be fulfilled by the husband or male partner of the mother under $\S \S 1: 6$ and 8 Föräldrabalk. Just like in heterosexual cases the law requires the existence of a stable relationship between the consenting female partner and the mother. They must be registered partners or living together within the meaning of the Sambolag (2003:376), which means that they must live together on a permanent basis as a couple and have a joint household.

An additional requirement in case of lesbian women is that the treatment of the mother of the child takes must take place in Sweden within the framework of the Lag (2006:351) om genetisk integritet m.m. ${ }^{86}$ If the treatment takes place abroad or in case of 'do-it-yourself' insemination the female partner of the mother is not treated as the legal parent of the child under $\S 1: 9$ Föräldrabalk. The reason for this is that if the fertilisation has taken place outside the scope of the Lag (2006:351) om genetisk integritet m.m., the donor is often a friend or at least an acquaintance of the women. In such a case it was deemed to be in the best interest of the child that the legal paternity of the donor shall be established. ${ }^{87}$ If the treatment of the mother takes place abroad the female partner is also not recognised under § 1:9 Föräldrabalk as the legal parent. The reason is that foreign hospitals operate under different conditions to Swedish hospitals which make it difficult to determine under which conditions the treatment has taken place. Moreover, if the insemination of the mother has taken place abroad, it can be difficult for the Swedish authorities to find out whether or not the treatment really took place in a hospital which creates uncertainty for the persons involved. ${ }^{88} \mathrm{~A}$ similar requirement has been described under English law in case of fertility treatment provided to unmarried couples: the unmarried partner of the mother is only the legal parent of the child if the treatment took place in a licensed clinic. ${ }^{89}$

The position of the sperm donor under Swedish law is regulated in § 1:5 (2) Föräldrabalk. It provides that the paternity of a sperm donor within the meaning of the Lag (2006:351) om genetisk integritet m.m. cannot be established. Thus in case of 'do-it-yourself' insemination

\footnotetext{
84 Prop. 1984/85:2, p. 20.

85 Prop. 2004/05:137, p. 43

86 See also Jänterä-Jareborg 2006b, p. 87.

87 Prop. 2004/05:137, p. 44.

88 Prop. 2004/05:137, p. 44

${ }^{89}$ Sections 36 and 43 Human Fertilisation and Embryology Act 2008.
} 
of a lesbian woman the legal paternity of the sperm donor can be established. Also, if it appears that the husband or the male partner of the woman did not consent or that his consent is ineffective the legal paternity of the sperm donor can be established. This is only different if the donor's sperm has been used in the framework of the Lag (2006:351) om genetisk integritet m.m. that implies, inter alia, that the fertility treatment must have taken place in a specially designated hospital and that the doctor has checked whether the consent of the husband or partner of the mother is effective. ${ }^{90}$

\subsection{Conclusion on the grounds for legal parentage}

In this chapter the grounds for legal parentage in Dutch, English, French, German and Swedish law have been examined. The ground for legal parentage is the central idea of who should be the legal parent of the child. In all legal systems under consideration legal maternity is at first instance based on childbirth. Childbirth used to be an obvious basis for legal maternity, but because of the possibility of egg donation and surrogate motherhood legislators have been forced to make a choice as to who should be considered the legal mother of the child. Even for these cases of differentiated motherhood, legal systems under consideration have chosen to base legal maternity on childbirth.

Legal systems differ as to the possibility to divest the birthmother of her legal maternity in cases where the parties involved agreed that another woman than the birthmother will take up the mother role. Under English law, the birthmother can be divested of her legal maternity relatively easily by a parental order in favour of gamete donors. Under French law surrogacy violates public policy. Therefore, it is not even possible for the commissioning mother to adopt her child if he has been born to a surrogate mother. However, although surrogacy violates French public policy, the birthmother has to right to maintain her anonymity. Thus also under French law, the legal maternity of the birthmother is not sacrosanct. The other legal systems are between these extremes.

The conclusion is that in the law on parentage in the different legal systems legal maternity is based on childbirth, but that the strength of the legal maternity of the birthmother differs in the legal systems at hand.

With regard to the second parent it has been explained that in the case of natural reproduction the laws on parentage in the legal systems under consideration aim to establish the legal paternity of the biological father. At the same time, each of the legal systems involved recognises that the establishment of the legal paternity of the biological father of the child in case of fertility treatment of the mother with donor sperm is not selfevident. In such a case it is not the biological father but the man (or woman) who consented to the treatment who is held responsible for the upbringing of the child, because he (or she) and the mother are responsible for the creation of the child. Moreover, it is often the consenting partner and not the sperm donor who shall take up the parent role in the upbringing of the child.

Although the legal systems agree on these main lines concerning the legal parenthood of the second parent, legal systems differ as to the exact effect that is attached to the partner's consent to the fertility treatment of the mother. English, French and Swedish law agree that in case of fertility treatment with donor sperm the consent of the partner replaces entirely the genetic affiliation as a ground for legal parenthood. That means that not only the consenting partner and the mother, but also the child has to accept the consenting partner as the legal father of the child.

90 Prop. 2004/05:137, p. 53. 
This is different under Dutch and German law which provide that a man's consent to fertility treatment only bars the man and the mother from contesting the legal paternity of the man. The child still has the possibility to contest the legal paternity of the consenting partner on the basis that he is not the biological father. Under German law it is not even possible to judicially establish the legal paternity of the consenting partner if he does not voluntarily acknowledge his paternity. Under Dutch law this is possible.

Although English, French and Swedish law agree on the replacement of genetic paternity by the consent to fertility treatment as a basis for legal parenthood, they differ in the exact requirements. Under French law only the consent of a man to the fertility treatment of the mother can be the basis for his legal paternity. Under English and Swedish law also the consent of the female partner of the mother can be the basis for her legal parenthood on account of the rules on parentage.

Under Swedish law the law on parentage does not pose special requirements on the form of the consent of the mother's partner. English law provides that the consent of the unmarried male partner and the consent of the mother's female with whom she is not in a civil union has to be in writing. However, in case of marriage or a civil union, the consent to the treatment does not need to be in a specific form. Under French law, the consent must be given in an authentic instrument before a judge or a civil law notary. In this way French law tries to guarantee that the couple is informed of the legal implications of their consent to the fertility treatment.

Under English law, the consent of the unmarried partner to the fertility treatment of the mother only establishes his legal paternity if the treatment takes place in a licensed clinic. This requirement is made to make sure that the unmarried partner of the mother shall be fully informed of the consequences that the fertility treatment are provided to him and the mother together. Swedish law provides the same for the legal parenthood of the female partner of the mother of the child. The female partner of the mother of the child shall only be treated as the parent of the child, if the fertility treatment of the mother takes place in a specially designated hospital in Sweden.

The conclusion is that there are various differences between the legal systems involved in relation to the consequences of consent to fertility treatment for the legal parentage of the child. Part of these differences can be explained by the fact that different legal systems try to meet certain objectives with different means. An example is the aim to inform the parties involved of the legal consequences of their consent to the fertility treatment. Under French law, this aim is pursued by posing formal requirements to a valid consent while under English and Swedish law this aim is pursued by requiring the parties involved to get treated in a clinic that is bound by the standards of the legal systems considered.

Another part of the differences can be explained by the fact that not all types of fertility treatment are possible under the legal systems involved. Under French law the lesbian partner of the mother cannot become the legal mother of the child, but French law also does not allow medically assisted fertility treatment for lesbian couples. This is different in England and Sweden. 


\section{Establishment and annulment of legal parentage}

The second function of the law on parentage is to determine how legal parentage is established and how established legal parentage can be contested. For the purpose of this thesis it is necessarey to have an insight into the different methods to establish and contest legal parentage, because these rules are the object of private international law on parentage: the choice of law rule that determines the law that applies to a person's parentage determines whether the parentage has to be established or contested in accordance with the rules of state A or state $B$.

The different legal systems under consideration provide for four methods to establish legal parentage. Legal parentage might be established automatically or ex lege as a result of a certain fact like giving birth, biological paternity, or marriage to the mother or a collection of facts like apparent status. Legal parentage can also be established by means of a juridical act like the acknowledgment of paternity or maternity. In this case, the national legal systems differ as to the requirements for the validity of the juridical act. Finally, legal parentage can also be established by a judgment.

In this chapter the different methods to establish legal parentage and the possibility to annul existing legal parentage will be examined. The aim of the chapter is to indicate the differences between national legal systems on parentage and to illustrate the necessity of private international law in this area of the law.

\subsection{Ex lege existence of parenthood}

Ex lege existence of parenthood means that legal parenthood exists automatically without any juridical action being required. In other words, the existence of legal parenthood does not depend on an action by one of the persons involved. Depending on the fact upon which the law establishes legal parenthood, legal parenthood can correspond with the basis of legal parentage in the legal system involved. For example, giving birth is the basis for legal maternity in all legal systems under consideration and most legal systems provide that the birthmother is the legal mother by dint of birth. In this case, legal maternity exists ex lege on the basis of the fact that the woman gave birth. However, the automatic establishment of the legal paternity of the mother's husband under Dutch, French, German and Swedish law does not guarantee that legal paternity corresponds with the basis for legal paternity. After all, the husband is not necessarily the biological father of the child.

In the case of ex lege existence of parenthood no action is required to establish legal parenthood. However, some action is required in order to create proof of the facts that establish legal parenthood (childbirth, biological paternity, marriage) or of the existence of the legal relationship itself (legal paternity). Evidence of legal parenthood shall be discussed in the third chapter of this part.

Ex lege establishment of legal parenthood exists under each of the legal systems under consideration. In this paragraph it will be argued that under English law legal parentage is always established ex lege. After that, the ex lege establishment of legal maternity under Dutch, German and Swedish law and the ex lege establishment of the legal paternity of the mother's husband under Dutch, French, German and Swedish law will be examined. 


\subsubsection{Ex lege existence of legal parentage under English law}

Under English law legal parentage always exists ex lege, also if it concerns paternity out of wedlock. 91 The question whose paternity or maternity exists automatically has been discussed in the previous chapter. ${ }^{92}$ It has been shown that in case of natural reproduction, the biological parents are the legal parents of the child. In case of assisted reproduction, legal parentage is defined in the Human Fertilisation and Embryology Act 2008. Per section 33 , the legal mother of the child is the woman who gave birth to the child, even if the child has been created with the ovum of another woman. The definition of the second legal parent in section 35 and further appeared to be more complicated. In broad terms, the person who consented to the fertility treatment of the mother is the considered the second legal parent of the child.

How do we know that under English law legal parentage exists ex lege? The proposition that parenthood exists ex lege is a typical continental way of stating the law because continental lawyers are very much concerned with the establishment of legal parenthood. Under continental civil law, the parent-child relationship does not have any legal effects if legal parenthood has not been established. However, from an English perspective the words 'establishment of legal parenthood' will not be interpreted as the bringing into existence of a legal relationship that did not exist before. Under English law legal parentage does not need to be created; it only has to be proven. From an English perspective the words 'establishment of legal parenthood' means that the existence of legal parenthood is proven.

We shall illustrate the proposition regarding legal parentage under English law on the basis of one example: the registration of birth. Section 10 Births and Deaths Registration Act 1953 provides:

Notwithstanding anything in the foregoing provisions of this Act [and subject to section 10ZA of this Act], in the case of a child whose father and mother were not married to each other at the time of his birth, no person shall as father of the child be required to give information concerning the birth of the child, and the registrar shall not enter in the register the name of any person as father of the child except [...].

According to this provision the unmarried 'father' of the child shall not be registered, unless certain conditions are fulfilled. Obviously one wants to know who is meant by the 'father'. Under legal systems like the French or the German, the word would mean legal father and on the basis of the provisions in the respective civil codes one investigates who is the child's legal father. In case of an unmarried father one will find that there is no legal father, unless someone acknowledged his paternity. It follows that continental legal systems put forward a formal concept of legal parenthood: parenthood does not depend on a material fact such as genetic affiliation or intention, but on a formality such as marriage or a formal procedure such as acknowledgment. This is different under English law. Under English law, parenthood is defined substantially, i.e. with reference to material facts. ${ }^{33}$ The first sentences in the part on fatherhood from a leading textbook on English family law state:

The position regarding who is the legal father is more complicated than that of the mother for while in general the genetic father (i.e. the man whose sperm fertilised the egg) is regarded as the legal father, this is not a universal rule. Conversely, there are

\footnotetext{
${ }^{91}$ Frank 2009, p. 69.

92 See § 2.2.2. Grounds for legal parenthood of the second parent under English law.

${ }^{93}$ For certain specified areas of law English law provides for a definition of paternity, such as for nationality law (section 50 (9) British Nationality Act 1981).
} 
occasions when, notwithstanding the absence of any genetic link a man will be treated as the legal father. ${ }^{94}$

The exceptions to which the author of the citation refers are the exceptions in the Human Fertilisation and Embryology Act. In case of assisted reproduction it is not always the biological father, but the person who consented to the fertility treatment who is the legal parent of the child. However, in case of natural reproduction, the biological father is the legal father of the child, independent of his marriage to the mother. ${ }^{95} \mathrm{~A}$ man's marriage to the mother only raises a rebuttable presumption that he is father of the child. However, this 'presumption of legitimacy' is only a rule of evidence; ${ }^{96}$ it is even a weak presumption. ${ }^{97}$ In the combined case of $S v S$ and $W v$ Official Solicitor Lord Reid held:

That means that the presumption of legitimacy now merely determines the onus of proof. Once evidence has been led it must be weighed without using the presumption as a make-weight in the scale for legitimacy. So even weak evidence against legitimacy must prevail if there is not other evidence to counterbalance it. The presumption will only come in at that stage in the very rare case of the evidence being so evenly balanced that the court is unable to reach a decision on it. I cannot recollect ever having seen or heard of a case of any kind where the court could not reach a decision on the evidence before it. 98

Not only in court proceedings, but also at the registration of the child's birth the presumption of legitimacy exists. However, also here the presumption is easily rebutted. The Handbook for Registration Officers instructs registration officers as follows:

In space 4 the registrar must enter the name and surname (in block capitals) of the father where he is married to the child's mother at the time of the birth. The registrar should ask: 'What was the full name and surname of the child's father at the date of the birth?' When the informant is the mother particular care should be taken to avoid asking for the information by a question such as 'What is your husband's name?'. 99

It turns out that if there is a father who has to be registered, it is the biological father of the child. This follows from the following passage of the instructions for the registration officer:

Under the Perjury Act 1911, a person is guilty of an offence if he/she wilfully gives a false answer to any question put by a registrar of births and deaths relating to the particulars required to be registered, or deliberately gives to the registrar false information about a birth or death, or makes a false statement with the intent to have it inserted in a register of births or deaths. In these circumstances the informant should state the facts which he/she considers to be true, and should not state that the mother's husband is the father of the child if it is known that he could not have been (e.g. by reason of his death or continuous absence from her over a long period). The informant would be committing an offence if he/she gave information for the registration of the

\footnotetext{
${ }_{94}$ Lowe \& Douglas 2007, p. 309.

${ }^{95}$ See also Vonk 2007, p. 46.

96 See also Frank 2009, p. 69; Frank 2005a, p. 97.

${ }_{97}$ See also Lowe \& Douglas 2007, p. 323, 324 where the relevant case law is described in more detail. Also Probert 2003, nr. 10-004; Mackay of Clashfern 2008, nr. 95.

98 [1972] AC 24.

99 Handbook for Registration Officers, p. B2.20-23c, par. 21, 22 (last update 1/1994/P1). See also Guide pratique international de l'état civil, Royaume-Uni (2002), § 3.3.1.3 (www.ciec1.org).
} 
birth as that of the child of the mother and her husband knowing that in fact, her husband was not the child's father. But see also para 31a.100

The above shows that references to father or mother are apparently references to the father and mother at common law or under the Human Fertilisation and Embryology Act. Hence, at common law and under the Human Fertilisation and Embryology Act, the parents are defined substantially (i.e. with reference to material facts on which parenthood is based) and not formally (i.e. with reference to a certain procedure which has conferred the status of legal parent on the person involved) as is the case under continental civil law. Consequently, if the method of establishing parenthood under English law has to be characterised, it has to be characterised as existence of legal parenthood ex lege.

The consequence of the fact that parenthood exists ex lege under English law is that English law does not have a procedure equivalent to the continental procedure of acknowledgment of parenthood. ${ }^{101}$ The registration of the unmarried father under English law strongly resembles acknowledgment of paternity, but it does not create legal parentage in the same way as continental law acknowledgment does. Likewise, English law does not have a judicial procedure for establishment or annulment of legal parentage since there is nothing to establish or to annul. English law only provides for a procedure to obtain a declaration of parentage, which is enough. ${ }^{102}$ Functionally a declaration of parentage is the same as a continental judicial procedure for establishment or annulment of parenthood but again, the difference is that under continental law those procedures affect the legal reality, while under English law the legal reality remains the same, but its appearance changes.

\subsubsection{Ex lege existence of legal maternity}

Legal maternity under Dutch and German law also exists ex lege. Under both legal systems, the civil codes state that the birthmother is the legal mother. Her legal maternity exists automatically; it is established by dint of birth. ${ }^{103}$

Swedish law does not have a general provision on the establishment of legal maternity. In the previous chapter it has been explainded that under Swedish law the basis for legal maternity is childbirth. ${ }^{104} \S 1: 7$ Föräldrabalk (1949:381) only provides that the birthmother is the legal mother of the child if the child is created with the ovum of another woman. Here the question is whether the legal maternity of the birthmother is established automatically or whether it depends on, for example, the registration of the mother's name on the birth record of the child. The answer can be derived from a decision of the Swedish Högsta Domstol of 17 October 2007.105 In this case the applicant wanted to change the information concerning the child's mother as it appeared in the Swedish population register, the Swedish alternative for the civil status register. The case was about the interpretation of $\S$ 13:2 Rättegångsbalk (1942:740). The article contains the following provision:

$2 \S$ An action for a declaration of whether or not a certain legal relationship exists may entertained on the merits if an uncertainty exists as to the legal relationship, and the uncertainty exposes the plaintiff to a detriment.

\footnotetext{
100 Handbook for Registration Officers, p. B23-d-31, par. 28 (last update unknown). 101 See also Lasok 1961, p. 128, 129.

102 Section 55A Family Law Act 1986 (inserted by the Child Support, Pensions and Social Security Act 2000).

103 Germany: § 1591 BGB. Netherlands: Article 1:198 Burgerlijk Wetboek.

104 See § 2.1. Grounds for legal maternity.

105 Högsta Domstolen, 17 October 2007, case nr. T 4816-05.
} 
If determination of the matter at issue depends upon the existence or non-existence of a certain disputed legal relationship, a request for a declaration thereon may be entertained.

Actions for declaratory judgments may be entertained in other cases where legislation so prescribes. ${ }^{106}$

The Högsta Domstol held that the list of actions on parentage in the Föräldrabalk (1949:381) was not exhaustive. The Föräldrabalk (1949:381) is only exhaustive for the actions it regulates, like judicial establishment and annulment of legal paternity. However, if the Föräldrabalk (1949:381) does not grant an action for a certain issue concerning parentage, an action still exists if the requirements of § 13:2 Rättegångsbalk (1942:740) are fulfilled. The requirements of this provision are that there is uncertainty about the existence of a legal relationship and that the uncertainty exposes the applicant to a detriment. According to the Högsta Domstol both requirements were fulfilled: maternity is a legal relationship and uncertainty about the child's maternal affiliation exposes the child to a detriment. Therefore, the child can apply for a declaration of legal maternity on the basis of $\S 13: 2$ Rättegångsbalk. ${ }^{107}$ If it is possible to apply for a declaration of legal maternity in the event of uncertainty about the maternal affiliation, legal maternity probably exists by dint of birth and its establishment does not depend on, for example, registration. After all, the existence of a legal relationship between the mother and the child is a prerequisite for the possibility to apply for a declaration on the basis of $\S 13: 2$ Rättegångsbalk.

Under French law, legal maternity does not exist ex lege, but it has to be established by the registration of the mother's name on the child's birth certificate or by her acknowledgement of maternity. 108

\subsubsection{Ex lege existence of the legal paternity of the husband under Dutch, French, German and Swedish law}

Another part in the law on legal parentage where ex lege existence of parenthood appears is the rule that the mother's husband is the child's legal father. This rule exists under all legal systems under consideration, except under English law. The reason why the existence of the legal paternity of the mother's husband is ex lege is because his paternity does not arise from any action. It is solely based on the marriage of the man with the legal mother of the child.

The rule that the husband is the legal father of the child is based on the Latin maxim pater vero is est quem nuptiae demonstrant (father however is the person designated by the marriage). The rule used to be the basis for the legitimate status of the child which on its turn was based on the view that the child should be begotten by two persons who were united by the bond of marriage, sexual intercourse outside marriage being rejected. Nowadays the legitimacy as a preferred status for the child has disappeared, but the empirical justification for the rule remains: in the vast majority of cases the husband of the mother is the biological father of the children born during the marriage. Likewise, a man who marries a pregnant woman is often the father and, the other way around, the legal systems under consideration recognised that it is not very likely that the ex-husband is the father of the child born after the dissolution of the marriage. ${ }^{109}$ Even French law, that still

\footnotetext{
106 Translation from http:// www.sweden.gov.se/content/1/c6/02/77/78/30607300.pdf. 107 See also already Socialstyrelsen 2005, p. 108; Kongstad 2003.

108 Article 311-25, 316 Code civil.

${ }^{109}$ France: Malaurie \& Fulchiron 2006, nr. 1129. Germany: BR Drucks. 180/96, p. 62 and 93; BT Drucks. 13/4899, p. 52 and p. 83; Gernhuber \& Coester-Waltjen 2006, § 52:27; Netherlands: Kamerstukken II, 1995-1996, 24 649, nr. 3, p. 8; Asser/De Boer 2006, nr. 698. Sweden: Prop. 1975/76:170, p. 132, Singer 2000, p. 129.
} 
connects legal fatherhood in part to the moment of conception, mitigates the effects of the rule in case the child is born during a divorce procedure.

Next to the empirical justification for the rule, French literature also emphasises a moral argument: the legal paternity of the husband is an essential effect of marriage. Legal parentage as an automatic effect of marriage gives weight and contents to the matrimonial bond. 110

The technical justification for the automatic legal paternity of the husband is that marriage is a certain connecting factor for the establishment of legal parentage. ${ }^{111}$ It is more certain than for example cohabitation, because marriage is easier to prove than cohabitation. For the same reason marriage instead of genetic paternity is used to establish legal paternity under Dutch, French, German and Swedish law. It is at this point that an important difference with English law becomes apparent. It has been argued above that under English law legal paternity is based on biological paternity instead of marriage. Marriage to the mother at the moment of birth only establishes a (weak) presumption of paternity; it merely determines the onus of proof. Apparently, legal certainty in legal parentage is valued differently under English law on the one hand and Dutch, French, German and Swedish law on the other.

Although Dutch, French, German and Swedish law each provide that the husband of the mother is the legal father of the child ex lege, they differ as to the precise formulation of the rule. The main issue is whether it is the husband at the moment of conception or at the moment of birth who is the legal father of the child.

Under Dutch law, the husband of the mother at the moment of birth of the child is the legal father of the child.112 The moment of conception is only taken into account in case of the death of the husband. If the marriage of the child's mother is dissolved by the death of her husband, the deceased husband is the legal father of the child who is born within 306 days after the dissolution of the marriage. After all, in such a case the child can be begotten by the deceased husband.113

A conflict arises when the mother remarries shortly after the death of her husband. If she remarries within 306 days after the death of her husband, the child can be conceived during the marriage with the deceased husband, while the child is born during the mother's marriage with the second husband. In such a case, Dutch law provides that the deceased husband is the legal father and not the second husband.114

Under German law $\S 5192$ (1) BGB provides that the husband of the mother at the moment of birth is the legal father of the child. Just like under Dutch law, this rule is extended to the husband of the mother at the moment of conception, if the marriage is dissolved by the death of the husband. $\S 5193$ BGB provides that the husband is also the legal father of the child if the marriage is dissolved by his death and if the child is born within 300 days after his death. After all, in such a case the child can be begotten by the deceased husband.

Under German law, the same conflict can arise as under Dutch law if the mother remarries shortly after the death of her first husband. Unlike Dutch law German law solves

\footnotetext{
110 Malaurie \& Fulchiron 2006, nr. 1133; Dekeuwer-Defossez 1999, p. 31.

111 Gernhuber \& Coester-Waltjen 2006, § 52:27.

112 Article 1:199 under a Burgerlijk Wetboek. The Dutch legislator intends to extent the rule to the female spouse of the mother. See consultation documents of the Ministry of Justice on lesbian parenthood of 14 December 2009 (consultation documents are available at http://www.justitie.nl/actueel/persberichten/archief2009/91215ouderschap-duomoeder-kan-straks-eenvoudig-en-snel.aspx). See also Forder 2009; Commissie lesbisch ouderschap en interlandelijke adoptie, Report 2007.

113 Article 1:199 under b Burgerlijk Wetboek.

114 Article 1:199 under b Burgerlijk Wetboek.
} 
this conflict in favour of the second husband. § 1593 BGB provides that the deceased husband shall not be the legal father of the child if the mother remarried after the death of the husband and before the birth of the child. In that case the second husband shall be the legal father of the child. If the paternity of the second husband has been annulled, the deceased husband will retroactively and ex lege be the legal father of the child.115

Swedish law provides for more or less the same regulation as Dutch and German law. § 1:1 Föräldrabalk (1949:381) states that the husband of the mother at the moment of birth is the legal father of the child. The article adds that the husband is also the legal father if the child is born 'within such a time after the husband's death that he could have begotten the child'. The law does not provide for a legal conception period. It was expected that disputes on the moment of conception of the child would be a rarity and therefore no legal provisions were enacted. If legal disputes arise on this point, the case should be referred to court.116

The conflict that arises if the mother remarries after the death of her husband 'at such moment that the deceased could still have begotten the child' and before the birth of the child is not regulated in the Föräldrabalk (1949:381). Only in the explanatory report to the Föräldrabalk (1949:381) the legislator stated that if the mother remarried after the death of her first husband and before the birth of the child the second husband shall be the legal father of the child, like under German law. ${ }^{117}$

Under French law, the regulation of the legal paternity of the husband is much more complicated than under Dutch, German and Swedish law. Per article 312 Code civil the husband is the legal father of the child if the child is begotten or born during the marriage.118 In order to determine whether or not the child is begotten during the mother's marriage one has to know the duration of a pregnancy: if one knows how long a pregnancy takes, one can determine the moment of conception. In order to determine the moment of conception, French law provides that the child is presumed to be conceived in the period between the 300th and the 184th day before his birth. The exact moment is determined in the interest of the child and it is allowed to rebut the presumption that the child is conceived between the 300th and the 184th day before his birth. ${ }^{119}$ Thus the starting point is that the man who is married to the mother in the period between the 300th and the 184th day before his birth is the legal father of the child.

However, article 312 Code civil also provides that the husband at the moment of birth is the legal father of the child. Of course it is possible that at the moment of conception the mother is married to another man than at the moment of birth. This conflict is solved by article 313 Code civil.

Article 313, second sentence Code civil provides that article 312 Code civil does not apply if the child is born during a divorce procedure because it was deemed unlikely that in such a case the husband would be the father of a child. ${ }^{120}$ In detail, article 313 Code civil provides that if the child is born more than 300 days after the judicial approval of the agreement settling the consequences of the divorce or the order for provisional measures on the basis of article 250-2 Code civil or the judicial decision establishing the nonreconciliation of the spouses, the presumption of paternity shall not apply.

\footnotetext{
115 Staudinger/Rauscher 2004, nr. 39; MünchKomm/Wellenhofer 2008, § 1593, nr. 22.

116 Prop. 1975/76:170, p. 133, 164. For the purpose of the investigation of the socialnämnd, socialstyrelsen published "conception tables" which indicate the conception period of the child (SOSFS 2004:16). The tables are also published in Socialstyrelsen 2005 .

117 Prop. 1975/76:170, p. 164.

118 Article 312 Code civil.

119 Article 311 Code civil.

${ }^{120}$ Leveneur 1995, nr. 875-5, p. 278 ; Hauser \& Huet-Weiler 1993, nr. 567, p. 328.
} 
The three moments which are mentioned as a starting point for the calculation of the 300-day period correspond with the different procedures for divorce under French law. In France, the judicial procedure for divorce matters depends on the ground for divorce: mutual consent, breakdown of community life or fault (article 229 Code civil).

If the spouses apply for divorce on the ground of mutual consent, they have to conclude an agreement, settling the consequences of the divorce (article 230 Code civil). The court has to approve of the agreement. Pursuant to article 313 Code civil, the husband is not the legal father of children who are born more than 300 days after the judicial approval. If the court, for what ever reason, refuses to approve the agreement it can order to execute the agreement or parts of it provisionally on the basis of article 250-2 Code civil. Also in this case, the husband is not the legal father of children who are born more than 300 days after these provisional measures have been ordered.

The procedure for divorce on other grounds than mutual consent starts with an attempt to reconcile the spouses (article 252 Code civil). If the spouses cannot be reconciled, the court will establish the non-reconciliation of the spouses (article 257-1 Code civil). According to article 313 Code civil, the husband is not the legal father of children who are born more than 300 days after this order.

If the court rejects the application for divorce or if the spouses nonetheless become reconciled with each other, the husband is only the legal father of the children who are born after the 180th day following the rejection or the reconciliation.

Effectively, the second sentence of article 313 Code civil reduces the conflicts of paternity to the cases where the divorce, the second marriage of the mother and the birth of the child (in this order) take place within 300 days after the homologation or the provisional measures or the non-reconciliation. If the child is born after the 300th day, he might be conceived during the mother's marriage with the first husband, but that is irrelevant. In such a case, article 313, second sentence Code civil simply provides that the first husband is not the legal father of the child and on the basis of article 312, the legal paternity of the second husband shall be established.

Another way of solving the conflict is by means of the first sentence of article 313 Code civil. The first sentence provides that the husband of the mother is not the legal father of the child when he is not mentioned on the birth certificate as father and when the child does not have apparent status with regard to him. One realises that under French law, there is no obligation to record the (legal) parents of the child at the registration of the birth. ${ }^{121}$ Thus, if the mother finds herself in the situation where her child has been conceived during her first marriage, but where she gave birth during her second marriage, the legal paternity shall be established of the husband who is recorded as the father. As a consequence, the husband who is not recorded as the father is not the legal father of the child provided that the child does not develop the apparent status of a child of the first husband.

If the child is born during a divorce procedure (art. 313, second sentence) or if his name is not mentioned on the birth record of the child (art. 313, first sentence) the husband shall be the legal father of the child nonetheless if the child develops apparent status with regard to him and if the legal paternity of no other man has been established.122

If the husband is not the legal father on the basis of article 313 Code civil, not only the child but also the mother and her (ex) husband are allowed to apply for judicial establishment of the legal paternity the husband, provided that the legal paternity of no other man has yet been established. ${ }^{123}$

\footnotetext{
${ }_{121}$ Article 57. Instruction générale relative à l'état civil du 11 mai 1999, par. 275, Journal Officiel nº 172 du 28 juillet 1999. 122 See article 314 Code civil. See also Massip 2006, nr. 50.

${ }^{123}$ Article 315 in conjunction with 329 Code civil.
} 
The French regulation of the legal paternity of the husband is much more complicated than under Dutch, German and Swedish law. But is it also different? French law on the one hand and Dutch, German and Swedish law on the other certainly differ when one considers the starting point of the regulation. After all, Dutch, German and Swedish law take as a starting point that the mother's husband at the moment of birth is the legal father of the child, while the French rule also involves the husband of the mother at the moment of conception in its starting point to determine legal paternity. An important consequence of this difference is that children who are born after the divorce of the mother are legally fatherless under Dutch, German and Swedish law. Under French law the ex-husband is the legal father as long as the child is born within 300 days after the dissolution of the marriage.

However rules from both French law and Dutch, German and Swedish law mitigate this difference. Under French law, the legal paternity of the husband of a divorcing couple can easily be avoided by article 313 Code civil. The effect of article 313 Code civil on the legal paternity of the husband comes close to the rules under Dutch, German and Swedish law.

On the other hand, Dutch, German and Swedish law still use the moment of conception to determine legal paternity in case the marriage of the mother is dissolved by death. If the child is conceived during the marriage, but born after the death of the husband the deceased husband is the legal father of the child under Dutch, German and Swedish law and also under French law.

It appears that French law on the one hand and Dutch, German and Swedish law on the other take a fundamentally different starting point to determine the legal paternity of the husband, but that these legal systems are brought closely together by the way in which the exceptions to the respective starting points are worked out.

Also there exists an interesting similarity between French and English law. Under French law the husband shall not be the legal father if he is not mentioned as such on the birth certificate and if the child does not develop apparent status with regard to him. The disapplication of the legal paternity of the husband by the informants of the birth under French law resembles the possibility under English law for the informants to rebut the presumption of legitimacy on registration.

\subsection{Establishment of parenthood by means of administrative action}

Every time the national legal system does not assign a legal parent to a child automatically, legal parenthood has to be established. Within the legal systems under consideration two kinds of administrative action to establish legal parenthood are distinguished. The first is the establishment of legal maternity under French law by the registration of her name on the child's birth record. The second is the acknowledgment of legal parenthood under Dutch, French, German and Swedish law.

Before turning to a comparative analysis of the different rules concerning the establishment of legal parenthood the question has to be asked why a legal system would require an administrative procedure to create a legal relationship between the child and his parents. The question is even more interesting, because it has been argued in the previous chapter that under English law legal parenthood exists automatically. Thus, apparently it is not selfevident to use the complex system of parentage law that exists in the legal systems on the European continent.

It has been shown that under English law the law on parentage is limited to the question how the terms father and mother are defined. It has been explained that father means biological father unless the Human Fertilisation and Embryology Act 2008 applies. The term mother means both at common law as well as under the Human Fertilisation and 
Embryology Act 2008 the woman who gave birth to the child. Under English law, the rest is evidence.

Under continental legal systems this is different. In the previous chapter it has been shown that if legal paternity exists ex lege, it is the legal paternity of the husband of the mother and not the legal paternity of the child's biological father. In cases of legal maternity the Dutch, German and Swedish legal systems connect legal maternity directly to giving birth. If the child is born out of wedlock legal paternity does not exist automatically, but it has to be established.

At least two reasons explain why continental legal systems do not define the terms mother and father substantively, as under English law, but use a system of establishment of legal parenthood. The first reason is the wish to create certainty concerning the legal parentage of the child. The second reason is that under certain legal systems the terms mother and father are legal concepts more than biological facts; under certain legal systems the concept of legal parent also reflects social parentage or the intention to take responsibility for the child in question.

\section{Legal certainty}

All legal systems under consideration have some kind of system to record the personal status of individuals and under all legal systems it is considered important that these registers are correct. The problem with parentage and registration is that the conception and the birth of the child are not witnessed by the person who has to record the information. The registration of information concerning a birth is by definition uncertain, because the information depends on hearsay.

There are different ways to deal with this problem of uncertainty. The first way seems to be the English approach. The registrar simply asks the relevant information concerning the birth of the child, including the parentage of the child. In order to pursue the informant to tell the truth, the law penalises lying. If later it is argued that the register contains incorrect information the system refers the parties to court to resolve the dispute and to establish the true facts. An important consequence of this system is that the trustworthiness of the register depends on the honesty of the informant.

Another way to deal with the problem of uncertainty is to derive the truth not primarily from the declaration of the persons involved but from public registers. The system replaces the uncertain information, like biological paternity, by more certain information, like the existence of a marriage or an acknowledgment of paternity. In this case, the registrar can easily check whether the statement that $X$ is the father of the child is correct. He simply checks whether $X$ is married to the mother of the child or whether the register contains an instrument of acknowledgement from $X$. The effect of this system is that the register is, at least in theory, always correct. It creates certainty for the individuals involved, third parties and the state. Another (adverse) effect is that the system has created another kind of truth. In this system of registration of births it is not the real truth that counts, but the legal truth that is constructed by the system.

Moreover, the Dutch, German and Swedish legal systems that base legal maternity directly on childbirth still depend on hearsay to record information concerning the mother of the child. As soon as the mother has been determined, the legal paternity can be derived from the public register. In the third chapter on evidence the different means that have been developed to strengthen this weak link in the chain to determine the legal parentage will be discussed.

Another point is that the certainty that is created with this second system is still relative. If the informant states that $X$ is the father of the child because the mother is married to $X$, the informant has to prove the marriage between the mother and $X$. In a well organised system 
this should not be a problem. The informant simply submits an excerpt from the national marriage register. However, if the marriage took place in a less well organised country evidence of the marriage still depends on the declaration of the individuals involved. For these kinds of cases, the second registration system is not more certain than the first.

An even bigger problem exists in the opposite situation where the informant states that the mother is not married. There is no register that guarentees that the mother is indeed not married anywhere in the world. In a system that does not want to use the statement of the informant as a primary source for registration this is a problem. This problem will be addressed in more detail in the third part. Here the point is to show that the certainty that continental legal systems try to create is still a relative certainty.

\section{Social parentage}

We have already seen in the first chapter that for the French and to a lesser extent the Dutch and the German legal system the concept of legal parent is more than a legal translation of a biological fact, even in case of natural reproduction. Legal parenthood represents biological parenthood as well as social parenthood.

French and Dutch law in various instances express the idea that the establishment of legal parenthood is based on the will of the persons involved to accept legal parenthood. Marriage to the mother is considered a tacit acceptance of the children born to her. ${ }^{124}$ The acknowledgment of paternity is an expression of the freely formed will of the acknowledger to establish his legal paternity concerning the child involved. ${ }^{125}$ It is only relatively recently that French and Dutch law allows judicial establishment of legal paternity, which forces legal paternity on the biological father or the consenting partner. ${ }^{126}$

Under Dutch, German and Swedish law, the will of the mother is also relevant in the establishment of legal paternity out of wedlock. It will be explained below that under both legal systems the mother has to consent to the acknowledgement of paternity. Under certain circumstances the consent of the mother can be bypassed by a judicial decision, but the establishment of legal paternity out of court without her consent is not possible.

Under French law the mother can even give birth anonymously, thereby avoiding the establishment of her legal maternity (below, under A). The establishment of legal maternity therefore depends on the will of the mother to accept the child as her own.

Once legal parentage has been established, the rules to contest legal parentage make sure that established social familial ties cannot be severed easily. ${ }^{127}$ Thus, by disconnecting legal parenthood from biological affiliation, it is possible to insert these kinds of considerations in the concept of legal parent.

\subsubsection{Establishment of legal maternity under French law}

Under French law legal maternity does not exist by dint of birth. Article 311-25 Code civil provides that legal maternity is established with regard to the mother by recording her name on the child's birth record. Thus, the administrative action that is required for the establishment of legal maternity is registration.

Contrary to the wording of article 311-25 Code civil, every woman, and not only the birthmother, who is mentioned on the birth record as the mother of the child shall be

\footnotetext{
124 France: Malaurie \& Fulchiron 2006, nr. 919, 1133. Netherlands: article 1:200 (2) Burgerlijk Wetboek.

125 See below § 3.2.2. Acknowledgment of parenthood.

126 France: Under French law judicial establishment is possible since 1912, but only under strict conditions (Malaurie \& Fulchiron 2006, nr. 917). It was only in 2006 that ordonnance 2005/759 was deleted from the civil code the requirement that judicial establishment of paternity was only possible if the applicant could establish a ground for serious suspicion (présomptions ou indices graves) (former article 340 Code civil). Netherlands: under Dutch law, the judicial establishment of legal paternity was officially introduced in the Burgerlijk Wetboek in 1998.

127 See § 3.5. Annulment of legal parenthood.
} 
considered the legal mother of the child. This follows inter alia from article 332 Code civil which provides that legal maternity can be contested by proving that the mother did not give birth to the child: if the recording of the name of another woman than the birthmother would not lead to legal maternity, there would be no need for article 332 Code civil. Unlike under Dutch and German law, the rules on parentage under French law are sometimes still formulated as rules of evidence instead of substantive rules. ${ }^{128}$ From a Dutch and German perspective this can be confusing.

The current version of article 311-25 Code civil has been inserted by ordonnance 2005/759 which entered into force the first of July 2006.129 Before the entry into force of the ordonnance the establishment of legal maternity was dependent upon on the marital status of the mother. If the mother was married, legal maternity was established by the recording of the mother's name on the birth record. Article 319 Code civil used to provide in this respect that the parentage of legitimate children was proven by their birth record. For illegitimate children, the birth record was not enough evidence for the establishment of legal maternity. Article 334-8 Code civil required an express acknowledgment of maternity.

Ordonnance 2005/759 heavily draws upon the advice of the Dekeuwer committee. The Dekeuwer committee advised the legislator in 1999 to cancel the difference in establishment of legal maternity for children born in and out of wedlock. ${ }^{130}$ The rationale used to be that the acceptance of motherhood by the birthmother in case of legitimate children was presumed on the basis of her marriage. In case of an unmarried mother the acceptance of legal motherhood could not be derived from her status. Therefore, the law required an explicit statement by the mother accepting her legal maternity. According to the committee this rationale for the differential treatment of the establishment of legal maternity no longer existed. Moreover, the recording of the birth as the connecting factor for the establishment of legal maternity is practical and it provides legal certainty because women cannot forget to acknowledge their legal maternity anymore.

The Dekeuwer committee considered but rejected the possibility to establish legal maternity by dint of birth. Such a rule would make it mandatory to record the name of the mother on the child's birth record. This was not considered desirable. It was feared that a woman in distress of her pregnancy would resort to illegal activities, if she could not be able to give up her child for adoption without indicating her name on the birth record. Moreover, in the view of the Dekeuwer committee the voluntary nature of the recording of particulars concerning the mother would avoid errors in the records of civil status. ${ }^{131}$

Under French law, the mother can avoid the establishment of her legal maternity by not entering her particulars on the birth record. Article 326 Code civil allows the mother to go one step further by requesting the protection of her anonymity. Despite the fierce disapproval of this possibility by the Dekeuwer committee - cette fiction rayonne de manière embarrassante dans le Code civil jusque sur la paternité qui, de fait, ne peut être établie ${ }^{132}$ - the legislator decided to maintain the mother's right to anonymity.

\subsubsection{Acknowledgment of parenthood}

The second administrative action to establish legal parenthood that exists in Dutch, French, German and Swedish law is acknowledgment of parenthood. Since under Dutch, German

\footnotetext{
${ }^{128}$ See also article 312 Code civil which is entitled 'the presumption of paternity' (la presumption de paternité). On the other hand, article 312 Code civil is formulated more as a rule than as a presumption: the child begotten or born during marriage has the husband as father (l'enfant conçu ou né pendant le mariage a pour père le mari).

129 Journal officiel, 6 July 2005.

${ }^{130}$ Dekeuwer-Defossez 1999, p. 55. The argumentation is taken over by the legislator, see Rapport nr. 1635 (Assemblée nationale), 12 ième législature by Etienne Blanc, p. 81, Rapport nr. 145 (Sénat), 2007-2008 by Henri de Richemont, p. 10-11. 131 Dekeuwer-Defossez 1999, p. 57-58. See also Rapport nr. 1635 (12ième législature) by Etienne Blanc, p. 81.

132 Dekeuwer-Defossez 1999, p. 42.
} 
and Swedish law the legal maternity of birthmother exists automatically, an acknowledgment of maternity is not possible under these legal systems. The mother of a child can only acknowledge her maternity under these legal systems if by virtue of the rules of private international law applicable foreign law requires an acknowledgment for the establishment of her legal maternity. ${ }^{133}$

Under Swedish law, the second parent of the child can also be a woman. This is not possible under Dutch, French and German law. ${ }^{134}$ Under Swedish law, the rules for acknowledgment by the male or the female partner of the mother of the child are the same.

French law is the only legal system under consideration which allows the mother of the child to establish her legal maternity by acknowledgment of maternity. The possibility is a left-over from the period before ordonnance 2005/759 when the legal maternity of the unmarried mother had to be established by her acknowledgment of maternity. Under the current legal system the function of acknowledgment of maternity under French law has become obsolete since the recording of the mother's name on the child's birth record is enough to establish her legal maternity (see previous paragraph). The rules for acknowledgement of maternity and paternity under French law are the same.

In this paragraph the acknowledgment of parenthood in the four legal systems under consideration will be compared with regard to the legal nature of the acknowledgment, the formal requirements for a valid acknowledgment, the required consents for a valid acknowledgment and the acknowledgment of adulterous and incestuous children. The possibility to contest legal paternity on the basis of acknowledgment is examined in $\S 3.5$. Annulment of legal parenthood.

\subsubsection{The legal nature of the acknowledgment of parenthood}

The common ground in the institutions of erkenning, reconnaissance, Anerkennung and bekräftelse is that they are considered juridical acts (rechtshandeling, acte juridique, Rechtsgeschäft, rättshandling) within their legal systems. ${ }^{135}$ Since the acknowledgement is a juridical act the starting point is that the acknowledgment only validly establishes legal parenthood if the acknowledgement is an expression of the intention to establish legal parenthood.

The fact that the validity of the acknowledgment depends on the acknowledger's will does not mean that intention is the ground for legal parenthood that follows from the acknowledgment. The effect of the acknowledgment is based on the presumption that the acknowledger is the biological father or - depending on the legal system involved - the consenting partner. This is shown inter alia by the fact that acknowledgment can be annulled if the acknowledger is not the biological father or the consenting partner.

A juridical act is only valid if it is an expression of the intention to establish a certain legal relationship. In case of acknowledgment of parenthood the acknowledger's intention must be to establish his or her legal parenthood vis-à-vis the child. The will of the acknowledger must have been formed freely. If the will is defective for example because of threat, mistake or deceit the juridical act is either null and void (i.e. non-existent) or can be annulled in the way prescribed by law. This basic rule of the concept of juridical acts is not accepted for acknowledgement under all legal systems involved. Under French law it is

\footnotetext{
133 See for example Germany: § 44 Personenstandsgesetz.

${ }_{134}$ However, the Dutch legislator is also considering the possibility for the female partner of the mother to acknowledge her parenthood. See Forder 2009; Commissie lesbisch ouderschap en interlandelijke adoptie, Report 2007 and the consultation documents of the Ministry of Justice on lesbian parenthood of 14 December 2009 (consultation documents are available at http://www.justitie.nl/actueel/persberichten/archief-2009/91215ouderschapduomoeder-kan-straks-eenvoudig-en-snel.aspx).

135 France: Malaurie \& Fulchiron 2006, nr. 1179. Germany: Gernhuber \& Coester-Waltjen 2006, § 52:42. Netherlands: Asser/De Boer 2006, nr. 715. Sweden: Saldeen 2005, p. 54.
} 
accepted that legal paternity based on acknowledgment can be annulled either by showing that the acknowledger is not the biological father of the child or by proving that the acknowledger's will was defective because of threat, mistake or deceit.136

Also in Swedish legal doctrine it is accepted that the acknowledgment of paternity can be annulled on the basis of a defective will. ${ }^{137}$ However, as will be shown below the establishment of legal parenthood out of wedlock under Swedish law is not at all voluntary. If the father of the child does not voluntarily establish his legal paternity by acknowledgment, the socialnämnd (a government authority) will see to it that his paternity shall be established by a judicial decision.

Under Dutch and German law it is not possible to annul an acknowledgment of paternity solely on the basis of the defective will of the acknowledger at the moment of the acknowledgment. Under German law, an acknowledgment of paternity is only ineffective if the requirements of $\S \S 1594-1597$ BGB are not fulfilled, i.e. if the child already has a legal father, if the required consents to the acknowledgment have not been given or if the acknowledgement is not drawn up in the prescribed form. 138

Under Dutch law article 1:205 (1) BW provides that the annulment of legal paternity on the basis of acknowledgment requires evidence of both a defective will and the absence of a genetic tie between the child and the acknowledger. The acknowledger and those who consented to the acknowledgment cannot apply for annulment of the acknowledgment, even if the acknowledger is the biological father of the child. ${ }^{139}$ Under Dutch law, the main grounds for nullity of an acknowledgment are described in article 1:204 BW. This article provides that an acknowledgment of paternity is null and void if the child already has two parents, if the required consents by the mother and/or the child have not been given, if the acknowledger is under the age of sixteen or if the acknowledger is married to another woman than the mother and did not obtain the consent of the court for his acknowledgment. An acknowledgment which is not drawn up in the prescribed form is also null and void. 140

An important consequence of the characterisation of acknowledgment of parenthood as a juridical act is that the truth of the statement of the acknowledger is irrelevant. The validity of the juridical act is in the first place determined by the freely formed will of the performer to establish the legal relationship in question. In the second place, the requirements for validity which are laid down in the law must be fulfilled. In none of the legal systems under consideration the truth of the statement, i.e. that the acknowledger is in fact the biological parent of the child, is a criterion for the validity of the acknowledgment.

The irrelevance of the truth of the acknowledgment for the establishment of legal parentage is an important difference with the acknowledgement of paternity under English law. Under English law the declaration of the man that he is the father of the child can, under certain circumstances, have as an effect that the man is mentioned on the birth record of the child as the child's father. ${ }^{141}$ However, the declaration of the man does not establish his legal paternity; it only raises a rebuttable presumption that he is the father. ${ }^{142}$ Moreover, if the man intentionally gives a false declaration, i.e. he declares to be the father while he knows he is not, the man commits a criminal offence. ${ }^{143}$ This is not the case under the continental legal systems.

\footnotetext{
${ }^{136}$ Malaurie \& Fulchiron 2006, nr. 1207-1210.

137 Walin \& Vängby vol. I, p. 1:15.

138 Gernhuber \& Coester-Waltjen 2006, § 52:64; MünchKomm/Wellenhofer 2008, § 1598, nr. 18; Staudinger/Rauscher $2004, \S 1598$, nr. 3,7 .

139 Kamerstukken II, 1995-1996, 24 649, nr. 3, p. 10, 20.

${ }^{140}$ Article 3:59 in conjunction with 39 Burgerlijk Wetboek.

141 Section 10 and 10A Births and Deaths Registration Act 1953.

142 See note 481 .

143 See note 100 .
} 


\subsubsection{The formal requirements for acknowledgment of parenthood}

All legal systems have formal requirements for a valid acknowledgment of parenthood. The formal requirements for the validity of an acknowledgment of paternity serve the same objectives in each of the four legal systems under consideration. The formal requirements have to guarantee the existence of evidence of the acknowledgment of paternity, they underline the seriousness of the acknowledgment and they must avoid overhasty actions. ${ }^{144}$

Dutch and French law require the acknowledgment to be drawn up in an authentic instrument (authentieke akte or acte authentique). ${ }^{145}$ An authentic instrument is a document drawn up by a public official with special evidential value. Under Dutch law, the authentic instrument has to be drawn up either by a civil status registrar or a civil law notary. The acknowledgment cannot be included in a testament, because otherwise the establishment of legal paternity remains concealed until the death of the acknowledger. ${ }^{146}$

Under French law, the instrument of acknowledgement can be drawn up by every public official who is empowered to draw up authentic instruments. The most obvious officials to draw up the instrument of acknowledgment are the civil status registrar and the civil law notary. Under French law, the inclusion of the acknowledgment of paternity or maternity in the testament of the acknowledger is permitted. ${ }^{147}$

For the administration of civil status there is another difference between the instrument of acknowledgment under French and Dutch law. Under French law there is a register of acknowledgments of paternity or maternity. In the 19th century the French system of registration of personal status was introduced in the Netherlands, but the register of acknowledgments has been abolished. Nowadays, the Dutch civil status registrar handles the acknowledgment of paternity in the same way as the German register (in more detail in chapter 4. Evidence of legal parentage).

Under German law § 1597 (1) BGB requires the öffentliche Beurkundung of the acknowledgment of paternity. The öffentliche Beurkundung of the declaration of acknowledgment of paternity means that a declaration is laid down in a public instrument. The effect of the offentliche Beurkundung is that the document obtains special evidential value. ${ }^{148}$ The most obvious public official to draw up an instrument of acknowledgment in German is the civil status registrar. ${ }^{149}$ The instrument can, however, also be drawn up by a civil law notary (Notar), the Amtsgericht, the Urkundsperson beim Jugendamt or the court which decides on a paternity dispute. ${ }^{150}$

Swedish law does not require a special document for the validity of the acknowledgment of paternity. It requires that the acknowledgment is in writing and witnessed by two persons. ${ }^{151}$

\subsubsection{The consent to acknowledgment of parenthood}

Under French law the declaration of acknowledgment of parenthood in the prescribed form is sufficient to establish legal parentage. Neither the father nor the mother needs the consent of the other legal parent for a valid acknowledgment.

\footnotetext{
144 France: Carbonnier 2004, p. 1041; Bénabent 2003, nr. 671; Leveneur 1995, nr. 934, p. 349. Germany: Gernhuber \& Coester-Waltjen 2006, § 52:62. Sweden: Singer 2000, p. 180.

${ }^{145}$ France: article 316 (3) Code civil. Netherlands: article 1:203 (1) Burgerlijk Wetboek.

146 Article 20a Wet of het Notarisambt. The article provides that notarial instruments containing a last will, shall not contain other juridical acts.

147 Hauser \& Huet-Weiler 1993, nr. 739, p. 501.

$148 \S \S 417,418$ Zivilprozessordnung.

$149 \S 44$ Personenstandsgesetz.

$150 \S 20$ Bundesnotarordnung; § 62 (1), under 1 Beurkundungsgesetz; § 59 (1) Achtes Buch Sozialgesetzbuch; § 180 Familienverfahrensgesetz.

151 § 1:4 Föräldrabalk (1949:381).
} 
However, under Dutch, German and Swedish law the acknowledger has to obtain consents in order for the acknowledgment to establish legal parentage. Under Dutch law article 204 (1) under c Burgerlijk Wetboek (BW) provides that the mother has to give her written consent prior to the acknowledgement if the child has not yet reached the age of 16 years. If the child has reached the age of 16 , the consent of the mother is no longer required. The consent of the mother is meant to protect her private life and that of her child. ${ }^{152}$

Per article 1:204 (1) under d BW, a child who has reached the age of 12 years has to consent to the acknowledgment of paternity. Together with article 1:204 (1) under c BW, it follows that the acknowledgment of paternity concerning a child between the age of 12 and 16 years requires the consent of both the child and the mother. The legislator deemed it selfevident that the child should give his consent to the acknowledgment; no further reasons were put forward. 153 Apparently the requirement of the consent of the child is a means for the child to protect his private life.

Pursuant to article 1:204 (3) BW, the begetter can apply to replace the consent of the mother or the child with the consent of the court if the mother or the child does not consent to the acknowledgment. If the begetter wants to acknowledge the child contrary to the will of the mother, the court has to balance the interests of the man against the interests of the woman and the child. The starting point of the procedure on substitution of consent is that both the child and the begetter have the right that their relationship is recognised in law. ${ }^{154}$ The court has to consent to the acknowledgment if the acknowledgment of paternity does not disturb the relationship of the mother with her child or the interest of the child. The interest of the child will be damaged as soon as the acknowledgment constitutes a threat to a stable, social psychological and emotional development of the child. Such a threat can exist if the acknowledgment shall have such a negative impact on the mother that she will be unable to guarantee a stable, social psychological and emotional development of the child. 155 The threat has been accepted in cases where the acknowledger had been convicted for assault of the mother. ${ }^{156}$

Article 1:204 (3) BW only applies to the begetter of the child. The begetter of the child is the man who fathered the child in a natural way. The sperm donor is not the begetter of the child. ${ }^{157}$ In the case leading to the decision of the Hoge Raad of the 24th of January 2003 a sperm donor applied for judicial consent to his acknowledgment of paternity. ${ }^{158}$ The man's sperm had been used to inseminate a woman from a lesbian couple. The insemination took place at home, without the involvement of medical doctors. Following the birth of the child, the donor demanded to be included in the education of the child and applied for judicial consent to his acknowledgment of paternity. The Court of Appeal rejected his application, because article 1:204 (3) BW only grants the begetter the right to judicial consent. However, the Hoge Raad held that article 8 ECHR grants the biological father with family life protection of that family life, irrespective how the pregnancy has come about. However, the protection of family life can be limited if that is necessary in a democratic society, inter alia to protect the rights of others.

According to the Hoge Raad the starting point for the application of article $8 \mathrm{ECHR}$ to the right of the sperm donor to establish his legal paternity, is that the right of the mother to

\footnotetext{
${ }^{152}$ Asser/De Boer 2006, nr 726.

153 Parlementaire Geschiedenis/Boek 1 Personen- en Familierecht 1962, p. 571. Also Vlaardingerbroek (Personen- en familierecht), Artikel 204, p. 13.

154 Kamerstukken II, 1995-1996, 24 649, nr. 3, p. 10,11. See also Asser/De Boer 2006, nr. 730.

155 Hoge Raad, 16 February 2001, NJ 2001/571; Hoge Raad, 16 February 2001, LJN AB0033.

156 E.g. Hoge Raad, 16 June 2006, LJN AW1860; Hoge Raad, 20 October 2006, LJN AY6202.

157 Kamerstukken II, 1995-1996, 24 649, nr. 3, p. 8.

158 Hoge Raad, 24 January 2003, NJ 2003/386, LJN AF0205.
} 
refuse her consent and to block the establishment of the legal paternity of the biological father is based on the protection of her family life with the child.

But the mother's right is limited. In a situation like the described, where the mother has custody of the child and lives together with him or her, the acknowledgement of paternity affects her family life with the child. Therefore, the refusal of consent by the mother to the acknowledgment of the biological father shall only violate the family life of the acknowledger if the mother has no relevant interest in the refusal of her consent. In such a case the refusal can amount to an abuse of right. Only if it has been established that the mother abused her right not to consent to the acknowledgment of the sperm donor, the biological father can apply for judicial consent. 159

It appears that the sperm donor is in a completely different situation to the begetter. The donor only has a right to judicial consent of his acknowledgment if he has family life with the child and if the mother abused her right not to consent. The begetter does not, however, have to show that he has family life with the child and he has a right to judicial consent unless it is shown that his acknowledgment of paternity seriously damages the mother's relationship with her child. In any event, if the court refuses to consent to the acknowledgement of paternity, neither the begetter nor the sperm donor can apply for the judicial establishment of their paternity. 160

The situation where the mother of the child refuses her consent to the acknowledgment of paternity of the begetter has to be distinguished from the situation where the mother consents to the acknowledgment of another man in order to block the acknowledgement by the begetter. In the latter case, the problem is that article 1:205 $\mathrm{BW}$ does not grant the begetter the right to contest the legal paternity of the first acknowledger. In such a case, the only chance for the begetter of the child is to contest the consent of the mother to the first acknowledgement on the basis of abuse of right. If the acknowledgement of the nonbiological father is set aside, the begetter can apply for judicial consent to his acknowledgment. The right of the begetter to contest the legal paternity of the acknowledger will be discussed in more detail in § 3.5.4. Locus stand.

Under German law § 1595 (1) BGB provides that a valid acknowledgment of paternity requires the consent of the mother, even when the child is of age. ${ }^{161}$ The aim is to strengthen the position of the mother with regard to the establishment of legal paternity. ${ }^{162}$ The consent of the mother cannot be replaced by a court order. Therefore, acknowledgment of paternity is not possible when the mother is not able or willing to give her consent. ${ }^{163}$ In that case, the man or the child has to apply for judicial establishment of paternity. Per $§ 1595$ (2) BGB, also the child has to consent to the acknowledgment of paternity if the mother does not have custody (elterliche Sorge) over the child anymore, which is if the child has reached the age of 18 years.

Under Swedish law § 1:4 (1) Föräldrabalk provides that a valid acknowledgment requires the consent of the child's mother, the socialnämnd (social welfare committee) and in certain circumstances of the child himself.

Per $\S 1: 4$ Föräldrabalk, the consent of the mother is only required as long as the child is a minor (omyndig) and as long as someone has custody (vårdnad) over the child. The consent

\footnotetext{
159 Hoge Raad, 18 May 1990, NJ 1991/374.

160 Under Dutch law only the child and the mother are allowed to apply for judicial establishment of paternity, article 1:207 (1) Burgerlijk Wetboek.

161 BR Drucks. 180/96, p. 95; BT Drucks. 13/4899, p. 85.

162 BT Drucks. 13/4899, p. 54.

163 BR Drucks. 180/96, p. 64 and 94; BT Drucks. 13/4899, p. 54 and 84.
} 
of the mother is meant to check on the truth of the acknowledgment; the idea is that the mother knows best who the biological father of the child is. 164

If the mother is not able to give her consent or if she refuses while the social welfare committee is convinced that a certain man is the father of the child, the social welfare committee can bring the case to court for judicial establishment of paternity. ${ }^{165}$ As soon as the child is of age or not under anyone's custody anymore, neither the mother nor the social welfare committee needs to consent to the acknowledgment of paternity. ${ }^{166}$ In such a case, the acknowledgment of paternity establishes legal paternity if the child consents and if the acknowledgment has been made in the prescribed form. The requirement of consent of the child is a means for the child to protect his private life. ${ }^{167}$ If the child refuses to consent, the man cannot establish his legal paternity because he is not allowed to apply for the judicial establishment of his paternity. 168

§ 1:4 (1) Föräldrabalk also requires the consent of the socialnämnd (social welfare committee) for the validity of the acknowledgment. The social welfare committee shall only consent if it is 'sufficiently certain' (tillräcklig säker) that the man is the father of the child.169

According to $\S 2: 1$ Föräldrabalk, the social welfare committee is obliged to investigate the child's parentage, if the child does not have a legal father. The obligation for the social welfare committee exists as long as the child is under the age of $18 .{ }^{170}$ There are various ways for the social welfare committee to be informed of the fact that a certain child does not have a legal father. The most obvious way is through a message from the tax authority (skatteverket), who is responsible for the registration of births. If it appears during the registration of the child's birth that the child does not have a legal father, the tax authority has to inform the competent social welfare committee. ${ }^{171}$ In case of annulment of paternity by a court, that court has to inform the competent social welfare committee.172

According to $\S 2: 4$ Föräldrabalk, the social welfare committee will make inquiries into the mother and other persons who can provide information as to the affiliation of the child. If the mother refuses to co-operate with the investigations of the social welfare committee, the social welfare officer should try to convince her by insisting on the importance of the establishment of legal paternity from a legal, social, psychological and medical point of view. ${ }^{173}$ In particular, the mother should be informed of the fact that the child will not receive child support, if she has no valid reason for not cooperating with the establishment of paternity. ${ }^{174}$ If the mother refuses to co-operate with the investigation because she is scared of the man, the social welfare officer should help her as far as possible, for example by promising her to keep her address information secret. ${ }^{175}$ If it turns out that further investigations will be detrimental to the health of the mother, the social welfare committee can decide to discontinue the investigations. ${ }^{176}$

If it appears from the investigation that the father and the mother of the child live together and if the social welfare officer has no doubts about the paternity of the mother's

\footnotetext{
164 Singer 2000, p. 182.

165 Socialstyrelsen 2005, p. 72; Singer 2000, p. 204.

166 Saldeen 2005, p. 54; Socialstyrelsen 2005, p. 74; Walin \& Vängby vol. I, p. 1:13.

167 Singer 2000, p. 184.

168 Singer 2000, p. 184.

169 § $1: 4$ jo. $2: 5 \mathrm{FB}$.

$170 \S 2: 1$ Föräldrabalk (1949:381). Socialstyrelsen 2005, p. 24, p. 91; Karnov/Saldeen 2007, Föräldrabalk, note 33; Walin \&

Vängby vol. I, p. 2:3.

171 § 7 (1) Förordning (2001:589) om behandling av personuppgifter i Skatteverkets folkbokföringsverksamhet.

172 Socialstyrelsen 2005 , p. 31 et seq.

173 Socialstyrelsen 2005, p. 42.

174 Socialstyrelsen 2005, p. 42 . Article 4 (1) Lag (1996:1030) om underhållsstod.

175 Socialstyrelsen 2005, p. 43.

176 § 2:7 (4) Föräldrabalk (1949:381). Socialstyrelsen 2005, p. 43.
} 
partner, the social welfare committee will consent to the acknowledgment without any blood testing being performed.177 If it appears however, that the mother has had sexual intercourse with more than one man during the conception period or if the social welfare officer for other reasons has doubts about the paternity of the child, the social welfare committee must convince the parties involved to submit to a comparative DNA analysis. ${ }^{178}$ The social welfare committee cannot force the parties to subject to such a test. If the parties refuse to co-operate, the social welfare committee should refuse its consent to the acknowledgment and it can refer the case to court. ${ }^{179}$ Ultimately, the court is empowered to enforce the execution of a paternity test. 180

§ 2:7 Föräldrabalk provides four grounds on which the social welfare committee may decide to discontinue the investigation in a certain case. According to the first indent of $\S 2: 7$ Föräldrabalk, the board may stop its inquiries if it proves impossible to find the necessary information to assess the question of paternity. This can be the case if the mother received fertility treatment abroad or if the mother does not co-operate at all. It should be noted however that the board should not give up too easily and that it is not bound by the information of the mother. 181

The second indent provides that the board may stop its inquiries if there is no prospect to get the paternity established in court. Before the board can decide to stop the inquiries on this ground, it should consult relevant specialists in the field of civil litigation and family law. ${ }^{182}$ Initially, the second indent has been inserted for the case where various men have been identified as the possible father, while paternity tests did not establish the paternity with enough certainty. ${ }^{183}$ However, this ground has become obsolete since nowadays paternity tests include a DNA analysis. 184

According to the third indent, the board may stop the investigation if the mother of the child or a specially appointed custodian has consented to the adoption of the child. Normally, the social welfare committee is also under the duty to investigate the paternity if the child has been placed for adoption. ${ }^{185}$ However, in order to avoid unnecessary delays in the adoption process, the board may discontinue the investigation if the mother refuses to co-operate or if for other reasons the investigation turns out to be too complicated. ${ }^{186}$

The final ground to stop the investigation into the affiliation of the child is when continuation would be detrimental to the mother or the child. If the committee discontinues the investigation, it will not consent to the acknowledgment of paternity. The decision of the social welfare committee to discontinue the investigation is not definitive; the committee can decide to continue its inquiries as soon as new information comes up. ${ }^{187}$ Moreover, the decision to discontinue the investigation as such does not exclude the possibility of judicial establishment of paternity.

For the procedure described above, it does not matter whether the child is born as a result of fertility treatment or as a result of natural procreation. ${ }^{188}$ The parenthood of the consenting partner (who can be either male or female) has to be established either by means of acknowledgment or through a judicial decision. As with naturally conceived children, it

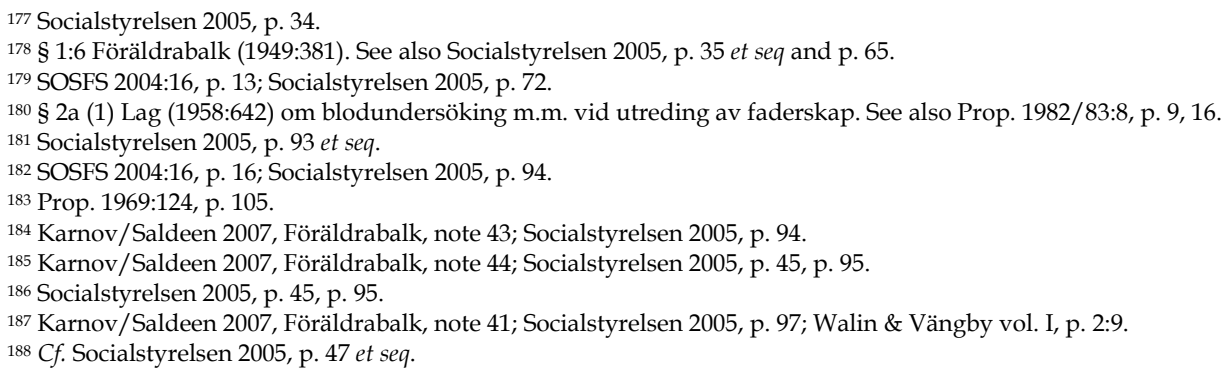


is the responsibility of the social welfare committee that the parenthood of the consenting partner shall be established.

If the child is born after fertility treatment but if the consenting partner and the treatment of the mother do not fulfil the requirements of $\S \S 1: 6,1: 8$ or 1:9 Föräldrabalk, the social welfare committee should endeavour to have the paternity of the biological father of the child established. ${ }^{189} \S \S 1: 6,1: 8$ and 1:9 Föräldrabalk have been explained in $\S 2.2 .5$. Grounds for legal parenthood of the second parent under Swedish law.

The preceding overview of the requirements of consent for a valid acknowledgment of paternity reveals a considerable diversity in policy. French law does not require any consent for a valid acknowledgment. The consents of the mother and the child under Dutch and German law mainly serve to protect their private lives, but a refusal to consent can be overruled. Under Dutch law the acknowledger can apply for judicial consent to his acknowledgment and under German law he can apply for judicial establishment of his legal paternity. Under Swedish law, the right of the mother to consent is meant to give the mother the possibility to make sure that only the real father acknowledges his paternity. This function is de facto taken over by the social welfare committee, which has extensive powers to make sure that the legal paternity of the biological father of the child shall be established. If the child has reached the age of 18 years only the consent of the child is required for a valid acknowledgment of paternity. Unlike for example under Dutch and German law, the refusal of the child to consent cannot be undermined by a legal procedure. If the child refuses to consent, the man cannot establish his legal paternity.

\subsubsection{The acknowledgment of an adulterous child}

An adulterous child is a child that either has been born to a woman who is married to another man than the father (adultery a matre) or who has been begotten by a man who is married to another woman than the mother of the child (adultery a patre).

German and Swedish law have a special regulation for the acknowledgment of adulterous children a matre. If a child is born to a married woman it has been shown that under the legal systems of France, Germany, the Netherlands and Sweden the husband is the legal father of the child, even if the child has been begotten by another man. 190 In such a case German and Swedish law allow for a special procedure for acknowledgment of paternity whereby the acknowledgment of paternity by the biological father sets aside the legal paternity of the husband at the moment of birth.

Under German law $\S 1599$ (2) BGB provides that the legal paternity of the husband shall not be established if the child is born after the spouses have petitioned for divorce and if another man acknowledges his paternity within one year after the divorce has become final. ${ }^{191}$ According to the legislator it is very unlikely that in these circumstances the husband of the mother is the father of the child, which justifies the absence of judicial supervision in the annulment of paternity. ${ }^{192}$ The mother, her husband and, as the case may be, the child have to consent to the acknowledgment of the other man.

Under Swedish law \& 1:2 Föräldrabalk provides for a similar rule. It states that the mother's husband shall not be the legal father of the child if the biological father acknowledges his paternity. The acknowledgment by the father of the child requires the consent of the husband of the mother. If the husband refuses to consent to the

\footnotetext{
189 Socialstyrelsen 2005, p. 51.

190 See § 3.1.3. Ex lege existence of the legal paternity of the husband under Dutch, French, German and Swedish law.

191 In such a case, the husband shall be recorded as the father until the divorce has become final (Hepting \& Gaaz 2006b, nr. V-193).

192 BR Drucks. 180/96, p. 63; BT Drucks. 13/4899, p. 53.
} 
acknowledgement, his legal paternity has to be contested in court before the man can acknowledge the child.

Only Dutch law has special rules for the acknowledgment of an adulterous child a patre. Pursuant to article 1:204 (1) under e BW, a man who is married to another woman at the time of the acknowledgment cannot acknowledge a child, unless the court has established that there is or has been a relationship between the acknowledger and the mother which may be regarded as sufficiently like a marriage or that there is a close personal relationship between the man and the child. The relationship has to exist at the moment of acknowledgment, but it is possible to obtain the judicial consent afterwards. This is especially relevant if a Dutch national acknowledged his paternity abroad, because in such a case the acknowledgment shall only be recognised if it complies with Dutch law. ${ }^{193}$ It is unsettled whether the restriction applies if the man is in a registered partnership or in a marriage with another man. 194

The reason to restrict the acknowledgment of adulterous children a patre was that it was deemed not to be in the interest of the child if the man could not legitimate the child by marrying the child's mother. Moreover, it was assumed that the marriage of the acknowledger would not benefit from an acknowledgment of a child who was born to another woman. ${ }^{195}$ In 1989 the Hoge Raad held that the absolute impossibility of the father to acknowledge a child from another woman than his wife violated article 8 ECHR since it did not allow any balancing of interests in case of the existence of family life between the married man and the child. ${ }^{196}$ In 1998, the initial idea was to abolish the special regulation for the acknowledgment of adulterous children a patre completely. Since the concept of legitimacy was abolished, it was no longer contrary to the interest of the adulterous child to be acknowledged. Moreover, the State Secretary was of the opinion that the prohibition constituted an unjustified discrimination of married and unmarried men. ${ }^{197}$ Parliament however did not agree. The marriage of the acknowledger had to be protected and an exception should be created in case of the existence of family life between the man and the child. ${ }^{198}$

Another justification has been attributed to article 1:204 (1) under e BW with the introduction of the Wet Conflictenrecht Afstamming (Conflict of Laws (Parentage) Act) in 2003. The Act states that article 1:204 (1) under e BW is of international public policy with respect to Dutch nationals: the acknowledgment of paternity by a Dutch national who is married to another woman than the mother of the child violates Dutch public policy unless a court consented to the acknowledgment. In this way the legislator tries to avoid the circumvention of adoption law. ${ }^{199}$ This point will be discussed in more detail in the part on national private international law.

\subsubsection{The acknowledgment of an incestuous child}

An incestuous child is a child that has been conceived as a result of sexual intercourse of two relatives. Under German law the establishment of legal parentage with regard to both

\footnotetext{
193 Hoge Raad, 28 April 2006, LJN AU9237; Rechtbank's-Gravenhage 13 February 2006, LJN AW9815.

194 Gerechtshof Amsterdam 5 August 2008, LJN BG2522, where the court held that article 1:204 (1) under e does not apply to a man who is in a registered partnership with another woman. See however also Rechtbank Arnhem, 26 April 2008, LJN BI3495 where the court held that contrary to the wording of article 1:204 (1) under e BW it also applied if the acknowledger is married to another man.

195 Kamerstukken II, 1995-1996, 24 649, nr. 3, p. 12.

${ }_{196}$ Hoge Raad, 10 November 1989, NJ 1990/450.

197 Kamerstukken II, 1995-1996, 24 649, nr. 3, p. 12. See also Kamerstukken II, 1996-1997, 24 649, nr. 6, p. 22.

198 Kamerstukken II, 1996-1997, 24 649, nr. 6, p. 23

${ }_{199}$ Kamerstukken II, 1998-1999, 26 275, nr. 3, p. 13 and 21.
} 
parents is possible in case of incestuous children.200 In Swedish law there is no provision that prohibits the establishment of legal parentage in an incestuous relationship per se. However, § 2:7 (4) Föräldrabalk provides for the possibility of a case by case approach with regard to the question whether legal parentage should be established between the father and the child, who is the offspring of an incestuous relationship. § 2:7 (4) Föräldrabalk allows the social welfare committee, in exceptional circumstances, to discontinue its investigations if it may be assumed that further inquires or court proceedings would be detrimental to the interest of the child or the mental health of the mother. It has been stated that incest or rape can be a reason to discontinue the investigations of the social welfare committee. ${ }^{201}$ If the social welfare committee decides to stop its inquiries on the basis of § 2:7 (4) Föräldrabalk, it has to justify its decision by means of an opinion of a psychologist or a psychiatrist. ${ }^{202}$

Under French law, it is not possible to establish legal paternity if the child is the offspring of an incestuous relationship and if legal maternity has already been established. ${ }^{203}$ The deletion of this prohibition has been considered, but the prohibition was deemed to be in the interest of the child. ${ }^{204}$ Also Dutch law does not allow the establishment of the legal parentage of both parents if the child is born as a result of incest. Article 1:204 (1) under a BW provides that an acknowledgment of paternity is null and void if it is done by a man who is not allowed to enter into a marriage with the mother pursuant to article 1:41 BW. Article 1:41 BW states that no marriage may be entered into between persons who either by birth or legal parentage are related to each other in the ascending or descending line or as brothers, sisters or as brother or sister. According to the legislator, the establishment of legal parentage in cases of incest would offend public decency and the interest of the child. 205

\subsection{Establishment of parenthood by apparent status}

Next to the automatic establishment of legal parentage and the establishment of legal parentage by an administrative action, legal parentage can be established on the basis of the apparent status of a child. Although the concept of apparent status is also known under Dutch law, it is only used to establish legal parentage under French law.

The apparent status is the factual appearance of a certain personal status. 206 Article 3111 Code civil provides that the apparent status of parentage is established by a sufficient collection of facts that indicates the descent of a person from a family to whom he is said to belong. The article also contains a non-exhaustive list of facts which together constitute an apparent status of parentage. These facts are that the child has been treated by the alleged parent as his or her child, that the alleged parent took care of the education and the

\footnotetext{
200 See in this respect reaction 31/2001 of the German Bar Association on principle 2 (2) together with principle 29 of the White Paper of the Council of Europe on principles concerning the establishment and legal consequences of parentage (2002). The German Bar Association states: “In Anm. 19 wird als Beispiel die Abstammung aus einer inzestuösen Beziehung angeführt. Es ist schon zweifelhaft, ob es überhaupt Fälle geben kann, in denen es dem Wohl des Kindes (unabhängig vom Alter des Kindes!) widerspricht zu erfahren, wer sein Vater ist. Die Abstammung aus Inzest kann aufkeinen Fall als Beispiel herangezogen werden. Die enge Verwandtschaft zwischen Vater und Kind lässt es im Gegenteil gerade geboten erscheinen, die Abstammung offen zu legen. Darüber hinaus ist nicht erkennbar wie das Verfahren gestaltet sein soll. Der Grundsatz soll (Anm. 19) die Möglichkeit des einzelnen Mannes seine Vaterschaft feststellen zu lassen, nicht betreffen. Es soll auch dem Kind unter allen Umständen möglich sein, seine genetischen Auskünfte über den oder die biologischen Elternteil (e) zu erlangen. Es ist nicht verständlich, wie dann die Feststellung der väterlichen Abstammung untersagt werden soll." (www.anwaltverein.de, under Presseservice, Stellungnahmen der Gesetzgebungs- und Fachausschüsse des DAV)

201 Prop. 1969:124, p. 105; Socialstyrelsen 2005, p. 96; Karnov/Saldeen 2007, Föräldrabalk, note 45; Walin \& Vängby vol. I, p. 2:9.

202 SOSFS 2004:16, p. 17; Socialstyrelsen 2005, p. 96.

${ }^{203}$ Article 310-2 Code civil.

204 Dekeuwer-Defossez 1999, p. 45.

205 Kamerstukken II, 1995-1996, 24 649, nr. 3, p. 19.

${ }^{206}$ Malaurie \& Fulchiron 2006, nr. 987 ; Morgand-Cantegrit 1993, p. 1.
} 
maintenance of the child, that the family, the society and the public authorities considered the alleged parent the parent of the child and that the child bears the name of the alleged parent. A harmonious collection of these facts indicates that the child is the child of the person involved. In contemporary case law especially the treatment by the alleged parent of the child as his own is an important factor which indicates the existence of apparent status. ${ }^{207}$ Apparent status is thus a social familial relationship that is proven by certain facts mentioned above. Concerning the quality of the relationship article 311-2 Code civil requires that the apparent status is continuous, peaceful, public and univocal.

Apparent status in French is called possession d'état (possession of status). A child can possess a status by de facto enjoying the rights (and duties) that are attached to the status of being the child of a particular person. The fact that a child possesses a certain status does not automatically mean that he has that status in law. For example, facts that a child bears the surname of Mr Jonathan Smith, that the child considers Mr Smith as his father and that $\mathrm{Mr}$ Smith considers the child as his own in conjunction with each other might lead to the conclusion that the child 'possesses' the status of being a child of Mr Smith. However, that does not necessarily mean that the legal paternity of Mr Smith has been established. If $\mathrm{Mr}$ Smith has never been married to the child's mother and if he did not acknowledge his paternity, Mr Smith is, in principle, not the legal father of the child. Still, the child possesses the status of being the legal child of Mr Smith.

For the sake of clarity it must be pointed out that apparent status or possession d'état only exists if the social familial relation indicates that a person is the father or mother of the child. Of course it is possible that the social reality of the child indicates that the child does not have a father: no man is taking responsibility for the child's education, the child bears the surname of his mother and the child does not consider a particular man to be his father. In this case it is said that the child does not have possession d'état, he does not have an apparent status indicating a person as his legal father.

In this thesis possession d'état will be translated with apparent status. It is the translation that is used in the English translation of the French civil code of Legifrance. The word 'apparent' in 'apparent status' indicates that the status is not based on the law but on a collection of facts mentioned in article 311-1 Code civil that can be observed by observing the day to day life of the child.

Under French law, the existence of apparent status has different functions. It has been shown above that the existence of apparent status with regard to the mother's husband is relevant for the establishment of his paternity. Article 313 Code civil provides inter alia that the husband is not the legal father of the child, if the child is born during the divorce procedure. However, the article adds that the husband shall be the legal father nonetheless if the child develops apparent status with regard to him. Article 313 Code civil also provides that the husband shall not be the legal father of the child, if his name is not mentioned on the birth record of the child as the father of the child and if the child does not have apparent status with regard to him. It will be shown below that the existence of apparent status is also relevant to determine the locus standi and the periods of limitation to contest legal parentage. 208

The function of apparent status that will be discussed in this paragraph is the establishment of legal parentage. In practice it will hardly happen that apparent status establishes legal maternity, because legal maternity under French law is established by the designation of the mother's name on the birth record of the child. ${ }^{209}$ Therefore, the

\footnotetext{
207 Hauser 2008, p. 215.

208 Articles 333 and 334 Code civil.

${ }_{209}$ Article 311-25 Code civil.
} 
paragraph especially refers to legal paternity although in theory it is also possible to establish legal maternity by apparent status.

The apparent status of a child can only establish legal parentage if legal parentage has not been established by a man's marriage to the mother or by a man's acknowledgment of his paternity. This already indicates that the establishment of paternity by apparent status is rare. It is especially meant for those cases where the father of the child died before he was able to acknowledge his paternity. ${ }^{210}$ For example, a child is born when the father is aged 23. He does not acknowledge his paternity. The child is time barred to apply for the judicial establishment of the man's paternity when the child is 28 and when the father is thus 51. ${ }^{211}$ If the father dies at the age of 65 without acknowledging his paternity, the only way for the child to establish his legal parentage vis-à-vis his (deceased) father is by means of apparent status.

The sole existence of the social reality that can be characterised as apparent status is not enough to establish legal parentage. ${ }^{212}$ The existence of apparent status itself has to be established and recorded in order to create legal certainty. There are two ways to create evidence of the existence of apparent status: either by an affidavit (acte de notoriéte) (art. 317 Code civil) or by a judicial decision establishing the existence of apparent status (art. 330 Code civil).

Article 317 Code civil provides that the parents or the child are allowed to apply to a judge of the tribunal $\mathrm{d}^{\prime}$ instance 213 for an affidavit (acte de notoriété) proving the apparent status of the child. The judge shall deliver the affidavit on the basis of the declarations of three witnesses. ${ }^{214}$ Next to their testimonies, the judge is may require additional information in order to determine whether or not the child has apparent status with regard to the parent involved.215

Under article 317 (2) Code civil it is possible to apply for the affidavit if the parent involved died before the birth of the child. Thus it is possible to establish apparent status with regard to an unborn child, for example by being involved in the pregnancy, or assisting the mother to medical consultations. ${ }^{216}$

Article 317 (3) (and 330, see below) provides that one has to apply for the affidavit within five years after the apparent status has ceased or within five years after the death of the parent involved. It is not clear whether the application will be disallowed when the apparent status continues after the five years following the death of the alleged father. Initially, the proposal for 317 (3) only provided that the right to apply for an affidavit ended five years after the apparent status had ended. The idea was that the death of the father would end the apparent status. However, critics pointed out that the death of the father does not end the child's apparent status. ${ }^{217}$ In the same way as it is possible to establish apparent status with regard to an unborn child, it is also possible to continue an apparent

\footnotetext{
${ }^{210}$ Hauser \& Huet-Weiler 1993, nr. 761. Circulaire relative à la présentation de l'ordonnance nr. 759-2005 du 4 juillet 2005 portant réforme de la filiation, Bulletin officiel du Ministère de la Justice, 25 October 2006, nr. 103, p. 109-211 (NOR: JUSC0620513C), at p. 154.

211 Article 321 Code civil provides that the period of limitation for actions on parentage is 10 years. For the child, the period starts running at his $18^{\text {th }}$ birthday.

212 Circulaire relative à la présentation de l'ordonnance nr. 759-2005 du 4 juillet 2005 portant réforme de la filiation, Bulletin officiel du Ministère de la Justice, 25 October 2006, nr. 103, p. 109-211 (NOR: JUSC0620513C), at p. $122,138$.

213 The tribunal $\mathrm{d}^{\prime}$ instance is one of the many courts of first instance in civil matters in the French judicial system.

214 Article 71 Code civil.

${ }^{215}$ Article 1157 Code de procédure civil. Circulaire relative à la présentation de l'ordonnance nr. 759-2005 du 4 juillet 2005 portant réforme de la filiation, Bulletin officiel du Ministère de la Justice, 25 October 2006, nr. 103, p. 109-211 (NOR: JUSC0620513C), at p. 140.

216 Massip 2006, nr. 28.

217 Massip 2006, nr. 28; Murat 2006, p. 19.
} 
status with regard to a deceased person. After all, the surviving child can still consider the deceased as his father, public authorities can still consider the man the child's father and the man can be considered the father of the child by their social environment. Therefore, the legislator added that the right to apply for an affidavit shall also end five years after the death of the father. The aim is to provide legal certainty which is important for the distribution of the deceased's estate. This suggests that it is the legislator's intent that the right to apply for an affidavit ends at least after five years after the father's death and possibly earlier if the apparent status ended before. However, this solution also raises questions. For example, how is it possible that apparent status which has ended establishes legal paternity, if article 311-2 Code civil demands that apparent status is continuous?

In addition to the possibility to record the existence of apparent status on the basis of article 317 Code civil, it is also possible to judicially establish the existence of apparent status on the basis of article 330 Code civil. The judicial procedure on the basis of article 330 Code civil is a contentious procedure usually directed against the persons against whom the applicant (usually the child) wants to invoke his legal parentage (usually the heirs of the alleged parents). ${ }^{218}$

The judicial establishment of the existence of apparent status has not only force of law between the parties but it even has an erga omnes effect: the existence of apparent status that has been established by the court on the basis of article 330 Code civil can also be invoked against persons who were not a party to the proceeding. ${ }^{219}$ Moreover, unlike the existence of apparent status that has been established in an affidavit, the apparent status that has been judicially established cannot be contested.220

The periods of limitation to apply for the judicial establishment of apparent status are longer than for an affidavit. Per article 330 Code civil, the judicial procedure can be started by every interested person within 10 years after the apparent status has ended or ten years after the death of the alleged parent.

The objective of a procedure on the basis of article 330 Code civil is not to prove biological affiliation, but to prove the existence of apparent status. ${ }^{221}$ Thus, for example, it has to be proven that the alleged father has treated the child as his own, that he contributed to the education of the child, that public authorities and/or the social environment of the child and the alleged father recognised the man as the father of the child and that the child in his daily life bears the name of the alleged father.222 Since there are social factors that have to be proven instead of genetic affiliation, the Cour de Cassation held that the parties in a procedure for judicial establishment of apparent status (art. 330) do not automatically have the right to a DNA test.223

A judicial procedure for the establishment of apparent status (art. 330 Code civil) should not be confused with a procedure for judicial establishment of legal paternity or legal maternity (art. 325, 327 and 329 Code civil) which will be discussed in the next paragraph. The procedures have in common that they lead to the establishment of legal parentage if the application is granted. However, the aim of a procedure for the judicial establishment of the

218 Article 1157 Code de procédure civil. Circulaire relative à la présentation de l'ordonnance nr. 759-2005 du 4 juillet 2005 portant réforme de la filiation, Bulletin officiel du Ministère de la Justice, 25 October 2006, nr. 103, p. 109-211 (NOR: JUSC0620513C), at p. 155. Malaurie and Fulchiron argue however, that the action for judicial establishment of apparent status is not directed against a specific person (Malaurie \& Fulchiron 2006, nr. 1237).

${ }^{219}$ Article 324 Code civil.

${ }_{220}$ Massip 2006, nr. 49.

221 Circulaire relative à la présentation de l'ordonnance nr. 759-2005 du 4 juillet 2005 portant réforme de la filiation, Bulletin officiel du Ministère de la Justice, 25 October 2006, nr. 103, p. 109-211 (NOR: JUSC0620513C), at p. $155,156$.

222 Article 311-1 Code civil.

${ }^{223}$ Cass. 1er civ., 6 December 2005, D. 2006, p. 99; Granet-Lambrechts \& Hauser 2006, p. 23; Granet-Lambrechts 2005, p. 1751. 
existence of apparent status is merely to create evidence of the apparent status of the child. 224 The apparent status has the same function as marriage to the mother or an acknowledgment of paternity: it raises a presumption that the man is the biological father of the child on the basis of which legal paternity is established. But that legal paternity can be contested if it is not in conformity with the biological affiliation of the child.225

This is a considerable difference with judicial establishment of legal paternity or maternity on the basis of articles 325,327 or 329 Code civil. In a procedure on the basis of these provisions, it must be proven that the alleged father is the biological father of the child or that the alleged mother gave birth to the child. Thus it is not possible to contest legal parentage that has been established on the basis of such a judgment.

Legal parentage that has been established on the basis of apparent status can be contested. Here three actions must be distinguished.

The first action is based on article 335 Code civil and makes it possible to contest the existence of apparent status which has been established in an affidavit. If the existence of apparent status has been established in an affidavit, the existence of apparent status can be contested by proving that the child does not have apparent status with regard to the person involved. Article 335 Code civil provides that legal parentage established by apparent status recorded in an affidavit (art. 317 Code civil) can be contested by every interested person who submits evidence to the contrary within ten years after the affidavit has been rendered. The existence of legal parentage that has been established in a judgment on the basis of article 330 cannot be contested. The judgment has force of law and an erga omnes effect (see above).

The second and the third actions contest the legal parentage that has been established by apparent status (either in an affidavit or in a judgment) on the basis that the legal parentage is not in conformity with the child's biological affiliation. However, there is disagreement as to the applicable legal regime if one contests legal parentage that has been established by apparent status in an affidavit (the second action). Malaurie and Fulchiron argue that it should be possible to prove either that the apparent status that has been recorded does not exist or that the legal parentage is not in conformity with the child's biological affiliation. ${ }^{226}$ This view is confirmed by a circular of the French Ministry of Justice. ${ }^{227}$ Massip, Granet-Lambrechts and Hauser argue that in an action based on article 335 Code civil it is only possible to prove that the recorded apparent status does not exist.228 According to Massip, the second action is subject to the general rules on actions on parentage contained in articles 318-324 Code civil. Until January 2009 the discussion as to the applicable legal regime was relevant, because until then article 335 provided a limitation period of five years. That period of limitation was extended in January 2009 to ten years, which is the same as the general period of limitation in matters concerning parentage (art. 321).229

The third action contests the legal parentage that has been established on the basis of apparent status in a judgment. From the wording of article 335 Code it is clear that this article does not apply to this kind of action. In fact, there is no specific provision to contest

\footnotetext{
224 Massip 2006, nr. 48.

${ }_{225}$ Massip 2006, nr. 49.

226 Malaurie \& Fulchiron 2006, nr. 1330.

227 See also Circulaire relative à la présentation de l'ordonnance nr. 759-2005 du 4 juillet 2005 portant réforme de la filiation, Bulletin officiel du Ministère de la Justice, 25 October 2006, nr. 103, p. 109-211 (NOR: JUSC0620513C), at p. 141, 165.

228 Massip 2006, nr. 59; Granet-Lambrechts \& Hauser 2006, p. 23, 24.

${ }^{229}$ Loi nr 2009/61 of 16 January 2009 ratifiant l'ordonnance ${ }^{\circ} 2005-759$ du 4 juillet 2005 portant réforme de la filiation et modifiant ou abrogeant diverses dispositions relatives à la filiation, Journal Officiel of 18 January 2009.
} 
the legal paternity that has been established in this way. The French Ministry of Justice holds the view that the legal parentage that has been established by apparent status the existence of which has been judicially established can be contested in a procedure for tierce opposition either on the basis that the apparent status does not exist or on the basis that the established legal parentage is not in conformity with the biological affiliation of the child. ${ }^{230}$

A procedure for third party opposition is based on article 324 Code civil and can only be started by persons who were not a party in the procedure leading to the contested decision. Thus if the child initiates an action on the basis of article 330 Code civil to judicially establish his apparent status and directs his action against the heirs of his deceased father, the heirs cannot contest the judgment by third party opposition because they were a party to the procedure. In that case, the heirs should be able during the procedure for judicial establishment of the existence of apparent status to prove that notwithstanding the apparent status of the child, the man is not the child's biological father and that therefore the legal parentage cannot be established.231 Massip argues that the judicial establishment of the existence apparent status is only about apparent status (art. 330 Code civil). Therefore, there is no room for a discussion on the child's biological affiliation in such a procedure. In his view, the legal parentage that has been established in this way can be contested in a separate procedure within ten years after the judgment establishing the existence of apparent status. 232

It must be realised though that it is often after the death of the alleged father that establishment of legal parentage by apparent status becomes relevant. After the death of the alleged father, it will be very difficult for the heirs or any other interested party to prove that the man in question is not the biological father of the child. The reason is that since 2004, article 16-11 (2) Code civil provides that it is forbidden to conduct DNA identification after a person's death for the purpose of establishing legal parentage, except if the deceased expressly consented to the examination during his lifetime.233

\subsection{Establishment of parenthood by judicial decision}

If legal parentage has not been established automatically or voluntarily it can be judicially established by a court. Judicial establishment of parenthood is a judicial procedure by which the court creates legal parenthood upon proof of the existence of a ground for legal parentage, such as genetic affiliation or consent to fertility treatment. ${ }^{234}$ Thus, the judicial establishment of legal parentage changes the personal status of the child. Therefore the judicial establishment of legal parentage is not allowed if the legal parentage of the child has already been established automatically by operation of the law or voluntarily by registration or acknowledgment of parenthood. ${ }^{235}$

Since judicial establishment of parenthood creates a legal relationship, a declaration of parentage under English law on the basis of section 55A Family Law Act 1986 is not a judicial establishment of parenthood. On the basis of this provision any person may apply to the High Court, a county court or a Magistrates' court for a declaration as to whether or not

\footnotetext{
${ }^{230}$ Circulaire relative à la présentation de l'ordonnance nr. 759-2005 du 4 juillet 2005 portant réforme de la filiation, Bulletin officiel du Ministère de la Justice, 25 October 2006, nr. 103, p. 109-211 (NOR: JUSC0620513C), at p. 157. See also Rapport nr. 145 (Sénat), 2007-2008 by Henri de Richemont, p.42, 43.

231 See also Malaurie \& Fulchiron 2006, nr. 1235, 1236.

232 Massip 2006, nr. 59, note 57.

233 See also Blauwhoff 2009, p. 238.

${ }^{234}$ France: article 325 - 331 Code civil. Germany: § 1600d BGB. Netherlands: 1:207 Burgerlijk Wetboek. Sweden: § 1:5 Föräldrabalk (1949:381).

${ }^{235}$ France: article 320 Code civil. Germany: § 1600d BGB (see also § 1594 (2) BGB). Netherlands: 1:207 (2) Burgerlijk Wetboek.
} 
a person named in the application is or was the parent of another person so named. Unlike the judicial establishment of parentage under Dutch, French, German and Swedish law or a parental order ${ }^{236}$ or an adoption order ${ }^{237}$ under English law, a declaration of parentage does not change the personal status of the child.238 Under English law, the biological parent or the consenting partner and the woman giving birth to the child are automatically the legal parents of the child. The declaration of parentage under English law will be discussed in the chapter on Evidence of legal parentage (below).

The national regimes for judicial establishment of legal parentage differ in various aspects. The most important aspects are the ground for judicial establishment of legal parentage, locus standi, periods of limitation and evidence.

\subsubsection{The ground for judicial establishment of legal parentage}

The general rule in the legal systems under consideration is that the court will establish legal parenthood if the existence of a ground for legal parentage is proved.

For Swedish law it has been argued that genetic affiliation and consent to fertility treatment are the grounds for legal parenthood and that childbirth is the ground for legal maternity. ${ }^{239}$ Thus in case of natural reproduction a Swedish court establishes the legal parenthood of the biological parents of the child. In case of artificial reproduction, the court establishes the legal parenthood of the man who consented to the fertility treatment. ${ }^{240}$ If the requirements of § 1:9 Föräldrabalk are fulfilled, the court establishes the legal parenthood of the woman who consented to the fertility treatment. The woman who gave birth to the child is always the legal mother. ${ }^{241}$ The legal paternity of the sperm donor cannot be judicially established if a consenting man or woman is regarded as the parent on the basis of $\S \S 1: 6,8$ or 9 Föräldrabalk. ${ }^{242}$

French law provides for three judicial actions that lead to the establishment of legal parentage. In the previous paragraph the judicial establishment of the existence of the apparent status (article 330 Code civil) has been discussed. In principle, genetic affiliation does not play a role in that procedure, because the procedure is about the establishment of the existence of apparent status.

Under articles 325 and 327 Code civil legal maternity and legal paternity are established if it is proven that the alleged mother gave birth to the child or that the alleged father is the biological father of the child. These two provisions are the general provisions for the establishment of legal maternity and legal paternity.

The third action that leads to the judicial establishment of legal paternity is set out in article 329 Code civil. Under article 329 Code civil, the (ex) husband of the mother, the mother herself and the child can apply for the judicial establishment of the legal paternity of the (ex) husband, if the (ex) husband's legal paternity has not been established as a result of article 313 Code civil. Article 329 Code civil is especially beneficial for the (ex) husband, because he does not have a right under article 327 to apply for the judicial establishment of his own paternity. Thus if the mother deprived her (ex) husband of his legal paternity by not mentioning his name on the birth record, he can regain his legal fatherhood through article 329 Code civil.

\footnotetext{
236 Section 30 Human Fertilisation and Embryology Act 1990 (parental orders in favour of gamete donors). 237 Section 39 Adoption Act 1976.

238 Next to procedures for judicial establishment of legal paternity continental legal systems also provide for the possibility to obtain a declaration as to the existence or non-existence of legal parentage. See article 1:26 Dutch BW, § 169 (1) German Familienverfahrensgesetz and § 13:2 Swedish Rättegångsbalk (1942:740).

${ }^{239}$ See chapter 2. Grounds for legal parentage.

$240 \S 1: 6,8$ Föräldrabalk (1949:381).

241 § 1:7 Föräldrabalk (1949:381).

242 § 1:5 (2) Föräldrabalk (1949:381). See also prop. 2004/05:137, p. 56.
} 
The ground for the judicial establishment under article 327 and 329 is the same. Under both articles it has to be proven that the alleged father or (ex) husband is the biological father of the child (or that he consented to the fertility treatment of the mother).

For German law it has been argued that genetic affiliation is always the basis for legal paternity and that childbirth is the basis for legal maternity. ${ }^{243}$ Legal maternity exists ex lege under German law and therefore it cannot be judicially established. Legal paternity does not always exist automatically. If the child does not have a legal father a German court only establishes the legal paternity of the biological father of the child. Even the legal paternity of the sperm donor can be judicially established. ${ }^{244}$ The legal paternity of the partner who consented to the fertility treatment cannot be judicially established.245

Under Dutch law a court can only judicially establish the legal paternity of the man who begot the child in a natural way or the man who, as a life companion of the mother, consented to the act that could have resulted in the conception of the child.246 Thus, unlike under German law, the legal paternity of the sperm donor cannot be established. The somewhat long-winded formulation of the Dutch article 1:207 (1) BW resulted in difficult situations. ${ }^{247}$ How to deal with the man who is married to another man and whose semen have been used to conceive a child with a surrogate in California? Can the Dutch court establish the judicial paternity of the Dutch man? The man did not beget the child in the natural way and he also did not consent to the fertility treatment of the surrogate as her lifecompanion. Still, the rechtbank Amsterdam had no problem in establishing the legal paternity of the Dutch man. ${ }^{248}$

Not all circumstances allow for the establishment of the legal paternity of the biological father or the consenting partner of the mother. Under Dutch and French law it is not allowed to establish the legal paternity of an incestuous child if the legal maternity of the mother has been established already. 249 It is deemed not to be in the child's interest to have the incestuous relationship recognised in law. 250

\subsubsection{Locus standi for judicial establishment of legal parentage}

The right to apply for judicial establishment of parenthood is restricted under all legal systems under consideration. The reason to restrict the locus standi of this action is its personal nature. Within the legal systems involved, there are two groups of persons who have standing: the persons directly involved (the child, the mother and the father) and their heirs.

With regard to the locus standi of the persons who are directly involved in the action, most legal systems provide an unrestricted right for the child and a restricted or dependant right for the mother. Only under German law both the child, the mother and the alleged father have the right to apply for judicial establishment of paternity on an equal footing. 251

Under Dutch law the child has an unrestricted right to apply for judicial establishment of paternity, but during the child's minority he or she is represented by a guardian ad hoc (bijzondere curator). ${ }^{252}$ The mother's right to apply for judicial establishment is restricted by a

\footnotetext{
243 See chapter 2. Grounds for legal parentage..

${ }^{244}$ MünchKomm/Wellenhofer 2008, § 1592, nr. 35; § 1600d, nr. 30; Staudinger/Rauscher 2004, § 1600, nr. 99; § 1600d, nr. 15.

245 MünchKomm/Wellenhofer 2008, § 1592, nr. 34.

246 Article 1:207 (1) Burgerlijk Wetboek.

247 See also note 38 .

248 Rechtbank Amsterdam, 5 March 2008, case number 36485/FA RK 06-1265 (not published).

${ }^{249}$ France: article 310-2 Code civil. Netherlands : article 1:207 (2) under b Burgerlijk Wetboek.

${ }^{250}$ France: Dekeuwer-Defossez 1999, p. 45. Netherlands: Kamerstukken II, 1995-1996, 24 649, nr. 3, p. 19.

251 § 1600e BGB. Staudinger/Rauscher 2004, § 1600c, nr. 11, 35, 41.

252 Article 1:212 Burgerlijk Wetboek.
} 
statutory period of limitation: she has to apply within five years from the child's birth or within five years from the moment at which she knows who the begetter of the child is. ${ }^{253}$

We have seen that under French law, three kinds of actions lead to the establishment of legal parentage. The judicial establishment of apparent status (art. 330 Code civil) has been discussed in the previous paragraph. The procedure for judicial establishment of the existence of apparent status can be started by any interested person.

On the basis of articles 325 and 327 Code civil only the child can apply for the judicial establishment of legal maternity (art. 325) or legal paternity (art. 327). On the basis of these provisions the legal parentage shall be established if it is proven that the woman gave birth to the child or that the man is the biological father of the child. Only the child can start the action, but during his minority the action can be started on behalf of the child by the parent whose legal parentage has already been established.254 Thus, during the minority of the child, the legal mother of the child is allowed to apply for the judicial establishment of paternity.

On the basis of article 329 Code civil the legal mother, her (ex) husband or the child can apply for the judicial establishment of the legal paternity of the (ex) husband if his legal paternity has not been established as a result of article 313 Code civil. The rationale of article 329 Code civil is that as a result of article 313 Code civil the mother can avoid the establishment of the legal paternity of her (ex) husband. If the mother conceals her pregnancy from her husband and does not mention his name at the recording of the birth, his paternity shall not be established. Article 329 Code civil gives the husband the possibility to respond to the actions of the mother if he believes that he is the biological father of the child. Article 329 Code civil only applies to the husband whose legal paternity has not been established as a result of article 313 Code civil. Thus, if the child is born out of wedlock the biological father does not have the possibility to apply for judicial establishment of his legal paternity on the basis of his biological paternity.

Under Dutch, German and French law the judicial establishment of legal paternity is a private matter. Under Swedish law it is also considered a matter of public concern. Under Swedish law the starting point is that only the child has the right to apply for judicial establishment of paternity. ${ }^{255}$ However, if the child does not have a legal father the socialnämnd is obliged to investigate the parentage of the child with a view to the establishment of legal paternity. ${ }^{256}$ If the socialnämnd has established that a man is the father of the child, his legal paternity can be established either by voluntary acknowledgement of paternity or by judicial establishment of his legal paternity. In that case, the socialnämnd has the right to apply for judicial establishment on behalf of the child.257 Moreover, during the minority of the child the mother with custody also has the right to apply for judicial establishment of paternity on behalf of the child.258 Neither the mother nor the alleged parent have their own right to apply for judicial establishment of paternity.

The second group of persons that may have standing to apply for judicial establishment of parenthood are the heirs of the persons who are directly involved and who have a right to

\footnotetext{
253 Article 1:207 (3) Burgerlijk Wetboek.

254 Article 328 Code civil.

$255 \S 3: 5$ (1) Föräldrabalk (1949:381).

256 § 2:1 Föräldrabalk (1949:381). German law used to have a similar regulation as Swedish law: automatic guardianship of the child welfare authority (Amtspflegeschaft). This has been abolished in 1998. Nowadays the unmarried mother voluntarily can ask the Jugendamt to assist in the establishment of legal paternity (§ 1712 BGB and $\S$ 52a Achtes Buch Sozialgesetzbuch. Gernhuber \& Coester-Waltjen 2006, § 60:14, 15).

257 § $3: 5$ (2) Föräldrabalk (1949:381). Singer 2000, p. 204; Socialstyrelsen 2005, p. 99.

$258 \S 3: 5$ (2) Föräldrabalk (1949:381)
} 
apply. Under German and Swedish law the heirs or the descendants do not have a statutory right to apply for judicial establishment of paternity after the child's death.

Under Dutch law however, the descendants in the first degree (afstammelingen in eerste graad) of the child (X) are allowed to apply for judicial establishment of paternity, but their right is restricted. They only have that right if the alleged father is still alive and on the condition that the right is exercised within one year after learning of the death of their parent $(X) .{ }^{259}$ The provision is meant to create consistency, because the child's descendants also have the right to contest legal paternity under the same conditions. ${ }^{260}$ However, the mother's descendants have no such right, although they have a right to contest legal paternity. The law does not interrupt the period of limitation for the descendants during their minority.

Under French law, more or less the same rule applies. Under French law the heirs (héritiers) have the right to exercise the right to apply for judicial establishment of paternity if the deceased died before expiry of the statutory period of limitation that applies to him.261 For judicial establishment of parenthood this means that the child's heirs can apply for judicial establishment of paternity if the child died before the ending of the statutory period of limitation. The period of limitation is ten years after the child has come of age.262

\subsubsection{Periods of limitation for judicial establishment of legal parentage}

In general the right to apply for judicial establishment of parenthood is not restricted in time, certainly not for the child. This is only different under French law. Under French law the child is the only person who can start an action for judicial establishment of legal maternity or legal paternity. Since there is no specific period of limitation, the general period of limitation for parentage applies. That means that the child has to start the action within ten years of his 18th birthday. ${ }^{263}$ During the minority of the child, the action can only be started by the parent of the child whose legal parenthood has been established. Thus, this person is barred as soon as the child reaches the age of 18 years.

On the basis of article 329 Code civil, the legal paternity of the husband can be established if it has not been established as a result of article 313 Code civil. The husband and the legal mother can only start this action during the minority of the child and the child has to apply within ten years after his 18th birthday.

Under Dutch and Swedish law the mother's right (and the right of the socialnämnd) is restricted in time. Under Dutch law, the mother has to apply within five years following the moment of birth or the moment she has become aware of the identity of the begetter. ${ }^{264}$ Under Swedish law the socialnämnd and the mother can only apply during the child's minority. 265

Under German law, the right to apply for judicial establishment of paternity is not restricted in time for any of the applicants. Even after the child has come of age, the alleged father and the mother have a statutory right to apply for judicial establishment of paternity. ${ }^{266}$

Both under Dutch and French law the rights of the descendants or the heirs of the child to apply for judicial establishment of legal paternity are derived from the rights of the child himself. Therefore, under Dutch law the descendant has to bring the action within one year

\footnotetext{
259 Article 1:207 (4) Burgerlijk Wetboek.

260 Kamerstukken II, 1996-1997, 24 649, nr. 30.

261 Article 322 Code civil.

262 Article 321 Code civil.

263 Article 321 Code civil.

264 Article 1:207 (3) Burgerlijk Wetboek.

$265: \S 3: 5$ Föräldrabalk (1949:381).

266 Staudinger/Rauscher 2004, § 1600e, nr. 33.
} 
after he learned of the death of the child.267 Under French law the heirs of the child have to start their action within the period of limitation that applies to the child. ${ }^{268}$

\subsubsection{Evidence in case of judicial establishment of legal parentage}

Most proceedings on judicial establishment of legal parentage are about the legal paternity of the child's biological father. Also, actions where the legal parentage is contested (next paragraph) are often about biological parentage. For a long time it was not possible to establish direct evidence of genetic affiliation. The law developed legal presumptions which, if proven, established or annulled legal paternity; some remain in force. Under Dutch and French law no legal presumptions for establishment or annulment of legal parentage exist anymore. The court can require certain evidence, like a comparative DNA analysis, ex officio. 269

Under English law there is still a presumption that the husband of the mother at the moment of the birth of the child is the father of the child, but even weak evidence can rebut the presumption. Section 26 Family Law Reform Act 1969 provides that 'any presumption of law as to the legitimacy or illegitimacy of any person may in any civil proceedings be rebutted by evidence which shows that it is more probable than not that that person is illegitimate or legitimate, as the case may be, and it shall not be necessary to prove that fact beyond reasonable doubt in order to rebut the presumption.' It has been shown that at registration of the birth the presumption can be rebutted by the statement of the mother that her husband is not the father of the child. ${ }^{270}$ In $S v . S$ and $W v$. Official Solicitor the Lord Reid held on the basis of section 26 Family Law Reform Act 1969 that the presumption of legitimacy merely determines the onus of proof. The evidence must be weighed without using the presumption. Only in the rare case that the evidence is so evenly balanced that the court cannot reach a decision, the presumption is decisive. ${ }^{271}$

Under English law, the registration of a man as a father on the birth record also raises a presumption that the man is the father of the child; it is prima facie evidence of his paternity. ${ }^{272}$ Again, the relevance of these presumptions on parentage must not be overestimated. Thorpe LJ held that "the paternity of a child is to be established by science and not by legal presumption or inference." 273

German and Swedish law still provide for legal presumptions to determine whether or not a person is the biological father of the child. Under German law $\S 1600 \mathrm{~d}$ BGB provides that the man who had intercourse with the woman during the conception period shall be presumed to be the father, unless his legal paternity is doubtful. The conception is presumed to have taken place between the 300th and 181st day before the birth of the child. However, these presumptions are only a secondary means of evidence. They are only used if it is not possible to obtain a comparative DNA analysis. ${ }^{274}$

\footnotetext{
${ }^{267}$ Article 1:207 (4) Burgerlijk Wetboek.

268 Article 322 Code civil.

${ }^{269}$ France: article 10, 143 Code de procédure civil. See also Malaurie \& Fulchiron 2006, nr. 1082. Netherlands: article 149

(1) Wetboek van Burgerlijke Rechtsvordering. See also Asser/De Boer 2006, nr. 738.

270 See note 99 .

271 [1972] A.C. 24.

272 Brierley $v$ Brierley and Williams [1918] P 257, 87 LJP 153; Re Goodrich, Payne v Bennett [1904] P 138; Jackson v Jackson and Pavan, [1964] P 25, [1960] 3 All ER 621, [1961] 2 WLR 58; Masson, Bailey-Harris \& Probert 2008, nr. 17-006; Lowe \& Douglas 2007, p. 322; Tapper 2004, p. 623; Mackay of Clashfern 2008, nr. 98. Lord Chancellor's Department Consultation Paper, Procedures for the determination of paternity and the law on parental responsibility for unmarried fathers, 1998, nr. 26.

${ }^{273}$ Re H and A (children) [2002] EWCA Civ 383, [2002] 2 FCR 469, par. 30.

274 BT Drucks. 13/4899, p. 88. See also Gernhuber \& Coester-Waltjen 2006, § 52:85; MünchKomm/Wellenhofer 2008, § 1600d, nr. 29.
} 
Swedish law has a similar provision. § 1:5 Föräldrabalk provides that the court shall declare that the man is the father of the child, if it turns out that the man had intercourse with the child's mother during the conception period and if it is probable (sannolikt), 275 in the light of all the circumstances that the man has begotten the child. The legal presumption is only used if it is not possible to execute a paternity test which establishes paternity. ${ }^{276}$

Under all legal systems under consideration a comparative DNA analysis is the most obvious way to prove genetic parentage both in actions to establish as well as to contest legal parentage. However, the conditions under which a court orders a DNA test differ considerably as well as the effects of a refusal of one of the parties to co-operate with a court order for a DNA test.

Under English law, section 20 of the Family Law Reform Act 1969 grants the court the power to order blood tests in cases in which the parentage of a person fails to be determined. In $S v . S$ and $W v$. Official Solicitor the House of Lords considered the question whether a bloods test should be ordered in a proceeding regarding the paternity and the legitimacy of a child.277 Lord Reid held that it is in the general interests of justice to require that all the evidence is presented and therefore, a blood test should be directed unless it is shown that the test would be contrary to the child's interest.

Thus the crucial question is when it is in the child's interest not to order a paternity test. There are hardly any cases in which the court found the conduction of a paternity test not in the child's interests. The trend in English case law seems to be to emphasise the need to know the truth about a child's affiliation. ${ }^{278}$ But there are examples of cases where the blood test was refused because it was not deemed to be in the interest of the child.

In Re CB (a minor) (blood tests) the applicant applied for a blood test to ascertain whether he or the mother's husband was the child's father. ${ }^{279}$ However, the major reason for $\mathrm{Mr}$ Justice Wall not to order blood tests seemed to be that he did not consider it relevant to order tests which could not be carried out anyway. After all, the mother at that time still had the statutory power to obstruct the taking of blood samples from the child.

In Re F (a minor) the applicant argued that he, instead of the mother's husband, was the child's father. ${ }^{280}$ The court refused to order a paternity test since, even were it to be established that the applicant was the child's biological father, his chances of obtaining parental responsibility and contact were remote.

In O. $v$ L. (blood tests) the mother requested blood tests to prove that her lover, and not her husband, was the child's father. ${ }^{281}$ The child and the husband had had contact for three years when the mother told the husband that he was probably not the father. It appeared that the mother's reason for requesting the blood tests was to exclude contact between the child and the husband. However, such exclusion was not deemed in the child's interests and therefore the application was rejected.

Under English law, the person cannot be forced to submit to a blood test.282 Bodily samples can only be taken with the consent of the person concerned. Lord Reid explained that 'the [...] reason is that English law goes to great lengths to protect a person of full age

\footnotetext{
275 Sannolikt indicates a certain level of proof. On a scale of four levels of proof, sannolikt is the second highest burden of proof. See Saldeen 1980, p. 55.

276 Prop. 2004/05:137, p. 51. Saldeen 2005, p. 69.

277 [1972] A.C. 24.

278 Masson, Bailey-Harris \& Probert 2008, nr. 17-007.

279 [1994] 2 FLR 762.

280 [1993] Fam 314.

281 [1995] 2 FLR 930

282 Section 21 (1) Family Law Reform Act 1969.
} 
and capacity from interference with his personal liberty'.283 If a blood test is ordered and a party refuses to co-operate, section 23 Family Law Reform Act 1969 allows the court to draw an adverse inference from the refusal to co-operate with a paternity test. ${ }^{284}$ The rule is different if the bodily sample has to be taken from a person under the age of sixteen years. In that case, the sample may be taken with the consent of the person who has care and control or, if that person does not consent, with the consent of the court. 285

Under French law the starting point is that in matters concerning legal parentage, evidence of genetic affiliation is given by a comparative DNA analysis. The Cour de Cassation even held that a DNA test in a proceeding on legal affiliation is de droit (as of right) meaning that the court is obliged to order a medical examination on the request of either party, unless there are legitimate reasons not to do so.286 The parties in a proceeding concerning legal parentage only have the right to a DNA test if the child's genetic affiliation is relevant to the resolution of the dispute. If the applicant has to challenge or establish the child's apparent status the genetic affiliation is irrelevant and neither party has a right to a DNA test. ${ }^{287}$ So far, the rule also applies to the annulment of legal parentage. ${ }^{288}$

Just like under English law, the personal liberty of individuals is protected. Article 16-11 Code civil provides that the genetic identification of persons is only allowed pursuant to a court order. The court order for a DNA test is essential, since without the order it is not at all possible to execute a DNA test. 289

In civil proceedings, DNA identification is only allowed for the purpose of determining questions of parentage and the person involved must consent beforehand to the execution of the tests. Hence, it is not possible to identify a deceased person with a DNA test if that person did not expressly consent to such test during his or her lifetime. If the person involved did not consent to a DNA test, it is necessary to resort to other means of proving that the deceased person is the father of the applicant. ${ }^{290}$ Performing a DNA test without the consent of the persons involved is a criminal offence. ${ }^{291}$

The applicant does not have a right to a DNA test if there are legitimate reasons not to order such a test. Legitimate reasons for rejecting a request for a DNA test are: that the request is only being made in order to delay the establishment of legal paternity, ${ }^{292}$ that the test is requested in order to establish legal parentage whereas the law prohibits such establishment, ${ }^{293}$ or in cases of fishing exercises or other abusive intentions. ${ }^{294}$

\footnotetext{
${ }^{283} S$ v. $S$ and $W v$. Official Solicitor [1972] A.C. 24.

284 Also: Re O; Re J (children)(blood tests: constraints) [2000] Fam 139; F. v Child Support Agency [1999] 2 FCR 385; Re G (parentage: blood sample) [1997] 1 FLR 360; Re H (a minor)(blood tests: parental rights) [1997] Fam 89; Re CB (a minor)(blood tests) [1994] 2 FLR 762.

285 Section 23 (3) Family Law Reform Act 1969.

286 Cass. 1er civ., 28 May 2000, 30 May 2000, D. 2001, p. 1427; Cass. 1er civ., 17 September 2003 (01-03.408), D. 2004, p. 659; LeGac-Pech 2001.See also Blauwhoff 2009, p. 263.

${ }^{287}$ Cass. 1er civ., 6 December 2005, D. 2006, p. 99; Granet-Lambrechts \& Hauser 2006, p. 23; Granet-Lambrechts 2005, p. 1751.

${ }^{288}$ Cf. Cass. Civ. 1er, 28 May 2008, D. 2008, 1624; RCDCiv. 2008, p. 464. See however Hauser argues that in case of annulment of legal paternity in conformity with the child's apparent status it could very well be that the Cour de Cassation will hold that a DNA test is only allowed if the applicant pleads a reasonable ground of suspicion in order to protect the stability of the legal parentage of the child (RCDCiv, 2008, p. 284).

289 Article. 16-11 (1) Code civil. See also in more detail Blauwhoff 2009, p. 264.

${ }^{290}$ For examples see; PASCAL \& Trapero 2005. See also Cass. Civ. 1er, 2 April 2008, D. 2008, 2121; RCDCiv. 2008,464 where the Cour de Cassation holds that article 16-11 Code civil applies to all cases instituted after its coming into force, the $7^{\text {th }}$ of August 2004.

${ }^{291}$ Article 226-25 Code pénal.

292 Cass. 1er civ., 14 June 2005 (03-19.325), D. 2005, p. 1804.

${ }^{293}$ Ferrand 2006, p. 454.

${ }^{294}$ Granet-Lambrechts 2006, p. 1143.
} 
French law does not have a provision comparable to the English section 23 Family Law Reform Act 1969. The Cour de Cassation held in 2003 that the refusal to co-operate with the court order for a paternity test is as such not enough to establish a presumption of paternity against that person. ${ }^{295}$ The party who requested the test has to submit further evidence which supports the paternity of the alleged father. ${ }^{296}$

Under Dutch law there are no statutory provisions on the use of DNA tests. In 2004, the Hoge Raad held that the use of a DNA test in matters concerning legal parentage is not mandatory. ${ }^{297}$ It is at the discretion of the court to determine whether or not a DNA test should be executed. The limits of that discretion were already determined in 2000, when the Hoge Raad laid down the criteria for the use of a DNA test in matters concerning judicial establishment of legal paternity.298 The Hoge Raad held that a DNA test can only be ordered if it is plausible, on the basis of facts and circumstances which have been established during the proceeding, that the man can be the begetter of the child. ${ }^{299}$ It does not need to be proven that the alleged father had intercourse with the mother during the conception period, but the sole allegation that the man is the father of the child is not enough. It is uncertain whether the same particularity of pleading is required if legal paternity is contested. 300

Under Dutch law persons cannot be forced to co-operate with a DNA test. ${ }^{301}$ The general rule is that the parties to a proceeding are obliged to co-operate with examinations ordered by the court. If one of the parties refuses to co-operate the court may draw such inferences from the refusal as appear proper in the circumstances. ${ }^{302}$ Usually this means that the court rules against the refusing party, but this is not necessarily the case. In the case leading to the decision of the Hoge Raad of the 15th of February 2008 the man contested his legal paternity that existed on the basis of his marriage to the mother. ${ }^{303}$ The court ordered a DNA test, but the mother refused to co-operate. In her view a DNA test constituted an unjustified and unnecessary interference with her physical and moral integrity since no reasonable ground existed for the doubt concerning the man's paternity. The court held that because no DNA test was executed and because the man did not plead concrete facts or circumstances to prove his claim, the application of the man for the annulment of his legal paternity had to be rejected. Thus, just like the Cour de Cassation, the Dutch Hoge Raad does not automatically grant the applicant his claim if the respondent does not co-operate with the DNA test. 304

\footnotetext{
295 Cass. 1er civ., 17 September 2003, D. 2004, p. 659. See also Jacques Massip, D. 2005, p. 660; Frédérique GranetLambrechts, D. 2004, p. 1420.

296 See also Malaurie \& Fulchiron 2006, nr. 1020; Granet-Lambrechts 2006, p. 1143; Pascal \& Trapero 2005.

${ }^{297}$ Hoge Raad, 11 June 2004, NJ 2005/116. On the Dutch law in this respect see also Blauwhoff 2009, p. 266.

${ }^{298}$ Hoge Raad, 22 September 2000, NJ 2001/647, m.nt. JdB.

${ }^{299}$ See also the former requirement under French law that the applicant for judicial establishment of legal paternity was only allowed to apply if she (or he) could establish serious indications for the man's paternity. Until the law reform in 2006, the requirement was contained in article 340 Code civil. In 2004 the Cour de Cassation already abandoned the requirement in its case law (Cass. 1er civ., 17 February 2004, D. 2005, 1826; Cass. 1er civ., 12 May 2004 , D. 2005, 1766; Cass. 1er civ., 14 June 2005, D. 2005, 1732; Cass. 1er civ., 14 June 2005 D. 2005, 1804. Cass. 1er civ., 14 June 2005 D. 2005, 1961) and decree 2005-759 formally deleted the requirement from the Code civil.

300 The question is raised by Advocate-General Langemeijer. He argues that modern techniques with which genetic affiliation can be determined with almost certainty, do not require that the applicant pleads facts and circumstances which cast doubt on his paternity (opinion in Hoge Raad, 15 February 2008, LJN BC1860). See however Asser/De Boer 2006, nr 702; Heida 2002, p. 129.

${ }^{301}$ Hoge Raad, 15 February 2008, LJN BC1860.

302 Article 198 (3) Wetboek van Burgerlijke Rechtsvordering.

303 Hoge Raad, 15 February 2008, LJN BC1860.

304 For examples see Heida 2002.
} 
Under Swedish law, the use of DNA tests in cases concerning parentage is regulated by the Lag (1958:642) om blodundersöking m.m. vid utreding av faderskap (Blood test act). ${ }^{305}$ Pursuant to this Act, the court can, on request of one of the parties or on its own motion, order any research to determine a person's genetic characteristics in order to determine the affiliation of the child. 306

In a proceeding for annulment of paternity based on acknowledgment or judicial establishment, the court can only order a paternity test if, after the acknowledgment or the judicial establishment, it turns out that the mother probably had sexual intercourse with another man. ${ }^{307}$ If that is proven, the other man with whom the mother had sexual intercourse must be summoned and subjected to the necessary medical examination. ${ }^{308}$ If it was already known before the establishment of paternity that the mother had intercourse with another man, the court cannot order a paternity test. From the parliamentary history it is clear that it is the applicant's knowledge concerning of the intercourse of the mother which determines whether the court can order a paternity test. ${ }^{309}$

The reason for limiting the possibility of ordering a paternity test is to avoid unfounded interference by others in the private lives of the father and child. ${ }^{310}$ The limitations on requesting a paternity test do not play a role in case of annulment of marital paternity. It is always possible to request a paternity test in proceedings for annulment of marital paternity. ${ }^{311}$

If the parties do not co-operate with the court order to undergo medical tests, they can be fined and ultimately they can be forced with police assistance to undergo the necessary examinations. 312 The possibility of invoking enforcement by the police is, in the case of children under the age of 18, limited: samples cannot be taken from a child by means of police assistance if that would be detrimental to the interest of the child. ${ }^{313}$

Under German law the starting point is that in matters concerning legal parentage (and other issues concerning personal status) the court is not bound by the evidence that is presented by the parties; the court has to investigate the matter ex officio by using all the sources that might clarify the issue including a DNA test (Amtsermittlung). ${ }^{314}$

There is no particular provision that protects the alleged father against fishing exercises in case of judicial establishment of legal paternity. The prevailing view is that such frivolous actions are not allowed because they violate the general principle of good faith (Treu und Glauben). ${ }^{315}$ This is different if legal paternity is contested. Under German law, the applicant who wants to contest legal paternity has to present an Anfangsverdacht (ground for

\footnotetext{
305 Lag (1958:642) om blodundersöking m.m. vid utreding av faderskap. See also Förordning (1969:624) om blodundersökning m.m. vid utredning. See also Singer 2007, p. 144.

306 § 1 Lag (1958:642) om blodundersöking m.m. vid utreding av faderskap. See also Karnov/Saldeen 2007, Föräldrabalk, note 1; Walin \& Vängby vol. I, p. 3:34.

307 § 1a (1) Lag (1958:642) om blodundersöking m.m. vid utreding av faderskap.

$308 \S 1$, last sentence Lag (1958:642) om blodundersöking m.m. vid utreding av faderskap.

${ }^{309}$ Prop. 1982/83:8, p. 12; Socialstyrelsen 2005, p. 66; Walin \& Vängby vol. I, p. 3:36.

310 Prop. $1982 / 83: 8$, p. 7.

311 Singer 2000, p. 221.

312 Section 2a (1) Lag (1958:642) om blodundersöking m.m. vid utreding av faderskap. See also Prop. 1982/83:8, p. 9, 16. 313 Section 2a (2) Lag (1958:642) om blodundersöking m.m. vid utreding av faderskap.

$314 \S 26$ Familienverfahrensgesetz. Since 1 September 2009 the procedural law for matters concerning parentage is laid down in the Familienverfahrensgesetz (FamFG) instead of the Zivilprozessordnung. See inter alia Stößer 2009; Löhnig 2009. On Amtsermittlung in matters concerning parentage see MünchKomm/Wellenhofer 2008, § 1600d, nr. 46; Staudinger/Rauscher 2004 , § 1600d, nr. 19; Helms 1999, p. 191.

315 Helms 1999, p. 208 with further references.
} 
reasonable suspicion) before his application will be heard at all. 316 According to the Bundesgerichtshof the person applying for annulment of his legal paternity must present circumstances which, when viewed objectively, cast doubt on the biological paternity of the applicant and which render the possibility of another man's paternity not entirely remote. ${ }^{317}$ Under Dutch law the rule is just the opposite. Under Dutch law the applicant has to establish an Anfangsverdacht in case of judicial establishment of paternity. 318

The reason for the requirement of an Anfangsverdacht, which is not based on a specific statutory provision, is meant to avoid paternity suits 'out of the blue'. The applicant for example has to establish that it is probable that the mother has had sexual intercourse with more than one men or at least another man than the legal father or that the legal father could not have intercourse with the mother during the conception period. ${ }^{319}$ The fact that the mother refused to submit to a paternity test, 320 limited fertility of the legal father ${ }^{321}$ or anonymous phone calls that the legal father is not the biological father in combination with lacking physical resemblance is ${ }^{322}$, as such, not enough to make an Anfangsverdacht.

One way of presenting an Anfangsverdacht is by means of a privately-ordered paternity test. ${ }^{323}$ However, in case of a paternity test it is important that all the parties involved consent to the test. In two decisions in 2005, the Bundesgerichtshof held that the use of paternity tests without the consent of the persons involved in order to make an Anfangsverdacht, is not permitted, because in the absence of consent there can be no absolute certainty that the material used for the DNA test is actually from the party involved. Moreover, the taking of samples without consent of the party involved violates that person's right to personal integrity as enshrined in Article 2 (1) of the German Constitution. ${ }^{324}$

Since the coming into force of $\S 1528$ a BGB on the first of April 2008 the Anfangsverdacht can easily be established by the legal father, the child and the mother. The provision has been inserted in the German civil code by the Gesetz zur Klärung der Vaterschaft unabhängig vom Anfechtungsverfahren. ${ }^{325}$ The provision is inserted pursuant to a judgment of the Bundesverfassungsgericht in which it held that the German constitution guarantees the legal father the right to know whether his legal child is also his biological child. ${ }^{326}$

$\S 1528$ a BGB allows the legal father, the mother or the child to apply to the court for an order to compel the legal father, the mother and the child to consent to a comparative DNA analysis and to co-operate with the taking of bodily samples. The remarkable characteristic of $\S 1598$ a BGB is that the DNA analysis will not be ordered by the court, which is normally the case in a procedure to contest or establish legal paternity. The court only compels the family members to co-operate, but the applicant has to arrange for the test himself. The idea is that the applicant can choose the kind of DNA test that suits him best, also with a view to the costs. ${ }^{327}$ If the applicant wants to use the results of the test later in a procedure to contest the paternity of the legal father, it must be made sure that the privately ordered test and the

\footnotetext{
316 BGH 22 April 1998 (nr. XII ZR 229/96), FamRZ 1998, p. 955; BGH 30 October 2002 (nr. XII ZR 345/00), FamRZ 2003, p. 155. See also Gernhuber \& Coester-Waltjen 2006, § 52:119; Ferrand 2006, p. 445; Rittner \& Rittner 2005, p. 945; Wellenhofer 2005, p. 665; Wolf 2005, p. 2417-2421, p. 2419; Staudinger/Rauscher 2004, § 1599, nr. 16, 17.

317 BGH 12 January 2005 (nr. XII ZR227/03), FamRZ 2005, 342. Also Ferrand 2006, p. 446.

318 See note 298 and 299.

319 MünchKomm/Wellenhofer 2008, § 1599, nr. 15.

320 BGH 12 January 2005 (nr. XII ZR60/03), NJW 2005, 497; FamRZ 2005, 665.

321 BGH 12 January 2005 (nr. XII ZR227/03), FamRZ 2005, 342.

322 BGH 12 December 2007 (nr. XII ZR 173/04), FamRZ 2008, 501.

323 Staudinger/Rauscher $2004, \S 1599$, nr. 21.

${ }^{324}$ BGH 12 January 2005 (nr. XII ZR60/03), NJW 2005, 497; FamRZ 2005, 665 and BGH 12 January 2005 (nr. XII ZR227/03), FamRZ 2005, 342. On these decisions see inter alia Ferrand 2006; Wellenhofer 2005, p. 666.

325 Bundesgesetzblatt 2008 Teil I nr. 28, p. 441. See also Helms 2008; Helms 2008a; Schwab 2008; Frank \& Helms 2007.

${ }^{326}$ Bundesverfassungsgericht 13 February 2007, 1 BvR 421/05.

327 BT Drucks. 16/6561, p. 13.
} 
test procedure comply with the official quality requirements of the German federal medical council (Bundesärztekammer).

The legal father, the mother and the child are obliged to co-operate with the privately arranged test. The person involved who does not comply with the order, can be forced to do so in a compulsory procedure. ${ }^{328}$ The result of the DNA test does not influence the personal status of the child. However, if the test shows that the man is not the father, it constitutes and Anfangsverdacht, on the basis of which the legal paternity can be contested.

No other persons than the legal father, the mother or the child can be compelled to consent to a privately arranged DNA test. The biological father who is not the legal father of the child can only be subjected in a procedure for judicial establishment of legal paternity ( $\S$ $1600 \mathrm{~d}$ BGB). The alleged biological father who is not the legal father of the child is also not allowed to apply for an order under § 1598a BGB. The legislator wanted to avoid the family life of the legal family being interrupted by a third person claiming to be the legal father of the child. ${ }^{329}$

Unlike in a procedure for annulment of legal paternity, the applicant in a procedure for consent for a privately arranged DNA test does not need to establish an Anfangsverdacht. The application is also not subject to a period of limitation. ${ }^{330}$ However, $\S 1598$ a (3) BGB allows the court to adjourn its decision if, also taking into account the interests of the legal father and the mother, the clarification of the biological affiliation of the child will lead to considerable harm to his wellbeing. The legislator especially thought of psychological and physical harm, like danger for suicide or aggravation of a serious illness of the child. ${ }^{331}$ The application shall not be rejected, but only adjourned. The period obviously depends on the circumstances of the case.

Thus, under German law there are three different scenarios for the order of a DNA test. A DNA test can be ordered in a procedure for judicial establishment of legal paternity. The applicant for judicial establishment of legal paternity does not need to establish an Anfangsverdacht. In a procedure to contest existing legal paternity, the applicant still has to raise an Anfangsverdacht, but it is easily established because the legal father, the child and the mother can be obliged to take part in a privately arranged DNA test. It is also possible that the Anfangsverdacht is established by showing that the legal father and the mother could not have had intercourse during the conception period. ${ }^{332}$ In that case the court can order a medical test ex officio or at the request of the parties if the Anfangsverdacht has been established. The persons involved are obliged to co-operate with the medical test if the testing method is effective and if the medical examination is harmless to the person's health. 333 A refusal to co-operate without a good reason or without any reason at all can ultimately be sanctioned with the taking of bodily samples by force..$^{334}$

\subsection{Annulment of legal parenthood}

Annulment of legal parenthood or the possibility to contest it (we shall use these phrases as synonyms) is a mechanism which provides for the possibility to bring legal parenthood in conformity with the grounds for legal affiliation. Therefore, procedures for annulment of legal parenthood only exist in legal systems that do not guarantee that legal parenthood is in

\footnotetext{
${ }^{328}$ BT Drucks. 16/6561, p. 13.

${ }^{329}$ BT Drucks. 16/6561, p. 12.

${ }^{330}$ BT Drucks. $16 / 6561$, p. 12. If the applicant wants to use the privately arranged DNA test to contest legal paternity, he or she must abide by the periods of limitation of $\S 1600 \mathrm{~b}$ BGB.

331 BT Drucks. 16/6561, p. 13.

332 See note 319

333 §372a (1) Zivilprozessordnung; § 178 Familienverfahrensgesetz.

334 §372a (2) Zivilprozessordnung; § 178 Familienverfahrensgesetz.
} 
conformity with the grounds for legal parentage. 335 It has been shown above that under English law, the legal parenthood of the birthmother and the biological father or the consenting partner exists by operation of law. Therefore, English law does not have a separate procedure to annul legal parenthood.

Also Dutch, German and Swedish law do not have a procedure for the annulment of legal maternity, because the legal maternity exists automatically under these legal systems. They only have a procedure for the annulment of legal paternity.

Under French law neither the procedures for the establishment of legal maternity, nor the procedures for the establishment of legal paternity guarantee that the legal parenthood of the biological parents or the consenting partner shall be established. Therefore, the law provides for a procedure to annul both legal maternity and legal paternity.

In most cases it is only possible to contest legal parentage in a judicial procedure. Procedures for annulment of legal parenthood are always restricted and there are a lot of possible restrictions: locus standi, statutory periods of limitation and additional requirements such as lack of capacity at the moment of acknowledgment or the absence of apparent status. Also, the rules on evidence restrict the possibility to contest legal parenthood in certain legal systems. In some particular cases it is possible to annul legal parentage in an administrative procedure.

\subsubsection{The ground for annulment of legal parenthood}

Under each of the legal systems considered, the ground for annulment of legal parentage is that the legal parentage does not correspond with the ground for legal parentage of the legal system involved. Thus, under Dutch and German law legal paternity can be contested if it is proven that the legal father is not the biological father of the child. 336 However, it will be shown in the following paragraph that aside from the lack of biological affiliation, Dutch law has a considerable list of additional requirements that must be fulfilled in order to contest existing legal parentage.

Under Swedish law, legal parenthood can be contested if it is proven that the legal father is not the biological father of the child. 337 In case of assisted reproduction the Föräldrabalk contains different definitions of legal paternity and legal parenthood. § 1:6 Föräldrabalk provides that in case of insemination of the mother the husband or cohabiting partner of the mother who consented to the insemination is the father if it is likely that the child has been conceived as a result of that insemination. \& 1:7 Föräldrabalk provides the same for the case when the egg cell of the mother or another egg cell has been fertilised outside the body of the mother with the consent of her husband or cohabiting partner. In these cases, the legal paternity can be annulled on the ground that the husband or partner did not consent or that the child is not born as a result of the insemination or the fertility treatment. 338

§ 1:9 Föräldrabalk provides that the female registered partner or cohabiting partner of the mother is the parent of the child if she consented to the fertility treatment of the mother and if the treatment took place within the framework of Swedish law. Under Swedish law only the legal paternity of the mother's husband exists ex lege. The female partner has to acknowledge her legal parenthood with the consent of the socialnämnd. ${ }^{339}$ The socialnämnd only consents if it has established that the requirements of $\S 1: 9$ Föräldrabalk are satisfied.

\footnotetext{
335 The possibility to set aside judicially established legal parenthood in a revision procedure falls outside the scope of this thesis.

${ }^{336}$ Germany: § 1599 (1) BGB. Netherlands: articles 1:200 (1), 205 (1) Burgerlijk Wetboek.

337 § 1:2 Föräldrabalk (1949:381).

338 Singer 2000, p. 341, 342.

$339 \S 1: 9$ (2) in conjunction with § 1:4 Föräldrabalk (1949:381).
} 
Therefore, in practice the annulment of the legal parenthood of the female partner of the mother is a rarity. Still, on the basis of $\S 1: 9$ in conjunction with $\S 1: 4$ (2), Föräldrabalk her legal parenthood can be annulled if the requirements of § 1:9 Föräldrabalk are not satisfied.

Under French law the ground to contest legal parentage is that the legal parentage is not in conformity with the biological affiliation of the child (except in case of artificial reproduction with donor semen). The applicant has to prove that the legal mother did not give birth to the child or he has to prove that the legal father is not the biological father of the child.

There are various regimes under which legal parentage can be contested. Above, the procedure to contest legal parentage that exists on the basis of apparent status has been discussed. ${ }^{340}$ Such legal parentage cannot only be contested on the basis that it is not in conformity with biological affiliation, but also on the basis that the apparent status (the title) that has been recorded in an affidavit (art. 317 Code civil) or established in a judgment (art. 330 Code civil) does not exist or does not have the quality to raise the presumption of paternity necessary to establish legal paternity. In the latter case, one does not contest the legal parentage as such, but the title for legal parentage.

The distinction between title and legal parentage also exists with regard to acknowledgment of paternity or maternity. Legal parenthood that exists on the basis of acknowledgment of paternity can be contested on the basis that it is not in conformity with the biological affiliation of the child; it can also be contested by arguing that the acknowledgment as such is not valid, for example because formal requirements are not fulfilled or because the acknowledger made the acknowledgment under the influence of a defective will. 341

This paragraph will focus on annulment of legal parentage that is not established by apparent status, but automatically (marital paternity), by registration (legal maternity) or by acknowledgment (legal paternity and maternity). For these cases the regime is set out in articles 332, 333 and 334 Code civil. Under these provisions legal parentage can only be contested if it is proven that the legal mother did not gave birth to the child or that the legal father is not the biological father of the child, unless the provisions on assisted reproduction apply (art. 311-19 and 20 Code civil). ${ }^{342}$ Next to these provisions, the public prosecutor has the right to apply for annulment under article 336 Code civil.

\subsubsection{Restrictions on judicial annulment of paternity under Dutch law}

Apart from the restrictions on annulment of legal paternity which will be discussed under the following headings, Dutch law contains a set of restrictions which are not found in the other legal systems. It concerns restrictions on the possibility to contest marital paternity and paternity established by of acknowledgment of paternity.

The legal parents cannot contest marital paternity under Dutch law if the man knew that the woman was pregnant before he entered into the marriage. ${ }^{343}$ This first exception is almost a literal copy of article 314 French civil code of 1804 . The rationale of this rule has been described by the French legislator as follows:

On présume alors qu'il n'a contracté le mariage que pour réparer sa faute personnelle ; on présume qu'un pareil hymen n'eut jamais été consenti, s'il n'eût persuadé que la femme portait dans son sein le fruit de leurs amours : et lorsqu'il a eu dans la conduite

\footnotetext{
${ }^{340}$ See $\S$ 3.3. Establishment of parenthood by apparent status.

${ }^{341}$ See $§ 3.2 .2 .1$. The legal nature of the acknowledgment of parenthood.

342 See $\S 2.2$. Grounds for legal parenthood of the second parent.

343 Article 1:200 (2) Burgerlijk Wetboek.
} 
de cette femme une telle confiance qu'il a voulu que leurs destinées fusses unies, comment pourrait-on l'admettre à démentir un pareil témoignage?344

At the introduction of the new Dutch family law the French justification was maintained. It was argued that most of the time the husband was the father of the child that was fathered before and born after the marriage. ${ }^{345}$

According to the legislator, it would go too far to uphold the husband's responsibility for his wife's children under all circumstances. ${ }^{346}$ Therefore, the exception does not apply if the mother deceived the man as to who had begotten the child. ${ }^{347}$ Deceit is defined in article 3:44 (3) Burgerlijk Wetboek. It means that someone persuades another person to perform a juridical act (e.g. marriage) by deliberately making any improper statement, by deliberately suppressing any fact that the suppressor was obliged to mention or by another artifice. The legislator suggested that the woman who does not tell her fiancé before the marriage that the child she is carrying could have been or was fathered by another man, commits deceit within the meaning of article 3:44 (3) Burgerlijk Wetboek. ${ }^{348}$

The second exception to the rule that the legal paternity can be contested on the ground that the legal father is not the biological father is contained in article 1:200 (3) Burgerlijk Wetboek. The husband and the mother cannot contest the husband's paternity if the husband consented to an act which could have resulted in the begetting of the child. The rationale of the exception is that on the basis of his marriage to the mother, the husband is responsible for the children who are born to his wife. ${ }^{349}$

Also the second exception does not apply if the mother deceived the man as to who had begotten the child. Thus, if the husband consented to fertility treatment with donor semen, but if the child is begotten by a friend of the mother, the husband is allowed to contest his legal paternity. The same applies if the husband allowed sexual intercourse with one specific person and the child is begotten by another person. 350

Also, in order to contest legal paternity on the basis of acknowledgment, Dutch law provides for additional requirements, in addition to the lack of genetic affiliation. If the acknowledgment took place during the child's minority, the child can apply without further restrictions for annulment of legal parenthood within the prescribed period of limitation (see next paragraph). If the acknowledgment took place after the child has come of age, the child has no right to apply for annulment of legal paternity at all. ${ }^{351}$

The legal parents can only contest legal paternity on the basis of acknowledgment if the acknowledgment or the consent to the acknowledgment has come about under the influence of threats, mistake, deceit or, if the acknowledgment was done during the minority of the acknowledger or the mother, undue influence (bedreiging, dwaling, bedrog of misbruik van omstandigheden). ${ }^{352}$ This can be the case if the mother deceived the acknowledger as to the paternity of the child. 353

\footnotetext{
${ }^{344}$ Motifs des lois du code civil des français, promulguées en l'an XI et l'an XII, Tome Premier, De l'imprimerie nationale (Paris, an XII, 1804), p. 147.

345 Parlementaire Geschiedenis/Boek 1 Personen- en Familierecht 1962, p. 1301.

346 Parlementaire Geschiedenis/Boek 1 Personen- en Familierecht 1962, p. 1304, 1307.

347 Article 1:200 (4) Burgerlijk Wetboek.

348 Kamerstukken I, 1997-1998, 24649, nr. 11a, p. 4.

349 Parlementaire Geschiedenis/Boek 1 Personen- en Familierecht 1962, p. 1303, 1307.

350 Kamerstukken I 1997-1998, 24649, nr. 11a, p. 4; nr. 11d, p. 5.

351 Article 1:205 (1) under a Burgerlijk Wetboek.

352 Article 1:205 (1) under b and c Burgerlijk Wetboek. The concepts threats, mistake, deceit and undue influence are defined in articles 3:44 and 6:228 Burgerlijk Wetboek.

353 Kamerstukken II, 1995-1996, 24 649, nr. 3, p. 20.
} 
Before the reform of Dutch law on legal parentage in 1998, annulment of acknowledgement on the basis of a defective will on the one hand and annulment of acknowledgment for lack of genetic affiliation on the other were two different actions. ${ }^{354}$ As a result of the law reform in 1998 the two actions have been merged and the applicant has to prove both a defective will on the part of the acknowledger or the consenting mother and he has to prove that the acknowledger is not the biological father of the child.

De Boer points out the parallel of the impossibility for the husband to contest his paternity if he knew before the marriage that his fiancée was pregnant and the strict requirements to contest legal paternity that exists on the basis of acknowledgment. In both cases the legal paternity can only be contested if the legal father or the mother can show deceit in case of marital paternity or threats, mistake, deceit or undue influence in case of acknowledgement. Where acknowledgment is the acceptance of legal paternity by means of a juridical act, marrying a pregnant woman is accepting legal paternity rebus ipsis et factis.355 In both cases, the legal father and the mother cannot dispose of their responsibility for the child which they consciously accepted. 356

\subsubsection{Annulment of legal parenthood and apparent status under French law}

Above, already two functions of apparent status in the French law on legal parentage have been discussed. The concept is relevant for the legal paternity of the mother's husband if the child is born during a divorce procedure or if the husband is not registered as the father on the child's birth record (art. 313 Code civil). ${ }^{357}$ The existence of apparent status can also establish legal parentage if the existence of apparent status is evidenced by an affidavit (art. 317 Code civil) or judgment (art. 330 Code civil). This function is especially relevant if the parent or parents of the child omitted to establish their legal parentage during their lifetime. ${ }^{358}$ The third function of apparent status will be discussed in this paragraph: its existence in conformity with the title of the child's legal parentage limits the locus standi and the period of limitation. 359

The title of the child's legal parentage is the document that is evidence of the child's legal parentage. According to article 310-3 Code civil these documents are the birth record and the instrument of acknowledgment. The birth record is evidence of the fact that the woman mentioned as the mother gave birth to the child. ${ }^{360}$ Marital paternity is proven by the birth record in combination with the marriage certificate. ${ }^{361}$ The instrument of acknowledgment proves legal paternity out of wedlock and in exceptional circumstances it also proves legal maternity. According to article 310-3 Code civil, legal parentage is also proven by the affidavit recording the apparent status of the child. Still, the affidavit itself is not a title for legal parentage, but the apparent status that is proven by the affidavit is the title for legal parentage. ${ }^{362}$

If the child has a title and a corresponding apparent status the locus standi and the period of limitation to contest the legal parentage that follows from the title are more restricted than when the title for legal parentage is not supported by apparent status. The origin of the rule is that if two means of evidence of parentage (the title and apparent status)

\footnotetext{
${ }^{354}$ Former articles 1:225 (1) and (2) Burgerlijk Wetboek. See also Kamerstukken II, 1995-1996, 24 649, nr. 3, p. 20.

355 Asser/De Boer 2006, nr. 703.

356 Kamerstukken II, 1995-1996, 24 649, nr. 3, p. 10.

${ }^{357}$ See § 3.1.3. Ex lege existence of the legal paternity of the husband under Dutch, French, German and Swedish law.

358 See $\$ 3.3$. Establishment of parenthood by apparent status.

359 Articles 333 and 334 Code civil.

360 Malaurie \& Fulchiron 2006, nr. 1013.

361 See also Malaurie \& Fulchiron 2006, nr. 1016. Circulaire relative à la présentation de l'ordonnance nr. $759-2005$ du 4 juillet 2005 portant réforme de la filiation, Bulletin officiel du Ministère de la Justice, 25 October 2006, nr. 103, p. 109211 (NOR: JUSC0620513C), at p. 122.

362 Cf Massip 2006, nr. 48.
} 
coincide, it is very unlikely that the person involved is not the parent of the child. In such a case one should not start a speculative discussion about the biological affiliation of the child that at the time could not be proven with certainty anyway. ${ }^{363}$ Nowadays the uncertainty with regard to the biological affiliation is not a valid argument anymore to restrict the possibility to contest legal parentage. However, the effect of the possibility to determine with such precision the genetic affiliation might destroy the existing family life. If a man, a woman and a child are living together as a family, others should not be allowed to contest the legal paternity of the man solely because he is not the biological father of the child. That is not in the interest of the child, it does not coincide with the social significance of parentage and it does not enhance legal certainty. ${ }^{364}$ Thus the restriction of the possibility to contest the legal parentage following from a title and supported by apparent status is based on the wish to protect existing social relations by restricting the number of people that can contest it and by providing for shorter periods of limitation (see below, for an overview of the periods of limitation).

If the title of legal parentage is not supported by apparent status, the chance is greater that the legal parentage is not in conformity with the biological affiliation of the child and the annulment of legal parentage does not affect existing social relations. Therefore, in such a case any interested person can contest the legal parentage within a period of ten years. ${ }^{365}$

\subsubsection{Locus standi for annulment of legal parenthood}

Various groups of persons may have an interest in contesting the existing legal parentage: the mother or the child may want to contest existing legal paternity to ban the legal father from their lives or to give the real father the possibility to establish his legal paternity. The legal father who is not the real father may not want to take responsibility of a child that is not his own. The biological father has an interest in the annulment of legal paternity in order to establish his own legal paternity. The heirs of the legal father have an interest in the annulment of legal parentage, because the fewer heirs the bigger their share in the estate of the deceased father. Also, the state has an interest in the annulment of legal parentage if legal parentage has been established solely in order to grant the child or the parent a right to reside on the territory or if parentage has been established by circumventing mandatory rules. These are only a few examples of the main stakeholders.

Although many persons have a potential interest in contesting the existing legal parentage, the number of persons that are allowed to apply for annulment of legal parentage is limited. In all legal systems the main reason to restrict the locus standi is the protection of the legal family and the private life of the members of that family. ${ }^{366}$ This common idea does not prevent the existence of considerable differences on this point among the legal systems under consideration.

\subsubsection{The child and his parents}

Under German law, the child and the legal parents have the right to apply for annulment of legal paternity. ${ }^{367}$ As will be explained below, the applicants' rights are not unrestricted; they are limited in time. Another restriction, which is also found in Dutch law, is that the legal parents are not allowed to apply for annulment of legal paternity if they have

\footnotetext{
363 Locré 1807, p. 145.

364 Dekeuwer-Defossez 1999, p. 26

${ }^{365}$ Dekeuwer-Defossez 1999, p. 51

${ }^{366}$ France: Massip 2006, p. 64. Germany: MünchKomm/Wellenhofer 2008, § 1600, nr. 1. Netherlands: Kamerstukken II, 1995-1996, 24 649, nr. 3, p. 18; Sweden: Singer 2000, p. 167.

$367 \S 1600$ (1) BGB.
} 
consented to the fertility treatment. 368 The second restriction has been inserted by the Gesetz zur weiteren Verbesserung von Kinderrechten of the 12th of April 2002.369 The legislator wanted to provide for a minimum regulation to protect the child conceived following fertility treatment with donor semen. ${ }^{370}$

Besides the members of the legal family, the alleged biological father also has a limited right to apply for annulment of legal paternity. The right of the alleged biological father follows from a decision of the Bundesverfassungsgericht from 2003.371 In that case, the biological father and the mother planned to have the child together. The man was involved in all preparations for the birth of the child and he and the mother decided on the name of the child. After the child was born, the mother refused to consent to the acknowledgment of the biological father. When he applied for the judicial establishment of his paternity, it appeared that the mother had already consented to the acknowledgment of paternity of a second man in order to block the establishment of the legal paternity of the biological father. 372

The Bundesverfassungsgericht held that the protection of the right of the biological father to be recognised in law as the legal father of the child does not automatically take precedence over the rights and duties that are conferred by law on the legal father of the child. From a constitutional point of view there is no objection against the choice of the legislator to protect the status of the legal father from actions by the biological father if a social familial relationship exists between the child and his legal parents. After all, if the legal paternity and biological paternity do not coincide one needs a criterion to make a choice. In establishing that criterion not only the interest of the biological father but also the interests of the legal parents and the child himself are at stake.

The exclusion of the biological father from the right to apply for annulment of legal paternity is based on the protection of the social familial relations. ${ }^{373}$ Therefore, the Bundesverfassungsgericht held that $\S 1600$ BGB violates article 6 (2) of the German Grundgesetz to the extent that it does not allow the biological father to apply for annulment of legal paternity if no social familial relation exists between the child and his legal father. If a man acknowledged his paternity without being the biological father of the child and if he does not live with the mother and the child together, there is no reason to exclude the biological father from the possibility to establish his legal paternity. 374

The decision of the Bundesverfassungsgericht has been incorporated in the German law by the Gesetz zur Änderung der Vorschriften über die Anfechtung der Vaterschaft und das Umgangsrecht von Bezugspersonen des Kindes, zur Registrierung von Vorsorgeverfügungen und zur Einführung von Vordrucken für die Vergütung von Berufsbetreuern of the 23rd of April 2004.375 Today, § 1600 (2) German civil code provides that the biological father is allowed to apply for annulment of legal paternity, but only if there is no social familial relationship (sozial-familiäre Beziehung) between the legal father and the child. Such a relationship is presumed to exist if the legal father has brought the child up and if the legal father lived or lives together with the legal mother and child. ${ }^{376}$ The right of

\footnotetext{
$368 \S 1600$ (5) BGB.

369 Bundesgesetzblatt 2002 Teil I nr. 23, p. 1239.

370 BT Drucks. 14/2096, p. 7.

371 Bundesverfassungsgericht 9 April 2003, 1 BvR 1724/01.

372 For a similar case before the Dutch Hoge Raad, see note 390 below.

373 BR Drucks. 13/4899, p. 58.

374 Bundesverfassungsgericht 9 April 2003, 1 BvR 1724/01, par. 55-87.

375 Bundesgesetzblatt 2004 Teil I nr. 18, p. 598. See also Höfelmann 2004; Wellenhofer-Klein 2003.

$376 \S 1600$ (4) BGB.
} 
the alleged biological father is restricted in order to protect legal certainty and the legal family. ${ }^{377}$

If the court annuls the legal paternity on the application of the biological father under $\S$ 1600 (2) BGB, the court ex officio has to judicially establish the legal paternity of the applicant. 378 The legislator deemed it unacceptable that the child would remain fatherless after a successful paternity suit by the biological father. ${ }^{379}$

Under French law, the locus standi to contest legal parentage depends on whether or not the child has a title in conformity with his apparent status. Often the title and the apparent status coincide. In such a case, only the child, the father, the mother and the person claiming to be the real parent can contest existing legal parentage (art. 333 Code civil).

If the title and the apparent status of the child do not reflect the same legal parentage, the legal parentage can be contested by any interested person (art. 334 Code civil). In such a case, the legal parentage that is contested is the legal parentage that has been established by the title and not the parentage that is reflected by the apparent status.

There is a difference of opinion as to when the apparent status must be in conformity with the title. Malaurie and Fulchiron argue that if the child has had an apparent status in conformity with the title of his legal parentage during a certain period of his life, article 333 Code civil should be applied instead of article 334 Code civil. 380 Massip holds a different view and argues that in principle article 333 Code civil only applies if the title and the apparent status coincide at the moment of the action. ${ }^{381} \mathrm{He}$ himself contends though that this view is difficult to reconcile with the text of article 333 Code civil which provides that the action to contest legal parentage is limited to five years after the apparent status in conformity with the title has ceased to exist. The text itself implies that the title and the apparent status do not need to be in conformity at the moment of the action. For example, four years after the apparent status has ceased the action as described in article 333 Code civil can still be exercised; in that case there is no apparent status in conformity with the title at the moment of the action.

It appears that the position of the biological father under French law is much better than under German law. Even if the child has apparent status with regard to his legal parents, which is for these purposes comparable to the German sozial-familiäre Beziehung, 382 the biological parents can contest legal parentage (art. 333 Code civil). Under German law, the biological father can only contest legal paternity if the child does not have a social familial relationship with the child (§ 1600 (2) BGB).

Under Dutch law, only the legal parents and the child have standing to contest the legal paternity of the mother's husband or the legal paternity which exists on the basis of acknowledgment of paternity. ${ }^{383}$ However, it has been shown above that the rights of the legal father and the legal mother are restricted. ${ }^{384}$ The husband and the mother cannot contest his legal paternity if he knew before the marriage that the woman was pregnant or if they consented to the act that could have resulted in the conception of the child. The acknowledger and the mother can only contest the legal paternity on the basis of acknowledgment of paternity if they can prove that the acknowledgement or the consent

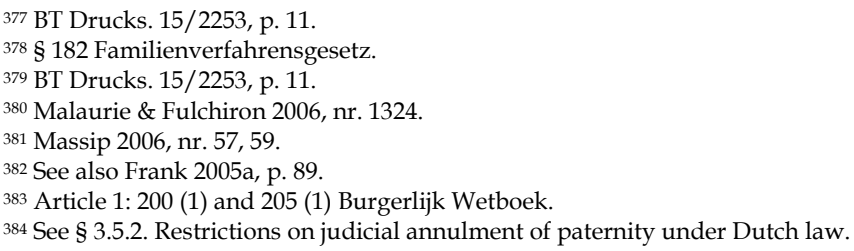


thereto was given under the influence of threats, mistake, deceit or, if the acknowledgment was done during the minority of the acknowledger or the mother, undue influence. These restrictions do not apply to the child that has been born during a marriage or that has been recognised during his minority. The child that has been recognised after he has come of age cannot contest the legal parentage of the acknowledger, because the child had to consent to the acknowledgment himself.

It appears that contrary to French and German law, the biological father does not have the right to contest the legal paternity of the husband of the mother or the man who acknowledged his paternity. This has given rise to the same kind of situations as in the case before the Bundesverfassungsgericht described above. ${ }^{385}$

Under Dutch law, the man cannot apply for the judicial establishment of his legal paternity, but instead he can apply for judicial consent to his acknowledgement if the mother does not consent to his acknowledgment. 386 Still, the mother can block the possibility of the begetter applying for judicial consent by consenting to the acknowledgment of paternity by a third man. Already before the 1998 reform of the Dutch law on legal parentage the Hoge Raad was asked to rule on these kind of cases.

On 22nd of February 1991 the Hoge Raad set out the rules for the begetter to contest the acknowledgment of paternity by another man. ${ }^{387}$ If the biological father has family life with his child within the meaning of article $8 \mathrm{ECHR}$, the criterion whether or not the man has a right to judicial consent to his acknowledgment, depends on whether or not the mother and the child share family life together. If that is the case, the biological father only has a right to judicial consent if the mother has no reasonable interest in the refusal of her consent. ${ }^{388}$ If, on top of that she has consented to the acknowledgment of paternity of a third man, her consent to that acknowledgment is ineffective if it is given with no other reason than to deprive the biological father of his rights following from article 8 ECHR. 389

After the reform of Dutch law on legal parentage, the Hoge Raad had to reconsider its case law which it did in its decision of the 12th of November $2004 .{ }^{390}$ In this case also, the mother consented to the acknowledgment of paternity of a man who was not the begetter. ${ }^{391}$ The begetter claimed that he repeatedly requested the mother to consent to his acknowledgment, but that was disputed by the mother. The child was born in 1996, on the 30th of March 2001 the begetter's lawyer requested the mother to consent to the father's acknowledgment. The mother refused and on the 17th of April 2001 the new boyfriend of the mother acknowledged his paternity concerning the child. On the 3rd of January 2002 the begetter applied for the first time for judicial consent to his acknowledgment.

The Hoge Raad observed that the legislator did not want to give the begetter the right to contest the legal paternity of the man who acknowledged paternity with the consent of the mother. In the view of the legislator, the begetter should apply for judicial consent if the mother refuses her consent to his acknowledgment. Only if the begetter could not apply for judicial consent because the mother had already consented to the acknowledgment of another man, the court has to determine whether the mother's consent is ineffective on the basis of abuse of right. ${ }^{392}$

\footnotetext{
385 See note 371 .

386 See § 3.2.2.3. The consent to acknowledgment of parenthood.

${ }^{387}$ Hoge Raad, 22 February 1991, NJ 1991/376.

388 See also Hoge Raad, 18 May 1990, NJ 1991/374 and note 159.

389 See also Hoge Raad, 20 December 1991, NJ 1992/598; Hoge Raad, 18 September 1998, NJ 1999/480; Hoge Raad, 17 December 1999, NJ 2000/121.

390 Hoge Raad, 12 November 2004, NJ 2005/248.

391 Since the reform of Dutch law on legal parentage, the law distinguished between the biological father, the begetter and the donor. See note 157.

392 Kamerstukken II 1996-1997, 24649, nr. 6, p. 21, 40.
} 
In the normal situation where the biological father has had enough time to apply for judicial consent to his acknowledgment, the mother only abused her right of consent if her consent to the acknowledgement of a third person is given with the sole objective to harm to interests of the begetter of the child and if there is thus no respectable interest in the refusal of her consent. 393

If, however, the begetter could not apply for judicial consent in time, for example because he did not know that he was the begetter of the child, the threshold to determine whether or not the mother abused her right allows for a balance of interests. In that case, the court has to determine whether the mother, taking into account the disproportionality between the interests of the begetter in his acknowledgment and the interest of the mother and the child, could have come to her decision in all reasonableness to consent to the acknowledgment of the other man. ${ }^{394}$

It appears that the begetter, who has been deprived by the mother of the possibility to apply for judicial consent to his acknowledgment, because the mother strategically consented to the acknowledgment of another man, is in a worse position than the begetter who can still apply for judicial consent. ${ }^{395}$

First of all, the references in the decision of the Hoge Raad of 2004 to its decision from the 20th of December 1991 suggests that the biological father who has been intentionally deprived of his possibility to apply for judicial consent, has to have had family life with the child (art. 8 ECHR) in order to be able to contest the acknowledgment of the third person. After all, that was also a requirement in the decision from 1991. The begetter who applies for judicial consent under article 1:204 (3) BW does not have to prove the existence of family life. This can be difficult if the birth of the child that has been fathered by him has been concealed from him by the mother.

Secondly, even if the begetter can prove family life, the criterion whether or not he has a right to establish legal paternity is not the same as in the case where the mother did not consent to the acknowledgment of paternity of another. If the mother consented to the acknowledgment of another man, the criterion is whether or not the mother could reasonably give her consent taking into account all relevant interests. The criterion for judicial consent under article 1:204 (3) BW is whether or not the acknowledgment of paternity disturbs the relationship of the mother with her child or the interest of the child.396

It appears that the German Bundesverfassungsgericht and the Dutch Hoge Raad have reached different solutions for the same case. Under German law § 1600 (2) BGB requires that no social familial relationship exists between the child and his legal father. If there is no social familial relationship between the child and his legal father, the biological father can contest the legal paternity of the acknowledger and have his own legal paternity established. $\S 1600$ (2) BGB does not require the existence of a social familial relationship between the begetter and the child.

Under the case law of the Hoge Raad the begetter can contest the acknowledgment if he has family life with the child. Possible family life between the child and the legal father seems irrelevant. However, it must also be established that the mother could reasonably give her consent to the other man taking into account all the interests involved. If family life exists between the child and the other man, the mother probably has a reasonable ground for her consent to his acknowledgment.

\footnotetext{
393 Hoge Raad, 12 November 2004, NJ 2005/248, par. 3.5.3.

${ }^{394}$ Hoge Raad, 12 November 2004, NJ 2005/248, par. 3.5.5.

395 See $§ 3.2 .2 .3$. The consent to acknowledgment of parenthood.

396 See note 155 .
} 
Under Swedish law only the child and the legal father have standing to contest marital paternity. ${ }^{397}$ The child can contest the legal paternity of the mother's husband himself as from the age of 15 years if he is sufficiently aware of the effects of his action. ${ }^{398}$ In all other cases, a legal representative (förmyndare or god man) shall act on behalf of the minor. ${ }^{399}$ In the normal situation where the mother has custody over the child, she is also the legal representative (förmyndare) of the child. ${ }^{400}$ As a result she is allowed to contest the legal paternity of her husband on behalf of the child. 401

If neither the husband nor the mother contests the legal paternity of the husband, the local public guardianship office (överförmyndare) can appoint a guardian ad litem (god man) to contest the legal paternity on behalf of the child. The criterion for the public guardianship office to appoint a guardian ad litem is that the interest of the child conflicts with the interest of the mother and/or her husband. 402 There are no official guidelines to determine whether or not conflict of interest exists if there are indications that the husband is not the father of the child. 403

The biological father who is not the legal father does not have the right to contest the legal paternity of the mother's husband. However, he can apply to the socialnämnd on the basis of $\S 1: 9$ Föräldrabalk and request them to investigate the affiliation of the child. 404 The investigation can only be started if there is no reasonable suspicion that the investigations will harm the child or the psychological well-being of the mother. ${ }^{405}$ The socialnämnd itself cannot contest the legal paternity of the husband, but the husband or the mother (on behalf of the child) can on the basis of the findings of the socialnämnd.

Swedish law does not have statutory provisions on standing to contest legal paternity on the basis of acknowledgment. It is generally accepted that the legal father and the child have standing. 406 It must be born in mind though that if the acknowledgement of paternity took place in Sweden the possible chance of annulling the legal paternity based on acknowledgment is not very high. After all, the acknowledgment is only valid if the socialnämnd consents and it only consents if it has established that the acknowledger is the biological father of the child.

\subsubsection{The heirs}

Under Dutch, French and Swedish law the heirs also have standing to contest legal paternity. Under German law, the heirs or the descendants do not have the right to contest existing legal parentage. Also, the law does not provide the possibility for the heirs to continue a proceeding which has been started by one of the possible applicants during his or her lifetime. ${ }^{407}$

Dutch law provides that if the legal father or mother dies before the expiry of the period of limitation, the descendants of the legal father or, as the case may be, the legal mother are allowed to contest the legal paternity of the husband or the acknowledger. ${ }^{408}$ The descendants have to apply within one year after the death of the legal parent involved or one year after the descendant has been informed of the legal parent's death. If the legal

\footnotetext{
397 § 3:1 and 3:2 Föräldrabalk (1949:381).

398 Walin \& Vängby vol. I, p. 3:13; Singer 2000, p. 159.

399 § 3:4 Föräldrabalk (1949:381).

400 § 10:2 Föräldrabalk (1949:381).

401 Socialstyrelsen 2005, p. 99; Singer 2000, p. 168.

$402 \S 11: 2$ (3) Föräldrabalk (1949:381).

403 Singer 2000, p. 164.

404 Prop. 1975/76:170, p. 140; Socialstyrelsen 2005, p. 99; Singer 2000, p. 170.

405 Socialstyrelsen 2005, p. 38.

${ }^{406}$ Karnov/Saldeen 2007, Föräldrabalk, note 17; Saldeen 2005, p. 77 Walin \& Vängby vol. I, p. 1:15; Singer 2000, p. 196.

${ }^{407}$ Staudinger/Rauscher 2004, § 1600, nr. 49.

408 Article 1:201 (1) and 205 (5) Burgerlijk Wetboek.
} 
parents do not have other descendants than the child in question, the parents of the deceased father or mother are allowed to contest the legal paternity of their son or their sonin-law.

If the child dies before the expiry of his period of limitation the descendants of the child are allowed to contest their parent's legal parentage within one year after the death of the child or one year after the descendant has been informed of the child's death. If the child was still a minor at the moment of his death, the descendant has to act within one year after the child would have come of age. ${ }^{409}$ The legal parents of the deceased child do not derive a right to contest the legal parentage from the child because they have a right to contest for themselves.

Under French law, it has been shown that the heirs have a right of their own to contest legal parentage, if the title of the legal parentage of the child and his apparent status do not coincide. In such a case, any interested person is allowed to contest the legal parentage of the child. Only if the child has an apparent status in conformity with his title for legal parentage, the locus standi to contest legal parentage is restricted. In that case, article 322 Code civil provides that the heirs of a deceased person are allowed to contest the legal parentage if the deceased died before the expiry of the applicable period of limitation. The heir has to act within that period of limitation. 410

Under Swedish law only the wife and the heirs of the deceased husband are allowed to contest his legal parentage if the husband did not live together with the child on a permanent basis and if the man during his life did not acknowledge his paternity. The heirs have to act within one year after the child has claimed (part of) the estate on the basis of his affiliation with the deceased. 411 The law does not provide for a similar regulation in case the legal paternity is based on acknowledgment of paternity but it has been accepted by the Swedish Högsta Domstol.412

\subsubsection{The state}

The last person who has the right to contest existing legal parentage is the public prosecutor in France and the Netherlands and the 'zustandige Behörde' (competent authority) in Germany. Standing for the state to contest legal parentage has been introduced in Dutch law in 1947, in French law in 1972 and in German law in 2008.413 The right of the public prosecutor to contest legal parentage relates in particular to legal parentage that has been established by acknowledgment of maternity or paternity. Under Dutch and German law, it is provided explicitly that the openbaar ministerie or the zustandige Behörde can only contest legal paternity based on acknowledgment and not legal paternity based on the marriage.414 French law used to provide the same. ${ }^{415}$ In order to cancel the differential treatment of legal parentage in and out of wedlock the French public prosecutor is formally allowed to contest both legal parentage on the basis of marriage and legal parentage out of wedlock since ordonnance 2005/759.

\footnotetext{
${ }^{409}$ Article 1:201 (2) and 205 (5) Burgerlijk Wetboek.

410 Malaurie \& Fulchiron 2006, nr. 1074.

411 § $3: 1$ (3) Föräldrabalk (1949:381).

412 Karnov/Saldeen 2007, Föräldrabalk, note 17.

${ }^{413}$ France: Loi nr. 72-3 of 3 January 1972. Germany: Gesetz zur Ergänzung des Rechts zur Anfechtung der Vaterschaft of 13 March 2008, Bundesgesetzblatt Teil I, 2008, p. 313. Netherlands: Wet van 10 juli 1947, Stb. H 232.

${ }^{414}$ Germany: § 1600 (1) under 5 BGB. Netherlands: article 1:205 (2) Burgerlijk Wetboek.

415 Former article 339 Code civil.
} 
Under French law the public prosecutor has the right to apply for annulment of legal parenthood on the basis of three grounds. A prerequisite in both cases is that the legal parent is not the biological parent of the child. 416

The first ground is that it appears from the register itself that the legal parentage is not in conformity with reality. This is for example the case if the age difference between the acknowledger and the child is too small or if the acknowledger is a transexual person. 417

The second ground for the public prosecutor to contest legal parentage is in case of fraude à la loi or evasion of the law. Evasion of the law in relation to parentage means that one uses the rules on legal parentage for a purpose that is prohibited by law. For example, the public prosecutor is allowed to apply for annulment of acknowledgment of legal paternity and maternity if the acknowledgment is in fact a circumvention of the law on adoption. Also in the case of surrogacy, the establishment of the legal maternity of another woman than the birthmother constitutes a fraude à la loi, because articles 16-7 and 16-9 Code civil provide that surrogacy violates French public policy.418

Another case of evasion of the law exists when the acknowledgment of paternity or maternity is only done to secure a right of residence in France either for the acknowledger or for the child. ${ }^{419}$ This case is characterised by the fact that the acknowledger does not have any intention to take responsibility for the upbringing of the child. An indication of such a case occurs when someone acknowledges his paternity concerning children born to different women with a foreign nationality.

The acknowledgment of paternity by a man who is not the biological father of the child is not considered an evasion per se, although one could argue that the proper way to establish a parent-child relationship with a non-biological parent is by adoption. However, the so-called reconnaissance de complaisance does not constitute an evasion of the law. The reconnaissance de complaisance is the acknowledgment of paternity by a man who is not the biological father of the child but only a step-parent. It is considered a part of French culture for the man to accept the children of his partner or wife who were born before their relationship or marriage. 420

The third ground is mentioned in the Code de procédure civil. Article 423 provides that beyond the specific cases described by law, the public prosecutor has the right to act in any case to defend the public policy (ordre public). This ground has been invoked in a case where the public prosecutor applied for the cancellation of a transcription on the French register of birth of a Californian birth certificate which mentioned two French commissioning parents as the legal parents of the child. 421

Under Dutch law, the power of the public prosecutor is limited to contesting legal parentage on the basis of acknowledgment. The public prosecutor can only apply for annulment if the acknowledger is not the child's biological father and if his acknowledgment violates Dutch

${ }^{416}$ Circulaire relative à la présentation de l'ordonnance nr. 759-2005 du 4 juillet 2005 portant réforme de la filiation, Bulletin officiel du Ministère de la Justice, 25 October 2006, nr. 103, p. 109-211 (NOR: JUSC0620513C), at p. 161.

417 Circulaire relative à la présentation de l'ordonnance nr. 759-2005 du 4 juillet 2005 portant réforme de la filiation, Bulletin officiel du Ministère de la Justice, 25 October 2006, nr. 103, p. 109-211 (NOR: JUSC0620513C), at p. 160, 161. Malaurie \& Fulchiron 2006, nr. 1204, 1338-1339; Massip 2006, nr. 60.

418 Circulaire relative à la présentation de l'ordonnance nr. 759-2005 du 4 juillet 2005 portant réforme de la filiation, Bulletin officiel du Ministère de la Justice, 25 October 2006, nr. 103, p. 109-211 (NOR: JUSC0620513C), at p. 161. Malaurie \& Fulchiron 2006, nr. 1340.

419 Circulaire relative à la présentation de l'ordonnance nr. 759-2005 du 4 juillet 2005 portant réforme de la filiation, Bulletin officiel du Ministère de la Justice, 25 October 2006, nr. 103, p. 109-211 (NOR: JUSC0620513C), at p. 161. Malaurie \& Fulchiron 2006, nr. 1340; Massip 2006, nr. 60.

${ }^{420}$ Massip 2006, nr. 60. See also Circulaire relative à la présentation de l'ordonnance nr. 759-2005 du 4 juillet 2005 portant réforme de la filiation, Bulletin officiel du Ministère de la Justice, 25 October 2006, nr. 103, p. 109-211 (NOR: JUSC0620513C), at p. 161.

421 Cass. Civ. 1er, 17 December 2008, RCDIP 2009, 320, note Lagarde. 
public policy. ${ }^{422}$ There are various reasons why an acknowledgment of paternity can violate Dutch public policy. Just like in France, the public prosecutor can apply for annulment of the acknowledgment of paternity if the age difference between the child and the acknowledger is too small. ${ }^{423}$ Another situation where the acknowledgment of paternity violates Dutch public policy is when the acknowledgment is done with the sole objective of acquisition of Dutch nationality by the child. At the end of the 1980s and the beginning of the 1990s it appeared that Dutch nationals acknowledged their paternity with regard to children from the Philippines and the Dominican Republic with the aim of exploiting the children for prostitution in the Netherlands. ${ }^{424}$ Apparently, the right of the public prosecutor to annul the acknowledgment of paternity was not enough to tackle this practice because the commotion led to change of the Dutch nationality law: since 1st April 2003 a child could no longer obtain Dutch nationality by the acknowledgment of legal paternity. ${ }^{425}$ This drastic step has, however, now been undone by Act of 27 th of June 2008.426

The German legislator introduced the right of the competent authority (zustandige Behörde) to contest legal parentage in 2008. The law uses this abstract term, since every state of the German federation determines for itself which authority is the competent authority. ${ }^{427}$

The introduction of the right of the competent authority to contest legal parentage was a response to the problem that in some cases the acknowledgment of paternity was used solely to grant the child or the acknowledger a right to reside in Germany. ${ }^{428}$

$\S 1600$ (1) under 5 BGB provides that the competent authority is allowed to contest the acknowledgment of paternity. The competent authority is not designated by the federal government but by the different legislators of the German states (länder), which explains the rather vague formulation.

The competent authority can contest the acknowledgment of paternity if the acknowledger is not the biological father of the child and if two additional requirements are fulfilled.

First of all, § 1600 (3) BGB provides that the public authority can only contest the legal paternity of the acknowledger if no social familial relationship exists or existed between the child and the acknowledger at the moment of the acknowledgement or the death of the acknowledger. ${ }^{429}$ A social familial relationship is presumed to exist if the legal father takes responsibility for the education of the child, which must be presumed if the man is married to the mother or if the man and the child lived together for a longer period.430The existence of a social familial relationship can also be established by proving facts that are an expression of the exercise of typical parental rights and duties, such as regular contact and contribution to the costs of the child's upbringing and education. ${ }^{431}$

\footnotetext{
422 Article 1:205 (2) Burgerlijk Wetboek.

${ }^{423}$ De Meijer 2003, p. 227, note 184.

424 De Meijer 2003, p. 227, 228; Van Iterson 1993.

${ }^{425}$ Article 4 (1) and 6 (1) under c Rijkswet op het Nederlanderschap. On the effects of this modification of the Dutch nationality act see inter alia Oderkerk 2006; Saarloos 2005; De Groot \& Saarloos 2004.

${ }^{426}$ Wet van 27 juni 2008 tot wijziging van de Rijkswet op het Nederlanderschap ter invoering van een verklaring van verbondenheid, en tot aanpassing van de regeling van de verkrijging van het Nederlanderschap na erkenning, Stb. $2008,270$.

${ }^{427}$ For an overview of the different competent authorities in the German states see Das Standesamt (2009/1), p. 29.

${ }^{428}$ BT Drucks. 16/3291. Under German law the right of the Staatsanwalt to apply for annulment of legal parentage had been abolished in 1961 because matters concerning legal parentage were considered a purely private matter. Moreover, the institution had been abused by the Nazi-regime during the Second World War to contest the legal paternity of Jewish men who were married with German women (Helms 2007 , p. 71; Henrich 2006b, p. 977).

${ }^{429}$ The concept of social familial relationship is also used in relation with the right of the biological father to contest the legal paternity of the legal father (§ 1600 (2) BGB).

430 § 1600 (4) BGB.

431 BT Drucks. 16/3291, p. 13.
} 
The second requirement is that it has to be proven that as a result of the acknowledgment the child or one of the parents obtained permission to enter Germany or to reside on German territory.

An obvious question is how the public authority is informed about an acknowledgment of paternity that has been done solely with the intention to give a person a right of residence in Germany. After all, no one checks whether or not a man who wants to acknowledge his paternity is indeed the biological father. An important link in the chain is the civil status registrar. The registrar shall refuse to draw up an acknowledgment of paternity when it is obvious that the acknowledgement is done solely with the aim to grant one of the parties involved a right of residence in Germany. ${ }^{432}$ If the registrar does not refuse to draw up the acknowledgment but still doubts the sincerity of the acknowledger he has to inform the competent foreign citizen's office (Ausländerbehörde). ${ }^{433}$ The duty to report suspicious cases applies to all public authorities.434 The foreign citizen's office shall examine the case and inform the competent authority who is allowed to contest the legal paternity of the acknowledger. 435

Indications for a suspicious case are that a man acknowledged his paternity concerning children born to different women with a foreign nationality or rumours that money has been paid to the man for his acknowledgment of paternity. Also, the fact that the acknowledger and the mother do not live at the same address can be an indication that the acknowledgment of paternity is not sincere, especially in relation with the fact that one of the persons involved obtained a benefit regarding his or her right to reside in Germany as a result of the acknowledgment of paternity. ${ }^{436}$

The position of the public prosecutor or the competent authority under Dutch, French and German law is not comparable with the position of the socialnämnd in Sweden. The public authorities under Dutch, French and German law have to protect the public interest. The socialnämnd in Sweden is only concerned with the question whether or not the child is legally affiliated with his real parents.

\subsubsection{Periods of limitation for annulment of legal parenthood}

Under Dutch, French and German law the right to contest legal parentage is not only restricted by a limitation of the persons with a right to apply, but also by periods of limitation. Different reasons are put forward for the use of periods of limitation. They have to force the persons involved to act promptly in order to make sure that clarity exists about the legal status of the child as soon as possible, they have to secure existing social familial relations, and they are meant to enhance legal certainty by stabilising the personal status of the child. 437

Under Dutch law, the child has to contest legal paternity within three years after he learned that his legal father is probably not his biological father. If the child learns of these facts during his minority the period of limitation is suspended until he has reached the age of 18 years. ${ }^{438}$ The rule is the same irrespective of whether legal paternity exists on the basis of

\footnotetext{
$432 \S 44$ Personenstandsgesetz. Cf Dutch law: article 1:18b Burgerlijk Wetboek, which provides that the registrar shall not draw up an instrument of civil status if it appears to him that the instrument violates Dutch public policy.

${ }^{433} \mathrm{Cf}$ in France the instrunction for civil status registrars provides that in suspicious cases they have to inform the public prosecutor (Instruction générale relative à l'état civil du 11 mai 1999, par. 307, Journal Officiel n 172 du 28 juillet 1999).

$434 \S 87$ (2) under 4 Aufenthaltsgesetz.

$435 \S 90$ (5) Aufenthaltsgesetz.

${ }^{436}$ BT Drucks. 16/3291, p. 15, 16. See also Berthold 2007, p. 80, 81.

437 France: Dekeuwer-Defossez 1999, p. 48-52. Germany: BR Drucks. 180/96, p. 97; BT Drucks. 13/4899, p. 87. Netherlands: Kamerstukken II, 1995-1996, 24 649, nr. 3, p. 17

438 Articles 1:200 (6) and 205 (4) Burgerlijk Wetboek.
} 
marriage or acknowledgment. If a man recognised the child when the child was of age, the child does not have standing to contest the legal paternity on the basis of acknowledgement. 439

The legal parents have to apply within one year. In case of legal paternity based on marriage, the period of limitation for the mother runs from the moment of birth. For the man, the period of limitation starts at the moment that he becomes aware of the fact that he is probably not the biological father. ${ }^{440}$

In case of legal paternity based on acknowledgment of paternity the situation is more complicated. It is recalled that legal paternity on the basis of acknowledgement can only be contested by the acknowledger or the mother if they can prove that they acted under the influence of threats, mistake, deceit or undue influence. In that case, the mother or the acknowledger has to apply within one year after the threats or undue influence has ended or one year after he or she discovered the deceit or the mistake.441

Under French law, article 321 Code civil there is a general period of limitation for matters concerning parentage. That period is ten years from the moment the person involved is deprived of the status he claims (in case of establishment of parentage) or ten years since the contested status has been established (in case of annulment of parentage). For the child, the period of limitation is suspended until he reaches the age of 18 years.

There are several exceptions to the general period of limitation. Article 333 Code civil provides that legal parentage that is based on registration (legal maternity), marriage (marital paternity) or acknowledgment (legal paternity or maternity) can be contested within five years if the title for the legal parentage and the apparent status of the child coincide. In that case, the applicant has to start the action within five years after the apparent status has ceased. However, the article adds that if the apparent status and the title coincide for five years continuously after the birth record or the instrument of acknowledgment has been drawn up, the legal parentage cannot be contested anymore. Thus, in fact, there are two periods of limitation that apply to the same action. The first period only starts as soon as the apparent status has ended; the second starts at the moment the birth record or the instrument of acknowledgment is drawn up if at that moment the child has an apparent status in conformity with the document involved.

The effect of article 333 Code civil is that for the vast majority of cases in which the title and the apparent status coincide, the period of limitation is five years from the moment the birth record or the instrument of acknowledgment has been drawn up. Although it is not stated explicitly, the prevailing view is that for the child, the period of limitation is suspended until his 18 th birthday. ${ }^{442}$

It is not hard to imagine exceptions to the general effect of article 333 Code civil: if the legal father leaves the mother and the child three years after the birth of the child, the child probably does not have a title and a similar apparent status for a continuous period of five years. Therefore, the second period will never expire. Only the first period is relevant with the effect that the legal paternity of the deserting man can be contested within five years after he has left the mother and the child (if that is the moment the apparent status ended).

If the title and the apparent status do not coincide, article 334 Code civil applies instead of article 333 Code civil. Article 334 Code civil provides that in such a case the legal parentage can be contested within the general period of limitation for actions on parentage,

${ }^{439}$ Article 1:205 (1) under a Burgerlijk Wetboek.

440 Article 1:200 (5) Burgerlijk Wetboek.

${ }^{441}$ Article 1:205 (3) Burgerlijk Wetboek.

442 Circulaire relative à la présentation de l'ordonnance nr. 759-2005 du 4 juillet 2005 portant réforme de la filiation, Bulletin officiel du Ministère de la Justice, 25 October 2006, nr. 103, p. 109-211 (NOR: JUSC0620513C), at p. 162. See also Massip 2006, nr. 57. 
i.e. ten years after the title for the contested legal parentage has been drawn up. For the child the period of limitation is suspended until his 18th birthday.

It follows from article 333 Code civil that the apparent status does not need to exist at the moment the applicant contests the legal parentage in order for the period of limitation of that provision to apply. ${ }^{443}$ After all, the first period of limitation only starts running if the apparent status does not exist anymore. Therefore, article 334 Code civil only applies if the child never had an apparent status in conformity with the title of his legal parentage. However, if it is argued that apparent status has existed but does not exist anymore at the moment of the action, it must be examined whether the apparent status that existed is continuous, peaceful, public and unequivocal. 444 Apparent status that is not continuous, peaceful, public and unequivocal is not relevant and in that case article 334 Code civil applies instead of article 333 Code civil.445

If legal parenthood solely exists on the basis of apparent status, the period of limitation is ten years from the moment the affidavit or the judgment has been rendered. If the legal parentage has been established by apparent status that has been recorded in a affidavit (art. 317 Code civil), article 335 Code civil provides in any event that the existence of apparent status can be contested within ten years after the affidavit has been drawn up. If one contest the legal parentage on the basis that the legal father is not the biological father, the period of limitation is also ten years. However, in this case the legal basis for the period of limitation is uncertain: it is either article 335 or article 321 Code civil which contains the general period of limitation. 446 The discussion is not very relevant because under both provisions the period is ten years.

If legal parentage has been established by apparent status that has been established in a judgment (art. 330 Code civil) the legal parentage can be contested via third party opposition on the basis of article 324 Code civil. There is no special period of limitation for this kind of procedure. Therefore, the general period of ten years (art. 321) applies.

Under German law, the periods of limitation to contest existing legal paternity are described in $\S 1600 \mathrm{~b}$ BGB. The legal father, the mother, the child and the biological father are allowed to contest the legal paternity within two years after they are informed of facts that cast doubt on the paternity of the legal father. The period does not start before the birth of the child or before the legal paternity has been established. 447

The biological father is not allowed to contest the legal paternity of another man if a social familial relationship exists between the child and his legal father or existed at the moment of the man's death. $448 \S 1600 \mathrm{~b}$ (1) states that the existence of a social familial relationship does not interrupt the period of limitation. It follows that if the biological father at the moment the social familial relationship ends already knew for more than two years that the legal father is not the biological father of the child, his period of limitation has expired without being able to exercise his right to contest the legal paternity.

The period of limitation that applies to the child is subject to special provisions. If the legal representative of the child did not contest the paternity of his legal father during the child's minority, the period of limitation for the child starts again from the moment the child

\footnotetext{
${ }^{443}$ Cf. notes 380 and 381.

444 Article 311-2 Code civil.

445 See also Malaurie \& Fulchiron 2006, nr. 1325.

${ }_{446}$ On this discussion see $§ 3.3$. Establishment of parenthood by apparent status. See also Circulaire relative à la présentation de l'ordonnance $\mathrm{nr}$. 759-2005 du 4 juillet 2005 portant réforme de la filiation, Bulletin officiel du Ministère de la Justice, 25 October 2006, nr. 103, p. 109-211 (NOR: JUSC0620513C), at p. 165. Malaurie \& Fulchiron 2006, nr. 1330, 1331; Massip 2006, nr. 59.

$447 \S 1600 \mathrm{~b}(2) \mathrm{BGB}$.

448 See note 375 .
} 
has reached the age of 18 years. The same applies mutatis mutandis to the incapacitated adult if his legal representative did not contest legal paternity during his incapacity. ${ }^{449}$ Moreover, $\S 1600$ (6) provides that the period of limitation starts running again at the moment the child learns of facts which make it unbearable for him to keep the legal paternity in existence, for example in case of the death of the legal father, a divorce between the mother of the child and its legal father, the marriage of the mother with the genetic father of the child. 450 In such situations, the child is given a second chance to consider the possibility to apply for annulment of the legal paternity of its legal father.

The fifth paragraph of $\S 1600 \mathrm{~b}$ BGB contains two general provisions on the interruption of the period of limitation. First of all, the period of limitation shall be interrupted if a procedure on the basis of $\S 1598$ a (2) BGB has started. The procedure which is meant is the procedure to clarify the biological affiliation of the child, which has been explained above.451 If the applicant who wants to contest the legal paternity cannot state sufficient facts to establish an Anfangsverdacht (reasonable ground for suspicion), he or she will first start a procedure under $\S 1598$ a (2) BGB to clarify the genetic affiliation of the child. After all, in that procedure the applicant does not have to state an Anfangsverdacht. ${ }^{452}$ During the procedure to clarify the biological affiliation of the child, the period of limitation to contest the legal paternity is interrupted until six months after the judgment in the procedure has become final. ${ }^{453}$ In this way, the applicant applying for clarification of the biological affiliation of the child ( $\$ 1598$ a BGB) can still contest the legal paternity ( $\$ 1600 b)$ if he or she starts the first procedure within the two year period of limitation. This is particularly important if the procedure on the clarification of the biological affiliation of the child is adjourned in the interest of the child ( $\$ 1598$ a (3) BGB). It is recalled that only the legal father, the child and the mother can apply for a clarification of the biological affiliation of the child under § 1598a BGB.

Per $\S 1600 \mathrm{~b}$ (5) BGB the period of limitation shall also be interrupted as long as the person with a right to contest the legal parentage is hindered in the exercise of his right by unlawful threats of another person.

Under Swedish law, the right to contest legal paternity is not subject to a period of limitation. The statutory period of limitation for the husband to apply for annulment of his paternity was removed in 1976.454 Before, the husband had to apply for annulment within three years after the child's birth. The reason not to subject the annulment of marital paternity to a prescription period is that it was deemed unnecessary to protect the legitimate status of the child because of the equalisation of the status of children born in and out of wedlock. Moreover, the interest of both the child and the father would be served if legal parentage would be in conformity with biological reality. ${ }^{455}$ Like the right of the husband, the right of the child to apply for annulment of the legal paternity of his mother's husband is not limited in time. This was already the case before the coming into force of Act 1976:612. ${ }^{456}$ Also, the right to apply for annulment of legal paternity based on acknowledgment is not limited in time. ${ }^{457}$ In addition, under English law, the right to apply for a declaration of parentage under section 55A Family Law Act 1986 is not subject to a period of limitation.

\footnotetext{
${ }^{449} \S 1600 \mathrm{~b}(3) \mathrm{BGB}$.

${ }^{450} \S 1600 \mathrm{~b}(4) \mathrm{BGB}$.

${ }^{451}$ See $\S$ 3.4.4. Evidence in case of judicial establishment of legal parentage.

452 BT Drucks. 16/6561, p. 12. See also Helms 2008a, p. 8.

${ }^{453} \S 1600 \mathrm{~b}(6)$ in conjunction with $\S 204$ (2) BGB.

${ }^{454}$ Saldeen 2005, p. 75.

455 Prop. 1975/76:170, p. 134; Walin \& Vängby vol. I, p. 3:3 and 3:6.

456 Prop. 1975/76:170, p. 137; Saldeen 2005, p. 75; Singer 2000, p. 158.

457 Singer 2000, 198.
} 
As mentioned above, the public prosecutor or the zustandige Behörde (competent authority) also has the right to contest legal parentage under Dutch, French and German law. ${ }^{458}$ Under Dutch law, the right of the public prosecutor to contest legal paternity on the basis of acknowledgment of paternity is not subject to any period of limitation. According to the legislator, the violation of Dutch public policy determines the latitude of the public prosecutor. It depends on the circumstances of the case whether or not the violation of Dutch public policy is remedied by the course of time. 459

Under French law, the right of the public prosecutor to apply for annulment of legal parentage is subject to the general period of limitation of ten years from the moment the disputed parentage has been established. The existence of apparent status in conformity with the title of legal parentage is irrelevant. 460

Under German law the competent authority has to act within one year after it has learned of facts from which it may be derived that no social familial relation exists between the child and the acknowledger of the child and that the establishment of legal paternity constituted an advantage with regard to the right to reside in Germany for one of the parties involved. ${ }^{461}$ In any event, the right to contest the legal paternity of the acknowledger expires after five years following the acknowledgment of paternity if the child is born in Germany or five years after the entry of the child into Germany.

\subsubsection{Administrative annulment of legal parenthood}

Administrative annulment of legal paternity means the process by which the legal paternity of a man is annulled without a court procedure. The possibility of administrative annulment of legal paternity is an exception to the general rule in the legal systems under consideration that legal paternity can only be annulled in a judicial procedure. Each legal system provides for some kind of exception to this rule.

Under Dutch law, administrative annulment of marital paternity is only possible in exceptional circumstances. Article 1:199 under b Burgerlijk Wetboek (BW) provides that the legal father of the child is the man whose marriage with the mother of the child is dissolved by his death within 306 days before the birth of the child. The rule is an extension of the main rule that the mother's husband at the moment of birth is the legal father of the child. ${ }^{462}$ However, article 1:199, under b BW continues: the legal mother of the child can contest the legal paternity of her deceased husband by lodging a declaration to that effect before the civil status registrar if she and her deceased husband were legally or factually separated since the 306th day before the child's birth. In that case the mother was not living together with her husband at the moment the child was begotten. Therefore, it is unlikely that he is the biological father of the child.

The Dutch regulation for administrative annulment of marital paternity is rather lengthy for quite an exceptional situation, not solely because it is very uncommon under Dutch law to apply for legal separation instead of divorce. ${ }^{463}$ Article 1:199 under b BW is a left over from the law on legal parentage before 1998. Under the old law, the legal father of

\footnotetext{
458 See $§ 3.5 .4 .3$. The state.

${ }^{459}$ Kamerstukken I, 1997-1998, 24 649, nr. 11a, p. 4.

${ }^{460}$ Circulaire relative à la présentation de l'ordonnance nr. 759-2005 du 4 juillet 2005 portant réforme de la filiation, Bulletin officiel du Ministère de la Justice, 25 October 2006, nr. 103, p. 109-211 (NOR: JUSC0620513C), at p. 160.

$461 \S 1600 \mathrm{~b}(1 \mathrm{a})$ in conjunction with $\S 1600$ (3) BGB.

462 Article 1:199 under a Burgerlijk Wetboek.

463 According to information from Statistics Netherlands (Centraal Bureau voor de Statistiek) in 2007 only 226 times a court allowed the legal separation of spouses. That is $0.7 \%$ of all divorce proceedings. In all other cases, the marriage was simply dissolved.
} 
the child was the husband at the moment of birth. The ex-husband was also the legal father if the child was born within 306 days after the divorce unless the mother remarried. ${ }^{464}$ The mother had no standing to contest his legal paternity in a judicial procedure but she had the possibility to contest his legal paternity by lodging a declaration before the civil status registrar if the child was born within 306 days after the divorce. An additional requirement was that another man would acknowledge his paternity to make sure that the child did not remain fatherless. If the marriage was dissolved by death of her husband, the mother could only contest the legal paternity of her deceased husband if they were legally and factually separated since the 306th day before the birth of the child.

Under the current law, the divorced husband is not automatically the legal father of the child anymore, but the deceased husband is. That is why the right of the mother to contest his legal paternity by lodging a statement before the civil status registrar remained in the civil code. 465 Still, under the current law the need for a special regulation for the mother is less urgent than under the old rules. Under the old law the mother had no standing to judicially contest the legal paternity of her husband; under the current rules she does have that right.

German and Swedish law also provide for a form of administrative annulment of legal paternity. Under German law § 1592 (2) BGB provides that the legal paternity of the husband can be set aside by the acknowledgment of paternity by another man. The requirements are that the child is born after the application for the divorce has been filed and that the other man acknowledges his paternity within one year after the divorce judgment has become final. Both the mother and her (ex) husband have to consent to the acknowledgment. ${ }^{466}$

The German provision has been inserted into German law at the reform of the law on legal parentage that entered into force in 1998. The purpose was to avoid expensive judicial proceedings in cases where all parties involved agree that the husband is not the father of the child. ${ }^{467}$ According to the legislator it is very unlikely that the husband of the mother is the father of the child if these conditions are fulfilled, which justifies the absence of judicial supervision in the annulment of paternity. ${ }^{468}$

Swedish law has a regulation similar to the German § 1592 (2) BGB. § 1:2 (3) Föräldrabalk provides that the legal paternity of the mother's husband shall be set aside if another man acknowledges his paternity. Unlike under German law, it is not necessary that the legal parents of the child applied for divorce.

Next to the normal requirements for acknowledgment of paternity such as the consent of the mother and the socialnämnd, the husband also has to consent to the acknowledgment. Just like in Germany, the reason to allow for an out of court annulment of martial paternity is based on efficiency and the wish to avoid judicial proceedings. ${ }^{469}$ The fear that the acknowledgment would be contrary to biological reality is taken away by the fact that the socialnämnd has to consent to the acknowledgment. The socialnämnd can only consent to the acknowledgment if it is convinced that the acknowledger is the biological father of the child. 470

\footnotetext{
${ }^{464}$ Former article 197 Burgerlijk Wetboek.

465 See also Kamerstukken II, 1997-1998, 24649, nr. 28, p. 3.

${ }^{466}$ Dutch law does not have a special provision for this kind of situation; the persons involved have to contest the legal paternity of the husband in a judicial procedure. Under the Dutch law before the reform in 1998, a similar rule existed in case the child was born after the divorce. See note 464 .

${ }^{467}$ BR Drucks. 180/96, p. 63; BT Drucks. 13/4899, p. 53.

468 For critical remarks: Gaul 2000; Veit 1999; Gaul 1997.

469 Prop. 1975/76:170, p. 137f.

470 See $\S 3.2 .2 .3$. The consent to acknowledgment of parenthood.
} 
Under French and English law there is no possibility to contest legal paternity out of court in the way it exists under Dutch, German and Swedish law. For English law, the reason is that legal paternity always exists automatically. The legal paternity of the biological father or the consenting partner does not depend on his marriage to the mother or his acknowledgment of paternity. Still, there are rules of evidence like the presumption of legitimacy. That presumption can be rebutted at the registration of the birth. ${ }^{471}$

The same applies to French law. Under French law it is not possible to change the personal status of the child with an administrative procedure. However, the mother can avoid the establishment of the legal paternity of her husband by not registering his name as the father on the birth record of the child. Article 313 Code civil provides that the husband of the mother shall not be the legal father of the child if he is not mentioned as the father on the birth record and if the child does not have apparent status with regard to him. It must be mentioned in this respect that in France the civil status registrar does not examine ex officio whether or not the mother of the child is married if the informant does not mention anything in this respect. He just records the information that is submitted to him. ${ }^{472}$ Also, if the child is born during divorce proceedings, the husband is not automatically the legal father of the child. Unlike under German law, the legal paternity of the husband is not set aside by the acknowledgment of paternity by another man; article 313 Code civil simply provides that the husband is not the legal father in such a case.

The second sentence of article 313 Code civil covers the types of situations where the German and the Swedish laws allow for acknowledgment of paternity. Article 313, second sentence Code civil provides that in case of petition for divorce or for judicial separation, the presumption of paternity shall not apply to a child born more than three hundred days after the date of either the approval of the agreement which regulates the whole consequences of the divorce or of the provisional measures taken under article 250-2, or of the ordonnance de non-conciliation, and less than one hundred and eighty days following either the final dismissal of the petition or a reconciliation.

\subsection{Conclusion on the establishment and annulment of legal parentage}

This chapter treats the different means to establish legal parentage under Dutch, English, French, German and Swedish law and to contest it. For this thesis, knowledge of the law of parentage in different legal systems is important because private international law on parentage is about the application of foreign law on parentage. Moreover, it will be shown that national systems on private international law are modelled on the national law on parentage in the legal system involved.

This chapter distinguishes four different methods to establish legal parentage, namely automatically, by means of an administrative action, by apparent status and by judicial establishment. To the extent that the method for establishment of legal parentage does not guarantee the establishment of the legal parenthood of the 'real' parent, the system is complemented with a procedure to contest existing legal parentage. The discussion on the rules to contest legal parentage focussed on the annulment of legal parentage on the basis that the legal parent is not the real parent of the child. The possibility to attack legal parentage way by arguing that the acknowledgment of parenthood is legally invalid or that the apparent status is inadequate has only been mentioned in an oblique way.

\footnotetext{
471 See $§$ 3.1.1. Ex lege existence of legal parentage under English law.

472 Article 57 (1) Code civil. Instruction générale relative à l'état civil du 11 mai 1999, par. 275, Journal Officiel n 172 du 28 juillet 1999. See also Malaurie \& Fulchiron 2006, nr. 1016.
} 
The study revealed an interesting difference between English law on the one hand and Dutch, French, German and Swedish law on the other. It appeared that under English law the legal paternity of the biological father always exists automatically, unless the definition of father in the Human Fertilisation and Embryology Act 2008 applies; in that case the legal paternity of the person defined as parent in the Act exists automatically. Under English law, parentage has been reduced to a problem of evidence, the only substantive problem being the definition of the terms father and mother. The Dutch, French, German and Swedish legal systems are based on a system of creation of legal relations on the basis of marriage, acknowledgement or apparent status.

We have explained this difference with two reasons. The first reason is the wish in continental legal systems to create legal certainty through the system of civil status registration. The second reason is the wish to insert social factors into the concept of legal parenthood. This perception of the concept of legal parent is strongly felt in French law where the Dekeuwer committee wrote:

La filiation découle tout à la fois du titre, de la possession d'état et de la vérité biologique, qu'il faut tantôt appréhender de manière isolée, tantôt cumuler, tantôt au contraire opposer. Le droit de la filiation est l'art de trouver les effets les plus appropriés à la multiplicité des combinaisons possibles. Sa complexité est naturelle. La réduire en deçà d'un certain seuil risque de créer de violentes injustices; mais une complexité excessive masque aussi incontestablement le sens du lien juridique. ${ }^{473}$

However, for the purpose of private international law the technical difference as such between English law on the one hand and Dutch, French, German and Swedish law on the other hand must not be overestimated. It is true that under English law, the man's name as the father on the child's birth certificate is prima facie evidence of the man's paternity. Thus his registration does not establish his legal paternity, but until the presumption has been rebutted the man is considered to be the father of the child. ${ }^{474}$ The obvious way to rebut the presumption is by proving in court with a DNA test that the man is not the father.

Under the other legal systems, a man is mentioned on the birth record on the basis of his marriage to the mother, his acknowledgment of paternity or the child's apparent status. However, if the man is not the biological father (or the consenting partner) in principle his legal paternity can be contested in court with the help of a DNA test.

Although the characterisation of the rules as evidential or substantive does not need to change the outcome of the case, it can be relevant in private international law. If the rules are characterised as rules of evidence, the question arises whether evidence is a substantive issue or a procedural issue and, if it is procedural, which connecting factor applies.

For the outcome of the case substantive considerations are more important. Various policy considerations have been discussed. First of all, the outcome of a case depends on whether the legal system allows the intention of the persons involved to influence the establishment of legal parenthood. On the one hand there are English and Swedish laws that do not allow the individual to influence the legal parentage of the child. English law does it by establishing legal parentage automatically; Swedish law does it by granting extensive powers to the socialnämnd to pursue and sometimes force the persons involved to establish the legal paternity of the biological father.

On the other hand is France. The state does not interfere in the establishment of paternity. The establishment of legal maternity and legal paternity is put in the hands of the

473 Dekeuwer-Defossez 1999, p. 25.

474 See section 4 Children Act 1989; section 26 Child Support Act 1991. 
mother by granting her the right to give birth anonymously and by making it possible not to register her husband as the father of the child.

In between are the Dutch and the German systems. Under these legal systems, the state does not interfere in the establishment of legal parentage. The mother cannot give birth anonymously, but she has considerable influence on the possibility for the man to establish his legal paternity out of wedlock. If she does not consent, the man cannot acknowledge his paternity. Under Dutch law, the mother has the most power because her consent cannot always be replaced by the consent of the court if the establishment of the legal paternity of the acknowledger shall damage the family life of the mother and the child. Under German law, the man can still bypass the refusal of the mother to consent by applying for the judicial establishment of his paternity.

The second policy consideration that influences the outcome of the case is the wish to protect established legal parentage. Established legal parentage is protected by limiting the possibility to contest legal parentage. The legislator can have different reasons to protect established legal parentage, for example the wish to protect social familial ties, legal certainty or the legal family. Under English and Swedish law there is hardly any protection. The possibility to contest legal parentage is not limited in time. Only the persons having standing are limited.

French law has a sophisticated system where the level of protection of existing legal parentage depends on the apparent status of the child. In the normal situation where the title and the apparent status are in conformity the legal parentage is protected by a period of limitation of five years and a limited locus standi.

German law has relatively short periods of limitation of two years for standard situations and restricted locus standi. Established legal parentage is best protected under Dutch law with very short periods of limitation (one year for the legal parents and three years for the child), limited locus standi and additional requirements that must be fulfilled in order to contest established legal paternity.

The final difference that may have an influence on the outcome of a case is the level of state interference in the establishment of legal parentage. On the one side of the spectrum is Sweden. Under Swedish law, it is the responsibility of the state to make sure that the legal paternity of the biological father or the consenting partner is established. Even in case of marital paternity, the socialnämnd can make inquiries into the biological affiliation of the child and thereby destabilising the family life in the interest of establishing the legal parentage of the biological father.

On the other hand is English law where the state does not interfere in the establishment of parentage. Dutch, French and German law are in between. The state does not interfere in the establishment of legal parentage on its own motion. However, the state has the right to contest existing legal paternity in order to protect public interests such as immigration (Dutch, French and German law), evasion of (adoption) law and the accuracy of the registers of civil status (Dutch and French law). 


\section{Evidence of legal parentage}

If legal parentage has been established, the next question is how its existence is proven. The question of evidence of legal paternity is especially relevant under English law because under English law legal paternity in most cases is based directly on biological paternity. Under continental legal systems evidence of legal parentage is less of a problem since the establishment of legal parentage is documented by instruments of civil status.

In this thesis it is important to understand the rules of evidence of legal parentage if, in private international law, the recognition of a legal status that has been acquired abroad has to be discussed. The recognition of a legal relation that exists abroad is only possible if the existence of the legal relation can be proven.

A discussion on evidence of legal parentage is closely related to a discussion on the meaning and the evidential value of information that appears on the child's birth record. For most people the birth record of the child is probably the primary source of information if they want to know the parentage of the child. Therefore, it is important to know the procedure that leads to the stating of the information on the birth record, the meaning of the information and the evidential value of that information.

\subsection{Evidence of legal parentage under English law}

For English law it has been argued that legal parentage exists automatically.475 Thus under English law, the only question is how to prove legal parentage. With regard to the evidential value of entries in the register of births, section 34 (2) of the Births and Deaths Registration Act 1953 only provides that 'an entry or a certified copy of an entry of a birth or death in a register, or in a certified copy of a register, shall not be evidence of the birth or death unless the entry purports to be signed by some person professing to be the informant and to be such a person as might be required or permitted by law at the date of the entry to give to the registrar information concerning that birth or death [...].'

A contrario the Births and Deaths Registration Act 1953 suggests that if the entry in the register purports to be signed by a qualified informant, it is evidence of the birth or the death. Of course, an entry in a register cannot be evidence of the birth as such; it must be evidence of facts that identify the birth such as the time and place of birth. The Act does not specify with regard to which facts concerning the birth or the death the register is evidence, nor does it indicate any special evidential value.

Next to the Births and Deaths Registration Act 1953 there are two common law presumptions to prove legal parentage. The first presumption is that the husband of the mother at the moment of conception or at the moment of birth is presumed to be father of the child (presumption of legitimacy). If the child is conceived during the first marriage and born during the second marriage the first husband is presumed to be the father of the child. ${ }^{476}$ The presumption may be rebutted by evidence which shows that it is more probable than not that that person is illegitimate or legitimate, as the case may be. 477 In 1972 in the combined case of $S v S$ and $W v$ Official Solicitor Lord Reid held:

That means that the presumption of legitimacy now merely determines the onus of proof. Once evidence has been led it must be weighed without using the presumption

\footnotetext{
475 See $§$ 3.1.1. Ex lege existence of legal parentage under English law.

476 Lowe \& Douglas 2007, p. 322.

477 Section 26 Family Law Reform Act 1969.
} 
as a make-weight in the scale for legitimacy. So even weak evidence against legitimacy must prevail if there is not other evidence to counterbalance it. The presumption will only come in at that stage in the very rare case of the evidence being so evenly balanced that the court is unable to reach a decision on it. I cannot recollect ever having seen or heard of a case of any kind where the court could not reach a decision on the evidence before it. 478

In 2002 Lord Justice Thorpe went even further and questioned whether nowadays the presumption of legitimacy still has any relevance:

Twenty years on I question the relevance of the presumption or the justification for its application. In the nineteenth century, when science had nothing to offer and illegitimacy was a social stigma as well as a depriver of rights, the presumption was a necessary tool, the use of which required no justification. That common law presumption, only rebuttable by proof beyond reasonable doubt, was modified by s 26 of the Family Law Reform Act 1969 by enabling the presumption to be rebutted on the balance of probabilities. But as science has hastened on and as more and more children are born out of marriage it seems to me that the paternity of any child is to be established by science and not by legal presumption or inference. Were the judge's order to stand in the present case the consequence would be a long and acrimonious trial of the paternity issue when, in the absence of the only decisive evidence, each side would resort to evidence of marginal or doubtful worth in the determination to prevail. Such a development would be wasteful of both legal costs and judicial time. ${ }^{479}$

Not only in court proceedings is the presumption of legitimacy loosing ground, but also at the registration of the birth it has been shown that the presumption can easily be rebutted by the informant. 480

The second presumption to prove legal parentage is that the registration of the name of the father on the birth record of the child is prima facie evidence of his paternity. ${ }^{481}$ The presumption does not specify whether the birth certificate is prima facie evidence of legal paternity or biological paternity. In most cases, it does not matter because often the biological father is also the legal father. However, it has been shown that under the Human Fertilisation and Embryology Act 2008 the biological father is not always the legal father.

If the registration of a man as father is prima facie evidence of his paternity it is important to know how a person can be registered as the father. The starting point under the Births and Deaths Registration Act 1953 is that the father shall only be registered as the father of the child if he and the mother are married to each other at the time of the child's birth. This is only different if the conditions of section 10 Births and Deaths Registration Act 1953 are fulfilled. Under section 10, a man shall be registered as the father either on request with the consent of the mother or on the production of a court order for which the paternity of the man had to be determined, such as an order for parental responsibility or an order for financial provisions. ${ }^{482}$

\footnotetext{
478 [1972] AC 24.

${ }^{479}$ Re H and A (children) [2002] EWCA Civ 383.

480 See note 99.

481 Brierley $v$ Brierley and Williams [1918] P 257, 87 LJP 153; Re Goodrich, Payne v Bennett [1904] P 138; Jackson v Jackson and Pavan, [1964] P 25, [1960] 3 All ER 621, [1961] 2 WLR 58; Masson, Bailey-Harris \& Probert 2008, nr. 17-006; Tapper 2004, p. 623; Lowe \& Douglas 2007, p. 322; Lord Chancellor's Department Consultation Paper, Procedures for the determination of paternity and the law on parental responsibility for unmarried fathers, 1998, nr. 26.

482 Section 10A Births and Deaths Registration Act 1953 provides the same as section 10 for the case where the birth of the child has already been registered without the registration of the father. In order to ensure the establishment of
} 
The registrar does not make specific inquiries. More in particular, the registrar does not require any evidence of the biological paternity of the man who is said to be the father of the child. However, it has been pointed out in the second chapter that giving wrong information to the registrar is a criminal offence. 483

The registration of the unmarried father with the consent of the mother has the same function as the acknowledgment of paternity under Dutch, French, German and Swedish law. The registration of the father with the consent of the mother can take four forms: the man and the mother both attend the registrar's office and sign the register together, the mother requests the registration of the unmarried father on the production of a statutory declaration of the unmarried father stating himself to be the father, the unmarried father requests his registration as father on the production of a statutory declaration of the mother stating that the man is the father of the child. The final possibility is that the mother or the unmarried father requests the registration of the unmarried father on the production of a parental responsibility agreement that complies with section 4 Children Act 1989 and that has not been brought to an end by a court order. All these forms of registration share important characteristics of an acknowledgment of paternity under Dutch, French, German and Swedish law. They are an administrative procedure to identify a man as the legal father of the child if the persons involved are in agreement, the procedure is voluntary and it requires the consent of the mother. The registration of the unmarried father with the consent of the mother also has similar effects. For example, the man who is registered as the father acquires parental responsibility and he is liable to pay maintenance.

The difference to a continental style acknowledgment is merely of a technical nature: unlike the acknowledgment of paternity, the registration of the unmarried father does not affect the personal status of the child. The effect of a continental style acknowledgment is that the child that was legally fatherless gets a legal father; under English law the child was never considered legally fatherless. Such a technical difference is perhaps less interesting for the comparative lawyer looking for functional equivalence. However, this technical difference raises some questions in relation with the application of foreign law under continental private international law. 484

So far the presumption of legitimacy and the presumption arising from the registration of the man as the father of the child have been discussed. The person who does not agree with the result of the presumptions has to prove that the man in question is not the (legal) father of the child. Under English law there is not just one procedure to determine the parentage of the child. Legal paternity can be raised as an incidental issue in a procedure on something else, such as succession or maintenance. In that case, findings on (legal) paternity only bind the parties, although they are evidence of paternity unless the contrary is proven. 485

Legal parentage may also be determined in a procedure for a formal declaration on parentage on the basis of section 55A Family Law Act 1986. A declaration of parentage on the basis of section 55A binds everyone. ${ }^{486}$ On the basis of section 55A Family Law Act 1986 any person may apply for a declaration as to whether or not a person named in the application is or was the parent of another person so named. If the court makes a declaration

paternity out of wedlock, the British government has announced plans in 2008 to require unmarried parents to jointly register the birth of their child (Dept. for work and pensions, Raising expectations and increasing support: reforming welfare for the future, Norwich: The Stationary Office (December 2008), at paragraph 7.10; Dept. for work and pensions, Joint birth registration: recording responsibility, Norwich: The Stationary Office (June 2008).

483 §3.1.1. Ex lege existence of legal parentage under English law.

$484 \S$ 6.7.3. Application of English law pursuant to continental private international law.

485 Section 12 Civil Evidence Act 1968.

486 Section 58 (2) Family Law Act 1986. 
of parentage under section 55A Family Law Act 1986, the birth of the child shall be reregistered in order to mention the correct man as the father of the child. 487

It is not necessary that the person named in the application still is the parent of the other person. An adopted child can also apply under section 55A to obtain a declaration that a person is his biological father and therefore was his legal father. ${ }^{488}$

Pursuant to section 55A any person may apply, but subsection three limits the scope of 'any person'. It provides that the court shall refuse to hear an application unless it considers that the applicant has a sufficient personal interest. Subsection four provides that a child always has sufficient personal interest to apply for a declaration of parentage, just like a man who wants to establish his paternity or the mother who wants to establish the paternity of a certain man. If a maintenance assessment has been made or if a maintenance assessment is in force against a man who denies to be the father of the child and where the case does not fall within the scope of article 26 (2) of the Child Support Act 1991, the person with care shall be treated as having a sufficient personal interest under article 55A. The requirement of a sufficient personal interest does not apply to the Secretary of State in as far as maintenance is concerned. For the rest the concept of 'sufficient personal interest' has not been defined. In its reaction to a Lord Chancellor's consultation paper on paternity and parental responsibility the Advisory Board on Family Law stated in this respect:

Others should be able to make an application with leave, if they have a proper interest in the issue. The definition of 'proper interest' was considered in some detail. It would, for example, include siblings who wanted to establish a right to inheritance, and other family members such as grandchildren. It should not include merely public interest (for example newspapers making applications to establish the paternity of public figures). ${ }^{489}$

Subsection five contains a safety clause to protect the best interests of the child. It provides that the court may refuse to hear the application for the determination of parentage if it considers that the application would not be in the best interests of the child. The concept of best interest has not been explained so far. No authorities have been found that explain in what kind of cases subsection five should be applied. It must be noted though that the bestinterest-of-the-child exception also exists with regard to the question whether or not a DNA test should be ordered in matters concerning parentage. 490 Situations in which the court does not order a DNA test in the best interest of the child could give an idea of the type of situation in which a declaration of parentage is not in the best interest of the child. ${ }^{491}$

The procedure for a declaration of parentage under section 55A Family Law Act 1986 fulfils the same function as procedures to contest and to establish legal parentage under Dutch, French, German and Swedish law. The procedure on the basis of section 55A Family Law Act 1986 allows the interested party to rebut the presumption of legitimacy or the presumption arising from the registration of a man as the father. This is also the function of a procedure to contest legal paternity under the other legal systems under consideration. If no legal presumption applies, section 55A Family Law Act 1986 allows the applicant to apply for a declaration of parentage to establish that a certain person is the father (or mother)

\footnotetext{
487 Section 55A (7) Family Law Act 1986; section 14A Births and Deaths Registration Act 1953.

${ }_{488}$ MvW (Declaration of Parentage) [2006 EWHC 2341 (Fam).

${ }^{489}$ Second Annual Report of the Advisory Board on Family Law (1998/99), Annex C, par. IV. Reaction on the Lord Chancellor's Department Consultation Paper, Procedures for the determination of paternity and the law on parental responsibility for unmarried fathers (1998).

490 See note 277

491 See cases mentioned in notes 280 and 281.
} 
of the child. This is essentially the same as a procedure for judicial establishment of paternity.

Also the conditions to apply for a declaration of parentage and its effect resemble the conditions to judicially contest or establish legal parentage. For example, only persons with a sufficiently personal interest can apply for a declaration of parentage and the declaration has an erga omnes effect; it can be invoked against everyone. However, the possibility to apply for a declaration of parentage under English law is not subject to a period of limitation. In comparison with the periods of limitation that apply to annulment of legal parentage under Dutch, French and German law, the absence of periods of limitation under English law is obviously an important difference. However, also under Swedish law the right to apply for annulment of legal parentage is not subject to a period of limitation.

Just like in the comparison between the registration of the unmarried father under English law and the acknowledgment of paternity under the other legal systems, the difference between a declaration of parentage on the one hand and judicial annulment or establishment of legal parentage on the other is that a declaration under English law does not change the personal status of the child; judicial annulment or establishment of legal parentage does.

\subsection{Evidence of legal parentage under Dutch, French and German law}

Evidence of legal parentage under Dutch, French and German law are treated together because these three legal systems have a similar system of documentary evidence to prove personal status in general and legal parentage in particular.

\subsubsection{Evidence of legal maternity}

\subsubsection{Dutch law}

Under Dutch law the registration of the woman who gave birth to the child is mandatory. ${ }^{492}$ In order to assure truth of the statement of the informant, the civil status registrar is allowed, but not obliged, to require a declaration of birth from a midwife or a doctor who assisted at the birth. ${ }^{493}$ If the registrar requires a declaration from a midwife or a doctor and if the informant is not able to submit the declaration, the registrar shall inform the public prosecutor and ask for directions. ${ }^{494}$ These provisions work out the general rule that the registrar is allowed to request the production of any document that is necessary to draw up instruments of civil status. ${ }^{495}$ If the persons involved do not produce the necessary documents, the registrar shall not draw up the instrument of civil status. ${ }^{496}$ The investigative power of the registrar of civil status has been laid down in the law in 1993 in order to combat fraud with respect to civil status. ${ }^{497}$

Under Dutch law article 1:22 (1) Burgerlijk Wetboek provides that the birth record proves to everyone that a child is born at the time and the place and to the woman mentioned on the record. For the rest, the birth certificate has the same evidential force as other authentic instruments. Authentic instruments are signed documents meant to serve as evidence that have been drawn up in the correct form by a competent public official who by

\footnotetext{
492 Article 43 Besluit burgerlijke stand 1994.

${ }^{493}$ Article 1:19e (8) Burgerlijk Wetboek. See also article 27 Besluit burgerlijke stand 1994.

${ }^{494}$ Article 1:19e (9) in conjunction with article 1:19b Burgerlijk Wetboek.

${ }^{495}$ Article 1:18 (2) Burgerlijk Wetboek.

496 Article 1:18b (1) Burgerlijk Wetboek.

${ }^{497}$ Kamerstukken II, 1990-1991, 21 847, n. 3, p. 14. Kamerstukken II, 1990-1991, 21 847, nr. 6, p. 9.
} 
law is ordered to report his observations and transactions in that way. 498 Authentic instruments are binding evidence (dwingend bewijs) of that which the public official has reported within the scope of his competence about his observations and transactions. 499 Binding evidence means that court is bound to accept the contents of the document as true until the contrary has been proven. 500

Article 1:22 (1) Burgerlijk Wetboek supplements the general provisions on the evidential value of authentic instruments. Without article 1:22 (1) Burgerlijk Wetboek the birth record would not be binding evidence of the time and place of birth and of the fact that the woman gave birth to the child. After all, the registrar is not present at the birth and thus does not observe the events himself.

It seems that the birth record itself is not evidence of legal maternity. The birth record is evidence of the fact that the woman mentioned on the birth record gave birth to the child and the law determines that the woman who gave birth to the child is the legal mother. ${ }^{501}$ In a purely international context it seems a rather academic discussion whether the birth record is evidence of childbirth or legal maternity, if legal maternity is based on childbirth. However in private international law the difference can be relevant.

Another point is that the evidential value which is attributed to the birth record in article 1:22 (1) Burgerlijk Wetboek is jeopardised by articles 1:209, 210 and 211 Burgerlijk Wetboek. These articles contain the rules to contest the legal status that is proven by the birth record either on the ground that the persons mentioned are not the legal parents (betwisting van staat) or on the ground that the birth record does not mention the legal parents (inroeping van staat).

For example, the birth record mentions Marina as the mother of the child. However, it was Anna and not Marina who gave birth to the child. At a certain moment in time, the child finds out about the situation and wants to change the birth record so that it reflects the correct status. In this case, one cannot just apply for a rectification of the birth record on the basis of article 1:24 (1) Burgerlijk Wetboek and rebut the presumption that is raised by the birth record according to article 1:22 (1) Burgerlijk Wetboek. 502

The 'rectification' of the birth record is also (and mainly) subject to the provisions of articles 1:209, 210 and 211 Burgerlijk Wetboek. Thus according to article 1:210 Burgerlijk Wetboek the action to contest the legal status that is proven by the birth record (betwisting van staat) or the action to invoke an existing legal status that does not follow from the birth record (inroeping van staat) is not subject to a period of limitation. Per article 1:211 Burgerlijk Wetboek only the child and his heirs can invoke an existing legal status. Per article 1:209 Burgerlijk Wetboek only the child can contest the legal status that follows from the birth record if the child has an apparent status in conformity with the birth record.

The mother who is mentioned on the birth record has to be accepted as the mother of the child until it has been established in conformity with the provisions of articles 1:209, 210 and 211 Burgerlijk Wetboek that she did not give birth to the child. ${ }^{503}$ Where under 1:22 (1) Burgerlijke Wetboek it can be sufficient to prove by means of a DNA test that the woman on the birth record did not gave birth to the child, this is not the case under articles 1:209, 210 and 211 Burgerlijk Wetboek.

\footnotetext{
498 Article 156 Wetboek van Burgerlijke Rechtsvordering.

499 Article 157 (1) Wetboek van Burgerlijke Rechtsvordering.

${ }^{500}$ Article 151 Wetboek van Burgerlijke Rechtsvordering.

501 Article 1:198 Burgerlijk Wetboek.

502 See also Rechtbank's-Gravenhage, 10 September 2007, LJN BB3282.

503 See also Hoge Raad 20 January 1950, NJ 1950/704; Asser/De Boer 2006, nr. 68; Saarloos 2006, p. 128.
} 


\subsubsection{French law}

Under French law the mention of the mother's name on the birth record is not mandatory. The birthmother has the right to give birth anonymously. ${ }^{504}$ If the informant states that a certain woman gave birth to the child, the registrar can request a declaration of birth by the midwife or the doctor who assisted at the birth. ${ }^{505}$ However, such a declaration is not mandatory and the law does not provide for consequences if the informant does not produce the document.

The French system with regard to the evidential value of the birth record is in the main along the same lines as the Dutch system. Or, one should say that the Dutch system of evidence of parentage looks like the French system, because the provisions of the Dutch articles 1:209, 210 and 211 Burgerlijk Wetboek are inherited from the French Code civil 1804.

Under French law the facts that are proven by a birth record are for example the date of birth, the place of birth and the fact that the woman who is mentioned as the mother gave birth to the child.506 The evidential value of the birth record with regard to these facts is determined by the general rules on evidential value of authentic instruments. Facts that are witnessed by the official himself are held to be true until inscription de faux. ${ }^{507}$ Facts that are not witnessed by the official who draws up the authentic instrument are held to be true until it has been proven that they are not. Facts concerning the birth fall within the second category, because the registrar usually does not witness the birth himself. ${ }^{508}$ It follows that the evidential value of the birth record with regard to facts concerning the birth is the same in France and the Netherlands.

The evidential value of the information concerning the mother is not determined by the general rules on evidence of authentic instruments, but by the law on parentage itself. The only way to delete the name of the mother from the birth record is by proving that the woman did not give birth to the child. That evidence can only be presented in a procedure on the basis of article 332 et seq. Code civil. 509 Since legal maternity is established by mentioning a woman on the birth record of the child,, 10 the birth record is evidence of legal maternity until it has been established within the limits (periods of limitation, locus standi) of article 332 et seq. Code civil that she did not gave birth to the child.

\subsubsection{German law}

Just like under Dutch law, legal maternity under German law exists automatically on the basis that the woman gave birth to the child.511 The registration of the mother on the birth record is also mandatory. At the declaration of the birth, the informant has to submit a declaration of birth of a midwife or doctor. ${ }^{512}$ If the registrar has doubts about the declaration of the informant he has to examine its correctness. ${ }^{513}$ The investigative power of the German is more extensive than under other legal systems. The persons involved are obliged to submit all necessary information and documents for a proper registration of the

\footnotetext{
504 Article 326 Code civil. See also article 57 Code civil.

${ }^{505}$ Quidelleur 2007, nr. 4, 5; Instruction générale relative à l'état civil du 11 mai 1999, par. 271, Journal Officiel n 172 du 28 juillet 1999.

506 Malaurie \& Fulchiron 2006, nr. 1013; Laroche-Gisserot 1997, nr. 523.

${ }^{507}$ Article 13 Décret n62-921 du 3 août 1962 modifiant certaines règles relatives aux actes de l'état civil.

508 Carbonnier 2004, nr. 258; Teyssié 2001, nr. 238; Laroche-Gisserot 1997, nr. 523.

${ }^{509}$ Neirinck 2006, p. 9. See also Granet-Lambrechts 2007b. These rules have been explained in § 3.5. Annulment of legal parenthood.

510 § 3.2.1. Establishment of legal maternity under French law.

511 § 1591 BGB.

$512 \S 33$ Verordnung zur Ausführung des Personenstandsgesetzes.

513 In general § 10 Personenstandsgesetz and in particular § 5 Verordnung zur Ausführung des Personenstandsgesetzes. See also BT Drucks. 16/1831, p. 44.
} 
child's birth.514 The production of the documents can be enforced with an administrative fine (Zwangsgeld). The registrar is also allowed to check the information that is submitted to him by the persons involved with the registers of other public authorities and to summon and question witnesses. 515

The evidential value of a birth record is determined by $\S 54$ Personenstandsgesetz. It provides that the registers on personal status prove marriage, birth and death and the declarations made about these events. The fact that the woman gave birth to the child is proven by the birth record. ${ }^{516}$ The facts mentioned are presumed to be true until it has been proven that they are not true. 517

If another woman than the birthmother is mentioned on the birth record, the name of the mother can be changed. According to Rauscher, two procedures are possible. 518 One can start a judicial procedure for rectification on the basis of $\S 48$ Personenstandsgesetz. It allows person involved (including the registrar and his supervisor) to start a procedure to correct the entry in a birth record that cannot be changed in an administrative procedure. 519 Another possibility is to apply for a declaration on the child's personal status on the basis of $\S 169$ Familienverfahrensgesetz (ex $\S 640$ Zivilprozeßordnung). In both procedures, the law does not limit the possibility to prove that the woman who is mentioned on the birth record did not give birth to the child.

\subsubsection{Evidence of legal paternity}

The standard rules under Dutch, French and German law are that legal paternity is either proven by the birth certificate in combination with the marriage certificate or by the instrument of acknowledgment of paternity. ${ }^{520}$ Under French law, legal paternity can also be proven with the instrument recording the apparent status of the child. ${ }^{221}$ But this is only one part of the story. For legal practice and private international law it is important to know what value can be attested to the entering of the man's name as father on the birth record or the entering of his acknowledgment on the birth record. It is important to know how a man appears on the birth record as father of the child. For that, one has to distinguish between legal paternity that exists ex lege and legal paternity that exists on the basis of a juridical act. Moreover, it is important to know what the evidential value is of the mention on the birth record as a man as father or of the mention of an acknowledgment of paternity.

\subsubsection{Dutch law}

The general principle of the Dutch system of registration of civil status is the birth record mentions a father if the child has a legal father. At the registration of birth the registrar has to determine ex officio the legal parentage of the child as it stands at the moment of birth.522 In order to execute this task registrar must investigate ex officio the legal parentage of the child; the parentage cannot be recorded solely on the basis of the declaration of the informant. Under Dutch law article 1:18 (2) Burgerlijk Wetboek provides that before drawing up an instrument of civil status (like a birth record) the civil status registrar is allowed to demand the production by the parties of any document in order to acquire the

\footnotetext{
$514 \S 10$ Personenstandsgesetz.

$515 \S 261$ Dienstanweisung für die Standesbeamten und ihre Aufsichtsbehörden. See also Hepting \& Gaaz 2006a, § 20 PStG, nr. 11-13.

${ }^{516}$ Hepting \& Gaaz 2006a, § 60 PStG, nr. 14; Gernhuber \& Coester-Waltjen 2006, § 51, nr. 3, note 3.

$517 \S 54$ (3) Personenstandsgesetz.

518 Staudinger/Rauscher 2004, § 1591, nr. 27.

519 Cf. § 47 Personenstandsgesetz.

520 France: Malaurie \& Fulchiron 2006, nr. 1016, 1017. Netherlands: Vat (Personen- en familierecht), art. 1:22 BW.

521 See § 3.3. Establishment of parenthood by apparent status.

522 Article 43 Besluit burgerlijke stand 1994.
} 
information that is necessary to draw up the instrument of civil status. He can also consult every public register. An important public registrar in this respect is the population register (gemeentelijke basisadministratie) which contains a description of the civil status of persons residing in the Netherlands. 523 At the registration of the birth, the information on the mother's personal status in the population register is the starting point for the civil status registrar. If the mother is registered as married, the informant does not need to submit evidence of the marriage of the mother. If the mother is registered as not married, the informant will need to submit evidence of the marriage if the informant claims that the mother is married. If the mother is not registered in the population register, the register shall determine the legal parentage of the child as if the mother is not married unless the informant proves that the mother is married. ${ }^{524}$

If the child does not have a legal father, legal paternity can be established by acknowledgment of paternity. An acknowledgment of paternity is a declaration by the man that he is the father of the child. Under Dutch law, the declaration only has legal effect if it is laid down in an instrument of acknowledgment drawn up by a civil status registrar or in an authentic instrument drawn up by a civil law notary. 525

In order to make sure that the acknowledgment shall be mentioned on the birth record, a civil status registrar or a civil law notary who draws up an instrument of acknowledgment is obliged to send a copy to the civil status registrar who keeps the birth record of the child involved. 526 The latter enters the acknowledgment on the birth record. 527 The registrar stating the acknowledgment on the birth record has to inform the registrar who drew up the acknowledgment of the entry; eighteen months after the latter has received the notification he destroys the instrument of acknowledgment. ${ }^{528}$ The instrument of acknowledgment shall not be destroyed as long as the registrar is not informed of the fact that it has been recorded on the birth record of the child. ${ }^{22}$ The idea is that it is not necessary to keep the instrument of acknowledgment if it has been recorded on the birth record, because in that case the acknowledgment of paternity can also be proven by the birth record. ${ }^{530}$

Under Dutch law, it is the registrar who draws up an instrument of acknowledgment who is primarily responsible to examine the validity of the acknowledgment. ${ }^{531}$ Therefore, a Dutch registrar does not draw up an instrument of acknowledgment if he is not satisfied that the acknowledgment establishes legal paternity. Thus he shall not draw up an instrument of acknowledgment if the child already has a legal father, if the required consents are not produced at the same time as the acknowledgment, if the man is married to

\footnotetext{
${ }^{523}$ Article 34 (1) Wet gemeentelijke basisadministratie persoonsgegevens (Wet GBA) provides that the register shall contain a description of the personal status of the person involved. The information on the personal status of comes from instruments of civil status or other (documentary) evidence as described in article 36 Wet GBA. Every person who expects to reside in the Netherlands for at least two thirds of half a year is obliged to register him- or herself in the municipality where he or she has his or her residence (art. 65 (1) Wet GBA).

524 Officiële Mededeling nr. 1/2002 inzake het opmaken van geboorteakten, Commissie van Advies voor de zaken betreffende de burgerlijke staat en de nationaliteit, Den Haag 28 mei 2002. The instruction from the Commissie van Advies can be found at http://www.justitie.nl/onderwerpen/wetgeving/over_wetgeving/privaatrecht/commissiesprivaatrecht/adviescommissie-inzake-burgerlijke-staat-en-nationaliteit.aspx.

525 Article 1:203 Burgerlijk Wetboek.

${ }^{526}$ For the civil status registrar: article 21 Besluit burgerlijke stand 1994. For the civil law notary: article 1:20e (3) Burgerlijk Wetboek.

527 Article 1:20 (1) Burgerlijk Wetboek.

528 Article 1:20f (2) Burgerlijk Wetboek.

529 Plasschaert 2002, p. 227.

530 Plasschaert 2002, p. 226.

531 This responsibility is not only common practice, but it also seems to follow from article 1:20 (1) Burgerlijk Wetboek. The article obliges the registrar who keeps the birth record to mention an instrument of acknowledgment on the birth record. The article does not provide for a possibility to reject the mention of the acknowledgment if it appears that it is not valid. Since the second registrar does not have an explicit statutory duty to check the validity of the acknowledgment, it becomes a responsibility for the registrar who authenticates the acknowledgment.
} 
another woman, if the acknowledger has not yet reached the age of 16 years or in the case of an incestuous child. ${ }^{532}$ In these cases an acknowledgment is null and void and does not establish legal paternity. ${ }^{533}$

An important element in determining the validity of the acknowledgment is the marital status of the mother of the child at the moment of birth. If the mother is married at the moment of birth, usually the husband is the father and an acknowledgment of paternity is not necessary. Therefore, before the Dutch registrar draws up an instrument of acknowledgment he will determine the marital status of the mother. If the mother is registered in the population register this is not a problem. In that case, the marital status of the mother can be derived from that register. But if the mother is not registered or if the population register is not correct, the acknowledger will have to prove to the satisfaction of the registrar that the mother is not married. Of course, it is not possible for the acknowledger to prove that the mother is not married anywhere in the world. However, depending on the countries involved he can submit declarations of foreign registers from the country of nationality or the country of the last habitual residence, that the mother is not registered as married.

Some Dutch civil law notaries are less stringent than civil status registers with regard to the examination of the personal status of the persons involved. This is problematic because the law prescribes that instruments of acknowledgment have to be stated on the birth record of the child. ${ }^{534}$ The law does not explicitly allow the registrar to verify the validity of an acknowledgment that has been done in the Netherlands. 535 Two interpretations are possible. In the first interpretation, the registrar is obliged to take notice of any instrument of acknowledgment on the birth record of the child even if it has been established by him that the acknowledgment is void. If it appears that the acknowledgment is void, the registrar has to inform the public prosecutor who can apply to the court for an order to strike out the acknowledgment. ${ }^{536}$ The disadvantage of this procedure is that it puts the burden of proof on the public prosecutor. The public prosecutor has to prove that the acknowledgment is invalid. This is a disadvantage because it does not allow a systematic check of the validity of the acknowledgment. After all, in order to determine whether or not the acknowledgment is valid one has to know for example the marital status of the mother at the moment of birth. If the mother is not registered in the Dutch population register, the authorities are dependent on information from the persons involved. Obviously, these persons will not produce any evidence that casts doubt on the validity of the acknowledgment as soon as it has been stated on the birth record. Therefore, in practice, the civil status registrar only takes notice of an instrument of acknowledgment from a civil law notary if it is proven to the satisfaction of the registrar that the mother is not married. ${ }^{537}$ Thus in practice, article 1:20 Burgerlijk Wetboek is interpreted as meaning that it only obliges registrars to take notice of a valid acknowledgment of paternity.

The law is not clear about the evidential value of the information concerning the father on the birth record. According to the general rules on the evidential value of authentic instruments of civil status, information on a birth record can be either binding evidence (dwingend bewijs) or non-binding evidence (vrije bewijskracht) of the truth of the information.

\footnotetext{
532 With regard to the consents it is explicitly mentioned in the parliamentary history that the instrument of acknowledgment can only be drawn up if the required consents are produced at the moment of the acknowledgment (Parlementaire Geschiedenis/Boek 1 Personen- en Familierecht 1962, p. 571).

533 Article 1:204 Burgerlijk Wetboek.

534 Article 1:20 (1) Burgerlijk Wetboek.

535 This is different if the acknowledgment has been done abroad (art. 1:20b (1) Burgerlijk Wetboek).

536 Article 1:24 (1) Burgerlijk Wetboek.

537 See also Plasschaert 2002, p. 325
} 
A birth record (or any other authentic instrument) is binding evidence of the information which the public official has reported within the scope of his competence about his observations and transactions. ${ }^{538}$ The mention of the name of a man in the box 'father' on the birth record is the conclusion of the registrar as to the legal parentage of the child, based on the information which has been presented to him and which he obtained himself. The information concerning the father is at the most, evidence of the fact that the registrar at the specific date concluded that the person involved is the legal father of the child.

With regard to the entry on the birth record that a man has acknowledged his paternity concerning the child, the legislator observed that the recording of the acknowledgment on the birth record is part of the birth record and has the same evidential value as the birth record. ${ }^{539}$ In view of the fact that the instrument of acknowledgment will be destroyed after its existence has been recorded on the birth record,540 it must be presumed that the statement on the birth record that $X$ acknowledged his paternity concerning the child involved is binding evidence of the fact the registrar himself established the existence of an authentic instrument of acknowledgement. 541

Next to the general rules on evidential value, the Dutch civil code contains three articles (art. 1:209, 210 and 211 Burgerlijk Wetboek) to contest the legal status that is proven by the birth record either on the ground that the persons named are not the legal parents (betwisting van staat) or on the ground that the birth record does not record the legal parents (inroeping van staat). Above, it has been concluded that these provisions attribute a specific evidential value to the information concerning the identity of the mother. With regard to paternity, the situation is less clear.

In 1950 the Hoge Raad held that an application to delete a man from the birth record who was named as the father did not constitute an action to contest the existence of the legal parentage that was proven by the birth record; according to the Hoge Raad the application only constituted an application for rectification under the current art. 1:24 (1) Burgerlijk Wetboek. Therefore, the former articles 318-321 (now articles 1:209, 210 and 211 Burgerlijk Wetboek) did not apply. ${ }^{542}$

In a similar case a man was named as the father of the child on the basis of his marriage with the mother. However, it appeared that the man was already dead before the child was born: the man died in 1944 while the child was born in 1947. Therefore, the man should never have been named as father in the first place because according to law at that time the husband was not the legal father of the child if the child was born more than 300 days after the dissolution of the marriage. 543

The Hoge Raad held that the application to change the birth record did not concern the woman who was named as the mother of the child, but that it only concerned her marital status. Therefore, the action did not concern an action to contest the legal status that is proven by the birth record (betwisting van staat), but only an application for rectification (now art. 1:24 (1) Burgerlijk Wetboek). In his note under this decision, Veegens wrote that an application to change the birth record constitutes merely a rectification and not a betwisting van staat, if the birth record contains facts that should not have been recorded and that can be changed without investigating the biological affiliation.

\footnotetext{
538 Article 157 (1) Wetboek van Burgerlijke Rechtsvordering. See also note 499.

${ }^{539}$ Kamerstukken II, 1990-1991, 21847, nr. 3, p. 27. Vat (Personen- en familierecht), art. 1:22 BW.

540 Article 23 (5) Besluit burgerlijke stand 1994.

541 See also article 157 (1) Wetboek van Burgerlijke Rechtsvordering.

542 Hoge Raad, 20 January 1950, NJ 1950/704. See also Hoge Raad, 21 December 1990, NJ 1991/741. These cases are also discussed by J. de Boer in his note under Hoge Raad, 21 December 2007, NJ 2008/321.

${ }^{543}$ Former article 309 Burgerlijk Wetboek.
} 
In 2003 the Hoge Raad was also confronted with an application to change the birth record of the child. ${ }^{544}$ The birth record stated that a certain Raul A had acknowledged his paternity concerning the child involved in Valencia, Venezuela. After the death of Raul A, his heirs contested that Raul A ever acknowledged his paternity and they applied for a rectification of the birth record of the child. The Hoge Raad held that article 1:209 Burgerlijk Wetboek is the starting point for the analysis of the case. Thus the existence of the legal parentage that follows from the birth record can only be contested by the child if the child has an apparent status in conformity with his birth record. However, article 1:209 Burgerlijk Wetboek does not prevent the correction of obvious errors and mistakes. ${ }^{545}$ With this reservation the Hoge Raad probably refers to its decision of $1950 .{ }^{546}$ In other words, the parentage of the child that follows from the birth record can be contested if it is based on an obvious error or mistake. This begs the question what is an obvious error or mistake.

According to Wortmann, examples of obvious mistakes are the husband who is mentioned as the father while he died more than 306 days before the birth of the child or the acknowledgment of paternity which is null and void on the basis of article 1:204 Burgerlijk Wetboek. ${ }^{547}$ This view suggests that obvious mistakes are mistakes in the registration of the legal parentage that can be proven with other instruments of civil status. ${ }^{548}$ That would mean that errors with regard to the determination of the legal father are almost always obvious errors because legal paternity is determined by other instruments of civil status such as the marriage certificate or the instrument of acknowledgment. Only legal maternity depends on childbirth and therefore only mistakes with regard to the registration of the mother would fall within the scope of articles 1:209, 210 and 211 Burgerlijk Wetboek. In this interpretation articles 1:209, 210 and 211 Burgerlijk Wetboek resemble the contestation d'état and the réclamation d'état under French law before the first of July 2006.

However, in the case of 2003, the question was whether or not the acknowledgment of paternity that was mentioned on the birth record really took place. The case concerned the legal paternity and not the legal maternity and it was still covered by article 1:209 Burgerlijk Wetboek. De Boer argues that the reservation that is made by the Hoge Raad is not correct and that the decision of the Hoge Raad from 1950 and 1990 should not apply anymore. Article 1:209 BW is meant to protect the interest of the child by giving only the child the right to contest a legal status in conformity with apparent status on the basis that the status does not exist. From that perspective, it does not matter whether the error in the birth record is obvious or not. Moreover, it is hard to determine which kinds of mistakes are obvious and which are not. ${ }^{549}$

In recent case law, the issue of apparent status gained new attention in the context of nationality law. It happens rather frequently that a Dutch national is named as the father in a foreign birth record concerning children who are born to a foreign mother. If it appears later that the Dutch national was married to another woman at the moment of his acknowledgment, or that the foreign mother was married to another man at the moment of the birth of the child, the Dutch authorities do not readily recognise the legal parenthood of the Dutch national who is named as the father on the birth certificate as a result of which the child does not have Dutch nationality. In such a case, the question arises whether the

\footnotetext{
544 Hoge Raad, 7 November 2003, NJ 2004/98.

545 Hoge Raad, 7 November 2003, NJ 2004/98.

546 J. de Boer in his note under Hoge Raad, 21 December 2007, NJ 2008/321.

547 S. Wortmann in her note under Hoge Raad, 7 November 2003, NJ 2004/98.

548 See also D.J. Veegens in his note under Hoge Raad, 20 January 1950, NJ 1950/704.

549 J. de Boer in his note under Hoge Raad, 21 December 2007, NJ 2008/321. In the same line Saarloos 2006.
} 
apparent status of the child vis-à-vis the Dutch national protects the legal parentage as it appears from the foreign birth certificate. 550

\subsubsection{French law}

Also under French law, the aim of the civil status registration system is that the birth record reflects the correct legal status of the child, but the registration process is different to under Dutch law. The first difference between Dutch (and German law) on the one hand and French law on the other hand is that the registration of the legal parents of the child is not mandatory. Article 55 Code civil provides that if the informant does not inform the civil status registrar about the identity of the father and mother of the child or one of them, nothing thereon shall be mentioned on the registers.

The second difference is that the French civil code does not oblige the registrar to investigate ex officio the (legal) truth of the declarations made to him and to examine the personal status of the persons involved. If the person who declares the birth does not state anything with regard to one or both of the parents, article 55 Code civil already provides that the registrar should not state anything with regard to the parents on the birth record. But also in the opposite situation where a person states that a certain man is the father of the child, the investigative power of the registrar to check whether that person is really the legal father is limited.

In principle the informant has to submit a declaration by the midwife or doctor assisting at the birth and the livret de famille or evidence of the identity of the mother together with the instrument of acknowledgment, if applicable. Furthermore, some documents concerning the determination of the child's name have to be submitted like a declaration for the choice of the surname and the birth certificates of previous children of the couple. ${ }^{551}$ If it is asserted that the mother of the child is married, the civil status registrar verifies the declaration on the basis of the documents that are submitted to him. However, even in the absence of documents proving the marriage the registrar has to register the child as a child of the marriage if the informant so indicates. ${ }^{552}$ In France there is no population register comparable to the Dutch gemeentelijke basisadministratie, but the marital status of the mother can be checked with her birth certificate. ${ }^{553}$

Also the procedure with regard to acknowledgment of paternity under French law is different to Dutch law. Under French law, the two major grounds for nullity of the acknowledgment of paternity are that the child is an incestuous child ${ }^{554}$ and that the child already has a legal father. ${ }^{555}$ In cases of incestuous children, the acknowledgment of paternity is void if legal maternity has already been established. ${ }^{556}$ If the civil status registrar is informed of the incest he must refuse to draw up the instrument of acknowledgment.557 However, there is no general obligation to examine ex officio whether or not the acknowledger is a close relative of the mother of the child. The same applies with regard to the acknowledgment of paternity concerning a child who already has a legal father. In this

\footnotetext{
550 Examples: Rechtbank 's-Gravenhage, 10 December 2009, case nr. 277374/HA RK 06-1186 (not published); Gemeenschappelijk Hof van Justitie van de Nederlandse Antillen en Aruba, 9 December 2008, LJN BH6203; Hoge Raad, 5 September 2008, LJN BD2711. See also Saarloos 2008.

551 Quidelleur 2007, nr. 4.

${ }_{552}$ Quidelleur 2007, nr. 12; Instruction générale relative à l'état civil du 11 mai 1999, par. 275, Journal Officiel n 172 du 28 juillet 1999.

${ }^{553}$ Article 76 Code civil states that the marriage of two persons shall be mentioned in the birth record of the persons concerned (for divorce see article 1082 Code de procédure civil). See also Quidelleur 2007, nr. 250; Instruction générale relative à l'état civil du 11 mai 1999, par. 420, Journal Officiel nº172 du 28 juillet 1999.

554 Article 310-2 Code civil.

555 Article 320 Code civil.

556 Article 310-2 Code civil

557 Quidelleur 2007, nr. 49.
} 
respect, the instruction for civil status registrars explicitly states that even if the registrar knows that the child already has a father, he still has to draw up the acknowledgment of paternity because if the existing legal paternity should be annulled, the acknowledgment of paternity automatically establishes legal paternity. .58

The registrar who drew up an instrument of acknowledgment has to send a copy to the registrar keeping the birth record of the child, in order to record the acknowledgment of paternity on the birth record of the child. ${ }^{559}$ Usually, it is the registrar who has to record the acknowledgment of paternity on the birth record of the child who notes that the acknowledgment is not valid. After all, he can see on the birth record of the child that if the child already has a father or if the mother and the acknowledger are close relatives. In that case, the acknowledgment of paternity shall not be recorded on the birth record. The registrar receiving a copy of the acknowledgment of paternity has to inform the public prosecutor. 560 The public prosecutor can apply for a judicial declaration and strike out the acknowledgment of paternity that appears in the register of the births of the registrar who drew up the acknowledgment. 561

The fact that French law leaves more room for the parties involved with regard to the parentage that shall be registered than Dutch (and German) law might suggest that the chance that the birth record does not reflect the correct legal parentage is bigger than under Dutch (and German) law. This is only true to a limited extent, because more than under Dutch and German law, the legal status of a child is determined by what is registered: the woman who is registered as the mother is the legal mother and the husband is not the legal father if he is not registered as such and if the child does not have apparent status with regard to him. 562

Having examined the procedure to determine who should be mentioned as father on the birth record, the second question is what is the evidential value of the information concerning the father's identity on the birth record. With regard to the evidential value of instruments of civil status it is provided that if they are dated, signed and bear the seal of the issuing authority they are evidence until inscription de faux. ${ }^{563}$ That means that the birth record must be considered true until it the contrary has been established in accordance with the articles 303 to 316 of the French code on civil procedure. These rules make it very hard to contradict an instrument of civil status. For example, the public prosecutor shall be informed of the fact that the instrument of civil status is contradicted with a view to start criminal proceedings, ${ }^{564}$ but if the applicant wrongfully claims that the instrument of civil status is not correct he is liable to pay to a civil law fine up to 3,000 euros.565

However, instruments of civil status are only true until inscription de faux with regard to facts that have been observed by the registrar himself. With regard to other facts, the instrument of civil status is considered true until the contrary has been proven. ${ }^{566}$ Both

\footnotetext{
558 Instruction générale relative à l'état civil du 11 mai 1999, par. 299, 300, Journal Officiel nº 172 du 28 juillet 1999.

${ }^{559}$ Instruction générale relative à l'état civil du 11 mai 1999, par. 311-1, Journal Officiel nº 172 du 28 juillet 1999.

560 Article 336-1 Code civil. Instruction générale relative à l'état civil du 11 mai 1999, par. 301, 304, Journal Officiel n 172 du 28 juillet 1999.

561 Article 423 Code de procédure civil. Unlike under Dutch and German law, the French system of civil status registration has a register for instruments of acknowledgment in the register of births. Thus, if the registrar who keeps the birth record of the child finds out that the acknowledgment of paternity is void, it has to be mentioned on the instrument of acknowledgment in the register of the births of the first registrar that the acknowledgment is void. Otherwise, the register of births of the first registrar will be evidence of legal paternity that does not exist.

562 Articles 311-25, 313 Code civil.

${ }^{563}$ Article 13 Décret n62-921 du 3 août 1962 modifiant certaines règles relatives aux actes de l'état civil.

564 Article 303 Code de procédure civil.

565 Article 305 Code de procédure civil.

566 Carbonnier 2004, nr. 258; Teyssié 2001, nr. 238; Laroche-Gisserot 1997, nr. 523.
} 
categories do not apply to the information concerning the identity of the father. The question is to what extent the mention of a man's name on the birth record is evidence of the establishment of his legal paternity. That is a question as to the existence of a legal relationship and it is therefore not governed by the general rules on the evidential value of instruments of civil status which relate to facts.

The law does not determine explicitly the evidential value of the information on the birth record concerning the father of the child. It seems that the parentage that follows from the birth record is at least accepted until it has been proven that the paternity has not been legally established. For example, if the birth record mentions a man as the father of the child on the basis of his marriage to the mother while in fact the man and the woman were already divorced more than 300 days at the moment of birth, the name of the father can be deleted from the record in a simple rectification procedure on the basis of articles 99 to 101 Code civil.567 The idea is that the rectification procedure applies in those cases where the birth record does not indicate the true legal status of the child. ${ }^{568}$ Therefore, if the birth record does not indicate the husband of the mother at the moment of birth, the child cannot apply for a rectification of his birth record to name that man as the father. After all, article 313 Code civil provides that the husband is not the legal father if he is not recorded as the father of the child and if the child does not have apparent status with regard to him. In that case, the only way to amend the birth record is to start a procedure for the judicial establishment of the legal paternity of the husband. 569

\subsubsection{German law}

Under German law, as under Dutch law, the legal parents at the moment of birth have to be named on the birth record. In order to assure the accuracy of the registers the German registrar has extensive investigative powers. It has already been shown that the informant can be asked to submit a declaration of the midwife or the doctor assisting at the birth. In order to determine the legal parentage of the child at the moment of birth, the registrar has to know whether the mother was married at the moment of the birth or whether the marriage is dissolved as a result of the death of the husband. In both cases the (ex) husband is the legal father of the child. ${ }^{570}$ In order to determine the marital status of the mother, the civil status registrar demands the production by the informant of evidence of the marriage if it is asserted that the mother is married or the birth certificate of the mother if it is asserted that she is not married. ${ }^{571}$ If the informant is not able to produce the necessary information and if the registrar cannot get the information from the registers of civil status that are kept by him, the registrar shall order the production of the evidence within a certain period of time. The production of information can be enforced with an administrative fine (Zwangsgeld). ${ }^{572}$ If the registrar doubts the truth of the declaration of the informant, he is obliged to verify it. In order to verify the declaration the registrar can summon and question witnesses and experts. ${ }^{573} \mathrm{He}$ is also allowed to make the necessary inquiries to other public

\footnotetext{
567 Cass. Civ. 1er, 14 May 1985, D. 1986, 59.

568 Carbonnier 2004, nr. 260.

569 See also Cass. Civ. 1er, 3 June 1980, D. 1981, 119. The Cour de Cassation held that the application to add to the birth record the mention that the mother was married at the time of birth could be made in a rectification procedure, but such a rectification does not establish the legal paternity of the husband.

$570 \S \S 1592$ and 1593 BGB.

$571 \S 33$ Verordnung zur Ausführung des Personenstandsgesetzes.

572 § 69 Personenstandsgesetz. § 206 Dienstanweisung für die Standesbeamten und ihre Aufsichtsbehörden.

573 § 261 Dienstanweisung für die Standesbeamten und ihre Aufsichtsbehörden.
} 
registers such as the population register that contains a description of the personal status of persons residing in Germany. ${ }^{574}$

If the legal paternity has not been established by the marriage of a man to the mother of the child, legal paternity can be established by acknowledgment of paternity. In that case, legal paternity is proven by the instrument of acknowledgment. In most cases, the instrument of acknowledgment is drawn up by a civil status registrar, but that is not the only competent authority. Under German law, there is a broad list of authorities that can draw up an instrument of acknowledgment: the civil states registrar (Standesbeamte), a civil law notary (Notar), the Amtsgericht, the Urkundsperson beim Jugendamt or the court which decides on a paternity dispute. .75

Under German law it is the responsibility of the registrar who keeps the birth record of the child to check whether or not the acknowledgment of paternity establishes legal paternity. However, under German law also the registrar who draws up the instrument of acknowledgment has to verify whether or not the acknowledgment of paternity shall establish legal paternity, by checking the identity of the acknowledger and the legal parentage of the child. If it appears to him that the acknowledgement does not establish legal paternity he shall make a note and inform the registrar who keeps the birth record of his findings. However, he shall not refuse to draw up the acknowledgment. 576 Even if the required consents are lacking or if the child already has a legal father the registrar will always draw up an instrument of acknowledgment. After all, the consents can be given later and as soon as the existing legal paternity is annulled the acknowledgment establishes legal paternity automatically. ${ }^{577}$

Only in one instance is the registrar not permitted to draw up an instrument of acknowledgment. $\S 33$ (1) Personenstandsgesetz provides that the registrar shall not draw up an instrument of acknowledgment if it appears to him that the legal paternity can be annulled on the basis of $\S 1600$ (1) under 5 BGB. This exception is a means to combat fraud with regard to nationality law and immigration law and has nothing to do with the personal status as such. 578

The registrar who drew up an instrument of acknowledgment shall send a copy to the registrar who keeps the birth record of the child. Also, the necessary consents of the mother and/or the child shall be sent to the registrar who keeps the birth record of the child. 579 If it appears to the registrar who keeps the birth record of the child that the acknowledgment of paternity has established legal paternity, and only then he shall record that on the birth record of the child. 580

The evidential value of German instruments of civil status is determined by $\S 54$ Personenstandsgesetz. The provision states that the registers of civil status prove marriage, birth and death and the declarations made about these events. The registers constitute binding evidence of the facts involved, meaning that the facts are presumed to be true until the contrary is proven. 581 The registers are also considered binding evidence of the legal

\footnotetext{
${ }^{574}$ Hepting \& Gaaz 2006a, § 20 PStG, nr. 11. The population register in Germany is the Einwohnermeldeamt. The Melderegister contains inter alia a description of the personal status of persons residing in Germany (§ 2 (1) under 14 and 15 Melderechtsrahmengesetz). A person who moves into a house in Germany ('wer eine Wohnung bezieht') is obliged to register him or herself in the Melderegister ( $\$ 11$ Melderechtsrahmengesetz). For an online list of Meldegesetzen of the different states of Germany see http://de.wikipedia.org/wiki/Meldegesetz.

$575 \S 44$ Personenstandsgesetz; § 20 Bundesnotarordnung; § 62 (1) sub 1 Beurkundungsgesetz; § 59 (1) Achtes Buch Sozialgesetzbuch; § 641c Zivilprozessordnung.

576 Hepting \& Gaaz 2006a, § 29a PStG, nr. 17-23.

577 Hepting \& Gaaz 2006b, V-90-93.

578 See in more detail note 428.

$579 \S 44$ (3) Personenstandsgesetz.

580 § 27 Personenstandsgesetz. See also Hepting \& Gaaz 2006a, § 29 PStG, nr. 19-31.

$581 \S 54$ Personenstandsgesetz.
} 
parentage of the child. Thus the naming of a man as father on the birth record of the child is binding evidence of his legal paternity and the note on the birth record that a man acknowledged his paternity concerning the child is binding evidence of the validity of the acknowledgement. 582

It follows that it is always possible to prove that the register of birth does not indicate the correct legal status of the child. There is only one exception to this rule. § 1598 (2) BGB provides that the acknowledgment becomes valid if it has been recorded in a register of civil status for at least five years, even if the requirements for validity are not fulfilled.

\subsection{Evidence of legal parentage under Swedish law}

Unlike under the other legal systems under consideration Sweden does not have a separate authority for the registration of civil status. In Sweden, the civil status of persons is registered by skatteverket (the tax authority). The tax authority only records the civil status; it does not assist at the coming about of juridical acts like marriage or acknowledgment of paternity.

The registration of civil status by the tax authority is governed by the Folkbokföringslag (1991:481) and subsequent legislation. ${ }^{583}$ The Folkbokföringslag establishes a population register comparable with the Dutch gemeentelijke basisadministratie persoonsgegevens. One difference between a population register and a civil status register is that in the civil status register births, marriages and deaths are recorded that occur in the district for which the register is kept. If the birth does not take place in the district, it will not be recorded in the register of that district. The objective of a population register is not solely to record events that determine the personal status, but it records information concerning the members of the population of a certain district. The civil status of these members is one of the elements that are recorded. The criterion to determine whether or not a person should be recorded in a population register is whether or not one resides in the particular district. It follows that for the purpose of registering the personal status of a resident of Sweden it does not matter very much whether or not he is born in Sweden. In both cases, the same information has to be recorded. The only difference is that if a person acquires residence in Sweden at his birth, the information concerning his birth and parentage is acquired differently to if the person is not born in Sweden.

For the Swedish registration system there are two kinds of births: the birth in Sweden of a person who has to be registered (folkbokförd) in the population register and the birth in Sweden of a person who must not be registered (folkbokförd) in the population register. 584

The main rule is that a child who is born shall be registered in the population register if the mother, the father ${ }^{585}$ or the person with custody is registered in the population register. Even if the child is born abroad to a woman who is registered in the Swedish population register the child shall be registered in the population register. ${ }^{586} \mathrm{In}$ this case, the information concerning the person of the child that has to be recorded is determined by the Lag (2001:182) om behandling av personuppgifter i Skatteverkets folkbokföringsverksamhet (Act (2001:182) on the handling of personal data in skatteverket's registration activities). §

\footnotetext{
582 Hepting \& Gaaz 2006a, § 29, nr. 93; § 29a, nr. 15; § 60, nr. 14, 28.

583 Other relevant pieces of legislation are the Lag (2001:182) om behandling av personuppgifter i Skatteverkets folkbokföringsverksamhet and the Förordning (2001:589) om behandling av personuppgifter i Skatteverketsfolkbokföringsverksamhet. Next to these texts, information on the functioning of the population registration system in Sweden has been collected from the instruction for registrars from the Intranet of the tax authority.

584 §1 (2) Folkbokföringslag (1991:481).

585 Only if the father has custody over the child (Instruction for registrars, § 7.3).

586 \& 2 Folkbokföringslag (1991:481).
} 
2:3 of this Act simply provides that information concerning the time and place of birth as well as the personal status of the person involved shall be recorded.

If the child is born in a hospital in Sweden, which is most often the case if the child is born in Sweden, the hospital is under a duty to declare the birth to the tax authority. ${ }^{587}$ In the rare situation where the child is not born in a hospital, the person with custody over the child has to report the birth within one month to the tax authority. 588 In both cases, the birth has to be declared with a special form that is provided by the tax authority. By making the hospital where the child is born responsible for the declaration of the birth, the legislator wants to guarantee as far as possible that the declaration of birth is effected correctly.

There are no detailed provisions on how the legal parentage of the child is established. The starting point is that the register has to contain accurate information concerning the person involved. ${ }^{589}$ If the tax authority receives a declaration of birth from a hospital and if the child has to be registered in the population register, the tax authority will determine the child's legal parentage itself. The basis for the tax authority to determine the legal parentage of the child is the information it has on the marital status of the mother. If the mother is registered in the population register as married, the tax authority will register the husband of the mother as the father of the child. ${ }^{590}$ If the mother is not married at the moment of birth, the tax authority will not register a man as the father. In that case, it will inform the competent socialnämnd (social welfare committee) in order to investigate the paternity. ${ }^{591}$

If the mother is not registered in the population register the birth of the child must also be recorded and reported to the tax authority. ${ }^{592}$ However, this child will not be registered in the population register and therefore, the rules that have been explained above do not automatically apply to this kind of cases.

Also if the mother is not registered in the population register the birth is in most cases declared to the tax authority by the hospital or the nursing home where the mother gave birth. 593 The information that has to be registered concerning the birth of a child who is not registered in the population register is determined by the tax authority itself. ${ }^{594} \mathrm{Up}$ until now the tax authority has not published an official decree on the information that has to be registered in such a case. The instruction for registrars provides that information concerning the birth (date and place), the parentage and the name has to be registered. Other information (nationality, custody) shall not be recorded.595

In order to determine the parentage of the child the tax authority has to know the marital status of the mother. After all, the instruction for registers provides that the husband of the mother at the moment of birth shall be registered as the father of the child; if the mother is not married no man shall be mentioned as the father.596 If the mother is not registered in the Swedish population register, the tax authority depends on the information from the woman who gave birth to the child to determine the marital status of the mother. There are no official rules on how the mother has to prove her marital status. If the mother states that she is not married, that information will be taken over without further inquiries if it is not contradicted by other documents. ${ }^{597}$ If the mother states that she is married it is not obligatory to submit evidence of the marriage. However, if the mother claims to be married

\footnotetext{
$587 \S 24$ (1) Folkbokföringslag (1991:481).

588 § 24 (2), (3) Folkbokföringslag (1991:481).

${ }^{589} \S 1: 4$ (5) Lag (2001:182) om behandling av personuppgifter i Skatteverkets folkbokföringsverksamhet.

590 § 1:1 Föräldrabalk (1949:381).

591 § 7 (1) Förordning (2001:589) om behandling av personuppgifter i Skatteverketsfolkbokföringsverksamhet.

$592 \S 1$ (2) Folkbokföringslag (1991:481).

593 See note 587.

594 § 4 (3) Förordning (2001:589) om behandling av personuppgifter i Skatteverketsfolkbokföringsverksamhet.

595 Instruction for registrars, § 7.3, under Registrering av nyfött barn som inte ska folkbokföras.

596 See note 595 .

597 Instruction for registrars, § 18.6, under Civilstånd.
} 
but does not submit evidence of the marriage, the tax authority will ask further questions to determine whether it is probable or not that the woman is married.

Next to the registration of the parentage of persons who are born in Sweden, the tax authority also registers in the population register the parentage of persons who are born abroad and immigrate to Sweden. Not every foreigner who resides in Sweden will be registered in the population register. Foreigners who need a residence permit are only registered in the population register if they have a valid residence permit. Thus, asylum seekers who are still in the application procedure for a residence permit are not recorded in the population register. Also foreign diplomatic staff are in principle not registered in the population register. ${ }^{598}$ If the foreigner qualifies for registration in the population register the parentage of the person involved is determined on the basis of foreign instruments of civil status and other means of evidence in combination with the Swedish rules on private international law in matters concerning parentage.

For the legal systems of the Netherlands, France and Germany it has been examined to what extent the registrars investigate the effects of the acknowledgment of paternity and who is responsible for what. This point is not relevant for Sweden, because under Swedish law the acknowledgment of paternity does not need to be authenticated. The formal requirements for a valid acknowledgment of paternity according to Swedish law are only that the acknowledgment is in writing and witnessed by two persons. ${ }^{599}$ In theory a person who acknowledged his paternity simply submits his declaration to the tax authority that checks whether the declaration established the legal paternity of the acknowledger. If it does, the tax authority will amend the records of the persons involved.

In practice, this is not the most obvious way to establish and register legal paternity out of wedlock. If the child is registered by the tax authority without a legal father, the tax authority shall inform the socialnämnd (social welfare committee) ${ }^{600}$ If the acknowledgment of paternity requires the consent of the socialnämnd, which is always the case if the child is a minor, ${ }^{601}$ the socialnämnd takes the initiative for the acknowledgment of paternity. ${ }^{602}$ The tax authority itself does not intervene in the procedure for acknowledgment or paternity. The socialnämnd examines the (biological) affiliation of the child and persuades the (biological) father or the female partner of the mother to acknowledge his paternity or her parenthood. The acknowledger, the witnesses and the persons that have to consent sign a special form from the socialnämnd. That form is sent to the tax authority that will amend the records of the persons involved.

Unlike under Dutch, French and German law the Swedish legal system does not grant a special evidential value to the information on the registers of civil status. The evidential value of the information in the population register is evaluated by the courts themselves. 603

Although the Swedish legal system does not grant a specific evidential value to the documents in general or the population record in particular, it is accepted in case law that documents that are meant to serve as evidence have a higher evidential value than documents that are not meant to serve as evidence. 604

Another aspect that reveals something of the evidential value of the population register is the way in which the contents of the register can be changed. The law does not provide

\footnotetext{
598 §§ 4, 5 Folkbokföringslag (1991:481).

599 § 1:4 Föräldrabalk (1949:381).

600 See note 591.

$601 \S 1: 4$ Föräldrabalk (1949:381).

602 § 2:1 Föräldrabalk (1949:381).

603 § 35:1 Rättegångsbalk (1942:740).

${ }^{604}$ Lindell 2004, p. 550, note 114.
} 
much guidance (or restraint) on the procedure to change the information concerning the personal status. Normally, a person who claims that his information is not correct applies to the tax authority for a change of the register. If it is proven to the satisfaction of the tax authority that the information concerning the person's personal status is not correct, for example if the ex-husband is registered as the father while the child is born after the divorce, the tax authority simply changes the information.

However, with the information concerning the identity of the mother, a key element in the determination of the legal parentage of the child, the tax authority has adopted a stricter approach. ${ }^{605}$ The approach has been developed in reaction to fraudulent conduct in matters concerning the registration of the personal status of foreigners. In order to circumvent immigration rules, women claimed to be the mother of persons who were in fact their siblings. According to the tax authority, information concerning the identity of a person's mother can only be changed if the person involved submits a judgment establishing his maternal affiliation. 606

\subsection{Conclusion on the evidence of legal parentage}

In this chapter the evidence of legal parentage under Dutch, English, French, German and Dutch law has been examined. First of all, this chapter underlines what has already been concluded in chapter two. Under English law, matters concerning parentage are to a large extent resolved by the law on evidence while under the other legal systems the establishment of legal parentage is considered a substantive matter. As a consequence, the meaning of information on the father on an English birth record is different to the meaning of information on the father on a birth record from France, the Netherlands, Germany or Sweden.

Information on the father on an English birth record is prima facie evidence of the fact that establishes the legal paternity. In most cases that fact is biological paternity. Under the other legal systems information concerning the father is not evidence of a fact, but evidence of the conclusion of the registrar concerning the legal paternity of the child. The conclusion of the registrar has no specific evidential value, except under German law. It has been shown that under German law it is accepted that the birth record is binding evidence of the legal paternity of the child.

If the information concerning the father on a continental birth record is merely the legal conclusion of the registrar, the question arises how much this conclusion is worth. A striking difference between a French registrar on the one hand and the Dutch and German registrars on the other hand is that the French registrar is more passive and the Dutch and German registrars are more inquisitive.

Both the Dutch and the German registrars also have the means at their disposal to enforce their legal obligation to clarify the personal status of the persons involved, especially the child and the mother. The French registrar is dependant on the information that is submitted to him. If the French registrar finds irregularities in the registration he has to inform the public prosecutor who can start a judicial procedure to rectify the registers.

The fact that the French registrar in comparison with his Dutch and German colleagues has fewer possibilities to examine the legal parentage of the child is partly compensated for by the fact that under French law the legal parentage depends to a certain extent on what is registered: a woman is the legal mother because she is registered as such and the husband is not the legal father if he is not named as such on the birth record.

\footnotetext{
${ }^{605}$ Socialstyrelsen 2005, p. 107, 108.

${ }^{606}$ See $\S 3.1 .2$. Ex lege existence of legal maternity.
} 
Under Dutch and German law the legal parentage as it follows from the law and the legal parentage as it follows from the instruments of civil status are much more separated. The legal parentage of the child follows from the civil code and if the birth record indicates a different parentage, the birth record can be changed relatively easily. There are some exceptions to this rule under Dutch and German law. It has been shown that under Dutch law the fact that the child has an apparent status in conformity with the birth record makes it more difficult to change the birth record, because in that case only the child has standing. Under German law, an invalid acknowledgement becomes valid if it has been recorded in a register of civil status for five years.

In Sweden, the legislator tries to make the registration of the birth independent of declarations of the persons involved. Hospitals report the birth to the tax authority which on its turn determines the parentage on the basis of the information it has on the persons involved. If it appears that the tax authority has made a mistake, the register can easily be changed if the person involved is able to prove that the child's legal parentage is different. The Swedish system is not watertight though. In cases of foreigners who are not registered in Sweden, the Swedish authorities still depend for the initial registration on information that is submitted to them by the persons involved. 


\section{Part 2 Private international law on parentage}

In the first part of this thesis the establishment of legal parentage in the legal systems of England and Wales, France, Germany, the Netherlands and Sweden has been examined. The reader has been presented an insight into the differences and similarities of the national rules on parentage. In this part the focus shifts from the national case to the international case: how do the national legal systems involved deal with problems of parentage in cases with a foreign element, i.e. if one of the individuals involved has a foreign nationality, domicile or residence.

The objective is to determine on the basis of an examination of the national systems of private international law the strengths and weaknesses from the perspective of EU law. In discussing the national systems of private international law two stages will be distinguished. First, chapters 5 and 6 will examine the establishment or annulment of legal parentage in cases with a foreign element when the action takes place on the territory of the member state involved by discussing international jurisdiction and applicable law. After that, chapter 7 examines how national systems on private international law deal with legal parentage that has been established or contested abroad. 


\section{International jurisdiction to establish and annul legal parentage}

This chapter examines the national systems of private international law on parentage from the perspective of the individual who has to declare the birth of a child, who wants to acknowledge his paternity or who goes to court in order to establish legal parentage or to contest it. In the next chapter the recognition of parenthood that has been established abroad will be discussed.

In this chapter the international jurisdiction of national civil status registrars and courts to determine the child's parentage will be studied. From the perspective of Europeanisation of private international law it is important not only to consider the courts and their international jurisdiction to determine the legal parentage of a child. It is expected that European law intervenes in the national choice of law process at the moment national legal systems result in conflict by recording different legal status. Thus, if one wants to discuss the Europeanisation of private international law on personal status one has to understand how it is possible that different Member States record different personal status for one person. Part of this question is answered by giving an overview of the international situations in which national registrars determine and record the parentage of a child. For the sake of convenience this will be called the international jurisdiction of registrars although the functions of the registrar and the function of a court in matters concerning parentage are different. The registrar records the status that is determined by him (Germany, Netherlands, Sweden and to a certain extent France) or that is declared to him (England), but his conclusions or observations do not have force of law; the birth record can be changed if it is wrong. In contrast, the establishment, annulment or determination of legal parentage by a court does have force of law at least inter partes and often also erga omnes.

\subsection{International jurisdiction of registrars in matters concerning parentage}

This paragraph examines the international jurisdiction of national civil status registrars to determine the child's parentage. At least on two occasions the civil status registrar has to determine the child's legal parentage. The first occasion is when the birth of the child is recorded. The second occasion is when a person acknowledges his paternity or her maternity and requests the statement of his or her name as the father or the mother on the child's birth record. The first part of this thesis has shown that these two events concerning a child's parentage are known in all legal systems under consideration. Depending on the national law, the civil status registrar can also have other tasks with regard to a person's parentage, like the authentication of a declaration contesting legal parentage.

\subsubsection{Registration of birth}

On the first occasion, the determination of the child's parentage is linked to the obligation to register the child's birth: if the registrar has to record the child's birth he also has to determine the child's parentage. ${ }^{607}$ Thus, in fact the first question is not when the registrar has international jurisdiction to determine the child's parentage, but when the registrar has to record the child's birth. All legal systems involved require that the birth of every child on the national territory be recorded within a certain period of time with the national authorities.

607 England: s. 1 Births and Deaths Registration Act 1953. France: art. 57 Code civil. Germany: § 21 Personenstandsgesetz. Netherlands: art. 43 Besluit Burgerlijke Stand 1994. Sweden: § 6 Lag (1990:1536) om folkbokföringsregister. 
Under Dutch, English, French and German law, the birth of a child has to be recorded with the civil status registrar of the municipality or district where the child is born (ambtenaar van de burgerlijke stand, officier de l'état civil, Standesbeamte). ${ }^{608}$ The period of time within which the birth of the child has to be declared differs. In the Netherlands and in France the birth has to be recorded within three days after the birth, in Germany the period is one week and in England forty-two days.609

Sweden does not have an independent service for the registration of personal status. Some functions which in England, France, Germany and the Netherlands are performed by the civil status registrar are in Sweden executed by skatteverket (the tax authority), but not all. For example, the tax authority records the births and deaths. ${ }^{610}$ Marriages are recorded but not solemnised by the tax authority. Marriages are solemnised either by a civil authority such as a judge from the district court or by a representative of one of the recognised religious communities in Sweden, such as the Church of Sweden.611 The birth of a child has to be recorded within one month after the birth. 612

Some legal systems also allow the registration of a birth which has taken place abroad, with the result that a person can have two (or more) birth records that can indicate a different legal status. Under French law, French nationals can either file the foreign birth certificate 613 in the national register of births or the birth can be recorded by the French diplomatic or consular agency in the country where the child is born. ${ }^{614}$ If the French authorities have recorded the birth, the filing of a foreign birth certificate is impossible. ${ }^{615}$ At the end of each year a copy of the registers of birth of the diplomatic and consular agencies is sent to the service central de l'état civil in Nantes that stores them.

English 616 and German ${ }^{617}$ law only provide for the possibility to register the birth of a national who is born abroad. It is not possible to file a foreign birth certificate with the English or German authorities. Under English law, the registration of foreign births is supervised by the Foreign and Commonwealth Office and not by the General Register Office. In Germany, the birth of a German national can be registered in Berlin either directly or via the German diplomatic or consular agency in the country of birth. ${ }^{618}$ The register office in Berlin West is also competent to record the birth abroad of a stateless person, a heimatloser Ausländer, a foreign refugee or an asylum seeker if the person is habitually resident in Germany. ${ }^{619}$

\footnotetext{
608 England: s. 1 Births and Deaths Registration Act 1953. France: art. 55 Code civil. Germany: § 18 Personenstandsgesetz. Netherlands: art. 1:19 Burgerlijk Wetboek.

609 England: S. 2 Births and Deaths Registration Act 1953. France: art. 55 Code civil. Germany: § 18 Personenstandsgesetz. Netherlands: art. 1:19e (6) Burgerlijk Wetboek.

610 § 1 Folkbokföringslag (1991:481).

611 § 4:3 Äktenskapsbalk (Marriage Act) (1987:230).

612 § 24 Folkbokföringslag (1991:481).

613 Article 47 Code civil, art. 7 Décret nr. 62-921 modifiant certaines règles relatives aux actes de l'état civil, art. 5 Décret nr. 2008-521 relatif aux attributions des autorités diplomatiques et consulaires françaises en matière d'état civil. The transcription of a (foreign) instrument of civil status or judgment is the action of the civil status registrar by which he reports on the registers the existence of an instrument of civil status which has been drawn up outside his district or the existence of a judgment concerning someone's personal status (Instruction générale relative à l'état civil du 11 mai 1999, nr. 207, Journal Officiel $n^{\circ} 172$ du 28 juillet 1999).

${ }^{614}$ Article 98 Code civil, art. 5 Décret nr. 2008-521 relatif aux attributions des autorités diplomatiques et consulaires françaises en matière d'état civil.

615 Article 98-4 Code civil.

${ }_{616}$ Section 41 (g), (h) and (i) British Nationality Act 1981; regs. 4 and 5 Registration of Overseas Births and Deaths Regulations (SI 1982/1123).

$617 \S 36$ Personenstandsgesetz.

${ }^{618}$ See also § 387 Dienstanweisung für die Standesbeamten und ihre Aufsichtsbehörden.

619 § 36 Personenstandsgesetz.
} 
Under Dutch law, certain diplomatic and consular agencies are allowed to record the birth of a Dutch national abroad, but in practice this almost never happens. ${ }^{620}$ Diplomatic and consular agencies usually refer the persons involved to the local civil status registrar. In principle it is not possible to record a birth if the child is born abroad. Dutch nationals also have the possibility to file the foreign birth certificate in the central register of births in The Hague. ${ }^{621}$ This possibility also exists for certain foreigners lawfully residing in the Netherlands. 622 Only if no birth record exists, Dutch nationals, foreigners lawfully residing in the Netherlands on the basis of article 8 under $\mathrm{c}$ and $\mathrm{d}$ of the Vreemdelingenwet 2000 and foreigners who need a birth record to add a marginal note can request the registrar to draw up a substitute birth record.623

Under Swedish law there is no possibility to record the birth of a Swedish national abroad or to file the foreign birth record with the Swedish authorities. As soon as the child acquires residence in Sweden, an entry in the population register will be prepared on the basis of the foreign birth record.

\subsubsection{Acknowledgment of parenthood}

We have seen that in each of the legal systems considered it is possible that at the moment of the birth registration no father is mentioned as the child's father. Under Dutch, French, German and Swedish law no father is mentioned immediately if the mother of the child is not married and if no man acknowledged his paternity prior to the birth of the child. Under English law, no father will be mentioned if the informant declares that the mother of the child is not married to the child's father at the moment of birth, either because she is not married at all or because she is married to someone else other than the child's father.624

We have also seen that in each legal system the registration of the unmarried father is subject to specific requirements. Under Dutch, French and German law, the unmarried father has to acknowledge his paternity. Acknowledgment of paternity requires a formal declaration by the man that is authenticated by the civil status registrar or another official like a civil law notary or a court.

Under Dutch, French and German law the international jurisdiction of officials to authenticate the acknowledgment of paternity or the consent thereto is not restricted: each civil status registrar is allowed to authenticate an acknowledgment of paternity and the place of birth of the child or the domicile of the acknowledger are irrelevant. ${ }^{625}$ This can be explained by the fact that the acknowledgment of paternity is only a declaration of the man that he is the child's father. The registrar authenticating the acknowledgment of paternity has to send the document to the registrar who keeps the child's birth record. ${ }^{626}$ Eventually, it is the registrar who keeps the birth record of the child concerned who determines on the basis of the applicable law whether the acknowledgment of paternity establishes legal

\footnotetext{
${ }^{620}$ Article 2 Consulair Besluit 1981 contains a list of consular agencies that are allowed to draw up Dutch instruments of civil status, including birth certificates.

621 Art. 1:25 (1) under a Burgerlijk Wetboek.

${ }^{622}$ Art. 1:25 (1) under b and (2) Burgerlijk Wetboek.

${ }^{623}$ Art. 1:25c Burgerlijk Wetboek.

${ }^{624}$ However, in order to ensure the establishment of paternity out of wedlock, the British government has announced plans in 2008 to require unmarried parents to jointly register the birth of their child (Dept. for work and pensions, Raising expectations and increasing support: reforming welfare for the future, Norwich: The Stationary Office (December 2008), at paragraph 7.10; Dept. for work and pensions, Joint birth registration: recording responsibility, Norwich: The Stationary Office (June 2008).

${ }^{625}$ France: Instruction générale relative à l'état civil du 11 mai 1999, nr. 294, Journal Officiel n 172 du 28 juillet 1999. Germany: Hepting \& Gaaz 2006a, § 26a PStG, nr. 10. Netherlands: Kampers, Evers \& Vat 2008, p. 223; Asser/De Boer 2006, nr. 720.

${ }^{626}$ France: Instruction générale relative à l'état civil du 11 mai 1999, nr. 311-1, Journal Officiel nº 172 du 28 juillet 1999. Germany: § 44 (3) . Netherlands: art. 1:20e (3) Burgerlijk Wetboek; art. 21 Besluit Burgerlijke Stand 1994.
} 
paternity and hence can be recorded on the child's birth record. ${ }^{627}$ The diligence with which the second registrar checks whether or not the acknowledgment of paternity established legal paternity varies. ${ }^{628}$

Under English law the registration of the unmarried father can be based on various grounds. The ground that resembles the acknowledgment of paternity under Dutch, French and German law is the registration of the unmarried father on the joint request of the father and the mother. The request can take different forms: either both parents go to the register's office in person and request the registration of the man as the child's father, or only the mother or the father goes in person to the registrar to make the request for the registration of the man's name as the father of the child. In the latter case, the parent who goes in person to the registrar has to make a declaration in the prescribed form that the man is the child's father. The person who does not attend the registration or the re-registration has to submit a statutory declaration stating that the man is the child's father. ${ }^{629}$

A statutory declaration is a solemn declaration made before a justice of the peace, notary public or other officer authorised to administer oaths. ${ }^{630}$ For the purpose of this thesis the difference between a declaration in the prescribed form and a statutory declaration is immaterial. In both cases it is a criminal offence to declare that someone is the father of the child if you know that he is not the child's father.

There is no limitation of the geographical jurisdiction of officials receiving the declaration in the prescribed form or a statutory declaration. Thus every official who is authorised to administer oaths can draw up a statutory declaration for the purpose of registering the unmarried father. Likewise, any registrar in England and Wales is authorised to receive the information that is necessary to name the unmarried father on the child's birth record. If the registrar who receives the information is not the registrar of the place where the child is born, he shall submit the information to the registrar of the place where the child is born. 631

The Swedish Föräldrabalk (1949:381) does not require the acknowledgment of paternity to be drawn up by a special authority. No authority authenticates the acknowledgment of paternity; the tax authorities only register a valid acknowledgment. However, since in Sweden a valid acknowledgment of paternity requires the consent of the socialnämnd (social welfare committee), 632 the man usually acknowledges paternity by signing a form, which is presented to him by the social welfare committee. The social welfare committee informs the tax authority of the acknowledgment that will enter the valid acknowledgment of paternity on the child's birth record. ${ }^{633}$ The social welfare committee only consents to the acknowledgment of paternity if it has ascertained that the acknowledger is the child's father.

The international jurisdiction of the social welfare committee to investigate the parentage of a child is governed by the Lag (1985:367) om internationella faderskapsfrågor

\footnotetext{
${ }_{627}$ Hepting \& Gaaz 2006a, § 29 PStG, nr. 42; § 29a PStG, nr. 55 and 56.

628 See chapter 4. Evidence of legal parentage.

${ }^{629}$ Registration of the unmarried father at the moment of the registration of birth is governed by s. 10 Births and Deaths Registration Act 1953. Registration of the unmarried if the child's birth has already been recorded is called 'reregistration' and is governed by s. 10A of the same Act. The requirements under s. 10 and 10A are basically the same. The requirements discussed here are mentioned in subsections 1 (a), (b) and (c).

${ }^{630}$ Section 18 Statutory Declarations Act 1835. The standard form for a statutory declaration of acknowledgment of paternity can be found at the website of the General Register Office (http://www.gro.gov.uk/Images/Form\%2016_tcm69-18028.pdf).

631 Section 9 (1), (4) and (5) Births and Deaths Registration Act 1953 in conjunction with regs. 13 and 15 The Registration of Births and Deaths Regulations 1987 (SI 1987/2088).

632 § 1:4 Föräldrabalk (1949:381).

633 § 4 Kungörelse (1973:810) om socialnämnds medverkan vid fastställande av faderskap, m.m.
} 
(Act on International Paternity Questions (1985:367)). § 3 of the Act on International Paternity Questions (1985:367) provides that the paternity can be established by acknowledgment of paternity with the help of the social welfare committee if the committee is under the obligation to investigate the child's affiliation according to $\S \S 2: 1,2: 8$ a or 2:9 of the Föräldrabalk (1949:381). ${ }^{634}$ These articles provide that the social welfare committee shall examine the affiliation if the child has his or her residence in Sweden. The term residence is defined inter alia in chapter $7 \S 2$ of the Act on certain international legal relationships relating to marriage and guardianship (1904:26). ${ }^{635}$ The article provides that when a person lives in a certain state he shall be considered to have his residence there if the settlement can be considered permanent taking into account the duration of the stay and other circumstances of the case.636

The examination of the child's affiliation by the social welfare committee is either conducted ex officio637 or upon request of the husband who is presumed to be the child's father or any other person with custody over the child.638 The place of residence of the alleged parent is irrelevant. ${ }^{639}$ Even if the alleged parent is living abroad, the social welfare committee shall commence an investigation with the help of the Swedish representation in the country where the person is living. ${ }^{640}$

Is it possible for a man who lives in Sweden to establish his legal paternity in Sweden concerning a child who lives abroad? Swedish law is not clear on this point. The first observation is that no Swedish authority is competent to assist the man in this case. The social welfare committee is not obliged nor allowed to investigate the affiliation of a child who does not live in Sweden. ${ }^{641}$ The tax authority cannot administer the acknowledgment of paternity because if the child has never lived in Sweden there is no entry of the child in the population register.

Can the man, in this case, establish his paternity simply by declaring in writing that he is the father of the child? Under Swedish law there is no choice of law rule for the acknowledgment of paternity in Sweden in cases where the social welfare committee is not competent to investigate the parentage of the child. There are only choice of law rules for the case that the acknowledgment takes place in Sweden with the assistance of the social welfare committee ( $\$ 3$ Lag (1985:367) om internationella faderskapsfrågor) or the case that the acknowledgment of paternity has taken place abroad ( 88 Lag (1985:367) om internationella faderskapsfrågor). Therefore, the Socialstyrelsen takes the view that it is not possible to establish legal paternity in Sweden by acknowledgment of paternity concerning a child who lives abroad; the man has to go to the country where the child lives. ${ }^{642}$

\subsection{International jurisdiction of courts in matters concerning parentage}

In this paragraph the international jurisdiction of national courts to hear an application for judicial establishment or annulment of legal parentage will be examined. The jurisdiction of

\footnotetext{
${ }^{634}$ Föräldrabalk (1949:381).

${ }^{635} \mathrm{Lag}$ (1904:26) om vissa internationella rättsförhållanden rörande äktenskap och förmynderskap. The definition of residence in this Act is a general definition which does not only apply to this act, but also to the term residence in the context of parentage (Socialstyrelsen 2005, p. 24).

${ }^{636}$ See also § 19 Lag (1990:272) om internationella frågor rörande makars och sambors förmögenhetsförhållanden (Act (1990:272) on international questions relating to matrimonial property and property of cohabitants).

637 \& $: 1$ and 2:8a Föräldrabalk (1949:381) in conjuction with § 7 Förordning (2001:589) om behandling av personuppgifter I Skatteverkets folkbokföringsverksamhet.

638 § 2:9 Föräldrabalk (1949:381). See also Socialstyrelsen 2005, p. 86.

${ }^{639}$ It is recalled that under Swedish law a child can either have a father and a mother or two mothers.

640 Socialstyrelsen 2005 , p. 77 and 78.

641 § 2:1 Föräldrabalk (1949:381).

${ }^{642}$ Socialstyrelsen 2005 , p. 28 . See also prop. $1984 / 85: 124$, p. 44
} 
courts in the Netherlands, France, Germany and Sweden to issue a declaration on the existence or non-existence of legal parentage or to order the change or amendment of registers of civil status will not be discussed. These kinds of declarations fall outside the scope of this thesis.

\subsubsection{International jurisdiction of courts under Dutch law}

Under Dutch law there is no specific provision for the international jurisdiction of Dutch courts in matters concerning the establishment or annulment of legal parentage. The international jurisdiction of Dutch courts in civil and commercial matters is dealt with in articles 1 to 14 of the Wetboek van Burgerlijke Rechtsvordering (Code on Civil Procedure).

The determination of the international jurisdiction of a Dutch court depends in the first place on whether the court has to be seized with a summons (dagvaarding) or a petition (verzoekschrift). If the parties seize the court with a writ of summons, the matter will be judged in a contentious procedure, while if they seize the court with a petition the case will proceed on the basis of a non-contentious procedure. In a purely internal situation, it is the Dutch civil code that determines whether a procedure is contentious or non-contentious and hence whether it has to be commenced with a summons or a petition. Under Dutch law disputes on parentage are tried in a non-contentious procedure. It has been argued that even in an international case, it is Dutch law that determines whether or not the issue is contentious. ${ }^{643}$ The reason for this is that the characterisation of a case as contentious or noncontentious is especially relevant for procedural matters like jurisdiction, the procedure for application to the court and the course of the procedure itself.

The international jurisdiction of Dutch courts in non-contentious proceedings is laid down in articles 3, 4 and 5 of the Wetboek van Burgerlijke Rechtsvordering. Article 4 applies to divorce and article 5 applies to matters relating to parental responsibility. The international jurisdiction for all other matters, which are tried in a non-contentious procedure, like parentage, is laid down in article 3.

The first ground for international jurisdiction is that the petitioner or one of the interested parties has his or her domicile or habitual residence in the Netherlands. The question of who can petition (locus standi) in a case concerning legal parentage is determined by the lex causae. The concept of 'interested party' for family matters other than divorce is laid down in article 798 (1) Wetboek van Burgerlijke Rechtsvordering. It defines an interested party as the person or persons whose rights or obligations are directly involved with the case. The interested parties have to be stated in the petition in order for the registrar of the court to be able to summon them. ${ }^{644}$ In cases of parentage, that means that the child and his or her legal parents have the status of interested parties. Also, the man whose paternity has to be established is an interested party because his personal status is directly involved.

The concept of domicile of a natural person in article 3 Wetboek van Burgerlijke Rechtsvordering is defined in article 1:10 (1) Burgerlijk Wetboek. It is the place where the person has his house and household (woonstede). If the person does not have a house and household his domicile is at the place of his actual residence (werkelijk verblijf). A child has the same domicile as the person who has custody over the child. If both parents have custody over the child and if they have different domiciles, the domicile of the child is with the parent at whose place the child actually resides or where he most recently resided.645

\footnotetext{
${ }^{643}$ Ibili 2007, p. 55.

${ }^{644}$ Article 799 (1) Wetboek van Burgerlijke Rechtsvordering.

${ }^{645}$ Article 1:12 Burgerlijk Wetboek.
} 
The concept of habitual residence of a person in article 3 Wetboek van Burgerlijke Rechtsvordering is not defined. It is the concept that is used in international treaties and conventions on private international law to locate a person.

The second ground for international jurisdiction in article 3 Wetboek van Burgerlijke Rechtsvordering is that the petition is related to a contentious proceeding over which the Dutch court has international jurisdiction. This ground is not relevant for cases on parentage. 646

The third ground for jurisdiction in article 3 Wetboek van Burgerlijke Rechtsvordering is that the case is sufficiently connected with the Dutch legal order. A sufficient connection with the Dutch legal order does not exist solely because the personal status of a Dutch national is involved. Either the interest of the Dutch state should be involved or other reasons have to justify that a Dutch court is seized if all persons involved live abroad. ${ }^{647}$

If the Dutch court cannot accept jurisdiction to establish or annul legal parentage on the basis of article 3 Wetboek van Burgerlijke Rechtsvordering, article 9 can provide a solution of last resort. The article contains a forum necessitates provision on the basis of which the Dutch court has jurisdiction if it appears that it is impossible to proceed abroad. The impossibility can be legal (no country accepts jurisdiction) or factual (as a consequence of war of natural disaster the courts of the country involved cannot be reached). It is not necessary that the case have a particular connection with the Dutch legal order. ${ }^{648}$

\subsubsection{International jurisdiction of courts under English law}

An English court in two kinds of procedures can determine parentage. Either a person applies for a declaration of parentage or legitimacy under sections 55A or 56 Family Law Act 1986 or parentage is raised as an incidental matter for example in a dispute about inheritance. ${ }^{649}$ If parentage is raised as an incidental matter, the court has jurisdiction to determine the child's parentage if it has jurisdiction to decide the main suit. The difference between a declaration of parentage or legitimacy under sections 55A or 56 Family Law Act 1986 on the one hand, and a determination of parentage as an incidental question on the other is that declarations of parentage or legitimacy bind every one. ${ }^{650} \mathrm{~A}$ determination of parentage as an incidental question that only binds the parties to the proceedings. 651

A declaration of parentage is a judicial determination whether or not a person is or was the parent of another person. ${ }^{652} \mathrm{~A}$ declaration of parentage under English law has the same function as judicial establishment or annulment under the continental legal systems discussed in this thesis. A declaration of legitimacy or legitimation is a judicial determination whether or not the person is the legitimate child of his parents or that the person has or has not become a legitimated person.653 Although the relevance of the concept of legitimacy has been reduced significantly under English law, the concept has not been abolished. Section 1 Family Law Reform Act 1987, which has been introduced to equate the status of legitimate and illegitimate children, only provides that references to any relationship between two persons shall, unless the contrary intention appears, be construed without regard to whether or not the father or mother or either of them have been married to each other at any time. Legitimacy may still be relevant in inheritance matters governed

\footnotetext{
${ }^{646}$ For examples where art. 3 (b) Wetboek van Burgerlijke Rechtsvordering applies see Kamerstukken II 1999-2000, 26 855, nr. 3, p. 30 .

${ }_{647}$ Kamerstukken II 1999-2000, 26 855, nr. 3, p. 32.

${ }_{648}$ Kamerstukken II 1999-2000, 26 855, nr. 3, p. 41.

${ }^{649}$ Collins 2006b, nr. 20-006; Morris, MacClean \& Beevers 2005, nr. 12.010.

${ }^{650}$ Section 58 (2) Family Law Act 1986.

651 Collins 2006b, nr. 20-006; Morris, MacClean \& Beevers 2005, nr. 12.010.

652 Section 55A (1) Family Law Act 1986.

653 Section 56 (1) and (2) Family Law Act 1986.
} 
by foreign law, succession to titles of honour and ascertaining domicile. 654 There is no equivalent for a declaration of legitimacy or legitimation under the continental legal systems under consideration because under these legal systems the concept of legitimacy has been abolished.

The jurisdiction of the English courts to render a declaration of parentage or legitimacy under sections 55A and 56 Family Law Act 1986 is determined by these provisions. Section 55A (2) Family Law Act 1986 provides that a court shall have jurisdiction to hear an application for a declaration of parentage if either of the persons named in the application is domiciled in England and Wales on the date of the application, or has been habitually resident in England and Wales for at least one year prior to the application.655 If either person named in the application has died before the application has been made, the courts of England and Wales have jurisdiction if that person was either habitually resident for at least one year prior to the date of his death or domiciled in England and Wales at the date of his death.

Section 56 (3) Family Law Act 1986 provides more or less the same with regard to the international jurisdiction to render a declaration of legitimacy or legitimation. Pursuant to this section, the court has jurisdiction if the applicant is domiciled in England and Wales at the date of the application or if he has been habitually resident there for at least one year prior to the application.

The difference between sections 55A and 56 (3) is that under 55A any person with an interest can apply for a declaration, while under section 56 only the child can apply. As a consequence, the court has jurisdiction under section 55A if one of the persons named in the application are domiciled or habitually resident in England and Wales, while under section 56 the courts only have jurisdiction if the applicant is domiciled or habitually resident there.

The domicile of the persons involved is determined by English law and not on the basis of foreign law. The law is too complicated to describe here in extenso. ${ }^{656} \mathrm{In}$ broad terms, English law distinguishes between a domicile of origin that is acquired by law at birth and a domicile of choice, which is acquired by his own acts and intention. Minors have a domicile of dependence. Thus, as a starting point, a legitimate child has the domicile of his father and if his father changes domicile, the domicile of the legitimate child changes accordingly. The domicile of an illegitimate child depends on the domicile of his mother and just as in the case of a legitimate child, if the child's mother's domicile changes, so will the domicile of the child.

An important feature of the English law on domicile is that a person does not need to reside in a certain jurisdiction in order to have his domicile there. For example, the domicile of origin is only lost by the intentional acquisition of a domicile of choice.

Declarations of parentage or legitimacy do not create legal parentage; they merely determine that it exists or existed in the past. Thus it is possible that the court determines that someone is the natural father of the child while he is not the child's legal father anymore. This can be the case if the child has been adopted and wants to amend his original birth record. 657

\footnotetext{
654 Clarkson \& Hill 2006, p. 379; North, Fawcett \& Carruthers 2008, p. 1142.

655 The persons which have to be named in the application are mentioned in Family Proceedings Courts (Family Law Act 1986) Rules 2001 (SI 2001/778, L. 14). This statutory instrument contains the form which has to be used for a application for a declaration of parentage. The application has to include the name of the person whose parentage is at issue, the person whose parenthood is at issue and any person who is acknowledged to be the father or mother of the person whose parentage is at issue. Even if the declaration of parentage is about the legal paternity of the father, the mother of the child is also respondent (if she is not the applicant) and vice versa.

${ }^{656}$ For a description of the law on domicile in more detail see e.g. Collins 2006a, nr. 6R-001 et seq; North, Fawcett \& Carruthers 2008, p. 154-179; Collier 2001, p. 37-54.

${ }^{657}$ M v W (Declaration of Parentage) [2006] EWHC 2341 (Fam.), [2007] 2 FLR 270.
} 
Under English law, there are two orders that also create a parent-child relationship: adoption orders and parental orders. Adoption orders fall outside the scope of this thesis. Parental orders are made under section 30 of the Human Fertilisation and Embryology Act 1990. Section 30 permits the English court to make an order for a child to be treated in law as the child of the parties to a marriage where the child has been conceived pursuant to a surrogacy agreement with the semen of at least one party to the marriage. The English court only has jurisdiction to make a parental order if the child's home is with the married couple and if at least one party to the marriage is domiciled in the United Kingdom, the Channel Islands or the Isle of Man. If neither the husband nor the wife are domiciled in these territories, the English court shall not make the order. ${ }^{658}$

\subsubsection{International jurisdiction of courts under French law}

Aside from provisions in bilateral treaties, ${ }^{659}$ French law does not have specific rules that determine the international jurisdiction of French courts. As a general rule, the provisions that determine the territorial competence in purely domestic cases also determine the international jurisdiction of the court. 660 The leading case of the Cour de Cassation in this respect is Pelassa v Charrière et autres of 19 October $1959 .{ }^{661}$ In that case, concerning a traffic accident that involved a French lady transported in a French bus that collided with an Italian bus in Italy, the Cour de Cassation held that the lower court correctly applied the principle according to which the internal rules on jurisdiction are applied to international cases. This rule has certain exceptions but these are not relevant for cases on parentage. ${ }^{662}$ Thus, in order to determine whether a French court has international jurisdiction to decide on an international parentage case, it has to be examined how the territorial competence of the French courts in a purely domestic case is determined.

The rules for territorial competence are contained in the Code de Procédure Civil (Code on Civil Procedure). 663 Since the Code de Procédure Civil does not contain special rules on the territorial jurisdiction of courts in matters concerning parentage, the general provisions apply. 664

The general provisions on the territorial jurisdiction of courts are contained in articles 42 until 43 Code de Procédure Civil. Per article 42 (1), the French courts have jurisdiction if the defendant lives in France. The place where the defendant lives is defined in article 43 as the place of the defendant's domicile. The concept of domicile is defined in accordance with article 102 Code civil that provides that a person has his domicile at the place of his main place of establishment. 665 If the defendant does not have a domicile, article 43 Code de Procédure Civil provides that the defendant is deemed to live at the place where he resides. The residence of the defendant in France is only a ground for jurisdiction if the defendant does not have a domicile in France or abroad. 666

\footnotetext{
${ }^{658} \operatorname{Re}$ G (Surrogacy: Foreign Domicile) [2007] EWHC 2814 (Fam); [2008] 1 FLR 1047 (Fam Div). for comments on this case see: Howe 2008; Cullen 2008.

${ }^{659}$ E.g. Convention franco-polonaise du 5 avril 1967 relative à la loi applicable, la compétence et l'exequatur dans le droit des personnes et de la famille.

660 Boiché 2008.

${ }^{661}$ Cour de Cassation, 19 October 1959, RCDIP 1960, 215. See also Audit 2008, nr. 343; Mayer \& Heuzé 2007, nr. 284; Cadiet \& Jeuland 2004, nr. 220.

${ }^{662}$ The exceptions concern jurisdiction in matters concerning the succession to immovable property and the jurisdiction in matters concerning seizure of assets and freezing injunctions, Mayer \& Heuzé 2007, nr. 287; Cadiet \& Jeuland 2004, nr. 227-229.

${ }^{663}$ In regulating the issue of territorial jurisdiction, the general rules do not distinguish between contentious and noncontentious proceedings, Cadiet \& Jeuland 2004, nr. 234.

664 Terré \& Fenouillet 2005, nr. 754.

665 Audit 2008, nr. 344; Cadiet \& Jeuland 2004, nr. 193; Julien \& Fricero 2003, nr. 149

666 Audit 2008, nr. 344; Mayer \& Heuzé 2007, nr. 285.
} 
If the French court does not have international jurisdiction on the basis of ordinary rules for jurisdiction, the second step is to check whether the French court has jurisdiction on the basis of article 14 or 15 Code civil. ${ }^{667}$ Article 14 Code civil provides that the foreigner, even when he does not live in France, can be sued in French courts for the execution of obligations that have been contracted to by him in France with a Frenchman. He can also be sued in French courts for obligations contracted by him abroad with a Frenchman. ${ }^{668}$ Article 15 Code civil regulates the opposite situation stating that a Frenchman can be sued in French courts for obligations contracted by him abroad, even with a foreigner. ${ }^{669}$

Articles 14 and 15 Code civil stem directly from the French Code civil as it applied in 1804, although their application has been changed significantly in the course of time. ${ }^{670}$ In explaining the meaning of articles 14 and 15 Code civil, French legal literature makes a distinction between the scope ratione personae and ratione materiae of the provisions.

The scope ratione personae is limited to persons who possess French nationality at the start of the proceedings. Whether the person possessed French nationality before the beginning of the proceedings, or whether he or she keeps on possessing it during the proceedings is irrelevant. ${ }^{671}$

Although according to the wording of articles 14 and 15 Code civil their scope ratione materiae is limited to contractual obligations, the Cour de Cassation extended their application to all fields of law in contentious proceedings. The articles also apply in contentious proceedings on the status and capacity of persons.672 In 2001 the Cour de Cassation recalled with regard to the application of article 14 Code civil in matters concerning parentage:

Mais attendu que la règle de compétence édictée au profit du demandeur français par l'article $14 \mathrm{du}$ Code civil s'impose au juge français et ne peut être écartée, si son bénéficiaire ne renonce pas à s'en prévaloir, que par un traité international; que, par motif adopté, la cour d'appel a décidé exactement que la Convention franco-marocaine du 10 août 1981 ne concernait pas les actions relatives à la filiation et qu'elle ne pouvait donc écarter l'application de l'article 14 du Code civil dont bénéficie Mme Y... du fait de sa nationalité française, seule prise en considération par les tribunaux français. ${ }^{673}$

It follows that in contentious proceedings, French courts always have international jurisdiction if either the applicant or the defendant has French nationality. One of the justifications for this ground of jurisdiction in matters concerning personal status is that it establishes a parallel between the jurisdictions to adjudicate and to legislate. ${ }^{674}$ After all, the person's nationality still is the predominant connecting factor to determine the applicable law in matters concerning personal status.

According to Audit articles 14 and 15 stem from the idea that the question of international jurisdiction of national courts touches upon the sovereignty of the state concerned. Contrary to the current view on jurisdiction, which is to regulate international jurisdiction on the basis of the private interest of the litigating parties, the predominant view

\footnotetext{
${ }^{667}$ On the subsidiary nature of articles 14 and 15 Code civil see Audit 2008, nr. 340; Cadiet \& Jeuland 2004, nr. 238.

${ }^{668}$ L'étranger, même non résidant en France, pourra être cité devant les tribunaux français, pour l'exécution des obligations par lui contractées en France avec un Français; il pourra être traduit devant les tribunaux de France, pour les obligations par lui contractées en pays étranger envers des Français.

${ }^{6} 9$ Un Français pourra être traduit devant un tribunal de France, pour des obligations par lui contractées en pays étranger, même avec un étranger.

670 Cadiet \& Jeuland 2004, nr. 230.

671 Mayer \& Heuzé 2007, nr. 291; Cadiet \& Jeuland 2004, nr. 232.

672 Audit 2008, nr. 360; Mayer \& Heuzé 2007, nr. 292; Cadiet \& Jeuland 2004, nr. 233.

673 Cass. Civ. 1er, 2 October 2001, Bull. Civ. No. 235, p. 149.

674 Cadiet \& Jeuland 2004, nr. 233
} 
at the time the Code civil came into force was that the state had an interest in conflicts which involve its own nationals. Therefore, the main concern of the drafters of the Code civil would be to give French nationals the possibility to obtain justice in French courts. ${ }^{675}$

Besides the international jurisdiction based on the internal jurisdiction rules, the French courts are also allowed to act as forum necessitatis. Thus, even if the courts do not have jurisdiction on the basis of ordinary rules on jurisdiction, the French courts have jurisdiction nonetheless to decide the matter if the courts of no other country can be seized and if the case has a certain connection with France. ${ }^{676}$

\subsubsection{International jurisdiction of courts under German law}

The international jurisdiction of German courts in matters concerning parentage is since 1 September 2009 regulated in $\S 100$ Familienverfahrensgesetz. The rule has been copied from $\S$ 640a (2) Zivilprozessordnung. ${ }^{677}$ It provides that in matters concerning parentage, the German courts have jurisdiction if either the child, the mother, the father or the alleged biological father have German nationality or are habitually resident (gewönliche Aufenthalt) in Germany. The term habitual residence is not defined in German law, contrary to the German concept for domicile, the Wohnsitz.678

$\S 100$ Familienverfahrensgesetz applies to all matters concerning parentage. In contrast to the position before the entry into force of the Familienverfahrensgesetz, it does not matter whether the matter is tried in a contentious or a non-contentious procedure. The reason is that under the Familienverfahrensgesetz all matters concerning parentage are tried in a noncontentious procedure. 679

\subsubsection{International jurisdiction of courts under Swedish law}

The jurisdiction of Swedish courts to establish or annul legal paternity is determined by $\S 4$ (1) Lag (1985:367) om internationella faderskapsfrågor (Act on International Paternity Questions (1985:367)). The paragraph provides for three grounds for jurisdiction. First of all, the Swedish court shall have jurisdiction if the child has his or her residence (hemvist) in Sweden. The rule is based on the interest of the child: a child who lives in Sweden should always be able to go to a Swedish court. 680

Under Swedish law, there is not one general statutory definition of residence. The definition of domicile from the Lag (1904:26) om vissa internationella rättsförhållanden rörande äktenskap och förmynderskap (Act on Conflict of laws regarding marriage and guardianship) is often cited as a general definition of residence in international family law. ${ }^{681}$ Chapter $7, \S 2$ of the Act provides that when a person lives in a certain state he shall be considered to have his residence there if the settlement can be considered permanent taking into account the duration of the stay and other circumstances of the case. ${ }^{62} \mathrm{~A}$ young child will often have his domicile in the same place as his mother if she is the primary caretaker. However, the Swedish concept of residence does not prevent the child from acquiring a residence separate from the domicile of his parents. In the end, the actual circumstances of the case are decisive. 683

\footnotetext{
675 Audit 2008, nr. 333. See also Mayer \& Heuzé 2007, nr. 290.

${ }^{676}$ Mayer \& Heuzé 2007, nr. 288.

677 BR Drucks. 307/07, p. 488.

678 § 7 BGB.

679 § 171 (1) Familienverfahrensgesetz. On the law before the entry into force of the Familienverfahrensgesetz see Staudinger/Henrich 2008, Article 19 EGBGB, nr. 111-113.

680 Prop. 1984/85:124, p. 14.

681 Prop. 1984/85:124, p. 40. Bogdan 2004, p. 148; Walin \& Vängby vol. II, Avd. 1 I:18; Lennart 1986, p. 334

682 See also § 19 Lag (1990:272) om internationella frågor rörande makars och sambors förmögenhetsförhållanden (Act (1990:272) on international questions relating to matrimonial property and property of cohabitants).

683 Örtenhed 1991, p. 60.
} 
The residence of the man in Sweden only constitutes a ground for jurisdiction of Swedish courts in matters concerning paternity if the man is the respondent and not if he is the applicant. This rule is based on the idea that if the child chooses to sue a man in Sweden for the establishment or annulment of legal paternity it will probably be in the interest of the child to do so and it is considered to be an advantage for the man if he is sued in the country of his residence. However, for the child and his mother it would be a disadvantage if they could be dragged into a legal procedure in Sweden while they are not living there. Therefore, the man cannot start a judicial procedure in Sweden on the basis of his residence there. 684

If a child who lives abroad wants to sue more than one man in order to determine who is his or her father, each of the men have to reside in Sweden in order for the Swedish court to have jurisdiction. Otherwise, the situation could arise that the Swedish court establishes the legal paternity in a case where neither the father nor the child live in Sweden. That possibility could give rise to abuses. 685

The third ground for jurisdiction is a residual ground: the courts of Sweden have international jurisdiction in matters concerning parentage if there are in view of the connection of the child, the mother or the father with Sweden, special reasons to conduct the proceedings in Sweden. This ground is applied restrictively. ${ }^{686}$ The fact that the child or the man has Swedish nationality is as such not enough to establish international jurisdiction for Swedish courts. Two reasons for this were put forward. First of all, the importance of nationality as a connecting factor is diminishing in Sweden as well as in other European countries. Secondly, it was feared that if the Swedish court's jurisdiction would only be based on the nationality of the persons involved while they had been residing abroad for a long time, the Swedish judgment would not be recognised in the country of residence. ${ }^{67}$

The special circumstances required to establish international jurisdiction for the Swedish court can, for example, consist of the fact that Swedish nationals live in a country that does not allow paternity suits. In such a case it can be reasonable to allow the parentage of the child to be determined in Sweden. Also stateless persons and refugees who are only staying in Sweden temporarily can submit their paternity dispute on this ground to a Swedish court. 688

$\S 4$ (2) Lag (1985:367) om internationella faderskapsfrågor creates a perpetuation fori: the jurisdiction of the Swedish courts will not be affected, if the facts to determine the jurisdiction of the Swedish courts have changed after the case has commenced in a Swedish court.

\subsection{Conclusions on international jurisdiction in matters concerning parentage}

This chapter examines the grounds of international jurisdiction for registrars and courts to determine the legal parentage of a child in England, France, Germany, the Netherlands and Sweden. It has been shown that the 'international jurisdiction' of the registrar to determine the legal parentage of the child is directly related with the obligation to register a birth. The jurisdiction of the registrars of a country to record a birth and hence to determine the child's parentage is based on the place of birth and on the nationality of the new-born child. The registration of the birth at the place of birth is mandatory under local law, while the registration of the birth with the authorities of the child's nationality is optional. The authorities of the different countries shall determine the child's parentage according to their

\footnotetext{
684 Prop. 1984/85:124, p. 15. Walin \& Vängby vol. II, Avd. 1 I:5.

685 Prop. 1984/85:124, p. 47. Walin \& Vängby vol. II, Avd. 1 I:24.

686 Prop. 1984/85:124, p. 17-18, 48. See also Pålsson 2006, nr. 3.105, 106.

687 Prop. 1984/85:124, p. 16.

688 Prop. 1984/85:124, p. 17, 18, 48. Bogdan 2004, p. 216; Walin \& Vängby vol. II, Avd. 1 I:5, 6.
} 
own local law including, as the case may be, the rules of private international law. The overlapping jurisdiction to record births can be a source of different legal status in the different registers.

With regard to the international jurisdiction to draw up an instrument of acknowledgment it has been shown that the situation is different because of the different nature of the instrument of acknowledgment. It appeared that in the countries where the declaration concerning the parentage of the child such as an acknowledgment of paternity has to be drawn up in a special form, the international jurisdiction of the public authority which is empowered to draw up the acknowledgment is not limited. This is explained by the fact that these authorities only record a statement of a declarant in a special form; they do not take (binding) decisions.

In Sweden the jurisdiction of the socialnämnd to consent to the acknowledgment of paternity is limited to those cases where the child is resident in Sweden. The restriction of the international jurisdiction of the socialnämnd can be explained by the fact that its consent is based on an examination into the biological paternity of the acknowledger. In order to perform such an examination into the facts of a particular case it makes sense to require a certain connection between the case and the country involved.

We have also seen that under Swedish law it is not possible for the man who lives in Sweden to establish his legal paternity by acknowledgment concerning a child who lives abroad. This is different in the other legal systems involved. Since the international jurisdiction' to administer oaths is not restricted, anyone can go to a Dutch, English, French or German registrar to obtain an authenticated version of his declaration or, in the case of England, a statutory declaration. Whether or not the declaration establishes legal paternity depends on the choice of law rules and the applicable law in the country where the question arises.

The overview of the grounds for jurisdiction of the national courts in matters concerning the establishment or annulment of legal parentage revealed great diversity. In the five legal systems at hand, the basis for jurisdiction depends on the concepts of nationality, domicile and habitual residence. On the one side of the spectrum is French law, allowing its courts to accept jurisdiction on the basis of domicile only if the defendant is domiciled in France. At the same time, French law expresses a fundamental belief that French nationals should be allowed to have their case tried in a French court, especially when the personal status of a French national is involved. More to the centre is German law that allows its courts to accept jurisdiction on the basis of both the nationality as well as the habitual residence of one of the parties to the dispute. On the other side of the spectrum are Dutch and English law. Both legal systems allow their courts to accept jurisdiction in matters concerning parentage only on the basis of the domicile or the habitual residence of one of the interested persons to the case. Nationality is not a ground for international jurisdiction in English law. Also under Dutch law, the Dutch nationality of one of the interested parties as such is not enough to establish the international jurisdiction of Dutch courts. Swedish law, like English and Dutch law only bases the jurisdiction of its courts in matters concerning parentage on residence, but the group of persons whose residence in Sweden establishes jurisdiction for Swedish courts is much more limited than under Dutch and English law. Under Dutch and English law the domicile or the habitual residence of one of the interested persons is enough, under Swedish law only the residence of the child and the residence of the alleged father if he is the defendant create a jurisdictional basis. 


\section{Applicable law to legal parentage}

In an international situation national registrars or courts that have to determine the legal parentage first have to select the applicable law to the child's legal parentage. The applicable law is selected on the basis of national conflict rules. In all legal systems the conflict rules on parentage are codified, except under English law. Under English law choice of law rules only exist on legitimacy and not (yet) on parentage.

In this paragraph the choice of law rules for the situation that the legal parentage has not yet been determined by a foreign registrar or court will be discussed. From a French or German perspective this might be a peculiar approach because under French and German conflict rules it does not matter whether or not a foreign registrar already has determined the legal parentage of a child.

However, in the second paragraph it will be shown that the Dutch and Swedish private international laws do distinguish between the situations where legal parentage has been established abroad already and where legal parentage has to be established by a national authority. For the purpose of private international law these legal systems do not consider the determination of legal parentage by a registrar as fundamentally different from the determination of legal parentage by a court.

\subsection{Scope of the applicable law on parentage}

Before turning to an examination of the conflict rules on parentage in Dutch, French and German law a brief overview of the issues that are determined by the law applicable (or the lex causae) to parentage will be presented. Issues that are not decided by the law applicable to parentage may be governed by the lex fori if they are characterised as procedural issues or they may fall within the scope of another conflict rule such as the conflict rule for the validity of juridical acts or the conflict rule for legal capacity of natural persons.

This paragraph does not necessarily apply to Swedish and English private international law. English law does not have choice of law rules concerning parentage and under Swedish law, the choice of law rules are designed in such a way that Swedish authorities almost always apply Swedish law. As a consequence, the distinction between substantive and procedural matters is not very relevant in this jurisdiction.

First of all the lex causae determines who the legal parents of a child are: is it the biological father or the man who consented to the artificial insemination with donor sperm of his spouse? Is it the woman who gave birth to the child or the woman whose egg cell has been used for the creation of the child?

The question which follows is solved by the lex causae; that question has to be distinguished from the question of how to construe the terms used in the conflict rule. French, German and Swedish private international law use the term mother in their conflict rules: in French law the parentage of the child is governed by the national law of the mother (art. 311-14 Code civil), in German law the national law of the mother or the law applicable to the effects of the mother's marriage can determine the applicable law to parentage (art. 19 EGBGB) and in Swedish law, § 2 Lag (1985:367) om internationella faderskapsfrågor (IFL) determines the applicable law to the legal paternity of man who is or was married to the child's mother. In all these cases the question arises how to construe the term 'mother' in a conflict rule which purpose it is to answer exactly that question. Various solutions are possible. 
First, it could be argued that the choice of law rules are part of national law and that therefore the meaning of their terms has to be defined in accordance with national law. ${ }^{689}$ Thus the term mother in the French article 311-14 Code civil is the woman who gives birth to the child and not the woman whose egg cell has been used.690 The disadvantage of this approach is that it seems artificial to define a term like mother on the basis of national law for the purpose of determining who the child's legal mother is. The result might be that the woman who provided the egg cell has to be considered the legal mother of the child on the basis of the national law of the birthmother.

Second, the term mother is construed as the woman who claims to be or who is alleged to be the mother of the child. ${ }^{691}$ Thus, the question whether the birthmother is the legal mother of the child has to be determined on the basis of her national law and the question whether another woman (the commissioning mother or the egg cell donor) is the legal mother has to be determined according to the national law of that woman. The disadvantage of this approach is that the application of the conflict rule can lead to a conflict which should be solved by that conflict rule, for example if both legal systems appoint different women as the mother of the child.

Third, the problem is somewhat masked by the formulation of the conflict rules on parentage. Under Dutch private international law article 1 (1) Wet Conflictenrecht Afstamming (WCA) regulates the question whether the child is legally affiliated with the woman to whom he is born and the man with whom she is or was married. Article 3 determines the applicable law to the question whether the child and the woman to whom the child is born is legally affiliated are legally affiliated by dint of birth. These rules take as a given that the birthmother is the legal mother of the child, while from a perspective of private international law this remains one of the questions.

Although at first sight it seems self-evident that the lex causae determines the basis for legal parentage, it appears that the national conflict rules are not designed to solve these kinds of fundamental conflict; Dutch, French and German conflict rules are designed with the idea that the applicable law on parentage only determines the means of establishment of the legal parenthood of the natural parents of the child. Although at the level of substantive law assisted reproduction and same sex parenthood is more and more taken into account, the rules on private international law have not been able to keep pace with this development.

The examples show that it is not practical to use terms like mother and father as the connecting factors of a choice of law rule that has to solve a conflict of laws on such fundamental issues as the basis of legal parentage. The Swedish conflict rules use the child instead of the mother as the connecting factor for parentage. The question whether the child is legally affiliated with the man with whom the child's mother is or was married is in principle solved by the law of the child's residence. Here, the use of the term mother does not need to be problematic because the mother is not the connecting factor.

Although a conflict of laws concerning the basis for legal parentage leads to challenging questions, the majority of cases are about the establishment of the legal maternity of the birthmother and the legal paternity of the biological father. After all, most children are still born as a result of natural reproduction and in case of natural reproduction almost each of the legal systems take as a starting point that the biological parents should be the legal parents. With regard to the establishment of legal parenthood in the case of natural procreation two issues exist.

${ }^{689}$ Considered but rejected: Henrich 2005a, p. 1147

${ }^{690}$ Lagarde in his note under Cass. Civ. 1er, 17 December 2008, RCDIP 2009, 320, at p. 326.

691 Staudinger/Henrich 2008, Article 19 EGBGB, nr. 78; Hepting \& Gaaz 2006b, IV-174, 278; Henrich 2005a, p. 1148; Looschelders 1999, p. 422-423. 
First of all, is it at all possible to establish legal parenthood? Some legal systems do not allow the establishment of legal parenthood or legal paternity if the children are born out of wedlock.

Secondly, if legal parenthood can be established how is it established? Is the woman who gives birth to the child the legal mother by dint of birth or does she have to acknowledge her maternity? ${ }^{692}$ With regard to legal paternity, the lex causae determines whether it is established by operation of the law or whether it needs to be acknowledged or judicially established. Thus, the lex causae determines whether the husband of the mother is the child's legal father, whether it is the husband at the moment of birth or at the moment of the conception of the child. Also, the rules of evidence (often rebuttable presumptions) according to which the moment of conception of the child has to be determined are provided by the applicable law to the child's parentage. 693

If legal parenthood is not established by operation of law, the lex causae determines whether it can be established by acknowledgment of maternity or paternity. The acknowledgment of parenthood involves questions of substance that are governed by the law applicable to parentage. It decides whether or not the acknowledger is entitled to acknowledge his or her parenthood, whether or not special rules apply in cases of acknowledgement of adulterous or incestuous children and whether the consent of for example the child or the mother is required and whether it can be replaced by the consent of a court.

The acknowledgment of parenthood also involves questions concerning formal validity: does the acknowledgment of parenthood have to be laid down in an authentic or public document or is a private document sufficient? Under French law, it is argued that the formal requirements for validity of an acknowledgment of parenthood are governed by the lex causae of the acknowledgment and not by the lex loci actus. 694

Under Dutch, German and Swedish law the formal validity of an acknowledgment of paternity is either governed by the lex loci actus or by the lex causae of legal parentage depending on which legal system validates the acknowledgment. Under Dutch law, article 10 Wet houdende algemene bepalingen der wetgeving van het Koninkrijk provides that the form of acts is governed by the law of the place where the act took place (lex loci actus). However, an act is also valid if it satisfies the requirements of the lex causae. 695 Under German law, the formal validity of a juridical act in general and of an acknowledgment of parenthood in particular is subject to article 11 EGBGB that, like the Dutch rule, provides that the formal requirements for validity are determined either by the lex loci actus or the lex causae of the legal relationship in question, in this case, legal parentage. In Sweden there is no separate conflict rule for the formal validity of juridical acts. However, § 3 (3) Lag (1985:367) om internationella faderskapsfrågor provides that the validity of an acknowledgment of paternity can be determined according to the lex loci actus or the law that applies to acknowledgment of paternity according to the first paragraph.

If legal parenthood does not exist ex lege and if it has not been established by acknowledgment of parenthood, the lex causae on legal parentage determines whether it can be established by a judicial decision. The lex causae on legal parentage also determines whether or not the legal parenthood can be contested. With regard to the possibility to

${ }^{692}$ France: Foyer \& Simon-Depitre 1973, nr. 104. Germany: Staudinger/Henrich 2008, Article 19, nr. 73. Netherlands: Article 3 Wet Conflictenrecht Afstamming.

${ }^{693}$ France: Mayer \& Heuzé 2007, nr. 609; Foyer \& Simon-Depitre 1973, nr. 102, 103. Germany: Hepting \& Gaaz 2006b, IV-374; Staudinger/Henrich 2008, Article 19, nr. 59

${ }^{694}$ Mayer \& Heuzé 2007, nr. 609, 754.

695 Strikwerda 2008, nr. 204. See also article 12 (1) Wetsvoorstel Vaststellings- en uitvoeringswet Boek 10 Burgerlijk Wetboek, Kamerstukken II 2009-2010, 32 137, nr. 2 (Proposal for book 10 of the Burgerlijk Wetboek on private international law). 
judicially establish or contest legal parenthood the lex causae determines the locus standi, the periods of limitation and the facts that have to be proven. ${ }^{6} 96$

\subsection{Dutch choice of law rules on parentage}

The Dutch choice of law rules on parentage are laid down in the Wet Conflictenrecht Afstamming 2002 (WCA) (Conflict of laws (Parentage) Act 2002). ${ }^{697}$ A proposal is pending in parliament to incorporate the provisions of the Wet Conflictenrecht Afstamming in the future book 10 Burgerlijk Wetboek on private international. ${ }^{698}$

Before the entry into force of the Wet Conflictenrecht Afstamming, the conflict rules on parentage were determined in case law. The starting point for the determination of the law applicable on parentage was article 6 Wet houdende algemene bepalingen der wetgeving van het Koninkrijk 1829 (General provisions on legislation Act 1829) which provides that laws concerning the rights, the status and the capacity of persons bind Dutch nationals even when they are residing abroad. ${ }^{69}$ On the basis of article 6, the nationality is the main connecting factor for legal parentage. ${ }^{700}$

The Wet Conflictenrecht Afstamming can be divided in three parts. The first part consists of the conflict rules on parentage (articles 1-7), the second part consists of the law applicable to the effects of parentage (article 8) and the third part consists of the recognition of legal parentage laid down in a foreign judgment or a foreign instrument of civil status. The Wet Conflictenrecht Afstamming entered into force on the first of May 2003. The Act only applies to the establishment of legal parentage after its entry into force and to judgments and instruments of civil status that have been drawn up after that date.701 The following scheme gives an overview of the structure of the WCA.

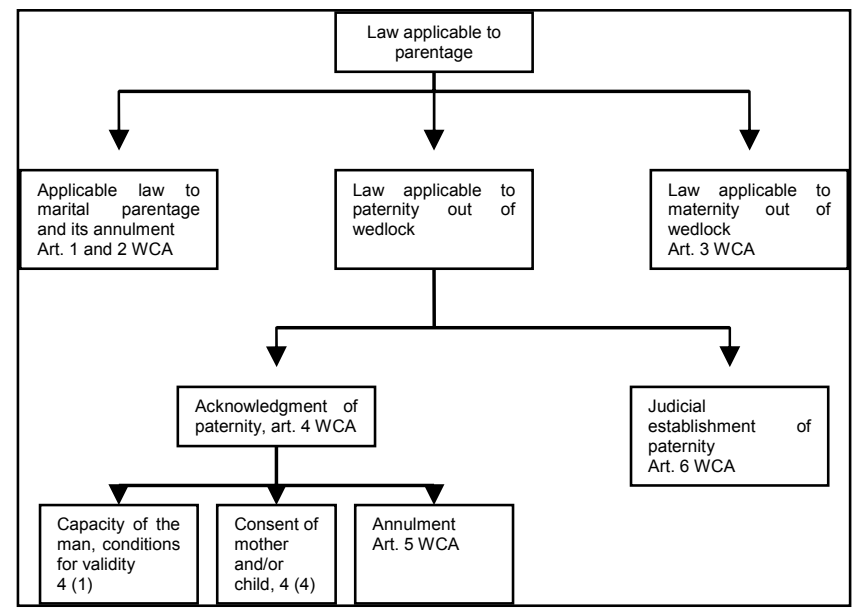

${ }^{696}$ France: Audit 2008, nr. 734, 735; Mayer \& Heuzé 2007, nr. 609. Germany: MünchKomm/Klinkhardt 2006, Article 19, nr. 27; With regard to judicial proceedings to contest legal parenthood, Andrae 2006, § 5, nr. 51.

697 Stb 2002, 153.

698 Kamerstukken II 2009-2010, 32 137, nr. 2.

${ }^{699}$ Cf. art. 3 (3) French Code civil.

700 On the choice of law rules on parentage under Dutch private international law before the entry into force of the Wet Conflictenrecht Afstamming see inter alia Vonken 1987, p. 12-79.

701 Article 11 WCA. 


\subsubsection{Applicable law to legal parentage based on marriage under Dutch PIL}

Article 1 (1) WCA provides that the question whether the child is legally affiliated with the woman to whom he or she is born and the man to whom she is or was married shall, in the first place, be determined by the law of the common nationality of the woman and the man. If the man and the woman do not have a common nationality, the law of their common habitual residence applies. If the alleged parents do not share a common habitual residence, the law of habitual residence of the child applies.

The nationality of the alleged parents and the child or their habitual residences shall be determined at the moment of the child's birth. However, if the marriage has been dissolved before the child's birth, the moment of the dissolution of marriage is decisive. ${ }^{702}$ The validity of the marriage is determined by Dutch conflict rules on marriage and not by the private international law of the lex causae. ${ }^{703}$

Article 1 (1) WCA is based on various considerations. First of all, the nationality as the main connecting factor is the starting point for the WCA as a whole because that connecting factor is more stable than the habitual residence and because the national legal systems of the main population of foreigners in the Netherlands - Turkey and Morocco - also apply the national law of the person to parentage. 704

Secondly, the connecting factor for legal parentage based on marriage should reflect the involvement of all the parties to the legal relationship, i.e. the child, the mother and the father. From that perspective, the common nationality of the alleged parents was deemed the best choice. ${ }^{705}$ The nationality does not need to indicate a genuine link with the country involved and the individual. Even if the person does not have any relationship with the country of his or her nationality, that nationality is still used as a connecting factor if the other (ex) spouse has the same nationality. ${ }^{706}$ However, if the mother and her (ex) husband have more than one nationality in common, they are deemed not to have any nationality for the purpose of the Act. ${ }^{707}$ The reason for this is that article 1 (1) WCA has to be applied by civil status registrars who are, according to the legislator, not equipped to determine whether there exists a genuine link between the person and the country of his nationality or to determine the effective nationality of a person with more than one nationality. 708

The third consideration for article 1 WCA is that the establishment of marital paternity should not be favoured. It is not always in the interest of the child and the other parties involved that the (ex) husband of the mother is the child's legal father. Moreover, a conflict rule which favours the establishment of marital paternity would cause unnecessary proceedings for annulment of marital paternity which should be avoided.709

It is not clear what should happen if the child is conceived during the first marriage of the mother and born during her second marriage. The question here is whether the registrar should take the first or the second husband as a starting point for the determination of the child's parentage. Take the following example. A Moroccan woman falls pregnant during her marriage with a Moroccan man. The marriage breaks down and shortly after the

\footnotetext{
702 Article 1 (2) WCA.

${ }^{703}$ Article 7 Conflict of Laws (Marriage) Act. Jordens-Cotran 2007, p. 531. Vonken argues that it should also be possible to determine the validity of a marriage on the basis of the conflict rules of the applicable law to parentage, if marriage is an incidental question (Vonken (Personen- en familierecht. Wet conflicterecht huwelijk), aant. 12).

704 Kamerstukken II 1998-99, 26 675, nr. 3, p. 2.

705 Kamerstukken II 1998-99, 26 675, nr. 3, p. 4 and 7.

706 Kamerstukken II 1998-99, 26 675, nr. 3, p. 8.

707 Article 1 (3) WCA.

708 Kamerstukken II 1998-99, 26 675, nr. 3, p. 8. Critical about this choice: De Groot 2000, p. 196; Vonken 2000, p. 17.

709 Kamerstukken II 1998-99, 26 675, nr. 3, p. 4.
} 
dissolution she marries a Dutch national. During the second marriage the child is born. Article 1 (1) WCA determines the applicable law to the relation between the child and the husband with whom the mother is or was married. Hence, both men can be the legal father. The first husband will be the legal father of the child because the man and the woman both have Moroccan nationality and according to this law, the child which is born within one year after the divorce is considered to be the child of the ex-husband. ${ }^{710}$ The second man will be the legal father of the child because the alleged parents do not share a common nationality and therefore the law of their common habitual residence applies which is Dutch law. According to Dutch law, the man who is married to the mother at the moment of birth is the legal father of the child.711 A possible way out of this dilemma is to give preference to the second marriage because the second husband is probably the biological father of the child. This choice would be supported by the rationale for the absence of a favouring connecting factor in article 1 (1) WCA, which is to avoid unnecessary actions for annulment of marital paternity.

The second question concerning article 1 (1) WCA is its field of application. The article is limited to legal affiliation on the basis of marriage between a man and a woman. The reason for this limitation is that the WCA is modelled on the Dutch substantive law on parentage, which only provides for three modes of establishment of legal paternity: on the basis of marriage, by acknowledgment of paternity or by judicial establishment. ${ }^{712}$ However, not every legal system provides for this traditional trilogy. Some legal systems automatically establish the legal paternity of the man with whom the mother has a registered partnership or with whom the mother has a de facto relationship. ${ }^{713}$ Moreover, it is not unlikely that in the near future the woman who is married to the mother who gives birth to the child is the child's legal parent. In fact, this option is being contemplated by the Dutch legislator. ${ }^{714}$ Under the WCA such provisions cannot be applied.715

The third problem is that the field of application of article 1 (1) WCA overlaps with the field of application of article 3 WCA. This article determines the law applicable to the relationship between the woman and the child who is born to her out of wedlock. This problem will be discussed in more detail below in the paragraph on the law applicable to the legal maternity for the child born out of wedlock.

\subsubsection{Applicable law to annulment of marital paternity under Dutch PIL}

Article 2 WCA determines the law applicable to the annulment of legal parentage based on marriage. The first paragraph provides that the law applicable to such an action is the law that applies to the existence of the legal parentage according to article 1 (1) WCA.

If the annulment is not possible according to that legal system, paragraph two provides that the court is allowed to apply one of the other legal systems of article 1 (1) WCA or the law of the habitual residence of the child at the moment of the action for annulment or Dutch law.

\footnotetext{
710 Article 154 (2) Mudawana. See also Jordens-Cotran 2007, p. 488.

711 Article 1:199 Burgerlijk Wetboek.

712 Jordens-Cotran 2002a, p. 262; Vonken 2000, p. 16.

${ }^{713}$ E.g. section 69Q Family Law Act 1975 (Australia).

714 See the draft proposal to insert the legal parenthood of the female partner of the mother in the law on parentage at the website of the Ministry of Justice: http://www.justitie.nl/actueel/nieuwsberichten/archief-2009/91215snellerouderschap-voor-duomoeder.aspx.

715 Also De Groot 2000, p. 194. The Minister suggested that rules like the one according to which the registered partner is automatically the legal father of the child did not exist. Therefore, the Act would not need to take such rules into account (Kamerstukken II 2001-02, 26 675, nr. 6, p. 3, 14).
} 
The recourse to a more favourable legal system for the annulment of marital legal parentage is only allowed if it is in the interest of the child (which will be determined by the court) and must be requested by the legal parents together.

The rationale behind this system is that as a starting point the law which applies to the establishment of marital parentage should also determine its annulment. 716 The favouring element of paragraph two is introduced in the interest of the child. In parentage cases the starting point is that it is in the interest of the child to be affiliated with his or her biological father. ${ }^{717}$

Article 2 (1) and (2) WCA give rise to various questions. First of all, article 2 WCA subjects the annulment of marital paternity to the lex causae of article 1 (1) WCA because logic demands that the law that governs the establishment should also govern the annulment. However, if the legal parenthood on the basis of marriage has been established abroad article 1 (1) WCA is not applied. On the basis of article $10 \mathrm{WCA}$, the parenthood as it appears on the foreign birth certificate will be recognised. In line with the decision of the Dutch Supreme Court of 1 October 2004,718 it must be presumed that in such a case the applicable law to the annulment of marital paternity is the law that has been applied to its establishment by the foreign registrar.

Secondly, it is not clear why the possibility to annul marital paternity should be favoured. ${ }^{719}$ After all, the conflict rule for the annulment of acknowledgment of paternity also does not favour the possibility for annulment. The reason for this is that according to Dutch substantive law the annulment of acknowledgment is very much restricted: 720 not only does the applicant have to prove that the acknowledger is not the biological father, but he or she must also prove a defective intention at the moment of the acknowledgment. 721 But Dutch substantive law does not favour the annulment of marital parenthood either.722 The regulation for annulment of marital paternity is the most restrictive among the legal systems under investigation in this thesis: the period of limitation is one year for the father and the mother and three years for the child and if the man knew before the marriage that the woman was pregnant, annulment by him and the mother is not even possible. ${ }^{723}$

A possible justification to favour the possibility to contest marital paternity is that per article 1 WCA it is possible that the ex-husband is the legal father of a child born after the dissolution of the marriage (if this is the effect of the law of the common nationality of the mother and her ex-husband, e.g. Moroccan law). It is not very likely that the ex-husband is the child's biological father. If, on top of that, foreign law would not allow the persons involved to contest the legal paternity of the ex-husband, that outcome would be likely to violate Dutch public policy.

The third question concerns the relation between article 1 and 2 WCA. Article 2, second paragraph allows the use of the other legal systems mentioned in article 1 WCA in the interest of the child. Does that also mean that the common nationality of the parents or their common habitual residence can be chosen at the moment of birth or at the moment of annulment?724

\footnotetext{
716 Kamerstukken II 1998-99, 26 675, nr. 3, p. 10.

717 Kamerstukken II 1998-99, 26 675, nr. 3, p. 10; Kamerstukken II 2001-02, 26 675, nr. 6, p. 16. See also De Groot 2000, p. 200

718 Hoge Raad, 1 October 2004, NJ 2004/622, LJN AP2680.

719 See also Vonken 2000, p. 20.

720 Kamerstukken II 1998-99, 26 675, nr. 3, p. 15.

${ }^{721}$ Article 1:205 (1) Burgerlijk Wetboek.

722 See also De Groot 2000, p. 200.

${ }_{723}$ Article 1:200 Burgerlijk Wetboek. See also § 3.5.2. Restrictions on judicial annulment of paternity under Dutch law.

724 See also Vonken (Personen- en familierecht. Het internationale afstammingsrecht), art. 2 WCA, aant. 1.2.
} 
If the aim is to bring legal parentage in conformity with biological reality, 725 the answer would be affirmative. After all, the more legal systems that can be applied, the bigger the chance that one system allows the annulment of legal paternity. From the perspective of proximity it makes sense to apply the law of the nationality of the parents or the law of their common habitual residence or the habitual residence of the child at the moment of the action. However, the text of the law suggests that the nationality and the residence of the legal parents have to be determined at the moment of birth. The fact that article 2 (2) WCA explicitly mentions the possibility to use the law of the habitual residence of the child at the moment of the action suggests that it is not possible to determine the nationality and the habitual residence of the parents at the moment of the action..$^{726}$

Next to the possibility to contest the legal paternity of the husband by means of a judicial procedure, article 2 (4) WCA also provides for the possibility to contest his legal paternity by means of a declaration that the husband is not the father before the civil status registrar. The provision is inspired by article 1:199 under b Burgerlijk Wetboek. ${ }^{727}$ Under Dutch law, the mother of the child is allowed to deny the paternity of her husband by a declaration before the civil status registrar, if the man and the woman were legally or factually separated during the conception period and if the husband died during the conception period and before the child's birth. ${ }^{728}$ Since Dutch substantive law allows for a form of administrative annulment of marital paternity, the legislator thought that in principle the persons involved should be able to use such a possibility if the lex causae allows it. However, in the interest of the child, article 2 (4) WCA does not favour the possibility of administrative annulment and it provides for two additional requirements. ${ }^{729}$

The starting point is that administrative annulment of marital paternity by the mother is possible if it is allowed under the law which applies to the existence of marital paternity under article 1 (1) WCA. An example is provided by the decision of the Gerechtshof Amsterdam. ${ }^{730}$ In this case the child was born within 300 days after the divorce of an American couple from California. At the birth registration in the Netherlands, the exhusband and the mother declared that the ex-husband was not the biological father of the child and a Dutch national acknowledged his paternity. The court held that the acknowledgment of the Dutch national was valid, because according to Californian law the paternity of the ex-husband could be set aside by means of joint statement by the mother and her ex-husband.

However, the article adds that whatever the lex causae provides, the administrative annulment is only possible if the (ex) husband agrees and if the legal paternity of another man is established at the same time. The additional requirements of article 2 (4) WCA are somewhat peculiar. First of all, it is unclear where the two additional requirements come from ${ }^{731}$ given that under Dutch substantive law neither safeguard exists. The woman can also contest her (ex) husband's legal paternity under article 1:199 under b Dutch Civil Code by means of a simple declaration if no other man acknowledges paternity.

The second problem with article 2 (4) WCA is that the provision is discriminatory. The woman is allowed to deny the paternity of her husband, but the husband is not allowed to deny his own paternity. Article 1:199 under b Burgerlijk Wetboek also only allows the mother to deny the paternity of her deceased ex-husband under certain circumstances. Still,

\footnotetext{
${ }^{725}$ Cf. Kamerstukken II 1998-99, 26 675, nr. 3, p. 10; Kamerstukken II 2001-02, 26 675, nr. 6, p. 16.

726 See also Jordens-Cotran 2002a, p. 265.

727 Kamerstukken II 1998-99, 26 675, nr. 3, p. 11.

${ }^{728}$ See $\S$ 3.5.6. Administrative annulment of legal parenthood.

${ }^{729}$ Kamerstukken II 1998-99, 26 675, nr. 3, p. 11.

${ }^{730}$ Gerechtshof Amsterdam 27 September 2001, NIPR 2003/158.

731 See also De Groot 2000, 198; Vonken 2000, p. 21.
} 
this does not justify the impossibility for the father contesting his own paternity by means of a simple statement before the civil status registrar if the lex causae allows it.

\subsubsection{Applicable law to the legal parentage between the woman and the child born out of wedlock under Dutch PIL}

Article 3 WCA provides the choice of law rule for maternal parentage of a child born out of wedlock. According to paragraph one, the national law of the mother determines whether the woman to whom the child is born is the legal mother by dint of birth. If the mother has more than one nationality, the law according to which legal maternity exists ex lege must be chosen.732 The second sentence of the first paragraph adds that if the birthmother has her habitual residence in the Netherlands, her maternity always exists by dint of birth. The second paragraph clarifies that the nationality of the mother has to be determined at the moment of birth of the child. The third paragraph reminds the reader that the Convention on the establishment of maternal descent of natural children (Brussels, 1962), supersedes the provisions of the first two paragraphs. ${ }^{733}$

According to the legislator, the connection to the national law of the mother is the result of the choice which is made in article 1 (1) WCA, which connects in the first place to the common national law of the mother and her (ex) husband. A coherent regulation requires that the law which determines whether or not the child is a child of the marriage (art. 1 WCA) should also determine the maternal affiliation if the child appears to be a child of that marriage (art. 3 WCA) ${ }^{734}$

However, article 1(1) WCA connects to the common nationality of the mother and her husband, which is not necessarily the nationality of the mother under article 3 WCA. It is possible that the mother and her (ex) husband do not have the same nationality or that they have more than one nationality in common. In both cases it is the law of the common habitual residence that will be applied to the legal parenthood of the mother and her (ex) husband. Thus, in case of a French-Moroccan mother and her French-Moroccan ex-husband, the legal parenthood of the mother and her ex-husband is not determined on the basis of their common nationality, but on the basis of their common habitual residence, let's say the Netherlands. Dutch law applies according to article 1 WCA. However, if only the maternal affiliation has to be determine, there is a choice between French and Moroccan law.

The second sentence of paragraph one makes an important exception to the main rule. It provides that legal maternity will be established by dint of birth, irrespective of the lex causae if the mother is habitually resident in the Netherlands. In order to avoid limping relations, if the national law of the mother does not establish legal maternity by dint of birth the mother always has the possibility to acknowledge her maternity if that would be necessary to satisfy requirements of foreign law. ${ }^{735}$

The second sentence of paragraph one in fact promotes article 1:198 Burgerlijk Wetboek to a special mandatory rule in case the birthmother habitually resides in the Netherlands at the moment of birth. Since most women who give birth in the Netherlands shall have their habitual residence there, it is difficult to see the relevance of the conflict rule of paragraph one. After all, for these cases article 3 WCA already sets the outcome, namely that legal maternity is established by dint of birth.

\footnotetext{
${ }_{732}$ Kamerstukken II 1998-99, 26 675, nr. 3, p. 12; Kamerstukken II 2001-02, 26 675, nr. 6, p. 19.

733 The main rule of the convention is that legal maternity shall be established by mentioning the mother on the birth record of the child. If the mother is not mentioned on the birth record she shall have the possibility to acknowledge her maternity. The convention contains unified substantive law and no private international law provisions.

${ }^{734}$ Kamerstukken II 1998-99, 26 675, nr. 3, p. 12.

735 Kamerstukken II 2001-02, 26 675, nr. 6, p. 19. See also Jordens-Cotran 2002a, p. 267; De Groot 2000, p. 203; Vonken 2000, p. 21
} 
Article 3 WCA in relation with article 1 (1) WCA raises the question what the civil status registrar should do when confronted with a woman who is not married at the moment of birth of the child, but who has been married in the past. Does the child's parentage have to be determined by article 1 (1) or article 3 WCA?

The answer is clear if articles 1 and 3 WCA are rephrased in terms of legitimacy and illegitimacy. In that case one first checks whether the child is legitimate on the basis of article 1 WCA. Only if the child is not legitimate article 3 WCA comes into play because in a legal system that distinguishes between legitimate and illegitimate children, a legitimate status is considered more favourable than an illegitimate status.

The reason why the structure of the WCA still reveals the old distinction between legitimacy and illegitimacy is that the report of the standing committee on private international law (Staatscommissie voor het internationaal privaatrecht) on parentage and conflict of laws is also based on this distinction.736 From the numerous references to this report in the parliamentary documents leading to the WCA, it appears that it was an important source of inspiration for the WCA. However, the report was published in 1990 when Dutch substantive law still made a distinction between legitimacy and illegitimacy. At the time of the proposal for the WCA (8th of July 1999), the terms legitimate and illegitimate were already deleted from the legislative vocabulary. Moreover, the legislator itself stated with regard to article 1 WCA that the establishment of paternity of an (ex) husband should not be favoured because the establishment of his legal paternity is not necessarily in the interest of the child.

\subsubsection{Applicable law to acknowledgment of paternity under Dutch PIL}

The law applicable to the acknowledgment of paternity is determined by article 4 WCA. Article 4 WCA only applies if the acknowledgment of paternity takes place in the Netherlands. The recognition in the Netherlands of legal paternity based on an acknowledgment abroad is governed by article 10 WCA.

The validity of an acknowledgment in the Netherlands is subject to two conflict rules. Article 4 (1) WCA states that the capacity of the man and the conditions for the validity of his acknowledgment are subject to the national law of the man. If acknowledgment of paternity is not possible according to the national law of the man, article 4 (1) WCA gives three alternatives: the law of the habitual residence of the child, the national law of the child or the law of the man's habitual residence. The rationale behind this cascade of connecting factors is that the establishment of legal parentage by acknowledgment of paternity is considered to be in the interest of the child. 737

However, article 4 (2) WCA provides for an exception to paragraph one. The Dutchman who is married to a woman other than the child's mother is only allowed to acknowledge his paternity, if he fulfils the conditions of Dutch law. An important requirement in this respect is that the Dutch national needs judicial consent for his acknowledgment if he is married to another woman than the legal mother of the child. ${ }^{738}$ The rationale is to avoid the circumvention of rules on intercountry adoption by Dutch nationals. ${ }^{739}$ Article 10 (2) WCA contains a similar rule: the acknowledgment of a married Dutchman abroad will only be recognised if the man fulfils the conditions of Dutch substantive law.

\footnotetext{
736 Staatscommissie IPR 1995.

${ }^{737}$ Kamerstukken II 1998-99, 26 675, nr. 3, p. 13.

738 Article 1:204, (1) under e Burgerlijk Wetboek.

739 Kamerstukken II 1998-99, 26 675, nr. 3, p. 13.
} 
The second part of the conflict rule for the validity of acknowledgment is contained in article 4 (4) WCA and determines the law applicable to the consents to acknowledgment of the mother and the child. The reason to subject the consents to acknowledgment to a separate conflict rule is that the legislator realised that some legal systems do not require the consent of the mother and/or the child. As a consequence, the approach favouring the possibility to acknowledge paternity under article 4 (1) WCA could lead to the situation that the Dutch woman, living in the Netherlands, would be deprived of her right to consent to the acknowledgment. That was considered unacceptable. ${ }^{740}$ Therefore, article 4 (4) WCA states that the national law of the mother determines whether the mother needs to consent and the national law of the child determines whether the child needs to consent. If these national laws do not provide for the possibility to establish legal paternity by acknowledgement of paternity, the necessity of consent is determined on the basis of the habitual residence of the mother or the child.

The nationality and the habitual residence for the purposes of article 4 (1) and 4 (4) WCA are determined at the moment the acknowledgment is done or the consent is requested. ${ }^{741}$ If the person has more than one nationality, the nationality which contributes to the aim of the conflict rule has to be chosen. ${ }^{742}$ Thus, if the acknowledger has two nationalities the nationality which poses the least conditions for the validity of the acknowledgment has to be chosen. If the mother has two nationalities, the nationality which provides her with the strongest right to oppose against the acknowledgment has to be chosen.

If the nationality and the habitual residence of the mother cannot be determined, the question whether or not she has to consent to the acknowledgment is, according to the Hoge Raad, determined by the law that applies to the acknowledgment according to article 4 (1) WCA. ${ }^{743}$ In the case at hand, the male applicant had Dutch as well as Moroccan nationality. He was married to a woman who also had Dutch and Moroccan nationality. The applicant wanted to acknowledge his paternity with regard to a child who was born in Morocco to a Moroccan woman. The habitual residence of the child's mother was unknown and the question arose whether her consent was required.

The Hoge Raad noted that article 4 (4) WCA could not be applied because the habitual residence of the mother was unknown. The aim of article 4 (4) WCA is to guarantee as much as possible that the acknowledgment is subject to the consent of the mother. Therefore, the law which applies to the validity of the acknowledgment according to paragraph one also applies to the question whether the mother should consent the acknowledgment, in a case where paragraph 4 cannot be applied. Only if the law that is determined by the first paragraph of article 4 WCA does not require any consent, the fourth paragraph applies.

It should be underlined that the Hoge Raad stated that article 4 (1) WCA only applies to the consent to the acknowledgement in the situation where article 4 (4) WCA cannot be applied as a result of the fact that the habitual residence of the mother is unknown. The Hoge Raad did not conclude that the law which applies according to article 4 (1) always applies to the consent of the mother.

With regard to article 4 WCA some critical remarks have to be made. First of all, in a worstcase scenario article 4 (1) WCA requires the civil status registrar to examine four legal systems for the conditions for acknowledgment. The provision states that the subsequent connecting factor only applies, if acknowledgment is not possible or not possible anymore

\footnotetext{
740 Kamerstukken II 1998-99, 26 675, nr. 3, p. 14

741 Article 4 (5) WCA.

742 Kamerstukken II 1998-99, 26 675, nr. 3, p. 13.

${ }^{743}$ Hoge Raad, 10 November 2006, LJN AY5698.
} 
according to the lex causae of the previous connecting factor. Thus, if only the fourth connecting factor (habitual residence of the man) leads to Dutch law, the registrar still has to examine whether the acknowledgment of paternity is possible according to the foreign legal systems appointed by the other connecting factors. The registrar cannot cheat and go to Dutch law immediately, since the instrument of acknowledgment has to state the law that has been applied. ${ }^{74}$ The obligation to research foreign law if one of the connecting factors leads to Dutch law and if Dutch law allows the acknowledgment is an unnecessary burden.

The second objection against article 4 WCA is that it might upset the balance within national legal systems. Imagine the case of a French acknowledger and a German/Dutch mother. Above it has been explained that the consent of the mother and the question whether her consent can be replaced should be governed by German law because German law gives her the strongest right. However, under German law the veto of the mother is compensated for by the fact that the alleged biological father has the right to apply for judicial establishment of his own paternity. ${ }^{745}$ Under Dutch law, the biological father cannot apply for judicial establishment of his own paternity, but if he is also the begetter he can request the court to replace the consent of the mother if she refuses to consent. ${ }^{746} \mathrm{By}$ submitting the requirement of consent and the possibility to replace the consent to German law, the man will not be able to apply for replacement of the consent of the mother. However, under article 6 (1) WCA the man is also not allowed to apply for judicial establishment of paternity because that action is governed by Dutch law as will be explained below. Although neither German nor Dutch law deprives the biological father/the begetter from the possibility to establish his legal paternity against the will of the child's mother, article 4 WCA has that effect.

The third question concerning article 4 WCA is raised in relation with article 1 (1) WCA. Article 4 WCA determines the law applicable to the validity of an acknowledgment and article 1 (1) WCA determines whether legal parenthood exists ex lege as a result of marriage; the annulment of marital paternity falls within the scope of article 2 WCA. All these provisions provide for a slightly different choice of law regime. The question arises which conflict rule regulates the applicability of rules like § 1599 (2) BGB (Germany) or § 1:2 (2) Föräldrabalk (Sweden), which determine that the legal paternity of the husband is set aside by an acknowledgment of paternity: is this a rule which limits the scope of the pater is estrule, thereby falling within the scope of article $1 \mathrm{WCA}$, is it a means of annulment of marital paternity falling within the scope of article $2 \mathrm{WCA}$, or does it determine the validity of an acknowledgment of paternity within the meaning of article 4 WCA? There are at least two indications that rules by virtue of which a valid acknowledgment of paternity sets aside the legal paternity of the (ex) husband do not fall within the scope of article 4 WCA.

First, the situations in which these rules apply are the same situation as described by article 2 (4) WCA. It provides that the question whether the mother of the child can annul the legal paternity of her husband is determined by the law according to which that legal paternity exists. In any event the legal paternity of another man must be established at the same time and the (ex) husband must consent to the acknowledgment. This is exactly what happens in case of $\S 1599$ (2) BGB or $\S 1: 2$ (2) Föräldrabalk: a man acknowledges his paternity with the consent of the mother and the (ex) husband as a result of which the legal paternity of the (ex) husband is set aside and the legal paternity of the acknowledger is established. It would be inconsistent to subject two kinds of provisions, i.e. provisions allowing the mother to annul marital paternity out of court and provisions allowing the acknowledger to set aside marital paternity, that regulate the same thing, i.e. the annulment

\footnotetext{
744 Article 4 (3) WCA.

$745 \S 1600$ e BGB.

746 Articles 1:207 (1) and 1:204 (3) Burgerlijk Wetboek.
} 
out of court of marital paternity in a situation in which the legal paternity of the (ex) husband is doubtful, to different choice of law regimes.

Second, the legislator indicated that the annulment of marital paternity out of court should not be favoured. ${ }^{747}$ However, this is exactly what happens if provisions such as $\S$ 1599 (2) BGB or Ch. $1 \S 2$ (2) Föräldrabalk fall within the scope of article 4 (1). That paragraph provides the possibility of the validity of an acknowledgment to $b$ determined according to four legal systems. It seems that if a man wants to establish his legal paternity with his acknowledgment of paternity while the legal paternity of another man exists on the basis of the law applicable per article 1 (1) WCA, the acknowledgement is only possible if the law applicable per article 1 (1) WCA allows marital paternity to be set aside by acknowledgment of paternity.

The fourth point concerning article $4 \mathrm{WCA}$ is that the article seems just a complicated way of saying that if Dutch nationals are involved or if the persons involved have their habitual residence in the Netherlands, Dutch law should be applicable. Only in rare cases where the Dutch legal order is not involved by means of nationality or habitual residence of either the mother or the acknowledger, less stringent systems of acknowledgment are acceptable. If that is the case, it is only a small step towards the application of the lex fori in all cases where the acknowledgment is in the Netherlands. And there are good reasons to make this small step.

First of all, it is much more practical to apply Dutch law to acknowledgments which take place in the Netherlands. Civil status registrars of small towns and villages are not equipped to apply foreign law.

Secondly, the rationale of the rule that a Dutch national can only acknowledge paternity according to Dutch law is to avoid the circumvention of the laws on intercountry adoption. But why should the Dutch legislator only prevent Dutch nationals from circumventing adoption laws? The circumvention of adoption laws by a foreigner living in the Netherlands is not less objectionable. This is even more true since the application of the Dutch rules to obtain a licence for intercountry adoption depends on residence and not on nationality. ${ }^{748}$

A similar argument can be made with regard to the choice of law rule for consents to acknowledgment of paternity (art. 4 (4) WCA). The rationale of the rule is that Dutch women should not be deprived of their possibility to protect their private life by giving consent to an acknowledgment of paternity. Apparently, also women with a nationality from a legal system that does not provide for the possibility to acknowledge paternity should be protected if they live in the Netherlands. This means that a Moroccan woman who lives in the Netherlands has the right to consent to an acknowledgment of paternity because according to Moroccan law the acknowledgment of paternity is not possible. However, a French woman living in the Netherlands does not have the right to consent to an acknowledgment, because French law allows the acknowledgment of paternity but does not require the consent of the mother. From the perspective of protecting the private life of the mother, this distinction does not make sense. Why does the Dutch legislator not grant protection to all mothers who live in the Netherlands?

Thirdly, the relationship between article 4 and 10 WCA raises the question of what function the application of foreign law plays in an acknowledgment that takes place in the Netherlands. Article 4 WCA would make much more sense if it would also apply to acknowledgments of paternity made abroad. In that case, the objective of international harmony of decisions would require taking foreign law into account. However, that function becomes redundant in the light of article $10 \mathrm{WCA}$, which states that legal paternity

\footnotetext{
747 Kamerstukken II 1998-99, 26 675, nr. 3, p. 11.

748 Article 2 Wet opneming buitenlandse kinderen ter adoptie.
} 
based on an acknowledgment, which has been validly done abroad, will be recognised in the Netherlands.

\subsubsection{Applicable law to annulment of acknowledgment of paternity under Dutch PIL}

Article 5 WCA determines the law applicable to the annulment of acknowledgment. It provides that the annulment of the acknowledgment is governed by the law which has been applied on the basis of article 4 (1) or (2) WCA. The annulment of the consents is subject to the law applied on the basis of article 4 (4) WCA.

With regard to article $5 \mathrm{WCA}$, the same problem exists as with regard to article 2 WCA: which law applies to the annulment of acknowledgment if the acknowledgment has been made abroad? Under the WCA, the applicable law to the action has to be determined on the basis of article 5 WCA, which states that the law which has been applied according to article 4 WCA shall determine whether annulment is possible. However, if the acknowledgment has been made abroad, no law has been applied pursuant to article 4 WCA. In that case, the foreign acknowledgment is recognised in the Netherlands on the basis of article 10 WCA. The Advocate General at the Dutch Hoge Raad suggests that in such a case the law which has been applied by the foreign registrar governs the annulment of the acknowledgment. ${ }^{749}$ The reason is that the objective of article 5 WCA is to make sure that the law that governs the establishment of paternity by acknowledgment also governs the annulment of the acknowledgment. 750

\subsubsection{Applicable law to judicial establishment of legal paternity under Dutch PIL}

According to article 6 (1) WCA the judicial establishment of legal paternity is subject to the same conflict rule as the legal parenthood on the basis of marriage (article 1 (1) WCA). The action for judicial establishment of paternity is governed by the common national law of the alleged father and the child's mother. If they do not have a common national law, the law of their common habitual residence applies and if they do not have a common habitual residence, the law of the child's habitual residence applies.

According to article 6 (2) WCA, the nationality or the habitual residence has to be determined at the moment the applicant applies for judicial establishment. If either the alleged father or the mother of the child is deceased at the start of the proceeding, the nationality and the habitual residence at the moment of their death is decisive. The habitual residence of the child is always determined at the beginning of the action. ${ }^{751}$ If the man and the mother have more than one nationality in common they are deemed not to have a common nationality for the purpose of article 6 WCA. ${ }^{752}$

Article 6 WCA does not favour the possibility to judicially establish legal paternity. According to a parliamentary report, the reason not to favour the possibility of judicial establishment of paternity is to protect the alleged father. ${ }^{753}$ According to the Minister judicial establishment is a far-reaching action because legal paternity is forced upon him. Moreover, the child also has a less drastic possibility at his or her disposal, namely an action for maintenance on the basis of biological paternity. In that case, the establishment of paternity falls within the scope of the conflict rule for the establishment of maintenance obligations, which provides for a conflict rule favouring the establishment of a maintenance obligation..$^{754}$

\footnotetext{
${ }^{749}$ Hoge Raad, 1 October 2004, LJN AP2680, NJ 2004/622.

750 Kamerstukken II 1998-99, 26 675, nr. 3, p. 15.

751 Article 6 (2) WCA.

752 Article 6 (3) WCA.

753 Kamerstukken II 2001-02, 26 675, nr. 6, p. 22.

754 Kamerstukken II 2001-02, 26 675, nr. 6, p. 22.
} 
De Groot argues that the absence of a cascade of connecting factors favouring the possibility to judicially establish legal paternity is disappointing. The man who begot the child should not be able to escape his legal paternity; only the anonymous donor should be protected against foreign law that allows the establishment of his paternity. ${ }^{755}$ The Gerechtshof Amsterdam held in 2006 that article 6 (1) WCA violates article 8 ECHR if it leads to a legal system that does not allow judicial establishment of legal paternity. ${ }^{756}$

As with article 2 (4) WCA (the law applicable to the administrative annulment by the child's mother) it is not clear why article 6 WCA is limited to the judicial establishment of legal paternity. Why is there no provision for the judicial establishment of maternity? The existence of legal maternity ex lege is not uniform across the legal systems under consideration. Therefore, it cannot be excluded that a child whose birth certificate has been drawn up abroad, needs an action for judicial establishment of maternity in the Netherlands.

\subsubsection{Applicable law to legitimation under Dutch PIL}

Although at the introduction of the WCA the concept of legitimation was already removed in the Dutch substantive law on parentage, the subject still had to be dealt with in private international law in the case that foreign law provides that a child who does not have a legal father automatically, gets a legal father as the result of the man's marriage to the child's mother. ${ }^{757}$

According to article 7 (1) WCA the law applicable to legitimation is determined in the first place by the Convention on the legitimation by marriage (Rome, 1970). ${ }^{758}$ The first article of this convention provides that the child shall be legitimated if the child is legitimated as a result of marriage or as a result of an administrative or judicial decision on the basis of either the law of the mother or the law of the father. If these national legal systems do not legitimate the child, article 7 (2) WCA provides that also the law of the habitual residence of the child can be taken into account.

In cases of legitimation, the validity of the marriage is usually a prerequisite and therefore an important incidental question for the determination of the child's status. Article 7 (3) WCA states that if one of the persons has Dutch nationality, the validity of the marriage has to be determined on the basis of Dutch private international law, in particular the Conflict of Laws (Marriage) Act. ${ }^{759}$

Does article 7 (3) WCA mean, a contrario, that the private international law of the lex causae determines the validity of the marriage if none of the parties to the marriage is Dutch? With regard to legitimation on the basis of the Rome Convention, the explanatory report to the convention states that the validity of the marriage is determined on the basis of the internal national law of either the mother or the father or on the basis of the law applicable according to the private international law of the lex causae, depending on which legal system validates the marriage. 760

Finally, article 7 (4) WCA provides that the habitual residence of the child or the nationalities of the father or the mother are determined at the moment of the marriage or, if the legitimation is the result of an administrative or judicial decision, at the moment of the decision.

\footnotetext{
755 De Groot 2000, p. 212. Differently Vonken 2000, p. 22.

756 Gerechtshof Amsterdam 9 February 2006, LJN AV2119. See also Gerechtshof 's-Hertogenbosch 27 November 2008, LJN BG6114; Rechtbank 's-Gravenhage 3 November 2008, LJN BG8815. In more detail § 6.7. Application of the conflict rule on parentage.

757 Kamerstukken II 2001-02, 26 675, nr. 6, p. 23.

758 Trb. 1972, 61.

759 Wet Conflictenrecht Huwelijk.

760 Explanatory report to the Convention on legitimation by marriage, Rome 10 September 1970, p. 6.
} 


\subsection{English choice of law rules on parentage}

Under English law there are neither rules at common law nor statutory provisions on choice of law in matters concerning parentage. Legal parenthood is determined on the basis of the lex fori. ${ }^{761}$ In reaction to the question whether the English registrar ever applies foreign law in order to determine the child's parentage (for example because both parents are domiciled abroad), the General Register Office replied that "at no point would a registrar take account, on initial registration of the domicile of either parent nor would they enquire as to parentage under foreign law."762

To understand why choice of law on parentage does not (yet) exist under English law, while it is considered a relevant issue under continental legal systems, the English approach towards the law applicable to personal status has to be examined.

The status of an individual has been described as 'the legal position of the individual in or with regard to the rest of the community.' ${ }^{763}$ In English law there is no fixed list of elements that constitute the status of an individual. Lord Justice Scott cited Dicey (1870) who enumerated seven kinds of status: parent and child, guardian and ward, infancy, legitimacy, husband and wife, lunatic and curator, corporations. ${ }^{764}$ The list Dicey specifies relates both to parentage and legitimacy as part of an individual's status. Also, the Human Fertilisation and Embryology Act suggests that parentage is a matter of status, by placing the head 'status' above the sections defining motherhood and fatherhood. However, leading English textbooks on family law suggest that a child's parentage and his status are two different things. 765

The main rule under English law is that a child is legitimate if his parents are married at the time of his conception or at the time of his birth. ${ }^{766}$ If the parents are not married, the person is illegitimate but he can be legitimated by the subsequent marriage of his parents. ${ }^{767}$ It follows that parentage is an incidental matter to determine the legitimacy of the child. The parentage of the child is the fact on the basis of which the law grants the child the status of legitimate or illegitimate child.

In law the establishment of parentage and the determination of the child's status are connected by the presumption of legitimacy. The presumption of legitimacy means that a child who is born to a married woman is presumed to be legitimate. ${ }^{768}$ The presumption implies that the husband of the mother at the time of birth is presumed to be the father of the child. After all, it follows from the definition of legitimacy that the child is only legitimate if the husband is the father of the child.

If one accepts that parentage is a merely question of fact instead of law it is understandable that English law only developed choice of law rules with regard to legitimacy and not with regard to parentage. After all, the law only determines whether or not legal relations (a certain personal status) exist. With regard to facts, the law only provides rules of evidence which may determine under which circumstances the existence of certain facts must be accepted.

\footnotetext{
${ }_{761}$ See also Henrich 2006a, p. 51; Lennart 1986, p. 348; Guimezanes-Durand 1973, p. 529.

762 E-mail from the General Register Office, 25 th of July 2008.

763 Mackay of Clashfern 2001b, nr. 33.

${ }_{764}$ Re Luck's Settlement Trusts, Re Luck Will Trusts, Walker v Luck [1940] Ch. 864, [1940] 3 All ER 307, CA.

765 See e.g. Mackay of Clashfern 2008, nr. 93 and 125; Lowe \& Douglas 2007, p. 305 and 341.

766 Lowe \& Douglas 2007, p. 341, 342.

767 Section 2 Legitimacy Act 1976.

768 Mackay of Clashfern 2008, nr. 94, note 2.
} 
For a long time, the legitimacy of the child was a relevant matter. For example, it was only in 2006 that the British legislator abolished the rule that only a legitimate child could acquire British nationality from his father. ${ }^{769}$

Nowadays the question of legitimacy is almost irrelevant. ${ }^{770}$ In the great majority of cases, the rights and duties between children and their parents are directly based on parentage. As a consequence, the conflict rules on legitimacy have become obsolete. What is left in law is a question of evidence, namely how to determine whether a certain person is the father (or mother) of the child.

Alongside the downfall of the concept of legitimacy, parentage has developed from a mere factual issue into a substantive matter. In both heterosexual and homosexual relations biological parentage has become only one of the grounds for legal parentage. ${ }^{771}$ The recognition of different grounds for legal parenthood in a national legal system has added an additional dimension to the law on parentage. Hence, even under English law it cannot be maintained that parentage is merely a matter of fact. The definition of the terms father and mother is a matter of law. Therefore, the issue of legal parentage must at least in theory lead to choice of law problems.

\subsubsection{Applicable law to legitimacy under English PIL}

Since legitimacy is a question of status, legitimacy is governed by the law of the domicile of the person involved. However, the domicile of a child depends on his status and therefore the domicile of the child cannot be the relevant connecting factor. Only a few cases have dealt with this problem.

In Shaw $v$ Gould (1868) the question was whether the children of Elisabeth could inherit under the will of John Wilson. ${ }^{772}$ By his will, he created a trust fund of 2,000 pounds for the benefit of his great niece Elisabeth and, after her death, for her legitimate children. In 1828 Elisabeth married Buxton in England. The marriage had been brought about by fraudulent conspiracy and Elisabeth and Buxton never lived together. In 1845 Elisabeth met John Shaw who proposed to marry her. Elisabeth agreed if she could divorce Buxton. For that purpose Elisabeth and John settle in Edinburgh. In 1846 they paid Buxton a sum of money to stay for 40 days in Scotland in order for the Scottish court to have jurisdiction to pronounce the divorce. The Scottish court pronounced the divorce of Elisabeth and Buxton and the same year Elisabeth and John Shaw married. Three children were born after the marriage.

According to the House of Lords, the question in this case was whether the Scottish divorce could be recognised in England. If the divorce could not be recognised the second marriage would be invalid as a result of which the children would be illegitimate. However, if the divorce could be recognised, the marriage would be valid and hence the children would be legitimate. The House of Lords unanimously held that the children were illegitimate, because the Scottish divorce could not be recognised in England.

It follows from Shaw $v$ Gould that a child is legitimate if he is born during the marriage of his parents and that the marriage has to be valid under English (private international) law. 773

In Re Bischoffsheim (1948) the Chancery Division of the High Court took a different stance. ${ }^{774}$ In this case, the testator settled a share in the trust of his estate on his

\footnotetext{
769 Section 50 (9A) British Nationality Act 1981 as amended by section 9 Nationality, Immigration and Asylum Act 2002, which entered into force on the $5^{\text {th }}$ of June 2006.

770 On the exceptional areas of the law where legitimacy still matters see inter alia Mackay of Clashfern 2008, nr. 125; North, Fawcett \& Carruthers 2008, p. 1142; Lowe \& Douglas 2007, p. 346.

${ }^{771}$ Chapter 2. Grounds for legal parentage.

772 [1861-1973] All ER Rep 874.

773 See also Brook v Brook (1861) 9 HL Cas 193; Re Paine [1940] Ch 46. Mackay of Clashfern 2003, nr. 338; Guttman 1959, p. 769-770.
} 
granddaughter Nesta for life and with remainder to her legitimate children. In 1908 Nesta marries Lord Richard Wellesley and two children are born to the marriage. Richard dies in 1914 and in 1917 Nesta marries Richard's brother, Lord George Wellesley. In 1920 a third child is born to Nesta and George, who is also called Richard. After the death of Nesta, the question arises whether Richard jr. has a right to the share of the estate of the testator as a legitimate child of Nesta.

If the decision of the House of Lords in Shaw $v$ Gould would be applied to this case, the Richard jr would not be a legitimate child of Nesta because the second marriage between Richard sr. and Nesta was not valid according to English law. However, the judge in Re Bischoffsheim held that 'where succession to personal property depends on the legitimacy of the claimant, the status of legitimacy conferred on him by his domicile of origin (i.e. the domicile of his parents at his birth) will be recognised by our courts, and that, if that legitimacy be established, the validity of his parents marriage should not be entertained as a relevant subject for investigation.' Also in other cases, lower courts have recognised the legitimacy of the child according to the child's domicile of origin although the marriage of the parents was not valid under English law. 775

The difference between Shaw $v$ Gould and Re Bischoffsheim is that in the latter case the validity of the parents' marriage was an incidental question to determine the legitimacy which was resolved by the (private international) law of the law that applies to the legitimacy. ${ }^{776}$ In Shaw $v$ Gould the validity of the marriage was resolved on the basis of English (private international) law.

The connecting factor for legitimacy in Re Bischoffsheim is the child's domicile of origin at the moment of his birth, which is the domicile of his parents. This is not entirely consistent with the prevailing view that the domicile of the child depends on the domicile of his father if the child is legitimate and on the domicile of the mother if the child is illegitimate. 777 It had been proposed to interpret Re Bischoffsheim in such a way that a child is legitimate, if the requirements of the laws of the domiciles of both the father and the mother at the moment of birth are fulfilled. ${ }^{778}$ In most cases, the mother and the father shall have a common domicile at the moment of birth. In that case, the common domicile of the parents is also the domicile of origin of the child.

If the mother and the father do not share a common domicile at the moment of birth, the proposed interpretation avoids the vicious circle which would arise if the domicile of origin of the child would govern the child's legitimacy. After all, the child's domicile of origin depends on his legitimacy and therefore the legitimacy cannot be based on the child's domicile of origin.

Yet another approach is found in Hashmi $v$ Hashmi (1970). ${ }^{779}$ In this case a Pakistani national first married in Pakistan, then contracted a second marriage in England, while the first marriage was not yet dissolved. Three children where born to the second marriage and the question arose whether these children were legitimate children. The court held that the children were legitimate, if the second marriage of the man was valid according to the law of his domicile, i.e. the law of Pakistan.

It has been argued that the court decided Hashmi $v$ Hashmi per incuriam by holding that for the legitimacy of the children it is sufficient if the marriage is valid by the law of the father's domicile. ${ }^{780}$ After all, according to Shaw $v$ Gould the validity of the second marriage

\footnotetext{
774 [1948] Ch. 78, [1947] 2 All ER 830.

775 Motala and others v Attorney-General, [1990] 2 FLR 261.

776 Cf. Collins 2006b, nr. 17-193.

777 North, Fawcett \& Carruthers 2008, p. 174, 1150; Collins 2006a, nr. 6R-090.

778 North, Fawcett \& Carruthers 2008, p. 1150; Collins 2006b, nr. 20R-009; Mackay of Clashfern 2003, nr 338.

779 [1972] Fam 36, [1971] 3 All ER 1253.

780 Mackay of Clashfern 2003, nr. 338, note 2.
} 
would have to be determined on the basis of English law. According to Re Bischoffsheim the court would have had to examine whether the second marriage was valid and hence whether the children were legitimate according to both the law of the father's as well as the mother's domicile.

Although the decision in Hashmi $v$ Hashmi is hard to reconcile with either Shaw $v$ Gould or Re Bischoffsheim, it seems to be in line with the statutory amendment to the common law on choice of law on legitimacy. Both the repealed section 2 (2) Legitimacy Act 1959781 as well as the current section 1 (2) Legitimacy Act 1976 provide that the English rule on legitimacy pursuant to a putative marriage only applies if the father of the child is domiciled in England at the time of the child's birth. Translating this provision into a bilateral conflict rule means that the legitimacy of a child is governed by the law of the domicile of the child's father at the moment of the child's birth. This is the rule which the court applied in Hashmiv Hashmi.

The struggle under English law to determine the appropriate connecting factor for legitimacy is very comparable with the discussion in continental legal systems. At least under French and Dutch law the nationality of a person is considered the natural connecting factor for his personal status. Nationality as a connecting factor to determine the child's parentage is just as problematic as domicile, since the nationality of a child depends on his parentage. It has been shown that under French and Dutch law this is one of the considerations to connect to the law of the mother's nationality (France) or the common nationality of the alleged parents (Netherlands).

\subsubsection{Applicable law to legitimation under English PIL}

Next to the case law on choice of law for legitimacy there is a separate line of case law and statutory provisions to determine the applicable law to the legitimation of the child. Legitimation is the process whereby an illegitimate child acquires the status of a legitimate child. Legitimation is often the result of the subsequent marriage of the child's parents.

At common law a cumulative connecting factor exists to determine the applicable law to the legitimation of the child by the subsequent marriage of his parents. The child shall be legitimated by the marriage of his parents if the requirements of the law of the father's domicile are fulfilled at the moment of birth and at the moment of marriage. ${ }^{782}$

The scope of application of the common law rules has been drastically curtailed by the Legitimacy Act 1926 and the Legitimacy Act 1976. Since the Legitimacy Act 1926 the child shall be legitimated by the subsequent marriage of his parents if the father of the child is domiciled in England at the moment of birth. ${ }^{783}$ Section 3 Legitimacy Act 1976 adds that the marriage of the child's parents shall legitimate the child if the child shall be legitimated according to the law of the father's domicile at the moment of the marriage. Under the Act it is no longer necessary that the requirements of the law of the father's domicile at the moment of birth are also satisfied.

The Legitimacy Acts only applies to legitimation by marriage. The child can also be legitimised by the acknowledgment of paternity. The choice of law rule for legitimation by acknowledgment of paternity still follows from common law. In Re Luck's Settlement Trusts (1940) the Court of Appeal held that at common law all forms of legitimation had to confirm with the law of the father's domicile both at the time of birth as well as at the time of the legitimation.784

\footnotetext{
${ }^{781}$ For the text of section 2 Legitimacy Act 1959 see Jones 1959, p. 723

782 Re Goodman's Trust (1881) 17 Ch D 266; Re Grove (1888) 40 Ch D 216. See also North, Fawcett \& Carruthers 2008, p. 1152; Collins 2006b, nr. 20R-048; Mackay of Clashfern 2003, nr. 340.

783 Now section 2 Legitimacy Act 1976

784 [1940] Ch 864, [1940] 3 All ER 307, CA.
} 


\subsubsection{Applicable law to parentage under English PIL}

The parentage of a child is the fact on the basis of which the law determines whether or not the child is legitimate. In times when the term parentage almost universally referred to the biological parents of the child, parentage could easily be treated as a fact. If parentage is considered a fact, its existence is merely a question of evidence. In that case, one does not need choice of law rules to determine the parentage of a child.

This approach is fundamentally different from the continental approach. Under continental law, if legal parentage has to be proved, one has to prove that a legal relationship has been established. Here, a conflict of laws can arise because different legal systems have different requirements for the establishment of the legal relationship in the same way as different legal systems have different requirements for a valid marriage.

However, it has been established that already for quite some time parentage does not refer to the child's biological parents only. Artificial reproduction methods and same sex parenthood have caused legislators to develop different definitions of the term 'parent'. The most interesting examples of this are English and Swedish law which provide that the child can have two mothers on the basis of the law on parentage. ${ }^{785}$

Since the legal systems differ as to the basis of legal parentage, under English law it is also possible that a conflict of laws with regard to parentage arises. This possibility has not yet received much judicial or academic attention.

Sections 33 (3), 35 (2) and 42 (2) Human Fertilisation and Embryology Act 2008 provide that the definitions of mother and father or parent in case of a marriage or a civil union apply 'whether the woman was in the United Kingdom or elsewhere at the time of the placing in her of the embryo or the sperm and eggs or her artificial insemination.'

The wording of the Act suggests that its definitions of father and mother have a universal application, meaning that the English courts are bound by these definitions irrespective of the child's place of birth or the nationality or the domicile of the persons involved.

However, the prevailing view in English literature is that sections 33 (3), 35 (2) and 42 (2) do not establish a choice of law rule. It is said to establish a rule of English law that is only applicable if English law applies by virtue of its choice of law rules. ${ }^{786}$

Lowe and Douglas argue that English law is applicable if at least one of the parties is domiciled or habitually resident in the United Kingdom at the time of the treatment or the insemination. ${ }^{787}$

Norrie addressed the problem of parentage in conflict of laws in more detail. In his view, it is the law of the country with which the relationship is most closely connected that should determine whether or not the relationship exists. Another possibility is to determine the existence of parentage on the basis of the lex causae that governs the issue to which parentage is an incidental question, like inheritance or maintenance. ${ }^{788}$

In English case law, there are not many examples where parentage is discussed in an international context and there are no decisions that formulate a choice of law rule on parentage. In order to understand why international cases have not lead to the development of choice of law rules, one must understand the legal framework within which these cases have to be decided. Three examples will be worked out.

\footnotetext{
785 See also article 538.3 Civil Code of Quebec. For a detailed discussion on the law of Quebec on this point see Leckey 2009.

786 Lowe \& Douglas 2007, p. 314; Collins 2006a, nr. 20-029.

787 Lowe \& Douglas 2007, p. 314.

788 Norrie 1994, p. 764.
} 


\subsubsection{Section 30 Human Fertilisation and Embryology Act 1990}

The first case is Re G (Surrogacy: Foreign Domicile). Re G concerned the establishment of the legal parenthood of a Turkish couple who got a child with the help of an English surrogate. ${ }^{789}$ After the birth of the child, who was originally registered as the child of the surrogate and her husband, the Turkish couple applied for a parental order under section 30 Human Fertilisation and Embryology Act 1990. The effect of a parental order is that the applicants shall be treated in law as the child's parents. ${ }^{790}$

In $\operatorname{Re} G$ the court did not make the order because it had no jurisdiction to do so. Pursuant to section 30 (3) under $b$ at least one of the commissioning parents has to be domiciled in a part of the United Kingdom or the Channel Islands; in this case both spouses were domiciled in Turkey.

From the English perspective, $\operatorname{Re} G$ does not give rise to a choice of law problem with regard to the question whether the legal parentage of the couple can be established by the parental order. English law allows the court to make a parental order if certain requirements are fulfilled. For example, the applicants must be married, the gametes of the applicants must have been used for the creation of the child and the court must be satisfied that the case does not involve commercial surrogacy. If the court has international jurisdiction pursuant to section 30 (3) to make the order, it will make the order if the other requirements of section 30 are fulfilled.

Thus, if one or both of the spouses in $\operatorname{Re} G$ had been domiciled in the UK the English court would have considered the requirements of English law to determine whether or not the couple would be entitled to a parental order.

Section 30 (5) Human Fertilisation and Embryology Act 1990 provides that the court can only make a parental order if the original parents of the child consent to the order. In $\operatorname{Re} X \mathcal{E}$ $Y$ (Foreign Surrogacy), the question was raised how it must be determined who the original parents of the child are. ${ }^{791}$

In $\operatorname{Re} X \mathcal{E} Y$ (Foreign Surrogacy) a British married couple, domiciled in the United Kingdom entered into a surrogacy agreement with a married Ukrainian woman. The Ukrainian woman was implanted with embryos conceived with donor eggs and fertilised by the sperm of the British man. Under Ukrainian law, the British commissioning parents automatically became the legal parents of the child. ${ }^{792}$ Under English law, the surrogate mother was the legal mother of the child and her husband was the legal father under section 28 Human Fertilisation and Embryology Act 1990 (now section 35). English law provided that the commissioning parents could only acquire parental status pursuant to a parental order on the basis of section 30 Human Fertilisation and Embryology Act.

Under Ukrainian law, the children were considered foreigners and therefore they were not allowed to stay in that country. Although the Ukrainian birth record of the children mentioned the British couple as the parents of the child, the children were denied British passports, because of the English law on parentage in case of surrogacy. In the end the children were given discretionary leave to enter the United Kingdom to allow the commissioning parents to apply for a parental order under section 30 Human Fertilisation and Embryology Act 1990.

\footnotetext{
${ }^{789} \mathrm{Re}$ G (Surrogacy: Foreign Domicile) [2007] EWHC 2814 (Fam); [2008] 1 FLR 1047 (Fam Div). For comments on this case see: Howe 2008; Cullen 2008.

790 S. 30 (1) Human Fertilisation and Embryology Act 1990.

791 [2008] EWHC 3030 (Fam). See also $W$ and B v H (Child abduction, Surrogacy) [2002] 1 FLR 1008; W and W v H (Child abduction and surrogacy) [2002] 2 FLR 252, [2002] Fam law 501.

792 Article 123 (2) Ukrainian Family Code.
} 
On the position of maternity the court notes that 'the effect of the provision [section 27 (1) and (3) Human Fertilisation and Embryology Act 1990, ks] is that in English law the Ukrainian woman (although biologically unrelated to the twins) is for all purposes the sole legal mother of these children.' From a private international law perspective the statement is equivocal since it is not clear whether the term 'English law' as used by the judge includes or excludes English choice of law rules.

Obviously, section 27 (1) determines for internal situations that the woman who gives birth to the child is the legal mother. However, several authors expressed the opinion that section 27 only applies if English law is applicable by virtue of English choice of law rules (that have not yet been formulated). ${ }^{793}$ Thus the question whether in English law the Ukrainian woman is the mother of the child depends on whether section 27 is applicable by virtue of English choice of law rules.

However, this analysis is not applied in $\operatorname{Re} X \mathcal{E} Y$ (Foreign Surrogacy). The judge first cites section 27 (1) and (3). Subsection (3) provides that subsection (1) applies whether the woman was in the United Kingdom or elsewhere at the time of the treatment. Then the judge makes the remark that in English law the Ukrainian woman is the legal mother of the child and finally he makes a parental order in favour of the commissioning parents.

This reasoning suggests that the court takes a different view to the authors cited above. It seems that the court takes the view that section 27 (3) contain a choice of law rule as a result of which the definition of legal maternity in subsection (1) always applies if legal maternity has to be determined or established by an English court. Why otherwise would he cite subsection (3) so explicitly and why would the parental order finally be given? After all, it would be unnecessary to make the parental order in favour of the commissioning parents, if the commissioning mother was already the legal mother of the child.

A second choice of law problem is treated in more detail by the court. One of the requirements for a parental order under section 30 is that the court must be satisfied that the original parents of the child have freely and with full understanding of what is involved agreed to the making of the parental order. The question therefore was whether the husband of the Ukrainian surrogate was the legal father of the child and hence whether or not he had to consent to the parental order. According to Ukrainian law he was not the legal father but according to section 28 (2) Human Fertilisation and Embryology Act he would be.

It was argued for the commissioning parents that section 28 could not be applied extraterritorially and hence that the Ukrainian husband was not the legal father. His legal paternity would have to be determined on the basis of Ukrainian law. According to the applicants sections 27 and 28 of the Human Fertilisation and Embryology Act 1990 would only apply extra-territorially in respect of British subjects or persons domiciled in the United Kingdom. The argument is probably based on the idea that the status of an individual is governed by the law of his domicile. Since the husband of the surrogate is not domiciled in the United Kingdom, English law (including section 28 Human Fertilisation and Embryology Act) could not be applicable to his legal paternity.

The court took a different stance. The question whether or not the husband of the surrogate is the legal father of the child has to be determined on the basis of section 28 . The judge held:

[...], I cannot for myself see how it bears on the issue before me which is not the status of the surrogate mother's husband under his law of domicile but the status conferred on

793 See note 786 . 
him by the law of the domicile of the applicants which is, in my judgment, the law applicable to all aspects of this case given that it is brought under the 1990 Act.

Thus English law applies because the applicants apply under section 30 of the Human Fertilisation and Embryology Act. The reason why foreign law was irrelevant to determining the legal paternity of the surrogate's husband on the basis of foreign law was expressed as follows:

In my judgment Parliament cannot be taken to have had any different intention (given the provisions of Section 28(8) of the 1990 Act) in relation to husbands of foreign domicile. The intention of Parliament was to recognise the particular relevance of marriage in surrogacy arrangements. I can see no reason why that should be affected by questions of domicile. The fact that the Ukrainian husband is relieved of responsibilities imposed on his English equivalent is not a valid reason given that the wife of each is in an identical position. This is a recognition of the particular position of the lawfully married husband and I see no reason why (given the statutory words) that should not be applied extra-territorially. It follows that in my view the Ukrainian husband's consent was required [...].

$\operatorname{Re} X \mathcal{E} Y$ (Foreign Surrogacy) allows us to draw some conclusions with regard to parentage in English private international law. First, if the applicants apply under section 30 Human Fertilisation and Embryology Act 1990 the court shall apply the English criteria to determine whether or not a parental order can be made. That is, if the applicants apply under section 30. In $\operatorname{Re} X \mathcal{E} Y$ (Foreign Surrogacy) the British couple could also apply under section 55A Family Law Act 1986 for a declaration of parentage (see the heading below).

Second, the term 'father of the child' in section 30 (5) must be construed in accordance with section 28. The construction of the term 'father of the child' is not treated as a separate, incidental question. On the contrary, sections 27,28 and 30 form one statutory scheme.

\subsubsection{Section 55A Family Law Act 1986}

Under section 55A Family Law Act 1986, the court shall make a declaration as to whether or not a person named in the application is or was the parent of another person so named if the requirements of the requirements of section 55A are fulfilled. Obviously, the question is how the applicable law to the construction of the term 'parent' shall be determined. To date, no cases have been reported where the court was forced to answer this question. If the commissioning parents in $\operatorname{Re} X \mathcal{E} Y$ (Foreign Surrogacy) would have applied under section Family Law Act 1986 instead of section 30 Human Fertilisation and Embryology Act 1990 the court would be forced to formulate such a rule.

One case that came close to raising this question is $U v W .{ }^{794}$ In $U v W$ the question was whether the man of an unmarried couple was the legal father of a child who was conceived in a fertility clinic in Rome. 795 An anonymous donor provided the sperm for the treatment. After the treatment but before the birth of the children, the relationship broke down. The man refused to financially maintain the children who were born to the woman as a result of the fertility treatment notwithstanding the fact that he agreed in Rome to acknowledge his paternity of any child born to the applicant as a result of the treatment. Therefore, the woman applied under section 27 of the Child Support Act 1991 in conjunction with section 55A Family Law Act 1986 for the establishment of the legal paternity of her ex-partner.

\footnotetext{
794 [1998] Fam 29.
}

795 [1998] Fam 29. 
Notwithstanding the fertility treatment in Rome, this case did not give rise to a choice of law problem, not even from a continental perspective. The man did not establish his legal paternity in accordance with Italian law; at least the decision does not mention that. The man only promised to acknowledge his paternity as soon as the child was born. In essence, the question was whether the legal paternity of the man was governed by English common law or by the Human Fertilisation and Embryology Act. With regard to the legal paternity of the unmarried partner of the mother, section 28 (3) of the Act provides:

If no man is treated, by virtue of subsection (2) above, as the father of the child but

a. the embryo or the sperm and eggs were placed in the woman, or she was artificially inseminated, in the course of treatment services provided for her and a man together by a person to whom a licence applies, and

b. the creation of the embryo carried by her was not brought about with the sperm of that man, then, subject to subsection (5) below, that man shall be treated as the father of the child.

Essential for the legal paternity of the unmarried consenting partner is that the unmarried couple received treatment in a licensed clinic. In $U v W$, the court held that because the fertility clinic in Rome did not have a licence under the Human Fertilisation and Embryology Act 1990, the ex-partner could not be considered the legal father of the child under section 28 (3). Hence, the ex-partner could not be obliged to pay maintenance for the children born to the woman as a result of the fertility treatment.

$U v W$ did not lead to choice of law problems. However, cases like $U v W$ are most likely lead to the development of choice of law rules on parentage. The application of English law when the court has jurisdiction to make a declaration of parentage under section $55 \mathrm{~A}$ contradicts the 'general principle of status' discussed by Lord Justice Scott in his dissenting opinion in Re Luck 'that, when created by the law of one country, it is or ought to be judicially recognised as being the case everywhere, all over the world.'796 In Re Goodman's Trust it has been observed in similar terms that 'the family relationship is at the foundation of all society, and it would appear almost an axiom that the family relation, once duly constituted by the law of any civilised country, should be respected and acknowledged by every other member of the great community of nations.' ${ }^{\prime 79}$ The 'universality of the status of an individual' precludes the systematic application of the English definition of father and mother.

If parentage is a matter of status as is suggested above, the competent jurisdiction to determine the parentage of an individual is the jurisdiction of his domicile, since domicile is considered the natural connecting factor for personal status. 798

However, the problem is more complex. Parentage involves three or more people: the putative father, the mother and the child. The child's parentage is part of the personal status of the child, but the legal paternity is part of the personal status of the father and the legal maternity is part of the personal status of the mother. Even if it has been established that the parentage must be governed by the law of the domicile, the question still remains the domicile of whom?

Another problem is that the domicile of the child depends on the domicile of his parents. A legitimate child acquires the domicile of his father and the illegitimate child acquires the

\footnotetext{
${ }^{796}$ Re Luck's Settlement Trusts, Re Luck Will Trusts, Walker v Luck [1940] Ch. 864, [1940] 3 All ER 307, CA.

797 Re Goodman's Trust (1881) 17 Ch. D. 266, CA.

798 North, Fawcett \& Carruthers 2008, p. 154.
} 
domicile of his mother. ${ }^{799}$ Therefore, the domicile of the child cannot be used to determine the child's parentage, since the child's domicile depends on the legitimacy of the child, which on its turn depends on parentage.

The facts of $\operatorname{Re} X \mathcal{E} Y$ (Foreign Surrogacy) may serve as an example of this problem. According to Ukrainian law, the British couple were the parents of the child, while according to English law the Ukrainian surrogate and her husband were the legal parents. If it is the law of the child's domicile that is applicable to his parentage, the domicile of the child has to be determined. However, the domicile of the child depends on his parentage.

In order to break this vicious circle one could work with an assumption. It is assumed that the British couple are the parents of the child. Under that assumption, the child would be domiciled in England and hence English law would be applicable. According to English law, the British couple are not the parents and hence, they are not the parents of the child under English (private international) law.

However, this approach leads to the unacceptable result that under English law the child does not have parents at all. After all, the second step would be to determine whether the Ukrainian parents are the legal parents according to English private international law. That is not the case, if that question is approached in the same way. Assuming that the Ukrainian surrogate and her husband are the parents of the child, the child is domiciled in Ukraine. According to the law of Ukraine the surrogate and her husband are not the legal parents of the child and therefore they are also not the legal parents under English (private international law).

It is one thing if English law would attribute different parents to the child than Ukrainian law would. Such a difference could perhaps be justified by referring to the variety of national laws on parentage and a diversity of connecting factors. However, a system that leaves a child completely without legal parents is unacceptable, not at the least because neither of the legal systems involved reaches this result.

The application by analogy of the choice of law rules for legitimacy does not offer a solution. It has been shown that the connecting factor for the legitimacy and the legitimation of the child is the domicile of the father. The application of the law of the domicile of the father to the parentage of the child leads to exactly the same problems as the application of the law of the child's domicile, since the question is to determine who the father is.

In order to avoid these problems, Norrie suggests that parentage should be treated as a relationship of three people which is recognised or not as the case may be. In his view, the parentage of a child should be governed by the law 'with which the relationship has the closest and most real connection.' 800

\subsubsection{Section 50 (9), (9A) British Nationality Act 1981}

The third situation where conflicts of parentage may arise is in the context of the acquisition of British nationality. Under certain circumstances a person is a British citizen if he descends from a British citizen. ${ }^{801}$ For that purpose, sections 50 (9) and (9A) British Nationality Act 1981 define the terms mother and father. 802 For the purpose of nationality law, the mother of a child is the woman who gave birth to the child. ${ }^{803}$ Thus a child who is born to a Californian surrogate for a British commissioning mother does not acquire British nationality.

The father (or parent) of the child for the application of the British Nationality Act 1981 is the persons who is treated as the parent under section 28 Human Fertilisation and

\footnotetext{
799 North, Fawcett \& Carruthers 2008, p. 174; Collins 2006a, 6R-090.

800 Norrie 1994, p. 762-764.

801 Sections 1 and 2 British Nationality Act 1981.

802 Cf Netherlands: Article 1, under c and d Rijkswet op het Nederlanderschap.

803 Section 50 (9) British Nationality Act 1981.
} 
Embryology Act 1990 or sections 35, 36, 42 or 43 Human Fertilisation and Embryology Act 2008. If no person is the parent on these grounds the child's father is any person whose paternity is proven in the prescribed way. The prescribed way to prove paternity for the purpose of British nationality is laid down in British Nationality (Proof of Paternity) Regulations 2006.804

According to the British Nationality (Proof of Paternity) Regulations 2006, legal paternity is proven if the man is named as the father of the child in a birth certificate issued within one year of the date of the child's birth. Legal paternity can also be proven by satisfying in other ways the competent authority that the man is the biological father of the child, for example by a court order or a DNA test. In $\operatorname{Re} X \mathcal{E} Y$ (Foreign Surrogacy), the birth certificate was not evidence of the paternity of the British commissioning father because under the Human Fertilisation and Embryology Act 1990, the husband of the surrogate was treated as the child's father.

It follows that in the context of nationality law, the development of choice of law rules on parentage is excluded, since British nationality law provides for its own definitions of father and mother.

\subsubsection{The law applicable to the evidence of parentage}

So far it has been discussed how to determine the applicable law to the legitimacy and the parentage of a child. It has been shown that where English law developed some choice of law rules on legitimacy, choice of law rules on parentage do not yet exist.

If it has been determined that the legal parents of the child are his biological parents, the second question is how biological parentage, especially paternity, must be proven. It has been shown in the first part that national legal systems have different rules and limitations on the possibility to prove biological paternity. There are presumptions of law, limitations on the use of DNA tests, periods of limitation and limitations of the locus standi. The question is whether English private international law allows the application of foreign rules to this kind of question.

The answers to these questions depend on the characterisation of these kind of issues as procedural or substantive. If a substantive issue it is governed by the lex causae, but if it is a procedural issue it is governed by the lex fori. In general, issues such as evidence, standing and periods of limitation are considered procedural, but there are so many exceptions depending on the field of law involved and the formulation of foreign law that it does not make much sense to speculate about these issues in relation to parentage, especially because there are no examples from case law to refer to. 805

One remark can be made though. An important point for the interpretation of English private international law is the formulation of the English statute on the basis of which one raises the issue of parentage. One example is the formulation of section 30 Human Fertilisation and Embryology Act 1990, which eliminates choice of law problems if a parental order is sought. If the court has jurisdiction to make a parental order, the requirements to be fulfilled are mentioned in section 30 and not based on foreign law. Another example could be section 55A Family Law Act 1986. Section 55A (2) determines when an English court has international jurisdiction to make a declaration of parentage. Section 55A (3) provides that the applicant must have sufficient personal interest in the determination of parentage in order to have standing. The wording of the provision does not seem to allow any limitation or extension of the locus standi on the basis of foreign law.

\footnotetext{
804 Statutory Instrument 2006/1496.

805 See for example the observations on the difference between substance and procedure in North, Fawcett \& Carruthers 2008, p. 75-109; Collins 2006a, nr. 7R-001-7-058; Mackay of Clashfern 2003, nr. 11-21.
} 


\subsection{French choice of law rules on parentage}

In France, the conflict rules on parentage are laid down in articles 311-14 until 311-18 Code civil. The rules were introduced at the reform of the law on parentage by the Act of 3 January 1972, which entered into force on 1 August 1972.806 They apply retroactively to children born before its entry into force. ${ }^{807}$ Ordonnance 2005/759 of 4 July 2005 on the reform of the law on parentage deleted the provision in the law applicable to legitimation and it deleted the concepts natural and legitimate parentage.

Under the current system, the starting point to determine the law applicable to the parentage of a child is laid down in article 311-14 Code civil. The article provides that parentage is governed by the national law of the mother or if she is unknown the national law of the child. There are two exceptions to the main rule. According to article 311-15 Code civil, the effects of the child's apparent status are determined in accordance with French law if the child and one or both of his or her parents have their habitual residence in France. The second exception is provided for in article 311-17 Code civil, which states that the acknowledgment of paternity and maternity is valid if it is done in conformity with either the national law of the acknowledger or the national law of the child.

The choice of law rules of the Act of 3 January 1972 were considered a legal revolution. 808 The goal for the reform of the substantive law on parentage as well as the conflict rules was to abolish or at least to reduce the discrimination of illegitimate children. At the level of conflict rules, this was expressed by formulating a conflict rule for parentage that did not distinguish between legitimate and illegitimate children. Therefore, the old distinction between the applicable laws for children born in and out of wedlock was removed. ${ }^{809}$ Besides this symbolic reason also a logical argument was put forward. ${ }^{810}$ In most cases concerning legal affiliation the paternity is uncertain and a legal proceeding often causes a shift from the status of natural child to legitimate child or the other way around: les familles authentiquement légitimes n'ont pas de proces de filiation. 811 It was deemed important that in such a case the same law would govern both natural and legitimate parentage, because the dividing line between the two statuses varies from legal system to legal system. 812

The conflict rules on parentage have been subject to severe criticism. ${ }^{813}$ It has been argued that the rules are equivocal, they lead to illogical results and to a dépeçage of the law applicable to personal status which at the very least increases the complexity of the regulation. ${ }^{814}$ Although the Act of 1972 removed the different connecting factors for legitimate and natural children, it introduced various other differentiations. For example, under the current conflict rules legal paternity and legal maternity are not always subject to the same law just like the different forms to establish legal parenthood out of wedlock and the effects of apparent status. The critique on the fragmentation of the law applicable to

\footnotetext{
806 Act nr. 72-3 of 3 January 1972, article 1 Official Journal 5 January 1972. The provisions on the conflicts of laws in matters concerning parentage were not included with the original proposal for Act nr. 72-3, which concerned the reform of affiliation law in general. The provisions were proposed during at the first parliamentary discussion and accepted without much discussion (Massip, Morin \& Aubert 1976, nr. 204).

807 Article 12 Loi nr. 72-3 of the third of January 1972, Journal Officiel 5 January 1972, p. 145-152.

808 Massip, Morin \& Aubert 1976, nr. 204; Huet 1973, p. 19.

809 Audit 2008, nr. 716; Foyer \& Simon-Depitre 1973, p. 15; Huet 1973, p. 22; Ponsard 1972, p. 768; Foyer 1970, p. 118.

${ }^{810}$ Massip, Morin \& Aubert 1976, nr. 207.

811 Rapport Jouzeau-Marigné au nom de la Commission des lois du Sénat (nr. 16, 1971-1972), p. 30.

812 Critical: Ponsard 1972, p. 769. The same argument has been used for Dutch choice of law rules on parentage, see note 734

813 See e.g. Audit 2008, nr. 717; Mayer \& Heuzé 2007, nr. 605.

${ }^{814}$ Huet 1973, p. 33 Ponsard 1972, p. 781. On the risks of a depeçage of the law applicable to parentage and the effects of parentage Huet 1973, p. 44; Batiffol \& Lagarde 1972, p. 2.
} 
parentage was not only an academic concern. Having examined the case law from the Tribunal de Grande Instance of Paris, Sutton concluded that:

A l'unité relative du mode antérieur de règlement des conflits de lois ils ont substitué une diversité de mécanismes dont chacun pose des problèmes spécifiques d'interprétation et dont, en outre, la concurrence possible est sujette à discussion. 815

\subsubsection{Applicable law to parentage under French PIL}

Article 311-14 Code civil provides that parentage shall be governed by the national law of the mother at the moment of birth of the child. If the mother is unknown, the parentage shall be governed by the national law of the child. The introduction of the national law of the mother as a connecting factor for parentage was a novelty. Before the Act of 1972, parentage out of wedlock was governed by the national law of the child and legitimate parentage was governed by the law applicable to the effects of marriage, which on its turn was determined by the Riviere-cascade consisting of the law of the spouses' common nationality followed by the law of their common habitual residence and the lex fori. 816

It was agreed that parentage should be governed by the law of the nationality. ${ }^{817}$ Even in France today, nationality is considered the natural connecting factor for matters concerning personal status. ${ }^{818}$ The only question for the drafters of the Act of 1972 was whose nationality should be chosen as a connecting factor. It was argued that the conflict rule should be simple and not discriminating. ${ }^{819}$ The choice to connect to the national law of the mother was justified on the ground that she was considered the natural protector of the child. ${ }^{820}$ This symbolic argument was supported by the argument that the nationality of the mother was a stable connecting factor because the mother was deemed to be certain (mater certa semper est). ${ }^{821}$ However, it follows already from article 311-14 Code civil itself that this is not always the case since the article provides for an alternative if the mother is unknown. 822

Another argument that has been put forward to justify the replacement of the old connecting factor for the national law of the mother as the connecting factor was that different connecting factors for legitimate and natural children constitute in fact a circular reasoning. ${ }^{823}$ First, it had to be presumed that the child was legitimate in order to determine whether the mother and the alleged father had a common nationality or a habitual residence and then it had to be checked on the basis of the lex causae whether the child was indeed legitimate. If the child was not legitimate on the basis of the lex causae one had to check on the basis of the national law of the child whether or not the natural parentage could be established.

Batiffol and Lagarde point out that this is not circular reasoning. ${ }^{824}$ After all, the premise in the determination of legitimacy was the biological maternity and the mother's marriage to the alleged father. From these facts, the applicable law was derived and on the basis of the

\footnotetext{
815 Sutton 1984, p. 202.

816 Audit 2008, nr. 714.

817 Foyer 1970, p. 113.

818 Audit 2008, nr. 713; Audit 2008, nr. 603.

819 Foyer \& Simon-Depitre 1973, nr. 3.

820 Rapport Jouzeau-Marigné au nom de la Commission des lois du Sénat (nr. 16, 1971-1972), p. 29.

${ }^{821}$ Massip, Morin \& Aubert 1976, nr. 207; Foyer \& Simon-Depitre 1973, nr. 19; Huet 1973, p. 25; Rapport JouzeauMarigné au nom de la Commission des lois du Sénat (nr. 16, 1971-1972), p. 30; Journal Official, Débats parlementaires, Assemblée nationale, 7 October 1971, p. 4301.

822 Batiffol \& Lagarde 1972, p. 5; Ponsard 1972, p. 773.

${ }^{823}$ Foyer \& Simon-Depitre 1973, nr. 19; Huet 1973, p. 24; Journal Official, Débats parlementaires, Assemblée nationale, 7 October 1971, p. 4301.

${ }^{824}$ Batiffol \& Lagarde 1972, p. 5. See also Ponsard 1972, p. 772
} 
applicable law, the question was answered whether the child had the status of legitimate child.

With regard to the law applicable to natural parentage the rule was that the national law of the child determined whether natural parentage could be established. In some legal systems, the nationality of a person depends on his or her parentage. Therefore, it was argued that also the connecting factor for natural parentage constituted circular reasoning. But the existence of circular reasoning depends on how you interpret the rule. Let us clarify this with an example. In France it has to be determined whether $X$ is the natural father of child C. X has Dutch nationality and Dutch nationality law provides that the child of a Dutch person automatically has Dutch nationality. It would constitute circular reasoning to argue that, given the French conflict rule for natural parentage, the existence of natural paternity of $X$ is presumed, as a result of which it is also presumed that the child has Dutch nationality as a consequence of which it has to be determined on the basis of Dutch law whether indeed $X$ is the natural father of $C$. In this case, the conclusion - the natural paternity of $\mathrm{X}$ - is clearly part of the premise. However, under French law the conflict rule was not interpreted in this way. 825 In applying the conflict rule for natural parentage, the courts connected to the nationality of the child which he or she already possessed at the moment of the action for the determination of natural paternity, for example on the basis of the legal relationship with the mother or on the basis of the birth of a country which provides that its nationality is passed on iure soli.

In addition to the critique on the justifications for the choice of the national law of the mother, the rule also seems difficult to reconcile with the principle of proximity. ${ }^{826}$ The application of the national law of the mother has as a consequence, for example, that in a case for judicial establishment of paternity of a French man, foreign law is applicable even if all the parties live in France if the mother has a foreign nationality. This effect was foreseen by the legislator, but it was expected that the effects would be mitigated by article 311-15 Code civil which provides that the apparent status has the effects according to French law if the child and one of the parents live in France. ${ }^{827}$

Also from the point of view of equal treatment of men and women, article 311-14 Code civil was and is not considered a success. ${ }^{828}$ Only taking into account the national law of the mother in determining the parentage of the child puts the father at a disadvantage at least from a symbolic point of view.

Article 311-14 Code civil connects the child's parentage first to the national law of the mother and if she is unknown the child's parentage will be determined by the national law of the child. The rule begs the question when the mother is deemed to be unknown: does she have to be unknown in law or in fact? 829

In 1996 the Cour de Cassation took the plunge in the case Imhoos. ${ }^{830}$ Imhoos was about the question whether the children and the grandchildren of Emile Imhoos, who was born in France in 1899, had French nationality. The French authorities had provided Mr Imhoos with a certificate declaring that he had French nationality, because it was presumed that he was born to unknown parents in France. Under those circumstances he would have French nationality on the basis of, at that time, article 8 (2) Code civil.

Almost 100 years later in 1994, the procureur de la République applied for annulment of the certificates. It was argued that Mr Emile Imhoos possessed Swiss nationality instead of

\footnotetext{
825 Batiffol \& Lagarde 1972, p. 5; Ponsard 1972, p. 772.

826 Audit 2008, nr. 717; Batiffol \& Lagarde 1972, p. 6.

${ }^{827}$ Rapport Jouzeau-Marigné au nom de la Commission des lois du Sénat (nr. 16, 1971-1972), p. 30.

828 Audit 2008, nr. 717; Mayer \& Heuzé 2007, nr. 607; Foyer 2002, p. 530; Ponsard 1972, p. 774.

${ }^{829}$ Foyer \& Simon-Depitre 1973, nr. 20; Huet 1973, 33; Batiffol \& Lagarde 1972, p. 6.

830 Cass. Civ. 1er, 11 June 1996, Bull.civ. no. 244, D 1997, Jur. P. 33; D 1997, p. 156; RCDIP 1997, p. 291.
} 
French nationality. As a consequence, the children and grandchildren of $\mathrm{Mr}$ Imhoos did not therefore possess French nationality.

The argument of the procureur de la République relied on the fact that although the mother of Mr Imhoos never acknowledged her maternity, her name was mentioned on the birth record of Mr Imhoos. According to Swiss law, this was enough to establish her legal maternity, but according to French law it was not. In order to determine whether Mr Imhoos had French nationality, it had to be decided whether he had a legal mother or not.

The legal maternity had to be determined on the basis of the French conflict rule for parentage, article 311-14 Code civil. The question was whether the establishment of legal maternity had to be determined on the basis of the national law of the mother or on the basis of the national law of Mr Imhoos at the moment of his birth. In fact the mother of Mr Imhoos was known, but not in law. The Cour de Cassation held:

La femme était mentionnée dans l'acte de naissance de l'enfant comme étant la mère, de sorte que celle-ci, étant ainsi identifiée, était connue au sens de l'article 311-14 C. civ., ce qui entraînait l'application de la loi personnelle de la mère de l'enfant au jour de sa naissance.

It would seem that the Cour de Cassation in Imhoos holds a straightforward idea of the concept of motherhood: the mother is the woman who gave birth to the child. How should the decision of the Cour de Cassation be interpreted in case of surrogacy? If the woman who is mentioned in the child's birth certificate is not the birthmother but the genetic mother or perhaps only a commissioning mother, is her nationality still to be used to determine the child's parentage? How to interpret article 311-14 Code civil when for example a child is born to a French woman with the egg cell of a Californian woman? Depending on the arrangements between the two women, the French woman will be the mother according to French law while the Californian woman will be the mother according to Californian law.

It is probable that the term mother in such a case has to be interpreted as birthmother. ${ }^{831}$ After all, surrogacy violates French public policy. ${ }^{832}$ It does not make sense to construct the terms of article 311-14 Code civil in such a way that they violate public policy. If it is unknown who gave birth to the child - which in case of surrogacy is not unlikely - it seems that the national law of the child determines his legal parentage.

How is article 311-14 Code civil applied if the mother has more than one nationality or no nationality at all? If the mother has no nationality at all, the law of her habitual residence applies. ${ }^{833}$ If the mother has more than one nationality and one of them is French, French law applies 834 and if she does not have French nationality, her effective nationality applies. ${ }^{835}$

Finally, it must be noted that article 311-14 Code civil applies to the establishment of legal maternity and legal paternity. Thus, it determines the law applicable to establishment ex lege and judicial establishment of maternity. 836 It also determines whether legal paternity

\footnotetext{
831 Also Lagarde in his note under Cass. Civ. 1er, 17 December 2008, RCDIP 2009, 320, at p. 326.

832 Article 16-7 in conjunction with 16-9 CC.

833 Massip, Morin \& Aubert 1976, nr. 206; Foyer \& Simon-Depitre 1973, nr. 22; Ponsard 1972, p. 774.

834 See for example Cour d'appel de Paris, 28 March 2002, nr. 2001/00558 where the court held that if the mother has both French and Moroccan nationality, French law applies to the judicial establishment of legal paternity.

835 Massip, Morin \& Aubert 1976, nr. 206; Foyer \& Simon-Depitre 1973, nr. 23; Ponsard 1972, p. 774.

836 For example: Cass. Civ. 1er, 20 February 2007, nr. 06-16059 (not published) where the Cour de Cassation quashed the decision of the cour d'appel because it applied French law to the judicial establishment of legal paternity instead of the national law of the mother, the law of Cape Verde.
} 
exists on the basis of some kind of presumption and whether judicial establishment of legal paternity is possible.

The latter function of article 311-14 Code civil - the determination of the law applicable to judicial establishment of paternity - has been widely criticised. 837 It is unclear why an action between the father and the child should be governed by the national law of the mother. Moreover, it was deemed inconsistent to subject the validity of the acknowledgment to a favouring connecting factor, while the possibility to judicially establish legal paternity is just subject to an ordinary multilateral conflict rule. Batiffol and Lagarde labelled it:

... la contradiction flagrante entre la sévérité de la solution pour la recherche de paternité et le laxisme des nouvelles règles sur la reconnaissance, la légitimation et l'action à fins de subsides. 838

\subsubsection{Effects of apparent status under French PIL}

Article 311-15 Code civil provides that if the child and his or her father and mother or one of them have their habitual residence in France, together or separated, the apparent status produces the effects according to French law, even if the other elements of the parentage are governed by foreign law. The rules on apparent status in matters concerning parentage are special mandatory rules (lois de police). 839 The provisions on apparent status protect the family peace, which should not be disturbed by the application of foreign law if the family habitually resides in France. ${ }^{840}$ Foyer justified the rule as follows:

...il [le législateur, ks] a été guidé par l'idée d'offrir aux enfants le bénéfice d'une loi «de justice et de vérité», cette idée se concrétisant par des mesures de caractère très différent, soit par la compétence de la loi française (art. 311-15), soit par des rattachements alternatifs (art. 311-16, 17 et 18), qui conduiront fréquemment à l'application de la loi française. Enfin, le législateur a vraisemblablement voulu transposer au plan international les principes fondamentaux consacrés en droit interne, et spécialement celui de l'égalité des filiations, posé par l'article 334 nouveau du Code civil. 841

In referring to the famous article 3 Code civil, Foyer also noted that the method of single sided conflict rules is not uncommon in French private international law. 842

Batiffol and Lagarde have questioned the soundness of the characterisation of the rules on apparent status as special mandatory rules. They argue that special mandatory rules are rules that regulate the political, economic or social organisation of a country. Rules that regulate the relationship between individuals, like the rules on the effects of apparent status, cannot be characterised as special mandatory rules in their view. ${ }^{843}$

Article 311-15 Code civil is not used very often in practice. ${ }^{844}$ One example where the article was used was in the case of Safir. ${ }^{845}$ Safir was born in France on the second of

\footnotetext{
${ }^{837}$ Huet 1973, p. 35; Batiffol \& Lagarde 1972, p. 16.

838 Batiffol \& Lagarde 1972, p. 17. The same criticism has been expressed with regard to the Dutch conflict rule for judicial establishment of paternity, see note 755 .

839 Journal Official, Débats parlementaires, Assemblée nationale, 7 October 1971, p. 4302.

840 Massip, Morin \& Aubert 1976, nr. 208; Huet 1973, p. 40; Ponsard 1972, p. 778.

${ }^{841}$ Foyer \& Simon-Depitre 1973, nr. 3. The opinion of Foyer in finding out the reasons of the legislator for the conflict rules in force is of particular interest because he chaired the parliamentary commission which proposed the conflict rules of article 311-14 and further (see Journal Official, Débats parlementaires, Assemblée nationale, 7 October 1971, p. 4301).

${ }^{842}$ Foyer \& Simon-Depitre 1973, nr. 38.

843 Batiffol \& Lagarde 1972, p. 9.

844 Foyer 1994, p. 129.

845 Cour d'appel de Lyon (2ième Ch.), 12 December 2000, JDI 2002, 475.
} 
February 1994. His mother has Moroccan nationality and his father has Algerian nationality. Safir's mother acknowledged her maternity on the day of the child's birth and the father acknowledged his paternity four years later on the 25th of April 1998. Apparently, the civil status registrar was not concerned with the fact that according to Algerian law, the establishment of legal paternity out of wedlock was not possible. All proceeded well until the parents disputed the exercise of their parental responsibility. In appeal the question was raised whether the paternity of the father was validly established.

The Court of Appeal of Lyon held first of all that foreign law that did not allow the establishment of legal paternity violated French public policy if the child habitually resides in France from the moment of his birth. Moreover, the court held that since all the persons concerned were habitually resident in France, article 311-15 Code civil provides that French law determines the effects of the child's apparent status. One of the effects, according to the former article 334-8 Code civil is that it establishes legal paternity out of wedlock. 846

Article 311-15 Code civil does not only apply to the effects of the existence of apparent status, but also to the effects of the non-existence of apparent status. ${ }^{847}$ An example can be found in the decision of the Tribunal de grande instance of Paris from the 1st of March 1977. ${ }^{848}$ Nadjeschda and Otto were married, but had been living apart since 1951. Both spouses had Austrian nationality. The marriage between Nadjeschda and Otto was dissolved in 1960 in Paris.

Katherine was born in 1955. Otto is not mentioned as the father on the birth certificates of the child and in 1967 Eugène sr. acknowledged his paternity. In 1975 Nadjeschda and her daughter Katherine applied for annulment of the acknowledgment of paternity of Eugène sr. They argued inter alia that by virtue of article 311-14 Code civil the legal parentage of the children was governed by Austrian law and that according to Austrian law, the children were the legitimate children of Otto.

However, the court held that on the basis of article 311-15 Code civil, the effect of the absence of apparent status of the legitimate children of Otto had to be determined in accordance with French law. The effect is that in the absence of apparent status and a mention of the husband's name on the child's birth record, the legal paternity of the mother's husband was not established automatically. ${ }^{849}$ Hence, Otto was not the legal father of the children and the acknowledgment of paternity by Eugène sr. was valid.

Notwithstanding the fact that article 311-15 Code civil is not often used in practice, the article constitutes an important exception to the rule of article 311-14 Code civil that legal parentage is governed by the national law of the mother. ${ }^{850}$ It has already been shown that on the basis of article 313 Code civil, the mother's husband is not the child's legal father if the child's birth is recorded without mentioning the name of the husband and if the child does not have apparent status with regard to him. Moreover, if the child has apparent status in conformity with his birth record, the period of limitation cannot exceed five years and the locus standi is determined by French law. ${ }^{851}$ In the absence of apparent status in conformity with the child's birth record, the period of limitation to contest legal parenthood cannot exceed 10 years. ${ }^{852}$ Finally, legal parentage exists if the child has apparent status with regard

\footnotetext{
846 Nowadays article 317 Code civil.

${ }^{847}$ Audit 2008, nr. 720; Massip 2006, nr. 76. See also Massip, Morin \& Aubert 1976, nr. 208; Foyer \& Simon-Depitre 1973, nr. 133 and 142.

848 TGI Paris, 1 March 1977, RCDIP 1978, 110; D. 1978, 63. See also TGI Paris, 30 April 1985, RCDIP 1986, 313.

${ }^{849}$ Former art. 313-1 Code civil (now art. 313 Code civil).

850 See also Massip 2006, nr. 76.

851 Art. 333 Code civil.

852 Art. 334 Code civil.
} 
to a certain person and if the existence of apparent status has been recorded or established by a court. 853

\subsubsection{Applicable law to acknowledgment of parenthood under French PIL}

Article 311-17 Code civil provides that the voluntary acknowledgment of paternity or maternity establishes legal parenthood if it is made in conformity with either the national law of the acknowledger or the national law of the child. It is generally accepted that the lex causae must be determined at the moment the acknowledgment of parenthood is made. ${ }^{854}$ This can be explained by the idea that the legal situation is connected to the moment of its coming into existence.

Article 311-17 Code civil favours the validity of the acknowledgment, 855 in the interest of the child. 856 The interest of the child as a justification to favour the validity of the acknowledgment of parenthood begged the question why the establishment of parenthood in general is not favoured. ${ }^{857}$ Article $311-14$ Code civil does not contain any favouring element, meaning that in case of judicial establishment of paternity the possibility to establish parentage is not favoured. Moreover, it can be questioned whether the current formulation of article 311-17 Code civil is the optimal way to serve the interest of the child. The interest of the child heavily depends on the circumstances of the case and it can be difficult to determine which law is the most favourable. 858 For example, the existence of a valid acknowledgment of paternity can make it impossible for the child to establish a legal relationship with his biological father.

The choice between the law of the acknowledger and the law of the child has to be made on the basis of the criterion which law establishes legal parenthood on the basis of the acknowledgment. The law which validates the acknowledgement applies and in a legal proceeding the court has to check ex officio that this law is actually applied. ${ }^{859}$ If the validity of the acknowledgment depends on either the national law of the acknowledger or the national law of the child, it follows that an acknowledgment is only null and void if the national law of both the acknowledger and the child provide that the acknowledgement is null and void. 860

In 1999 the Cour de Cassation also held that the requirements to contest the truth of the acknowledgment of paternity or maternity are determined by the law applicable according to article 311-17 Code civil. ${ }^{861}$ Thus, with regard to the nullity of the acknowledgment as well as the annulment, article 311-17 Code civil contains a cumulative connecting factor. It must be possible to contest the acknowledgment both on the basis of the national law of the acknowledger and the national law of the child. If, for example, the period for annulment is prescribed according to the national law of the acknowledger, but not according to the national law of the child, the legal paternity on the basis of the acknowledgement cannot be contested.

\footnotetext{
853 Art. 317, 330 Code civil.

854 Audit 2008, nr. 731; Foyer \& Simon-Depitre 1973, nr. 81; Ponsard 1972, p. 784; Massip, Morin \& Aubert 1976, nr. 211.

855 Foyer \& Simon-Depitre 1973, nr. 45, 51; Batiffol \& Lagarde 1972, p. 17.

856 Audit 2008, nr. 721; Huet 1973, p. 46 and 48. See also Foyer \& Simon-Depitre 1973, nr. 3; Ponsard 1972, p. 782.

857 See also Ponsard 1972, p. 784.

858 Huet 1973, p. 52.

${ }^{859}$ Foyer \& Simon-Depitre 1973, nr. 58, 68; Ponsard 1972, p. 782. Hesitant: Batiffol \& Lagarde 1972, p. 18. It has also been argued that the applicable law is chosen by the acknowledger at the moment of the acknowledgment, Huet 1973, p. 51.

${ }^{860}$ Cass. Civ. 1er, 6 July 1999, Bull.civ. no. 225, p. 146; D 1999, 483; JCP 2000, 1380. See also Massip, Morin \& Aubert 1976, nr. 211; Batiffol \& Lagarde 1972, p. 19.

861 Cass. Civ. 1er, 6 July 1999, Bull.civ. no. 225, p. 146; D 1999, 483; JCP 2000, 1380.
} 


\subsubsection{Relationship between articles 311-14 and 311-17 Code civil}

Article 311-14 Code civil provides that the national law of the mother or the child applies to the child's legal parentage. Article 311-17 Code civil provides that the acknowledgment of parenthood is governed either by the national law of the acknowledger or the national law of the child. Two questions have been raised concerning the relationship between article 311-14 and 311-17 Code civil.

The first question is whether the validity of the acknowledgment of paternity can also be determined by article 311-14 Code civil or whether it is exclusively governed by article 311-17 Code civil. Mayer and Heuzé argue that there are good reasons to apply the national law of the mother (art. 311-14) also to the validity of the acknowledgment of paternity. ${ }^{862}$ First of all, in their view, the formulation of article 311-17 Code civil does not exclude the application of article 311-14 Code civil to the acknowledgment of paternity. Moreover, taking into account that the judicial establishment of paternity is governed by article 311-14 Code civil, it would be strange if (involuntary) judicial establishment of paternity would be possible according to the national law of the mother, while at the same time voluntary acknowledgment of paternity would not be possible because the national law of the acknowledger or the child does not allow it. At the same time, they admit that the prevailing view is that acknowledgment of paternity is exclusively governed by the law applicable according to $311-17$ Code civil. ${ }^{863}$

The exclusive nature of article 311-17 Code civil is also the prevailing view in case law. In 1976 the Cour d'Appel de Paris held that article 311-14 Code civil applied to the annulment of the acknowledgment of paternity, but that the nullity or the validity of the acknowledgment is exclusively governed by the law applicable according to article 311-17 Code civil.864 The case concerned the child Michel who was born on the 27th of January 1969 to a stateless mother, Annick D. in Lausanne, Switzerland. On the 29th of April 1969, Kostia de D. acknowledged his paternity and Michel was legitimated as a result of the marriage between Annick and Kostia on the 19th of August 1969. The spouses subsequently divorced by decision of the court of Lausanne on the 29th of June 1973. Kostia discovers that he is not the biological father of Michel and he applies for annulment of his acknowledgment. According to the Cour d'appel of Paris, the annulment of the acknowledgment of paternity is governed by the law applicable according to article 311-14 Code civil. In the absence of a national law of the mother (she was stateless), the court applied the law of the mother's domicile, Swiss law. According to Swiss law, the annulment of the acknowledgment of paternity on the basis that the acknowledger was not the biological father of the child was not possible.

The court continues that per article 311-17 Code civil the acknowledgement of paternity is only valid if it is valid according to the national law of the acknowledger (French law) or the national law of the child (Swiss law). Article 311-14 Code civil does not come into play. According to both legal systems, the acknowledgment of paternity is only valid if the intention of the acknowledger at the moment of the acknowledgment of paternity was not defective. In this case however the will of Kostia to acknowledge Michel was formed by the mendacious statements of Annick, that Kostia was the biological father of her child. As a result, the acknowledgment of paternity was not valid, but null and void.

Subsequent case law, including the a decision of the Cour de Cassation in 1999, supports the decision of the Cour d'appel that the validity of the acknowledgment of parenthood is solely governed by article 311-17 Code civil, although it does not distinguish anymore between the annulment of acknowledgment on the one hand and the nullity or the

\footnotetext{
862 Mayer \& Heuzé 2007, nr. 613. See also Audit 2008, nr. 723.

863 Foyer 2002, p. 526.

${ }^{864}$ Cour d'appel de Paris, 11 May 1976, RCDIP 1977, 109; JDI 1977, 656.
} 
validity of the acknowledgement on the other; both issues fall solely within the scope of article 311-17 Code civil. 865

However, in breach of this consistent line of case law, the Cour de Cassation held on the 14th of June 2005 that the national law of the mother (Lebanese law) applied to the action for annulment of the acknowledgment of paternity. 866

The second question that arises regarding the relationship between article 311-14 and 311-17 Code civil is the problem of conflicting results concerning the child's legal parentage. The problem is only discussed by Audit ${ }^{867}$ and no case law has been found that deals with a conflict of legal parentage resulting from the application of articles 311-14 and 311-17 Code civil.

A conflict of parentage in French private international law exists if the husband or exhusband of the mother is the child's legal father on the basis of the national law of the mother (art. 311-14) and if another man validly acknowledges his paternity on the basis either his own national law or the national law of the child (art. 311-17). Different situations have to be distinguished.

First, the national law of the mother provides that her (ex) husband is the legal father of the child, while according to the national law of the acknowledger the child does not have a legal father.

Second, the national law of the mother provides that her (ex) husband is the legal father of the child and according to that law his legal paternity can be set aside by the acknowledgment of paternity of another man.

Third, the national law of the mother provides that her (ex) husband is the legal father of the child; his legal paternity also exists according to the national law of the acknowledger but only according to the national law of the acknowledger the legal paternity of the husband can be set aside by the acknowledgment of paternity.

In essence, the question is how to define the scope of articles 311-14 and 311-17 Code civil. There seems to be no problem if the (ex) husband of the mother is not the child's legal father according to her national law. In that case, the child does not yet have a legal father so acknowledgment is possible. In determining whether the (ex) husband is the legal father of the child, special attention has to be paid to rules like article 313 Code civil. This provision determines the circumstances in which the pater is est-rule does not apply, irrespective of the existence of an acknowledgment of paternity by another man. Therefore, there is good reason to bring such rules within the scope of article 311-14 and not within the scope of article 311-17 Code civil. Hence, if limitations on the pater is est-rule fall within the scope of application of article 311-14 Code civil, an acknowledgment that is governed by French law is invalid if the national law of the mother provides without limitation that the husband of the mother at the moment of conception is the child's legal father, even if the child is born at a moment at which, according to French law (e.g. art. 313 Code civil), the (ex) husband would not be the child's legal father.

In other words, if the legal paternity of the (ex) husband of the mother exists on the basis of the law applicable per article 311-14 Code civil, but if it does not exist on the basis of the law applicable per article 311-17 Code civil, legal paternity cannot be established by means of acknowledgment. Article 311-17 is an exception to article 311-14 Code civil that only applies to the validity of an acknowledgment of parenthood. 868

\footnotetext{
865 Cass. Civ. 1er, 6 July 1999, Bull.civ. no. 225, p. 146; D 1999, 483; JCP 2000, 1380; Cour d'appel de Paris, 13 January 2000, D 2000, 898; Cour d'appel de Lyon, 12 December 2000, JDI 2002, 475; Cour d'appel de Paris, 16 April 1996, D. 1997, 344 ; TGI Paris 13 February 1979, RCDIP 1980, 79.

866 Cass. Civ. 1er, 14 June 2005, Bull civ. no. 243, p. 206.

867 Audit 2008, nr. 725.

868 TGI Paris, 12 July 1982, RCDIP 1983, 461, D. 1983, 200. See also Audit 2008, nr. 725.
} 
The real problem exists in the characterisation of national provisions that provide that under certain circumstances the legal paternity of the husband is set aside by an acknowledgment of paternity. Examples of such rules are § 1599 (2) BGB (Germany) or § 1:2 (2) Föräldrabalk (Sweden). Roughly speaking, these rules provide that the legal paternity of the husband is set aside if another man validly acknowledges his paternity. On the one hand these rules limit the scope of application of the pater is est-rule, but on the other hand they also provide the circumstances under which an acknowledgement of paternity is valid. The application of such provisions of foreign law is not discussed in literature or in case law.

Although French law does not have a provision similar to are § 1599 (2) BGB or § 1:2 (2) Föräldrabalk, there used to be the a contrario interpretation of article 334-9 Code civil. 869 Article 334-9 Code civil provided that an acknowledgment of paternity was null and void if the child's legitimate status was established in his birth record and if the child had an apparent status in conformity with that legitimate status. This provision was interpreted $a$ contrario meaning that if the child did not have the apparent status of legitimate child, the acknowledgment of paternity was possible. ${ }^{870}$ Thus, if the child was begotten or born during the marriage but if the child did not have apparent status with regard to the husband of the mother, the acknowledgment of paternity by another man was allowed.

The application of article 334-9 a contrario was discussed in an international context in a decision of the Tribunal de grande instance of Paris of the 30th of April 1985. ${ }^{871}$ Jeanne, a French national and Nicolaas, a Dutch national, marry each other on the 8th of May 1965. As from 1977, Nicolaas and Jeanne lived separately, while Jeanne lived with Christian, a French national. On the 16th of January 1979 Jeanne gave birth to a son, Tao. His birth record mentions Nicolaas as his legal father because at that moment Jeanne and Nicolaas were still married. The marriage was dissolved on the 19th of September 1979. On the 19th of February 1981, Christian acknowledges his paternity concerning Tao and on the 14th of March 1981 Jeanne and Christian marry each other.

On the 25th of July 1985, Jeanne and Christian initiated proceedings against Nicolaas to contest his legal paternity. Jeanne and Christian invoked inter alia article 334-19 Code civil $a$ contrario, arguing that the acknowledgment of paternity of Christian was valid because per article 311-17 Code civil, French law determines the validity of the acknowledgment of paternity is governed by the national law of the acknowledger, i.e. French law. Without much explanation the court rejected this interpretation stating:

Attendu que la circonstance que l'enfant ait fait l'objet d'une reconnaissance par un Français ne permet pas davantage la substitution de la loi française à la loi réglant la filiation, encore que cette reconnaissance puisse être régie par la loi personnelle de son auteur conformément à l'article 311-17; que ce texte en effet ne définit pas une règle de conflit, mais se limite à poser les conditions de validité de la reconnaissance.

If the court does not allow the application to the acknowledgment of paternity of article 3349 Code civil a contrario via article 311-17 Code civil, it probably also would not allow the application of provisions erasing the legal paternity of the husband in favour of the legal paternity of the acknowledger via article 311-17 Code civil.

Audit mentions yet another situation in which article 311-17 Code civil can lead to conflicting results: two men acknowledge their paternity concerning the same child and according to their national laws both acknowledgments are valid. ${ }^{872}$ This situation

\footnotetext{
869 The provision was deleted by ordonnance 2005/759, which entered into force the 1st of July 2006

870 Hauser \& Huet-Weiler 1993, nr. 672-677.

871 TGI Paris, 30 April 1985, RCDIP 1986, 313.

872 Audit 2008, nr. 725.
} 
presupposes that either the law applicable to the second acknowledgment does not contain a rule like article 320 Code civil, § 1594 (2) BGB (Germany) or article 1:204 (1) under f BW (Netherlands) which state that an acknowledgment of paternity is invalid if the legal paternity of another man already exists, or that the first acknowledgment of paternity is invalid according to the law applicable to the second acknowledgement of paternity.

Audit argues that such a conflict could be resolved on the basis of biological truth: the legal father is the acknowledger who is the biological father of the child. ${ }^{873}$ The solution seems to be inspired by former article 311-12 Code civil that provided that conflicts of legal parentage in a purely national situation had to be solved on the basis of biological truth. However, as a result of Ordonnance 2005/759 on the reform of the law on parentage, article 311-12 Code civil has been replaced by article 320 Code civil that provides that legal parentage that has been validly established obstructs the establishment of legal parentage that contradicts the first until the first parentage has been contested in legal proceedings. 874 From that perspective, a conflict of acknowledgments of paternity following from article 311-17 Code civil has to be solved on the basis of chronology: the acknowledgment of paternity that has been done first takes precedence over the second acknowledgment.

\subsection{German choice of law rules on parentage}

The German choice of law rules on parentage are laid down in articles 19, 20 and 23 of the Einführungsgesetz zum Bürgerlichen Gesetzbuche (EGBGB) (Introductory Act to the Civil Code). The current choice of law rules on parentage were introduced by the Introductory Act by the Gesetz zur Reform des Kindschaftsrechts of the 16th of December 1997 (Child Law Reform Act 1997). The provisions entered into force on the first of July 1998.

The principle aim of the Kindschaftsrechtreformgesetz was to abolish the difference in treatment between children born in and out of wedlock both in the German civil code and in German private international law. .875 Before the entry into force of the Act of 1997, articles 19 and 20 already contained provisions on choice of law in matters concerning legitimacy and illegitimacy which were introduced by the Gesetz zur Neuregelung des Internationalen Privatrechts of the 25th of July 1986. The Act of 1997 unified the choice of law rules for legitimate and illegitimate legal parentage and it promoted the habitual residence of the child as the primary connecting factor.

The current choice of law rules do not have retroactive effect and only apply to children born on or after the first of July 1998.876 The moment of the establishment or annulment of legal parentage is not relevant. 877

The structure of the choice of law regulation is relatively simple. Article 19 (1) EGBGB determines the law applicable to the establishment of legal parenthood. The question whether someone has to consent to the acknowledgment of paternity is determined by the law applicable according to article 23 EGBGB. The law applicable to contest legal parenthood is determined by article 20 EGBGB.

\subsubsection{Applicable law to the establishment of parentage under German PIL}

Article 19 (1) EGBGB provides for a set of three connecting factors to determine the child's legal parentage: the child's parentage can be determined by the law of the habitual residence of the child, the law of the nationality of the parents or the law which applies to the general

\footnotetext{
873 Audit 2008, nr. 725.

${ }^{874}$ On the replacement of article 311-12 by article 320 see Massip 2006, nr. 33.

875 BT Drucks. 13/4899, p. 51, 137.

876 Staudinger/Henrich 2008, Art. 19 EGBGB, nr. 5

877 MünchKomm/Klinkhardt 2006, Art. 19 EGBGB, nr. 52.
} 
effects of marriage. The idea is that the establishment or the existence of legal parentage should be favoured. 878

The choice for the habitual residence of the child as the first connecting factor was mainly inspired by the principle of proximity. The child is most closely connected to the law of his direct environment, which is the law of his habitual residence. ${ }^{879}$ Moreover, by connecting legal parentage to the habitual residence of the child, the legislator created a parallel between the law applicable to the establishment of parentage and the law applicable to certain effects of legal parentage such as child protection and maintenance obligations. 880 Furthermore, habitual residence as a connecting factor for legal parentage often allows for the application of the lex fori by the civil status registrar at the moment of the recording of the birth. That is obviously easier than applying foreign law. ${ }^{881}$ The application of the lex fori is also stimulated by the fact that the connection to the child's habitual residence is not fixed in time but that it is wandelbar: in principle the law applicable to the child's legal parentage changes, if the child changes his or her habitual residence. ${ }^{882}$

In order to favour the establishment of parentage article 19 EGBGB provides that legal paternity can also be based on the national law of the alleged father and legal maternity can also be based on the national law of the alleged mother. The same applies to judicial establishment of paternity or maternity. 883

With regard to the establishment of legal maternity, the national law of the woman who gave birth to the child determines whether her maternity exists by dint of birth or whether she has to acknowledge her maternity in order to establish her legal maternity.

If the parent concerned has more than one nationality, Article 5 (1) EGBGB provides that the nationality with which the person is most closely connected shall apply. However, if one of the nationalities is German, that one shall be decisive. If the parent concerned does not have a nationality or if his or her nationality cannot be determined, the reference to the parent's national law shall be understood as reference to the law of his or her habitual residence. ${ }^{884}$ Just as the connection to the habitual residence of the child, the connection to the national law of the parents is variable and not fixed in time. 885

The final possibility to establish the child's legal parentage is on the basis of the law applicable to the general effects of the mother's marriage. It is generally assumed that the law that applies to the effects of marriage only determines whether the mother and her husband are the child's legal parents. ${ }^{886}$ On the basis of the law applicable to the effects of marriage, it is not possible to determine whether another man can validly acknowledge his paternity.

It has been disputed that legal maternity can be established on the basis of the lex causae appointed by this third connecting factor. Backmann argues that legal maternity cannot be determined on the basis of the law applicable to the effects of the mother's marriage. He argues that legal maternity could only be determined on the basis of this law if it depended on the existence of marriage and he states that no legal system exists that establishes legal maternity on the basis of the mother's marriage with her husband. ${ }^{887}$ However, it must be

\footnotetext{
878 Staudinger/Henrich 2008, Article 19 EGBGB, nr. 24; Andrae 2006, § 5, nr. 16; MünchKomm/Klinkhardt 2006, art. 19 EGBGB, nr. 14; Hepting \& Gaaz 2006b, IV-227; Looschelders 1999, p. 421.

879 Schäkel 2004, p. 39.

880 BT Drucks. 13/4899, p. 137.

881 BT Drucks. 13/4899, p. 137.

${ }^{882}$ Staudinger/Henrich 2008, Art. 19 EGBGB, nr. 14; Andrae 2006, § 5, nr. 12; MünchKomm/Klinkhardt 2006, art. 19

EGBGB, nr. 18; Hepting \& Gaaz 2006b, IV-204; Kropholler 2006, p. 407.

883 Hepting \& Gaaz 2006b, IV-415.

${ }^{884}$ Article 5 (2) EGBGB. See also Staudinger/Henrich 2008, Art. 19 EGBGB, nr. 18.

885 Staudinger/Henrich 2008, Art. 19 EGBGB, nr. 15; Andrae 2006, §5, nr. 14.

886 Hepting \& Gaaz 2006b, nr. IV-186, MünchKomm/Klinkhardt 2006, Art. 19, nr. 12.

887 Backmann 2002, p. 100.
} 
remembered that until recently French law provided that the mother's name on the child's birth record only established her legal maternity if she was married. If the mother was not married, her legal maternity was not established solely by the statement of her name on the child's birth record. ${ }^{888}$ It cannot be excluded that there are still legal systems that apply this rule.

A woman's legal maternity can be determined on the basis of the habitual residence of the child, her national law or the law that applies to the effects of her marriage. If it has been established that the legal mother of the child is married, the legal paternity of her husband can be established on the basis of the same legal systems. In other words, from the perspective of the third connecting factor the question whether $\mathrm{Mr} X$ is the child's legal father depends on a) whether $\mathrm{Mr} \mathrm{X}$ is married and b) whether his wife is the child's legal mother according to article 19 (1) EGBGB. The term mother refers to the mother who claims to be the mother of the child. Thus in case of surrogacy, this can be the surrogate mother or the commissioning mother. ${ }^{889}$ The question whether the mother is validly married has to be answered in accordance with the German conflict rule for the validity of a marriage. 890

The law applicable to the general effects of marriage is determined by article 14 EGBGB. It provides that first, the law of the common nationality of the spouses or the last common nationality during the marriage if one of the spouses still possesses that nationality applies. If there is no common nationality, the law of the common habitual residence applies or the law of the last common habitual residence during the marriage, if one of the spouses still resides there. If there is not even a (last) common habitual residence, the law with which the spouses are most closely connected applies. Unlike the connection to the habitual residence of the child or the nationality of the parents, the connection to the general effects of marriage is fixed in time. Article 19 (1) EGBGB states that the applicable law has to be determined at the moment of the child's birth. If the marriage has been dissolved before as a result of the death of the husband, the moment of his death is decisive.

It will be rare that the third connecting factor provides for a third system of law to be applicable to the establishment of parentage. ${ }^{891}$ After all, only if the parents during their marriage never had a common nationality and if they never had a common habitual residence in the same country as the child, can it be possible that a third system of law is applicable.

Two issues are extensively debated in the German legal literature with regard to the construction of article 19 EGBGB. The first is the existence of a hierarchy among the connecting factors and how to solve a conflict of parentage which might result from the application of this article. The second is the problem of conflit mobile which results from the fact that the connection to the habitual residence of the child and the nationality of the parents is not fixed in time.

\subsubsection{The hierarchy among the connecting factors and conflicting results in German PIL}

A minority of legal scholars argue that there is a hierarchy among the connecting factors of article 19 (1) EGBGB, meaning that one should first check whether parentage exists on the basis of the law of the habitual residence of the child. ${ }^{892}$ Only if legal parentage does not

\footnotetext{
888 Former articles 319, 334-8 and 337 French Code civil.

889 Henrich 2005a, p. 1148.

890 Staudinger/Henrich 2008, Art. 19 EGBGB, nr. 19; MünchKomm/Klinkhardt 2006, Art. 19 EGBGB, nr. 35; Kropholler 2006, p. 408.

891 Also Hepting \& Gaaz 2006b, IV-184.

892 Andrae 2006, § 5, nr. 27; Backmann 2002, p. 106.
} 
exist according to that law, the nationality of the alleged parents or the law applicable to the effects of marriage come into play.

This interpretation of article 19 EGBGB is based on the wording of article 19 EGBGB and the wish of the legislator to establish a parallel between the law applicable to legal parentage and other fields of law. Also, the fact that a subsidiary relationship between the connecting factors will reduce the amount of conflicting results has been advanced in support of this interpretation.

However, the prevailing view is that there is no hierarchy between the connecting factors of article 19 (1) EGBGB. ${ }^{893}$ Hence, the connecting factor on the basis of which legal parentage can be established in the easiest and fastest way must be chosen. This approach means that if one of the legal systems involved establishes legal parenthood by operation of the law, that legal system is applicable. Only if there is no legal system which establishes legal parenthood automatically, the legal system which allows for the establishment of legal parenthood by means of acknowledgment or judicial decision applies.

The choice for an alternative relationship between the different connecting factors is based on the principle which underlies the provision of article 19 (1) EGBGB, namely that the establishment of legal parentage should be favoured. It has also been argued that in most cases an alternative relationship between the different connecting factors makes it easier to apply article 19 (1) EGBGB. ${ }^{894}$ After all, if the registrar or the judge knows that legal paternity exists on the basis of the national law of the alleged father because he is familiar with that system of law, he does not need to check whether it perhaps also exists on the basis of the law of the child's habitual residence. ${ }^{895}$

Depending on one's view on the hierarchy between the connecting factors of article 19 (1) EGBGB, it is more or less likely that its application leads to conflicting results.

In case of a subsidiary relationship, conflicting results are only possible if legal parenthood is not established according to the law of the child's habitual residence. In that case, one has to apply the law of the alleged parent's nationality. Although, conflicting results under this approach will be rare, it is possible that there are two or more alleged parents who both have different nationalities. If the alleged fathers or mothers are the legal parents of the child according to their own national laws, one has a conflicting result. 896

In case of an alternative relationship between the connecting factors, conflicting results are more likely. There are two kinds of conflicts.

The first kind of conflict is the case where there is a conflict about the ground for legal parenthood. This kind of conflict can be illustrated with an international surrogacy agreement. A German couple goes to California to arrange for a surrogacy agreement with a local surrogate mother. The legal maternity of the German commissioning mother will be determined either on the basis of the law of the child's habitual residence or on her national law. In this case, both connecting factors point to German law. Hence, the surrogate and not the commissioning mother is the legal mother of the child. ${ }^{897}$ However, if the commissioning mother is an American woman from California living in Germany, the situation is different. In that case, the surrogate mother is still the legal mother of the child by virtue of the law of the child's habitual residence (German law), but the commissioning mother is the legal mother on the basis of her national law. 898

\footnotetext{
${ }^{893}$ Frank 2009, p. 65; Helms 2009, p. 293; Staudinger/Henrich 2008, Article 19 EGBGB, nr. 22; Kropholler 2006, p. 409; Hepting \& Gaaz 2006b, IV-235; MünchKomm/Klinkhardt 2006, Article 19 EGBGB, nr. 14; Sturm 2003, p. 355.

894 Hepting \& Gaaz 2006b, IV-247.

895 Different under Dutch law, see note 744.

896 Backmann 2002, p. 107.

897 § 1591 German Civil Code.

898 See also Henrich 2005a, p. 1147.
} 
The prevailing view is that the conflict should be resolved by considering the birthmother to be the child's legal mother. The reason for this is that $\S 1591$ BGB provides that the birthmother is the child's legal mother. This provision of German substantive law is meant inter alia to discourage surrogacy. ${ }^{899}$ This policy of the German legislator should be decisive in solving the conflict of parentage. 900

Henrich agrees that in case of surrogacy the term mother has to be construed as the woman who claims to the mother. ${ }^{901}$ If the application of article 19 EGBGB leads to a conflict of parentage, the choice between the commissioning mother and the birthmother has to be made on the basis of the interest of the child. The question is however, whether the interest of the child has to be constructed in the abstract or with a view to the circumstances of the case. If the interest of the child has to be determined in the abstract, the establishment of the legal maternity of the birthmother takes precedence over the legal maternity of the commissioning mother: on the basis of the interest of the child, the German legislator provided in $\S 1591$ BGB that the birthmother should be the child's legal mother. If the interest of the child has to be determined with a view to the facts and circumstances of the case at hand, it might be that the child is better off with the commissioning mother. ${ }^{902}$

If the result of the application of article 19 EGBGB has been determined, the second step is to determine whether the result violates German public policy, since the German legislator stated that $\S 1591$ BGB is meant to discourage surrogacy. Relevant factors according to Henrich are the extent to what the German legal order is involved in the case (Inlandsbeziehung), how much the surrogate mother has been paid and whether the commissioning parents circumvented the application of German law by going abroad..$^{903}$

The second kind of conflict exists because legal systems have different methods to establish legal parenthood. In this case, the grounds of both legal systems involved can be the same, for example the establishment of the legal paternity of the biological father, but the way to establish his paternity is different. This kind of conflicts typically arises with legal paternity.

It is possible that legal paternity exists on the basis of the national law of the alleged father, but not on the basis of the law of the habitual residence of the child. It is also possible that two different systems of law appoint two different men as the legal father of the child. The conflicts between legal systems which have the same ground for legal parentage are solved on the basis of the best interest of the child.

According to the prevailing view this means that if legal paternity exists as a result of one connecting factor, this connecting factor should be applied, even if it is unlikely that the man is the biological father of the child. It is deemed to be better for the child to have at least a legal father who is probably not his or her real father than to have no legal father at all.904

The application of article 19 (1) EGBGB is problematic if a man acknowledges his paternity after the birth of the child, while the legal paternity of the ex-husband of the mother has been established by operation of the law. In this case four possible solutions are proposed and all four can be found in case law.

The first reasoning is that the acknowledgment of paternity does not establish legal paternity. First, the legal paternity of the ex-husband has to be annulled and then another

\footnotetext{
899 BT Drucks. 13/499, p. 82.

${ }^{900}$ Hepting \& Gaaz 2006b, IV-282. See also MünchKomm/Klinkhardt 2006, Article 19 EGBGB, nr. 16; Wedemann 2006, p.141; Looschelders 1999, p. 423; Otte 1999, p. 199.

901 Henrich 2005a, p. 1148.

902 Henrich 2005a, p. 1148-1149.

903 Henrich 2005a, p. 1150-1152.

${ }_{904}$ Helms 2009, p. 294; Frank 2009, p. 67; Hepting \& Gaaz 2006b, IV-435; Kropholler 2006, p. 410; Sturm 2003, p. 355; Oprach 2001, p. 326; Dörner 2000, p. 122.
} 
man can validly acknowledge paternity. In this case, the choice between the connecting factors is solved on the basis of the Prioritätsprinzip.

The Bayerische Oberlandesgericht reached this conclusion in $2002 .{ }^{905}$ In this case the marriage of the Turkish woman with her Turkish husband was dissolved on the 15th of June 1998. The child was born to a Turkish woman in September 1998. On the 19th of November 1998 another Turkish national acknowledged his paternity with regard to the child with the consent of the mother. The question was whether the acknowledgment of paternity established the legal paternity of the Turkish national.

The Bayerische Oberlandesgericht held that the choice between the different connecting factors had to be made on the basis of the interest of the child. In this case, the civil status registrar at the moment of birth had the choice between Turkish law as the national law of the ex-husband and German law as the law of the habitual residence of the child. According to German law the child would not have a legal father at the moment of birth (the second man only acknowledged paternity two months after the birth), while according to Turkish law the ex-husband would be the child's legal father. In such a case, preference had to be given to the legal system that immediately establishes legal paternity. As a result, the acknowledgment of paternity by the second man did not establish his legal paternity, as the legal paternity of the ex-husband had to be contested first. 906

The Bayerische Oberlandesgericht held obiter that its decision would have been different if the child would have had two different fathers at the moment of birth. This is possible, for example, if the man acknowledged his paternity before, as opposed to after, the child's birth. In that case, both the legal paternity of the ex-husband and the legal paternity of the acknowledger exist at the moment of birth. In such a case, the court would have decided the issue in favour of the acknowledger because it is more likely that he is the child's biological father. 907

The Oberlandesgericht Celle in a decision also reached this conclusion on the 29th of May 2006. ${ }^{908}$ A child was born in Germany to a Vietnamese woman in February 2004. In November 2003, i.e. before the child's birth, the woman divorced her Vietnamese husband and a German national acknowledged his paternity of the child. The woman consented to the acknowledgment of paternity the same day.

On the basis of the law of the child's habitual residence, the German national was the child's legal father: according to German law the ex-husband is not the legal father of a child who is born after the dissolution of the marriage and the acknowledgment of paternity was valid.

On the basis of the national law of the ex-husband, Vietnamese law applied to his legal paternity. According to Vietnamese law, the husband of the mother at the moment of conception is the child's legal father. According to the court, the choice between the legal paternity of the German and the Vietnamese men had to be determined on the basis of the interest of the child. Since both legal systems established the legal paternity of the men at the moment of birth, that could not be a decisive factor. Instead, the choice had to be based on presumed biological reality. As a general rule, the court held that it had to be presumed that

\footnotetext{
905 BayObLG, 11 January 2002 - 1Z BR 51/01, StAZ 2002, 143. See also OLG Hamm, 7 April 2008, FamRZ 2009, 126; LG Leipzig, 31 July 201 - 01 T 4670/01, StAZ 2002, 146; AG München, 7 May 2001 - 721 UR III 397/00, StAZ 2002, 147; OLG Schleswig, 19 August 2002 - 2 W 6/02, StAZ 2003, 170; OLG Frankfurt am Main, 31 August 2001 - 4 WF 57/01, StAZ 2003, 239. See also Hepting 2002.

906 Frank 2009, p. 67; MünchKomm/Klinkhardt 2006, Article 19 EGBGB, nr. 15; Sturm 2003, p. 358; Sturm 2001, p. 455; Looschelders 1999, p. 421.

${ }_{907}$ Helms 2009, p. 295; Staudinger/Henrich 2008, Artikel 19 EGBGB, nr. 40; MünchKomm/Klinkhardt 2006, Artikel 19 EGBGB, nr. 15; Hepting \& Gaaz 2006b, IV-437; Frank argues that in such a case still the ex-husband should be mentioned as the legal father (Frank 2009, p. 68).

908 OLG Celle, 29 May 2006 - 18 W 2/06, StAZ 2007, 82.
} 
it is more likely that the acknowledger is the child's biological father instead of the exhusband.

In this case however, the presumption did not apply: the acknowledger had admitted that he was paid to acknowledge his paternity so that the children could have the right to reside in Germany and he was convicted for offences against the German Aliens Act. Under these circumstances, the presumption that it is more likely that the acknowledger is the child's legal father as opposed to the ex-husband did not apply. Consequently, the Vietnamese man had to be considered the child's legal father.

A variation on the first reasoning is that the legal paternity of the ex-husband can be annulled by the acknowledgment of paternity of another man, if according to the law that applies to the legal paternity of the ex-husband the acknowledgment of paternity has this result. 909

The third reasoning is that the acknowledgment of paternity by a second man establishes legal paternity if two conditions are fulfilled. Firstly, one of the connecting factors of article 19 EGBGB appoints a legal system according to which the ex-husband of the mother is not the legal father of the child. Secondly, that legal system provides that the acknowledgment of paternity by the second man establishes his legal paternity. In this case, the choice between the connecting factors is not based on the Prioritätsprinzip but on the Günstigkeitsprinzip: the connecting factor that appoints a legal system according to which the legal paternity of the biological father is established has to be applied. ${ }^{910}$

This reasoning was followed by the Amtsgericht Hannover in its decision of the 13th of May 2002.911 The divorce between the Cape Verdean mother and her Nigerian husband became final on the 6th of July 2001. A child was born on the 12th of July 2001. A Dutch national wanted to acknowledge his paternity with the consent of the mother. According to Nigerian law, the husband of the mother was the child's legal father. According to Dutch law (national law of the acknowledger) and German law (law of the habitual residence of the child) the ex-husband was not the legal father of the child and the Dutch man could acknowledge his paternity.

The court held that in this case, the argument in favour of the Prioritätsprinzip did not apply: it was not necessary to apply Nigerian law in order to secure the legal parentage of the child, because the Dutch man testified in court that he wanted to acknowledge his paternity concerning the child. In other words, the child would not be fatherless. In such a case, the court held that article 19 EGBGB had to be interpreted in such a way that it would lead to the establishment of the legal paternity of the man who was most likely the biological father of the child. According to the court, this case had to be distinguished from the case where there is no man who wants to acknowledge his paternity. In that case, it is more favourable for the child to be legally affiliated with the mother's ex-husband.

According to the fourth reasoning, the acknowledgment of paternity establishes legal paternity if the law that is applied to the acknowledgment provides that the effect of the acknowledgment is that the legal paternity of the (ex) husband shall be annulled. If German law applies to the acknowledgment, the effect of the acknowledgment of paternity on the legal paternity of the ex-husband of the mother is determined by $\S 1599$ (2) BGB. This paragraph states that the husband of the mother shall not be the legal father of the child if the child is born after an application for divorce has been made and if another man acknowledges his legal paternity within one year after the divorce has become final with the

\footnotetext{
909 MünchKomm/Klinkhardt 2006, Article 19 EGBGB, nr. 17. OLG Hamm, 7 April 2008, FamRZ 2009, 126.

910 Staudinger/Henrich 2008, Artikel 19 EGBGB, nr. 40; Henrich 1998a, p. 2.

911 AG Hannover, 13 May 2002 - 608 F 4451/01, IPRax 2005, 356. Also OLG Frankfurt, 31 August 2001 - 4 WF 57/01, FamRZ 2002, 688; StAZ 2003, 239.
} 
consent of the mother and her ex-husband. 912 § 1599 (2) BGB has also been applied if the child has been born after the divorce has become final (instead of between the application for divorce and the decision) and if the ex-husband is still the child's legal father on the basis of foreign law. 913

\subsubsection{Conflit mobile under article 19 EGBGB}

Article 19 EGBGB does not provide the moment in time to determine the habitual residence or the nationality of the persons involved. The determination of the law applicable to the general effects of marriage for the determination of parentage is only fixed at the moment of the birth of the child or at the moment of the dissolution of the marriage by the death of the husband if that happens prior to the birth of the child.

To the extent that the applicable law to the child's legal parentage depends on the habitual residence of the child or the nationalities of the parents, the starting point is that the applicable law to parentage changes if the habitual residence of the child or the nationalities of the parents change: the conflit mobile in matters concerning parentage is accepted.914

The acceptance of the conflit mobile guarantees, that the law applicable to legal parentage corresponds with the law applicable to maintenance and that the legal parentage of the child shall be governed by a legal system with which the parties have a genuine connection. ${ }^{915}$ Moreover, it has been argued that a positive side effect of the acceptance of conflit mobile is that the judge or civil status registrar shall be able to apply the lex fori more often because in most cases where a German judge or registrar is seized, the child will have his or her habitual residence in Germany. 916

The disadvantage of the acceptance of conflit mobile is that it destabilises the legal status of the child: at least theoretically a child could lose or gain a parent by changing his or her habitual residence. ${ }^{917}$ For example, under French law the ex-husband of the mother can be the legal father of the child if the child is born within 300 days after the dissolution of the marriage.918 Under German law, this is not the case. Thus, if at the moment of birth, and before the registration of the birth, the child born to a German couple has his or her habitual residence in France, the ex husband will be the legal father of the child according to German private international. However, if the child later changes his or her habitual residence to Germany, the legal paternity of the ex husband no longer exists because German law is then applicable.

The instability of the child's legal affiliation status which results from the acceptance of the conflit mobile has been the subject of considerable debate in Germany. ${ }^{919}$ The prevailing view is that the effects of the conflit mobile have to be determined in accordance with general principles concerning conflit mobile. ${ }^{920}$ Until the legal parentage of the child has been officially recorded, the conflit mobile is fully accepted. However, as soon as the child's legal parentage has been officially recorded in accordance with foreign law which is applicable according to article 19 EGBGB and if as a result of the conflit mobile German law becomes applicable, the parentage as it is laid down in the birth certificate shall be recognised. This is called an Eingangsstatutenwechsel: German law as opposed to foreign law becomes applicable as a result of the conflit mobile. If, as a result of the conflit mobile foreign law becomes

\footnotetext{
912 Hepting \& Gaaz 2006b, V-234, 354; Hepting 2000, p. 39; Looschelders 1999, p. 422.

913 Hepting \& Gaaz 2006b, V-238.

914 BT Drucks. 13/4899, p. 137.

915 Dörner 2000, p. 124.

916 BT Drucks. 13/4899, p. 137.

917 Hepting \& Gaaz 2006b, IV-204; Dörner 2000, p. 124; Otte 1999, p. 197.

918 Article 312 in conjunction with Article 311 (1) Code civil.

919 For references to the discussion see Muschter 2003.

920 Andrae 2006, § 5, nr. 12; Hepting \& Gaaz 2006b, IV-209; Dörner 2000, p. 125/126.
} 
applicable, foreign law determines whether the vested rights shall be recognised or not. This is an Ausgangsstatutenwechsel or neutraler Statutenwechsel.

An example is found in the decision of the OLG Hamm from 2004.921 A German national acknowledged his paternity concerning a child born to a Dominican woman in the Dominican Republic. According to German law (national law of the man) the acknowledgment was not valid, because the mother did not consent. However, according to the law of the Dominican Republic the acknowledgment is valid, because the consent of the mother is not required. Later, the child moved to Germany, the relationship with the mother ended and the man wanted to contest his acknowledgment. The OLG Hamm held that the conflit mobile in this case (the child's habitual residence changed from the Dominican Republic to Germany) did not have as a consequence that the acknowledgment became invalid.

\subsubsection{Applicable law to the consents to acknowledgment under German PIL}

Article 23 EGBGB provides that the national law of the child governs the consent of the child and any person with whom the child is legally affiliated to a declaration concerning parentage, surname or adoption. A declaration concerning parentage is for example the acknowledgment of paternity or maternity. The national law of the child has to be determined at the moment of the acknowledgment of parenthood; the nationality that the child acquires as a result of the acknowledgment is irrelevant. ${ }^{922}$ If the child does not have a nationality at the moment the acknowledgment is made, the habitual residence of the child has to be applied. ${ }^{923}$ If the child has more than one nationality, the law of his effective nationality is applicable. If one of the nationalities of the child is German, German law always applies. ${ }^{924}$

The reason to subject the consent to the acknowledgment of paternity (or any other declaration mentioned in article 23 EGBGB) to a separate conflict rule is that the right to consent is considered so fundamental that it should be subjected to the law of the nationality of the person involved. On the basis of the interest of the child, the choice has been made to subject all consents to the law of the child's nationality. It would be too cumbersome to require further accumulation of legal systems. ${ }^{925}$

From the legal systems under consideration only the Dutch Wet Conflictenrecht Afstamming also provides for a separate rule to determine the law applicable to the consent to acknowledgment of paternity. 926 Under both legal systems the conflict rules only apply to the consent of the child and his relatives.

Unlike under article 23 EGBGB, article 4 (4) Wet Conflictenrecht Afstamming subjects the requirement of consent of the child to the national law of the child and the consent of the mother to her national law. If these legal systems do not allow the establishment of legal paternity by means of acknowledgment, the laws of the habitual residences of the child and the mother respectively have to be applied.

The difference between Dutch and German law results from different justifications for a separate conflict rule for the law applicable to the consent to acknowledgment of paternity. In Germany the key issue is to protect the interest of the child and to make sure that a fundamental part of the acknowledgement (the right to consent) is subjected to this law.

\footnotetext{
921 OLG Hamm, 18 June 2004, FamRZ 2005, 291.

922 Staudinger/Henrich 2008 Art. 23 EGBGB, nr. 5, 8; MünchKomm/Klinkhardt 2006, Art. 23 EGBGB, nr. 3; Hepting \& Gaaz 2006b, V-247.

${ }_{923}$ Art. 5 (2) EGBGB.

924 Art. 5 (1) EGBGB.

925 BT Drucks. 10/504, p. 72.

926 See $\S 6.2$. Dutch choice of law rules on parentage.
} 
Under Dutch law, the main point was to protect the (Dutch) women against a man who wants to acknowledge his paternity against her will.

The consents that are required according to the law appointed by article 23 EGBGB are additional to the consents that are applicable according to the law which applies to legal parentage per article 19 EGBGB. ${ }^{927}$ For example, if a Dutch man wants to acknowledge his paternity concerning a German child aged seventeen years old, Dutch law is applicable to the acknowledgment on the basis of article 19 EGBGB. According to Dutch law, the acknowledgment of paternity only requires the consent of the child. 928 However, as a result of article 23 EGBGB, the consents which are required for a valid acknowledgment according to German law also have to be obtained and therefore also the mother of the child has to consent to the acknowledgment of paternity. ${ }^{929}$ The law applicable according to article 23 EGBGB also applies to the question whether the consent of a person can be replaced by the consent of someone else, for example, a court.930

The second sentence of article 23 EGBGB provides that instead of the national law of the child, German law shall be applicable if that is required in the interest of the child. The second sentence is meant to be applied in adoption cases especially. ${ }^{931}$ Its application in case of acknowledgement of paternity is not clear and not many cases have been reported where it has been applied. 932

One example is the decision of the Amtsgericht Tübingen from 1997.933 In 1993 a man acknowledged his paternity concerning a child who, at that moment, was 15 years old. On the basis of article 23, first sentence EGBGB the law of Bosnia-Herzegovina applied to the consent of the mother and according to that law a valid acknowledgment of paternity requires the consent of the mother. According to German law at the time - that is before the entry into force of the Gesetz zur Reform des Kindschaftsrechts on the 16th of December 1997 - a valid acknowledgment of paternity required only the consent of the child, represented by the Kreisjugendamt. The mother refused to consent to the man's acknowledgement of paternity but the court, on the basis of article 23, second sentence EGBGB, applied German law and as a result the consent of the Kreisjugendamt was sufficient to validate the man's acknowledgment of paternity.

In this case, the establishment of the man's paternity was in the interest of the child because the child wanted the establishment himself and the name of the child in his passport did not correspond with the name on his birth record as a result of the fact that the man's paternity was not established.

\subsubsection{Applicable law to contest legal parentage under German PIL}

Per article 20 EGBGB, legal parenthood can be contested according to each law on the basis of which it exists according to article 19 EGBGB. Thus if according to the law applicable on the basis of article 19 EGBGB the husband's mother at the moment of birth is the child's legal father, his legal paternity can be contested on the basis of each legal system appointed by article 19 EGBGB according to which the mother's husband is the child's legal father. The legislator did not clearly indicate the objective of article 20 EGBGB, but it seems that the provision aims to bring the legal parentage of the child into conformity with his biological affiliation. It must be born in mind that according to German law in case of artificial

927 BT Drucks. 10/504, p. 72; Staudinger/Henrich 2008, Art. 23 EGBGB, nr. 8; MünchKomm/Klinkhardt 2006, Art. 23 EGBGB, nr. 5, 17; Hepting \& Gaaz 2006b, V-247.

928 Art. 1:204 (1) under c and d Burgerlijk Wetboek.

$929 \S 1595$ (1) BGB.

${ }^{930}$ BT Drucks. 10/504, p. 72.

931 BT Drucks. 10/504, p. 73.

932 Hepting \& Gaaz 2006b, V-252; MünchKomm/Klinkhardt 2006, Art. 23 EGBGB, nr. 33.

933 AG Tübibingen, 4 July 1997 - 2 GR 20/97, StAZ 1998, 182. 
insemination with donor sperm, the child has the right to contest the legal paternity of the consenting partner of the mother on the basis that he is not the biological father of the child. 934

The prevailing view is that there is no hierarchy among the connecting factors for legal parentage. Thus the connecting factor that appoints a legal system according to which it is the easiest to annul legal parentage shall be chosen.935

Article 20 EGBGB does not indicate at which moment the habitual residence or the nationality under article 19 EGBGB have to be determined. The objective of the legislator was that the law that governs the establishment of legal parentage should also govern its annulment. ${ }^{936}$ Therefore, the prevailing view is that the applicable law to the annulment of legal parentage has to be determined at the moment at which the contested legal parentage has been established. 937 Consider for example a decision of the OLG Celle from 2007.938 A German national acknowledged his paternity concerning three children born to his Columbian partner. The man was not the biological father of the children and the acknowledgments took place in Columbia in 2001. The German and the Columbian national marry each other in 2003 in Columbia after which the family moves to Germany. In 2004 the man finds out that the Columbian woman mainly entered into the relationship with him in order to obtain a right to reside in Germany. The man petitioned for divorce and contested his paternity.

The court held that the acknowledgment of paternity in Columbia was valid in Germany: pursuant to article 19 EGBGB, the acknowledgment is valid if it is valid according to the law of the place of the child's habitual residence at the moment of the acknowledgment; therefore Columbian law applied and according to that law the acknowledgment was valid.

With regard to the applicable law to contest his legal paternity, the court considered that according to Colombian law the man was time barred from contesting his acknowledgment. Also, according to German law, the period of limitation to contest legal paternity had expired. Therefore the man's claim was rejected.

Henrich holds the opposite view when he gives the following example: a Ukrainian national who acknowledges his paternity in the Ukraine concerning a child who lives in the Ukraine, can contest his acknowledgment on the basis of German law when the child acquires habitual residence in Germany. 939

Next to the application of the legal systems that are appointed by article 19 EGBGB, the second sentence of article 20 EGBGB provides that the child can in any event base his claim for the annulment of legal parentage on the law of his habitual residence. The additional connecting factor is based on the interest of the child. ${ }^{940}$ The habitual residence of the child for the purpose of the second sentence of article 20 EGBGB has to be determined at the moment of the action for annulment of legal parentage and not at the moment of the establishment of legal parentage. ${ }^{941}$

\footnotetext{
934 § 1600 (1) and (5) BGB.

935 Staudinger/Henrich 2008, Article 20 EGBGB, nr. 16; MünchKomm/Klinkhardt 2006, Article 20 EGBGB, nr. 3; Hepting \& Gaaz 2006b, V-335; Kropholler 2006, p. 410; Backmann 2002, p. 115. Differently: Andrae 2006, § 5, nr. 47. 936 BT Drucks. 13/4899, p. 138.

937 Andrae 2006, § 5, nr. 43; MünchKomm/Klinkhardt 2006, Article 20 EGBGB, nr. 2, note 5; Muschter 2003, p. 102 and 105.

938 OLG Celle, 7 March 2007, NJW-RR 2007, 1456.

939 Staudinger/Henrich 2008, Article 20 EGBGB, nr. 20. See also OLG Hamm, 18 June 2004, FamRZ 2005, 291: according to the court, the habitual residence of the child at the moment the paternity is contested is decisive. Therefore, a German national who acknowledged his paternity in the Dominican Republic, had to contest his paternity on the basis of German law because at the time the man initiated the action, the habitual residence of the child was in Germany.

940 BT Drucks. 13/4899, p. 138

941 Andrae 2006, § 5, nr. 44; Muschter 2003, p. 104.
} 
The law that applies to the annulment of legal paternity also determines inter alia the locus standi. It determines who is allowed to apply for the annulment of legal paternity. However, the right of the German public authority ${ }^{942}$ to apply for the annulment of legal paternity on the basis of $\S 1600$ (1) under 5 BGB is a special mandatory rule that applies irrespective of the applicable law. ${ }^{943}$ The right of the public authority to apply for annulment of legal paternity is meant to combat sham acts, i.e. the acknowledgment of paternity with the sole aim to give the child, the acknowledger or the mother the right to reside in Germany. ${ }^{944}$

\subsection{Swedish choice of law rules on parentage}

The Swedish private international law on parentage is regulated in the Lag 1985:367 om internationella faderskapsfrågor (IFL) (Act on International Paternity Questions). The structure of the Act resembles very much the Dutch Wet Conflictenrecht Afstamming. § 2 until 7 determine the applicable law if the legal parentage has to be established in Sweden; § 7 and 8 regulate the recognition in Sweden of judgments and instruments of civil status establishing parentage.

The IFL entered into force on 1 July 1985 and it applies also to judgments and instruments of civil status drawn up before that date. ${ }^{945}$ The IFL was amended in 2005 to provide for the possibility under Swedish law that under certain circumstances the legal parenthood of the female partner of the mother can be established by acknowledgment or judicial establishment of legal parenthood. ${ }^{946}$

The IFL only applies to the establishment and annulment of legal paternity and to the establishment and annulment of the legal parenthood of the female partner of the child's mother. The law does not specify which law applies to the question who is the legal mother of the child. Bogdan argues that the rules of the IFL should be applied analogously to cases where the legal maternity is at stake. ${ }^{947}$

The starting point of the IFL is that the law of the child's residence (hemvist) applies to the child's legal parentage. This starting point is based on the idea that it is in the child's interest to be subjected to the law of the place where he or she is growing up. Moreover, it was thought that the application of the law of the child's residence to the child's legal parentage facilitates the recognition of Swedish decisions abroad while at the same time it results in rules that are easy to apply in practice because the courts and administrative authorities will often be able to apply their own law. 948

\subsubsection{Applicable law to legal parentage based on marriage under Swedish PIL}

$\S 2$ Lag 1985:367 om internationella faderskapsfrågor states that the man who is or was married to the mother shall be the child's legal father if that follows from the law of the state where the child has his residence (hemvist) at the moment of birth. If no man is considered the child's legal father according to that law, the law of the state of the child's nationality at the moment of birth applies. However, if the child has his residence in Sweden at the moment of birth, only Swedish law is applicable.

\footnotetext{
942 Every state of the German federation determines for itself which public authority is empowered under $\S 1600$ (1) under 5 BGB to apply for annulment of legal paternity (BT Drucks. 16/3291, p. 12; BR Drucks. 624/06, p. 18)

943 BT Drucks. 16/3291, p. 13; BR Drucks. 624/06, p. 19.

944 See $\S 3.5$. Annulment of legal parenthood.

945 Övergångsbestämmelser (transitory provisions) 1 and 3 Lag 1985:367 om internationella faderskapsfrågor.

946 Lag (2005:444) om ändring i lagen (1985:367) om internationella faderskapsfrågor.

947 Bogdan 2002, p. 747. See also Bogdan 2004, p. 211; Walin \& Vängby vol. II, Avd. 1 I:15.

948 Prop. 1984/85:124, p. 12.
} 
The rationale behind $\S 2$ is that the law of the child's residence is the law with which the child is most closely connected. Moreover, the choice for the law of the residence of the child to govern legal paternity in combination with the starting point that the Swedish courts have jurisdiction if the child resides in Sweden has as a consequence that Swedish courts often apply Swedish law. ${ }^{949}$

The reason to consider also the national law of the child, if the law of his residence does not establish paternity, is inspired by the fact that in other legal systems nationality as opposed to residence, is still the leading connecting factor in matters concerning personal status. By adding the possibility to determine marital paternity on the basis of the national law of the child, the legislator wanted to guarantee that a presumption for marital paternity that applies in the country of the child's residence - whether on the basis of national law or by virtue of local private international law - also applies in Sweden. ${ }^{950}$ However, if the law of the child's nationality establishes the legal paternity of another man than the law of the child's residence, the latter law takes precedence over the first. ${ }^{951}$ This can be the case if the mother remarried soon after her divorce. If the child was begotten during the first marriage and born during the second marriage, legal systems differ as to whether the first or the second husband is the child's legal father.

$\S 2$ adds that if the child at the moment of birth acquires residence in Sweden, Swedish law applies and the national law of the child is irrelevant. In practice $§ 2$ means that if the persons involved are born outside Sweden and submit an extract from the child's birth record from the country of the child's residence at the moment of birth the Swedish registration authority does not need to check the contents of the national law of the child. 952 They can just copy the information on the birth record. After all, it is presumed that the foreign registrar either applied the law of the child's residence or the national law of the child.

The concept of residence (hemvist) in Swedish private international law is defined in chapter $7 \S 2$ of the Act on certain international legal relationships relating to marriage and guardianship (1904:26). ${ }^{953}$ The article provides that when a person lives in a certain state he shall be considered to have his residence there if the settlement can be considered permanent taking into account the duration of the stay and other circumstances of the case. ${ }^{954}$ Although the article primarily applies within the framework of this Act, it is considered to express a general definition for the concept of residence in Swedish private international law. 955

The explanatory report states that in order to establish residence, it is not necessary that the person has the intention to stay for ever in the state where lives. It is enough that he or she has the intention to stay in that place for the time being and that he or she does not have definite plans to leave the country. But also a person who knows that he will leave the country at a certain moment in time can establish his residence at the place where he lives. That can be the case if the person plans to stay in the country for a considerable amount of time. ${ }^{956}$

\footnotetext{
949 Prop. 1984/85:124, p. 21.Walin \& Vängby vol. II, Avd. 1 I:6.

950 Prop. 1984/85:124, p. 22.Walin \& Vängby vol. II, Avd. 1 I:7.

951 Prop. 1984/85:124, p. 22.Walin \& Vängby vol. II, Avd. 1 I:7.

952 Prop. 1984/85:124, p. 42. Walin \& Vängby vol. II, Avd. 1 I:19.

953 Lag (1904:26) om vissa internationella rättsförhållanden rörande äktenskap och förmynderskap.

954See also § 19 Lag (1990:272) om internationella frågor rörande makars och sambors förmögenhetsförhållanden (Act (1990:272) on international questions relating to matrimonial property and property of cohabitants).

955 Prop. 1984/85:124, p. 40. Bogdan 2004, p. 148; Walin \& Vängby vol. II, Avd. 1 I:18; Lennart 1986, p. 334.

956 Prop. 1984/85:124, p. 41. Walin \& Vängby vol. II, Avd. 1 I:18.
} 
The residence of the child is usually with the mother or another person that has custody of the child. ${ }^{957}$ If the child is not yet born at the moment the paternity issue arises, the residence or the nationality of the child is replaced by the residence or the nationality of the child's mother. 958

It follows that a child born in Sweden does not necessarily acquire a Swedish residence. Therefore, at least in theory, § 2 Lag 1985:367 om internationella faderskapsfrågor does not guarantee that the Swedish registrar always applies Swedish law. In theory, the registrar would be obliged to determine for each child his residence at the moment of birth. This is not how it works in practice. Skatteverket has explained that a Swedish registrar does not apply foreign law to determine the legal parentage of a child born in Sweden.

$\S 2$ IFL is limited to legal paternity based on marriage. The existence and the validity of a foreign marriage are determined by the Act on certain international legal relationships relating to marriage and guardianship (1904:26). ${ }^{959}$ If, according to the law of the place of the child's residence at the moment of birth a man is the legal father on the basis of stable cohabitation with the mother, a registered partnership and so on, it has been argued to apply $\S 2$ analogously. 960

\subsubsection{Applicable law to acknowledgment of parenthood under Swedish PIL}

The acknowledgment of paternity in Sweden always requires the consent and the cooperation of a Swedish socialnämnd (social welfare committee). Above, it has been explained that the social welfare committee is only allowed and obliged to examine the child's parentage if the child has his residence in Sweden.961 $\$ 3$ (2) IFL provides that the acknowledgment of paternity in such a case shall be governed by Swedish law.

If Swedish law applies to the acknowledgment of paternity, it also answers the question whether the acknowledgment of paternity annuls the legal paternity of another man. ${ }^{962}$ For example, this means that if the mother's (ex) husband is the child's legal father on the basis of the law of the child's residence at the moment of birth (\$2), the child, the mother or someone else can request the social welfare committee to start an investigation into the child's affiliation on the basis of $\S 3$ (1) IFL in conjunction with § 2:9 Föräldrabalk (1949:381) at the moment the child acquires residence in Sweden.

If the social welfare committee finds that not the mother's (ex) husband, but someone else is the biological father of the child, the acknowledgment of paternity by the biological father can annul the legal paternity of the (ex) husband if the requirements of $\S 1: 2(2)$ Parents and Children Code (1949:381) are satisfied. ${ }^{963}$

The rule that the acknowledgment of paternity conducted by the social welfare committee is governed by Swedish law can be problematic if the biological father of the child lives abroad. Therefore, \& 3 (3) of the Act on International Paternity Questions (1985:367) provides that an acknowledgment of paternity which is made abroad is also valid as to the form, if it fulfils the formal requirements of the law of the place where the acknowledgment is made. This means, for example, that if the child's father lives abroad, his

\footnotetext{
957 Bogdan 2004, p. 51; Walin \& Vängby vol. II, Avd. 1 I:19.

${ }^{958} \S 11$ Lag (1985:367) om internationella faderskapsfrågor.

959 Lag (1904:26) om vissa internationella rättsförhållanden rörande äktenskap och förmynderskap. Walin \& Vängby vol. II, Avd. 1 I:17.

960 Prop. 1984/85:124, p. 40. In fact, § 2 IFL has the same problem as the Dutch article 1 WCA. Both articles are confined to legal paternity based on marriage, while in other legal systems legal paternity can be based on other formal or informal relationships.

961 See $§ 5$.1. International jurisdiction of registrars in matters concerning parentage.

962 § 5 (2) Lag (1985:367) om internationella faderskapsfrågor.

963 See also Socialstyrelsen 2005, p. 86.
} 
acknowledgment of paternity does not need to be witnessed by two persons if this requirement cannot be fulfilled in the place where he lives. In such a case it suffices if the acknowledgment fulfils the formal requirements of the place where it is done, for example that the acknowledgment is authenticated by a civil status registrar if it is made in the Netherlands. 964

If the child is not resident in Sweden, the social welfare committee shall not investigate the child's affiliation. 965 The question whether or not an acknowledgment of paternity made abroad establishes legal paternity is not determined by $\S 3$ IFL, but by $\S 8$ IFL.

$\S 6 a$ (1) IFL provides that the legal parenthood of the female partner of the mother of the child shall be established by acknowledgment of parenthood with the cooperation of a Swedish social welfare committee if the social welfare committee is obliged to investigate her legal paternity under § 2:8a or 9 Föräldrabalk (1949:381). Both provisions require that the child is resident in Sweden. The social welfare committee shall apply Swedish law to the establishment of the legal parenthood of the female partner. It must be noted that according to Swedish law, the female partner of the mother is only considered the legal parent of the child if the fertility treatment for the mother and her partner have taken place in a Swedish hospital. 966 If the legal parenthood of the female partner has been established abroad by acknowledgment of paternity, the recognition is governed by $\S 8$ IFL.

\subsubsection{Applicable law to judicial establishment of legal parenthood under Swedish PIL}

Per § 5 Lag 1985:367 om internationella faderskapsfrågor (IFL) the judicial establishment of legal paternity is governed by the law of the place of the child's residence at the moment of the judicial decision at first instance. Hence, if the child's residence changes during the proceeding for the judicial establishment of paternity at first instance, the applicable law changes too. ${ }^{967} \S 11$ of the Act on International Paternity Questions (1985:367) clarifies that if the child died before the case is decided at first instance, the applicable law shall be determined at the moment of the death of the child. It is assumed that $\S 5$ also applies to judicial establishment of legal maternity if legal maternity does not exist ex lege. 968

The conflict rule of $\S 5$ in combination with the rules on international jurisdiction of $\S 4$ has as a consequence that Swedish courts mostly apply Swedish law in case of judicial establishment of legal parenthood. It has been shown above that the main ground for international jurisdiction of Swedish courts in matters concerning parentage is the residence of the child. 969

$\S 5$ does not apply to the judicial establishment of the legal parenthood of the lesbian partner of the mother. Swedish law always applies if the Swedish courts have jurisdiction to hear a case for the establishment of the legal parenthood of the lesbian partner of the child's mother. ${ }^{970}$

The international jurisdiction of Swedish courts to hear a case for the establishment of the legal parenthood of the lesbian partner of the child's mother is determined by $\S 4$ IFL, which has been discussed above. ${ }^{971}$ The exception to $\S 5$ in case of judicial establishment of legal parenthood of the lesbian partner can be explained by the fact that almost no country

\footnotetext{
964 Prop. 1984/85:124, p. 45. Walin \& Vängby vol. II, Avd. 1 I:23.

965 See notes 641 and 642

${ }_{966}$ Ch. 1, § 9 Föräldrabalk in conjunction with ch. 6, § 2 or ch. 7, § 4 Lag (2006:351) om genetisk integritet m.m.

967 Prop. 1984/85:124, 50. Walin \& Vängby vol. II, Avd. 1 I:28.

968 Bogdan 2002, p. 747; Walin \& Vängby vol. II, Avd. 1 I:28.

${ }^{969}$ See $§$ 5.2.5. International jurisdiction of courts under Swedish law.

970 § 6a (3) Lag (1985:367) om internationella faderskapsfrågor (Act on International Paternity Questions (1985:367)).

971 The grounds for international jurisdiction in matters concerning paternity ( $\$ 4$ IFL) equally apply to a case on the legal parenthood of the lesbian partner of the mother (§ 6a (2) IFL).
} 
in the world that makes it possible that two women are the parents of the child on the basis of the law on parentage.

\subsubsection{Applicable law to contest legal parenthood}

For the determination of the applicable law to the annulment of legal paternity the Lag 1985:367 om internationella faderskapsfrågor (IFL) distinguishes between three cases: the annulment of legal paternity based on acknowledgment, the annulment of legal paternity which is based on something else than marriage and the annulment of marital paternity by means of the establishment of the legal paternity of another man.

Per $\S 6$ IFL the annulment of legal paternity which is based on acknowledgment is governed by the law which determines the validity of the acknowledgment according to the Lag 1985:367 om internationella faderskapsfrågor.

If the acknowledgment took place in Sweden with the cooperation of the Swedish socialnämnd (social welfare committee), Swedish law has been applied to the validity of the acknowledgment of paternity and therefore it also governs the question whether the acknowledgment of paternity can be annulled.

If the acknowledgment is made abroad, the applicable law to the validity of the acknowledgment is determined by $\S 8$ IFL. This article provides that the acknowledgment is valid, if it is valid according to the law of the place of the child's residence or the residence of the acknowledger or according to the national law of either the child or the acknowledger. As a consequence, the annulment of paternity based on an acknowledgement which is done abroad is only possible if the annulment is possible according to all the legal systems that govern its validity. 972

$\S 6$ IFL provides for one important exception. If the annulment of legal paternity is sought on the basis that the acknowledger is not the child's biological father, Swedish law can always be applied. The exception is based on the idea that it is a basic principle of Swedish law on parentage that it must be possible to establish the legal paternity of the biological father. ${ }^{973}$ As a consequence, the exception of $\S 6$ IFL is the main rule in Swedish legal practice. Only if the annulment of legal paternity is not possible according to Swedish law, might foreign law come into play.

If the legal paternity is not based on acknowledgment of paternity, the applicable law to its annulment is determined by $\S 5$ (1) IFL. The law of the residence of the child at the moment of the decision in first instance determines whether the legal paternity can be annulled. If the child has died before the court of first instance renders its decision, the child's residence at the moment of death is decisive. ${ }^{974}$

$\S 5$ (2) contains an additional rule concerning the annulment of marital paternity. The question whether the legal paternity of the mother's (ex) husband can be annulled by the establishment of the legal paternity of another man is not governed by $\S 5$ (1), but by the law that applies to the establishment of the legal paternity of the other man. If the legal paternity has been established by a foreign court, the question whether the establishment of the legal paternity annuls the legal paternity of the mother's (ex) husband is determined by the law which has been applied by the foreign court to the judicial establishment of paternity. ${ }^{975}$ Also, the question whether the acknowledgment of paternity annuls the legal paternity of the mother's husband is governed by the law that applies to the validity of the acknowledgment.

\footnotetext{
972 Prop. 1984/85:124, 53. Walin \& Vängby vol. II, Avd. 1 I:9.

973 Prop. 1984/85:124, 26.

974 § 11 Lag (1985:367) om internationella faderskapsfrågor (Act on International Paternity Questions (1985:367)).

975 Prop. 1984/85:124, 8/9. Walin \& Vängby vol. II, Avd. 1 I:8/9.
} 
$\S 5$ and 6 of the Act on International Paternity Questions (1985:367) do not apply to the annulment of the legal parenthood of the lesbian partner of the child's mother. Per § 6a (3) Swedish law always applies in such a case. The jurisdiction of the Swedish courts is determined by $\S 4$.

\subsection{Application of the conflict rule on parentage}

In this chapter, the principal question is how national registrars and courts determine the legal parentage of a child in an international situation, while the legal parentage has not yet been established abroad. The answer to this question is not only given by the choice of law rules on parentage and the selection of the relevant connecting factor, but also by the way in which the conflict rule and foreign law is applied. For the outcome of the case it is relevant to know whether a referral to foreign law includes the choice of law rules of the foreign legal system (renvoi). For the outcome of the case it is also relevant to know to what extent different foreign laws on parentage are accepted (public policy exception). In the light of the conclusions in the first part of this thesis on the difference between English law on the one hand and Dutch, French, German and Swedish law on the other hand, also the application of English law in the Dutch, French, German and Swedish legal systems and vice versa has to be considered.

\subsubsection{Renvoi in choice of law on parentage}

The question of renvoi is whether a reference to foreign law means a reference to the internal law of that legal system or whether it includes a reference to the foreign choice of law rules. If a national system of private international law accepts renvoi, it means that a reference to foreign law includes the choice of law rules of that legal system. There are various degrees in the acceptance of renvoi. Renvoi can be accepted only if the foreign choice of law rule refers to the applicable law of the forum as a result of which the forum law shall be applicable. A more extensive acceptance of renvoi means that the foreign choice of law rule is also taken into account if it refers to the law of the state of a third state.

The question of renvoi is to determine the criterion to decide whether or not and to what extent renvoi should be accepted. Is the problem of renvoi only a matter of interpretation of the choice of law rules of the forum? Did the legislator mean that a reference to the national law of the person should include or exclude the choice of law rules of that legal system? Or is renvoi a strategic device of the courts and the legislator to reach better solutions in private international law in the case at hand?

In Dutch private international law, the general approach is that the renvoi is not accepted. ${ }^{976}$ In Meijers' view the approach to renvoi depends on one's perception of private international law. 977 Those who argue that the choice of law rules are rules from a supra-national level reject renvoi, because in their view there is only one correct conflict rule for each matter. A foreign court that is using a different connecting factor simply misinterpreted international law. 978

Those who consider choice of law rules to be part of national law will accept renvoi if the conflict rule expresses the recognition of the sovereignty of the foreign legislator. Meijers cites Lerebours-Pigeonnière who argues that if choice of law rules were only meant to provide for practical and efficient solutions, questions of personal status would be subject to the law of the domicile of the person. The fact that legislator submits these issues to the

\footnotetext{
976 Strikwerda 2008, nr. 74; Staatscommissie IPR 2002, p. 31-33; Kosters \& Dubbink 1962, p. 287.

977 Meijers 1955. See also Meijers 1938. See also Kosters \& Dubbink 1962, p. 288.

978 Meijers 1955, p. 380.
} 
national law of the person is based on the idea that the sovereignty of the state extents over the personal status of its nationals. ${ }^{979}$ If foreign choice of law rules are an expression of the sovereignty of the state involved, the question of renvoi is whether or not the sovereignty of the foreign state is recognised and it should only be recognised if it wants to be recognised by means of its own choice of law rules. 980

The Dutch view on choice of law rules is that they are based on the idea that the rule should provide an efficient solution in an international case. ${ }^{981}$ Thus, the choice of the national legislator that the legal parentage of a child is governed by the common national law of the parents, should not be undermined by the acceptance of renvoi as a result of which suddenly the law of the habitual residence of the child is applicable.

The rejection of renvoi under Dutch private international has to be judged in combination with the discussion on the limits of the scope of application of the choice of law rules of the forum. Since the objective of private international law is to establish efficient solutions in international cases and decisional harmony, the national choice of law rules are under certain circumstances set aside and replaced by foreign choice of law rules. However, the foreign choice of law rules that are chosen do not depend on the law that is applicable according to Dutch choice of law rules. In private international law on parentage it depends on the place where the birth certificate is drawn up. ${ }^{982}$

Nor is the renvoi accepted in French private international law on parentage,. 983 Some authors against the current conflict rules hoped that the acceptance of renvoi would mitigate the adverse effects of the current rules: On peut d'ailleurs espérer que le réalisme triomphera indirectement par le biais du renvoi. 984

The effect of accepting the renvoi would be that eventually a legal system would be applicable that was accepted as the applicable legal system by the different systems of private international law involved in the international situation. However, the French courts, which in general are favourable towards the acceptance of renvoi, rejected its application in matters concerning parentage. In 1976 the Cour d'Appel of Paris held that

...l'article 311-14 du Code Civil ne laisse pas à la loi personnelle de la mère le soin de déterminer les règles de conflit applicables à la filiation mais contient une désignation directe et impérative de la loi applicable ; que l'application d'une loi différente de celle ainsi désigné aboutirait à violer la règle française de conflit et à la vider en fait de toute portée véritable. 985

The Cour de Cassation came to the same conclusion with regard to article 311-17 Code civil and rejected the renvoi.986 The courts follow the view of Simon-Depitre and Foyer that the renvoi should not be accepted because the national law of the mother was not a generally accepted connecting factor for parentage. The acceptance of renvoi would have as a result that the legal parentage of the child would be governed by a legal system other than the

\footnotetext{
979 Meijers 1955, p. 387.

980 Meijers 1955, p. 384.

981 Meijers 1955, p. 388, 389.

982 See $§ 7.2 .1$. Recognition of legal parentage under Dutch private international law.

983 Boiché 2008.

984 Batiffol \& Lagarde 1972, p. 7. See also Huet 1973, p. 29; Ponsard 1972, p. 776.

985 Court of Appeal Paris, 11 May 1976, RCDIP 1977, 109. For references to more case law see Audit 2008, nr. 728.

986 Cass. Civ. 1er, 6 July 1999, Bull. Civ. I, nr. 225, p. 146, D 1999, 483; Déf. 2000, 109; JCP 2000, 1380.
} 
national law of the mother which would jeopardise the legislator's policy that was pursued with this particular connecting factor. 987

With regard to article 311-17 Code civil it has been argued that the acceptance of renvoi is hard to justify because if the legislator wanted to have more or different connecting factors to determine the validity of an acknowledgment of parenthood, it would have disposed that. 988

The French rejection of renvoi is based on similar considerations as in the Netherlands: with the formulation of a choice of law rule the legislator expresses its view on the legal system that is most suitable to provide for a just solution in the international case.

In German private international law article 4 (1) EGBGB provides that a reference to foreign law includes the foreign choice of law rules. The renvoi is accepted because it would help to attain the international harmony of decisions. 989 Article 4 (1) EGBGB adds that the renvoi shall only be accepted in as far as it does not contradict the aim of the conflict rule.

In relation with Articles 19, 20 and 23 EGBGB, Article 4 (1) EGBGB means that reference to the law of the habitual residence of the child, the law of the nationalities of the parties or the law to the general effects of marriage, includes the conflict rules of these legal systems. However, the renvoi should not contradict the aim of the conflict rule.

It is generally accepted that in case of Articles 19 and 20 EGBGB, the acceptance of renvoi would contradict the aim of the conflict rule if it limits the number of applicable legal systems. ${ }^{990}$ Some discussion in the margin remains. It has been argued that the renvoi should only be accepted if the internal law of the lex causae does not allow for the establishment of legal parentage. ${ }^{91} \mathrm{~A}$ more pragmatic approach is that the acceptance of renvoi is just as alternative as the choice between the connecting factors themselves, as long as the result is the establishment of legal parentage. ${ }^{992}$

In case of Article 23 EGBGB - the law applicable to the consent to acknowledgement - it has been argued that the acceptance of renvoi contradicts the aim of the conflict rule, if it leads to the application of a legal system that does not give the child or his or her legal parent the right to consent to the acknowledgment of parenthood. ${ }^{993}$ Some argue that renvoi under Article 23 EGBGB should not be accepted since the wording of the provision suggests that it refers to the substantive provisions of the foreign law and not its private international law. 994

Under Swedish law, the renvoi is not accepted. A reference to foreign law means a reference to the substantive law of the legal system involved and it does not include the foreign rules on private international law. ${ }^{995}$ The reason for this is that it is deemed to be difficult to interpret and to apply foreign private international law as it is often not codified. This holds true especially for administrative authorities who have to apply the private international law on parentage most of the time. Such authorities are not equipped to extensively examine the private international law of foreign legal systems.

\footnotetext{
987 Foyer \& Simon-Depitre 1973, nr. 24, 25. See also Foyer 1994, p. 138-139. For the reasons behind article 311-14 Code civil see $§$ 6.4.1. Applicable law to parentage under French PIL.

988 Mayer \& Heuzé 2007, nr. 616. See also Foyer in his note under TGI Paris, 23 November 1993, 22 and 29 November 1994, RCDIP 1995, 703, at p. 717.

989 Kropholler 2006, p.165f.

990 OLG Hamm, 7 April 2008, FamRZ 2009, 126; OLG Nürnberg, 25 April 2005, FamRZ 2005, 1697. Staudinger/Henrich 2008, Article 19 EGBGB, nr. 25; Kropholler 2006, p. 410; MünchKomm/Klinkhardt 2006, Article 19 EGBGB, nr. 23.

991 Andrae 2006, § 5, nr. 30.

992 Hepting \& Gaaz 2006b, IV-260.

993 Staudinger/Henrich 2008, Article 23 EGBGB, nr. 6.

994 Hepting \& Gaaz 2006b, V-249.

995 Pålsson 2006, p. 38; Prop. 1984/85:124, 12. Walin \& Vängby vol. II, Avd. 1 I:4
} 
Bogdan explains the rejection of renvoi under Swedish private international law by arguing that under Swedish law a conflict rule expresses the Swedish interpretation of the closest connection between a case and a certain legal system. Accepting the renvoi would mean that the courts would thwart the intention of the legislator, which is not acceptable. ${ }^{996}$

Just as under Dutch private international law the rejection of renvoi in matters concerning legal parentage must be appreciated in the light of the fact that Swedish private international law has different choice of law rules for parentage depending on whether the parentage has to be established in Sweden or whether it has already been established abroad. 997 That means that decisional harmony, which in Germany is cited in support of renvoi, is attained under Swedish private international law in another way.

\subsubsection{Public policy exception in choice of law on parentage}

In the first part it has been shown how legal systems on parentage can differ. Differences can even be greater in comparison with legal systems that uphold the distinction between legitimate and illegitimate children and legal systems that have a different view on same sex parenthood and assisted reproduction.

The extent to which differences in foreign law are accepted by the forum is determined by the public policy exception. The public policy exception in private international law is characterised by the fact that its content differs according to time and place and that it cannot be determined in the abstract. Therefore, it is not possible to make an exhaustive list of foreign legal provisions that violate the public policy of the forum.

It is possible though to consider the decisions of national courts where foreign law has been applied and to examine whether or not the foreign law violated the public policy of the forum. The list that results from this consideration is only indicative, not least because certain decisions are rendered by lower courts.

This paragraph will focus on case law from Dutch and French courts. English law does not have choice of law rules concerning parentage. It has been concluded that so far the English courts apply English law to determine the parentage of a child. Since English courts are not confronted with foreign law in matters concerning parentage, they also do not need the public policy exception to avoid the application of foreign law that violates fundamental principles of English law. Also in Sweden, the national authorities (courts and registrars) almost always apply Swedish law. The public policy exception is only relevant in Swedish private international law on parentage in cases of the recognition of parentage that has been established abroad.

German case law also does not provide many examples of the application of the public policy exception in relation with article 19 and 20 EGBGB. 998 The reason is the same as under Swedish law: the effect of article 19 EGBGB is that in cases of establishment of parentage in Germany often German law applies. Foreign law can apply if it provides that the exhusband is the father if the child is born within 300 days after the dissolution of the marriage. It has been shown above that such a rule does not violate German public policy even if it prevents the biological father from acknowledging his paternity.

Dutch and French courts have been forced to invoke the public policy exception more often, because nationality as a connecting factor easily imports foreign law to establish or contest parentage. Four typical situations will be discussed which give rise to public policy concerns in applying foreign law.

\footnotetext{
996 Bogdan 2004, p. 56, 57.

997 See $\S$ 7.2.9. Recognition of legal parentage under Swedish private international law.

998 Andrae 2006, § 5, nr. 34; MünchKomm/Klinkhardt 2006, Article 19 EGBGB, nr. 49.
} 
In the first case the connecting factor leads to a legal system that does not allow the establishment of legal paternity out of wedlock. This is, for example, the case under Moroccan law. In February 2006, the Gerechtshof Amsterdam rendered an extensive reasoned judgment on the question whether the impossibility to establish legal parentage violates Dutch public policy. ${ }^{999}$ The case was about a child who was born from a relationship between a Moroccan woman and a Moroccan Dutch man. Under article 6 of the Wet Conflictenrecht Afstamming (WCA) the application of the mother for judicial establishment of the legal paternity of the man was governed by Moroccan law, the law of their common nationality. According to Moroccan law judicial establishment of legal paternity out of wedlock is not possible.

The court held that the impossibility to judicially establish legal paternity infringed upon the private life of the child, protected by article 8 (1) ECHR. In its examination whether the infringement was justified, the court observed that the legislator made a deliberate choice not to favour the possibility of judicial establishment of legal paternity with a cascade of connecting factors. The reason for this was that on the one hand the judicial establishment of legal paternity has serious consequences for the alleged father, while on the other the child can also sue for maintenance without judicial establishment of legal paternity. Because of this deliberate choice of the legislator, the fact that foreign law does not allow the judicial establishment of paternity should in principle be accepted, unless it would result in an unjustified infringement of the private life of the child. The court observed that the possibility of the child to sue for maintenance without establishing legal paternity did not justify the infringement of the child's private life.

In its decision the focus of the Gerechtshof Amsterdam is not so much on the question whether or not Moroccan law is in violation of article 8 ECHR and Dutch public policy. The court held that the choice of law procedure of article 6 WCA violates article 8 ECHR if it leads to a legal system that does not allow judicial establishment of legal paternity. The court concluded that Dutch public policy requires the application of Dutch law when article 6 WCA leads to the application of a legal system that does not allow for the establishment of legal paternity out of wedlock.

It is not entirely clear whether the Gerechtshof Amsterdam held that Moroccan law is in violation of Dutch public policy or that article 6 WCA itself violates Dutch public policy. From a dogmatic point of view the latter conclusion would not be entirely sound. The conflict rule of the forum itself cannot be in violation of the public policy of that same forum. It is the applicable law that can violate the public policy of forum. Still the message of the court is clear: foreign law that does not allow the establishment of legal parentage will not be applied. 1000

The Gerechtshof 's-Hertogenbosch reached a similar conclusion in November 2008.1001 In a similar case as described above, the court held that article 6 WCA or at least the result of the referral, i.e. the application of Moroccan law, infringed upon the rights of the persons involved under article 8 ECHR. Just like the Gerechtshof Amsterdam, the Gerechtshof 'sHertogenbosch held that in such a case the Dutch public policy requires the application of Dutch law.

The Gerechtshof 's-Hertogenbosch held obiter that on the basis of article 8 ECHR the child has a right to apply for the judicial establishment of the paternity of his begetter if the requirements of article 1:207 Dutch civil code have been fulfilled. This consideration raises the question whether the court is willing to apply any foreign law that restricts the right of the child to judicial establishment of legal paternity, for example by periods of limitation.

\footnotetext{
999 Gerechtshof Amsterdam 9 February 2006, LJN AV2119.

1000 See also Rechtbank Rotterdam 21 December 2006, LJN AZ6489.

1001 Gerechtshof's-Hertogenbosch 27 November 2008, LJN BG6114.
} 
In October 2007, the Gerechtshof 's-Gravenhage was also confronted with Surinam law that does not allow the judicial establishment of legal paternity. ${ }^{1002}$ For the interpretation of this case it is important to note that from the 1st of April 2003 until the 1st of March 2009 a child that is recognised by a Dutch national did not automatically get Dutch nationality. ${ }^{1003}$ Dutch nationality was only granted automatically if a Dutch national was married to the mother at the moment of birth or if the legal paternity of a Dutch national had been judicially established. ${ }^{1004}$ Moreover, judicial establishment of legal paternity after a valid acknowledgment of paternity is in principle not possible after a valid acknowledgment of paternity.

In the case before the Gerechtshof 's-Gravenhage the man did not acknowledge his paternity but instead the mother applied for judicial establishment of his paternity. In this way the parents of the child wanted to make sure that the child would get Dutch nationality. Article 6 (1) WCA led to the application of Surinam law that does not allow the judicial establishment of legal paternity.

The court held that in this case the impossibility to judicially establish legal paternity did not violate Dutch public policy because legal paternity could also be established by acknowledgment of paternity. The fact that acknowledgment of paternity did not confer Dutch nationality upon the child was not enough reason to declare Surinam law (or art. 6 WCA) in violation of Dutch public policy. Moreover, the Hoge Raad had held in 2006 that a child acquired Dutch nationality if a Dutch national acknowledged his paternity and if the child could submit judicial evidence of his biological affiliation. ${ }^{1005}$

Thus, Surinam law did not make the establishment of legal paternity impossible and the judicial establishment of legal paternity was not necessary in order for the child to obtain Dutch nationality. Therefore, neither Dutch public policy nor article 8 ECHR was violated.

Beside the fact that it is possible that foreign law does not allow the establishment of legal parenthood, it is also possible that foreign law poses more or different requirements to the establishment of legal parenthood. For example, certain legal systems provide that legal maternity out of wedlock has to be established by acknowledgment of legal maternity, while under Dutch law legal maternity always exists automatically. It is not likely that on this point foreign law shall be declared in violation of Dutch public policy, because it has been shown that article 3 (1) Wet Conflictenrecht Afstamming provides that legal maternity always exists automatically if the woman habitually resides in the Netherlands. As a consequence, it is not likely that a Dutch registrar has to apply foreign law in order to determine legal maternity.

With regard to establishment of legal paternity by acknowledgment of paternity, Dutch law is stricter than most foreign legal systems and therefore it is not likely that foreign law on acknowledgment of paternity will be held to violate Dutch public policy for this reason.

In France, the Cour de Cassation also had to rule on the acceptability of foreign law prohibiting the establishment of legal paternity out of wedlock. In 2007, the Cour de Cassation had to rule on the nationality of a certain Hachemi X.1006 Hachemi argued that he was a French national because his father was also a French national. However, the Cour de Cassation held that the legal parentage of Hachemi was, by virtue of article 311-14 Code

1002 Gerechtshof 's-Gravenhage 3 October 2007, NIPR 2008, 7. Appeal for cassation rejected: Hoge Raad, 12 December 2008, LJN BG1113.

1003 Wet van 27 juni 2008 tot wijziging van de Rijkswet op het Nederlanderschap ter invoering van een verklaring van verbondenheid en tot aanpassing van de regeling van de verkrijging van het Nederlanderschap na erkenning, Stb. 2008, 270. The Act entered into force on the 1st of March 2009 (Stb. 2009, 1).

1004 Articles 3 (1) and 4 (1) Rijkswet op het Nederlanderschap.

1005 Hoge Raad, 26 January 2007, NJ 2007, 73, LJN AZ1624.

1006 Cass. Civ. 1er, 25 April 2007, RCDIP 2008, 81. 
civil, governed by Algerian law. Algerian law does not allow the establishment of legal parentage out of wedlock.

The Cour de Cassation held that Algerian law did not violate French public policy. Hachemi came to France in 1994 but he did not live in France at the date his father obtained French nationality. Therefore, the French legal order was not sufficiently involved in order to justify the application of the public policy exception against Algerian law.

Further, there is a constant line of decisions where the Cour de Cassation held that foreign law that does not allow the establishment of legal paternity only violates French public policy if the child is French or if the child habitually resides in France. ${ }^{1007}$

With regard to legal maternity the Cour de Cassation is much stricter. In 2007, the court held that the former rule of French law that the inclusion of the name of the mother on the birth certificate of the child was not enough to establish legal maternity, violates article 8 ECHR.1008

There is a clear difference in the approach between the Dutch Gerechtshof Amsterdam and Gerechtshof 's-Hertogenbosch on the one hand and the French Cour de Cassation on the other. The Dutch courts based the child's right to apply for judicial establishment of paternity directly on article 8 ECHR. Referring to article 1 ECHR, the court observed explicitly that the rights and obligations following from the European Convention on Human Rights apply to everyone who is within the jurisdiction of the state parties to the Convention. Thus, foreign law that deprives the child from his right to a legal father cannot be applied by a Dutch court, according to the Gerechtshof Amsterdam.

The French Cour de Cassation holds a more moderate view. It does not base the right to the establishment of legal paternity on article $8 \mathrm{ECHR}$ and it does also not give it an absolute status. Only if the child is French or habitually resides in France, foreign law has to allow the establishment of legal paternity.

Foreign law that is stricter than French law on the establishment of legal parenthood can violate French public policy. One example is the decision of the Cour de Cassation that the former French rule according to which legal maternity did not exist automatically, but had to be established through acknowledgment of maternity, violates article 8 ECHR. ${ }^{1009}$ The decision was rendered on the 13th of March 2007. Since the first of July 2006, French law provides that the recording of the name of the mother on the birth record of the child establishes her legal maternity. The acknowledgment of maternity is not necessary anymore to establish legal maternity. ${ }^{1010}$ The modification of French law was based inter alia on the consideration that different regimes for the establishment of legal maternity depending on whether the child would be born in or out of wedlock violate article 8 ECHR. ${ }^{1011}$ From this perspective, the decision of the Cour de Cassation is not surprising. If old French law is in violation of article $8 \mathrm{ECHR}$ it is hard to see why foreign law that requires an acknowledgment of maternity is not in violation of article $8 \mathrm{ECHR}$.

\footnotetext{
1007 Cass. Civ. 1er, 10 May 2006, Bull. civ. 2006, nr. 226; Cass. Civ. 1er, 10 February 1993, D 1994, 66; RCDIP 1993, 620; JDI 1994, 124. See also Cour d'appel de Lyon, 12 December 2000, JDI 2002, 475 where the court held that the impossibility of an Algerian national to acknowledge his paternity concerning a Moroccan child violated French public policy.

1008 Cass. Civ. 1er, 13 March 2007, RCDIP 2008, 81. See also Cass. Civ. 1er, 14 February 2006, D 2006, 1029.

1009 Cass. Civ. 1er, 13 March 2007, RCDIP 2008, 81.

1010 Article 311-25 Code civil.

1011 Rapport Blanc au nom de la Commission des lois constitutionnelles, de la législation et de l'administration générale de la République sur le projet de loi (nr. 1504) habilitant le gouvernement à simplifier le droit, Assemblée Nationale, nr. 1635,12 e législature, p. 81-82.
} 
No cases have been found where the Cour de Cassation had to rule on the acceptability of additional requirements for the validity of an acknowledgment of paternity such as, for example, the consent of the mother or the child. It has been argued that the requirement of consent of the mother for the validity of the acknowledgment violates the principle of equality and therefore French public policy.1012 In any event, foreign law that makes it more difficult to establish legal paternity by acknowledgment of paternity is hard to reconcile with article 311-17 Code civil that favours the validity of the acknowledgment of parenthood.

The public policy exception has also been raised in cases where foreign law does not allow the annulment of legal paternity, while this would be possible according to the internal law of the forum. Obstacles to the annulment of legal paternity can prevent the child from establishing legal parentage with his biological parent.

Although both French and Dutch law attach important weight to the establishment of the legal paternity of the biological father, both legal systems at the same time restrict the possibility to contest existing legal paternity. Therefore, foreign law that does not allow annulment of legal paternity cannot violate public policy only for that reason. There must be a specific reason to justify the application of the public policy exception against a legal system that does not allow the annulment of legal paternity.

With regard to Dutch private international law it must be observed that article 2 (2) WCA allows the persons involved in the procedure for annulment of marital paternity to choose for Dutch law or another legal system mentioned in article 2 (2) WCA if all parties involved agree and if the choice for Dutch law is in the interest of the child. ${ }^{1013}$ As a result, recourse to the public policy exception can be avoided if all parties involved agree on the application of Dutch law or another legal system that allows the annulment of marital paternity. ${ }^{1014}$ However, a choice of law is not always possible for example if the legal father of the child cannot be found.

In 2005, the Dutch Rechtbank Amsterdam ruled on the application for annulment of marital paternity of the Ethiopian mother of a child.1015 The court held that the rule of Ethiopian law that only the husband can apply for annulment of his legal paternity violates the principle of equality of men and women and therefore Dutch public policy. In 2008, the Rechtbank Haarlem reached the same conclusion in a similar case.1016

The French Cour de Cassation ruled in 1999 on the annulment of legal paternity based on acknowledgment. ${ }^{1017}$ Per article 311-17 Code civil, annulment of legal paternity based on acknowledgment is only possible if it is possible according to the national law of the acknowledger as well as the national law of the child. In the case at hand, that meant that both the requirements of French and German law had to be fulfilled.

According to German law annulment was not possible anymore because the period of limitation had lapsed. The Cour de Cassation held that the fact that the period of limitation for annulment of legal paternity based on acknowledgment in German law was much shorter than under French law did not violate French public policy. According to the Advocate General, important considerations were that German law did not preclude annulment altogether and that it was proven that the man had already doubted his paternity before the period of limitation had lapsed.

\footnotetext{
1012 Foyer 2002, p. 531. See also Malaurie \& Fulchiron 2006, nr. 1183.

1013 See $\S$ 6.2.2. Applicable law to annulment of marital paternity under Dutch PIL.

1014 Rechtbank Haarlem 12 July 2005, NIPR 2005, 231, LJN AU0321.

1015 Rechtbank Amsterdam, 23 November 2005, LJN 7503.

1016 Rechtbank Haarlem, 22 July 2008, LJN BD9278.

1017 Cass. Civ. 1er, 6 July 1999, Bul. civ. 1999, nr. 225; D 1999, 483.
} 
But in 1993, the Tribunal de grande instance of Paris went further. ${ }^{1018}$ It held that the impossibility for the acknowledger under Peruvian law to contest his legal paternity did not violate French public policy because the case had only very limited ties with France: the acknowledger was a German national working in Latin America and the mother had Peruvian nationality staying only temporarily in France for studies. The intensity of the connection of the case with France seems to constitute an important factor in determining whether or not foreign law violates French public policy.

In 1991 the Cour d'appel of Paris held that Yugoslavian law that did not allow at all the annulment of legal paternity based on acknowledgment violated French public policy, because it deprived the child of the possibility to establish legal parentage with the child's biological father. 1019 Therefore, the court replaced Yugoslavian law by French law with which the case, in the court's view, was most closely connected.

So far examples of the application of the public policy exception have been presented where foreign law is stricter than the internal law of the forum. It is also possible that foreign law is more permissive either with regard to the establishment of legal parentage or with regard to its annulment.

Dutch case law does not provide many examples where foreign law that is more permissive concerning the establishment of legal parenthood violates Dutch public policy. With regard to legal maternity it is hard to imagine that foreign law is more permissive since according to Dutch law legal maternity exists automatically. With regard to legal paternity one has to distinguish different situations. Foreign law that establishes automatically the legal paternity of the ex-husband of the mother does not violate Dutch public policy. ${ }^{1020}$ The possibility that the ex-husband is the legal father of the child born after the divorce is taken into account by article 1 (1) WCA which determines the applicable law to the establishment of legal parentage between the child, his mother and the man with whom the mother is or was married.

With regard to acknowledgment of paternity, it is at first sight hard to imagine how foreign law can violate Dutch public policy if article 4 (1) WCA provides for four connecting factors to determine the right of the man to acknowledge his paternity. However, nothing is further from the truth. The cascade of connecting factors of article 4 (1) WCA has to be appreciated in connection with article 4 (2) WCA which provides that a person with Dutch nationality can only acknowledge his paternity if the requirements of Dutch law are satisfied and also article 4 (4) WCA that subjects the consent of the mother and the child to the acknowledgement to a different choice of law rule.

The effect of these two provisions is that foreign law and the public policy exception have a limited role to play when it comes to acknowledgement of paternity. The Dutch rules on acknowledgment of paternity are d'ordre public when the man has Dutch nationality and the Dutch rules on consent to acknowledgment are d'ordre public when the mother or the child have Dutch nationality or habitually reside in the Netherlands. ${ }^{1021}$

When it comes to the annulment of legal paternity it is not impossible that foreign law is more permissive than Dutch law. Dutch law does not allow the husband or the mother to contest the husband's legal paternity if the man knew before the marriage that the mother was pregnant and neither the acknowledger nor the mother are in principle allowed to contest the legal paternity of the acknowledger.

\footnotetext{
1018 TGI Paris, 23 November 1993, RCDIP 1995, 703.

1019 Cour d'appel de Paris, 5 December 1991, D 1992, 290.

1020 Gerechtshof 's-Gravenhage 14 December 2005, NIPR 2006, 178.

1021 See $\S 7$.2.1.3. Exceptions to recognition.
} 
Since article 2 (2) WCA favours the possibility to contest marital paternity it is not likely that foreign law that is more permissive than Dutch law would violate public policy, as long as the parties to the dispute agree and the annulment of legal paternity is in the interest of the child.

This argument does not hold true for legal paternity based on acknowledgment, since article 5 WCA does not favour the annulment of such legal paternity. The legislator recognised that it is not unlikely that under foreign law it is easier to contest an acknowledgment of paternity. It concluded that it is up to the court to determine in a concrete case when foreign law violates pubic policy. However, especially if a Dutch child is involved the court would have to take into account the Dutch view on the (im)possibility to contest an acknowledgment of paternity. ${ }^{1022}$

French case law does not seem to have a problem with foreign law that is more permissive regarding the establishment of legal parentage. With regard to the legal paternity of the husband, the question is whether the provisions of article 313 Code civil are d'ordre public and override the application of foreign law that does not reject the establishment of the legal paternity of the husband in the circumstances described in article 313 Code civil. Article 313 Code civil provides that the husband of the mother shall not be the legal father of the child if he is not named on the birth record and if the child does not have apparent status with regard to him.

It is not likely that foreign law will be held to violate French public policy if it does not respect this rule. The prevailing view is that on the basis of article 311-15 Code civil French law governs the effects of the presence but also of the absence of apparent status if either the child or one of his parents habitually resides in France. In other words, from the moment that one of the parties habitually resides in France, article 313 Code civil applies and it is not necessary to apply the public policy exception. ${ }^{1023}$

With regard to acknowledgment of parenthood it is hardly possible that foreign law is more permissive than French law because French law hardly poses any requirements to the validity of the acknowledgment.

Foreign law that is more permissive with regard to judicial establishment of legal paternity does not seem to violate French public policy. ${ }^{1024}$ French law used to require the establishment of a serious ground of suspicion before the application for judicial establishment of paternity was allowed. ${ }^{1025}$ Foreign law that did not make such a requirement did not violate French public policy. According to the Cour de Cassation, foreign law should provide for serious guarantees that the biological paternity is established and that the alleged father can state his defence. ${ }^{1026}$

Regarding foreign law that is more permissive with regard to the annulment of legal parenthood the Cour de Cassation held that foreign law that has longer periods of limitation does not violate French public policy. ${ }^{1027}$ It must be observed though that per article 311-15 Code civil the effects of apparent status are determined by French law if one of the parties to the dispute habitually resides in France. The existence and the absence of apparent status have an effect on quite a few aspects of the application for annulment of legal paternity, such as locus standi and the periods of limitation. ${ }^{1028}$ Thus, if one of the parties habitually

1022 Kamerstukken II 1998-99, 26 675, nr. 3, p. 15.

1023 See $\S$ 6.4.2. Effects of apparent status under French PIL.

1024 Guiho 1991, nr. 21.

1025 For article 340 (2) Code civil: La preuve [of paternity, ks] ne peut en être rapportée que s'il existe des présomptions ou indices graves.

${ }_{1026}$ Cass. Civ. 1er, 9 October 1984, Bull. civ. 1984, nr. 250, RCDIP 1985, 643, JDI 1985, 906. See also Guiho 1991, nr. 22. 1027 For references to case law see Guiho 1991, nr. 24.

1028 Articles 333 and 334 Code civil. 
resides in France, French law applies to these issues and it is not necessary to consider the application of the public policy exception with regard to these issues.

\subsubsection{Application of English law pursuant to continental private international law}

Before starting this paragraph on the application of English law on parentage in continental legal systems, two cases will be described to illustrate the problem at hand. The first is the case of Mary and Peter. ${ }^{1029}$ Mary Therese Malone, an Irish national gives birth to a daughter, Shelley, in the Netherlands on the 31st of January 1988. The father of the child is the English national, Peter Vaughan Gill. The parents of the child are not married and therefore the Dutch civil status registrar who records the birth does not name Peter as the father of the child on the birth record.

On the 3rd of February 1988, Peter wants to establish his paternity by the acknowledgement of his paternity before the civil status registrar in Amsterdam. The registrar does not allow Peter's acknowledgment of paternity. According to the registrar, English law is applicable to Peter's acknowledgment and in his interpretation of English law, Shelley could not be registered under his name and he could not be registered as her father.

Despite various declarations of the British consulate in Amsterdam that English law does not oppose the registration of Peter as the father the Dutch registrar persists in his refusal to allow Peter to acknowledge his paternity. The registrar is even backed by the Ombudsman of Amsterdam and the district court of Amsterdam. Mary and Peter are dragged into an administrative battle, which ends before the European Commission of Human Rights.

The second case is the one of two Dutch nationals, Fred and Tonnie. ${ }^{1030}$ Fred and Tonnie are not able to have children. They have contacted Martha, an English national living in England who is willing to carry a child for them. In July 2004 Martha gives birth to a daughter, Anna, who has been conceived with the semen of Fred. The English civil status registrar who recorded the birth named Fred as the father of Anna on her birth record. In the Netherlands, Fred and Tonnie apply to the Rechtbank 's-Gravenhage and request amongst others the recognition of Fred's paternity under article 10 Wet Conflictenrecht Afstamming. After all, Fred is named as the father on the English birth record. ${ }^{1031}$

The court holds that Fred's paternity cannot be recognised since it violates Dutch public policy. According to the court the recording of the name of the Fred on the birth record means that according to English law he is presumed to be the biological father of the child. Moreover, English law does not attach the same legal effects to the inclusion of Fred's name on the birth record as Dutch law does. After all, according to English law, the recording of the name of the father on the birth record does not necessarily mean that legal parentage has been established between the man and the child.

The point of these examples is to show the confusion that exists among Dutch authorities about English law on parentage. It was only in 2006 that the Nederlandse Vereniging van Burgerzaken (Dutch Association on Civil Status Registration) informed its members that an acknowledgment of paternity under English law is possible. ${ }^{1032}$ This is quite amazing. The idea that under English law before 2006 no rights and obligations could exist between a father and his illegitimate child is unfounded. For example, since the Family Law Reform

\footnotetext{
1029 European Commission of Human Rights 11 April 1996, application number 24001/94.

1030 Rechtbank's-Gravenhage 1 February 2006, number FA RK 05-3693 (not published).

1031 On article 10 Wet Conflictenrecht Afstamming see $\S 7.2 .1$. Recognition of legal parentage under Dutch private international law.

1032 Verhoeven 2006; Verhoeven 2007.
} 
Act 1969 illegitimate children and their parents have reciprocal rights to share in each other's intestacy as if the child had been born legitimate. ${ }^{1033}$

The doubts concerning English law in the Netherlands also exist in Sweden. The explanatory report to the Swedish Lag 1985:367 om internationella faderskapsfrågor also provides that the choice of law rules on an acknowledgment of paternity made abroad only apply to an acknowledgement that has a constitutive effect instead of only an evidential function. ${ }^{1034}$ It refers to the acknowledgment under English law which strictly speaking only has an evidentiary and not a constitutive effect.

The application of English law in continental legal systems poses distinctive problems in the different continental legal systems. In the first part it has been concluded that under English law, parentage is to a large extent a factual matter. The only legal matter is the definition of the terms legal father and legal mother. It has been shown that the legal father of a child is often the biological father of the child, unless the definition of father of the Human Fertilisation and Embryology Act 2008 applies. As a consequence, the English registrar in most cases has to register the biological father of the child. Therefore, if English law is applicable pursuant to Dutch, French or German choice of law rules, the Dutch, French or German registrar has to name the biological father of the child.

Continental registrars apparently feel uneasy recording the biological father of the child as such. They work in a system that obliges them to record the legal parents of the child and that holds the registrars responsible for recording the true legal status of the child. Moreover, registrars are used to the fact that legal parentage is based on the law and official documents instead of facts and statements of (unreliable) individuals. After all, the whole point of continental law on parentage is to provide an alternative for recording the biological father, to make sure that the legal status of a child can be easily ascertained and established.

The French registrar will have fewer problems applying English law, since the French registrar is not obliged to record the legal parents of the child and, just like under English law, the investigative powers of the French civil status registrar are limited.

The Dutch and German registrars are not left unguided completely. If the registrar has found that he has to record the biological father the second step is that he was to determine how biological paternity (i.e. legal paternity) is proven. This brings us to the question of the law applicable to evidence. It has to be determined which law applies to the fact that must be proven and how that fact must be proven.

Under both Dutch and German law the prevailing view is that the lex causae determines the object of proof. ${ }^{1035}$ Thus if English law applies to the child's parentage English law determines the facts that must be proven to establish legal parentage.

With regard to the question how the facts of the lex causae must be proven, the Dutch State committee on private international law (Staatscommissie voor het internationaal privaatrecht) advised to extend article 14 (1) of the convention on the law applicable to contractual obligations (1980) to all areas of private law. Thus, the lex causae applies to the extent that it contains rules which raise presumptions of law or determine the burden of proof. Also under German law, the prevailing view is that the lex causae applies to the existence of presumptions and the burden of proof. ${ }^{1036}$ It follows that in relation to parentage the lex causae determines the existence of legal presumptions concerning legal

\footnotetext{
1033 Law Commission Report No 118 on Illegitimacy (1982), p. 7.

1034 Prop. 1984/85:124, p. 59.

1035 Geimer 2005, nr. 2260. Staatscommissie IPR 2002, p. 68.

1036 Geimer 2005, nr. 2284, 2340.
} 
paternity. Thus, if English law is applicable to the parentage of a child, the Dutch or German registrar has to apply the English presumption of legitimacy. ${ }^{1037}$

However, it has been shown that under English law the presumption of legitimacy is a weak presumption. At the registration of the child's birth it can be rebutted by a statement by the declarant that the mother's husband is not the father of the child. Under Dutch and German private international law, the prevailing view is that the force of the presumption of legitimacy is also governed by the lex causae. Thus, the Dutch or German registrar who is bound to record the name of the biological father of the child if English law is applicable, should not record the name of the mother's husband if he is told that the husband is not the biological father of the child.

The question arises whether the accepting attitude towards the English law presumption of legitimacy is compatible with the task of the Dutch and German registrar to record the (legal) truth and to examine it ex officio. Can the low English standard to rebut the presumption of legitimacy be applied in the Dutch or German registration system that sets a high standard for the accuracy of the register records? Two observations must be made in this respect.

First, unlike under Dutch and German law the presumption of legitimacy under English law does not establish legal paternity. Like any presumption of law it only raises a presumption that the husband is the legal/biological father. It follows that the accuracy of the Dutch and the German registers of civil status is not so much endangered by the low standard for the rebuttal of the presumption of legitimacy as well as by the application of English law itself. Even if the Dutch or German registrar would not allow the rebuttal of the presumption of legitimacy, that attitude does not guarantee a higher degree of accuracy of the register records, on the contrary. If the persons involved state that the mother's husband is not the biological father of the child in most cases that is probably true.

The second observation is that under English law one commits an offence if one wilfully makes a false answer to any question put to him by the registrar. ${ }^{1038}$ Thus, in England the accuracy of the register of births is enforced by criminal law provisions. That puts the low standard for the rebuttal of the presumption of legitimacy in a different perspective. After all, the incentive for the declarant to tell the truth to an English registrar does not exist if English law is applied by a Dutch or German registrar.

Whether the lack of penalising provisions under Dutch and German law is sufficient to refuse the rebuttal of the presumption of legitimacy by a statement of the persons involved is doubtful. After all, under French law the reconnaissance de complaisance ${ }^{1039}$ is discouraged by the civil liability of the acknowledger. ${ }^{1040}$ The lack of such liability under Dutch and German law has never provoked the argument that the French rules on acknowledgment of paternity should not be applied.

So far the application of the English presumption of legitimacy by Dutch and German registrars has been discussed. In the case of Mary and Peter discussed above, the problem was not the application of the presumption of legitimacy. After all, the child was born out of wedlock. If the child is born out of wedlock, English law does not have a presumption of law for legal paternity. As soon as the birth of the child has been recorded, the inclusion of a man's name as the father establishes a presumption of law that he is the legal father.

\footnotetext{
1037 See also OLG Hamm, 7 April 2008, FamRZ 2009, 126.

1038 Section 4 Perjury Act 1911. On the various offences concerning the registration of births see Hailsham of St. Marylebone 1998, nr. 527-535.

1039 The establishment of legal paternity by the acknowledgment of paternity of a man who is not the biological father of the child.

${ }^{1040}$ Instruction générale relative à l'état civil du 11 mai 1999, nr. 307, Journal Officiel nº 172 du 28 juillet 1999.
} 
However, that presumption is not of much help to the Dutch or German registrar if they have to record the birth. After all, at that moment there is no birth record as yet.

In this case English law provides in sections 10 and 10A Births and Deaths Registration Act the requirements for an unmarried father to be named in the birth record. Either one submits a joint declaration by the mother and the alleged father or one submits one of the listed documents for which legal paternity had to be determined. The question is whether there is a legal basis in Dutch and German private international law for the application of sections 10 or 10A Births and Deaths Registration Act if English law applies to the parentage of the child.

Under Dutch private international law, there is some case law from lower courts supporting the view that admissibility of means of evidence and their evidential force is governed by the lex causae. ${ }^{1041}$ That implies that the means to ascertain biological paternity for the purpose of recording the birth would be governed by English law. That view creates a legal basis for the Dutch registrar to apply sections 10 or $10 \mathrm{~A}$ Births and Deaths Registration Act to the determination of legal paternity out of wedlock. The application of these sections by the Dutch or German registrar would mean that the registrar draws up an instrument of acknowledgment with the consent of the child's mother.

In this paragraph the application of English law by the registrar at the moment of the recording of the birth has been discussed. A legal basis in Dutch and German private international law has been found for the Dutch and German registrar to apply English law in the same way as the English registrar does.

The application of English law in the way described above can be problematic if English law applies to the acknowledgment of paternity (art. 4 (1) Dutch Wet Conflictenrecht Afstamming or art. 19 (1) German EGBGB), while another legal system, let's say Dutch law, applies to the legal paternity of the husband of the mother (art. 1 (1) Dutch Wet Conflictenrecht Afstamming or art. 19 (1) German EGBGB). In that case, the question arises whether the legal paternity of the husband that exists on the basis of Dutch law can be set aside by a statement of the persons involved at the moment of the recording of the birth that the husband is not the biological father and whether the English national can be named on the birth record as the father.

For Dutch law it has been argued that the legislator probably intended to create a hierarchy between the law applicable to martial paternity (or the law applicable to legal paternity that exists ex lege) (art. 1 and 2 Wet Conflictenrecht Afstamming) and the law applicable to acknowledgment of paternity (art. 4 Wet Conflictenrecht Afstamming). ${ }^{1042}$ Under the Wet Conflictenrecht Afstamming, one would first have to check whether it is possible to contest the legal paternity of the husband via the applicable law of article 2 (4) Wet Conflictenrecht Afstamming. If that is possible, the acknowledgment of paternity is governed by the law applicable according to article 4 Wet Conflictenrecht Afstamming.

Under German law, the conflicting results of article 19 EGBGB have also already been the subject of study. It appeared that there is not one accepted solution, except that the best interest of the child is the criterion for the choice between the legal paternity of the husband and the unmarried father. ${ }^{1043}$

\footnotetext{
1041 Van het Kaar 2008, p. 48; Van het Kaar 2003, p. 476, note 6. For Germany see Geimer 2005, nr. 2334 where it is explained that the degree of certainty (Beweismaß) that is required to accept the existence of a certain fact is governed by the lex causae.

$1042 \S$ 6.2.4. Applicable law to acknowledgment of paternity under Dutch PIL.

$1043 \S 6$ 6.5.1.1. The hierarchy among the connecting factors and conflicting results in German PIL.
} 


\subsection{Conclusion on applicable law in matters concerning parentage}

This overview on national choice of law rules shows a bewildering diversity of solutions for conflict of laws on legal parentage. Every solution has its own peculiarities and uncertainties which remain often undetermined because choice of law in matters concerning parentage is not a subject that gives rise to a massive production of case law.

The first point that catches the eye is that under English law no choice of law rules have yet been developed. Three causes have been put forward to explain this situation: parentage is to a large extent a matter of fact, most issues concerning the determination of facts are characterised as procedural issues instead of substantive issues and therefore governed by the lex fori and the jurisdiction of English courts to determine legal parentage or to render a parental order depends to a large extent on the domicile of the parties which is also the most important connecting factor for personal status. It has been shown that notwithstanding these circumstances, at a certain moment in time the development of choice of law rules on the definitions of legal father and legal mother is inevitable.

Among the Dutch, French, German and Swedish legal systems the first observation relates to the formal scope of the national conflict rules. Under French and German law, the choice of law rules on parentage have a universal scope which means that they apply irrespective of the domicile, residence or the nationality of the persons involved.

Under Dutch and Swedish law, the choice of law rules have a limited formal scope. Under Dutch law, the choice of law rules only apply to acts and facts concerning parentage that take place in the Netherlands. If acts and facts have taken place abroad, article 10 Wet Conflictenrecht Afstamming applies. ${ }^{1044}$

In Sweden, the situation is just the opposite. In Sweden the lex fori applies if the birth or the acknowledgment takes place in Sweden. Only in a procedure in a Swedish court for judicial establishment or annulment of legal parenthood a conflict rule applies: the action is governed by the law of the domicile of the child. Since the jurisdiction of Swedish courts is also based on the domicile of the child, the courts almost always apply Swedish law.1045 Choice of law rules to determine the legal paternity of the (ex) husband or the acknowledgment of parenthood are only relevant if the child is born abroad or if the birth takes place abroad. ${ }^{1046}$

The second difference among the systems of private international law in France, Germany, the Netherlands and Sweden is the formulation of the choice of law rule for parentage. A preliminary observation in this respect is that it has been shown that the use of terms like father and mother are not very convenient in choice of law rules on parentage, whose purpose it is to determine who the legal father and mother of the child are. In all legal systems it appears that the choice of law rules on parentage are designed to solve problems concerning the establishment of legal parenthood of the biological parents. However, with a view to the development and the internationalisation of artificial reproduction this preoccupation with natural reproduction is not justified. Only the Swedish Lag 1985:367 om internationella faderskapsfrågor provides for a special regulation to deal with the legal parenthood of the female partner of the mother.

\footnotetext{
1044 See $\S 7.2 .1 .2 .2$. The legal facts or acts must have been established abroad.

1045 On jurisdiction of Swedish courts in matters concerning parentage: § 5.2.5. International jurisdiction of courts under Swedish law.

$1046 \S$ 7.2.9. Recognition of legal parentage under Swedish private international law.
} 
Regarding the connecting factor for legal parentage three different starting points have been distinguished. The main connecting factor in French law is the nationality of the mother, in German and Swedish law the habitual residence of the child and in the Netherlands the (common) nationality of the parents. This apparent difference in connecting factors is hard to assess, because these connecting factors are not more than a starting point. The four different legal systems all have their own distinctive repertoires of rules that serve as a supplement or an exception to the main rule.

Additions to the main connecting factor have different functions. They may have a purely technical function to solve the case where the main connecting factor cannot be applied. Thus, in French law the main connecting factor for parentage is supplemented by the connecting factor 'national law of the child' in cases where the mother of the child is unknown. In Dutch law, the common nationality of the parents is supplemented with the connecting factor 'common habitual residence' and 'habitual residence of the child' in case there is no common nationality or a common habitual residence.

A second function of additions to the main connecting factor is to favour a certain result. The main connecting factor for legal parentage under German law is supplemented with the national laws of the alleged parents and the law that applies to the effects of marriage. The additional connecting factors for legal parentage are meant to favour the establishment of legal parentage. Under Dutch and French private international law the establishment of legal parentage is only favoured in cases of acknowledgment of paternity (or, with regard to France, maternity). The effect is dépeçage, where different elements of the establishment of legal parentage are subjected to different law selecting mechanisms. It has been shown that both under Dutch and French law this might lead to strange and even conflicting results. In Swedish private international the favouring element of the choice of law rule only applies in cases where the birth or the acknowledgment took place abroad; if they took place in Sweden, Swedish law applies.

Although all four legal systems favour the establishment of legal parentage, in general or in specific circumstances, they differ as to the effect of the favouring-principle on the choice of law procedure in case of annulment of legal paternity. In French law, article 311-17 Code civil states that an acknowledgment of parenthood is valid if it is valid either according to the national law of the child or the national law of the acknowledger.

The effect of this approach towards the validity of acknowledgment of parenthood is that in order to annul legal paternity on the basis of acknowledgment one has to fulfil the cumulative requirements of the legal systems of the national law of the child and the acknowledger. It has been shown that the public policy exception has to be applied if the effect is that the legal paternity cannot be contested and if the case is closely connected with France.

Swedish law has in principle the same approach: in order to contest legal paternity on the basis of an acknowledgment of paternity done abroad one has to fulfil the requirements of all the legal systems referred to in $\S 8$ Lag 1985:367 om internationella faderskapsfrågor. However, one major exception renders the effect of this provision almost completely obsolete: if the annulment is sought on the basis that the acknowledger is not the biological father of the child, Swedish law can always be applied. As a consequence, in most cases the Swedish court shall reach a result that is based on Swedish law or does not differ from the result that would have been reached on the basis of Swedish law.

Under Dutch law, the establishment of legal parentage is only favoured in case of establishment of legal paternity by acknowledgment of paternity. Article 4 (1) WCA provides for four connecting factors to establish legal paternity. However, the annulment of legal paternity based on acknowledgment is neither favoured nor disfavoured. Per article 5 
WCA the annulment of legal paternity based on acknowledgment is governed by the law that governs the establishment of legal paternity by acknowledgment.

Under German private international law, the establishment as well as the annulment of legal parentage is favoured: in order to establish legal paternity all the connecting factors of article 19 EGBGB can be used and according to article 20 EGBGB all the connecting factors that establish legal paternity can be used to annul legal paternity. Like in Sweden, the aim is to allow the establishment of legal parentage of the biological parents.

A third function of additions to the main connecting factor is protecting the application of fundamental principles of the national law on parentage. In Swedish private international law the public policy is enough protection because it will be very rare that a Swedish court applies foreign law. However, under Dutch, French and German law this is different.

Under French law, the effects of apparent status are determined by French law if the child or one of the parents habitually resides in France. The aim of this rule is to guarantee the application of a fundamental principle of French law on parentage that existing family life should not be disturbed.

Under German law, the requirement of consent is subjected to an additional conflict rule. The question whether or not someone, like the mother, has to consent to an acknowledgment of paternity is governed by the laws that apply to legal parentage according to article 19 EGBGB; if no one has to consent on the basis of those legal systems, article 23 EGBGB adds the national law of the child or German law. Apparently, the German legislator attaches great weight to the consent of the mother and/or the child in matters concerning parentage.

Also, the Dutch choice of law rules on parentage have reached a high degree of materialisation. Administrative annulment of marital paternity is only possible if certain substantive requirements are satisfied: legal maternity is always established ex lege if the birthmother habitually resides in the Netherlands; Dutch nationals can only acknowledge paternity in accordance with Dutch law; the consent of the mother and the child to acknowledgment of paternity is governed by a separate conflict rule in order to protect their right to consent; the possibility to annul legal paternity on the basis of acknowledgment of paternity is not favoured as opposed to the possibility to annul marital paternity. Add to this list the situations in which the application of foreign law is overridden by the public policy exception and the question arises if it would not make more sense to substitute the choice of law rules by application of the lex fori.

Another more subtle example that shows the influence of internal law of choice of law solutions is the way in which annulment of marital paternity by an acknowledgment of paternity is solved. Legal systems like the French and the Dutch that do not allow the annulment of marital paternity by the acknowledgment of paternity of another man treat the effects of such an acknowledgment under the choice of law rule for annulment of marital paternity and not under the choice of law rule for the validity of an acknowledgment of paternity.

Under French law, the question of the annulment of marital paternity is solely governed by article 311-14 Code civil. Article 311-17 Code civil only applies to the requirements for a valid acknowledgment of parenthood, but does not determine the effect of the acknowledgment on legal paternity that exists on the basis of the law applicable per article 311-14 Code civil.

The Dutch system provides for the same solution. It has been argued above that provisions like § 1599 (2) BGB (Germany) or § 1:2 (2) Föräldrabalk (Sweden) fall within the scope of article 1 (1) instead of article 4 (1) Wet Conflictenrecht Afstamming. If the (ex) 
husband is the child's legal father on the basis of article 1 (1) WCA, it is probably not possible under the WCA to argue that an acknowledgment of paternity is valid if one of the four legal system referred to in article 4 (1) WCA provides that the acknowledgement of paternity sets aside the legal paternity that exists on the basis of the law applicable per article 1 (1) WCA.

Legal systems that do allow for the annulment of marital paternity by means of an acknowledgment of paternity are more likely to qualify the national rule as a rule determining the validity of the acknowledgment. Under German and Swedish law, the possibility to contest marital paternity by an acknowledgment of paternity is governed by the law that applies to the acknowledgment of paternity. If the law applicable to the acknowledgment of paternity contains a provision like $\S 1599$ (2) BGB or $\S 1: 2$ (2) Föräldrabalk, the acknowledgment is possible even if the existence of the legal paternity of the (ex) husband is governed by another legal system which does not know such provisions.

The effect of this characterisation is that if the acknowledgement is made in Germany or Sweden, the acknowledgment of paternity can almost always set aside marital paternity even if this is not possible according to the law that applies to marital paternity.

So far the comparative overview of the choice of law rules on parentage shows that the blind and neutral Savignian choice of law rule does not exist in the legal systems under consideration. The systems of private international law favour the establishment of legal parentage in general (Germany) or in certain situations (France, Netherlands, Sweden) and all four systems of private international law are construed in such a way that the peculiarities of the national legal systems on parentage are applied in the international case.

Next to the choice of law procedure the outcome of the international case is also influenced by the values underlying the national law on parentage by the application of the public policy exception, sometimes in combination with article 8 ECHR.

In German and Swedish private international law on parentage the role of the public policy exception is limited. In Sweden, this can be explained by the fact that the choice of law procedure already guarantees that the solutions in an international case are based on or at least in conformity with Swedish law. In German private international law the choice of law rules often allow the choice between different legal systems for establishment and annulment of legal parenthood in order to reach the objective of the choice of law rule, i.e. establishment of legal parenthood and to advance a parallel between legal and biological parentage. As a result, both in German and Swedish private international law on parentage one does not need a correcting mechanism.

This is different in Dutch and French private international law. First of all, not all elements of the parental status are favoured, only acknowledgment of parenthood and secondly, the starting point is that the national law applies to legal parentage. The effect of the nationality as a connecting factor as opposed to domicile or habitual residence is that one has to apply foreign law more often. The effect of the absence of a favoured approach is that public policy exception becomes more important. 


\section{Recognition of legal parentage}

In the first part of this chapter questions of jurisdiction and applicable law concerning the establishment of legal parentage in an international case have been examined. However, from the perspective of free movement of persons the question is raised whether legal parentage that has been established in one Member State is recognised in another Member State. A key element of this question is when a legal system considers legal parentage to be established. In this chapter it will be examined to what extent legal parentage that has been established abroad will be recognised under the national systems of private international law under consideration. A general distinction is made for legal parentage that is laid down in a judgment and legal parentage that is not laid down in a judgment.

\subsection{Recognition of legal parentage in foreign judgments}

\subsubsection{Recognition of foreign judgments on parentage under Dutch law}

Foreign judgments in the Netherlands are recognised automatically, without any formal procedure if they fulfil the requirements for recognition. ${ }^{1047}$ Article 1:20b BW allows the Dutch registrar of civil status to record the foreign judgment affecting the personal status on the relevant register of civil status in the Netherlands. For judgments on legal parentage specifically, the requirements of article 9 Wet Conflictenrecht Afstamming (WCA) also have to be fulfilled. Thus a foreign judgment establishing legal paternity can be included in the birth record of the child in the Netherlands.

The registrar of civil status decides independently on the mention of the foreign judgment; there is no supervision by the public prosecutor's office (openbaar ministerie) anymore. In case of doubt, the civil status registrar can ask the Advisory Commission on Civil Status and Nationality for advice. ${ }^{1048}$

According to article 1:20b BW, the requirements for a foreign judgment to be recorded on a Dutch register of civil status are that the judgment is rendered by a competent authority in accordance with local rules and that it does not violate Dutch public policy. The requirement that the judgment must have been rendered by a competent authority in accordance with local rules only means that the court must have been empowered according to the laws of its own country to render the judgment. ${ }^{1049}$ Whether or not the judgment violates Dutch public policy has to be determined in light of article 9 WCA.

The record of the foreign judgment by the civil status registrar is not final. The record can be deleted by court order upon request of the public prosecutor's office or an interested party if it appears that the foreign judgment does not fulfil the requirements for recognition. 1050 In order to achieve certainty on the recognition of a foreign judgment on personal status any interested party can apply for a declaration that the foreign judgment can be recognised. ${ }^{1051}$

The requirements for the recognition of a foreign judgment establishing legal parentage, whether or not in relation with article 1:20b BW, are determined by article 9 of the WCA. It

\footnotetext{
1047 Strikwerda 2008, nr. 270; Verheul 1989, p. 61, 67.

1048 Articles 1:29-29f BW.

1049 See note 1186 .

1050 Article 1:24 (1) BW.

1051 Article 1:26 (1) BW.
} 
states that an irrevocable foreign judicial decision whereby legal familial ties on account of parentage are established or altered shall be recognised in the Netherlands. Whether or not the judgment is irrevocable has to be determined according to foreign law, just like the question whether or not the foreign authority is a judicial authority. Foreign law also determines whether or not legal familial ties haven been established by means of the judgment. ${ }^{1052}$

Article 9 (1) WCA formulates three exceptions to the rule that foreign judgments on parentage shall be recognised. First of all, a foreign judgment shall not be recognised if the foreign court did not have jurisdiction. The WCA does not provide a list of possible grounds for jurisdiction; there should have been an internationally accepted basis for the jurisdiction of the foreign court. ${ }^{1053}$ This is obviously the case if the foreign court accepted jurisdiction on a basis on which the Dutch court also would accept jurisdiction, but it does not need to be. 1054

The second exception to the recognition of the foreign judgment is that the foreign court did not base its decision on a proper procedure. The exception guarantees that the party that did not institute the proceeding is informed of the proceeding, that he had a reasonable opportunity to defend himself and that there was a thorough investigation into the arguments of the parties. ${ }^{1055}$ Thus a Swedish judgment violated Dutch public policy because is it was established that the Swedish court did not officially inform the man of the proceedings against him. It was also not proven to the satisfaction of the court that the man had knowledge of the proceedings. ${ }^{1056}$

The third exception to recognition of the foreign judgment is that it manifestly violates Dutch public policy. There are not many cases where a Dutch court held on the basis of article 9 WCA that a foreign judgment on the establishment or annulment of legal parenthood was in violation of Dutch public policy. One example is from the rechtbank 'sGravenhage from 2009. The court refused to recognise a Californian decision holding that two men were the legal parents of the child, because the decision did not establish the legal maternity of the surrogate mother. ${ }^{1057}$ This decision will be discussed in more detail below at the recognition of foreign instruments of civil status under Dutch law.

The second paragraph of article 9 (2) WCA explicitly states that the foreign judgment on parentage does not violate Dutch public policy on the sole ground that another law has been applied than would have been applied in a Dutch procedure.

The final exception to recognition exists if the foreign judgment is irreconcilable with an irrevocable decision of a Dutch court as regards the determination or alteration of the same legal familial ties. It seems reasonable to assume that the final exception only applies if the foreign decision has been rendered after the Dutch decision. ${ }^{1058}$

\subsubsection{Recognition of foreign judgments on parentage under English law}

Under English law there are no statutory rules on the recognition of foreign judgments on parentage or legitimacy. Also at common law no specific rules for the recognition of such decrees have been developed. In order to examine how foreign decrees on paternity are treated, it is recalled that abroad a person can obtain various kinds of decrees establishing (or contesting) parentage. The foreign decree can be a free standing order which is solely

\footnotetext{
1052 Vonken (Personen- en familierecht. Het internationale afstammingsrecht), article 9 WCA, aant. 1.1.

1053 Vonken (Personen- en familierecht. Het internationale afstammingsrecht), article 9 WCA, aant. 1.3.2; Strikwerda 2008, nr. 270.

1054 See $\$$ 5.2.1. International jurisdiction of courts under Dutch law.

1055 Strikwerda 2008, nr. 270

1056 Hof 's-Gravenhage 20 November 2002, NIPR 2003/4.

1057 Rechtbank 's-Gravenhage, 23 November 2009 (328511/FA RK 09-317) (not published).

1058 Vonken (Personen- en familierecht. Het internationale afstammingsrecht), article 9 WCA, aant. 1.6.
} 
about the establishment or annulment of legal paternity. The foreign decree can also establish (or contest) paternity for the purpose of something else, like maintenance or inheritance.

In England and Wales, one can do basically two things with the foreign decrees. First, one could rely on the foreign decree to amend the English birth record of the child or one could submit the foreign decree as evidence of paternity in an English procedure where the establishment of paternity is relevant. Second, if the foreign court established the paternity of a man to determine the applicant's right to maintenance, the applicant in England will probably apply for the recognition and enforcement of that maintenance decree.

\subsubsection{Foreign judgments on parentage as evidence of paternity}

In the Netherlands an Englishman begets a child with a Dutch woman. After the child's birth the man does not acknowledge his paternity and leaves for England. The woman applies to a Dutch court for judicial establishment of the legal paternity of the English national (art. 1:207 Dutch Burgerlijk Wetboek). The Dutch court has international jurisdiction since the applicant habitually resides in the Netherlands (art. 3 (1) Dutch Wetboek van Burgerlijke Rechtsvordering) and it shall apply Dutch law since the mother and the alleged father do not have a common nationality (art. 6 Dutch Wet Conflictenrecht Afstamming). The legal paternity of the Englishman is established. Since the man has left for England, the Dutch mother sues the man in England for the payment of maintenance. In the judicial procedure before the English court, the mother submits the Dutch judgment as evidence of the man's paternity. Is the English court bound to accept the decision of the Dutch court that the Englishman is the legal father of the child?

If the applicant in an English procedure invokes the foreign judgment establishing legal paternity, the applicant is pleading that the judgment is res judicata and as such raises an estoppel against the unsuccessful party. ${ }^{1059}$ The effect of the estoppel raised by a foreign judgment establishing legal paternity is that the parties cannot deny the existence of legal paternity and the grounds (facts) on which the decision is based in a subsequent procedure. ${ }^{1060}$ The foreign judgment is res judicata if it is recognised in England. ${ }^{1061}$

For the requirements for recognition of foreign judgments, English legal doctrine distinguishes between foreign judgments in rem and in personam.1062 $\mathrm{A}$ judgment is in rem if it is a judgment of a court of competent jurisdiction determining the status of a person or thing or the disposition of a thing.' All other judgments are in personam. ${ }^{1063}$ Foreign judgments establishing the legal parentage of a child are thus judgments in rem because they affect or determine the status of the child. ${ }^{1064}$

A judgment in rem will be recognised if it has been given by a court which is internationally competent to do so. 1065 This also applies to foreign decrees on parentage.1066 There are no established criteria to determine the international jurisdiction of a foreign court to determine a child's parentage. It has been held though that the English courts should recognise in any event a jurisdiction which they mutatis mutandis claim for themselves. ${ }^{1067}$

\footnotetext{
1059 North, Fawcett \& Carruthers 2008, p. 516, 544. See also Tapper 2004, p. 93, note 97.

1060 Tapper 2004, p. 95.

1061 On the relationship between recognition of foreign judgments and res judicata see Barnett 2001.

1062 Cf. North, Fawcett \& Carruthers 2008, p. 516 and 534; Collins 2006a, nr. 14R-018, 14R-048, 14R-099.

1063 North, Fawcett \& Carruthers 2008, p. 532; Tapper 2004, p. 94, 95.

1064 North, Fawcett \& Carruthers 2008, p. 533. See also MacFarlane v. Macartney [1921] 1 Ch. 522 where Astbury J. observed that the declaration as to paternity in a Maltese affiliation order 'determines the status of a child and is clearly in rem.'

1065 North, Fawcett \& Carruthers 2008, p. 534.

1066 Norrie 1994, p. 760.

1067 Re Valentine's Settlement [1965] Ch 831, CA [1965] 2 All ER 226 (with regard to recognition of adoption); Travers $v$. Holley, [1953] P. 246, [1953] 2 All ER 794 (with regard to recognition of divorce).
} 
With regard to foreign declarations on parentage that means that they are recognised if at least one of the parties was either domiciled or habitually resident in the country of the court that gave the declaration. 1068

Despite the fact that the declaration on parentage has been given by a court with international jurisdiction, the judgment can be refused recognition on the basis of one of the grounds for non-recognition. The grounds that could be of relevance in relation to foreign decrees on parentage are that that the foreign judgment is obtained by fraud; that the foreign judgment is contrary to the public policy of English law; that the foreign judgment is obtained in breach of article 6 ECHR; that the foreign judgment concerns the enforcement of foreign revenue, penal or public laws; that the foreign judgment is contrary to natural justice; that the foreign judgment is on a matter previously determined by an English court; or that the judgment is on a matter previously determined by another foreign court. ${ }^{1069}$

A foreign decree on parentage as such cannot be used as a basis for the re-registration of a child's birth. Section 14A Births and Deaths Registration Act 1953 only allows the reregistration of a birth pursuant to a declaration of parentage on the basis of section 55A or 56 Family Law Act 1986. The General Register Office explained that if a person submits a foreign judgment establishing legal parentage he or she shall have to obtain a declaration of parentage on the basis of that foreign judgment in a procedure under section 55A Family Law Act 1986. On the basis of the English declaration, the English birth record can be amended. 1070

The fact that foreign judgments on parentage cannot be used to re-register a birth of a child born in England at first sight suggests that there is no automatic recognition of foreign decrees on personal status. However, this is only true in case of re-registration of births. In a procedure in an English court the foreign judgment can be invoked to plead an estoppel without the necessity to follow some kind of recognition procedure. This will be shown under the next heading.

\subsubsection{Recognition of judicial establishment of paternity in relation with foreign decrees on maintenance or succession}

If a foreign court has determined the parentage of a child in the course of a procedure on maintenance or succession, the recognition in England of the parentage is not an independent issue. Two examples are provided.

In Doglioni v Crispin (1866) Francisco Jose Crispin obtained a decree from the court of Faro (Portugal) in 1853 declaring that he was the illegitimate son of Henry Crispin and that he was entitled to his father's estate. ${ }^{1071}$ The sister of Henry Crispin, Maria Doglioni, appealed to the highest court in Portugal, but the judgment was upheld. For the purpose of this thesis it must be noted that there was one judgment both establishing the paternity of Henry Crispin as well as declaring that Francisco was entitled to the estate of Henry Crispin. ${ }^{1072}$

In England, Francisco instituted proceedings against Maria Doglioni and her husband for the part of the estate that was in England. Maria disputed that Francisco was the son of her brother and that even if he would be his son he would not be entitled to the estate.

In the Court of Probate the question whether Francisco was the son of Henry Crispin was decided not on the basis of the recognition of the foreign judgment but by a special jury.

\footnotetext{
1068 Cf. section 55A (2) Family Law Act 1986.

1069 North, Fawcett \& Carruthers 2008, p. 146-149, 551-569.

1070 E-mail from the General Register Office of the 15 th of April 2009.

1071 (1866) LR 1 HL 301. See also Trafford v Blanc (1887) LR 36 Ch D 600.

1072 In 1852 another Portuguese court already declared that Francisco was the illegitimate son of Henri Crispin. However, this free standing establishment of paternity is not relied upon in the English procedure.
} 
The Lord Chancellor stated in this regard that 'I hardly understand why the fact of the Respondent being the natural son of Henry Crispin, which was the very foundation of the whole claim in the Courts in Portugal, and which was established to the satisfaction of the foreign court, and entered into and formed part of the judgment, was singled out for trial.' Apparently the legal paternity of Henry Crispin had to be recognised with the rest of the Portuguese judgment.

Lord Cranworth held that the decision of the Portuguese courts 'is absolutely binding on the Courts of this country.' He continues to observe that the issue of paternity has been tried by a special jury. Only with regard to the property issues he discusses the requirements for recognition, especially the requirement that the Portuguese court had to have jurisdiction: 'no principle can be better established then that the administration of the personal estate of a deceased person belongs exclusively to the country in which he is domiciled at his death.' This statement only relates to the property part of the Portuguese judgment and not to the part on the personal status of the child.

The situation in MacFarlene v. Macartney (1921) was similar to Doglioni v Crispin. ${ }^{1073}$ In MacFarlene $v$. Macartney the fiancée of the deceased applied in Malta for a declaration that the deceased was the father of her child and that therefore the child had a right to an alimentary allowance from the estate of the deceased. The Maltese Court of Appeal granted the declaration in 1920. In England the question arose whether the child could enforce the alimentary allowance.

Just as in Doglioni $v$ Crispin, the case is about a foreign judgment containing both the judicial establishment of paternity as well as something else, in this case a right to an alimentary allowance. In discussing the possibility to recognise the judgment, the court focuses exclusively on the alimentary allowance. Requirements for the recognition of the establishment of paternity by the Maltese Court are not discussed. Judge Astbury only observes that 'the declaration as to paternity determines the status of the child and is clearly in rem, but so far as the judgment imposes any obligation on the assets to meet the 751 a year maintenance, it is, notwithstanding its language, a mere judgment in personam [...].'

The judge recognised that the establishment of parentage and the maintenance are two separate parts. However, since the applicant seeks the recognition and enforcement in England of the maintenance obligation it is apparently not necessary to discuss the possibility to recognise the judicial establishment of paternity.

\subsubsection{Recognition of foreign judgments on parentage under French law}

In France, foreign judgments concerning personal status are recognised automatically if they fulfil the requirements for recognition. ${ }^{1074}$ The requirement of a special procedure for recognition of foreign judgments on personal status would make the personal status of people uncertain and it would disturb the social order. ${ }^{1075}$ The only requirement to use a foreign judgment in France is that the judgment is legalised and translated. Consequently, a foreign judgment on the legal parentage can be mentioned on the birth record of the person involved in France without the permission of a French court. ${ }^{1076}$

The decision to record a foreign judgment on a French register of civil status is taken by the Procureur de la République of the district where the recording is requested. The Procureur examines whether the judgment fulfils the requirements for recognition. ${ }^{1077}$ The

\footnotetext{
1073 [1921] 1 Ch. 522.

1074 Audit 2008, nr. 482; Mayer \& Heuzé 2007, nr. 399. Instruction générale relative à l'état civil du 11 mai 1999, nr. 582, Journal Officiel $\mathrm{n}^{\circ} 172$ du 28 juillet 1999.

1075 Audit 2008, nr. 482.

1076 Instruction générale relative à l'état civil du 11 mai 1999, nr. 584, Journal Officiel nº 172 du 28 juillet 1999.

1077 Instruction générale relative à l'état civil du 11 mai 1999, nr. 585, Journal Officiel nº 172 du 28 juillet 1999.
} 
decision to allow a foreign judgment to be recorded on a French register of civil status does not have force of law and can be contested.

In order to remove all doubt and to establish with force of law whether or not the foreign judgment has effect in France, persons involved can start an action en exequatur or an action en inopposabilité. ${ }^{1078}$ Originally an action en exequatur is only used to obtain permission to execute a foreign judgment. 1079 However, the Cour de Cassation also allows the procedure to establish whether or not the foreign judgment can be recognised in France.1080

An action en inopposabilite is the opposite of an action en exequatur and the aim for the application is to obtain a declaration that the foreign judgment cannot be invoked in France against the applicant. 1081

The recognisability of a foreign judgment can also be established as an incidental issue in another procedure. ${ }^{1082}$ Thus, the recognisability of a foreign judgment establishing legal parentage can, for example, be judged in a procedure on nationality, inheritance or maintenance. ${ }^{1083}$

The requirements for recognition of a foreign judgment are not codified, but established by the Cour de Cassation. In Cornelissen $v$ Avianco Inc, the Cour de Cassation held that the three conditions for recognition of a foreign judgment are that the foreign court had international jurisdiction, that the foreign judgment does not violate French public policy and that the foreign judgment does not constitute a fraude à la loi.1084

With its decision in Cornelissen the Cour de Cassation removed the requirement that the foreign court should have rendered a decision in conformity with the law that would be applicable according to the French choice of law rule. ${ }^{1085}$

The first requirement that the foreign court has international jurisdiction has been explained in Simitch.1086 The Cour de Cassation held that the foreign court has jurisdiction if the jurisdiction of the French court in the matter is not exclusive, if the dispute is connected with the country of the foreign court in a 'characteristic' manner and if the choice for the foreign court was not fraudulent.

The requirement that the jurisdiction of the French court in the matter is not exclusive used to be a considerable hurdle for the recognition of a foreign judgment in France. Article 15 Code civil provides that a French national can be summoned before a French court with regard to contracts concluded abroad even with foreigners. Notwithstanding the wording of the article, it extends over all areas of private law including the law on parentage. ${ }^{1087}$

It used to be standing case law that article 15 Code civil gave the French courts exclusive jurisdiction over French nationals, if the French national did not renounce his right to be sued in France. ${ }^{1088}$ The rule also applied to judgments on parentage. However, in Prieur (2006) the Cour de Cassation held that article 15 Code civil did not establish an

\footnotetext{
1078 Instruction générale relative à l'état civil du 11 mai 1999, nr. 582, Journal Officiel nº 172 du 28 juillet 1999. 1079 Article 509 Code de procédure civil.

1080 Audit 2008, nr. 497; Mayer \& Heuzé 2007, nr. 412; Niboyet \& De Geouffre de la Pradelle 2007, nr. 630-2, 652, 653.

1081 Audit 2008, nr. 496; Mayer \& Heuzé 2007, nr. 407; Ancel \& Lequette 2006, nr. 24-25.

1082 Audit 2008, nr. 494; Niboyet \& De Geouffre de la Pradelle 2007, nr. 630-2.

1083 See for example Cour d'Appel de Versailles, 30 November 2006, nr. 05/07895 on the recognition of a Tunesian judgment establishing paternity in a dispute on succession in France.

1084 Cass. Civ. 1er, 20 February 2007, D 2007, 1115; RCDIP 2007, 420.

1085 Cuniberti 2007, p. 938; Mayer \& Heuzé 2007, nr. 364, 385; Niboyet \& De Geouffre de la Pradelle 2007, nr. 664.

1086 Cass. Civ. 1er, 6 February 1985, D 1985, 469; RCDIP 1985, 369.

1087 See § 5.2.3. International jurisdiction of courts under French law.

1088 Audit 2008, nr. 470; Mayer \& Heuzé 2007, nr. 376.
} 
exclusive ground of jurisdiction excluding the jurisdiction of the court of a country with which the dispute is characteristically connected. 1089

The second requirement for the jurisdiction of the foreign court is that the dispute must be characteristically connected with the country of the foreign court. The Cour de Cassation does not provide hard and fast criteria to determine the existence of such a characteristic connection. It has to be established on the basis of all the relevant facts in the case at hand whether or not there was a characteristic connection.

In Simitch the question was whether the English courts had jurisdiction to rule on a divorce between a British national, Mrs Fairhurst and an American national, Mr Simitch. The Cour de Cassation held that a characteristic connection existed because Mrs Fairhurst was a British national, she lived in Britain, Mr Simitch had property in Britain, Mr Simitch and Mrs Fairhurst were married in Britain and they had their matrimonial home there.

In Prieur the question was about the recognition in France of a Swiss divorce judgment. In this case the characteristic connection existed because both the man and woman were both born in Switzerland, they married in Switzerland, Swiss law applied to their marriage contract and they were residents there.

The third requirement for jurisdiction of the foreign court is that the choice for the foreign court is not fraudulent. The concept of fraud in French private (international) is unknown to Anglo-Saxon private international law. ${ }^{1090}$ In French private international law the choice for the foreign court is fraudulent when 'one pleads abroad with the principle aim to invoke the judgment in the country where one lives and where the courts would have refused to render that judgment; fraud means that one tries to get something indirectly, what one cannot get directly.' 1091

It has been argued that the importance of the examination of fraud in a particular case will increase now the Cour de Cassation abolished the requirement that the foreign judgment should be based on the law that would have been applicable according to French choice of law rules. ${ }^{1092}$

The second requirement for the recognition of the foreign judgment is that the judgment should not violate French public policy. The requirement includes both substantive as well as procedural public policy. 1093

With regard to legal parentage, a proper procedure means inter alia that the establishment of paternity is based on solid evidence. The judicial establishment of legal paternity solely on the basis of a declaration of the mother that the man is the child's father is not enough, not even if the alleged father refused to appear in court. ${ }^{1094}$ However, the statement of the mother was enough evidence in combination with the refusal of the man to cooperate with a comparative blood test. 1095 Also, the statement of the mother in combination with a comparative blood test was enough evidence. ${ }^{1096}$

\footnotetext{
1089 Cass. Civ. 1er, 23 May 2006, D 2006, 1846; RCDIP 2006, 871, JDI 2006, 1365. See also Audit 2008, nr. 470; Mayer \& Heuzé 2007, nr. 376.

1090 Tetley 1994.

1091 Mayer \& Heuzé 2007, nr. 393.

1092 Cuniberti 2007, p. 938; Niboyet \& De Geouffre de la Pradelle 2007, nr. 669.

1093 Cass. Civ. 1er, 4 October 1967, RCDIP 1968, 98, note Lagarde. Mayer \& Heuzé 2007, nr. 384; Niboyet \& De Geouffre de la Pradelle 2007, nr. 666; Audit 2008, nr. 474.

1094 Cass. Civ. 1er, 10 March 1982, RCDIP 1982, 724; Cass. Civ. 1er, 17 February 1982, Bull. civ. 1982, nr. 75.

1095 Cass. Civ. 1er, 3 April 1990, Bull. civ. 1990, nr. 80. See also Guiho 1991, nr. 25-27.

1096 Cass. Civ. 1er, 16 November 1983, Bull. civ. 1983, nr. 271. See also Mayer \& Heuzé 2007, nr. 384.
} 
With regard to personal status, it has been argued that a foreign judgment on the personal status of French national that is not based on French law runs the risk to violate French public policy. ${ }^{1097}$ The application of French law to matters of personal status of French nationals used to be guaranteed by the requirement that the foreign judgment should be based on the law that would have been applicable according to French choice of law rules, but that rule has been abolished by the Cour de Cassation in Cornelissen $v$ Avianco Inc.

The final requirement for the recognition of the foreign judgment is that the judgment does not constitute a fraude à la loi. It has been pointed out that this requirement is hard to reconcile with the abolition of the requirement that the foreign judgment should be based on the law that would have been applicable according to French choice of law rules. 1098 After all, if there is no obligation to apply the law of a certain legal system, it is also not possible to evade the application of that law. Niboyet and De Geouffre de la Pradelle write that the requirement simply means that the foreign judgment should be free of fraud, which includes all kinds of fraud like fraude au jugement, fraude aux droits d'autrui, fraude à la loi.1099

An example of fraud with regard to legal parentage is the case of Mennesson. ${ }^{1100}$ In this case two French nationals contacted a surrogate mother in California. Pursuant to a court order of a Californian court they were mentioned as the parents of the child who were born to the Californian surrogate on the birth certificate of the child. The Californian order violates French public policy, 1101 but it also constitutes a fraud: the French nationals only go to California to obtain a result that cannot be obtained in a French court.

A requirement for the recognition of a foreign judgment, which is not mentioned in Cornelissen $v$ Avianco Inc, is that the foreign judgment should not be irreconcilable with another earlier judgment. ${ }^{1102}$

\subsubsection{Recognition of foreign judgments on parentage under German law}

Under German private international law a foreign judgment shall be recognised automatically if the judgment fulfils the requirements for recognition. It is not necessary to start some kind of recognition procedure. 1103

The civil status registrar can mention a foreign judgment on establishment or annulment of legal parenthood on the birth record of the child, if the judgment fulfils the requirements for recognition. ${ }^{1104}$ The Verwaltungsbehörde examines whether the foreign judgment has legal effect, whether the decision has erga omnes effect and whether the requirements for recognition are satisfied.1105

The decision of the Verwaltungsbehörde is not binding. In order to get a conclusive decision on the recognisability of the foreign judgment, the person involved can start a procedure on the basis of $\S 108$ (2) Familienverfahrensgesetz.

If the recognition of foreign judgments on legal parentage is not regulated by a bilateral treaty, ${ }^{1106}$ the grounds for non-recognition are mentioned in § 109 Familienverfahrensgesetz.

\footnotetext{
1097 Mayer \& Heuzé 2007, nr. 389.

1098 Mayer \& Heuzé 2007, nr. 391, 392; Niboyet \& De Geouffre de la Pradelle 2007, nr. 669.

1099 Niboyet \& De Geouffre de la Pradelle 2007, nr. 668.

1100 Cour d'appel de Paris, 25 October 2007, nr. 2006/507.

1101 Article 16-7 and 16-9 Code civil.

1102 Mayer \& Heuzé 2007, nr. 450; Niboyet \& De Geouffre de la Pradelle 2007, nr. 670-675.

$1103 \S 108$ (1) Familienverfahrensgesetz.

$1104 \S 27$ (1) Personenstandsgesetz.

$1105 \S 286$ Dienstanweisung für die Standesbeamten und ihre Aufsichtsbehörden.

1106 For an overview of the different bilateral treaties see Staudinger/Henrich 2008, Article 19 EGBGB, nr. 115; Article 20 EGBGB, nr. 100.
} 
The first requirement for the recognition of a foreign judgment on parentage is that the foreign court had international jurisdiction to hear the case. $\S 109$ (1) under 1 Familienverfahrensgesetz explicitly provides that the foreign court must have had jurisdiction according to the German jurisdiction rules.1107 The grounds for jurisdiction in matters concerning parentage are mentioned in § 100 Familienverfahrensgesetz. ${ }^{1108}$

Furthermore, $\S 109$ provides that the foreign judgment can be refused recognition if the defendant or the respondent did not appear in the foreign proceeding and has not been properly informed about the proceeding. Also, if the foreign decision conflicts with a recognised judgment or a German judgment, which has been rendered before the date of the judgment at issue, the foreign judgment shall not be recognised.

Finally, the foreign judgment shall not be recognised if the effect of the recognition leads to a result which is incompatible with German public policy, especially with regards fundamental rights. The public policy exception in case of recognition of foreign judgments encompasses substantive as well as procedural public policy. The fact that the foreign court established biological paternity on the basis of something other than a DNA test as such does not violate public policy. ${ }^{1109}$ However, if on the one hand the alleged father denied having had sexual intercourse with the mother, if he stated that the mother had had sexual intercourse with several men during the conception period because of prostitution and if he offered to cooperate with a DNA test, while on the other hand the testimony of the mother of the child's mother is the only evidence on which the foreign (Polish) court established the man's paternity, the judgment would violate German public policy. ${ }^{1110}$

\subsubsection{Recognition of foreign judgments on parentage under Swedish law}

The recognition of a foreign judgment on parentage that has been given by a competent court shall be recognised automatically in Sweden. ${ }^{1111}$ If the judgment concerns a person who is registered in the Swedish population register, it is the skatteverket (tax authority) who checks whether the foreign judgment on parentage fulfils the requirements for recognition and whether it can be recorded on the record of the person involved.1112

If there is doubt about the recognition of the judgment in Sweden, a party to the foreign proceeding whose right is in question or the Swedish authority that has to decide on the question can apply to the Swedish Court of Appeal for a declaration on the recognisability of the foreign judgment. 1113 The Swedish Högsta Domstol extended the circle of applicants to the heirs of the deceased father in a case for the recognition in Sweden of a judicial establishment of a deceased man by a court from Madagascar. ${ }^{1114}$

Foreign judgments on the establishment or annulment of legal paternity shall be recognised in Sweden if the requirements of $\S 7$ (1) of the Act on International Paternity Questions (1985:367) are fulfilled. The starting point on the recognition of foreign judgments in Sweden is the same as under English private international law: a foreign judgment on parentage shall be recognised if with a view to the residence or the nationality of the parties or another connection, there were sufficient reasons for the foreign court to accept jurisdiction.

The Swedish legislator recognised that various European legislations have more extensive grounds for jurisdiction in matters concerning parentage than Swedish law. For

\footnotetext{
1107 Hepting \& Gaaz 2006a, § 29, nr. 52.

1108 See § 5.2.4. International jurisdiction of courts under German law.

1109 For an overview of the case law see Staudinger/Henrich 2008, Article 19 EGBGB, nr. 123.

1110 Bundesgerichtshof, 26 August 2009, FamRZ 2009, 1816.

$1111 \S 7$ Lag (1985:367) om internationella faderskapsfrågor.

1112 Prop. 1984/85:124, p. 62. See also Socialstyrelsen 2005, p. 85.

1113 § 9 Lag (1985:367) om internationella faderskapsfrågor.

1114 Högsta Domstolen 1 April 1999, NJA 1999, 181. See also Pålsson 2006, nr. 3.128.
} 
example, the nationality or residence of the child's mother or the nationality of the child or the legal father may serve as a sufficient ground for jurisdiction. The fact that the foreign court founded its jurisdiction on a ground which is not known under Swedish law is not enough to refuse the recognition of the judgment in Sweden. ${ }^{1115}$

The exceptions to recognition are mentioned in $\S 7$ (2). First of all, the foreign judgment shall not be recognised if the respondent did not defend him or herself and if he or she was not informed of the proceedings in due time or if the respondent for other reasons has not been given the opportunity to plead his case. The point is that the respondent must be informed of the fact that proceedings are brought against him or her. If the respondent has defended him or herself he or she apparently knew about the proceedings. Therefore, the exception is limited to those cases where it appears from the judgment that the respondent has not defended him or herself.1116

The Swedish Högsta Domstol discussed the first exception in 1999. A court in Madagascar established the legal paternity post mortem of a Swedish national who lived in Sweden during his life, on the application of the child's mother who lived in Madagascar.1117 In Madagascar, the suit was directed against the father of the deceased putative father. The court established the legal paternity of the deceased on the basis of documents that proved the existence of an intimate relationship between the mother and the deceased during the conception period.

In Sweden, the daughter of the deceased objected to the recognition of the judgment. It was argued that the father of the deceased was not properly informed of the procedure and was not given enough time to defend himself. According to the Swedish Högsta Domstol this was immaterial. It appeared from the text of the foreign judgment that the father had been heard. Moreover, the fact that the father at the relevant time knew about the proceeding and the statement of the father in the Swedish court that he was convinced that his son was the father made it unnecessary to examine whether the father was properly informed and had enough time to prepare his defence.

In 2008 the first exception was also raised in the context of the recognition of a judgment on paternity from a Croatian court.1118 In 1964 the court of Pula (Croatia) held that a certain JZ was the legal father of a girl AM. The father died in 2003 and his widow and her daughter EN object to the recognition of the Croatian judgment in Sweden. They argue that JZ has not been summoned correctly and that he did not defend himself during the court proceedings, nor did he appoint a representative to plead his case.

The Högsta Domstol observed that $§ 7$ (2) first indent applies to serious shortcomings in the foreign procedure that have as an effect that the defendant did not have the opportunity to plead his case. In order to determine whether the foreign judgment was the result of such a defective judicial procedure, the court examines what the position of the defendant would be under Swedish law.

If the residence of the defendant in a paternity suit is unknown, the court shall appoint a special representative to look after the interests of the alleged father. In such a case, the absence of the defendant during the proceeding cannot preclude that the judgment can be invoked against him.

In the case at hand, the judgment from Croatia mentioned that the residence of the alleged father was unknown and that the mother of the defendant had been appointed as his representative. On her turn the mother appointed another representative to plead on

\footnotetext{
1115 Prop. 1984/85:124, 29/30. Walin \& Vängby vol. II, Avd. 1 I:11.

1116 Prop. 1984/85:124, 57. Walin \& Vängby vol. II, Avd. 1 I:36.

1117 Högsta Domstolen 1 April 1999, NJA 1999, 181. See also Pålsson 2006, nr. 3.128.

1118 Högsta Domstolen 5 May 2008, NJA 2008, N 31.
} 
behalf of her son and according to the judgment that person indeed objected to the establishment of the man's paternity. Nevertheless, the Croatian court came to the conclusion that the man was the father of the child and established his legal paternity.

Taken into account these circumstances, the Högsta Domstol held that JZ was deemed to have pleaded his case and that the Croatian judgment could not be denied recognition on the ground that JZ was not summoned correctly and that he did not appear in person during the proceedings.

According to the second, the third and the fourth indent of $\S 7$ (2) the foreign judgment shall not be recognised if it contradicts a Swedish judgment, or another foreign judgment that is recognised in Sweden and of which the legal proceeding had been started earlier, or if it contradicts a valid establishment of paternity in another form then a judgment and if that establishment had been done before the foreign proceeding begun, for example establishment of paternity by means of acknowledgment.

On the basis of the fifth and the sixth indent of $\S 7$ (2) the foreign judgment shall not be recognised if a legal proceeding is pending in Sweden or if a legal proceeding is pending abroad and if the foreign proceeding can result in a judgment that shall be recognised in Sweden.

In addition to the ground for refusal in $\S 7$ (2), the foreign judgment shall not be recognised if it violates Swedish public policy (\$ 12). A foreign judgment on parentage may violate Swedish public policy if the man is not the biological father of the child. The fact that foreign law has been applied that is strange or unacceptable from a Swedish perspective cannot lead to the conclusion that the judgment itself violates Swedish public policy. ${ }^{1119}$

In the Madagascar case referred to above, the Swedish Högsta Domstol held that the fact that the heir of the deceased putative father was not able to express her view in the foreign proceeding does not violate Swedish public policy, although under Swedish law such a case would have to be directed against the heir. ${ }^{1120}$

Also, the fact that the foreign court did not establish the legal paternity on the basis of a DNA test is not enough to offend Swedish public policy. After all § 1:5 Föräldrabalk (1949:381) also allows the Swedish court to establish legal paternity without a DNA test on the basis of legal presumptions. ${ }^{1121}$

\subsection{Recognition of legal parentage in foreign documents}

In each legal system there is an obligation to register the birth of a newborn child. If the legal parentage does not exist automatically or ex lege, it has to be established. Also, out of court, the establishment of legal parentage requires the involvement of a public official. This public official can be a civil law notary, a registrar of civil status or an institution like the socialnämnd or the tax authority. These institutions have three things in common: they are public authorities, they are not courts and their involvement in the establishment of legal parentage is mandatory.

The official procedures concerning the establishment of legal parentage produce different kinds of official or public documents. The most important documents are the birth certificate and the instrument of acknowledgement of paternity or maternity. In the end the objective of these documents is to serve as evidence of the child's birth and of the legal parentage of the child.

1119 SOU 1983:25, p. 143; prop. 1984/85:124, p. 31.

1120 Högsta Domstolen 1 April 1999, NJA 1999, 181.

1121 Högsta Domstolen 5 May 2008, NJA 2008, N 31. 
On the basis of the assumption that that in every country legal parentage is officially documented by documents drawn up by or with the assistance of public officials the Dutch legislator introduced a recognition method in Dutch private international law on parentage. In the other legal systems such a recognition system is lacking. There, the 'recognition' of parentage that is not laid down in a court judgment depends on the lex causae.

In this paragraph first the way in which the recognition method in matters concerning legal parentage has been worked out in Dutch private international law will be examined. With regard to the other legal systems being considered it will be examined how they solve the issues that in Dutch private international law are solved by the recognition method.

\subsubsection{Recognition of legal parentage under Dutch private international law}

\subsubsection{Background of the Dutch recognition rules on legal parentage}

Each time legal parentage is established abroad, the question can arise whether it also exists in the Netherlands. Whether or not the question will come up depends on the instances where parentage is relevant. Thus, the question of recognition of legal parentage that has been established abroad can arise in relation with maintenance or inheritance if a person claims rights on the basis of his legal affiliation with the alleged debtor or the deceased.

However, in Dutch practice it seems that maintenance and inheritance are not the areas of law where the recognition of parentage often leads to problems or disputes. In practice, the recognition of legal parentage that has been established abroad raises problems especially in relation to claims to Dutch nationality and in relation to registration of persons and personal status.

With regard to claims to Dutch nationality it is relevant to mention that the starting point of Dutch nationality law is that a child acquires Dutch nationality if one of his legal parents is Dutch. ${ }^{1122}$ The concepts of mother and father for the purpose of Dutch nationality law are defined in article 1 under c and d of the Rijkswet op het Nederlanderschap 1984 (Dutch Nationality Act 1984). The mother of the child is the woman who gave birth to the child and the father of the child is the man with whom the child has a legal familial tie in the first degree in the ascending line. Whether or not a legal familial tie exists with the father is determined by the Dutch private international law rules on parentage that are contained in the Wet Conflictenrecht Afstamming (WCA).

The recognition of legal parentage that has been established abroad is also a relevant issue for population registration. The Wet Gemeentelijke Basisadministratie Persoonsgegevens (Wet GBA) obliges every person who expects to reside in the Netherlands for 6 months or more at least two thirds of his time to register himself with the municipal authorities. ${ }^{1123}$ At the registration the person is obliged to provide information and evidence concerning his personal status. ${ }^{1124}$ The means of evidence to prove one's personal status are listed in article 36 (2) Wet GBA and include foreign instruments of civil status.

The population register should not be confused with the civil status registers. Per article 1:25 BW foreign birth certificates of Dutch nationals and foreigners lawfully residing in the Netherlands can be filed in the register of births in The Hague. A foreign birth certificate can only be filed in a Dutch register if the legal relations that are mentioned on the certificate are recognised by the Dutch rules on private international law. Before the coming into force of the Wet Conflictenrecht Afstamming legal relations could only be recognised if they were valid according to the applicable law on legal parentage. If the legal relationship did not

\footnotetext{
1122 Article 3 (1) Rijkswet op het Nederlanderschap.

1123 Article 65 (1) Wet GBA.

1124 Article 65 (3) Wet GBA.
} 
exist according to the applicable law, the foreign birth certificate was considered to violate Dutch public policy. ${ }^{1125}$ Under de Wet Conflictenrecht Afstamming the recognition of the legal relations mentioned in the birth certificate is regulated by article 10 WCA.

Article 1:20b (1) BW provides that the civil status registrar shall mention on the Dutch records of births, marriages or registered partnerships instruments and judgments that are drawn up abroad in conformity with local rules by a competent authority and that have an effect similar to the instruments and judgments mentioned in article 1:20 BW (former art. 1:21 BW). On the basis of this provision, the civil status registrar can mention an acknowledgement of paternity that has been authenticated abroad on a Dutch birth record. Of course, the acknowledgment of paternity can only be mentioned on a Dutch birth certificate if it establishes legal paternity. Also, the effects of the foreign instrument of acknowledgement fall within the scope of article 10 WCA.

Article 10 (1) Wet Conflictenrecht Afstamming provides that legal facts or legal acts establishing legal familial ties that have come into existence abroad shall be recognised if they are recorded in an instrument drawn up by a competent authority in accordance with local provisions. The recognition of legal facts or acts shall be refused if there is a lack of a proper investigation or legal process prior to the creation of the instrument, ${ }^{1126}$ or if the recognition of the legal facts or acts would be manifestly contrary to Dutch public policy. ${ }^{1127}$ The sole fact that another law has been applied by the foreign registrar is no reason to conclude that the legal fact or act violates Dutch public policy. ${ }^{1128}$ The application of the public policy exception with regard to acknowledgment of paternity has been worked out further in paragraph 2 of article 10 WCA. Finally, legal acts or facts that are irreconcilable with a decision of a Dutch court concerning the same person's parentage that has become irrevocable shall not be recognised.

Under article 10 WCA, a conflict of laws on parentage is solved by means of recognition of foreign public documents instead of selecting the applicable law. The recognition method is also found in the Dutch private international law act on names, article $5 \mathrm{a}$ Wet Conflictenrecht Namen. It provides that the surname or first names of a person which have been established abroad at his birth or which have been altered abroad as a result of a change in his personal status shall be recognised, if the name has been recorded in a public document by a competent authority in accordance with the local rules on private international law.

Also, article 40 of the Statuut voor het Koninkrijk der Nederlanden (Charter for the Kingdom of the Netherlands) contains a recognition rule for personal status for the different countries within the Kingdom of the Netherlands. It provides that authentic instruments drawn up in the Netherlands, the Dutch Antilles or Aruba are enforceable throughout the entire Kingdom. In 2007, the Hoge Raad held on the basis of article 40 that a marriage between two women celebrated in the European part of the Kingdom has to be recognised in Aruba, despite the fact that Aruban law does not allow same sex marriages. ${ }^{1129}$

\footnotetext{
1125 Commissie regelgeving burgerlijke stand. Report 1988, p. 16; Kamerstukken II 1998/99, 26 675, nr. 3, p. 19; Struycken 1982 , p. 23. See however also p. 20 where it is argued that legal relations that have been established in violation of Dutch choice of law rules have to be recorded.

${ }_{1126}$ Art. 10 (1) in conjunction with art. 9 (1) under b WCA.

1127 Art. 10 (1) in conjunction with art. 9 (1) under c WCA.

1128 Art. 10 (1) in conjunction with art. 9 (2) WCA.

1129 Hoge Raad, 13 April 2007, LJN AZ6095.
} 


\subsection{Legislative development}

Before examining the details of article 10 Wet Conflictenrecht Afstamming the rationale behind the recognition method of articles $10 \mathrm{WCA}$ and $5 \mathrm{a}$ WCN has to be found. Why are the conflict rules set aside and replaced by a recognition rule?

Article 5a WCN was introduced by Act of 24 December 1998 and entered into force on the on the 15th of February 1999.1130 The Wet Conflictenrecht Afstamming was introduced by Act of 14 March 2002 and entered into force on the 1st of May 2003.1131 The preparatory documents to the Acts do not explain much about the doctrinal background of these provisions. This is to a certain extent remarkable given the fact that the provisions introduce a new method in Dutch private international law.

In the explanatory report to the Act introducing article $5 \mathrm{a} \mathrm{WCN}$, the recognition rule for names that have been recorded in foreign public documents is justified by two arguments. ${ }^{1132}$ First of all, it is a standing practice to record in the population register the name of the person as it appears on his birth certificate, even if this name is not in conformity with the Dutch choice of law rule on names. The same practice existed with the filing in the Netherlands of foreign birth certificates of Dutch nationals. In such cases, the name on the foreign birth record was taken over, even if according to Dutch law the name of the Dutch national would be different. The reason for this practice was first of all that an alteration of the name on the basis of Dutch choice of law rules can meet with strong resistance of the person involved. Second of all, the application of the Dutch choice of law rule might cause confusion concerning the identity of the person involved, if the name of the person on the basis of the Dutch choice of law rule is not the same as his name on for example his birth certificate.

In the explanatory report to the Wet Conflictenrecht Afstamming the legislator refers to a series of decisions of the Dutch Hoge Raad to justify the recognition rule of article 10 WCA. 1133

In 1986, the Hoge Raad rendered a decision in the case of Tamara. Tamara was born in Spain on the 9th of June 1983 to a Dutch mother and a Spanish father. ${ }^{1134}$ The Spanish father acknowledged his paternity concerning Tamara while he was still married to another woman than Tamara's mother. According to Dutch law at that time, the acknowledgment of paternity by a man who is married to another woman than the mother of the child was not possible.

On the 19th of February 1984 Tamara and her mother established themselves in the Netherlands. The question arose whether Tamara was a Dutch national or whether she had to apply for a residence permit. If the acknowledgment of paternity by her Spanish father was valid in the Netherlands, Tamara would not have acquired Dutch nationality via her mother; if the acknowledgment was invalid, she would.

According to the Hoge Raad, the starting point in this case was that the acknowledgment of paternity was valid, because it was valid according to Spanish law, the acknowledger was Spanish, the child was born in Spain and the child had her habitual residence there. ${ }^{1135}$ Moreover, the acknowledgment by a married Spanish national in Spain did not violate Dutch public policy.

\footnotetext{
1130 Stb. 1999, 2; entry into force, Stb. 1999, 43.

1131 Stb. 2002, 153; entry into force, Stb. 2003, 161.

1132 Kamerstukken II 1997/98, 25 971, nr. 3, p. 1, 2.

1133 Kamerstukken II 1998/99, 26 675, nr. 3, p. 21.

1134 Hoge Raad, 18 April 1986, NJ 1987, 926, RvdW1986, 79.

1135 Hoge Raad, 18 April 1986, NJ 1987, 926, RvdW1986, 79, par. 4.2.
} 
In this case the Hoge Raad did not formulate a classical bilateral conflict rule for the validity of an acknowledgment of paternity; it merely stated the circumstances justifying the recognition of the foreign acknowledgment of paternity.

In 1992, the Hoge Raad rendered a decision in the case of a child referred to as T.K... ${ }^{1136}$ The father acknowledged his paternity concerning the child in Ghana on the 11th of January 1986, approximately seven months after the father obtained Dutch nationality by naturalisation. As a result of the acknowledgment of paternity in Ghana, the child claimed to have acquired Dutch nationality. The Dutch state argued that the acknowledgment of paternity was not valid in the Netherlands because according to Dutch private international law the acknowledgment of a Dutch national is only valid if the requirements of Dutch law are fulfilled.

The Hoge Raad did not agree. It held that an acknowledgment of paternity which is made abroad is valid in the Netherlands if it fulfils the formal and substantive requirements of the law of the habitual residence or the domicile of child, the mother or the acknowledger at the moment of the acknowledgment or the law of nationality of the child or the mother at the moment of the acknowledgment. ${ }^{1137}$

Since the Hoge Raad allowed determining the validity of an acknowledgement of paternity on the basis of almost every possible connecting factor, it could as well be argued, according to the legislator, that an acknowledgement that validly established legal parentage abroad should be recognised in the Netherlands. ${ }^{1138}$

This view was confirmed by the Hoge Raad in 2001, just before the coming into force of the WCA. ${ }^{1139}$ In this case the child was born in 1982 in Ghana. The father obtained Dutch nationality in 1993 by naturalisation. However, his son did not share in the naturalisation. Therefore, in 1999 he wanted to acknowledge his paternity concerning his son, who had been living in the Netherlands since 1993. The effect of the acknowledgment of paternity would be that his son would acquire Dutch nationality. The Dutch civil status registrar refused to authenticate the acknowledgment of paternity because the Ghanaian birth certificate of the child already named the man as the father of the child. That birth certificate had also been used to register the child in the Dutch population register. That suggests that the father had relied earlier on the Ghanaian birth certificate to prove his paternity.

The Hoge Raad held that according to Dutch private international law the starting point is that legal parentage that has been established abroad shall be recognised in the Netherlands. ${ }^{1140}$ The problem however in this case was, that the father argued that according to Ghanaian law the record of his name as the father on the birth certificate was not enough to conclude on the basis of Ghanaian law that he was the father of the child. The Hoge Raad quashed the decision of the Court of Appeal, because the Court of Appeal did not sufficiently examine this claim. It had to examine whether according to Ghanaian law it could be presumed on the basis of the birth certificate that the man was the father of the child.

The three cases that have been described above show a gradual development of the recognition rule in matters relating to parentage, more in particular legal paternity on the basis of acknowledgment. It must be contended though that the recognition rule (2001) does not necessarily follow from the cascade of connecting factors (1992).

In France a German national acknowledges his paternity concerning a German child. Ten years later the man argues that his acknowledgment is void because he acted under the

\footnotetext{
1136 Hoge Raad, 31 January 1992, NJ 1993, 261, RvdW1992, 39.

1137 Hoge Raad, 31 January 1992, NJ 1993, 261, RvdW1992, 39, par. 3.2.3.

1138 Kamerstukken II 1998/99, 26 675, nr. 3, p. 21.

1139 Hoge Raad, 13 July 2001, NJ 2002, 215, RvdW 2001, 132, JOL 2001, 432.

1140 Hoge Raad, 13 July 2001, NJ 2002, 215, RvdW 2001, 132, JOL 2001, 432, par. 3.5.
} 
influence of deceit on the part of the mother. In the Netherlands the court has to determine whether or not the acknowledgment of paternity is void. The first question that has to be answered is which law applies to the validity of the acknowledgment.

Under the decision of the Hoge Raad of 1992 the acknowledgment is valid, if it is valid inter alia according to the national law of the child or the habitual residence of the acknowledger or the child at the moment of the acknowledgment. It means that under the choice of law rule elaborated in 1992, the acknowledgment is not void on the basis of deceit. After all, German law does not allow contesting the acknowledgment on the basis of a defective intension.

Under the decision of the Hoge Raad of 2001 and under article 10 WCA, the validity of the acknowledgment is governed by the locus actus or the law of the authority who drew up the public document involved. ${ }^{1141}$ In the example the man acknowledged his paternity in France and therefore French law applies to the validity of the acknowledgment. Under French law it is possible to contest the acknowledgment on the basis of a defective intension and therefore the Dutch court would have to conclude that the acknowledgment is void.

The example shows that both conflict rules must be based on different considerations. The cascade of connecting factors favours the validity of the acknowledgment of paternity, which is considered to be in the interest of the child. ${ }^{1142}$ The recognition rule recognises the legal status of the place where the relevant act to place. The choice for the lex loci actus can have different reasons: protection of acquired rights, protection of presumed expectations of the persons involved, alignment of registers on personal status or an easy solution for civil status registrars and other national authorities.

The case law described above only applies to legal parentage that has been established abroad. In 1997, the Hoge Raad ruled on the validity of an acknowledgment of paternity which was made in the Netherlands. 1143 The whole range of connecting factors to determine the validity of the acknowledgment that was offered in its decision of 1992 was out of sight.

In 1997, the Hoge Raad held that according to Dutch private international law the national law of the acknowledger governs the acknowledgment of paternity. However, if according to the national law of the acknowledger it is not possible to establish legal parentage with a child born out of wedlock and if the child is closely connected with another legal system that does allow the acknowledgment of paternity, that other law has to be applied in the interest of the child.1144

It appears that already since 1992 the Hoge Raad adopted a differentiated approach to the applicable law to acknowledgment of paternity. That system resembles very much the system of the Swedish private international law on parentage, the Lag (1985:367) om internationella faderskapsfrågor, discussed below. If the acknowledgment had been made abroad, the Court provides not less than eight connecting factors to validate the acknowledgment. If the acknowledgment is done in the Netherlands, the starting point is that the national law of the acknowledger applies.

The differentiated approach shows that the Hoge Raad attached great value to upholding a legal parental status that has been acquired abroad. Therefore, it recognised that the choice of law rule for a legal act like acknowledgment has to provide for more connecting factors than the choice of law rule for the creation of a legal act in the Netherlands. After all, you do not know which law is applicable to the acknowledgment of paternity in foreign legal systems.

\footnotetext{
1141 Vonken 2006, nr. 97; Struycken 2001, p. 37 (see also Struycken 2005).

1142 Th.M. de Boer \& Kotting 1989, p. 81.

1143 Hoge Raad, 7 November 1997, NJ 1998, 438, RvdW1997, 217.

1144 Hoge Raad, 7 November 1997, NJ 1998, 438, RvdW1997, 217, par. 3.3.
} 
Under article 10 Wet Conflictenrecht Afstamming the recognition method has been extended from paternity on the basis of acknowledgment to parentage in general. It refers to legal acts and facts that established legal parentage. Obviously, the objective of article 10 WCA is to protect the parental status that has been acquired abroad, but why? And how?

\subsection{Doctrinal explanation of articles 5a WCN and 10 WCA: fait accompli or recognition?}

\section{The judgment of the Dutch Hoge Raad of 26 September 2008}

On the 26th of September 2008 the Hoge Raad rendered a judgment on the interpretation of article $5 \mathrm{a} \mathrm{WCN}$ in which it explained its doctrinal background. ${ }^{1145}$ In the case a Dutch man and a Dutch woman married in Hungary on the 10th of July 2004. At the time of the marriage their domicile and habitual residence remained in the Netherlands; they only went to Hungary to marry there.

According to the Hungarian marriage certificate the woman had chosen the surname of her husband. Upon return in the Netherlands, the spouses recorded their marriage in the Dutch marriage register in The Hague and the Dutch record showed the husband's name as the new name of the woman. After all, article 5a WCN provides that the alteration of a person's surname abroad as a result of a change in his personal status shall be recognised in the Netherlands. In this case, the registrar assumed on the basis of the Hungarian marriage certificate that the surname of the woman had changed as a result of her marriage there and therefore her name was also changed in the Dutch register.

The Hoge Raad observed on the basis of an analysis of the explanatory report to the Wet Conflictenrecht Namen that article $5 a$ (1) WCN is an expression of the idea that under certain circumstances the choice of law rule should be disregarded and that a certain legal status must be accepted as a fait accompli.

The main rule in Dutch private international law on names is that that a person's name is determined by the law of his nationality. Application of the main rule can lead to an unacceptable result if the person involved expected his name to be the name which has been recorded in his foreign birth certificate. In such a case, article $5 a$ (1) WCN allows for the application of a fait accompli exception, in accordance with the requirements of the provision.

It follows, according to the Hoge Raad, that there is no reason to apply article $5 \mathrm{a}$ WCN if the person involved did not rely on the alteration of his name abroad, but on the contrary expected that his name would still be governed by the law applicable according to the Dutch choice of law rule. Such an expectation can in particular exist for Dutch nationals residing in the Netherlands and whose personal status is altered abroad. In such a case it cannot be generally assumed that the person involved expected the alteration of his name recorded in the foreign public document to have any effect on the name he bears in the Netherlands under Dutch law.

How should the registrar apply this ruling in a concrete case? The Hoge Raad explains that if a Dutch national who resides in the Netherlands applies for the recording of his foreign marriage in the Dutch marriage register, it cannot be assumed that the person involved expected that, contrary to Dutch law, his name had been changed as a result of the marriage. In such a case, article 5a WCN can only be applied at the instigation of the person involved. If the person involved indicates that he does not want his name to be altered, the Dutch registrar has to accept that wish. In order to protect the legal certainty, the person involved is only allowed to make this choice at the registration of his foreign marriage in the Netherlands and the choice of the person shall be authenticated in a public document.

1145 Hoge Raad, 26 September 2008, RvdW 2008/887, LJN BD5517. 
The two points of interest in this decision are first that the recognition rule in article $5 \mathrm{a}$ $\mathrm{WCN}$ is seen as an exception to the general choice of law rule, second that the application of the exception of article $5 \mathrm{a}$ WCN depends on the expectations (unlike the Advocate General, the Court does not write 'legitimate' expectations) of the person involved concerning the law applicable to his name. The Hoge Raad puts the choice between the application of the choice of law rule of the forum or the fait accompli exception at the disposition of the person involved.

The decision has been severely criticised by Jessurun d'Oliveira. ${ }^{1146}$ In essence he argues that article 5a WCN is not based on the fait accompli exception. Article 5a WCN simply regulates the recognition of a legal status which has been recorded in a foreign public document. Therefore, according to Jessurun d'Oliveira, article $5 \mathrm{a} W C N$ is not an exception to the choice of law rule on names and the applicability of article $5 \mathrm{a} \mathrm{WCN}$ cannot depend on arguments relating to the fait accompli exception. In order to appreciate this critique the meaning of the fait accompli exception has to be examined.

The second question that is raised by the judgment is what it means for article 10 WCA and the recognition of parentage that has been established abroad. Article 5a WCN and 10 WCA are the same provisions for two different areas of private international law: names and parentage. If article 5a WCN is based the fait accompli exception it is difficult to see why article $10 \mathrm{WCA}$ is not.

\section{The development of fait accompli exception in Dutch PIL}

In the Netherlands, the necessity of the fait accompli exception has been established by Meijers. In 1934 he published an article on the application of renvoi in private international law, on the limits of the application of the conflict rules of the forum and the recognition of faits accomplis. 1147

The starting point for Meijers was that private international law should first and foremost provide for just and effective solutions in international cases. Therefore, the alteration of rights and obligations as a result of crossing borders should be limited as much as possible. In his view it could not be accepted that a debtor is relieved from this obligation solely by establishing himself in another country and it is undesirable that two people who are considered married in one country are suddenly cohabitants as a result of emigration.

Meijers showed that the application of renvoi does not always guarantee the required legal certainty or stability of rights and obligations. If a child is born in Germany to two Moroccan nationals his parentage is established there according the law of his habitual residence, i.e. German law. If the family moves to the Netherlands, the parentage of the child is governed by the law of the common nationality of the alleged parents, i.e. Moroccan law. In such a case, the acceptance of renvoi by the Dutch authorities does not guarantee that the parentage of the child in the Netherlands is the same as in Germany. The effect of the Dutch conflict rule could be a disturbance of existing family life and that cannot be accepted.

According to Meijers, the establishment of just and effective solutions requires that in certain circumstances the national conflict rule has to be set aside. The differences between national systems of conflict laws may hinder the effective solution of private international law problems. The conflict of systems of conflict laws leads to limping relations, disturbs the international harmony of a legal status and thereby hinders international social and economic movement. Reasonableness requires us to find a solution for these conflicts. ${ }^{1148}$

\footnotetext{
1146 Jessurun d'Oliveira 2009, p. 42-44. More approving of the judgment: Frohn 2008.

1147 The article has been republished in Meijers 1955. See also Meijers 1938.

1148 Meijers 1955, p. 389, 392.
} 
In finding the solution, Meijers seemed to be well aware of the failure of vested rights doctrines. After all, legal relations do not grow on trees; they are the product of a legal system or (judicial) decisions. ${ }^{1149}$ An often-quoted passage of Von Savigny proves this basic proposition of private international law:

Denn welche Rechte wohlerworben sind, können wir nur erfahren, wenn wir zuvor wissen, nach welchem örtlichen Rechte wir den vollgezogene Erwerb zu beurteilen haben. ${ }^{1150}$

The existence of a status can only be recognised if it can be derived from a legal rule or a (judicial) decision. Thus if Meijers wanted to set aside the choice of law rules of the forum in the interest of an effective solution of the private international case, he had to find another way to determine the applicable law.

In his view, at the national level the possibilities to solve the conflict of systems of conflict rules were limited. Only if at the moment of the establishment of the legal act or fact all the conflict rules of the countries involved refer to the same legal system, the conflict rule of the forum could be ignored. In such a case the forum, asked to rule on the existence of the status at a later time, should apply the conflict rule of the countries involved at the moment of the establishment of the legal fact or act.1151 In this way, Meijers was able to avoid the pitfalls of the vested rights doctrine. The existence of the status was derived from the legal systems involved at the moment of its coming into existence, and the required unanimity of the legal systems involved makes a choice of law rule redundant.

The ideas of Meijers were taken over in various proposals. They have been applied in article 21 (2) of the Loi uniforme relative au droit international prive 19671152 and in article 2 of the Dutch Schets van een algemene wet betreffende het internationaal privaatrecht (Proposal for a general code on private international law). ${ }^{1153}$

Both articles provide that if a legal relationship has been established or annulled abroad in accordance with the law that was applicable according to the conflict rules of the states with which the legal relationship was substantially connected at the moment of its establishment or annulment, the establishment or the annulment shall be recognised in the Netherlands even if another law would be applicable according to the Dutch conflict rule.

The codifications of Meijers' idea pose two requirements before the national conflict rule is set aside. The legal relationship must have been established or annulled abroad and all the legal systems to which the relationship was substantially connected at the moment of its establishment or annulment must appoint the same legal system. If the legal systems involved do not appoint the same legal system, the applicable law should be selected with the choice of law rule of the forum.

The proposals imply that if the Dutch legal order is involved at the moment of the creation of a status, for example, through residence or nationality, the Dutch choice of law rule should be applied, either because there is unanimity on the applicable law among the

\footnotetext{
1149 Mayer 2005, p. 548.

1150 Savigny 1849, § 361, p. 132.

1151 Meijers 1955, p. 395.

1152 The Loi uniforme relative au droit international privé 1967 was a treaty for the Benelux countries. It never entered into force.

1153 Schets van een algemene wet betreffende het internationaal privaatrecht, published in 1992 by the Ministry of Justice. Already in 1982 there was a departmental working paper that contained a proposal for the codification of Dutch private international law, but that proposal and its explanatory notes have never been made public (Departementale voorontwerp van wet tot regeling van het internationaal privaatrecht, stand oktober 1982).
} 
legal systems involved or because in the absence of unanimity Dutch choice of law rules are applicable.

Therefore, the codifications of Meijers' idea still left a lot of space for the national choice of law rules and thus for possible conflicts between national systems of conflicts law. Meijers also thought that this was a feeble result, but in his view further coordination of the national systems could only be realised at an international level.1154

Still the idea of vested rights and a broader application of the fait accompli exception kept exerting attraction. In the words of the editors of Cheshire, North \& Fawcett 'it no doubt stresses one of the principle objects of private international law for, as has been shown, one of the elementary duties of a civilized court is impartially to protect existing rights even though they originated abroad.'1155

The thesis of Joppe (1987) provides an effort to broaden the scope of the fait accompli exception. ${ }^{1156}$ In her view the fait accompli exception should not only protect existing legal relations or status that have come into existence in contravention of the choice of law rules of the forum, but also legal relations and status for which the private international law of the forum does not provide a conflict rule. She gives the example of the trust. Another example would be the mahr, a dowry according to Islamic law. ${ }^{1157}$

Just like Meijers, Joppe has to answer the question when there is a fait accompli on the basis of which the existence of a legal status can be construed. In her view, this question consists of two sub-questions. ${ }^{1158}$

The first question is when it is justified to set aside the choice of law rules of the forum. In Joppe's view, the recognition of a fait accompli is a transitory problem: the persons involved geared their behaviour to a certain legal system and in the course of time, for one reason or another, they end up in a forum with different choice of law rules. In such a case, the legitimate expectations of the persons involved during a certain period of time justify the relinquishment by the forum of its own choice of law rules. In her view, the forum should relinquish its choice of law rules if the persons involved could not foresee that the law of the forum would be or become involved. ${ }^{1159}$

If the forum has decided to set aside its choice of law rules, the second question is for what to substitute them. Here, Joppe distinguishes three types of situations. 1160 In the first situation the case at hand originally is an internal case, for example a Dutch national acknowledging his paternity concerning a Dutch child living in the Netherlands. Usually the normal choice of law rules will provide an adequate solution in this type of cases and the fait accompli exception does not have a role to play here.

In the second situation the case is from the start connected with more than one legal system, but all the legal systems involved solve the case in the same way. If the Dutch legal order later becomes involved, it should recognise the existence of the legal status on the basis of the fact that the legal systems involved at the moment of its creation are in agreement on the validity. This is the same case as described by Meijers.

The third situation is the most exciting one. From the start the case involves more than one legal system, but the results of the systems are not the same. According to Meijers, the Dutch court would in such a case have to apply its own choice of law rules. Joppe however

\footnotetext{
1154 Meijers 1955, p. 396.

1155 North, Fawcett \& Carruthers 2008, p. 24.

1156 Joppe 1987.

1157 Rutten 2007.

1158 Joppe 1987, p. 199. See also Meijers 1955, p. 392.

1159 Joppe 1987, p. 207, 208.

1160 Joppe 1987, p. 209-220.
} 
argues that if it follows from the factual circumstances that the persons involved complied with one of the legal systems involved, the law of that legal system should govern the legal status or relationship.

Joppe relies heavily on the legitimate expectations of the persons involved to justify the relinquishment of the choice of law rules of the forum. The choice of law rules are replaced by the recognition of a maatschappelijk fait accompli (socially established facts), i.e. the legitimation of the factual social circumstances of the case by one of the legal systems involved. In case of personal status, her idea resembles the French idea of possession d'état (bezit van staat, apparent status). Also in case of possession d'état it is the existence of a certain social reality (the living together as man and wife, the education of a child as his own child) that may give rise to the creation of legal relations (marriage, parentage).

The new insights into the fait accompli exception found their way into the Report on general provisions on private international law published by the Dutch State committee on private international law in 2002.1161 Article 10 of this Report provides:

If a fact produces legal effects according to the law that is applicable pursuant to the private international law of a state involved, the same legal effects can be recognised in the Netherlands even if that would contravene the law that is applicable according to Dutch private international law, if non-recognition would result in an unacceptable violation of the legitimate expectations of the parties or the legal certainty [translation $\mathrm{ks}]$.

The description of the fait accompli exception from 2002 differs on certain points from its predecessors. Under the article 21 (2) of the Loi uniforme relative au droit international privé 1967 and article 2 of the Dutch Schets van een algemene wet betreffende het internationaal privaatrecht the criterion for a fait accompli is that the status exists according to the law that applies according to the choice of law rules of the states substantially involved. Under article 10 of the Report, the status must exist according to the private international law of a state involved. Thus unanimity among the states involved is no longer required.

The second difference between the article 10 of the Report and its predecessors is that article 10 explicitly states that the fait accompli exception protects the legitimate expectations of the parties or the legal certainty. Article 21 (2) of the Loi uniforme relative au droit international privé 1967 and article 2 of the Dutch Schets van een algemene wet betreffende het internationaal privaatrecht only provided that if all legal systems substantially involved recognised the establishment or annulment of the legal relationship, it shall be recognised in the Netherlands even if it contravenes the Dutch choice of law rule on the subject. It did not explain why the legal relationship was recognised.

A final amendment to article 10 of the Report is that the fait accompli exception only works if the violation of the legitimate expectations or the legal certainty is unacceptable. In that respect, the new description is narrower than its predecessors. Under those provisions the fait accompli was accepted from the moment that it was proven that all legal systems substantially involved recognised the existence of the legal relationship.

Recognition on the basis of fait accompli or a foreign public document: two of a kind?

According to Jessurun d'Oliveira, the major fallacy in the judgment of the Hoge Raad of the 26th of September 2008 is the conclusion that article 5a Wet Conflictenrecht Namen is based on the fait accompli exception. ${ }^{1162}$ Most Dutch writers indeed distinguish recognition of legal

1161 Staatscommissie IPR 2002.

1162 See note 1146 
relations described in public documents from recognition on the basis of the fait accompli exception. ${ }^{1163}$ The first is derived from the doctrine on the recognition of foreign judgments and is referred to as 'procedural recognition' and the second is a product of the discussion on the conflict of national systems of conflict rules, as described above.

According to Lemaire, the difference between recognition on the basis of a foreign judgment and recognition on the basis of fait accompli lies in the construction of the right that is recognised. ${ }^{1164}$ In case of recognition on the basis of fait accompli, the question is whether the existence of a legal status can be accepted in contravention to choice of law rules of the forum. The main difficulty here is how to determine the existence of the alleged legal status if it is not on the basis of the choice of law rules of the forum.

In case of recognition on the basis of a foreign judgment, the question is not whether a legal status exists. Within the legal order of the court rendering the judgment, the legal status of the persons involved exists as described in the judgment. It is because within that legal order the judgment has force of law so that it is clear that the person involved acquired a certain legal status. Therefore, with foreign judgments the main question is not whether a legal status exists, but whether the foreign court had international jurisdiction to create or establish the status in the case at hand.

By treating the recognition of legal acts and facts laid down in foreign pubic documents under the same heading, 1165 it is suggested that the method of recognition of foreign judgment can be applied without difficulty to foreign public documents relating to parentage and names. Mayer shows however that this is a misconception.

In analysing the different methods of recognition, Mayer distinguishes between the recognition of decisions and the recognition of 'situations'. 1166 The distinction follows from the premise that legal relations are either based on the law or on a binding decision. If a court has determined the status of a person the judicial decision can be recognised or not, as the case may be, because within the legal order of the court the legal status is described in the judgment with force of law. ${ }^{1167}$ Or in the words of Lemaire, if there is a judgment calling into existence a particular legal relationship it can hardly be denied that the person or persons involved acquired a right. ${ }^{1168}$ In such a case, it is not necessary to select a legal system to determine the existence of the alleged right.

Instruments of civil status (especially those on parentage) do not contain decisions with the force of law. It has been shown in the first part of this thesis that their primary purpose is to prove facts, like the birth of a person or the acknowledgment of parenthood. ${ }^{1169}$ The description of a person's legal parentage in a birth certificate is only a provisional conclusion on the status of the person involved according to the law, including the private international law of the registrar recording the birth. ${ }^{1170}$ The instrument of acknowledgment is only a declaration of a person in a prescribed form. Whether the acknowledgment of paternity establishes legal paternity, depends on the applicable law.

Judgments can be recognised because they create rights and obligations; public documents on parentage do not create rights and obligations. Therefore, a status described in a birth certificate cannot be recognised as if it were a decision. Or in the words of Callé:

\footnotetext{
1163 Jessurun d'Oliveira 2009; Vonken 2006, nr. 78 and 89; Joppe 1987, § 7.2 and 7.3. See differently De Boer in § 4 of his note under Hoge Raad, 13 July 2001, NJ 2002/215.

1164 Lemaire 1968, p. 321.

1165 See also the heading of chapter 5 of the Wet Conflictenrecht Afstamming: the recognition of foreign judicial decisions, legal facts and legal acts establishing or altering legal familial ties.

1166 Mayer 2005.

1167 See also Mayer 1973, nr. 21.

1168 Lemaire 1968, p. 321.

1169 See chapter 4. Evidence of legal parentage.

1170 See also Staatscommissie IPR 1995, p. 140.
} 
Lorsque l'acte ne produit pas d'effet décisionnel, une méthode de reconnaissance d'efficacité n'a pas de sens. La modification de l'état de droit n'étant pas l'effet d'une décision publique, il est absurde de la reconnaître.1171

According to Mayer, the introduction of recognition into the realm of conflict of laws requires the crystallisation of that relationship. Crystallisation is what Joppe calls respecting legitimate expectations: a legal relationship crystallises if the persons involved legitimately expected that the relationship existed and if that conclusion is supported by the legal system involved.

Mayer gives two examples of how a legal relationship could crystallise or how legitimate expectations could arise. The first is the involvement of a public authority that produces a public document and the second is the existence of apparent status (possession d'état). ${ }^{1172}$

Mayer's analysis shows that recognition of a legal status on the basis of fait accompli and its recognition on the basis of foreign public documents are just two ways to give effect to the same idea. That is that choice of law rules have to be set aside to allow the smooth functioning of international social and economic movement.

The recognition of a fait accompli as described by Joppe (maatschappelijk fait accompli) is Mayer's crystallisation on the basis of apparent status. The recognition of legal relations on the basis of foreign public documents is Mayer's crystallisation on the basis of the involvement of a foreign public authority.

Mayer points out that the recognition method in the realm of conflict of laws is not neutral. It favours the alignment of the legal and the factual situation in order to protect the legitimate expectations of the persons involved. This characteristic of the recognition method in the field of conflict of laws avoids the pitfalls of the vested rights doctrine. It makes it possible to choose the applicable law if the different legal systems involved lead to different outcomes.

Law selection on the basis of alignment of the legal situation with the factual situation is also present in the Dutch rules on recognition of public documents and the recognition on the basis of the fait accompli exception. Article 5a WCN explicitly refers to the rules of private international law of the authority that produced the foreign public document. Article 10 of the Report on general provisions on private international law requires that the legal relationship be based on the private international law of one of the countries.

\section{Evaluation of the rationale of article 10 WCA}

It follows from the preceding paragraph that recognition on the basis of fait accompli and recognition of foreign documents are two concepts originating from the same idea. It is therefore not a priori excluded to use the rationale for recognition of a fait accompli to interpret provisions on recognition of foreign public documents. But even if it is contended that articles 5a WCN and article 10 WCA are based on the fait accompli exception, the question still remains whether the decision of the Hoge Raad is correct and what the implications are for article 10 WCA.

According to the Hoge Raad, the objective of article $5 \mathrm{a} W \mathrm{WN}$ is to protect the legitimate expectation of the person involved that he bears the name as mentioned in the foreign public document. Therefore, if the person did not even expect that his name would be as described in the foreign instrument of civil status, but instead relied on Dutch law, there is no reason to apply article $5 \mathrm{a} \mathrm{WCN}$.

1171 Callé 2004, nr. 522.

1172 On apparent status under Dutch private international law see Saarloos 2008, Saarloos 2006. 
The effect of this judgment is that the Hoge Raad de facto introduced a choice of law for the person involved. After all, it is the person involved that has to indicate whether she relied on her national law or on the foreign registration of her name.

Law selection in the area of surnames on the basis of a choice of law by the person involved or, in terms of the Hoge Raad, the expectations of the person involved is not per se wrong. On the contrary, the name of an individual is such a highly personal aspect of one's personal status with such a low risk of a conflict of interests (especially when it concerns adults) that acceptance of party autonomy seems a priori justified.

However, it must be born in mind that where public documents and registration of personal status is involved, the expectations or the desire of the person involved is not the only interest at stake. The explanatory report to article $5 \mathrm{a} \mathrm{WCN}$ also referred to the risk of confusion concerning the identity of a person if foreign documents mention a different name than the Dutch records on personal status. ${ }^{1173}$ The avoidance of confusion or legal certainty can also be a reason to accept a certain situation as a fait accompli. 1174

This leads us to the question whether the risk of confusion as a result of different names in public documents in different countries is real or merely apparent. The views differ and much depends on the concrete circumstances of the case.

In theory, the problem can be described as follows. If a person obtained a residence permit for the Netherlands, the name on the residence permit is based on the population register (gemeentelijke basisadministratie persoonsgegevens). Thus if the name in the population register for whatever reason differs from the name on the passport of the person, the name of the person on his residence permit will also differ from the name in the passport. In such a case, problems might arise in those situations where the person has to submit both his passport and his residence permit. At least in theory, this can arise every time the person crosses the border.

At the international level, various institutions have recognised this as a real problem. The European Court of Justice described the problem of different surnames in different countries as follows:

[...] it is common ground that such a discrepancy in surnames is liable to cause serious inconvenience for those concerned at both professional and private levels resulting from, inter alia, difficulties in benefiting, in one Member State of which they are nationals, from the legal effects of diplomas or documents drawn up in the surname recognised in another Member State of which they are also nationals. 1175

Differing surnames are also considered to be a serious problem by the Commission International de l'État Civil. It has produced several conventions with the aim to create international harmony of decisions in relation to surnames. ${ }^{1176}$ In the explanatory report to the Convention on the issue of a certificate of differing surnames (1982) an example was given of a French national with different names in France and German:

These differing names are obviously likely to cause him administrative, fiscal or banking difficulties, notably if he travels outside the Federal Republic of Germany, has assets in France or a third country or wishes to transfer moneys from one State to

\footnotetext{
1173 Kamerstukken II 1997/98, 25 971, nr. 3, p. 2.

1174 Staatscommissie IPR 2002, p. 42, article 10 (fait accompli).

1175 Case C-148/02, Garcia Avello v. État belge [2003] ECR I-11613, §36. See also case ECJ 14 October 2008, case C-353/06 (Grunkin and Paul) Rec. 2008, p.I-7639, § 23.

1176 Convention on the recognition of surnames, Antalya (2005); Convention on the issue of a certificate of differing surnames, The Hague (1982); Convention on the recording of surnames and forenames in civil status registers, Berne (1973).
} 
another. That such difficulties are real and serious is, moreover, demonstrated by the demands for remedial action to be taken made in the course of interventions in the European Parliament. 1177

On the other hand it is submitted that the 'difficulties' that may result from limping surnames must not be overestimated. An official of the civil status register of the municipality of Amsterdam explained that the registry does not even have forms to issue a certificate of differing names, since nobody asks for the certificate.

In the Hungarian marriage case the woman was a Dutch national, living in the Netherlands. If her contacts with Hungary remain limited to incidental holidays, the chances are rather small that she will suffer from the fact that the Hungarian marriage certificate mentions a different name to her Dutch identity papers. After all, she can prove her marriage with the Dutch registration of the Hungarian marriage, which contains the name of the woman according to Dutch law.

Also, the European Court of Human Rights does not seem to be impressed by the threats of limping surnames. In Heidecker-Tiemann the applicant argued that the refusal of the German authorities to recognise the name of the child under English law constituted a violation of article 8 ECHR. With regard to the question whether the limping surnames would constitute any problems, the Court observed:

[...] the applicant had been able to use his compound name within his social sphere and would continue to do so. It further observes that the use of the unregistered compound name in every day life does not appear to create any serious problems or inconveniences to the applicant. In the view of these circumstances the Court finds that the refusal by the German authorities to register the compound surname did not constitute a lack of respect for the applicants' private and family life under Article $8 \S 1$ of the Convention. ${ }^{1178}$

Still, Dutch case law provides some horrifying examples where a limping personal status caused severe problems for the person involved. In 2008, the Dutch Raad van State (highest court in administrative matters) upheld the refusal of the Dutch State to naturalise a Turkish national on the ground that the identity of the person could not be determined. ${ }^{1179}$ The problem was that the Dutch population register mentioned that the man was born in 1986 . In 2000 the man applied and obtained a rectification of his date of birth in Turkey. The decision of the Turkish court had not been recognised in the Netherlands. Hence, according to the birth record the man was born in 1983 while according to the Dutch population register he was born in 1986. According to the Raad van State, this difference justified the refusal to grant the naturalisation.

It appears that a limping relation with regard to personal status (name, date of birth) creates a risk of confusion and administrative difficulties. However, the materialisation of the risk depends on the circumstances of the case and the field of law (immigration and nationality law) involved. If this is true, one could argue that the choice between application of the choice of law rule or the recognition of the foreign name as a fait accompli should be left to the person involved. After all, that person with the help of the registrar will be in the best position to determine whether his situation requires international harmony of decisions or not.

\footnotetext{
1177 Explanatory report to the Convention on the issue of a certificate of differing surnames (1982), p. 1.

1178 ECHR 6 May 2008 (Heidecker-Tiemann v Germany), application number 31745/02.

1179 Raad van State 9 July 2008, JV 2008/448. See also Raad van State 29 October 2008, LJN BG1879. On the problem of identification of persons and personal status in immigration matters see Boeles 2003.
} 
In relation to article $10 \mathrm{WCA}$, the question arises whether the judgment should have consequences for the recognition of legal parentage that has been established abroad. Let us imagine the case of a Moroccan man and an Algerian woman. Both live in the Netherlands. They are recently divorced and the woman returns to Algeria to give birth. After the birth, she returns to the Netherlands to resume her daily life there. In Algeria, the ex-husband is recorded as the legal father because the child is born within 300 days after the divorce. In the Netherlands, the legal paternity of the ex-husband would have been governed by Dutch law (in the absence of a common nationality, the legal paternity of the ex-husband is governed by the law of the habitual residence of the ex spouses, art. 1 WCA). Is it possible that the woman argues in this case that her ex-husband should not be recognised as the legal father of the child because she did not expect Algerian law to be applicable and that Dutch law should be applied instead? And does it matter what her ex-husband expects? If he wants to be the legal father of the child can he argue that he expected that Algerian law would be applicable and that his expectations are legitimate given the existence of the Algerian birth record? And what would be the justification for favouring the person who relied on the birth record instead of the real and substantive connection of the case with the Netherlands?

We can also imagine the opposite situation. Two Dutch men are married; they live in the Netherlands and would like to have a child. To cut a long story short, they contact a surrogate mother in California who in the end gives birth to their child. ${ }^{1180}$ The child is handed over to them and in California the men are recorded on the birth record as the legal parents of the child. In the Netherlands they record the American birth record in the register of births in The Hague and they want to be recorded as the fathers of the child in the population register. Should the register argue here that only one man can be recorded as the father of the child, because the men could not legitimately expect Californian law instead of Dutch law to be applicable?

The application of article 10 WCA on the basis of the (legitimate) expectations of the persons involved seems to be beside the point. The point of article $10 \mathrm{WCA}$ is to provide and protect legal certainty in private international law. If the recognition of legal parentage does not only depend on the public policy exception but also on the legitimate expectations of the persons involved there is a risl that the objective to relieve the courts from questions on conflicts of laws on parentage and to provide for guidance for civil status registrars and others that have to apply the private international law on parentage ${ }^{1181}$ will be thwarted.

\subsubsection{Requirements for recognition under article $10 \mathrm{WCA}$}

Article 10 (1) Wet Conflictenrecht Afstamming provides that legal facts or legal acts establishing legal familial ties that have come into existence abroad shall be recognised if they are recorded in an instrument drawn up by a competent authority in accordance with local provisions. In this paragraph these requirements will be examined in more detail.

\subsection{Competent authority}

The foreign instrument must have been drawn up by a competent authority in accordance with local provisions. The term 'instrument' is a translation for the Dutch word akte. According to Dutch law, an instrument is a signed document which is meant to serve as evidence. ${ }^{1182}$ The requirement that the instrument must be drawn up by a competent authority (bevoegde instantie) excludes private documents. However, neither the law nor the

\footnotetext{
${ }^{1180}$ See J. Müller, 'Moeder onbekend', NRC Handelsblad 4 October 2008, Zaterdag bijvoegsel, p. 6, 7. 1181 Kamerstukken II 1998/99, 26675, nr. 3, p. 2, 20; Kamerstukken II 2001/02, 26675, nr. 6, p. 2. 1182 Article 156 (1) Dutch code on civil procedure.
} 
explanatory report to the WCA gives any indication as to what kind of documents or authorities are meant.

The instrument must be drawn up by a 'competent authority'. Vonken argues that the competence of the authority depends on the existence of sufficiently close connection between the place of the authority and the case at hand. The competence or jurisdiction of the registrar should be based on acceptable grounds for jurisdiction in order to guarantee a certain proximity between the case and the registrar. ${ }^{1183}$ This interpretation is not necessarily correct.

First of all, it has been shown that the 'international jurisdiction' of registrars in national legal systems does not depend on proximity between the case and the legal order under which the registrar is operating. ${ }^{1184}$ The registrar in the country of birth is obliged to record the birth as soon as possible, because the child needs a birth certificate to participate in society. The 'jurisdiction' to authenticate declarations of acknowledgment is not restricted. This has been explained by the fact that the authentication of an acknowledgment is not a decision. Whether or not the authentication has legal effect, depends on the applicable law. ${ }^{1185}$ If at the national level the power of the registrar to register certain events is not based on considerations of proximity, it is not self-evident to require proximity for the recognition of the legal relations that are described in the foreign instrument.

Secondly, the concept of 'competent authority' appears at different places in Dutch law in relation to foreign instruments. At these places, 'competent authority' means an authority which according to its own law is empowered to execute a certain task, in this case the recording of births and acknowledgments.

On the basis of articles 1:22b and $25 \mathrm{BW}$ foreign instruments of civil status can be used in the Dutch registration system if they are drawn up by a competent authority in accordance with local rules. Articles 1:22b and $25 \mathrm{BW}$ on the one hand and article 10 WCA are complementary provisions. Articles $1: 22 \mathrm{~b}$ and $25 \mathrm{BW}$ determine the relevant conditions to use foreign instruments of civil status in the Netherlands and article 10 WCA determines the conditions for recognition of the legal relations that are mentioned in the foreign instrument of civil status. Logically, the concept competent authority in articles 1:22b and 25 BW must mean the same as in article 10 WCA.

The concept of an instrument drawn up by a competent authority according to local provisions has been explained by the Dutch Hoge Raad in its decision of the 14th of June 1985.1186 With regard to the former article 23 (1) Besluit Burgerlijke Stand 1969 (now article 1:25 BW) the court held that if the foreign instrument comes from a country that has an organisation comparable to the Dutch civil status registration service the document has to emanate from that organisation in order to qualify for filing in the registers of civil status in The Hague. If the document comes from a country that does not have an organisation comparable to the Dutch civil status registration service, the document can be filed if it has been drawn up by a person who is competent to draw up such documents according local law or local customs with the aim to record information concerning the birth.

The concept of 'competent authority' is also used in article 10 Hague Convention of 14 March 1978 on Celebration and Recognition of the Validity of Marriages which has been ratified by the Netherlands and article 5 (4) Wet Conflictenrecht Huwelijk (Conflict of Laws (Marriage) Act). According to these provisions the marriage shall be presumed valid until

\footnotetext{
1183 Vonken (Personen- en familierecht. Het internationale afstammingsrecht), art. 10 WCA, aant. 1; Vonken 2006 , nr. 97. $1184 \S 5$.1. International jurisdiction of registrars in matters concerning parentage.

${ }^{1185}$ Also in the context of enforceable authentic instruments under article 57 Brussels I Regulation (art. 50 Brussels Convention), it has been argued that the international jurisdiction of the notary, who like the civil status registrar authenticates documents, by the nature of the office does not depend on jurisdictional requirements that exist for courts (Geimer 2000, p. 369).

1186 Hoge Raad, 14 June 1985, NJ 1986/604, RvdW1985/124.
} 
the contrary is established, if a marriage certificate has been issued by a competent authority. Also here, 'competent authority' has nothing to do with proximity. The explanatory report to the Convention states that it has to be determined on the basis of the law of the state of the authority, whether or not the authority was competent to issue the instrument in question. ${ }^{1187}$

Article 2 Wet Conflictenrecht Adoptie (Conflict of laws (Adoption) Act defines an adoption as a decision by a competent authority by which legal familial ties are established. Also, here the explanatory report clearly notes that 'competent' means that the authority has the power to grant an adoption decision. ${ }^{1188}$

Yet Vonken's interpretation of the concept of 'competent authority' raises the fundamental question whether or not the recognition of the legal parentage must be made dependent on the existence of proximity or some sort of connection between the case and the law that has been applied.

One of the arguments of the Dutch State committee on private international law against the recognition of foreign instruments on parentage was that it would be hard to make the recognition of foreign instruments dependent on the existence of a reasonable ground for jurisdiction and that therefore the application of the choice of law rules on parentage had to make sure that the situation was governed by a law with which the case was closely connected.1189

However, in the explanatory report to the Wet Conflictenrecht Afstamming the legislator stated explicitly that it would go too far to require the application of the Dutch choice of law rules by foreign authorities. The fact that foreign authorities applied a different law cannot be a reason not to recognise their decisions or, in other words, their conclusions concerning the legal status of the person involved. The Dutch choice of law rules are not d'ordre public. ${ }^{1190}$

These considerations leave the impression that the legislator does not care so much about which law has been applied and whether any proximity exists between the case and the applicable law. If the legal parentage of a child has crystallised in a foreign public document that parentage is recognised unless the existence of parentage in the particular case violates Dutch public policy. It seems that if there is still a role for proximity to play, it is within the context of the public policy exception.

\subsection{The legal facts or acts must have been established abroad}

With regard to the requirement that legal facts and acts must have been established abroad the question has come up whether it means that the act or fact must have taken place outside the territory of the Netherlands or the document must come from a foreign authority, for example the embassy of a foreign country in the Netherlands. ${ }^{1191}$

The meaning that the act or fact must have taken place abroad is first of all suggested by the text of article 10 (1) WCA which states that the legal acts and facts must have been established abroad and not that the instrument must come from a foreign authority. Second of all, from the explanatory report it is clear that the Dutch conflict rules are meant to apply to acts and facts that took place in the Netherlands. ${ }^{1192}$

\footnotetext{
1187 Malmström 1978, p. 23

1188 Kamerstukken II 2001-02, 28 457, nr. 3, p. 9.

1189 Staatscommissie IPR 1995, p. 140.

1190 Kamerstukken II 1998/99, 26675, nr. 3, p. 21.

1191 The same question is raised by Vat in relation with article 1:20b BW (Vat (Personen- en familierecht), article 1:20b BW).

1192 Kamerstukken II 1998-99, 26 675, nr. 3, p. 7.
} 
On the other hand, the legislator clearly indicated that Dutch conflict rules on parentage are not d'ordre public. ${ }^{1193}$ Thus the legislator does not really care which law applies to the effects of an acknowledgment of paternity as long as a law is applied.

From that perspective it would be possible to apply article 10 (1) WCA even if the document only emanates from a foreign authority operating on Dutch territory. Moreover, article 10 (2) WCA guarantees that with such an acknowledgment of paternity mandatory provisions of Dutch law cannot be circumvented. Thus from a policy perspective there does not seem to be a fundamental reason to limit the recognition of foreign instruments to cases where the fact or act has taken place abroad.

\subsection{The legal facts or acts must have been laid down in an instrument}

Just before the entry into force of the Wet Conflictenrecht Afstamming, the Dutch Hoge Raad in its decision on 13 July 2001 formulated a rule similar to article 10 (1) WCA.1194 In that case the question was whether it could be concluded on the basis of the inclusion of the man's name on the child's birth certificate from Ghana that he was the child's legal father. The court held:

$3.4[\ldots]$. In the present case the father and the son have argued that according to Ghanaian law the sole fact that a man is named on the child's birth record as the father of the child is not enough to conclude that a legal familial tie exists between him and the child that is equivalent to a familial tie that according to Dutch law is established by the acknowledgment of paternity. It does not appear from the judgment of the Court of Appeal that it took this argument into consideration [translation ks].

The Hoge Raad referred the case to the Gerechtshof Leeuwarden which held:

3. Considering the application of the first applicant and the judgment of the Hoge Raad of 13 July 2001, the court only has to determine the question whether, considering the status and the evidential value of the Ghanaian birth certificate according to Ghanaian law, the paternity of the first applicant and the parentage of the second applicant according to Ghanaian law have been established and whether according to Ghanaian law a legal familial tie exists between the first and the second applicant that is comparable to the legal familial tie that is established by acknowledgment of paternity according to Dutch law, which in that case shall be recognised by Dutch private international law as such a legal familial tie [translation ks]. ${ }^{1195}$

The Hoge Raad and the Court of Appeal proceed in two steps in order to determine whether the man who is mentioned in the birth certificate is the legal father of the child. First, it has to be determined whether the record of the man's name on the child's birth record is enough to conclude that a legal familial tie exists between him and the child. If the answer is no, the man will not be recognised as the legal father under Dutch law.

If the document is evidence of the existence of legal paternity, the second step is to determine whether the legal relationship between the man and child is comparable to the legal relationship which exists according to Dutch law between a child and a legal parent. The first step has been rephrased by article 10 (1) WCA. It states that foreign juridical acts and facts shall be recognised if they have been laid down in an instrument.

${ }_{1193}$ Kamerstukken II 1998-99, 26 675, nr. 3, p. 21.

1194 Hoge Raad, 13 juli 2001, NJ 2002/215, LJN ZC3630.

1195 Gerechtshof Leeuwarden 30 juli 2003, LJN AI0710. 
The first step begs the question what is meant by a legal fact or act 'laid down in a foreign instrument'. Let us first consider the different instruments on legal parentage and their possible meanings.

The function of a foreign instrument is to prove facts. A birth record is evidence of a fact, like the date and place of birth and that the woman mentioned on the birth record gave birth to the child mentioned in the birth record. The instrument of acknowledgment is evidence of the fact that the man or the woman made the declaration as is recorded in the instrument. National law often invests these documents with a special evidential value concerning the facts and declarations they contain. For example, under English law the birth certificate is prima facie evidence of paternity. ${ }^{1196}$

It is also possible that the foreign instrument proves the existence of a legal relationship. For example, article 1:6 BW provides that the birth certificate is evidence of the surname of the person involved; article 10 Convention of 14 March 1978 on Celebration and Recognition of the Validity of Marriages provides that a marriage certificate is evidence of the existence of a valid marriage. ${ }^{1197}$ These are exceptions to the rule that documents prove facts and that the law determines whether or not a legal relationship exists on the basis of that fact.

A third possible meaning is that the birth certificate or another instrument of civil status describes the existence of a legal relationship, for example by naming a man as father on the birth record or by recording the existence of an acknowledgment of paternity. This is the case with birth records in continental European countries. The naming of a father on the birth record is not evidence of a fact. It is the conclusion of the registrar as to the legal parentage of the child, based on an examination of the facts and the applicable law.

The difference with the second situation is that in the third situation the law does not grant a special evidential value to the conclusions of the registrar. If it is disputed that the man is the legal father it is not enough to show the birth record. One has to prove for example that the man was married to the mother at the moment of birth or that he validly acknowledged his paternity. At the same time, out of court the birth certificate is accepted in many cases as evidence of legal parentage because of the trust that is placed in the authority issuing the certificate.

A fourth possible meaning is that the naming of a person as parent on the birth record does not mean anything. It was in fact what was pleaded by Ghanaian applicant in the case which was decided by the Hoge Raad on the 13th of July 2001, discussed above. ${ }^{1198}$ The Gerechtshof Leeuwarden, to which the case was referred after the decision of the Hoge Raad, observed that the registrar in Ghana only registers what is presented and that he does not verify whether the information is correct. Moreover, according to Ghanaian law, the recording of the name of the father on the birth record is no evidence of the legitimacy or illegitimacy of the child. ${ }^{1199}$ As a consequence, the recording of the name of the man on the birth record was not enough to conclude that he was the legal father of the child. Another example where the recording of the name of the father does not have a relevant meaning is in case of some legal systems that allow the naming of a fictive father on the birth certificate in order to mask the illegitimacy of the child.1200

\footnotetext{
$1196 \S 4.1$. Evidence of legal parentage under English law.

1197 See also art. 5 (4) Wet Conflictenrecht Huwelijk.

1198 Hoge Raad, 13 juli 2001, NJ 2002/215, LJN ZC3630.

${ }^{1199}$ Gerechtshof Leeuwarden 30 juli 2003, LJN AI0710.

1200 Hungary: art. 41 Gesetz Nr. IV/1986 über die Änderung des Gesetzes Nr. IV/1952 über die Ehe, die Familie und die Vormundschaft. Spain: art. 191 Ausfürungsverordnung v. 14.11.1958 zum Gesetz über das Zivilregister. Poland: art. 42 (2) Gesetz über das Recht der Personenstandsurkunden, 29 September 1986. See also Gubbels 2006, p. 22 , note 59.
} 
If it has been established what the information on the foreign instrument means, the second step is to determine whether or not it relates to 'legal facts or acts'. Thus, if it has been established that the mention of a woman's name on the birth record means that she has given birth to the child, this is a legal fact. Giving birth is a legal fact if the law provides that the woman who gave birth to the child is the legal mother of the child. But which law is decisive?

According to Th. M. de Boer, this question has to be answered according to the national law of the person whose maternity (or paternity) is at stake.1201 The law of the place where the birth record has been drawn up is in his view too accidental.

However, it must be born in mind that the aim of article $10 \mathrm{WCA}$ is to free the registrars and courts from the hassle of applying a choice of law test in cases of instruments on parentage from abroad. ${ }^{1202}$ It has already been shown that from a dogmatic point of view this is not possible. Facts and acts are legal facts and acts because the applicable law attaches legal consequences to the existence of the facts and acts. Still the intention of the legislator can be worked out by applying the law, including the private international law that has been applied by the authority that drew up the instrument involved (lex fori). The systematic application of the lex fori assures in most cases the relations that appear from the foreign instrument are recognised. ${ }^{1203}$

It is true that the involvement of a public authority can be quite accidental, but the objective of article $10 \mathrm{WCA}$ is not to find the law with which the legal relationship is most closely connected. Article $10 \mathrm{WCA}$ is meant to protect legitimate expectations, legal certainty and to make the life of registrars and courts easier.

If article 10 WCA indeed refers to the lex fori or the law of the authority that drew up the foreign instrument, the phrase 'legal acts or facts that have been laid down in an instrument' means the following.

If the foreign instrument is evidence of a fact or act (giving birth, biological paternity, acknowledgment of paternity or maternity) the instrument contains a legal fact or act if the lex fori establishes legal parenthood on the basis of the fact involved.

For example, under English law the naming of a man as father on the birth record is prima facie evidence of his paternity. Except in cases where the Human Fertilisation and Embryology Act 2008 applies, the birth certificate proves biological paternity. An English birth certificate is an instrument containing a legal fact, because according to English law the biological father is the legal father of the child.

If the foreign instrument is evidence of a legal relationship (legal paternity, a valid acknowledgment) there is no need to consider any applicable law, until the relationship is contested. In that case, the Dutch authorities trust that the foreign registrar applied his own law correctly. ${ }^{1204}$ Still, also in this case, the lex fori is decisive. Thus the existence or nonexistence of the legal parentage has to be argued on the basis of that law.

The recognition method in relation to birth certificates from common law countries (England, Ghana) has not been applied consistently in Dutch case law. Before going to the

\footnotetext{
1201 Note under Hoge Raad, 13 July 2001, NJ 2002/215.

1202 Kamerstukken II, 1998/99, 26675, nr. 3, p. 6, 7, 20.

1203 See also Vonken 2006, nr. 97; Struycken 2001, p. 37 (see also Struycken 2005).

1204 This approach is the same as under article 5a Wet Conflictenrecht Namen. Article 5a WCN provides that the determination or alteration of a name laid down in a foreign instrument, drawn up by a competent authority in accordance with local rules of private international law are is in the Netherlands. Taken literally, the provision obliges the foreign registrar to check whether or not the registrar applied his own private international law correctly. However, in practice the name as it appears on the birth record is taken over until the correctness is disputed (Frohn 2008, p. 280; Staatscommissie IPR 2002).
} 
next paragraph, three cases will be studied where lower courts applied the recognition method to birth certificates from England and Ghana.

The first example is provided by the decision of the court of Amsterdam from 2002.1205 The court had to determine whether or not the mention of a man's name on a Ghanaian birth record meant that the man was the legal father of the child. The court held:

5.6 [...]. In examining the question whether between Ganah and Albert a legal familial tie exists that is comparable to the legal familial tie that is established by an acknowledgment of paternity according to Dutch law already, the starting point is that an acknowledgment of paternity under Dutch law is a legal act by the man. That means that a document which does not show that a man has performed such an act in respect of the child - whatever the consequences according to foreign law of such a mention may be - in any event does not establish a legal familial tie that is equivalent to the legal familial tie which is established by an acknowledgment of paternity under Dutch law.

The court takes as a starting point that if a child is born out of wedlock, legal paternity has to be established by a legal act (acknowledgment of paternity). That assumption is erroneous. In the first part it has been shown that under English law legal paternity always exists automatically. It does not make sense to require the establishment of paternity by acknowledgment, in a legal system that does not use this concept.

Since the birth certificate came from Ghana which has a legal system based on the common law system, the best approach would have been to examine the grounds for legal paternity according to Ghanaian law and then to examine whether the birth certificate is evidence of such a ground or whether the birth certificate in Ghana is accepted as prima facie evidence of paternity, as under English law.

The approach that is advocated by the court leads to the result that the legal paternity of children born out of wedlock in countries with a common law system cannot be recognised. Such an approach is clearly unacceptable.

Another example that shows the struggle of Dutch courts with the recognition of legal parentage from a foreign instrument is provided by the court of 's-Gravenhage from 2006.1206 The court had to determine whether the legal paternity of a Dutch national who was mentioned as the father on an English birth certificate could be recognised in the Netherlands. The man was married to a Dutch woman and they lived together in the Netherlands. Since the woman could not have children, they contacted a surrogate mother in England who carried a child for them. The child was created with the sperm of the Dutch national. Since the Dutch national was the biological father and since the Human Fertilisation and Embryology Act 1990 did not apply, it was not the husband of the surrogate but the Dutch national who was named as the father on the child's birth record. With regard to the recognition of his paternity in the Netherlands the court held:

[...]. First of all, the question has to be answered whether the contents of the English birth certificate can be recognised in the Netherlands. [...] It has not appeared that the decision of the English registrar lacks a proper investigation or procedure. The next question that has to be answered is whether the recognition of the decision (i.e. the decision to name the commissioning father on the birth certificate) violates Dutch public

\footnotetext{
1205 Rechtbank Amsterdam, 24 September 2002, case number 02.0419H, LJN AE8134.

1206 Rechtbank 's-Gravenhage, 1 February 2006, case number FA RK 05-3693, 245595 (not published). For the continuation of the case see Rechtbank 's-Gravenhage, 10 December 2007, case number FA RK 06-4380, 269480, LJN BC5651.
} 
policy. The court finds that this is the case. It follows from the advice of the IJI that the naming of the commissioning father on the English birth certificate according to English law means that he is presumed to be the father of the child, which can be rebutted. Furthermore, the naming of a man as the father on an English birth certificate does not have the same effects as such a naming on a Dutch birth certificate. According to English law, such a naming does not per definition imply the creation of legal familial ties [read 'legal parentage', ks], while the mention of the acknowledger as the father on a Dutch birth certificate has as a consequence the creation of legal familial ties between the acknowledger and the child - with all the rights and obligations attached to it according to Dutch law. The recognition of the legal fact that the father acknowledged the child would therefore mean that the court recognises more than is meant by the naming on the English birth certificate. On this ground, the court finds that the recognition of the English birth certificate in as far as the mention of the father as acknowledger is concerned, is in violation of Dutch public policy.

It is doubtful whether the conclusion is correct that the naming of a man as the father on an English birth certificate violates Dutch public policy, because the inclusion of the name of the father is only a presumption of paternity. This approach means that it is impossible to recognise a man as the legal father if the birth certificate has been drawn up in England.

It is true that the significance of the inclusion of a man as father on an English birth certificate means something other than on a Dutch birth certificate. Under English law the naming is evidence of (biological) paternity and under Dutch law it is evidence that legal paternity has been established. But it has been explained above that foreign instruments cannot be recognised as if they were self-supporting judgments, because they are not. Instruments of civil status only have a meaning or value in relation to a certain legal system.

In the context of English law, it is clear that the English birth certificate has the same meaning as a Dutch birth certificate. In the first part it has been explained that under English law the man who is named as the father can only be deleted from the birth certificate by proving that he is not the biological and therefore legal father of the child. That is the same under Dutch law. The only difference is that the action to contest the paternity under Dutch law is much more restricted than under English law. Still, that should not matter for the recognition in the Netherlands of the legal paternity of the Dutch national under English law. After all, if later someone wants to contest the paternity of the Dutch national, English law is applicable. ${ }^{1207}$

The third example also comes from the court of 's-Gravenhage. ${ }^{1208}$ As in the case before the court of Amsterdam, the court in this case had to determine whether the legal paternity of a man mentioned on a Ghanaian birth certificate could be recognised as the father. The court held:

[...]. Furthermore, in the decision dated 21 November 2005 mentioned before it has been observed - with reference to a decision of the court of Amsterdam, department of administrative law dated 15 December 1995 - that according to the court of Amsterdam Ghanaian law does not distinguish between children born in or out of wedlock and that between a father and his (biological) child legal familial ties exist from the moment of birth.

However - according to a decision of the Court of Appeal of Leeuwarden dated 30 July 2003 (LJN AI0710) - the sole circumstance that a man is mentioned in the birth record of

${ }^{1207}$ Article 5 Wet Conflictenrecht Afstamming. See also Hoge Raad, 1 October 2004, NJ 2004/622, LJN AP2680.

1208 Rechtbank's-Gravenhage, 10 March 2008, case number FA RK 04-486, 214829, LJN BC6198. 
a child as the father is according to Ghanaian law not enough to conclude that between this man and the child a legal familial tie exists comparable with the legal familial tie which is created under Dutch law as a consequence of the acknowledgment of paternity. In a concrete case, relevant facts and circumstances - according to Ghanaian law - have to be taken into account to determine whether a legal familial tie has been actually created. The establishment of legal paternity in Ghana is regulated in articles 9 and 10 of the Maintenance of Children Decree 1977, which entered into force on 1 March 1978. The court refers to this law to determine whether the man is the legal father of the children according to Ghanaian law. Relevant facts according to Ghanaian law are: a) the question where a name giving procedure has taken place, b) the naming of the father on the birth record, c) the education and maintenance of the child, d) the declaration of the mother on the paternity of the man.

The citation reflects the same interpretation that has been advocated above. On the basis of the Maintenance of Children Decree 1977, the court examines whether the man who is named on the birth record is considered the legal father under Ghanaian law. Apparently, the court takes the stance that under Ghanaian law, the birth certificate is not enough evidence but taken the birth certificate together with other circumstances reveals that the man is considered the father under Ghanaian law. Therefore, the birth certificate is said to contain a legal fact.

\subsection{The legal facts or acts must have established legal familial ties}

Under Dutch law, a legal familial tie exists between a child and his or her legal parents. ${ }^{1209}$ The term legal familial tie was introduced in Dutch law in order to replace the concepts of legitimate and illegitimate children. ${ }^{1210}$ The terms legal parentage and legal familial tie are interchangeable.

According to the Hoge Raad, the second requirement in order to be able to recognise legal parentage is that the legal familial ties that exist according to foreign law can be equated with a legal familial tie according to Dutch law. ${ }^{1211}$ Also, article 10 WCA requires that the legal fact or the legal act establishes legal familial ties, but unlike the Hoge Raad, the provision does not mention a comparison between legal familial ties under foreign law and under Dutch law. In fact, the requirement that the foreign instrument must be evidence of a legal fact or act already implies that the fact or act must have established legal familial ties. After all, a legal fact or legal act is a fact or act to which the law attaches legal consequences. Which other consequences could be meant in the Choice of Law (Parentage) Act, than the establishment of legal parentage? Therefore, it can be doubted whether the third and the fourth requirement for recognition are really two different criteria.

Certain government authorities have interpreted the second requirement of the decision of the Hoge Raad and article 10 (1) WCA in such a way that it has to be established that legal parentage under foreign law has more or less the same effects as legal parentage under Dutch law. ${ }^{1212}$ For children born during a marriage the equivalence is presumed but for children born out of wedlock it has to be established that the father is obliged to maintain the child and that the child has the right to succeed to his property. The underlying assumption is that if the legal system does not recognise any rights and obligations between the child and his father on the basis of their parentage, their relationship cannot be characterised as legal parentage within the meaning of Dutch law.

\footnotetext{
1209 Article 1:197 Burgerlijk Wetboek.

${ }^{1210}$ Kamerstukken II 1995-1996, 24649, nr. 3, p. 1.

1211 Hoge Raad, 13 juli 2001, NJ 2002/215, LJN ZC3630, par. 3.4

1212 Evers e.a. 2003, p. 54.
} 
The typical situation is the case of Hachemi before the French Cour de Cassation.1213 In this case, a French national was mentioned as the father in the Algerian birth certificate of the illegitimate child Hachemi. The question arose whether or not Hachemi had French nationality on the basis of the French nationality of this father, while Algerian law does not recognise a legal relationship between a father and his illegitimate child. If the case had concerned Dutch nationality, the ruling of the Hoge Raad from 2001 would probably lead to a negative answer, because apparently Algerian law does not allow the establishment of parentage of illegitimate children.1214

\subsubsection{Exceptions to recognition}

The recognition of legal facts or acts shall be refused if there is a lack of a proper investigation or legal process prior to the creation of the instrument, ${ }^{1215}$ or if the recognition of the legal facts or acts would be manifestly contrary to Dutch public policy.1216 The sole fact that another law has been applied by the foreign registrar is no reason to conclude that the legal fact or act violates Dutch public policy. ${ }^{1217}$ The application of the public policy exception with regard to acknowledgment of paternity has been worked out in paragraph 2 of article 10 WCA. Legal acts or facts that are irreconcilable with a decision of a Dutch court concerning the same person's parentage that has become irrevocable shall not be recognised.1218

\subsection{Lack of proper investigation}

Neither the WCA nor the explanatory report to the WCA explains what the requirement means that the recognition of legal facts or acts can be refused because of a lack of proper investigation. What is not meant is that the foreign registrar has examined the biological affiliation of the child or in some other way has checked the truth of the statements of the informant concerning the birth of the child. This is also not done by Dutch civil status registrars. Under Dutch law, the registrar does not systematically check the truth of the statements of the informant. Only with regard to the time and place of birth and the woman to whom the child is born, the registrar can require a written declaration from a midwife or doctor, but such a declaration is not mandatory.1219

What the Dutch registrar does check on recording a birth or authenticating an acknowledgment of paternity is the child's legal parentage according to the applicable law. Thus, at the recording of the birth the registrar examines ex officio whether or not the mother of the child is married. The information concerning the marital status comes from the informant, but also from the population register if the mother resides in the Netherlands. If a man wants to acknowledge his paternity with regard to a certain child, the registrar checks whether the acknowledgment will indeed establish legal paternity: he examines whether the child already has a legal father and whether the requirements for a valid acknowledgment are fulfilled.

\footnotetext{
${ }^{1213}$ Cass. Civ. 1er, 25 April 2007, RCDIP 2008, 82.

1214 Statements about the contents of Algerian law are based on information from the judgment of the Cour de Cassation.

1215 Art. 10 (1) in conjunction with art. 9 (1) under b WCA.

1216 Art. 10 (1) in conjunction with art. 9 (1) under c WCA.

1217 Art. 10 (1) in conjunction with art. 9 (2) WCA.

1218 Art. 10 (1) in conjunction with art. 9 (3) WCA.

1219 Article 1:19e (8) Burgerlijk Wetboek. See also Plasschaert 2002, p. 576.
} 


\subsection{Irreconcilable with a decision of Dutch court}

Legal acts or facts that are irreconcilable with a decision of a Dutch court concerning the same person's parentage that has become irrevocable shall not be recognised. It does not seem to matter whether the Dutch judgment is given before or after the foreign instrument has been drawn up. After all, although the legal parentage described in a foreign instrument is recognised, the foreign instrument does not contain a decision which establishes with force of law the legal parentage of the child involved. If the Dutch court is not bound by the conclusions of Dutch registrar there is no reason why it should be bound by the conclusions of a foreign registrar.

\subsection{Violation of Dutch public policy}

Legal facts or acts that establish or change a person's parentage shall not be recognised if they violate Dutch public policy. The contents of the public policy exception have been worked out for acknowledgment of paternity in article 10 (2) WCA. The list of circumstances that violate Dutch public policy of article 10 (2) WCA is not exhaustive. Legal acts or facts that have been established abroad can violate Dutch public policy for other reasons.

\section{Article 10 (2) under a WCA - circumvention of adoption law}

Article 10 (2) under a WCA provides that the acknowledgment of paternity by a Dutch national violates Dutch public policy if according to Dutch law the man is not entitled to acknowledge his paternity. Article 10 (2) WCA mainly refers to article 1:204 (1) under e BW which provides that a man who is married to another woman than the mother of the child is not allowed to acknowledge paternity, unless the court has established that a close personal relationship exists between him and the child's mother or between him and the child.

The reason for article 10 (2) under a WCA is to avoid that a Dutch national circumvents the rules on (intercountry) adoption simply by acknowledging his paternity of a child abroad.1220 Since under most legal systems a valid acknowledgment of paternity does not require any evidence of biological paternity, it would be very easy to circumvent the laws on intercountry adoption simply by making a declaration of acknowledgment.

Although the prevention of avoidance of the laws on intercountry adoption is necessary, article 10 (2) under a WCA is not unproblematic. Two cases of the Hoge Raad on this provision from 2005 and 2006 will be discussed first.

In 2005 the Hoge Raad ruled on the recognition of an acknowledgment of paternity by a Dutch national in Turkey. ${ }^{1221}$ The man was a Turkish national who obtained Dutch nationality in 1997. The child A was born in 2001 and the man acknowledged his paternity in the same year. The mother of the child is a woman referred to as $C$, but at the moment of the acknowledgment of paternity the man was married to D. The only question to be determined by the Hoge Raad was whether the provision of article 10 (2) under a WCA also applied before the entry into force of the WCA in 2003.

The Hoge Raad held that also after the reform of Dutch law on parentage the main rule is that a married man cannot acknowledge his paternity concerning the child born to woman other than his wife. Moreover, the legislator had already expressed in the proposal for the WCA that article 1:204 (1) under e BW was considered an important tool in the prevention of avoidance of adoption law. Therefore, according to the Hoge Raad, it cannot

1220 Kamerstukken II 1998/99, 26 675, nr. 3, p. 21. Those rules are the Convention of 29 May 1993 on Protection of Children and Co-operation in Respect of Intercountry Adoption and the Dutch Wet opneming buitenlandse kinderen ter adoptie (Act on the reception of foreign children with a view to adoption). 1221 Hoge Raad, 27 mei 2005, NJ 2005/554, LJN AS 5109. 
be argued that the prohibition of article 1:204 (1) under e BW only became part of Dutch public policy at the entry into force of the WCA in 2003.

In the case at hand, the conclusion of the Hoge Raad meant that the legal paternity of the man could not be recognised unless it was established that a close personal relationship exists between him and the child's mother or between him and the child. This point was further elaborated in the second decision of the Hoge Raad in 2006.

In 2006 the Hoge Raad had to rule on the recognition of the acknowledgment of paternity by a Dutch national in Vietnam. ${ }^{1222}$ Since the first of May 2001, the Dutch couple lived in Vietnam. On the 23rd of October 2001 a child was born to a Vietnamese woman. A few days after the birth, the child was received in the family of the Dutch couple to be raised by them. On the 8th of February 2002 the Dutch man acknowledged his paternity concerning the child in Vietnam.

With a view to article 10 (2) under a WCA in conjunction with article 1:204 (1) under e BW, the man applied in the Netherlands for a declaration that at the moment of his acknowledgment a close personal relationship exists between him and the child's mother or between him and the child.

In order to prove the close personal relationship the man made the following declaration. He had had a one-night stand with the mother of the child in Hanoi. Six months later the mother told him that she was pregnant and that she would have to leave the child in an orphanage since she lacked the financial means to take care of the child. The Dutch couple decided to take up the responsibility for the child's upbringing. After the child's birth they gave the mother some money to set up her own business and all contacts between the man and the mother ceased.

Before the Hoge Raad the matter boiled down to two questions. The first was whether a Dutch court could establish the close personal relationship retroactively, thus after the acknowledgment had been made. On behalf of the Dutch state it was argued that judicial approval of the acknowledgement had to be obtained before the acknowledgment, because otherwise it would be too easy to avoid the rules on intercountry adoption.

The Hoge Raad held that it had been established that a close personal relationship already existed at the moment of the acknowledgment. Therefore, the man fulfilled the substantive requirements of article 1:204 (1) under e BW. From that perspective, only the fact that the existence of a close personal relation had not been established prior to the acknowledgment would not lead to the conclusion that the acknowledgment violated fundamental principles of Dutch law.

The second question was whether or not the acknowledger had to prove that he was the biological father of the child. Again, from the perspective of preventing the avoidance of intercountry adoption rules, such a requirement could be well imagined. But here also, the Hoge Raad did not agree.

The Hoge Raad held on the basis of the parliamentary reports concerning article 1:204 (1) under e BW that the provision does not require the acknowledger to prove his biological paternity. The only thing that has to be proven is the existence of a close personal relationship at the moment of the acknowledgment.

In order to appreciate article 10 (2) under a WCA and the case law of the Hoge Raad, the first question that has to be answered is what exactly is avoidance of the law on intercountry adoption? The answer to this question is not at all simple, given the fact that under Dutch law the acknowledgement of paternity is under certain circumstances considered to be an

1222 Hoge Raad, 28 April 2006, NJ 2006/557, LJN AU9237. 
acceptable substitution for adoption. This can be the case if the biological father is unknown or if he does not take any notice of the child. ${ }^{1223}$

Another problem is that no adequate definition exists to separate the law on parentage from the law on adoption. The Hague Adoption Convention and the Dutch Wet Conflictenrecht Adoptie (Conflict of laws (Adoption) Act) only provide that an adoption is the decision of a competent authority which creates a permanent parent-child relationship. ${ }^{1224}$ This is not a satisfactory definition because the judicial establishment of paternity is also a decision which creates a permanent parent-child relationship and it is not an adoption.

In fact, as long as at the national level the acknowledgment of paternity is valid without evidence of biological paternity, and as long as it is accepted on the national level that acknowledgment of paternity can be an acceptable substitute for adoption, it will be hard to fight the avoidance of adoption law in an international context.

The prevention of the avoidance of the law on intercountry adoption - and the application of the public policy exception against the recognition of the parentage in general - is also complicated by the possible existence or development of family life between the acknowledger and the child in the country where the legal parentage is recognised.

In the case before the Hoge Raad in 2006, it was established that a close personal relationship existed between the acknowledger and the child at the moment of the acknowledgment. However, in his note Struycken notes that the existence of a close personal relationship was to a large extent based on facts that took place after the acknowledgment of paternity. This observation raises the question whether article 10 (2) under a WCA can affect legal parentage that has already been established abroad.

Let us change the facts of the Vietnamese case a little. In that case, the purpose of the litigation was to establish the Dutch nationality of the child, based on the child's affiliation with the Dutch man. Let us assume that the child's nationality is not an issue. The child has been raised by the Dutch couple in Vietnam for 20 years. After 20 years, the man dies intestate. The woman returns to the Netherlands with the child who, in the meanwhile, has reached the age of 20 . Would it really be possible in such a case to argue that the child cannot succeed to the estate of the deceased because the acknowledgment violated Dutch public policy?

It must be observed that the Dutch rules on intercountry adoption themselves have a limited scope of application in time. If the adoptive parents have accepted a foster child in their family with a view to adoption while they were habitually resident abroad, they will not be subject to the Dutch rules on intercountry adoption if they have raised and educated the child in that country for at least one year. ${ }^{1225}$

Moreover, from the perspective of European law it seems that even if a close personal relationship (read: family life) developed after the acknowledgment of paternity, article 8 ECHR will not allow an unrestricted application of the public policy exception. It will have to be argued why the infringement of the family life is justified in the concrete case.1226

\footnotetext{
1223 Asser/De Boer 2006, nr. 717.

1224 Article 2 (2) Hague Adoption Convention; article 2 Wet Conflictenrecht Adoptie. On possible definitions of adoption see also G. Parra-Aranguren, Explanatory report on the Convention on protection of children and co-operation in respect of intercountry adoption (1994), nr. 87-94.

${ }^{1225}$ Article 14 Wet opneming buitenlandse kinderen ter adoptie (Act on the reception of foreign children with a view to adoption).

${ }^{1226}$ See in the context of an adoption ECHR 28 June 2007 (Wagner and J.M.W.L. $v$ Luxemburg), application number, 76240/01.
} 
The third problem with regard to article 10 (2) under a WCA in conjunction with article 1:204 (1) under e BW is that it is a rather selective means to avoid the avoidance of the law on intercountry adoption. Article 1:204 (1) under e BW provides that a man who is married to another woman than the mother of the child cannot acknowledge his paternity unless a close personal relationship exists between him and the child or the mother of the child. But what about the man who is married to another man or the man who has a registered partnership with another woman or another man?1227

It seems that article 10 (2) under a WCA in conjunction with article 1:204 (1) under e BW is one of the few provisions that discriminates heterosexual married couples compared to homosexuals and registered partners. But why? There is no sound reason. In fact, article 1:204 (1) under e BW is never meant to prevent the avoidance of the law on (intercountry) adoption. The provision has been inserted in 1996 in the proposal for the reform of the law on parentage on the instigation of the Christian parties to protect the sanctity of marriage.1228 In 1999 the provision suddenly appeared in the explanatory report to the WCA as a means to prevent the avoidance of the law on intercountry adoption.

\section{Article 10 (2) under b WCA - consent of the mother or the child}

Article 10 (2) under b WCA provides that the acknowledgment of paternity violates Dutch public policy if, where the consent of the mother or the child is concerned the requirements of the law applicable according to article 4 (4) WCA are not complied with. Above it has been explained that article 4 (4) WCA states that the consent of the mother and the child to the acknowledgment of paternity is governed by the national law of the mother or the child respectively. If that legal system does not know the concept of acknowledgment of paternity, the law of the habitual residence of the mother or the child applies. Article 10 (2) under b WCA has been inserted in order to prevent that the man can undermine the right of a Dutch woman or a woman who is living in the Netherlands to veto the acknowledgment of paternity by going abroad. ${ }^{122}$ The explanatory report states that the consent of the mother or the child does not need to appear from the foreign instrument. It is enough that the mother's consent can be deduced form the circumstances of the case, for example the fact that the mother requests the registration of the acknowledgment in the Netherlands. ${ }^{1230}$

\section{Article 10 (2) under c WCA - sham act}

Article 10 (2) under c WCA provides that the acknowledgment of paternity shall not be recognised if it constitutes a sham act. Sham acts are a major concern in Dutch law on personal status (marriage, parentage, adoption). ${ }^{1231}$ An acknowledgment of paternity is a sham act, if the acknowledgment is done only with the purpose to give the acknowledger or the child a right to reside in the Netherlands. ${ }^{1232}$

Not only via the WCA but also via the Rijkswet op het Nederlanderschap (RwNed) (Dutch Nationality Act), the legislator has tried to combat the possibility to acknowledge paternity concerning a child solely to grant the child a right of residence in the Netherlands. On the first of April 2003 certain amendments to the Rijkswet op het Nederlanderschap entered into force as a result of which the acknowledgment of paternity by a Dutch national did not automatically confer Dutch nationality upon the child.1233

\footnotetext{
1227 See also Rechtbank Arnhem 26 April 2008, LJN BI3495; Gerechtshof Amsterdam 5 August 2008, LJN BG2522. 1228 Kamerstukken II 1996/97, 24 649, nr. 6, p. 23; kamerstukken II 1996/97, 24 649, nr. 7.

1229 Kamerstukken II 1998/99, 26 675, nr. 3, p. 21.

1230 Kamerstukken II 1998/99, 26 675, nr. 3, p. 21.

1231 See for example article 6 (3) Wet conflictenrecht adoptie; articles 1:25 (4), 44 (1) under k, 71a, 80a (7), 205 (2) BW.

1232 Kamerstukken II 1998/99, 26 675, nr. 3, p. 21.

1233 Rijkswet van 21 December 2000 tot wijziging van de Rijkswet op het Nederlanderschap met betrekking tot de verkrijging, de verlening en het verlies van het Nederlanderschap, Stb. 2000, 618.
} 
However, it appeared that the measure was too drastic. The effect of the measure was that a child who was born to an unmarried foreigner and her Dutch partner did not get Dutch nationality if the man acknowledged his paternity after instead of before the birth of the child.1234 Therefore, the amendments were reversed as from the first of March 2009.1235

Nowadays, article 4 (2) RwNed provides that if the man acknowledged his paternity concerning a child before the child has reached the age of seven years, he or she will be a Dutch national. If the child is seven years or older, but still under the age of eighteen, the child acquires Dutch nationality on the basis of the acknowledgment of paternity by a Dutch national if it is proven that the man is the child's biological father (art. 4 (4) RwNed).

So far there are no judicial decisions where the acknowledgment of paternity has been refused recognition on the basis that it is a sham act. Dutch case law only provides examples where courts observe that the acknowledgment of paternity does not constitute a sham act, because the acknowledger is the biological father and/or because he and the woman had a stable relationship for an appreciable period of time. ${ }^{1236}$

From 1 March 2009, the ability of the registrar to combat sham acts has been reinforced. It follows from article 4 (2) and (4) Rijkswet op het Nederlanderschap (Dutch Nationality Act) that a child who has been recognised by a Dutch national after the child has reached the age of seven years only acquires Dutch nationality if it is proven by means of a DNA test that the acknowledger is the biological father of the child. ${ }^{1237}$

\section{Public policy and surrogacy}

In 2009 the court of 's-Gravenhage held on two occasions that a foreign birth certificate that does not name the birthmother of the child, while it is known who gave birth to the child, violates Dutch public policy.

The first decision concerned a case of a Dutch surrogate and two Dutch men who were the commissioning parents. ${ }^{1238}$ The three persons lived in the Netherlands. The surrogate mother gave birth anonymously in France to make sure that she did not appear on the child's birth certificate. One of the men acknowledged his paternity before the French civil status registrar.

The court held that the French birth certificate violated Dutch public policy. It observed that according to international law (article 7 Convention on the Rights of the Child) the child has the right to know his origins as much as possible. According to the court, it is for the child at a later moment in his life to form his identity as he wishes. For that the child must have access to all the information on his affiliation. Therefore, article 1:198 Burgerlijk Wetboek, establishing the legal maternity of the birthmother, is such a fundamental rule of Dutch family law that it expresses Dutch public policy. A birth certificate that does not name the birthmother while she is known therefore violates Dutch public policy.

Also the acknowledgment of paternity could not be recognised. The court held that the acknowledgment requires the consent of the mother. The conclusion of the court is remarkable, because the legislator observed that the consent of the mother does not need to appear from the instrument of acknowledgment. It is sufficient that her consent can be derived from the circumstances of the case (see above), in this case the surrogacy agreement.

\footnotetext{
1234 On this problem in more detail: Oderkerk 2006; Saarloos 2005; De Groot \& Saarloos 2004.

1235 Wet van 27 juni 2008 tot wijziging van de Rijkswet op het Nederlanderschap ter invoering van een verklaring van verbondenheid, en tot aanpassing van de regeling van de verkrijging van het Nederlanderschap na erkenning, Stb. 2008, 270.

1236 E.g. Rechtbank's-Gravenhage 7 February 2008, LJN BG4404; Rechtbank Zwolle 14 February 2006, LJN AV4694.

1237 See also Besluit DNA-onderzoek vaderschap, Stb. 2008, 270.

1238 Rechtbank's-Gravenhage, 14 September 2009, LJN BK1197.
} 
The second decision concerned a case of a Dutch and an American man who lived in the United States of America. ${ }^{1239}$ Their children were born to a Californian surrogate mother. At the moment of the birth all the persons involved habitually resided in the USA. The Californian court determined that the two men were the legal parents of the child and they also appeared as the parents on the Californian birth certificates of the children. Shortly after the birth of the children, the family moved to the Netherlands.

The court of 's-Gravenhage refused to recognise the two men as the legal parents of the child on the basis of the same reasoning as in the case of the French birth certificate. Since the Californian authorities did not establish the legal maternity of the birthmother, neither the documents nor the parenthood of the commissioning parents could be recognised.

It is doubtful whether the second judgment is correct. It has been explained above in the context of article 3 WCA, that according to the legislator art. 1:198 Burgerlijk Wetboek (the birthmother is the child's legal mother) only mandatorily applies if either the birthmother has Dutch nationality or if she habitually resides in the Netherlands at the moment of birth. ${ }^{1240}$ In this case, the birthmother has American nationality and at the moment of birth she habitually resided in California.

\subsubsection{Recognition of the non-existence of legal parentage}

Article 10 WCA applies to legal acts and facts that have established or modified legal parentage that are laid down in a document. But what about legal parentage that has not been established abroad? What happens if the foreign birth certificate of the child does not indicate a legal father, because according to the law (including choice of law rules) of the authority that drew up the birth certificate legal paternity has not been established?

With regard to foreign judgments the legislator indicated that article 9 WCA only applies to foreign judgments establishing or modifying legal parentage and not to judgments that rejected the application. ${ }^{1241}$ Does that mean that if the foreign registrar concludes on the basis of his own (private international) law that legal paternity has not been established that the Dutch registrar has to check on the basis of the choice of law rules of the WCA whether indeed the child does not have a legal father?

It has been explained above that article $10 \mathrm{WCA}$ is meant to give effect to the fait accompli principle by protecting the legitimate expectations of the persons involved and the legal certainty. ${ }^{1242}$ The birth certificate does not establish legal parentage, but it proves the legal parentage of the child. It must therefore be presumed that the expectations which are based on the birth certificate relate to the legal parentage of the child as a whole and not only to the legal parentage of the parents whose parentage has been established according to the birth certificate. Only if the parentage as it appears from the birth certificate is not in accordance with the lex fori, can the birth certificate be amended.

\subsubsection{Existing legal parentage that is not registered}

Article 314 Code civil provides that the husband of the mother is not the legal father of the child if he is not named on the birth record as father and if the child does not have apparent status with regard to him. However, if the husband is not named on the birth record but if the child does have apparent status with regard to him the husband is the legal father of the child.

\footnotetext{
1239 Rechtbank's-Gravenhage, 23 November 2009 (328511/FA RK 09-317) (not published).

$1240 \S$ 7.2.1. Recognition of legal parentage under Dutch private international law.

1241 Kamerstukken II 1998-99, 26 675, nr. 3, p. 19, 20.

$1242 \S 6$.2.3. Applicable law to the legal parentage between the woman and the child born out of wedlock under Dutch PIL. On surrogacy and the Dutch public policy exception see also Saarloos \& Van Berkel 2008.
} 
On the basis of article $10 \mathrm{WCA}$, the Dutch authorities recognise on the authority of the French birth certificate that the child does not have a legal father. But which law applies to the claim of the husband that he is the legal father because the child has apparent status with regard to him? Is it French law because the birth certificate of the child has been drawn up in France or does it depend on the Dutch choice of law rule?

It has been explained above that the recognition of foreign instruments is an exception to the application of the Dutch choice of law rules, based on the fait accompli principle to protect legitimate expectations and legal certainty. Under article $10 \mathrm{WCA}$, the description of a certain status in a birth certificate is sufficient to establish a fait accompli. In principle that would mean that if the birth certificate does not indicate the husband as the father of the child and if the registrar did not make a mistake at the moment of the registration, the applicable law to the question whether apparent status establishes legal paternity after the registration of the birth is determined by Dutch choice of law rules.

\subsubsection{Recognition of foreign instruments of civil status under Dutch law}

The two problems with regard to foreign instruments of civil status are how to determine whether or not the instrument is authentic instead of false and how to determine the evidential force of the document with regard to the statements and facts it mentions.

Dutch authentic public documents that purport to be authentic public documents are automatically recognised as such. ${ }^{1243}$ This is not the case with foreign authentic public documents if only because the Dutch courts and civil servants are not familiar with the characteristics of foreign authentic instruments and public documents. The authenticity of a foreign public document is established by means of the legalisation of that document. It is not necessary that the document is an authentic document within the meaning of Dutch law. Regarding documents on civil status, the document has to be drawn up by a public authority that is competent to draw up documents on personal status and the document must have been drawn up in accordance with local rules.1244

Legalisation is the formality by which the Dutch diplomatic or consular agents certify the authenticity of the signature, the capacity in which the person signing the document has acted and, where appropriate, the identity of the seal or stamp which it bears. ${ }^{1245}$ Article 1:26b BW in conjunction with article 986 (3) Wetboek van Burgerlijke Rechtsvordering provides that in adjudicating on the question whether a foreign public document concerning a person's status can be recorded in a Dutch register of civil status, the court has the possibility to demand the legalisation of the foreign document. ${ }^{1246}$ However, for civil servants, a Ministerial circular states that the starting point in the Netherlands is that every foreign public document has to be legalised before it can be taken into consideration. ${ }^{1247}$ Public documents emanating from countries with which the Netherlands has concluded a legalisation treaty are exempted from legalisation. ${ }^{1248}$

In private international law in general and in French and German private international law in particular the relationship between the law applicable to legal parentage and recognition

\footnotetext{
${ }^{1243}$ Article 159 (1) Wetboek van Burgerlijke Rechtsvordering.

1244 Article 10 (1) Wet Conflictenrecht Afstamming; article 1:20b (1), 25 (1) Burgerlijk Wetboek. See also note 1186.

1245 Article 2 Convention of 5 October 1961 Abolishing the Requirement of Legalisation for Foreign Public Documents; Circulaire legalisatie en verificatie buitenlandse bewijsstukken, alsmede toepassing DNA onderzoek in gevallen waarin bewijsstukken ontbreken, Staatscourant 2006/91, p. 13 et seq.

1246 See also Hoge Raad, 5 September 2003, NJ 2005/4, m.nt. SW; RvdW 2003/138; JOL 2003/407.

${ }^{1247}$ Circulaire legalisatie en verificatie buitenlandse bewijsstukken, alsmede toepassing DNA onderzoek in gevallen waarin bewijsstukken ontbreken, Staatscourant 2006/91, p. 13.

1248 For an overview of the countries with which the Netherlands has concluded a legalisation treaty: www.minbuza.nl/legalisatie.
} 
of foreign instruments of civil status is that foreign instruments of civil status prove statements and facts on the basis of which the applicable law to legal parentage determines whether or not legal parentage exists. ${ }^{1249}$ In this relationship questions arise with regard to the evidential value of the foreign public document: to what extent does it have to be presumed that the statements recorded in the document are actually made and to what extent does it have to be presumed that the statements and the facts that are recorded are true. However, these questions do not arise under article 10 (1) Wet Conflictenrecht Afstamming. Above, it has been explained that article 10 (1) WCA requires that the foreign document is evidence of the existence of a legal act or fact under the law of the place where the document was drawn up. At first sight, this is a somewhat peculiar requirement, because the special evidential value of public documents like a birth certificate or an instrument of acknowledgment of parenthood relates only to facts or statements and not to legal relations. For example, under Dutch law, article 1:22 (1) BW states that the birth certificate proves that at the place and time mentioned on the birth certificate a child is born to the woman mentioned in that certificate. For the rest, instruments of civil status have the same evidential value as authentic instruments in general. 1250 Thus, the Dutch birth certificate may only be considered evidence of legal maternity because article 1:198 BW provides that the legal mother of the child is the woman to whom the child is born. Legal paternity is proven by the birth certificate in combination with the marriage certificate of the mother. ${ }^{1251}$ The naming of a man as father on the birth certificate has no special evidential value. An instrument of acknowledgment is evidence of the fact that the man acknowledged his paternity. ${ }^{1252}$ For the establishment of legal paternity under Dutch law that is enough, because for the establishment of legal paternity it does not matter whether or not the acknowledger is the biological father of the child. ${ }^{1253}$ In practice, the entering of the name of a man as father on the birth record of a child or the recording of an acknowledgment of paternity will carry some weight, since under Dutch law legal paternity has to be mentioned on the birth certificate and Dutch registrars are generally very precise, even scrupulous when it comes to determining the legal parentage of a child. But still, if the legal paternity of a man is disputed the entering of his name as father or the recording of his acknowledgment is only a beginning of evidence. Article 10 (1) WCA transforms this beginning of evidence into some sort of presumption that the man who is named as the father in these documents is the legal father. ${ }^{1254}$

\subsubsection{Recognition of legal parentage under English private international law}

The traditional approach towards the recognition of personal status in English private international law is that the family relation, once duly constituted by the law of any civilised country, should be respected and acknowledged by every other member of the great community of nations.' 1255 The only question is when a family relationship is duly constituted.

There is no evidence that English private international law takes the same stance with regard to the recognition of legal parentage that has been laid down in a public document as Dutch private international law does. It has been suggested that English law should adopt

\footnotetext{
1249 See also Van de Velden 2007, p. 239.

1250 Article 1:22 (3) BW.

1251 Vat (Personen- en familierecht), art. 1:22 BW, aant. 1.

1252 Article 157 (1) Wetboek van Burgerlijke Rechtsvordering.

1253 Asser/De Boer 2006, nr. 715.

1254 See also Boeles 2003, p. 73.

1255 Re Goodman's Trust (1881) 17 Ch. D. 266, CA.
} 
such an approach, 1256 but it is not yet present in any branch of English private international law on personal status.

With regard to legitimacy for example the registration of a child as legitimate or legitimated in a foreign country is as such not relevant to determine the legitimacy of the child under English law. The legitimacy and legitimation of the child depends on the choice of law rules for these issues which have been discussed above. ${ }^{1257}$ Only if the legitimacy or the parentage has been established in a judgment, it is not the applicable law but the jurisdiction of the foreign court which primarily determines whether the parental status granted by the foreign judgment is recognised. ${ }^{1258}$

Another example is the way in which English private international law deals with the question whether a marriage that has been celebrated abroad exists in England. Also with regard to marriage, the current method under English private international law is one of choice of law rather than recognition. Since 1858 the lex loci celebrationis only governs the formal validity of the marriage. The prevailing view is that the essential validity of the marriage depends on the laws of the domiciles of both spouses at the time of the marriage (dual domicile doctrine). ${ }^{1259}$

To date, the courts have not been invited to develop choice of law rules on legal parentage, but considering the approach which is used with regard to legitimacy and marriage it is likely that future rules will be based on a choice of law method rather than a recognition method.

The absence of a recognition method with regard to legal parentage under English law is indirectly illustrated by $\operatorname{Re} X \mathcal{E} Y$ (Foreign Surrogacy). ${ }^{1260}$ In this case a British couple goes to Ukraine to have a child with the help of a Ukrainian surrogate mother. The Ukrainian birth record of the child named the British couple as the legal parents of the child. However, the British authorities did not recognise the couple as the legal parents of the child on the basis of the Ukrainian document. In his decision Judge Hedley does not discuss any choice of law rules to determine the parentage of the child. The reason for this was that the commissioning parents applied under section 30 Human Fertilisation and Embryology Act 1990 for a parental order. However, the very fact that the commissioning parents had to apply under section 30 already indicates that the parentage that has been established abroad as such is not decisive.

\subsubsection{Recognition of foreign instruments of civil status under English law}

Unlike under Dutch, French and German law there is no general procedure to determine the authenticity of foreign instruments of civil status. There is no requirement under English law to legalise foreign public documents in order for them to be admissible before judicial or administrative authorities in the United Kingdom. ${ }^{1261}$ With regard to birth certificates it is argued that the procedure for acceptance of such certificates is at the discretion of the authority or institution requiring its production. In general terms such duly certified documents are accepted on face value. ${ }^{1262}$

At common law the general rule is that registers and certified extracts from registers kept outside England and Wales are admissible as evidence before English courts and administrative authorities. The requirements for admissibility were formulated inter alia by Lord Selborne in 1889:

\footnotetext{
1256 Norrie 1994, p. 763.

1257 § 6.3. English choice of law rules on parentage.

1258 See for example Trafford $v$ Blanc (1887) LR 36 Ch D 600.

${ }^{1259}$ North, Fawcett \& Carruthers 2008, p. 896; Collins 2006b, nr. 17R-054.

1260 [2008] EWHC 3030 (Fam).

1261 Ready 2007, p. 15, 33

1262 Ready 2007, p. 22; Phipson, Malek \& Auburn 2005, nr. 41-52.
} 
Foreign registers of baptisms and marriages, or certified extracts from them, are receivable in evidence in the Courts of this country, as to those matters which are properly and regularly recorded in them, when it sufficiently appears (in the words of Mr. Hubback's learned work on Evidence) that they "have been kept under the sanction of public authority, and are recognised by the tribunals of the country" (i.e. of the country where they are kept) "as authentic records." 1263

Per section 7 (2) of the Civil Evidence Act 1995 this common law rule still has effect. Expert evidence might be required to determine whether or not a foreign a document is an extract from a register that "has been kept under the sanction of public authority, and are recognised by the tribunals of the country as authentic records." However, for certain countries orders have been made on the basis of which documents that purport to be issued in those countries as an official copy of an entry in a register mentioned in the order and which purports to be authenticated shall, without evidence as to the custody of the register or of inability to produce it without any further proof, be received as evidence that the register contains such an entry. ${ }^{1264}$

At common law, an entry in a register of birth is prima facie but not conclusive evidence of the truth of the facts that are required by statute to be entered in it. ${ }^{1265}$ Pursuant to Registration of Births and Deaths Regulations 1987 the prescribed particulars required to be registered for a live birth are the place and date of the birth, the name, surname and sex of the child, the name, surname, place of birth and occupation of the father and the mother of the child and information concerning the informant. ${ }^{1266}$ The particulars concerning the father of the child shall not be registered if the father and the mother are not married except in the cases of section 10 Births and Deaths Registration Act 1953. An entry in the birth register and a true certified copy of that entry are prima facie evidence of the place and date of birth. ${ }^{1267}$ According to the prevailing view the entry of a man's name on the child's birth record is also prima facie evidence of his (biological) paternity. ${ }^{1268}$ For the purpose of British nationality, the British Nationality (Proof of Paternity) Regulations 2006 provide that a birth certificate issued within one year of the date of the child's birth is evidence of paternity. ${ }^{1269}$

Applying the common law rule to foreign public documents on civil status, it means that they are evidence of the facts that are required by statute to be mentioned in these documents. With regard to documents of civil status from France, Germany and the

\footnotetext{
1263 Lyell v Kennedy (1889) 14 App Cas 437. See also Ready 2007, p. 35; Phipson, Malek \& Auburn 2005, nr. 32-67. 1264 S. 5 Evidence (Federal Republic of Germany) Order 1970, SI 819. See also s. 3 Evidence (France) Order in Council 1937, SI 515; s. 5 Evidence (The Netherlands) Order 1970, SI 284. The registers mentioned in the orders include the registers of civil status. For a complete overview see Phipson, Malek \& Auburn 2005, nr. 32-74.

1265 Brierley v Brierley and Williams [1918] P 257, 87 LJP 153; Re Goodrich, Payne v Bennett [1904] P 138; Jackson v Jackson and Pavan, [1964] P 25, [1960] 3 All ER 621, [1961] 2 WLR 58; Masson, Bailey-Harris \& Probert 2008, nr. 17-006, 009; Lowe \& Douglas 2007, p. 322; Tapper 2004, p. 623; Mackay of Clashfern 2001a, nr. 98. Lord Chancellor's Department Consultation Paper, Procedures for the determination of paternity and the law on parental responsibility for unmarried fathers, 1998, nr. 26.

1266 Reg. 7 Registration of Births and Deaths Regulations 1987, SI 1987/2088.

1267 Phipson, Malek \& Auburn 2005, nr. 32-81.

1268 Jackson v Jackson and Pavan, [1964] P 25, [1960] 3 All ER 621, [1961] 2 WLR 58; Masson, Bailey-Harris \& Probert 2008, nr. 17-006, 009; Lowe \& Douglas 2007, p. 322; Tapper 2004, p. 623; Mackay of Clashfern 2001a, nr. 98. Lord Chancellor's Department Consultation Paper, Procedures for the determination of paternity and the law on parental responsibility for unmarried fathers, 1998, nr. 26.

1269 S. 2 (a) British Nationality (Proof of Paternity) Regulations 2006, SI 2006/1496.
} 
Netherlands orders provide that all matters that are recorded in the registers shall be deemed, until the contrary is proved, to be regularly recorded therein. ${ }^{1270}$

However, it is important to observe that birth certificates from France, Germany and the Netherlands are no evidence of biological paternity. They also do not purport to be. At best, they are evidence of the fact that the legal paternity of the man who is mentioned as the father has been legally established. Dutch, French and German law require the registration of the legal father of the child, even if it is contended that he is not the biological father of the child.

\subsubsection{Recognition of legal parentage under French private international law}

Under French private international law legal parentage only exists if it exists according to the law that applies to legal parentage per articles 311-14, 311-15 and 311-17 Code civil. Whether legal parentage exists between the child and the persons mentioned as father and mother in the birth certificate according to the law of the place where the birth record or the instrument of acknowledgment of parenthood has been drawn up is irrelevant.1271

The approach can be illustrated by the decision of the Cour de Cassation of the 14th of July 2005. The Cour de Cassation decided the question whether a certain X possessed French nationality. ${ }^{1272} \mathrm{X}$ would only be a French national if he was legally affiliated with a French mother. The name of this mother was recorded in his Gabonese birth certificate. Since the mother was French, article 311-14 Code civil provided that French law applied to the existence of legal maternity. According to French law at that time, i.e. before the Ordonnance 2005-759 of the fourth of July 2005 on the reform of the law on parentage, the recording of the unmarried mother on the child's birth record did not establish her legal maternity. Thus, in this case the Cour de Cassation held that $X$ did not posses French nationality, because legal maternity had not been established.

The reasoning can be found in the decisions of the Cour de Cassation of the 14th of February 2006 and the 13th of March 2007.1273 In these cases also, the applicant claimed French nationality on the basis of the recording of his mother's name on his foreign birth certificate. However, in these cases the court held that the rule that legal maternity was not established by the recording of the mother's name on the child's birth record violated articles 8 and 14 of the European Convention on Human Rights.

The same reasoning is also found with regard to legal paternity. In its decision of the 25th of April 2007 the Cour de Cassation decided that Hachemi X did not posses French nationality. ${ }^{1274}$ Hachemi $X$ was born out of wedlock in Algeria and his Algerian birth certificate mentioned Abdelkader $X$ as his father, who possessed French nationality. However, the legal paternity of Abdelkader $X$ was governed by Algerian law, the national law of the mother of Hachemi X (art. 311-14 Code civil). According to Algerian law, the establishment of legal paternity concerning a child born out of wedlock is not possible. Consequently, the legal paternity of Abdelkader X had not been established and Hachemi X did not possess French nationality.

This approach is also applied in the practice of the French civil status registration. If a French national is born abroad, his foreign birth certificate can be transcribed on the French register of births. However, the French authorities shall refuse the transcription of the foreign birth certificate of a French national, if the foreign birth certificate is not in

\footnotetext{
1270 S. 4 Evidence (Federal Republic of Germany) Order 1970, SI 819. See also s. 2 Evidence (France) Order in Council 1937, SI 515; s. 4 Evidence (The Netherlands) Order 1970, SI 284.

1271 In more general terms: Mayer \& Heuzé 2007, nr. 472; Note P. Lagarde under Cass. Civ. 1er, 12 February 1963, RCDIP 1964, 121.

1272 Cass. Civ. 1er, 14 June 2005, Bull. civ. 2005, nr. 256.

1273 Cass. Civ. 1er, 14 February 2006, Bull. civ. 2006, nr. 73; Cass. Civ. 1er, 13 March 2007, RCDIP 2008, 82.

1274 Cass. Civ. 1er, 25 April 2007, RCDIP 2008, 82.
} 
accordance with French law.1275 If the transcription is refused, the birth of the person can be registered by the French authorities directly on the basis of article 98 Code civil. The same applies to the recording of a foreign instrument of civil status on a French birth record. If for example a man acknowledged his paternity in the Netherlands concerning a child that is born in France, the French registrar of civil status that has recorded the birth of the child can record the Dutch acknowledgment on the child's birth record. He shall only record the Dutch acknowledgment, if the acknowledgment establishes legal paternity according to the lex causae of the French conflict rule on parentage. ${ }^{1276}$

\subsubsection{Recognition of foreign instruments of civil status under French law}

The question which law applies to the existence of legal parentage has to be distinguished from the question which law applies to the evidence of the facts that lead to the establishment of legal parentage. It is a general rule of French private international law that the lex causae also governs certain questions of evidence like the object of evidence and the burden of proof. 1277 With regard to parentage, the law applicable to parentage also decides the means of evidence. ${ }^{1278}$ -

The facts that have to be proven in order to determine someone's legal parentage are usually proven with instruments of civil status: the birth certificate proves that the child is born at a certain date and place to a certain woman, the instrument of acknowledgment proves that a certain man acknowledged his paternity concerning a certain child.

The question whether or not a foreign instruments of civil status has evidential value is determined by article 47 Code civil. It is the codification of case law of the Cour de Cassation that irregularities in foreign documents of civil status deprive the foreign document of any evidential value. 1279

The current version of article 47 Code civil provides that every instrument of civil status concerning a French national or a foreigner drawn up abroad in the customary form is admissible as evidence unless it appears from other instruments or documents, external facts or elements in the instrument itself or the necessary verifications that the instrument is irregular, forged or that the facts mentioned do not correspond with reality. ${ }^{1280}$ The provision does not abolish the requirement to legalise foreign instruments of civil status. In 2009 the Cour de Cassation reaffirmed that on the basis of international custom foreign instruments of civil status, in this case a birth certificate, have to be legalised to use them in France, unless treaty provisions determine otherwise. ${ }^{1281}$

The concept of 'instrument of civil status' has been defined by the Cour de Cassation in Suhami $v$ Venture. ${ }^{1282}$ This complicated case was about the succession to the estate of Benjamin Suhami. The dispute was between the children of the cousin of the deceased, referred to as the Venture family, and the children of Yako Suhami, the brother of the

\footnotetext{
1275 Instruction générale relative à l'état civil du 11 mai 1999, nr. 510, Journal Officiel nº 172 du 28 juillet 1999.

1276 Instruction générale relative à l'état civil du 11 mai 1999, nr. 224, Journal Officiel nº 172 du 28 juillet 1999.

1277 Audit 2008, nr. 446 et seq.

1278 Audit 2008, nr. 734; Mayer \& Heuzé 2007, nr. 609; Foyer 1985, nr. 32; Note G. Wiederkehr, under Cass. Civ 1 er, 16 July 1974, RCDIP 1975, 461; note A. Ponsard under Cour d'appel de Dijon, 24 October 1967, JDI 1969, 87. See also Cass. Civ. 1er, 28 March 2006, Bull. civ. 2006, nr. 178.

1279 Cass. Civ. 1er, 25 February 2003, RCDIP 2003, 437; Cass. Civ. 1er, 2 May 2001, RCDIP 2002, 71; Cass. Civ. 1er, 24 October 2000, RCDIP 2001, 332; Cass. Civ. 1er, 29 November 1994, RCDIP 1995, 543; Cass. Civ. 1er, 14 June 1983 , RCDIP 1984, 316.

1280 Article 47 Code civil: Tout acte de l'état civil des Français et des étrangers fait en pays étranger et rédigé dans les formes usitées dans ce pays fait foi, sauf si d'autres actes ou pièces détenus, des données extérieures ou des éléments tirés de l'acte lui-même établissent, le cas échéant après toutes vérifications utiles, que cet acte est irrégulier, falsifié ou que les faits qui y sont déclarés ne correspondent pas à la réalité. On the application of article 47 Code civil see BidaudGaron 2006.

1281 Cass. Civ. 1er, 4 June 2009, RCDIP 2009, 500. See the note of Lagarde for references to earlier case law. 1282 Cass. Civ. 1er, 14 June 1983, RCDIP 1984, 316.
} 
deceased and referred to as the Suhami family. The Venture family disputed that Yako Suhami was in fact the brother of Benjamin Suhami and thus that the children of Yako Suhami were entitled to succeed to the estate. The children of Yako Suhami submitted three Turkish documents to prove their legal affiliation with Benjamin Suhami: a document called 'acte de mariage', an excerpt from the record of Yako Suhami from the Turkish register of civil status and a judgment of the court of Izmir stating that the children of Yako Suhami were entitled to the estate of Benjamin Suhami.

The Cour de Cassation did not accept any of these documents as instruments of civil status within the meaning of article 47 Code civil. The court defined an instrument of civil status as a document in which a foreign public authority records in an authentic manner an event on which the personal status of one or more persons depend.

Neither of the documents presented to the court fulfilled these requirements. The 'acte de mariage' contained irregularities and it recorded events that happened almost 100 years earlier, the excerpt from the register of civil status concerning Yako Suhami did not establish that his father was the same man as the father of Benjamin Suhami and the judgment of the court of Izmir did not relate to the personal status of the persons involved.

The prevailing view is that only documents recording births, acknowledgements of paternity or maternity, marriages and deaths can be recognised as an instrument of civil status within the meaning of article 47 Code civil. ${ }^{1283}$

The requirement of article 47 Code civil that the foreign instrument of civil status is drawn up in the customary form means that the document must have been drawn up by a the public official who is empowered to record events concerning one's personal status on the basis of the local law. Thus if according to the country where the document has been drawn up, births, marriages and deaths are recorded by religious authorities, those documents also fall within the scope of article 47 Code civil. ${ }^{1284}$ Moreover local law determines the formal requirements for the authenticity of the document, the information that can be recorded, the time within which that information has to be recorded and the requirement of witnesses. ${ }^{1285}$

The distinction in French private international law between the existence of legal parentage and the recognition of foreign documents also exists with regard to the establishment of legal parentage by acknowledgment of paternity or maternity.

However, under inter alia Dutch, French and German law an acknowledgment of paternity or maternity is only valid if it has been laid down in an authentic document. Hence, an acknowledgment of parenthood in French private international law involves issues of evidence, form and substance which are all subject to a different choice of law regime.

In two cases concerning the law applicable to the means of evidence of a marriage, the Cour de Cassation held that the means to prove an act, i.e. marriage, can be determined either by the law of the place where the act took place or by the lex fori. ${ }^{1286}$ Applied to acknowledgment of paternity or maternity it means that the method to prove whether or not a man or a woman made a declaration acknowledging his or her parenthood is governed by either the law of the place where the declaration is made or the lex fori.

\footnotetext{
1283 Cour d'appel de Paris, 15 December 1987, D.I.R. 1988, 25; Bidaud-Garon 2006, p. 65 ; Instruction générale relative à l'état civil du 11 mai 1999, nr. 486-3, Journal Officiel n 172 du 28 juillet 1999.

1284 The same approach has been taken by the Dutch Hoge Raad, 14 June 1985, NJ 1986/604, RvdW 1985/124, see note 1186.

1285 Bidaud-Garon 2006, p. 66; Instruction générale relative à l'état civil du 11 mai 1999, nr. 486-2, Journal Officiel nº 172 du 28 juillet 1999.

1286 Cass. Civ. 1er, 25 November 1981, RCDIP 1982, 701; Cass. Civ. 1er, 12 February 1963, RCDIP 1964, 121.
} 
However, unlike in the case of marriage, the law applicable to the means of evidence in case of acknowledgment is often not very relevant if the applicable law to the form requires that the acknowledgment is laid down in an authentic instrument. If the applicable law to the form of the acknowledgment requires the acknowledgment to be laid down in an authentic document, that document has to be submitted, otherwise the acknowledgment of paternity or maternity is not valid anyway.

The prevailing view in French private international law is that the law that applies to legal parentage also determines whether or not the acknowledgment has to be laid down in an authentic document. ${ }^{1287}$ If the lex causae requires the acknowledgment of paternity or maternity to be laid down in an authentic document the next question is whether a foreign document can be recognised as an authentic document.

A first example is provided by the decision of the Tribunal de grande instance of Seine. 1288 On the 24th of October 1960 a child was born in Royan, in the west coast of France. The child was born to an unmarried mother who argued that the legal paternity of the German national Von Wallenberg had been established by his voluntary acknowledgment of paternity. As evidence, the mother submitted an instrument of acknowledgment that had been drawn up by a German civil law notary in Berlin on the first of November 1960.

The court held that the validity of the acknowledgment is governed by the national law of the child, i.e. French law. French law requires the acknowledgement of paternity to be laid down in an authentic document. The German document had been drawn up validly according to German law and therefore could be used in France. Since all the requirements of French law had been fulfilled, the legal paternity of the German national was established.

The decision of the Cour de Cassation of the 20th of November 1979 provides another example. ${ }^{1289}$ A French national had registered a birth in Tunisia. At the same the man had acknowledged his paternity although according to Tunisian law, the establishment of legal paternity out of wedlock was not possible. Fifteen years later, the man disputed the validity of his acknowledgment because of irregularities concerning the form of the acknowledgment.

The Cour de Cassation held that it was the exclusive right of the lower court to determine whether the registration fulfilled the requirements of Tunisian law. This being the case, the Tunisian birth certificate that also contains the acknowledgment of paternity was valid in France on the basis of article 47 Code civil. With regard to the validity of the acknowledgment, the Cour de Cassation only stated that because of article 311-17 Code civil the acknowledgment is valid.

The anonymous annotator explains that per article 311-17 Code civil French law applies to the formal requirements for a valid acknowledgment. According to French law, the acknowledgment has to be laid down in an authentic document and per article 47 Code civil the Tunisian birth certificate can be recognised as such.

On the 12th of January 1994 the Cour de Cassation decided on the legal paternity of a French national who acknowledged his paternity in Germany before a local civil status registrar. ${ }^{1290}$ In France, the man argued that the acknowledgment should not have been recognised by the lower court. He argued that the acknowledgment should fulfil the formal requirements of French law (national law of the acknowledger) and that the lower court should have examined ex officio whether or not the requirements of French law were fulfilled.

1287 Mayer \& Heuzé 2007, nr. 609;Audit 2008, nr. 734; Instruction générale relative à l'état civil du 11 mai 1999, nr. 500, Journal Officiel $n^{\circ} 172$ du 28 juillet 1999.

1288 TGI Seine, 24 October 1960, RCDIP 1962, 507.

1289 Cass. Civ. 1er, 20 November 1979, Bull. civ. I, 1979, nr. 287, D.I.R. 1981, 161.

1290 Cass. Civ. 1er, 12 January 1994, RCDIP 1994, 557. 
The Cour de Cassation disagreed. It held that a voluntary acknowledgment of paternity of a natural child made in a foreign country has effect in France in the same way that instruments of civil status have evidential value in France, without the necessity to subject the foreign instrument of acknowledgment to an exequatur procedure.

This decision of the Cour de Cassation is equivocal. In his note Pamboukis argues that the Cour de Cassation means that an acknowledgement of paternity that has been drawn up abroad establishes legal paternity in France if it establishes legal paternity in the country where it has been drawn up. In his view, the Cour de Cassation does not apply the law selecting method anymore to the validity of an acknowledgment of paternity, but the recognition method that is also used for foreign judgments, since the Cour de Cassation does not state the law that applies to the validity of the acknowledgment of paternity. ${ }^{1291}$

However, the only thing the Cour de Cassation states is that a foreign instrument of acknowledgment has effect in France in the same way as other foreign documents of civil status and that it is not necessary to apply for an exequatur in order for the foreign instrument to have effect. Although the court's statement is perhaps somewhat minimalist in view of the argument of the applicant, it goes far to argue on the basis of this decision that the Cour de Cassation disregarded the law selecting method to determine the validity of an acknowledgment of paternity.

\subsubsection{Recognition of legal parentage under German private international law}

The method of recognition of legal parentage in German private international law is the same as under French private international law: under German private international law legal parentage only exists if it exists according to the law that is appointed by the conflict rules of articles 19, 20 and 23 EGBGB.1292 Thus the German civil status registrar who is requested to mention the acknowledgment of paternity in the child's birth record has to examine whether the instrument of acknowledgment presented to him establishes legal paternity according to the applicable law of article 19 and 23 EGBGB.1293 It does not matter whether the instrument of acknowledgment is drawn up in Germany or abroad.

Although the method to solve a conflict of laws in matters concerning parentage under German law is the same as in France, there are two important differences in the way the method is applied. First of all, the main connecting factor for parentage under German law is the habitual residence of the child while under French law it is the national law of the mother. Second, under German law the renvoi is accepted while under French law this is not the case in matters concerning legal parentage.

The effect of these two differences is that the legal parentage of child as it is recorded in his birth record in most cases also exists under German private international law. After all, in most cases the child is born and the birth of the child is recorded in the country of his habitual residence. The local register determines the law applicable to the legal parentage of the child in accordance with his own rules on private international law, which is recognised by German private international law since in German private international law the renvoi is accepted. Moreover, the prevailing view is that if the child changes his habitual residence, the effect of the conflit mobile shall not be that the child looses a legal parent; vested rights shall be protected. ${ }^{1294}$

\footnotetext{
1291 Note C. Pamboukis under Cass. Civ. 1er, 12 January 1994, RCDIP 1994, 557, at 563. See also Audit 2008, nr. 482. 1292 Wagner 2006, p. 747.

1293 § 286 Dienstanweisung für Standesbeamten und ihre Aufsichtsbehörden; Hepting \& Gaaz 2006a, § 29 PStG VI-39, 42; § 29a PStG VII-56; Wagner 2006, p. 747; MünchKomm/Klinkhardt 2006, Article 19 EGBGB, nr. 59.

1294 See note 920
} 


\subsubsection{Recognition of foreign instruments of civil status}

Just as French private international law provides, under German private international law the recognition of legal parentage has to be distinguished from the recognition of foreign instruments of civil status. The recognition of foreign documents of civil status means that the foreign document is accepted in Germany as a means of evidence to prove facts (birth certificate) or declarations (instrument of acknowledgment of paternity or maternity) that are relevant for the personal status of an individual. It has been shown that under French law article 47 Code civil provides that foreign instruments of civil status have evidential force in France if certain requirements are fulfilled, but it does not define the evidential force. Under German law this is different.

The instrument of civil status is a subcategory of the broader concept of public documents (öffentliche Urkunden). A foreign document qualifies as a public document within the meaning of German law, if the document has been drawn up by a public official, if the public official is empowered to draw up such a document and if the document has been drawn up in the form prescribed by the law under which the public official operates. ${ }^{1295}$

The authenticity of German authentic public documents that purport to be authentic public documents is automatically recognised. ${ }^{1296}$ Regarding a foreign public document $\S$ 438 Zivilprozessordnung provides that its authenticity has to be determined by the court on the basis of the circumstances of the case. The second paragraph provides that authenticity of the foreign public document can be proven by legalisation of that document by a consul of the German Federation.

Also the Dienstanweisung für Standesbeamten und ihre Aufsichtsbehörden (Work instruction for civil status registrars and their supervisors) provides that civil status registrars in case of doubt about the authenticity of foreign public documents have to require the legalisation of the foreign document. 1297 This obligation has been interpreted as meaning that the civil status registrar always has to persuade himself of the authenticity of the foreign document, either by requiring the legalisation of that document or on the basis of the circumstances of the case that lead to the conclusion that the document is not false. ${ }^{1298}$

If it has been established that the foreign document is authentic and not false, the next question is whether the facts mentioned in the document are true or whether the declaration that is recorded has really been made. The evidential force of German instruments of civil status is determined by $\S 54$ Personenstandsgesetz (Personal Status Act). It provides that the records in the registers of births, marriages and deaths are evidence of the birth, the marriage or the death and the information mentioned concerning these events. With regard to births, this other information is for example the date and the place of birth and the acknowledgment of parenthood if it is recorded on the birth record. ${ }^{1299}$ However, paragraph three states that it is allowed to prove that the recorded facts are not correct. $\S 54$ (2) Personenstandsgesetz provides that certificate of birth, marriage or death has the same evidential value as the records in the register. However, these rules do not apply to foreign documents of civil status; their evidential value is determined by $\S 415$ and 418 Zivilprozessordnung. ${ }^{1300}$

$\S 415$ (1) Zivilprozessordnung provides that documents that have been drawn up in the prescribed form by a public official within the limits of the authority of his office and that treat of statements made before that official establish sufficient evidence that the statement

\footnotetext{
1295 Zeyringer 1999, p. 195.

$1296 \S 437$ (1) Zivilprozessordnung.

1297 § 109 Dienstanweisung für Standesbeamten und ihre Aufsichtsbehörden.

1298 Zeyringer 1999, p. 197.

${ }^{1299}$ Hepting \& Gaaz 2006a, § 60 PStG, IV-25, 26.

1300 OLG Köln 3 December 2004, StAZ 2006, 53; Hepting \& Gaaz 2006a, § 66 PStG, III-15; Zeyringer 1999, p. 195.
} 
has been made as recorded. The second paragraph provides that a statement recorded incorrectly can be proved.

According to $\S 418$ (1) and (3) Zivilprozessordnung public documents with another content than is meant in $\S \S 415$ and 417 Zivilprozessordnung, establish sufficient evidence of the facts that has been testified about, if the testimony is based on the own perception of the public official who drew up the document. For a foreign instrument of acknowledgment of parenthood, the effect of $\S 415$ (1) Zivilprozessordnung is that the foreign document is sufficient evidence that the declarant acknowledged his paternity, or as the case may be, maternity.

However, the problem with regard to acknowledgment of parenthood in private international law is not so much whether or not the person involved made a statement, but whether he or she made the statement in the right form. It has been shown that in French private international law, the law applicable to legal parentage also determines the form in which the acknowledgment of parenthood has to be made. This is different under German private international law. Article 11 (1) EGBGB provides that formal requirements for the validity of a juridical act are governed either by of the law that applies to the juridical act or the law of the place where the act is done. Article 11 (1) EGBGB also applies to the formal validity of an acknowledgment of parenthood, which includes the question whether or not a valid acknowledgment requires some sort of authentication. ${ }^{1301}$

With regard to a foreign birth certificate $\S \S 415$ and 418 Zivilprozessordnung mean that the foreign birth certificate only proves that the declarant made the statements concerning the birth. With regard to the truth of the statements - is the child really born at the place and the time mentioned? - the foreign birth record does not have a special evidential value; $\S 54$ PStG does not apply. ${ }^{1302}$ This might be different if the foreign civil status registrar is obliged to examine the truth of the statements made concerning the birth of the child. In that case, the foreign document could fall within the scope of $\S 418$ as a result of which the document establishes sufficient evidence of the facts. ${ }^{1303}$ Based on the decision of the European Court of Justice in Dafeki, 1304 an exception exists with regard to document of civil status drawn up in a Member State of the European Union. Although these documents do not fall within the scope of $\S 54 \mathrm{PStG}$, it is recognised that the facts they mention are true unless there are concrete indications relating to the case involved that the facts might not be true.1305

Thus in contrast to a German birth certificate, a foreign birth certificate does not establish sufficient evidence of the recorded facts. For a German civil status registrar the starting point is that they themselves determine whether or not the foreign document establishes sufficient evidence. ${ }^{1306}$ If the registrar doubts whether the facts mentioned in the document are true, he can apply to the German diplomatic or consular mission in the country where the document comes from. That mission can conduct an examination into the truth of the facts mentioned in the document. ${ }^{1307}$

\subsubsection{Recognition of legal parentage under Swedish private international law}

In the Swedish legal system the recognition of parentage that has been established abroad is an issue that arises each time a person who is born abroad settles in Sweden. It has already been explained that in Sweden there is no separate civil status registration system. Instead,

${ }_{1301}$ Staudinger/Henrich 2008, Article 19, nr. 68; Andrae 2006, § 5, nr. 37; MünchKomm/Klinkhardt 2006, Article 19, nr. 48.

1302 Hepting \& Gaaz 2006a, § 66 PStG, III-18.

1303 Zeyringer 1999, p. 196.

1304 ECJ 12 December 1997, case C-336/94 (Dafeki), Rec. 1997, p. I-6761.

1305 OLG Köln 3 December 2004, StAZ 2006, 53; Hepting \& Gaaz 2006a, § 66 PStG, III-13, 14; Zeyringer 1999, p. 196.

1306 Zeyringer 1999, p. 197.

${ }^{1307}$ Hepting \& Gaaz 2006a, § 66 PStG, III-20; Zeyringer 1999, p. 200. 
every person who resides in Sweden has to be registered in the population register which contains amongst other things a description of the personal status of the person involved. The authority that is responsible for the population registration is the Swedish tax authority (skatteverket).

The recognition of legal paternity that has been established by a foreign court has been discussed above. Legal parentage that has not been established by a judgment only exists if it complies with the Swedish choice of law rules on parentage. These choice of law rules are found in the Lag 1985:367 om internationella faderskapsfrågor (IFL).

Just as under Dutch private international law, Swedish private international law provides that legal parentage that has been established abroad is treated differently from legal parentage that is established in Sweden. However, the Lag 1985:367 om internationella faderskapsfrågor does not make this distinction explicitly.

$\S 2$, second sentence IFL states that if the child is born in Sweden the legal paternity of the (ex) husband of the mother is determined according to Swedish law, provided that the child resides in Sweden at the moment of his birth. Although a child who is born in Sweden is not per definition also domiciled in Sweden, the effect of $\S 2$, second sentence is that a Swedish registrar always applies Swedish law if he has to determine the whether or not the (ex) husband is the legal father of the child.

However, if Swedish law would always be applicable to the question whether or not the (ex) husband is the legal father of the child it could be possible that the man who is considered the legal father of the child during the first part of the child's life is not considered the child's legal father anymore if the family moves to Sweden. This is undesirable. Therefore, the first sentence of $\S 2$ IFL provides that the question whether the (ex) husband of the mother of the child is the legal father shall be determined by the law of the residence of the child at the moment of birth. If the husband is not the father according to that legal system the law of the child's nationality at the moment of birth shall be applied. ${ }^{1308}$ If the law of the child's residence appoints another man as the legal father than the law of the child's nationality, the law of the domicile takes precedence over the law of the nationality. In this way it is prevented that the child has more than one father.

In a child immigrates to Sweden § 2 IFL is said to mean the following. ${ }^{1309}$ If it appears from a birth certificate or other public document from the child's country of residence that the mother's husband is the legal father according to that law, his legal paternity can be recorded in the Swedish population register without the necessity to investigate what the law of the child's nationality provides.

This hint from the legislator has been taken over in the work instruction for registration officers. ${ }^{1310}$ It provides that the husband of the mother at the moment of birth shall be registered as the father. Only if the alleged father was not married to the mother at the moment of birth, the existence of his legal paternity has to be proven. It seems that Swedish law and practice do not run in parallel.

A strict application of the choice of law rule to children who did not acquire a Swedish residence at birth would be that the Swedish registrar establishes first the residence of the child at the moment of birth and the contents of that law. Just copying the legal father from the foreign birth record may result in errors since the place of birth is not necessarily the child's residence at birth. However, one could argue that the efficiency that is gained by the possibility of copying the foreign birth record out weighs the few errors that might result.

\footnotetext{
${ }^{1308}$ The rule can also be applied to the ex lege establishment of legal paternity on something else than marriage, like cohabitation or a registered partnership (prop. 1984/85:124, p. 40).

1309 Prop. 1984/85:124, p. 42.

1310 The work instruction for population registrars is available at the intranet of the Swedish tax authority.
} 
Another problem is that the registrar of the child's residence does not necessarily apply his internal law. Take the following example. The child is born in country $\mathrm{X}$ and acquires his residence there. According to the internal law of country $X$ the ex-husband of the mother is still considered the legal father of the child. However, the choice of law rules of that country provide that the national law of the child at the moment of birth apply to the child's legal parentage. The child has Swedish nationality. According to Swedish law, not the exhusband of the mother but the husband at the moment of birth is the legal father of the child (§ 1:1 FB).

The birth record of the child, which is drawn up by the competent authority of country $X$, will name the second husband as the legal father. However, according to Swedish (private international) law, the first husband is the father. According to the working instruction for Swedish population registrars, the Swedish registrar shall not check this and names the second husband as the father of the child.

If the Swedish legislator is prepared to distinguish between children who acquire a Swedish domicile at birth and those who do not, the question arises whether it would not be better to refer to the domicile of the child at the moment of birth, including the choice of law rules of that legal system in the case of a child who does not acquire a Swedish domicile at birth. Assuming that in most cases a child acquires the residence of his place of birth, the Swedish registrar can, in most cases, simply transcribe the original birth certificate of the child. Under the current law, this approach does not seem feasible since the explanatory report explicitly states that the renvoi shall not be accepted.1311

With regard to establishment of legal parentage by acknowledgment of paternity § 3 (2) IFL provides that if the socialnämnd is involved in the establishment of paternity, Swedish law shall be applied. The socialnämnd is involved if the child resides in Sweden.

If legal paternity has been established by acknowledgment abroad § 8 (1) IFL states that the legal paternity is recognised in Sweden if the acknowledgment of paternity fulfils the requirements of the national law or the law of the domicile of the either the acknowledger or the child. If the child or the man has more than one nationality at the moment of the acknowledgment of paternity, the laws of all the countries involved can be taken into account. 1312 In practice this means that a foreign acknowledgment of paternity almost always is valid in Sweden.

We find a parallel here with Dutch law. The Dutch Hoge Raad held in 1992 that an acknowledgment of paternity which is made abroad is valid in the Netherlands if it fulfils the formal and substantive requirements of the law of the habitual residence or the domicile of the child, the mother or the acknowledger at the moment of the acknowledgment or the law of nationality of the child or the mother at the moment of the acknowledgment. 1313 This case law resulted in the rule that legal parentage that has been established abroad shall be recognised in the Netherlands, irrespective of any applicable law.

The second paragraph of $\S 8$ IFL adds that the formal validity may also be determined on the basis of the law of the place where the acknowledgment is done. The residence or the nationality of the child or the man has to be determined at the moment of the acknowledgment of paternity. ${ }^{1314}$

\footnotetext{
1311 Prop. $1984 / 85: 124$, p. $12,42$.

1312 Prop. 1984/85:124, 60. Walin \& Vängby vol. II, Avd. 1 I:40.

1313 See note 1136.

1314 Prop. 1984/85:124, 60. Walin \& Vängby vol. II, Avd. 1 I:40.
} 
Even if the acknowledgment of paternity fulfils the requirements of one of the legal systems mentioned in the first paragraph, the acknowledgment shall not be recognised in case of one of the five situations mentioned in $\S 8$ (3).

The first four situations concern cases where the foreign acknowledgment of paternity conflicts with another establishment of legal paternity. Thus, § 8 (3) under 1 provides that the foreign acknowledgment of paternity shall not be recognised if it contradicts a judicial decision on paternity which is valid in Sweden if the proceeding had started before the acknowledgment has been done. It is immaterial whether the judicial decision comes from a Swedish or a foreign court. ${ }^{1315}$ The second indent provides the same with regard to a Swedish or foreign establishment of paternity other than by judicial decision, for example by means of acknowledgment. The third indent provides that a foreign acknowledgment of paternity shall not be recognised if the acknowledgment has been done while at the same time a judicial procedure for the establishment of paternity was pending in a Swedish court. The fourth indent provides the same for the case where the foreign acknowledgment of paternity is done while at the same time a judicial procedure for the establishment of paternity has been started abroad which can lead to a decision which shall be recognised in Sweden.

$\S 8$ (3) under 5 provides that a foreign acknowledgment of paternity shall not be recognised in Sweden if the acknowledgment is manifestly incorrect. Only if the persons involved agree that the acknowledger is not the biological father of the child or if it is clear from other circumstances of the case that the acknowledger is not the biological father, should the fifth indent be invoked. ${ }^{1316}$ In cases of artificial reproduction, the paternity of the biological father is replaced by the parenthood of the person who according to Swedish law should be the child's legal parent. 1317

Next to the grounds to refuse the recognition of the foreign acknowledgment of paternity in Sweden which are mentioned in $\S 8$ (3), $\S 12$ of the Act on International Paternity Questions (1985:367) adds that a foreign acknowledgment of paternity shall not be recognised if it is manifestly contrary to basic principles of Swedish law (public policy exception).

$\S 8$ of the Act on International Paternity Questions (1985:367) only applies to acknowledgment of paternity as a result of which legal paternity is established. It does not apply to the formal acknowledgment of paternity which only has an evidential function. ${ }^{1318}$ This statement from the explanatory report refers to the discussion that has been laid out above on the meaning of an acknowledgment of paternity under English law. ${ }^{1319}$ It has been shown that under English law an acknowledgment of paternity does not establish legal paternity. On the basis of an acknowledgment of paternity under English law the acknowledger shall be named on the child's birth record as the father of the child, which constitutes only prima facie evidence of the man's paternity. Hence, the acknowledger shall not be considered the legal father of the child in Sweden on the basis of his acknowledgment under English law, because the acknowledgment does not establish legal paternity.it has been argued above that this approach is not necessarily the right one.

\footnotetext{
1315 Prop. 1984/85:124, 61. Walin \& Vängby vol. II, Avd. 1 I:41. 1316 Prop. 1984/85:124, 61. Walin \& Vängby vol. II, Avd. 1 I:42. 1317 Prop. 1984/85:124, 61. Walin \& Vängby vol. II, Avd. 1 I:42. 1318 Prop. 1984/85:124, 59. Walin \& Vängby vol. II, Avd. 1 I:39. ${ }^{1319}$ See § 4.1. Evidence of legal parentage under English law; § 6.7.3. Application of English law pursuant to continental private international law.
} 


\subsubsection{Recognition of foreign instruments of civil status under Swedish law}

Unlike under Dutch, French and German law there is no requirement under Swedish law to legalise foreign public documents in order for them to be admissible before judicial or administrative authorities in Sweden. ${ }^{1320}$ In Sweden, the evidential value of foreign instruments of civil status is the same as for domestic instruments. However, unlike under Dutch, French and German law, Swedish law does not accord a privileged evidential value to Swedish instruments of civil status: all evidence in Sweden is evaluated on the basis of the principle of free evaluation of evidence. ${ }^{1321}$

\subsection{Conclusion on recognition}

In chapter 6 the construction of the choice of law rules in Dutch, French, German and Swedish private international law has been examined. It was noted that under English law no choice of law rules on parentage have been developed yet. The comparative overview of the national choice of law rules on parentage showed how much national law on parentage influences the outcome of the international case by means of the choice of law rules and the public policy exception.

Chapter 7 examined the national systems of private international law from the perspective of a person requesting the recognition of his legal parentage that has been established abroad. However, this perspective reveals a bewildering variety of approaches. Roughly speaking the choice of law method and recognition method are used to solve international cases on parentage.

In the case of the choice of law method the existence of legal relations is determined by the forum on the basis of the applicable law. The applicable law is determined by the conflict rule which is based on the presumption that the connecting factor indicates a close connection between the case and the applicable law. Next to a close connection certain substantive considerations also play an important role, as has been shown in the first part.

In the case of the recognition method the forum does not determine whether or not the legal relationship exists, but it determines whether or not the relationship can be recognised. The problem with the recognition method is how to determine the existence of a legal relationship.

The question whether to determine the existence of a legal relationship either through choice of law or by recognition must be distinguished from the recognition of the evidential value of foreign instruments of civil status. It has been shown that legal systems differ as to whether foreign instruments must be legalised, i.e. whether the foreign authorities have to certify the authenticity of the signature on the instrument. Under English and Swedish law, legalisation is not mandatory, while it is mandatory under Dutch, French and German law. Legalisation is a means to establish the authenticity of the foreign instrument.

If it has been established that the foreign instrument is authentic and not forged, the next question is how to determine its evidential value. If the existence of legal parentage is determined through a choice of law method, the evidential force of foreign civil status instruments is important to establish the facts on the basis of which the lex causae determines the existence of legal relations. In the Dutch recognition system the evidential value of foreign instruments of civil status is not an independent question anymore. Under the recognition system, the legal relations that are described in the instrument are recognised. Hence, it is not necessary to establish the facts separately. In fact, it is the recognition rule

\footnotetext{
${ }^{1320}$ Bylander \& Andersson 2007, 13, 15.

1321 Lindell 2004, p. 422.
} 
(art. 10 Wet conflictenrecht afstamming) that accords evidential value to foreign instrument of civil status.

We have seen that all legal systems involved apply the recognition method to judgments on the establishment or annulment of legal parentage. The recognition method seems particularly suitable to deal with judgments, because judgments have force of law and sometimes they even have an erga omnes effect. As a result the existence of legal parentage can easily be determined by reading the judgment. With regard to foreign judgments on parentage all legal systems have more or less similar criteria although there are some differences as to how the criteria are interpreted. The first requirement for recognition of a foreign judgment on parentage is that the foreign court had jurisdiction to render a judgment. In German private international law the jurisdiction of the foreign court is determined on the basis of the German grounds for jurisdiction. This also seems to be the case under English law, although there is no precedent relating to parentage to support that view. In Dutch, French and Swedish law the foreign court should have accepted jurisdiction on reasonable grounds. In Dutch private international law an internationally recognised ground for jurisdiction is required. Swedish private international law uses a similar description but adds that the domicile and the nationality of the parties should be taken into account in determining whether or not there was a reasonable ground for jurisdiction. The French Cour de Cassation requires a characteristic connection between the dispute and the state of the court rendering the judgment. Other requirements are that the foreign judgment should not violate the international public policy of the forum and the judgment should have been rendered on the basis of a proper procedure. The final requirement is that the judgment should not conflict with a judgment of forum or a previously recognised foreign judgment.

If the legal parentage does not exist on the basis of a court judgment, the starting point in all legal systems under consideration is that the existence of legal parentage is determined by the choice of law method. However, Dutch private international law provides for an important exception to the application of the choice of law rule: the exception of recognition.

Article 10 Wet Conflictenrecht Afstamming has been discussed extensively and provides that legal parentage that has been established or modified abroad shall be recognised if certain requirements are fulfilled. The exception is based on the expectations of the parties that have been raised by the involvement of a public authority in their case and the protection of legal certainty.

It appeared that the application of the fait accompli principle with regard to foreign instruments on legal parentage necessarily involves different kinds of reasoning depending on the type of information that is in the foreign instrument (fact or legal relationship).

It has been argued that if article $10 \mathrm{WCA}$ is about protecting legal certainty and expectations of the persons involved, the provision probably has been formulated too narrowly: not only the establishment or modification of legal parentage should be recognised but also its non-existence if it appears from the foreign instrument that the foreign authority determined the parentage of the child in general as opposed to the parentage with regard to one parent.

The final observation that has been made with regard to the exception of recognition in Dutch private international law on legal parentage is that the exception cannot entirely be based on the premise that a legal relationship exists. There are two reasons for this. Firstly, (foreign) instruments on parentage are mainly about evidencing facts and declarations. The description of legal relations like legal parentage is only a secondary function. The facts and declarations that are evidence by the foreign instrument only constitute a legal relationship in combination with the rules of a legal system. Secondly, the description of legal relations 
in an instrument of acknowledgment is not conclusive and subject to judicial review. Therefore, it is important to know which legal system governs the legal relationship if its existence is challenged in a Dutch court. It has been argued that the lex fori, the law including the private international law of the foreign public authority, applies. Thus, the lex fori determines whether or not a fait accompli exists; article 10 WCA determines the requirements for the recognition of the fait accompli; the Dutch choice of law rules determine the applicable law to subsequent changes in the fait accompli, either ex lege or by legal act. Subsequent changes to the fait accompli that are established abroad and laid down in a public document are governed by article 10 WCA.

In French, German and Swedish private international law the choice of law method is applied to legal parentage that has been established abroad. These legal systems do not have an exception of recognition in a case of legal parentage that is not based on a judgment.

With regard to the method the French and the German system are very similar because they both have choice of law rules with a uniform scope of application, irrespective of the place where the child is born or where the legal parenthood has been acknowledged. However, with regard to the effects of the conflict rules on legal parentage that has been established abroad the German and the Swedish rules are more alike.

We have seen that in French private international law on parentage, the main connecting factor for legal parentage is the national law of the mother and for acknowledgment of parenthood the national law of the acknowledger and the national law of the child. Compared with habitual residence or domicile, nationality as a connecting factor will more often cause the situation in which the French authorities apply a legal system that has not been applied by the foreign registrar because it is more likely that a woman does not give birth in the country of her nationality than that she does not give birth in the country of her habitual residence. The effect is enhanced by the fact that in French private international law the renvoi is not applied in matters concerning parentage. If the woman has her habitual residence at the moment of birth in the country of her nationality, it does not matter that the French do not accept the renvoi: the registrar recording the birth shall apply the same law as the French authorities on the basis of nationality, habitual residence or the lex fori. If the woman does not give birth in the jurisdiction of her nationality, the acceptance of renvoi in France could have as a result that the French authorities would apply the same law as the registrar registering the birth. There is no certainty though. It would depend on the connecting factor for legal parentage in the country of nationality of the mother and in the country where the child is born and on the attitude towards renvoi in these jurisdictions. If the child is born in a jurisdiction where the registrar applies the national law or the law of the domicile of the father to determine the legal parentage of the child, the French authorities also run the risk of applying a different legal system to the authorities that recorded the birth.

Both the German and the Swedish choice of law rules have as an effect that in most cases legal parentage that has been established abroad shall be recognised in these countries. In German private international law the primary connecting factor is the habitual residence of the child. Although the German conflict rule does not state it explicitly, the prevailing view is that the connection has to be made at the moment the parentage is established by a foreign authority which is in most cases when the birth is recorded. The choice of law rule also provides for other connecting factors in order to favour the establishment of legal parentage. If the aim of article 19 EGBGB is to establish legal parentage, it makes sense to apply the provision in such a way that the legal parentage that has been established abroad 
shall be recognised in Germany. This aim is facilitated by article 4 (1) EGBGB which provides that a reference to foreign law includes the choice of law rules of that legal system if that would be in conformity with the objective of the German choice of law rule in question. Thus, in practice, the German authorities can take over the birth certificate that has been issued by the registrar of the place of the habitual residence of the child at the moment of birth.

Swedish private international law works more or less the same. It has been shown that in Sweden, the choice of law rule on marital parentage (or legal parentage that exists ex lege) has a limited scope of application. It only applies if the child did not establish residence in Sweden at the moment of his birth, which in most cases means that the child is born abroad. The Swedish choice of law rule is based on the assumption that the foreign registrar either applies the national law of the child or the law of his domicile to his legal parentage. It has been shown that the assumption is not necessarily true: the Dutch and the French choice of law rules connect to the common nationality of the parents and the national law of the mother respectively. However, in practice the difference will not be that big because the child often has the same nationality as his parents. Thus as long as the child is born in the country of his habitual residence or nationality, the Swedish registrar will take over the nationality as it is described on the foreign birth certificate.

An apparent difference between German and Swedish private international law, is that German law accepts the renvoi and Swedish law does not. However, in matters concerning legal parentage, the effect of this difference is limited. According to Swedish private international law the foreign birth certificate will be accepted if it is in accordance with either the national law or the law of the domicile of the child at the moment of birth. Assuming that legal systems in matters concerning parentage either connect to the nationality or the domicile, the German system leads to the same result as the Swedish: the law of the habitual residence is applied, but if that legal system refers to the nationality the renvoi will be accepted if it establishes legal parentage. At least in theory, the German rule seems more precise. If the foreign registrar neither applies the law of the child's nationality nor the law of the child's domicile to the legal parentage, the Swedish authorities shall not recognise the legal parentage that has been described on the birth certificate. But then it must also be mentioned that the application of the German conflict rule can be problematic if the birth has been recorded by another registrar than the registrar of the habitual residence of the child at the moment of birth.

In theory it is possible that the different connecting factors in the German and Swedish choice of law rule lead to a differing status of the child. According to the law of the habitual residence of the child, $\mathrm{Mr} \mathrm{X}$ is the legal father and according to the national law of $\mathrm{Mr} \mathrm{Y}, \mathrm{Mr}$ $\mathrm{Y}$ is the legal father of the child. If legal parentage has been established abroad this situation does not arise. It has been shown that in German law the problem of conflicting paternities arose at the recording of a birth in Germany, not in relation with legal paternity that has been established abroad. It is exceptional that two men are actively claiming to be the father of the child. Disputes about legal parentage typically arise between the state and the parties involved (the state considers the child to be without parents or considers a person to be the legal parent who should not be the legal parent according to the parties involved) or between the mother and the (alleged) father (the father wants to establish his legal paternity and the mother does not consent or the other way around).

The opposite situation of conflicting legal parenthood is in theory also possible: the foreign birth certificate does not indicate a legal father. If the choice of law rules favours the establishment of legal parentage the recognising authority would be expected to examine $e x$ officio whether or not the legal paternity has been established according to one of the legal 
systems applicable according to the choice of law rule of the forum. Apparently, it requires such a rare set of circumstances that it does not lead to problems in practice. 


\section{Part 3 European private international law on personal status}

The previous parts examined the national legal systems on parentage and on private international law in five Member States. This part shall examine the influence of European law and in particular the provisions on European citizenship on the private international law on civil status in general and parentage in particular. To that end, first the rights of residence, free movement and equal treatment of European citizens as explained in the case law of the European Court of Justice (ECJ) will be discussed. Notably in Garcia Avello and Grunkin and Paul the Court indicated that a limping surname is in principle not compatible with EU law. Therefore, it must be examined to what extent the case law on surnames can be applied to other elements of a person's civil status, in particular to parentage. In the final paragraph the question will be discussed whether the principle of mutual recognition can be implemented in the area of civil status. 


\section{The rights of European citizens}

In this paragraph the rights of EU citizens under the Treaty on the Functioning of the European Union (TFEU) will be examined. The objective is to put the decisions in Garcia Avello and Grunkin and Paul into their European law context. The concept of EU citizenship was introduced in the EC Treaty in 1993 with the entry into force of the Maastricht Treaty (1992). From that moment on, every person holding the nationality of a Member State was a citizen of the Union. ${ }^{1322}$

One of the most important rights of an EU citizen is, according to article 21 (1) TFEU, the right to move and reside freely within the territory of the Member States, subject to the limitations and conditions laid down in the Treaty and by the measures adopted to give it effect. The measures article 21 (1) TFEU refers to is secondary EU law which implements the free movement of persons. Nowadays, the most important piece of secondary legislation in this respect is the Citizens' Rights Directive (2004/38/EC) which entered into force on the 30th of April 2004. The Citizens' Rights Directive consolidated nine existing directives on free movement of persons, including directive 90/364/EEC on the right of residence, directive 90/365/EEC on the right of residence for employees and self-employed persons who have ceased their occupational activity and directive 93/96/EEC on the right of residence for students.

Since the introduction of the concept of European citizenship (1993) and thus already before and after the entry into force of the Citizens' Rights Directive (2004) the rights of citizens have also been shaped by the case law of the European Court of Justice.

\subsection{The free movement of persons before the Treaty of Maastricht}

Before the Treaty of Maastricht (1992) free movement of persons under the Treaty establishing the European Economic Community (1957) only referred to the free movement of workers (art. 48 EEC), self-employed persons and companies (art. 52 EEC) and service providers and recipients (59 EEC). The right of free movement of these classical factors of production was worked out in various directives and regulations, such as the Regulation on Free movement of workers ${ }^{1323}$ and the Regulation and the Directive on the right to remain. ${ }^{1324}$

The Single European Act (SEA) (1986) was the starting point for the enlargement of the personal scope of the right to free movement. The SEA introduced the concept of the internal market in the EEC Treaty. The internal market is a policy objective. The goal of the European Community was to establish before the end of 1992 an 'area without internal frontiers in which the free movement of goods, persons, services and capital is ensured in accordance with the provisions of this Treaty.' 1325

At the introduction of the Single European Act it was realised that the free movement of persons could not be limited to the classical factors of production. Article 8a (2) (now art. 26 (2) TFEU) expresses the political intend of the drafters to complete the internal market and

\footnotetext{
1322 Article 20 TFEU.

${ }^{1323}$ Regulation (EEC) no 1612/68 of the Council of 15 October 1968 on freedom of movement for workers within the community as amended by regulation $312 / 76$.

1324 Regulation (EEC) no. 1251/70 of the Commission of 29 June 1970 on the right of workers to remain in the territory of a Member State after having been employed in that state; Council Directive of 17 December 1974 concerning the right of nationals of a Member State to remain in the territory of another Member State after having pursued therein an activity in a self-employed capacity $(75 / 34 / \mathrm{EEC})$.

1325 Article 13 SEA inserted article 8a in the EEC Treaty, now article 26 (2) TFEU.
} 
to implement the Commission's programme described in the White Paper on the Internal Market. ${ }^{1326}$ In this White Paper on the Internal Market the Commission relates the free movement of persons in the first place with the free movement of employees and selfemployed persons. ${ }^{1327}$ However, in the same document it is also recognised that the free movement of persons should not be restricted to the workforce. The White Paper takes as an example the free movement of students 'in whose hands the future of the Community's economy lies.' 1328

What follows is a gradual expansion of the personal scope of the right to free movement, away from the idea that the right should only apply to economically active persons. ${ }^{1329}$ The aim of the Commission was to create a general right of free movement of nationals of the Member States, but that proposal was not accepted by the Council.1330 Instead, the right of free movement for persons is regularly awarded to well defined groups of people as opposed to all the nationals of the Member States. Thus the student directive, the directive on the right of residence of persons of sufficient means and the directive for the right of residence of retired persons were enacted.1331

The essence of these directives is that in order to benefit from the right of free movement, nationals of the Member States do not necessarily need to be economically active. The only requirement is that the person (and his family) does not become a burden on the social security system of the host state. Thus, nationals of the Member States only have the right to move and reside within the territory of the Member States if they have sufficient means to maintain themselves (and their families) and if they are covered by an all risk health insurance. 1332

\subsection{Free movement and equal treatment of EU citizens after the Treaty of Maastricht}

The Treaty of Maastricht inserted the concept of European citizenship in European law to facilitate the integration of the Member States beyond economic cooperation. ${ }^{1333}$ According to article 21 (1) TFEU, every citizen of the Union shall have the right to move and reside freely within the territory of the Member States, subject to the limitations and conditions laid down in this Treaty and by the measures adopted to give it effect. The Court's case law on article 21 (1) TFEU explains two aspects of the provision. It explains the conditions and limitations on the right to reside on the territory of the Member States and the consequence of the right to reside, namely the right to be treated equally.

\subsubsection{The right to reside on the territory of the Member States}

One of the first cases explaining the limitations and the conditions for the right to reside on the territory of another Member State on the basis of article 21 (1) TFEU is Baumbast. ${ }^{1334}$ In that case, the question was whether Mr Baumbast, a German national, had the right to live in the UK although he did not work there (he worked in China and Lesotho for a German

\footnotetext{
1326 White Paper on the Internal Market, COM (85) 310 FINAL.

$1327 \S 88$ White Paper.

1328 § 94 White Paper.

1329 Barnard 2007, p. 250; Carlier 2007, nr. 7.

1330 Closa 1992, p. 1142.

1331 Council Directive of 28 June 1990 on the right of residence (90/364/EEC); Council Directive of 28 June 1990 on the right of residence for the employees and self-employed persons who have ceased their occupational activity (90/365/EEC); Council Directive of 29 October 1993 on the right of residence for students (93/96/EEC).

1332 Article 1 directive 90/364/EEC (repealed).

1333 See in more detail: Evans 1984.

1334 ECJ 17 September 2002, case C-413/99 (Baumbast and R $v$ Secretary of state for the Home Department) Rec. 2002, p. I7091.
} 
company) and that the UK Immigration Adjudicator found that he did not fulfil the requirements of the directive on the right of residence (90/364/EEC) (Baumbast's German sickness insurance did not cover emergency treatment in the UK).

The Court's reasoning commenced promisingly for Mr Baumbast. According to the Court, article 21 (1) TFEU expresses the idea that the right to free movement of persons is no longer subject to the condition that the person involved is economically active:

84. As regards, in particular, the right to reside within the territory of the Member States under Article 18(1) EC, that right is conferred directly on every citizen of the Union by a clear and precise provision of the EC Treaty. Purely as a national of a Member State, and consequently a citizen of the Union, Mr Baumbast therefore has the right to rely on Article 18(1) EC.

However, at the same time, the Court acknowledged that the right to reside within the territory of another Member State is subject to limitations and conditions laid down by European Union law and by the measures adopted to give it effect. ${ }^{1335}$ Thus despite the strong rhetoric of EU citizenship being the fundamental status of an EU citizen 1336 and granting the person a right of free movement regardless of any economic activity pursued, the right of residence remained dependant upon the conditions of one of the directives on free movement of persons. ${ }^{1337}$

In the case of Mr Baumbast that meant that he only had the right to live in the UK under article 21 (1) TFEU, if he fulfilled the requirements of the directive on the right of residence (90/364/EEC). The concept of European citizenship did not bring Mr Baumbast any advantages. If the Court had stopped here, Mr Baumbast would have been obliged to leave the UK, because the UK Immigration Administrator found that the requirements of directive 90/364/EEC were not fulfilled.

However, the Court helped Mr Baumbast somewhat. First of all, the Court suggested that in taking its decision the UK Immigration Administrator did not rightly apply all the relevant provisions of European Union law. 1338 But more importantly, the Court held that the conditions and limitations on the right of EU citizens to reside in another Member State in directive 90/364/EEC had to be applied in accordance with general principles of EU law, in particular the principle of proportionality. 1339 According to the Court the refusal of the UK to grant Mr Baumbast a residence permit solely on the basis that his German sickness insurance did not cover emergency treatment in the UK was disproportionate. ${ }^{1340}$

The principle of proportionality was not mentioned in directive 90/364/EEC. As a sort of deus ex machina the principle was triggered by the European citizenship of Mr Baumbast. Also the Citizens' Rights Directive ${ }^{1341}$, which since 30 April 2004 provides the requirements for residence, does not mention the proportionality principle as an exception to the requirements for residence. ${ }^{1342}$

\footnotetext{
1335 Baumbast, par. 85 .

1336 Baumbast, par. 82. See also ECJ 20 September 2001, case C-184/99 (Grzelczyk v Centre public d'aide sociale d'OttigniesLouvain-la-Neuve) Rec. 2001, p. I-6193, par. 31.

1337 Baumbast, par. 85-87. See also ECJ 29 April 2004, joined cases C-482/01 and C-493/01 (Orfanopoulos v Land BadenWürttemberg and Oliveri v Land Baden-Württemberg) Rec. 2004, p. I-5257, par. 47-48.

1338 Baumbast, par. 88-89.

1339 See also ECJ 23 March 2006, case C-408/03 (Commission v Belgium) Rec. 2006, p. I-2647, par. 39; ECJ 7 September 2004, case C-456/02 (Trojani v Centre public d'aide sociale deBruxelles) Rec. 2004, p. I-7573, par. 36.

1340 Baumbast, par. 90-93.

1341 Directive 2004/38/EC of the European Parliament and of the Council of 29 April 2004 on the right of citizens of the Union and their family members to move and reside freely within the territory of the Member States.

1342 See also De Waele 2009, nr. 460-467.
} 


\subsubsection{EU citizens' right to equal treatment and beyond}

The EU citizen who has the right to reside on the territory of another Member State has, within the scope of the Treaty, the right to be treated equally with the nationals of the host Member State. The Court based this right directly on art. 18 TFEU and today, this right is also laid down in article 24 of the Citizens' Rights Directive. ${ }^{1343}$

In the case law of the European Court of Justice there is a development that not only discriminatory rules on the basis of nationality are prohibited, but every rule that is liable to hinder the right of free movement and residence of EU nationals is also prohibited.

National rules that are discriminatory or that hinder the free movement or residence of EU nationals can be justified if they are based on objective considerations, independent of the nationality of the persons concerned and if they are proportionate to the legitimate aim of the national provision.

At the same time, the Court recognises the difference between national rules that are discriminatory and national rules which merely cause disparate treatment. Although disparities among the legal systems of the Member States may cause inconveniences for free movers, the rules that cause them are not in violation of EU law. This paragraph shall examine the different building blocks of the right to equal treatment for EU citizens (discrimination, restriction, justification and disparity) on the basis of the case law that applies them.

\subsubsection{The right not to suffer discrimination}

Article 18 TFEU provides that within the scope of the Treaty and without prejudice to any special provisions contained therein, any discrimination of the basis of nationality shall be prohibited. In this paragraph the different types of discrimination that the Court has recognised in its case law in the context of citizenship shall be described.

\section{Martinez Sala and Grzelczyk - direct discrimination on the basis of nationality}

The most obvious situation where the EU citizen is treated unequally is where a national from one Member State resides on the territory of another Member States and is not treated equally with the nationals of the host Member State. This was the case in Martinez Sala. ${ }^{1344}$

Ms Martínez Sala is a Spanish national who lived in Germany since 1968. At the material time, Ms Martínez Sala is unemployed. Moreover, from 1984 until 1994 she did not have an official residence permit. In 1994 she is issued an official residence permit, but until that time she only has documents certifying that the extension of her residence permit had been applied for. That document proves that she is entitled to stay, but it is not an official residence permit.

In 1993, thus after being a resident in Germany for more than 24 years, Ms Martínez Sala applies for a child-raising allowance. Her application is refused for the sole reason that she is not able to produce an official residence permit. In these circumstances, the question of the referring German court is whether Community law precludes a Member State from requiring nationals of other Member States to produce a formal residence permit to receive child allowance.

The European Court of Justice observes that German law is not discriminatory to the extent that a child-raising allowance, next to other material requirements, is conditional upon the claimant being permanently or ordinarily resident in Germany. However, next to the residence requirement, foreigners also have to produce a formal residence permit.

${ }^{1343}$ Directive 2004/38/EC of the European Parliament and the Council of 29 April 2004 on the right of citizens of the Union and their family members to move and reside freely within the territory of the Member States.

${ }_{1344}$ ECJ 12 May 1998, case C-85/96 (Martínez Sala v Freistaat Bayern) Rec. 1998, p. I-2691. See also for example ECJ 24 November 1998, case C-274/96 (Criminal proceedings against Horst Otto Bickel and Ulrich Franz) Rec. 1998, p. I-7637. 
None of the parties to the proceeding dispute that German law constitutes unequal treatment. However, the German government disputes that the facts of the case come within the material and personal scope of EU law at all. Therefore, according to government, Ms Martínez Sala could not invoke article 6 EC (now art. 18 TFEU), according to the German government.

With regard to the material scope of EU law the Court explains that a child-raising allowance is a social advantage within the meaning of article 7 (2) of Regulation 1612/68. Therefore, the case comes within the material scope of EU law.

With regard to the personal scope of the EU law, the Court states that there is not enough information to determine whether Ms Martínez Sala is a worker within the meaning of the article $48 \mathrm{EC}$ (now art. $45 \mathrm{TFEU}$ ). But even if she could not be qualified as a worker, she is in any event within the personal scope of the provisions on European citizenship. According to the Court:

63. It follows that a citizen of the European Union, such as the appellant in the main proceedings, lawfully resident in the territory of the host Member State, can rely on Article 6 of the Treaty in all situations which fall within the scope ratione materiae of Community law $[\ldots]$.

The decision in the case of Ms Martínez Sala is interesting because it explains both the material and the personal scope of article 18 TFEU. It is innovative because the right to equal treatment is detached from being economically active and linked directly to the status of EU citizenship. Even directive 90/364/EEC on the right of residence did not confer a right to equal treatment on nationals of the Member States.

In Grzelczyk the Court stretched the right to equal treatment a little more, by changing the conditions mentioned in Martinez Sala. ${ }^{1345}$ Mr Grzelczyk is a French national who studied in Belgium. On the basis of the directive on the right of residence for students (93/96/EEC), he had the right to reside in Belgium in order to get access to 'vocational training' there. The directive required the student involved to declare that he has sufficient resources to avoid becoming a burden on the social assistance system of the host Member State and that he is covered by all-risk sickness insurance.

Mr Grzelczyk indeed maintained himself for three years. However, in the fourth year of his studies he applied for the Belgian minimum subsistence allowance, minimex. Although granted at first instance, the allowance was withdrawn later on the ground that $\mathrm{Mr}$ Grzelczyk was not a Belgian national. Belgian law provided that only EU nationals from other Member States who were a worker within the meaning of EC regulation 1612/68 on freedom of movement for workers could be granted the minimex. Since Mr Grzelczyk was not a worker, he could only be granted the minimex if he was a Belgian national, which was not the case. 1346

In these circumstances, the Belgian court asked the ECJ whether articles 6 and 8 EC (now art. 18 and 20 TFEU) preclude national legislation that makes the entitlement to a noncontributory social benefit, such as the minimex, conditional upon the claimant being a worker within the meaning of EC regulation 1612/68, while this requirement does not apply to nationals of the host Member State.

The Court reiterated that within the sphere of application of the Treaty discrimination on the basis of nationality is, in principle, prohibited by article 18 TFEU. The scope of

1345 ECJ 20 September 2001, case C-184/99 (Grzelczyk v Centre public d'aide sociale d'Ottignies-Louvain-la-Neuve) Rec. 2001, p. I-6193.

${ }_{1346}$ See also ECJ 7 September 2004, case C-456/02 (Trojani v Centre public d'aide sociale deBruxelles) Rec. 2004 , p. I-7573. 
application of article 18 TFEU must be determined in conjunction with the provisions of the Treaty concerning citizenship of the Union:

31. Union citizenship is destined to be the fundamental status of nationals of the Member States, enabling those who find themselves in the same situation to enjoy the same treatment in law irrespective of their nationality, subject to such exceptions as are expressly provided for.

The scope of article 18 TFEU in Martinez Sala depended on the material and the personal scope of EU law. In that decision, the material scope of EU law referred to the subject of the regulation invoked (child-raising allowance) which was a subject that fell within the scope of EU law. The personal scope of EU law referred to the kind of persons who were covered (not only economically active persons, but any national of a Member State lawfully residing in the territory of another Member State). In Grzelczyk the Court merged the personal and material scope:

32. As the Court held in paragraph 63 of its judgment in Martinez Sala, cited above, a citizen of the European Union, lawfully resident in the territory of a host Member State, can rely on Article 6 of the Treaty in all situations which fall within the scope ratione materiae of Community law.

33. Those situations include those involving the exercise of the fundamental freedoms guaranteed by the Treaty and those involving the exercise of the right to move and reside freely in another Member State, as conferred by Article 8a of the Treaty (see Case C-274/96 Bickel and Franz [1998] ECR I-7637, paragraphs 15 and 16)

The material scope of EU law no longer depended upon the subject of the regulation invoked (i.c. the minimum subsistence allowance), but on the question whether the person involved made use of his fundamental freedoms, in this case the right to reside on the territory of another Member State.

Since the material scope of EU law does not depend on the subject at issue in the contested national legislation, but on the question whether the case involves fundamental EC rights, all national legislation, regardless of its subject, must be able to stand the nondiscrimination test of article 18 TFEU.

\section{Bidar - indirect discrimination on the basis of nationality}

EU citizens also have the right not to suffer indirect discrimination on the basis of nationality. In Bidar, the UK refused the French student Dany Bidar a subsidised student loan. ${ }^{1347} \mathrm{Mr}$ Bidar accompanied his mother to the UK in 1998 where she had to undergo medical treatment. During that period Mr Bidar stayed with his grandmother as her dependant. He completed his secondary education in the UK and in September 2001 he started a course in economics at University College London.

Mr Bidar was not the child of a worker and therefore he resided in the UK as a student. Directive 93/96 on the residence rights for students explicitly provided that the directive does not establish any entitlement to the payment of maintenance grants. Under the English Student Support Regulations 2001, a person is only eligible to receive a student loan if he is settled in the UK within the meaning of the Immigration Act 1971 and if the residence requirements of Schedule 1 to the Student Support Regulations 2001 are satisfied. Mr Bidar 
fulfilled the residence requirements, but as a student he could not obtain the status of being settled in the UK.

There were quite a few hurdles to take before the Court could conclude that Mr Bidar was entitled to the student loan. First of all, the Court decided in previous cases that student maintenance allowances did not fall within the material scope of the Treaty. However, referring to the provisions of citizenship of the Union that conclusion had to be reconsidered. As the Court already held in Garcia Avello (below), a citizen of the Union who lawfully resides in another Member State is within the scope of the application of the Treaty. ${ }^{1348}$ The subject of the dispute is irrelevant. Also the fact that the application to social assistance could result in expulsion under directives 90/364 and 93/96 did not affect the fact that maintenance assistance to students falls within the scope of application of the Treaty.

The second hurdle was to determine whether the conditions for granting subsidised student loans were based on objective considerations independent of nationality. The Court recalled that the principle of equal treatment prohibits not only direct discrimination on the basis of nationality but also all covert forms of discrimination 'which, by applying other distinguishing criteria, lead in fact to the same result'. ${ }^{1349}$ In this case, the residence requirements and the requirement that a student must be settled in the UK within the meaning of the Immigration Act constitute unequal treatment on the basis of nationality, because they are more easily satisfied by nationals than by foreigners.

The residence requirement of three years could be justified by the objective of ensuring a certain degree of integration of the student in the UK. However, the requirement that the student must be settled in the UK within the meaning of the Immigration Act could not be justified, because as a foreign student he could not obtain that status. ${ }^{1350}$

\section{Garcia Avello - different cases treated equally}

Another type of discrimination is presented by Garcia Avello. ${ }^{1351}$ The case concerned two children with dual Belgian-Spanish nationality who lived in Belgium. The children were born in 1988 and 1992 and at birth they were given a family name in accordance with Belgian law, Garcia Avello. In 1993, both children were registered with the Spanish consulate in accordance with Spanish law under the name Garcia Weber. ${ }^{1352}$

In 1995, the children's parents apply to the Belgian Minister of Justice to change the name of their children in accordance with Spanish law from Garcia Avello to Garcia Weber. The Minister of Justice refused the application and the parents brought an application for annulment before the Belgian Conseil d'État. This court submitted a 12 lines long question to the European Court of Justice, which in essence asked whether the principles of Community law relating to European citizenship precluded a national authority from refusing to change the name of a child with Belgian and Spanish nationality, in accordance with Spanish law and tradition.

The first issue addressed by the European Court of Justice was whether the case came within the material scope of the EU law. It is recalled that in Grzelczyk the Court more or less merged the concepts of personal and material scope. The material scope of the EU law does not depend on the subject of the regulation invoked (i.c. the rules on the change of surnames), but on the question whether the person involved made use of his fundamental freedoms to move and reside within the territory of the Member States.

\footnotetext{
1348 Bidar (judgment), par. 42.

1349 Bidar (judgment), par. 51.

1350 Bidar (judgment), par. 60 and 61.

${ }^{1351}$ ECJ 2 October 2003, case C-148/02 (Carlos Garcia Avello v État belge) Rec. 2003, p. I-11613. The relevance of this case for national choice of law rules will be examined in the next paragraph.

1352 The source for the year of registration at the Spanish consulate is the lawyer of the parents, Mr P. Kileste.
} 
In Garcia Avello the children were born in Belgium and at the material time they were still living there. Thus, although they did not make use of their right to move from one Member State to another, they did reside in Belgium and they held the nationality of another Member State. Therefore, the children were nationals of one Member State lawfully resident on the territory of another Member State. Hence, the case came within the scope of EU law. Having the status of EU citizenship and falling within the scope of EU law, the children enjoy the right not to suffer discrimination on the grounds of nationality (art. 18 TFEU).

Advocate General Jacobs held that if the Minister's policy on the one hand allows the change of surnames on the basis of serious grounds, but on the other hand systematically refuses to change the surname when the grounds are linked to the possession of another nationality, the policy discriminates on the basis of nationality. ${ }^{1353}$ The Court follows the Advocate General. After recalling that the children enjoy the right not to suffer discrimination on the grounds of nationality, it states:

31. It is in this regard settled case-law that the principle of non-discrimination requires that comparable situations must not be treated differently and that different situations must not be treated in the same way (see, inter alia, Case C-354/95 National Farmers' Union and Others [1997] ECR I-4559, paragraph 61).

Thus the question is whether the children with Spanish and Belgian nationality are, for the purpose of Community law, comparable to children with only Belgian nationality. That is a precarious question, because article 18 TFEU explicitly prohibits distinguishing between persons on the basis of their nationality.

The Court observed that both groups are not in an identical position. After all, persons with Belgian and Spanish nationality have different surnames in different Member States, while this is not the case for persons only holding Belgian nationality. Thus, the first group suffers from all kinds of inconveniences that do not exist for the second group.

Since children with Spanish and Belgian nationality are not in the same situation as children with only Belgian nationality, the refusal to change the surname of persons from the first group on the basis of the general policy on the change of surnames, constitutes discrimination which is only allowed if it is justified by objective considerations independent of the nationality of the persons concerned.

In contrast to the Advocate General, the Court does not explicitly conclude that the refusal to change the surname amounts to discrimination on the basis of nationality. The Court only concludes that the refusal is discriminatory and that by itself already has to be justified.

To the extent that the Court implies by reference to article 12 EC (now art. 18 TFEU) that the refusal of the Minister of Justice to change the surname of the children constitutes discrimination on the basis of nationality (see also the opinion of Advocate General Jacobs above), the conclusion is not convincing. ${ }^{1354}$ After all, the rule that EU citizens 'enjoy the right not to suffer discrimination on the grounds of nationality' only tells us that nationality is not a relevant difference between EU citizens. Article 18 TFEU does not explain which differences between two situations are relevant and must be taken into account in order to avoid treating different situations the same.

In the case at hand, it is fair to say that by treating them equally the Belgian Minister discriminates Spanish/Belgian nationals against Belgian nationals, because the Spanish/Belgian person suffers inconveniences that are not suffered by the Belgian nationals. However, it is hard to see what it has to do with article 18 TFEU.

1353 Garcia Avello (opinion AG), par. 63.

1354 See also Frank 2005b, p. 162. 
Moreover, the problems associated with a limping surname do not only exist for persons with a double nationality. Persons with a single nationality who since birth reside on the territory of another Member State can also suffer from the same problems. The situation in Garcia Avello is only one modality of a more general problem, namely a collision between national systems of private international law or decisional disharmony leading to a limping legal relationship. As will be seen in Grunkin and Paul below, the real issue here from an EU law perspective is not discrimination on the basis of nationality, but a restriction on the free movement of EU citizens. ${ }^{1355}$

Another point in Garcia Avello is that it is the refusal of the Belgian Minister of Justice which in the end violates EU law; Spanish law is kept out of range. However, the limping surname is not only the fault of Belgian law. It results from the fact that for the purpose of surnames Belgium applies Belgian law to Belgian nationals, irrespective of any other nationality and Spain does exactly the same. The refusal of the Belgian Minister of Justice to change the surname is only a logical consequence of this approach. The Spanish authority would probably have reacted in a similar way. The fact that the birth of the children was first recorded in Belgium and only later at the Spanish consulate is also irrelevant for the Court.

It follows that Garcia Avello (and Grunkin and Paul below) constitute a particular situation which is different from the other discrimination cases. In all the other cases discussed so far, the source of the complaint was rooted in one legal system: a national legal system refusing to grant social benefits to persons who does not fulfil nationality or residence requirements. In Garcia Avello, the problem of the children is caused by a collision of two national legal systems.

\section{$D^{\prime}$ Hoop - discrimination on the basis of exercising free movement rights}

Yet another typical fact pattern where the right to equal treatment brings relief is the one in $D^{\prime}$ Hoop. ${ }^{1356}$ Marie-Nathalie D'Hoop is a Belgian national who completed her secondary education in France. After that, she went to university in Brussels. Having completed her studies, Ms D'Hoop applied for a tide-over allowance, an allowance for young people who have just completed their studies and are seeking their first job. Her application was refused on the ground that she did not complete her secondary education in Belgium.

The difference between D'Hoop on the one hand and Martinez Sala and Grzelczyk on the other is, that in $D^{\prime}$ Hoop the applicant complaints about the legislation of the Member State of her nationality, her home Member State. In Martinez Sala and Grzelczyk the applicant attacked the legislation of the host Member State.

In these circumstances the European Court of Justice in $D^{\prime} H o o p$ answered the question whether it is compatible with EU law to refuse a tide-over allowance on the sole ground that the person involved completed her secondary education in another Member State.

The Court starts by explaining the scope of the provisions on EU citizenship in EU law. It repeats the considerations from Grzelczyk. Ms D'Hoop is a national of a Member State and therefore she has the status of a EU citizen. Union citizenship is destined to be the fundamental status of nationals of the Member States which entitles them to equal treatment irrespective of nationality, in cases that come within the scope of EU law. A case falls within the scope of EU law if the person involved exercised her right of free movement. So far, nothing new. Then, the Court comes with a peculiar interpretation of the right to equal treatment for the case at hand:

\footnotetext{
1355 Also Fallon 2004, p. 43

1356 ECJ 11 July 2002, case C-224/98 (Marie-Nathalie D’Hoop v Office national de l'emploi) Rec. 2002, p. I-6191.
} 
30. In that a citizen of the Union must be granted in all Member States the same treatment in law as that accorded to the nationals of those Member States who find themselves in the same situation, it would be incompatible with the right of freedom of movement were a citizen, in the Member State of which he is a national, to receive treatment less favourable than he would enjoy if he had not availed himself of the opportunities offered by the Treaty in relation to freedom of movement.

It is clear that Ms D'Hoop is treated differently compared to her fellow Belgians who did not exercise their right of free movement in order to study abroad. However, such difference in treatment has nothing to do with the nationality of Ms D'Hoop. In other words, Ms D'Hoop is not discriminated against on the basis of her nationality, but on the basis that she studied abroad. The Court agrees and expands the scope of the discrimination provision again:

34. By linking the grant of tide-over allowances to the condition of having obtained the required diploma in Belgium, the national legislation thus places at a disadvantage certain of its nationals simply because they have exercised their freedom to move in order to pursue education in another Member State.

35. Such inequality of treatment is contrary to the principles which underpin the status of citizen of the Union, that is, the guarantee of the same treatment in law in the exercise of the citizen's freedom to move.

Thus in D'Hoop, the Court broadened the scope of the right to equal treatment of EU citizens. Not only should the nationality of the person involved not be determinative for his or her treatment in the host state (Martinez Sala, Garcia Avello), but also the fact that he or she made use of his or her right to free movement should not matter for his or her treatment in the home state. ${ }^{1357}$

\subsubsection{The right not to be hindered in the exercise of the right to free movement and residence}

\section{De Cuyper}

De Cuyper is the first case in the context of EU citizenship where the Court abandoned analysis on the basis of equal treatment in favour of an analysis based on a restriction to free movement. 1358

Mr De Cuyper is a Belgian national who spent his working life in Belgium. From 1997 he was granted an unemployment allowance from the Belgian government. In $1999 \mathrm{Mr}$ De Cuyper makes a declaration to the Belgian authorities that he is living alone in Belgium. However, during an inspection in 2000 it appeared that he did not live in Belgium, but in France. The effect under Belgian law is that Mr De Cuyper lost his entitlement to the unemployment benefit from the date he left Belgium. The European Court of Justice had to answer the question whether the requirement that the applicant for an unemployment allowance must have his habitual residence in Belgium is compatible with the provisions on Union citizenship.

The Court first states that the right of EU citizens to move and reside freely within the territory of the Member States is not unrestricted. It is made conditional upon limitations and conditions laid down in EU law. For Mr De Cuyper this means that it must be decided whether EU law allows him to enjoy his Belgian unemployment allowance in France.

${ }_{1357}$ See also ECJ 29 April 2004, case C-224/02 (Heikki Antero Pusa v Ossuspankkien Keskinäinen Vakuutusyhtiö) Rec. 2004, p.I-5763.

1358 ECJ 18 July 2006, case C-406/04 (Gérald De Cuyper v Office national de l'emploi) Rec. 2006, p.I-6947. 
Advocate General Geelhoed explained that article 21 TFEU simply guarantees EU citizens the right to move and reside freely within the territory of the Member States. ${ }^{1359}$ The logical effect is that measures which restrict the freedom to move and reside are prima facie incompatible with article 21 TFEU. A similar conclusion had already been drawn by the Court in Bosman in the context of the free movement of workers. ${ }^{1360}$ The Advocate General thus states:

107. It would not therefore seem necessary to interpret Article 21 TFEU [now art. 21 TFEU, ks], which sets out a right to freedom of movement and of residence without reference to a prohibition on discrimination, as meaning that it may only apply where a measure is discriminatory.

108. The question, rather, is whether a measure imposes any restriction on the exercise of the right to move and reside freely by a citizen of the Union, and if so whether such a restriction may be justified.

The Court observes that regulation $1408 / 71$ on the application of social security schemes to employed persons and their families moving within the Community, does not allow Mr De Cuyper to enjoy his Belgian unemployment benefit in France. But that is not the end of the story for the Court. In referring to i.a. D'Hoop, the Court holds:

39. It is established that national legislation such as that in this case which places at a disadvantage certain of its nationals simply because they have exercised their freedom to move and to reside in another Member State is a restriction on the freedoms conferred by Article 21 TFEU on every citizen of the Union [...].

40. Such a restriction can be justified, with regard to Community law, only if it is based on objective considerations of public interest independent of the nationality of the persons concerned and proportionate to the legitimate objective of the national provisions.

It follows that the Court has two ways to deal with more or less the same circumstances. In $D^{\prime}$ Hoop the facts concern a Belgian national who is refused a social benefit from the Belgian state, because she went to secondary school in France. In De Cuyper the facts concern a Belgian national who is refused an allowance by the Belgian state because he resides in France. In the first case, the Court reasons on the basis of equal treatment: the Belgian rule violates EU law because it discriminates against Belgians who exercise their right of free movement, compared with Belgians who don't. In De Cuyper, the Court simply holds that the residence requirement is a restriction of his freedom to move and reside. Both argumentations are present in later case law, but the reasoning on the basis of restriction to free movement prevails. ${ }^{1361}$

\footnotetext{
1359 De Cuyper (opinion AG), par. 104-108.

1360 ECJ 15 December 1995, case C-415/93 (Union royale belge des sociétés de football association ASBL v Jean-Marc Bosman) Rec. 1995 , p. I-4921.

1361 Argumentation on the basis of discrimination: ECJ 9 November 2006, case C-520/04 (Pirkko Marjatta Turpeinen) Rec. 2006, p.I-10685, par. 20. Argumentation on the basis of restriction: ECJ 26 October 2006, case C-192/05 (Tas-Hagen and Tas v Raadskamer WUBO van de Pensioen- en Uitkeringsraad) Rec. 2006, p.I-10451, par. 31; ECJ 11 September 2007, case C76/05 (Schwarz and Gootjes-Schwarz v Finanzamt Bergisch Gladbach) Rec. 2007, p.I-6849, par. 93; ECJ 23 October 2007, case C-11/06 and C-12/06 (Ghiannon Morgan v Bezirksregierung Köln and Iris Bucher v Landrat des Kreises Düren) Rec. 2007, p.I-9161, par. 25; ECJ 22 May 2008, case C-499/06 (Halina Nerkowska v Zakład Ubezpieczeń Społecznych Oddział w Koszalinie) Rec. 2008, p.I-3993, par. 31.
} 


\section{Grunkin and Paul}

In $D^{\prime}$ Hoop and De Cuyper the applicants were hindered in the exercise of their right of free movement and residence by the state of their nationality. This was also the case in Grunkin and Paul, but this case deals with a completely different subject. ${ }^{1362}$ Instead of social security allowances, the case questions the compatibility of the German conflict rules on surnames with the provisions on European citizenship.

Leonard Matthias is born on 27 June 1998 in Denmark. His parents are Stefan Grunkin and Dorothee Paul. All the persons involved have only German nationality. In accordance with Danish private (international) law, Leonard Matthias is recorded in Denmark under the surname Paul, which is later changed into Grunkin-Paul.

The parents also want to register their child with the German authorities in Niebüll. However, according to German private international law, the surname of the person is governed by the national law of the person involved, irrespective of his residence. Thus the surname of Leonard Matthias is determined in accordance with German law. According to German law, the parents must chose between Grunkin or Paul, but a combination of these names is not possible. Hence, the German registrar refuses to record Leonard Matthias under the surname Grunkin-Paul. However, the parents of Leonard Matthias also refuse to make a choice. Therefore, the registrar of Niebüll applies to the Amtsgericht Niebüll to ask for directions. In this procedure, the Amtsgericht refers a question to the European Court of Justice on the compatibility of the German choice of law rule with the provisions on European citizenship. ${ }^{1363}$

Advocate General Jacobs contends that the German choice of law rule in this case does not discriminate on the basis of nationality, because it treats all Germans in the same way. However, the AG simply finds that the practical difficulties resulting from the limping surname 'constitute a clear obstacle to the child's right as a citizen to move and reside freely within the territory of the Member States.' Therefore he concludes that it is 'totally incompatible with the status and rights of a citizen of the European Union [...] to be required to bear different names under the laws of the different Member States.' 1364

Despite this forceful language, the case fizzles out. On 27 April 2006, the Court holds that it does not have jurisdiction to answer the question, because it finds that in this case the Amtsgericht Niebüll does not exercise a judicial function. ${ }^{1365}$ Three days after the disappointing result Mr Grunkin applies again to the registrar in Niebüll to have his child registered under the name Grunkin-Paul. The application is denied and six days later $\mathrm{Mr}$ Grunkin files an appeal with the Amtsgericht Flensburg. This court refers the same question to European Court of Justice, namely whether in the light of article 12 and 21 TFEU the German choice of law rule on surnames is valid in so far as it provides that the law relating to names is governed by nationality alone. This time, the ECJ accepts jurisdiction. ${ }^{1366}$

Advocate General Sharpston does not want to discuss the merits of national systems of private international law. She explains that it is not the compatibility of nationality as a connecting factor with EU law that had to be determined, 'but only the validity of its effect, in combination with Paragraph 1617 BGB, in precluding the registration of a surname lawfully formed and already registered in Denmark.' 1367 Therefore, according to the

\footnotetext{
1362 ECJ 14 October 2008, case C-353/06 (Grunkin and Paul) Rec. 2008, p.I-7639.

1363 ECJ 27 April 2006, case C-96/04 (Standesamt Niebüll) Rec. 2006, p.I-3561.

1364 Standesamt Niebüll (opinion AG), par. 54 and 56.

1365 ECJ 27 April 2006, case 96/04 (Standesamt Stadt Niebüll) Rec. 2006, p.I-3561.

1366 ECJ 14 October 2008, case C-353/06 (Grunkin and Paul) Rec. 2008, p.I-7639.

1367 Grunkin and Paul (opinion AG), par. 49.
} 
Advocate General, the Court's task in this case 'is rather to assess the non-recognition of a name against the standards of Community law.'1368

The Court follows the Advocate General and reformulates the question which it was called upon to answer. The new question is 'whether articles 18 TFEU and 21 TFEU [now art. 18 and 21 TFEU, ks] preclude the competent authorities of a Member State from refusing to recognise a child's surname, as determined and registered in a second Member State in which the child - who like his parents, has only the nationality of the first Member State was born and has been resident since birth.'

After the Court's decision in Garcia Avello, there is no surprise that the case of Grunkin and Paul also falls within the scope of EU law. After all, Leonard Matthias is an EU citizen who is lawfully resident on the territory of another Member State. Still, the situation is not completely the same as in Garcia Avello. In that case the Belgian/Spanish children were resident in Belgium about which legislation they complained. It was the Spanish nationality of the children that brought them within the scope of Community law. In Grunkin and Paul, the German child resides in Denmark and his parents complain about the legislation of the Member State of his nationality.

In Grunkin and Paul the Court does not argue along the lines of discrimination. Combining its decisions in D'Hoop and Garcia Avello, the Court could have argued that although there is no discrimination on the basis of nationality, German nationals who exercised their fundamental rights are discriminated against compared with Germans who did not, because the choice of law rule does not take into account the specific problems that arise from the fact that they exercised their free movement rights. Instead of this rather complicated argument, the Court states:

22. Having to use a surname, in the Member State of which the person concerned is a national, that is different from that conferred and registered in the Member State of birth and residence is liable to hamper the exercise of the right, established in Article 21 TFEU, to move and reside freely within the territory of the Member States.

In retrospect, this reasoning would also have solved the case in Garcia Avello in a more convincing way. There, the Court simply could have said that the refusal of the Belgian Minister to grant a change of surname is liable to hamper the exercise of the right of free movement given the inconveniences that arise out of the fact that the person has an equivocal surname.

\subsubsection{Objective justifications for discrimination and hindrances to free movement}

If the court has found that a national rule or policy is discriminatory or restrictive of the free movement of persons, the next question is whether the national rule or policy can be justified. The possibility of justification depends on whether the case concerns direct discrimination on the basis of nationality on the one hand or indirect discrimination or a restriction of free movement on the other hand.

In the case of direct discrimination on the basis of nationality, the unequal treatment can only be justified on the basis of express provisions in EU law. Thus article 24 (1) Citizens' Rights Directive provides that 'subject to such specific provisions as expressly provided for in the Treaty and secondary law, all Union citizens residing on the basis of this directive in the territory of the host Member State shall enjoy equal treatment with the nationals of that Member State within the scope of the Treaty.' Thus direct discrimination on the basis of

1368 Grunkin and Paul (opinion AG), par. 50. 
nationality is for example allowed in the interest of public policy, public security or public health. ${ }^{1369}$

In the case law of the European Court of Justice on citizenship the justification of direct discrimination on the basis of nationality does not play an important role. In the cases which involved direct discrimination (Martinez Sala, Grzelczyk, Trojani), the issue of justification was hardly discussed.

In case of indirect discrimination on the basis of nationality (Bidar), discrimination on the basis of exercising fundamental freedoms ( $D^{\prime}$ Hoop) or restriction to free movement (Grunkin and Paul) the possibilities for justification are broader. In those cases, the discriminatory or restrictive rule, policy or measure can be justified if it is based on objective considerations independent of the nationality of the persons concerned and if application of the rule, policy or measure is proportionate to the legitimate aim concerned. ${ }^{1370}$ In the context of the freedom of establishment (art. 43 EC) the Court held in Gebhard:

37. It follows, however, from the Court's case-law that national measures liable to hinder or make less attractive the exercise of fundamental freedoms guaranteed by the Treaty must fulfil four conditions: they must be applied in a non-discriminatory manner; they must be justified by imperative requirements in the general interest; they must be suitable for securing the attainment of the objective which they pursue; and they must not go beyond what is necessary in order to attain it. ${ }^{1371}$

For purpose of this thesis, it is instructive to see how the Court deals with the justifications that are put forward for the limping surnames of the children in Garcia Avello and Grunkin and Paul.

\section{Garcia Avello - justifications}

The Court concluded that the refusal of the Belgian Minister of Justice to change the names of the children from Garcia Avello to Garcia Weber was discriminatory, since the policy did not take account of the difficulties to which the children were subjected as a result of their limping surname. This policy could not be justified.

In short, the policy of the Belgian Minister of Justice on the change of surnames was guided by the principle of immutability of surnames. That principle means that surnames cannot be changed unless there are very weighty reasons. A limping surname was apparently not serious enough.

According to Belgium the importance of the principle of immutability of surnames is shown by the fact that it was a longstanding principle which was implemented at 6 Fructidor Year II (6 September 1794) in order to avoid risks of confusion as to the identity or parentage of those concerned. ${ }^{1372}$ However, history and tradition are not particularly convincing to justify discrimination. Also, the policy to avoid confusion as to the identity and the parentage of the child by setting a high threshold for a change of surname could not convince the Court.

\footnotetext{
1369 Article 27 (1) Directive 2004/38/EC of the European Parliament and the Council of 29 April 2004 on the right of citizens of the Union and their family members to move and reside freely within the territory of the Member States. See also Barnard 2007, p. 255.

1370 ECJ 15 March 2005, case C-209/03 (Dany Bidar v London Borough of Ealing) Rec. 2005, p.I-2119, par. 54; ECJ 11 July 2002, case C-224/98 (Marie-Nathalie D'Hoop v Office national de l'emploi) Rec. 2002, p. I-6191, par. 36; ECJ 14 October 2008, case C-353/06 (Grunkin and Paul) Rec. 2008, p.I-7639, par. 29. See also ECJ 2 October 2003, case C-148/02 (Carlos Garcia Avello v État belge) Rec. 2003, p. I-11613, par. 39.

1371 ECJ 30 November 1995, case C-55/94 (Reinhard Gebhard v Consiglio dell'Ordine degli Avvocati e Procuratori di Milano) Rec. 1995, p.I-4165.

1372 Garcia Avello (judgment), par. 40; Garcia Avello (opinion AG), par. 68.
} 
Advocate General Jacobs acknowledged that preventing confusion is a legitimate aim, but questioned the necessity of the strict Belgian policy, by referring to the British flexibility in this matter:

69. I would accept that the aim of preventing confusion over identity by placing limitations on the right to change surnames is a legitimate one. It is desirable to avoid such confusion both in relations between the individual and the authorities and in relations among individuals. Excessive freedom in such matters might well offer opportunities for criminal or dishonest behaviour.

70. However, such dangers should not be exaggerated. It has not been found necessary in other Member States, for example the United Kingdom, to restrict changes of surname on this ground. In any event, the very existence of official registration of a change of name is likely to reduce the chances of confusion, whether intentional or otherwise, going undetected. And in order to establish lineage, identity of surname seems unlikely to be either sufficient or necessary in most legal systems.

The Court added:

42. [...] Furthermore, it is common ground that, by reason in particular of the scale of migration within the Union, different national systems for the attribution of surnames coexist in the same Member State, with the result that parentage cannot necessarily be assessed within the social life of a Member State solely on the basis of the criterion of the system applicable to nationals of that latter State. In addition, far from creating confusion as to the parentage of the children, a system allowing elements of the surnames of the two parents to be handed down may, on the contrary, contribute to reinforcing recognition of that connection with the two parents

In essence, both the Court and the Advocate General stated that the application of the principle of immutability of surnames is not sufficient and necessary to avoid confusion. In terms of Gebhard: the measure is not suitable to secure the attainment of the objective.

The Danish Government argued in support of the Belgian practice that the application of Belgian law to all persons with Belgian nationality (irrespective of any other nationality) facilitates the integration of the person in Belgium which, according to Denmark, was the objective of the principle of non-discrimination. According to the Advocate General, integration is not at all the objective of the prohibition of discrimination:

72. I would moreover take issue with the argument that the principle of nondiscrimination seeks essentially to ensure the integration of migrant citizens into their host Member State. The concept of 'moving and residing freely in the territory of the Member States' is not based on the hypothesis of a single move from one Member State to another, to be followed by integration into the latter. The intention is rather to allow free, and possibly repeated or even continuous, movement within a single 'area of freedom, security and justice', in which both cultural diversity and freedom from discrimination are ensured.

The Court, instead of letting itself being enticed to making bold statements on the purpose of non-discrimination, merely rejected the argument for lack of proportionality:

43. Second, with regard to the objective of integration pursued by the practice in issue, suffice it to point out that, in view of the coexistence in the Member States of different 
systems for the attribution of surnames applicable to those there resident, a practice such as that in issue in the main proceedings is neither necessary nor even appropriate for promoting the integration within Belgium of the nationals of other Member States.

Not only from the perspective of European law, but also from the perspective of private international law, the arguments submitted to justify the Belgian policy on the change of surnames do not cut ice.

The argument that the refusal to change the surname is warranted by the aim to avoid confusion does not make sense: a limping surname rather creates confusion. The Advocate General considered in this respect:

56. Second, obvious practical difficulties may ensue for the children from the fact that their surname as recorded by the Belgian authorities differs from that recorded by the Spanish authorities. One example, pointed out by counsel for Mr Garcia Avello at the hearing, might be the possession of an educational qualification issued in Belgium in a name not recognised as that of the holder in Spain; others are given in the Explanatory Report to the 1982 Hague Convention.

Also the Danish argument that the application of the Belgian law facilitates integration is not convincing. In the discussion on the choice between domicile and nationality as a connecting factor for personal status, the choice for domicile is sometimes defended on the basis of integration. ${ }^{1373}$ The idea is that integration of foreigners is facilitated if they are governed by the law of the place where they live. That is probably also the reason why Denmark applies the law of the residence of a person to determine his surname. ${ }^{1374}$ However, according to Belgian law, the name is governed by a person's nationality and Belgium refuses to change the name because it treats the children solely as Belgians. That has nothing to do with integration.

This brings us to the real source of the problem in Garcia Avello, which is the question whether the systematic preference of the nationality of the forum is compatible with EU law. Today Belgian private international law, and many other legal systems, provide that if a person amongst others has the nationality of the forum, only that nationality will be taken into account for the purpose of private international law, irrespective of close or closer ties with the law of one of the person's other nationalities. ${ }^{1375}$

By enacting such a rule, the state deliberately accepts the risk of a limping surname. The refusal to change the name is only a logical consequence of this rule. The policy on surnames is only designed for internal cases. That is also why only Belgians can apply to the Belgian Minister of Justice for a change of surname. The problems of persons with double nationality are known, but simply ignored in national and international legislation. ${ }^{1376}$

Legislators have justified the preference for their own nationality with practical reasons. The systematic application of the nationality of the forum in the case where the person has more than one nationality is easy for the national courts and administrative authorities

\footnotetext{
1373 Kronke 2004, p. 462; Mosconi 2000, par. 2; De Winter 1969, par. 23a.

1374 See ECJ 14 October 2008, case C-353/06 (Grunkin and Paul) Rec. 2008, p.I-7639.

1375 See article 3 (2) Belgian Code on private international law (Wet van 16 juli 2004 houdende het Wetboek van international privaatrecht). See also article 2 Dutch Conflict of Laws (Names) Act (Wet conflictenrecht namen); article 5 (1) German Introductory Act to the Civil Code (EGBGB).

1376 See for example also par. 3.2 Explanatory Report to the Convention on the law applicable to surnames and forenames, Munich 1980 (via www.ciec1.org) provides: The problem of dual nationality was omitted from the scope of the convention. Although it must be recognised that this is a topical problem, it was finally decided that the subject of names of dual nationals was too limited in scope for a rule to be laid down.
} 
because it leads to the application of the lex fori with which they are most familiar. It also creates legal certainty. 1377

Although it is praiseworthy to strive for practical solutions in private international law, it cannot be the only reason for the supremacy of the nationality of the forum. In fact, the policy of the Belgian Minister of Justice in Garcia Avello can hardly be considered practical if it leaves the person involved with a limping surname.

The French private international law scholars Batiffol and Lagarde give more fundamental reasons for the supremacy of the nationality of the forum and it should be considered whether such fundamental reasons would be able to stand the test of EU law.

The first reason for the forum to take into account, in cases of dual nationals, the nationality of the forum state only, focuses on the unilateral character of nationality law. ${ }^{1378}$ It is for every state to determine who its nationals are. Therefore, for example the French court - as an organ of the French state - is required to consider everyone a French national who is designated as such by French nationality law. In that respect, the fact that a foreign state also grants the person the nationality of that state is irrelevant for the French court. According to Batiffol and Lagarde there is no conflict of nationality laws for the French court in the case of a person with two nationalities of which one is the nationality of the forum state; in such a case French nationality law regulates the nationality of the person in terms that prevent the French court to take into account foreign nationality law.

The second argument to prefer the nationality of the forum over a foreign nationality is that the use of nationality as a connection implicitly marks the scope of application of the law of the forum. ${ }^{1379}$ If French law grants rights and obligations to French nationals, the scope of application of French law is implicitly determined by French nationality law. Therefore all French nationals are subject to those rights and obligations even if they possess another nationality. Nationals cannot escape the rights and obligations that follow from the membership of the nation. ${ }^{1380}$ The bond between a person and his nation is a natural state of affairs that cannot be readily dissolved. ${ }^{1381}$

However, the idea that it follows naturally and logically that a person is governed by the laws of his nation is outdated. ${ }^{1382}$ Moreover, it is doubtful at the least whether the presumed bond between a nation and its nationals or the power of a sovereign nation over its nationals can justify any restriction on the free movement of EU citizens.

Although EU citizenship is derived from the nationalities of the Member States, the rights that are attached to it are not. It is EU law that grants EU citizens the fundamental right to move and reside freely within the territory of the Member States. The effect of the supremacy of EU law is that national sovereignty to impose the law of the forum to its nationals is limited by the EU citizens' fundamental rights under EU law.

Advocate General Maduro in Rottmann called this the 'miracle of EU citizenship'.1383 While on the one hand European citizenship reinforces the bond of nationality, because it is through the nationality of a Member State that one acquires European citizenship, on the other hand European citizenship emancipates nationals from their nations, because it creates a bond between Europeans that transcend the nation.

\footnotetext{
1377 Belgium: Explanatory Report to the Code on private international law (published in J. Erauw and M. Fallon (ed.), De nieuwe wet op het internationaal privaatrecht, Wolters Kluwer Belgium (2004), p. 59-219, at 86). Germany: BT Drucks. 10/504, p. 40.

1378 Batiffol \& Lagarde 1993, nr. 78, p. 119.

1379 Batiffol \& Lagarde 1993, nr. 78, p. 121.

${ }^{1380}$ Demolombe 1847, par. 97, p. 45; Locré 1836, p. 304, 312

1381 Manchini 1851, p. 30-32.

1382 De Winter 1969, par. 20.

1383 Opinion 30 September 2009, case C-135/08 (Janko Rottmann v Freistaat Bayern), par. 23.
} 
In conclusion, it must be realised that despite the multilateral nature of national conflict rules, the national choice of law rule is still a unilateral approach to private international law cases. Despite the fact that a case is connected with more than one legal system, every legal system decides for itself which legal system has to govern the case.

Thus French law, via its choice of law rules, may determine that in a particular case the surname is determined by German law, while Dutch law may provide that in the same case Dutch law is applicable, without taking account of what the other legal systems provide.

In the absence of an overarching legislator, every legal system is free to determine which law has 'jurisdiction' to regulate the case at hand, without bothering too much about the adverse consequences for the persons involved. This freedom, rooted in the concept of national sovereignty, is restricted by EU law.

Thus Garcia Avello is an example of a case whereby the Member States have jurisdiction to regulate the subject involved (surnames) as they see fit. Member States can solve the issue on the basis of the lex fori, the nationality of the person or the domicile of the person. For EU law, it does not matter how the Member States exercise their regulatory jurisdiction on surnames.

However, if the different forms of regulation collide in such a way that it restricts the fundamental rights of the person involved, EU law intervenes. At that point there are two options. Either the restriction on free movement is justified as a result of which the person involved has to suffer the disadvantages, or the restriction is not justified and has to be resolved. The Court in Garcia Avello does not explain how the unjustified discrimination resulting from the collision of Spanish and Belgian law on surnames has to be resolved. It simply held that articles 18 and 20 TFEU preclude the Belgian Minister of Justice from refusing to change the surname of the children. It is for the national court to make sure that the name will indeed be changed.

\section{Grunkin and Paul - justifications}

In Grunkin and Paul the surname of the child Leonard Matthias which had been established in accordance with Danish law was not recognised under German law, because according to German private international law the name of the child is determined in accordance with the law of the child's nationality, which is German. The non-recognition of the name that has been established in Denmark is a restriction.

On the question whether the restriction was justified, the German government focuses on the suitability of nationality as a connecting factor for surnames and the objections against compound or double-barrelled surname. The question of the referring court also went in this direction by asking whether article 10 EGBGB is compatible with EU law 'in so far as it provides that the law relating to names is governed by nationality alone.'

At the first protest against the German refusal to recognise the Danish surname Advocate General Jacobs did not even bother to discuss any justifications. Referring to the Court's decision in Garcia Avello, he simply concluded that it is 'totally incompatible with the status and rights of a citizen of the European Union - which is 'destined to be the fundamental status of nationals of the Member States' - to be required to bear different names under the laws of different Member States.' 1384

After the Court dismissed the case for lack of jurisdiction, it was brought a second time before the Court. This time Advocate General Sharpston seemed more sympathetic to the sensitivity of the case, but in the end it did not help the German government very much.

1384 Opinion 30 June 2005, case C-96/04 (Standesamt Niebüll), par. 56. 
The Advocate General stresses that the issue in Grunkin and Paul is not whether the use of nationality as a connecting factor is compatible with EU law. The only question is whether the effect of the choice of law rule in combination with the applicable law violates Leonard Matthias' fundament rights under EU law. ${ }^{1385} \mathrm{In}$ other words, as has been concluded on the basis of Garcia Avello, Member States are free to determine the surname of EC citizens as they see fit and to set up the technical legal frame work that best suits their national system, but in the end the result or the effect of the national system must be compatible with EU law.

Interestingly, the Advocate General finds it significant that the main proceedings concern a situation in which the surname was determined and registered at birth in accordance with the applicable Danish law, and modified and re-registered shortly after birth in accordance with the same applicable law, before [sic] any application was made to register it with the German authorities.' 1386 Her emphasis on the fact that the Danish registration was first is singular both from the perspective of private international law and EU law.

From the perspective of private international law every legal system is sovereign to provide the rules on how to determine the surname of a person in an international case. The recording of the birth under another legal system does not as such impose a particular solution. Moreover, the fact that a name has not been recorded in Germany does not mean that the person does not have a name under German law.

From the perspective of EU law, it also does not seem to matter which recording is first. In Garcia Avello, first the Belgium authorities determined the name of the children and only a few years later the Spanish authorities. Still, in the end it was Belgian law that had to yield to the supremacy of EU law and not Spanish law. Therefore, it has been concluded above that it is the limping surname as such that restricts free movement and not so much the fact that a second determination of the surname is not in accordance with the first.

The Advocate General does not only indicate why, in her view, the arguments of the German government do not justify a restriction on Leonard Matthias' free movement right. She also hints at two reasons that could have justified such a restriction.

First of all, 'if national law totally precluded the possibility of siblings bearing different surnames, it could perhaps be justifiable to refuse to register a name that would give rise to such a situation' ${ }^{\prime} 1387$ Thus, substantive reasons to restrict the free movement are allowed, but only as long as they are applied consistently.

Second of all, the Advocate General suggests that evasion could be a reason not to recognise a surname that has been established abroad: 'It might also be justifiable to refuse to recognise a name given in accordance with the law of another Member State to which a child is connected by birth but not nationality, if the place of birth is shown to have been chosen simply in order to circumvent the rules of the Member State of nationality, without there being any other real connection with that place.' 1388

Here, the Advocate General touches upon an important consequence of the direction in which the Court is pushing international family law: what are the limits of mutual recognition? Up until now the Court systematically refused to accept evasion of the law as a valid justification to restrict the free movement. The Court's case law on the recognition of legal personality of corporations shows that it is hardly compatible with EU law that the free

\footnotetext{
1385 Opinion 24 April 2008, case C-353/06 (Grunkin and Paul), par. 49.

1386 Grunkin and Paul (opinion AG), par. 51.

1387 Grunkin and Paul (opinion AG), par. 86.

1388 Grunkin and Paul (opinion AG), par. 86.
} 
movement depends on intention. ${ }^{1389}$ Also in the context of European citizenship the Court held in Chen that the UK had to recognise the Irish nationality of a child, even though the mother went from China to Northern Ireland solely for the purpose that her child would acquire Irish nationality. The fact that there was not a genuine connection with Northern Ireland was irrelevant. ${ }^{1390}$

In principle, there is no difference from the perspective of EU law between a person who moves to another Member State to buy a product that is not available in his home state and a person who goes to another Member State to benefit from a legal rule that is different from the rule in his home state. Both the product and the legal relationship cannot be refused in the home state solely because they are not available in the home state. The home state has to formulate substantive reasons, for example that the product is dangerous or that the legal relationship infringes upon the rights of others, to justify its refusal.

The Advocate General concludes that her approach does not require major changes to the national systems of private international law. It would 'simply [emphasis added] require them to allow greater scope for recognising a prior choice of name validly made in accordance with the laws of another Member State. To that extent, it involves no more than an application of the principle of mutual recognition which underpins so much of Community law, not only in the economic sphere but also in civil matters.' 1391

The Court's ruling on the justification of the restriction of Leonard Matthias' free movement right is less telling. ${ }^{1392}$ The German government argued that nationality as a connecting factor to determine the surname of a person must be upheld because it provides certainty and continuity. Compared to the domicile or habitual residence, the nationality of a person is often simply proven with a passport and it is not likely to change so easily.

The Court has another interpretation of certainty and continuity and holds that the surname of Leonard Matthias in this case is everything but certain and continuous. Since in this concrete case nationality as a connecting factor does not meet its objective (i.e. determine the name with certainty and continuity), it cannot be accepted as a justification for the restriction of free movement. 1393

According to the German government nationality as the connecting factor for surnames ensures that siblings have the same surname. Obviously, this is only true if all the siblings have the same nationality, but the Court does not analyse the argument. It simply holds that Leonard Matthias does not have siblings and that therefore such an argument cannot justify a restriction of free movement in this particular case.1394

Besides the preservation of nationality as a connecting factor, the German government also has a problem with compound or double-barrelled surnames for all kinds of practical reasons. Although, according to the Court, practical difficulties do not justify a restriction on fundament rights, double-barrelled surnames are not banned systematically from the German registration system. After all, the choice of law rules on surnames (art. 10 EGBGB) allow a German child to have surname in accordance with the law of another nationality of one of his parents, including a double-barrelled surname. Thus, because German nationals

\footnotetext{
1389 ECJ 30 September 2003, case C-167/01 (Kamer van Koophandel en Fabrieken voor Amsterdam v Inspire Art Ltd) Rec. 2003, p. I-10155; ECJ 9 March 1999, case C-212/97 (Centros Ltd v Erhvervs- og Selskabsstyrelsen) Rec. 1999, p. I-1459. See also literally Opinion Advocate General Sharpston 25 June 2009, case C-73/08 (Nicolas Bressol, Céline Chaverot v Gouvernement de la Communauté française), par. 95 with reference to case law.

1390 ECJ 19 October 2004, case C-200/02 (Kunqian Catherine Zhu and Man Lavette Chen v Secretary of State for the Home Department) Rec. 2004, p. I-9925.

1391 Grunkin and Paul (opinion AG), par. 91.

1392 ECJ 14 October 2008, case C-353/06 (Grunkin and Paul) Rec. 2008, p.I-7639.

1393 Grunkin and Paul (judgment), par. 32.

1394 Grunkin and Paul (judgment), par. 33
} 
are not consistently barred from having a double-barrelled surname, the policy to discourage such names cannot justify a restriction on fundamental rights. ${ }^{1395}$

Similarly to the Advocate General the Court also gives a hint as to what could be submitted as a justification for the restriction of free movement rights. It states:

38. In addition, it must be pointed out that no specific reason was cited before the Court that might possibly preclude recognition of the child Leonard Matthias's surname, as conferred and registered in Denmark, for instance that that name was contrary to public policy in Germany.

Thus the public policy exception could constitute a justified restriction on free movement. Still, the application of the exception would need to stand the test of EU law. 1396

In conclusion it must be observed that the ruling of the Court in Grunkin and Paul confirms its ruling in Garcia Avello. The mere fact that a child has a limping surname restricts his free movement right and unless there are objective justifications the restriction has to be removed. Inconsistent justifications with no regard to the restrictions on free movement caused by a limping surname are bound to fail.

Another point to be taken into account is that neither the Court nor the Advocate General are interested in the question whether nationality is an appropriate criterion to determine the applicable law given the prohibition to discriminate on the basis of nationality of article 18 TFEU. They focus on the result on national law, which is the recognition of the name.

\section{Pfeiffer - justifications in case of a real conflict of interest}

So far, case law emerging from the notion of EU citizenship has been analysed. It has been shown that EU citizenship has extended the rights of citizens towards the Member States to exercise their rights of free movement and residence. The case law which has been discussed so far, especially the decisions of the Court in Garcia Avello and Grunkin and Paul leave the impression that the EU has hijacked the private international law on civil status by injecting it with the concept of mutual recognition. What is left of the Member States' sovereignty in civil status affairs, if compound surnames cannot be kept out of the registers anymore?

The radical pictures that the Court has painted in its decisions in Garcia Avello and Grunkin and Paul have to be put in perspective by its decision in Pfeiffer. ${ }^{1397}$ The case deals with trade names and emerged from the provisions on the freedom of establishment.

Pfeiffer Großhandel $\mathrm{GmbH}$ operates supermarkets in Austria under the trade name 'Plus kauf park'. That trade name has been registered with the Austrian patent office since 1969. Löwa also operates (discount) supermarkets in Austria. The parent company of Löwa is the German Tengelmann Warenhandelsgesellschaft. Tengelmann operates on the Austrian market not only through Löwa, but also through Plus Warenhandelsgesellschaft. Löwa owns the trade name 'Pluspunkt' and Plus Warenhandelsgesellschaft owns 'Plus prima leben und sparen'.

Tengelmann wants to develop one corporate identity with the same style of presentation for all its supermarkets throughout Europe. On the basis of this policy, Löwa

1395 Grunkin and Paul (judgment), par. 37.

${ }_{1396}$ More clarity on the application of the public policy exception can be expected from the Court's ruling in case C208/09 Sayn-Wittgenstein (pending case). There the question is whether article 18 EC precludes legislation pursuant to which the competent authorities of a Member State refuse to recognise that part of the surname of a (grown up) adopted child, determined in another Member State, which contains a title which is inadmissible in the former Member State, including under constitutional law.

1397 ECJ 11 May 1999, case C-255/97 (Pfeiffer Großhandel GmbH v Löwa Warenhandel GmbH) Rec. 1999, p. I-2835. 
changes the name of 17 of its 139 supermarkets to 'Plus prima leben und sparen', which echoes the text mark of its sister company Plus Warenhandelsgesellschaft.

Pfeiffer seeks an order from the commercial court in Vienna to restrain Löwe from using its new trade name on the ground that 'Plus prima leben und sparen' can easily be confused with 'Plus kauf park'. On the basis of Austrian law, the court finds indeed that Löwe must be restrained from using the trade name 'Plus prima leben und sparen'.

Since the case affects intracommunity trade the commercial court in Vienna stays proceedings and submits a question for preliminary ruling to the ECJ. The court essentially asked whether articles 30 and 52 EC preclude a provision of national law which does not allow a trade name to be used as the specific designation of an undertaking where there is a risk of confusion.

The ECJ starts by reiterating that the freedom of establishment applies both to natural and legal persons. This freedom is restricted by national measures that place the companies from another Member State in a less favourable situation than companies from the state of establishment. A restraining order such as the one sought by Pfeiffer restricts the freedom of an undertaking from another Member State to exercise its freedom of establishment, because the order makes it impossible for Tengelmann to develop through its subsidiary Löwe a uniform policy of presenting their business. But none the less, the restriction is allowed:

21. However, where such a restriction on the right of establishment is brought about by a provision of national law whose primary aim is to safeguard trade names against the risk of confusion, it is justified by overriding requirements in the general interest pertaining to the protection of commercial and industrial property.

$[\ldots]$

23. Furthermore, as the Advocate General pointed out in points 63 to 68 of his Opinion, the restraining order sought by Pfeiffer in the main proceedings is suitable for securing the attainment of the objective pursued and does not go beyond what is necessary for that purpose, since the national court has concluded on the basis of its national law that a risk of confusion does in fact exist.

Pfeiffer does not deal with private international law but it gives an example where a name lawfully established in one Member State does not need to be recognised in another Member State.

The difference between Pfeiffer on the one hand and Garcia Avello and Grunkin and Paul on the other hand is that Pfeiffer presents a genuine conflict of interest between Pfeiffer and Löwe. In balancing the interests on the basis of Austrian law, the Austrian judge concludes that the interest of Pfeiffer not to be confused with Löwe prevails over the interest of Löwe to have a uniform presentation of the business. This balancing of private interests is the prerogative of the Member States and as long as it is done in a non-discriminatory manner, the Member States are free to balance the conflicting interests as they see fit.

How different are the situations in Garcia Avello and Grunkin and Paul. In these cases there is no conflict of interest at all. Who would be hurt if Diego and Esmeralda are named Garcia Weber instead of Garcia Avello? What does it matter that Leonard Matthias is called Grunkin-Paul instead of Grunkin or Paul?

The chance that a citizen fights with the authorities over his surname although there is no real conflict of interest is relatively high in the area of surnames. The (private international) law on surnames is in general rather symbolic and arguably more concerned with the interests of the administration than with the interests of the persons involved. 
Pfeiffer shows that when the law on names (in this case trade names) really solves a conflict of interest between private parties the Court is less likely to interfere. For that, it does not matter whether the private parties involved are companies or individuals.

\subsubsection{Disparate treatment does not constitute discrimination or a restriction (Schempp)}

So far the line is pretty clear. The Court declared the status of EU citizen to be the fundamental status of nationals of the Member States as a result of which they have the right not to be discriminated against on the basis of nationality. The Court dealt with several types of discrimination on the basis of nationality (direct, indirect, reverse discrimination) and gradually, the Court went 'beyond the model of discrimination'. 1398 Not only has the EU citizen the right to be treated equally with the nationals of the host Member State, but the right to move and reside may not be restricted.

However, EU law is not concerned with all legislative disparities between the laws of the Member States that make free movement less attractive. Schempp shows that also in the context of European citizenship the concept of disparate treatment applies. 1399

In Schempp Mr Schempp paid a maintenance allowance to his ex-wife in Austria. $\mathrm{Mr}$ Schempp complained that he was discriminated against. If his ex-wife had lived in Germany, he would have been allowed to deduct the maintenance allowance from his taxable income, because under German law the maintenance would in principle be added to the taxable income of the ex-wife. However, since his ex-wife was living in Austria where her maintenance was not added to her taxable income, German law did not allow Mr Schempp to deduct the maintenance allowance from his taxable income.

The first hurdle in this case was that not Mr Schempp, but his ex-wife exercised her right to free movement as a result of which Mr Schempp has to pay more taxes in Germany. Thus, the first question was whether Mr Schempp came within the scope of EU law or whether his tax obligations were a purely internal matter.

The Court held that 'since the exercise by Mr Schempp's former spouse of a right conferred by the Community legal order had an effect on his right to deduct tax in his Member State of residence, such a situation cannot be regarded as an internal situation with no connection with Community law.' 1400

The second question was whether German law was discriminatory. Was Schempp not allowed to deduct his maintenance payments for the sole reason that his wife exercised her right of free movement (cf. D'Hoop) or was there something else? Or, in the words of Advocate General Geelhoed, does the criterion on which the differential treatment is based relate directly or indirectly to nationality. ${ }^{1401}$

The rule under German law in a purely internal situation is that maintenance payments can be deducted from the taxable income of the maintenance debtor (Mr Schempp), if the maintenance creditor (Schempp's ex-wife) is subject to unlimited income tax liability in Germany. The amount of money that can be deducted by the debtor is part of the taxable income of the maintenance creditor.

The maintenance payment by the debtor can also be deducted, if the maintenance creditor resides in another Member State or a State of the EEA and if it is proven that the maintenance payments form part of the taxable income of the maintenance creditor in the state of his or her residence.

Therefore, the Advocate General observed that the deductibility of the maintenance payments in Germany does not depend on nationality, but relates to the fiscal treatment of

\footnotetext{
1398 Barnard 2007, p. 273, 440; Jacobs 2007, p. 597.

1399 ECJ 12 July 2005, case C-403/03 (Egon Schempp v Finanzamt München) Rec. 2005, I-6421.

1400 Schempp (judgment), par. 25.

1401 Schempp (opinion AG), par. 28.
} 
the maintenance payment in the Member State where the maintenance creditor resides. According to the Advocate General, Mr Schempp cannot compare himself with the situation in which his ex-wife lived in Germany. ${ }^{1402}$ After all, if his ex-wife lived in Germany 'there is a logical and systematic relationship between permitting a deduction of maintenance payments on the side of the taxpayer responsible for paying the maintenance allowance and the taxability of these amounts as income on the side of the recipient of these payments.' However, because his wife lived in Austria where her maintenance allowance is not taxed 'there is no systematic link between the fiscal treatment of Mr Schempp's income and his former spouse's income.'

The Court reiterates its settled case law that 'article 12 EC [now art. 18 TFEU] is not concerned with any disparities in treatment, for persons and undertakings subject to the jurisdiction of the Community, which may result from divergences existing between the various Member States, so long as they affect all persons subject to them in accordance with objective criteria and without regard to their nationality.' 1403

With the Advocate General the Court concludes that maintenance paid to a person in Germany cannot be compared to maintenance paid to a person in Austria, because of the difference in fiscal treatment of maintenance allowances in these Member States. ${ }^{1404}$

With regard to the application of article 21 TFEU alone, the Court observes that the Treaty offers no guarantee to a citizen of the Union that transferring his activities to a Member State other than that in which he previously resided will be neutral as regards taxation. Given the disparities in the tax legislation of the Member States, such a transfer may be to the citizen's advantage in terms of indirect taxation or not, according to circumstances'. ${ }^{1405}$

The point is that according to German law the maintenance allowance must be taxed, either through the income of the maintenance creditor or through the income of the maintenance debtor. If it is not taxed through the income of the maintenance creditor, because she lives in a country where received maintenance is not taxed, the allowance has to be taxed through the income of the debtor. ${ }^{1406}$

\footnotetext{
1402 Schempp (opinion AG), par. 30.

1403 Schempp (judgment), par. 34.

1404 Schempp (judgment), par. 35.

1405 Schempp (judgment), par. 45.

1406 Although this is quite clear, there was on peculiarity left. If Schempp's ex-wife would have lived in Germany her maintenance allowance would not be taxed because her income was below the tax threshold. Under the German principle for the fiscal treatment of maintenance that should have meant that Mr Schempp would not be able to deduct the payment from his taxable income.

However, German law does not require evidence of taxation if the maintenance is paid to a person in Germany. Thus the real question in the case of Schempp was whether German law was discriminatory because evidence of taxation of the maintenance allowance was required if the recipient lived abroad while it was not required if the recipient lived in Germany.

The Court observed that this was not the question which it was called upon to answer. The question merely was whether Community law precludes a taxpayer in Germany from being able to deduct the maintenance paid to his former spouse in Austria. Moreover, following the Commission, the grounds for non-taxation of the maintenance payments in Germany (ex-wife does not have enough income) cannot be equated to the grounds for non-taxation of the maintenance in Austria (the character of maintenance allowance). ${ }^{1406}$

However, for German law the ground for non-taxation on the side of the creditor seems irrelevant. The only reason why the principle for the fiscal treatment of maintenance would not apply in this case is because if the ex-wife would have lived in Germany there would have been no requirement for the debtor to prove that the maintenance paid by him was actually taxed on the side of the creditor.

Still, for the purposes of this thesis the message is clear. After all, if the ex-wife would have had enough income to be taxed in Germany, the maintenance allowance would have been taxed through her income and Mr Schempp would have been allowed to deduct his payment from his taxable income. However his ex-wife lives in Austria. Even if she would have had enough income to be taxed in Germany, her maintenance allowance would still not have been taxed in Austria because of the nature of the allowance. Therefore, under the German principle for the fiscal treatment of
} 
The difference between on the one hand disparate treatment which must be accepted and on the other discrimination and restrictions to free movement which are not allowed, unless justified can be illustrated by contrasting Schempp with Pusa and Turpeinen.

In Pusa a Finnish national lived in Spain. ${ }^{1407}$ In Finland he received an invalidity pension which was attached by an attachment order as a result of a debt owed by him to a Finnish bank. Under Finnish law only a part of a person's income can be attached in order to grant the person a minimum income. The part that can be attached is calculated on the basis of the person's income after taxes (net income).

Under the double taxation agreement between Finland and Spain, the pension of $\mathrm{Mr}$ Pusa, which he received in Finland, is taxed in Spain. Since Mr Pusa did not pay income tax in Finland, the Finnish authority administering his pension calculated the attachable part of his pension on the basis of his gross pension, instead of his net pension. The question referred to the Court is whether the Finnish law on enforcement is in conformity with article 18 EC (now art. 21 TFEU).

Advocate General Jacobs argued that discrimination on the basis of nationality is not necessary for article $18 \mathrm{EC}$ (now art. 21 TFEU) to apply. In his view the criterion is that 'no unjustified burden may be imposed on any citizen of the European Union seeking to exercise the right to freedom of movement or residence'. ${ }^{1408}$ Thus, 'if a person receives a pension subject to an attachment order in one Member State, and the rules of that Member State mean that less will be withheld from his pension if he resides there than if he resides in another Member State, it is clear that such treatment may deter him from moving to take up such residence'. ${ }^{1409}$

The Court still applies the principle of equal treatment as formulated in $d^{\prime}$ Hoop. It holds:

21. It is therefore necessary to establish whether, in a situation such as that in the main proceedings, the Law on enforcement introduces, as between Finnish nationals who continue to reside in Finland and those who have established their residence in Spain, a difference of treatment which places the latter at a disadvantage simply because they have exercised their right to move freely and whether, if proved, such a difference of treatment can, where appropriate, be justified [...].

The Court concludes that Finnish law places Mr Pusa at a disadvantage by virtue of exercising his right to move and reside freely in the Member States (par. 31). After all, if he had remained in Finland, his net pension would be decisive. However, since the Finnish authorities did not take account of the income tax paid by Mr Pusa in Spain, the attachable part of his income in Finland was calculated on the basis of his gross pension. Therefore, the Finnish rule amounts to unequal treatment which cannot be justified (par. 33).

Turpeinen also concerned a Finnish national who lived in Spain. ${ }^{1410}$ Her income consisted solely of a retirement pension which she received from the Finnish authorities in Finland. Under the double taxation agreement between Finland and Spain, the retirement pension was only taxed in Finland.

For the purposes of determining the amount of income tax due, Finnish law distinguished between persons who lived in Finland (general tax payers) and persons who

maintenance, Mr Schempp would not have been allowed to deduct his payment. This negative effect of free movement for Mr Schempp is called disparate treatment which in the absence of harmonisation is not resolved by EU law.

1407 ECJ 29 April 2004, case C-224/02 (Heikki Antero Pusa v Ossuspankkien Keskinäinen Vakuutusyhtiö) Rec. 2004, p. I-5763.

1408 Pusa (opinion AG), par. 22.

1409 Pusa (opinion AG), par. 24.

1410 ECJ 9 November 2006, case C-520/04 (Pirkko Marjatta Turpeinen) Rec. 2006, p. I-10685. 
lived abroad (limited tax payers). The income tax for general tax payers was calculated on the basis of a progressive scale, while the income tax of limited tax payers was calculated on the basis of a flat rate of $35 \%$.

In the case of Mrs Turpeinen, Finnish law meant that by moving to Spain she suddenly had to pay $35 \%$ instead of $28.5 \%$ income tax. Like Mr Schempp, Mrs Turpeinen argued that the raising of her tax liability was the direct result of her exercising her right of free movement under article 21 TFEU. Unlike in Schempp, both the Court and the Advocate General agree. They hold that the Finnish law amounts to unequal treatment. After all, a different tax regime applies to Finnish nationals residing in Finland and Mrs Turpeinen, who availed herself of the right of free movement, while both receive all or almost all of their income in Finland. ${ }^{1411}$

The difference between Schempp on the one hand and Pusa and Turpeinen on the other hand is that in Schempp the disadvantage for Mr Schempp is not caused by one Member State, but by the fact that the legal systems of two Member States are not compatible. The reason why Mr Schempp could not deduct his maintenance payment to his ex-wife in Austria was not because his ex-wife exercised her right of free movement, but because she moved to a Member State where her received maintenance was not taxed. If his ex-wife would have moved to another Member State where her maintenance would be taxed, $\mathrm{Mr}$ Schempp would be allowed to deduct his payment from his taxable income.

In Pusa and Turpeinen, the disadvantage for the persons involved is solely caused by Finnish law. Finnish law refuses to take into account the income tax which is due in Spain (Pusa) and Finnish law levies higher taxes on an income paid in Finland if the receiver lives abroad instead of in Finland (Turpeinen).

\subsection{Conclusion on the rights of EU citizens}

The effects of European citizenship in EU law are twofold. First of all, it grants European citizens a right to reside on the territory of other Member States. In principle, the conditions are laid down in secondary EU law, notably the Citizens' Rights Directive (2004/38/EC). The conditions laid down in the Citizens' Rights Directive have to be applied proportionally (Baumbast).

Secondly, and more important for this thesis, European citizenship grants EU citizens the right of equal treatment. Discrimination on grounds of nationality is not allowed. In Garcia Avello the Court finds that Belgian law was discriminatory, because it did not allow a child to bear a surname, which it bears in accordance with Spanish law.

Gradually, the Court's focus shifts from discrimination to restrictions on free movement. The question is no longer whether an EU citizen is discriminated against in the exercise of his right of free movement. The question is whether national law restricts the exercise of his right of free movement. Thus, in Grunkin and Paul the Court concluded that a limping surname restricted the right of free movement.

Discriminatory and restrictive national rules have to be distinguished from national rules that merely cause disparate treatment. Unlike discrimination and restrictions, disparate treatment is caused by the fact that two or more national legal systems are not compatible and is an inherent effect of the coexistence of national legal systems.

Still, the border line between restrictive rules and rules that cause disparate treatment is very thin. National rules on surnames perfectly fit the definition of rules that cause disparate treatment. The law on surnames affects all persons subject to it in accordance with objective criteria and without regard to nationality (Grunkin and Paul suggests that EU law is

1411 Turpeinen (judgment),par. 24, 31. 
not concerned with nationality as a connection to determine the applicable law). Moreover, a limping surname is like disparate treatment caused by national legal systems that do not connect. However, the Court held that a limping surname is a restriction on free movement and not disparate treatment.

Apparently, the Court views the name as a part of the person and not as a right or an obligation that may vary depending on the applicable law. An analogy with the law on free movement of goods might be instructive. The laws on the labelling of products differ from Member State to Member State. Just as a Spanish manufacturer is not obliged to peel off the label from a bottle of olive oil which he wants to market in the Netherlands, a person from Spain (resident or national) is not obliged to change his name if he resides in the Netherlands.

Although from the perspective of EU law the analogy between the name of a person and the label of a bottle of olive oil is still imaginable, the comparison between private (international) law on surnames and rules on labelling is less evident. Unlike product rules, the essential object of private law is to regulate social and economic relations between private persons by balancing the different interests involved. Therefore, the principle of mutual recognition cannot be applied in the same way in civil law as it is in the area of product rules and labelling. 


\section{The application of Garcia Avello and Grunkin and Paul to civil status}

From the case law on free movement and equal treatment of EU citizens, it appears that limping surnames constitute a restriction on the free movement of persons. Unless the states involved can justify the restriction, it has to be resolved.

It is not common ground that the decision of the Court in Grunkin and Paul also applies to other elements of a person's civil status. In the aftermath of Garcia Avello some scholars sought to extend the decision of the Court to civil status in general. After all, the nonrecognition of marriage and parentage is likely to have a far greater restrictive effect on free movement than a limping surname. ${ }^{1412}$

In Grunkin and Paul Advocate General Sharpston states that the application of the principle of mutual recognition 'underpins so much of Community law, not only in the economic sphere but also in civil matters.' 1413 However, there is some tension between this broad statement and her final remark that the determination of a person's surname involves identification which is a specific matter, separate from legal status or capacity. In the view of the Advocate General 'it would not necessarily follow that a ruling with regard to names should be extrapolated to such other matters.'1414

Funken agrees and explains that the confusion that can arise from a limping surname has a particular influence on free movement in cases where the person involved has to prove his identity for national authorities. Such confusion is, in her view, different from inconveniences following from a limping marriage or parental status. ${ }^{1415}$ She refers to Schempp 1416 to argue that just as EU law does not guarantee to a citizen of the Union that transferring his activities to another Member State will be neutral as regards taxation, EU law also does not guarantee that a transfer from one Member State will not affect his civil status. ${ }^{1417}$

Likewise Sommer argues that EU law is not concerned with disparities in treatment which may result from divergences existing between the various Member States so long as the affect all persons subject to them with objective criteria and without regard to their nationality. Limping legal relations are a direct consequence of the fact that different Member State have different legal systems. Therefore, he argues, EU law is not concerned with the disparities resulting from such differences. ${ }^{1418}$

It remains to be seen whether names and civil status are indeed so different from the perspective of community law that a difference in treatment of both subjects under EU law is justified. If Garcia Avello and Grunkin and Paul are only about identification of persons, civil status is indeed less relevant. However, article 21 (2) TFEU grants EU citizens the right to move and reside freely on the territories of the Member States. The essence of that right is seriously curtailed if the person can only exercise it by giving up his or her family members.

The comparison between tax law (Schempp) and civil status is not entirely convincing. If a person is moving from Germany to Austria it is indeed not convincing to argue that his

\footnotetext{
1412 Henrich 2005b, p. 423; De Groot \& Rutten 2004, p. 282.

1413 Grunkin and Paul (opinion AG), par. 91.

${ }_{1414}$ Grunkin and Paul (opinion AG), par. 93.

${ }^{1415}$ Funken 2009, p. 178.

1416 ECJ 12 July 2005, case C-403/03 (Egon Schempp v Finanzamt München) Rec. 2005, I-6421.

1417 Funken 2009, p. 180. Also Mansel 2006, p. 710.

1418 Sommer 2009, p. 276, 277.
} 
right of free movement is hindered because he has to pay more income tax in Austria than in Germany. The fact that as a result of a movement from, for example, Poland to the Netherlands a person has to pay more tax is inherent in the differences in tax law in the Member States. It is generally known and accepted.

But it is different for civil status. There is a common understanding that a person's civil status should not change while crossing the border; name and civil status are a part of the person involved and should remain with him wherever he goes. ${ }^{1419}$ Moreover, name often depends on marriage and parentage. It is therefore not evident to treat the recognition of name and civil status differently under EU law.

In Dafeki Advocate General La Pergola stated that 'it cannot be accepted that an individual's status, in the sense of his legal position within the legal system in question - in this instance the Community legal system - should be evaluated differently depending on the law of the State in which he is residing or working within the territory of the Community.' He explains that 'it would be contrary to the very idea of integration were a right to exist and be enforceable in one Member State but not in another because the civil status of the person concerned - and more specifically his age, upon which that right depends - is assessed differently within the Community, though the Community itself is conceived, also for the purposes under consideration here, as being a single area without internal frontiers.' 1420

Moreover, in its case law the ECJ at various instances insisted that free movement of persons is restricted if beneficiaries of the right of free movement cannot bring their family members with them. For example, in Metock the Court held that:

62. [...] if Union citizens were not allowed to lead a normal family life in the host Member State, the exercise of the freedoms they are guaranteed by the Treaty would be seriously obstructed.

and

64. The refusal of the host Member State to grant rights of entry and residence to the family members of a Union citizen is such as to discourage that citizen from moving to or residing in that Member State, even if his family members are not already lawfully resident in the territory of another Member State. ${ }^{1421}$

Metock was about the right of entry and residence of a third country national as a spouse of an EU citizen. The existence of the marriage as such was not disputed. Still, as Baratta points out, if the national private international law rules on the recognition of marriage and parentage should fall outside the scope of Community law, a citizen's right to move with his or her family members would be deprived of its effectiveness. ${ }^{1422}$

The following paragraphs shall examine the effects of the application of the principle of mutual recognition as it appears in the Court's case law on the national systems of private international law on civil status (marriage, parentage and name).

\footnotetext{
1419 See also Lipp 2009 , p. 6; Baratta 2007, p. 4; Henrich 2005c, p. 676; Lagarde 2004, p. 231.

1420 Opinion 3 December 1996, case C-336/94 (Eftalia Dafeki v Landesversicherungsanstalt Württemberg) Rec. 1997, p. I6761, par. 6.

${ }_{1421}$ ECJ 25 July 2008, case C-127/08 (Metock and others v Minister for Justice, Equality and Law Reform) Rec. 2008, p. I-6241. See also ECJ 11 July 2002, case C-60/00 (Carpenter $v$ Secretary of State for the Home Department) Rec. 2002, p. I-6279, par. 39.

1422 Baratta 2007, p. 6.
} 


\subsection{The origin of the principle - Cassis de Dijon}

The principle of mutual recognition finds its origins in the law on the free movement of goods, more in particular in the Court's ruling in Cassis de Dijon. ${ }^{1423}$ In that case, the applicant imported Cassis de Dijon, a blackcurrant liqueur from France into Germany. The competent authority in Germany refuses permission to sell the liqueur in Germany, because it does not contain a sufficient percentage of alcohol. The applicant argued that the German rule constituted a restriction on the free movement of goods.

As a starting point the Court held that in the absence of common rules relating to the production and marketing of alcohol, it is for the Member States to regulate all matters relating to the production and marketing of alcohol. Obstacles to the movement within the Community resulting from disparities between the national laws relating to the products in question must be accepted in so far as those provisions are necessary to satisfy mandatory requirements relating in particular to the effective fiscal supervision, the protection of public health, the fairness of commercial transactions and the defence of the consumer. ${ }^{1424}$

The principle of mutual recognition means that goods lawfully produced and marketed in one Member State can be sold in another Member State, provided that the product offers a comparable protection of the different legitimate interests involved. 1425 A leading textbook on EU law formulates the effect of the principle of mutual recognition as follows:

The result of Cassis is to replace dual regulation of a product (by both the home and host states) with single regulation (home state) which, under the principle of mutual recognition, the host state is required to respect. Thus, Cassis introduces the principle of home state control and, in doing so, gives extra-territorial effect to the laws and standards laid down by the home state. ${ }^{1426}$

The principle of mutual recognition coordinates the application of technical regulations of Member States to goods. So it fulfils for the different national technical regulations on goods the function that private international law fulfils for the different national systems of private law.

Treating a person's civil states like blackcurrant liqueur means that a limping civil status that is the consequence of dual regulation of that person's civil status by the different national systems of private (international) law is prevented by requiring the host state to respect the regulation of the civil status by the home state.

For example, if in Grunkin and Paul the Danish legislator through the law on surnames and the Danish choice of law rules on surnames has balanced the different interests at stake in determining the child's surname (wishes of the parents, cultural traditions, well-being of the child) which in the concrete case leads to the surname Grunkin-Paul, the German authorities should not balance the different interests again through the application of German private (international) law which perhaps leads to a different outcome.

Still, two important questions remain. The first question is how to determine the home state. ${ }^{1427}$ In case of goods, the home state is the state where the goods are produced and marketed for the first time. That is quite straightforward. But what is the home state of a person's civil status? Is that the state of his nationality, his domicile, his habitual residence,

\footnotetext{
${ }^{1423}$ ECJ 20 February 1979, case 120/78 (Rewe-Zentral AG v Bundesmonopolverwaltung für Branntwein (Cassis de Dijon)), Rec 1979, p. 649.

1424 Cassis de Dijon (judgment), par. 8.

${ }^{1425}$ Commission interpretative communication on facilitating the access of products to the markets of other Member States: the practical application of mutual recognition, OJ 2003/C 265/02.

1426 Barnard 2007, p. 113.

1427 Israël \& Saarloos 2007, p. 660.
} 
place of birth, place of marriage, place of death, place of acknowledgment of paternity? Why is it in Grunkin and Paul that Denmark and not Germany is the home state?

The second question relates to the race to the bottom. In Cassis de Dijon, the German government argued that if it was not allowed to set minimum requirements for the percentage of alcohol in fruit liqueur, the effect would be that the EU imposes the lowest alcohol percentage as the common standard for Europe. ${ }^{1428}$

With regard to civil status this race to the bottom means that if one Member State allows gay marriage, same sex parenthood or compound surnames or other, in the view of some Member States, outrageous expressions of legal libertarianism, in the end all Member States would have to accept it. However, according to Barnard, the mandatory requirements in the case law on free movement of goods (or the objective justifications in the free movement of persons, ks) are meant to avoid such a race to the bottom, by allowing 'for (residual) host state control where an important interest of the host state is at issue.' 1429

\subsection{Finding the home state of a person's civil status}

In the current state of affairs and in the absence of European harmonisation the principle of mutual recognition does not establish one particular Member State as the home state of a person's civil status. ${ }^{1430}$ The Member States are free to determine the 'jurisdiction' of their registrars to record a birth and to determine the civil status of the child at birth. They are equally free to instruct their registrar as they see fit, both with regard to choice of law and substantive law. However, if the different systems of the Member States collide and cause a limping legal relationship, one of them has to explain why it does not take over the regulation of the other Member State.

From the analysis of the case law above it appears that two factors may justify the decision of a Member State not to recognise a civil status that has been established abroad. Firstly, in Grunkin and Paul the Court hinted that the public policy of the Member State could justify a restriction on free movement. ${ }^{1431}$ Secondly, on the basis of the comparison of Pfeiffer with Garcia Avello and Grunkin and Paul the hypothesis has been formulated that if there is a concrete conflict of interest in an area where the EU does not have legislative competence, the balancing of interests to solve the matter is a prerogative of the Member State. Both factors shall be discussed in more detail. After that, the role of national choice of law rules in this interpretation of the principle of mutual recognition will be evaluated.

\subsection{Public policy as an objective justification}

The Court's decision in Garcia Avello shows that at this stage of the development of mutual recognition the principle does not work chronically. In contrast to the judgments under Brussels I and II, the principle that is being developed by the Court does not prefer the first registration of a person's civil status over the second.

At first sight this might seem unsatisfactory: if parents are not allowed to give their child a compound surname in the state where he is born, they simply record the birth also in another Member State that allows compound surnames. However, a closer look reveals that the situation is not as strange as it may seem.

In the first place, the parents who want to shop for a preferred name or parentage for their child have only limited possibilities. After all, it is not possible to record the birth of a

\footnotetext{
1428 Cassis de Dijon (judgment), par. 12.

1429 Barnard 2007, p. 113.

1430 Cf. Israël \& Saarloos 2007, p. 661; Michaels 2006, p. 230.

1431 Grunkin and Paul (judgment), par. 38.
} 
child anywhere. In the second part of this thesis it has been shown that in the Member States that have been examined there are three possible 'shops'. ${ }^{1432}$ The child must in any event be recorded with the authorities of the place of birth. Usually the birth can also be recorded with the authorities of the state of nationality. In addition some Member States have a detailed population register which also might require the determination of the name and the parentage of a child if the child resides in that state.

Thus, in the most complex case the parents at birth can import a name or a parental status from one of the three Member States into the other two. In fact, the principle of mutual recognition puts these national legal systems of these three Member States with each other in competition. ${ }^{1433}$ As long as the parents are in agreement they can pick the name or the parental status that they like most.

Secondly, the question is raised why is it so bad that parents who cannot get a compound surname in Germany, record the birth of their child in Denmark in order to force Germany via EU law to recognise the compound surname? In Grunkin and Paul the Court suggests that as long as the compound surname does not violate German public policy, the persons involved are free to import whatever status they want. ${ }^{1434}$

\subsection{The relevance of a concrete conflict of interest between the persons involved}

Far less explicit is the idea that the duty to recognise a legal relationship that has been established abroad depends on the existence of concrete conflict of interest between the parties involved if the dispute concerns an area where the EU does not have legislative competence.

Let us change the facts of Grunkin and Paul in order to illustrate what is meant with a concrete conflict of interest. Leonard Matthias is born in Denmark. This time his parents are no longer on speaking terms and they cannot agree on a surname for the child. Let us imagine that in the absence of a choice Danish law grants the child the surname of the mother, Paul. The birth of the child is also recorded with the German authorities and they, in the absence of a choice by the parents, give the child the surname of the father, Grunkin. The result is a limping surname: in Denmark the name of the child is Paul and in Germany his name is Grunkin.

Since the principle of mutual recognition does not work on the basis of chronology (Garcia Avello) the mother cannot force the German authorities to recognise the name simply because the Danish name was established first. Since the father opposes the name of the mother, the mother is also precluded from invoking the restriction on the free movement of the child that is caused by his limping surname.

The principle of mutual recognition through the concept of objective justifications allows the German legislator to explain that in balancing the interests of the persons involved, for example, the interest of the father takes precedence over the interest of the mother. The principle of mutual recognition as it follows from Garcia Avello and Grunkin and Paul does not solve a case that involves a conflict of interest. The balancing of interests in the area of surnames still belongs to the exclusive competence of the Member States. As long as German law applies in a non-discriminatory fashion, Community law simply does not provide any criteria to determine whether the father or the mother decides the name of the child. Therefore, the Court cannot but accept the reasons for the German law as a

\footnotetext{
1432 The acknowledgement of paternity is one of the few elements of a child's civil status where the jurisdiction of registrars is not limited and which therefore allows for unrestricted forum shopping.

1433 Cf Barnard 2007, p. 113.

1434 Grunkin and Paul (judgment), par. 38.
} 
justification for the restriction on free movement. The Court exercised the same kind of restraint where private law or tax law allegedly restricted the free movement of goods. ${ }^{1435}$

\subsection{The role of choice of law rules - nationality as a connecting factor}

In Grunkin and Paul the referring court tried to persuade the ECJ to say something about nationality as a connecting factor. However, the Court, at the instigation of the Advocate General avoided the question and treated the issue as matter of recognition. The Advocate General observed that in the case at hand it was not necessary to consider the German choice of law rule on surnames as a whole but only the validity of its effect in combination with the applicable law. ${ }^{1436}$

Indeed, the limping surname of Leonard Matthias was not caused by the fact that Germany uses nationality as a connecting factor. Also, the systematic application of the lex fori by the German authorities would have caused a limping surname for Leonard Matthias. Therefore, a discussion on nationality as a connecting factor would have missed the point, namely whether the child's limping surname could be justified.

In fact, Grunkin and Paul shows that in the context of mutual recognition the question with regard to choice of law rules is not so much whether nationality or any other connecting factor as such is compatible with EU law. The question is whether choice of law has any function at all in a system of mutual recognition.

In Grunkin and Paul the argument of the German government that the double-barrelled surnames cannot be accepted for practical reasons is unconvincing if through German choice of law rules double-barrelled surnames are admitted to the system anyway. ${ }^{1437}$ Also in Garcia Avello, the argument of the Belgian government that the national policy avoids confusion as to identity and parentage could not be maintained, because within Belgium different systems for the attribution of surnames coexist as a result of choice of law rules. ${ }^{1438}$ Thus, as a result of the application of foreign law through national choice of law rules, it becomes more difficult to defend the policy behind the substantive law of the forum as an objective justification.

It must also be presumed that a Member State shall have difficulties defending the nonrecognition of legal parentage if that is the result of the application of foreign law through a national choice of law rule.

For example, a child is born to an Italian woman who lives in Germany. The child is born within 300 days after the divorce from her Italian husband. However, the child is begotten by her new French partner with whom she is living together in Germany. The French national acknowledges his paternity before the birth of the child. Therefore, in Germany the legal paternity is governed by German law (habitual residence of the child), French law (nationality of the acknowledger) or Italian law (nationality of the ex-husband and the law applicable to the effects of marriage).

At the moment of birth German and French substantive law establish the legal paternity of the acknowledger; according to Italian law the ex-husband is still the father of the child (art. 231 in conjunction with art. 232 (1) Italian Civil Code). In this case on the basis of the

1435 ECJ 7 March 1990, case 69/88 (Krantz GmbH \& Co v Ontvanger der directe belastingen and Kingdom of the Netherlands) Rec. 1990, p. I-583, par. 10; ECJ 24 January 1991, case C-339/89 (Alsthom Atlantique SA v Compangie de construction mécanique Sulzer SA) Rec. 1991, p. I-107, par. 15; ECJ 13 October 1993, case C-93/92 (CMC Motorradcenter GmbH v Pelin Baskiciogullari) Rec. 1993, p. I-5009, par. 10.

1436 Grunkin and Paul (opinion AG), par. 49.

1437 Grunkin and Paul (opinion AG), par. 83.

1438 Garcia Avello (judgment), par. 42. 
Günstigkeitsprinzip, the German registrar most probably applies German law to determine the parentage of the child at birth (art. 19 EGBGB, habitual residence of the child). ${ }^{1439}$ Therefore, in Germany the French acknowledger is considered the legal father of the child.

In order for the child to get a French passport, the French embassy or consulate has to determine on the basis of French private international law whether the French national is indeed the legal father of the child. Under French law, the legal paternity of the ex-husband is determined by the national law of the mother at the moment of birth (art. 311-14 French Civil Code). French private international law refers to Italian law according to which the exhusband is the child's legal father (art. 231 in conjunction with art. 232 (1) Italian Civil Code). Hence, the acknowledgment of paternity is not valid in France and the French national is not considered the child's legal father. Conclusion: no French nationality for the child.

Under the principle of mutual recognition France would have to explain why it does not recognise the new partner as the father of the child. If the woman had been French the Italian presumption would not apply. In that case, French law would govern the legal parentage of the child and under French law the ex-husband is not the legal father of the child. If the aim is to establish the legal paternity of the biological father, the French authorities would have to explain why it is more likely that the ex-husband is the biological father if the mother is Italian than when the mother is French.

It is also possible that the aim of the rule is that the Italian legislator wants to protect the sanctity and preferred status of marriage as a moral good by imposing the aforementioned presumption on its people. In this reading, the legal paternity of the ex-husband is not so much a means to establish the legal paternity of the biological father of the child, but a symbol that should persuade the Italians to be faithful towards their spouse until the marriage has been legally dissolved.

French law on parentage reflects a different morality. Under French law the husband at the moment of conception is not necessarily the legal father (art. 312 et seq. French Civil Code). It is hard to see why the ECJ would tolerate the restriction on the family's right of free movement for reasons that are not fundamental in French family law.

The only possibility left is to justify the non-recognition of the parentage that has been established in Germany on the basis that it is a fundamental principle of French law that the legal parentage of a child is governed by the national law of the mother. That is also what the German government argued in Grunkin and Paul with regard to the applicable law to surnames. There the Court held that the question is not about the suitability of nationality as a connecting factor, but about recognition. If the decision of Grunkin and Paul applies to civil status in general, no connecting factor or method of private international law on parentage is superior to another if it does not lead to decisional harmony.

Thus while on the one hand the application of foreign law through national choice of law rules makes it difficult to defend the national policy behind the applicable law as an objective justification, the Court on the other hand does not seem to have a problem with national conflicts systems as such.

As early as in 1969 the Court held in Walt Wilhelm that a German rule according to which the German authorities would apply German anti-cartel measures only to German nationals did not violate article 7 EC (now article 18 TFEU). ${ }^{1440}$ The applicant argued that he was placed in a disadvantageous situation compared with nationals from other Member States, because they were not caught by the German anti-cartel legislation. The Court held that discrimination on the basis of nationality is prohibited, but that article 18 TFEU is not

${ }^{1439}$ On the Günstigkeitsprinzip $§ 6.5 .1 .1$. The hierarchy among the connecting factors and conflicting results in German PIL.

${ }^{1440}$ ECJ 13 February 1969, case 14/68 (Walt Wilhelm and others v Bundeskartellamt) Rec. 1969, p. 1. 
concerned with any disparities in treatment which may result from divergences existing between the laws of the different Member States. So if Mr Wilhelm is treated more severely under German law, simply because German law is tougher with cartels than, for example, Austrian law, that does not violate the principle of equal treatment.

In Hoorn the Court was more explicit. ${ }^{144}$ The case concerned the pension rights of a Dutch national who performed forced labour in Germany during the Second World War. On the basis of a Complementary Agreement between Germany and the Netherlands, the periods of insurance completed by Dutch nationals in Germany were deemed to have been completed under the Dutch insurance system. Mr Hoorn complains that his periods of insurance are worth less under the Dutch system than under the German system and therefore he applies to the German competent authority. He argues inter alia. that he is discriminated against, because German workers who performed forced labour receive a higher pension than Dutch workers who performed the same kind of forced labour.

The Court does not agree. It observes that the Complementary Agreement does not discriminate on the basis of nationality; 'it merely determines the applicable law to the workers concerned without stating the scope of the benefits.' ${ }^{1442}$ The unequal treatment is the direct result of the fact that Dutch and German law on the calculation of pensions differ. Since every Member State is free to determine the amount of pensions, the unequal treatment among the European citizens that follows from differences in national law does not qualify as discrimination on the basis of nationality.

The Court has adopted the same approach in (international) family law. Johannes concerned the apportionment of pension rights under German law. ${ }^{1443}$ According to German law, pension rights which have been acquired by one spouse during the marriage have to be shared with the other spouse as soon as the marriage is dissolved by divorce. In the case, $\mathrm{Mr}$ Johannes, who acquired pension rights as an official of the European Communities, contested the German rule because it would be discriminatory. Mr Johannes argued that according to German choice of law rules, the national law of the ex-spouses applied to the apportionment of their pension rights. In his case that meant that German law applied and hence that half of his pension rights belonged to his ex-wife. He submitted that within the EU only Germany and the Netherlands require the apportionment of pension rights after divorce and therefore he was placed in a more disadvantageous situation compared with nationals from other Member States who would apply to a German court to settle the effects of a divorce. ${ }^{1444}$

The Court simply held that neither the national provisions regulating the applicable law to the effects of marriage nor the substantive provisions fall within the scope of the Treaty. ${ }^{1445}$ Since Garcia Avello, it is clearly no longer correct that national (conflict) rules on the effects of marriage as such fall outside the scope of EU law per se. After all, even with regard to subjects that fall within the competence of the Member States, such as family law, the Court consistently held that Member States when exercising that competence have to comply with EU law. ${ }^{1446}$

However, even if the provisions involved could be tested against EU law, it must be concluded that Mr Johannes is not discriminated against. After all, Member States are free to regulate the effects of marriage, also with regard to the apportionment of pension rights. The unequal treatment among European citizens that follows from the fact that Member

1441 ECJ 28 April 1994, case C-305/92 (Albert Hoorn v. Landesversicherungsanstalt Westfalen) Rec. 1994, p. I-1525.

1442 Hoorn (judgment), par. 12.

1443 ECJ 10 June 1999, case C-430/97 (Jutta Johannes v Hartmut Johannes) Rec. 1999, p. I-3475.

${ }^{1444}$ On the facts see more clearly Johannes (opinion AG), par. VI.

1445 Johannes (judgment), par. 27.

1446 Garcia Avello (judgment), par. 25. 
States have different laws on this issue is not discriminatory. Also, national rules that coordinate the coexistence of different national legal systems are not discriminatory solely because they use nationality as a connecting factor. ${ }^{1447}$ This view is also confirmed by Advocate General Sharpston in Grunkin and Paul:

62. It is true that the rule in Paragraph 10 of the EGBGB distinguishes between individuals according to their nationality, but such distinctions are inevitable where nationality serves as a link with a particular legal system. It does not, by contrast, discriminate on grounds of nationality. The purpose of the prohibition of such discrimination is not to efface the distinctions which necessarily flow from possession of the nationality of one Member State rather than another (which are clearly maintained by the second sentence of Article 17(1) EC) but to preclude further differences of treatment which are based on nationality and which operate to the detriment of a citizen of the Union [emphasis AG].

Only if a legal system maintains different conflict rules for the same issue depending on a person's nationality, national law is liable to discriminate on the basis of nationality. This was the case in Boukhalfa. ${ }^{1448}$ In this case, a Belgian national is working for the German embassy in Algiers. According to German law, the conditions of employment for German diplomatic staff are determined in accordance with German law, while the conditions of employment for non-German diplomatic staff is determined in accordance with the law of the place where the person is working. In this case, the Court held that the German regulation discriminated on the basis of nationality. For the same reasons, the Court held in a series of decisions that the requirement of a cautio judicatum solvi violates the principle of equal treatment. After all, only foreigners (either by residence or by nationality) have to pay the security for costs. ${ }^{1449}$

It follows that in the view of the Court, choice of law rules are the unavoidable consequence of the coexistence of national legal systems. In the absence of harmonisation, the Member States are free to regulate the coexistence of the different systems of private law. Any system is allowed, as long as it is applied without discrimination and as long as it does not restrict the exercise of free movement rights.

A similar balancing exercise between EU law on the one hand and the power of Member States to regulate the coexistence of different national systems of law exists in the area of international tax law. Private international law and international tax law have in common that they are both complicated systems through which states regulate the coexistence of different national legal systems. Where private international law seeks amongst others to avoid limping legal relations, the object of international tax law is to prevent or alleviate double taxation.

Just as in private international law, different treatment on the basis of residence or nationality is commonly accepted in international tax law. Therefore, Advocates General have urged the Court more than once to act cautiously. In Schumacker Advocate General Léger cited the warning that:

\footnotetext{
1447 Puljak 2003, nr. 385-387.

1448 ECJ 30 April 1996, case C-214/94 (Boukhalfa v. Bundesrepublik Deutschland) Rec. 1996, p. I-2253.

${ }_{1449}$ ECJ 2 October 1997, case C-122/96 (Saldanha and MTS Securities Corporation v Hiross Holding AG) Rec. 1997, p. I122/96; ECJ 20 March 1997, case C-323/95 (Hayes v Kronenberger) Rec. 1997, p. I-1711; ECJ 26 September 1996, case C43/95 (Data Delecta Aktiebolag) Rec. 1996, p. I-4661.
} 
... it is clear that the concept of de facto non-discrimination could very easily result in the disintegration of national tax systems. Even were the Court to limit itself to the elimination of the differences in tax treatment between tax-payers based on nationality or on residence, the resulting chaos in income tax would be considerable. ${ }^{1450}$

In order not to upset the national systems of international tax law, the Court recognises in principle that persons may be taxed differently according whether they reside or not in the state where they earn their income.

Advocate General Geelhoed explained that disparate treatment (as in Schempp) and quasi-restrictions following from the division of tax jurisdiction are the natural effect of the coexistence of different national systems of tax law. Distortions of economic activity resulting from these phenomena are not for the Court to resolve, but for the legislature. He advised that because of the casuistic and fragmented nature of judicial intervention 'the Court should be cautious in giving an answer to questions arising before it raising issues of a systematic nature.' 1451

With regard to private international law, Advocate General Sharpston in Grunkin and Paul also emphasised that the Court should be cautious to interfere with the 'complex mechanisms' of private international law. In her view, 'this is clearly an area in which it behoves the Court to tread softly, and with care.' 1452

In order not to overturn the complex system of private international law, the Advocate General insisted that the Court should not encroach to any unnecessary extent on Member States' competence in matters of private international law and the Court should not adjudicate between habitual residence and nationality as a connecting factor in private international law. ${ }^{1453}$

Also in legal literature it has been admitted that mutual recognition as it stands now does not substitute the choice of law rules of the Member States. Fallon and Meeusen argue that mutual recognition does not determine the applicable law in a private international law case. The concept only functions as an exception to the choice of law analysis of Member States in a similar way as public policy works as an exception on the choice of law analysis in the national system of private international law.1454

Michaels states that mutual recognition functions in addition to the existing systems of private international law. ${ }^{1455} \mathrm{He}$ explains that, just like different vested rights theories, the principle of mutual recognition in private international law is based on the idea that the creation of a right by a competent legal order and the enforcement of that right in another legal order can and should be separated.

\footnotetext{
1450 Opinion 22 November 1994, case C-279/93 (Finanzamt Koeln-Altstadt v Roland Schumacker), Rec. 1995, p. I-225, par. 39. 1451 Opinion 23 February 2006, case C-374/04 (Test claimants in class IV of the ACT group litigation) Rec. 2006, p. I-11673, par. 39.

1452 Grunkin and Paul (opinion AG), par. 39-41.

1453 Grunkin and Paul (opinion AG), par. 46, 50.

1454 Fallon 2004, p. 76; Fallon \& Meeusen 2002, p. 61 et seq.

1455 Michaels 2006, p. 234. See also Michaels 2008, p. 1628.
} 


\section{Implementation of Garcia Avello and Grunkin and Paul}

According to Advocate General Sharpston in Grunkin and Paul the recognition of the child's name that has been established in Denmark is nothing more than the application of the principle of mutual recognition which has been developed in the area of the free movement of goods (Casis de Dijon ${ }^{1456)}{ }^{1457}$ The previous paragraph has shown that in the current state of the case law, the principle of mutual recognition in civil status has only a limited scope. This paragraph shall examine different ways to implement the principle of mutual recognition in civil status. After all, in the words of Advocate General Fennelly, 'persons are not products and the process of migration for the purpose of employment or establishment abroad, including preparation therefore, cannot be so neatly divided into (mass) production and marketing stages.'1458

\subsection{The Dutch response to Garcia Avello}

Some national legislators and authorities have given a narrow meaning to the Court's decision in Garcia Avello. While it has been argued that the Court's decision requires us to rethink the traditional approach to a conflict of national conflict rules, some legislators only amended their rules on the change of surnames. ${ }^{1459}$

For example, the Dutch Conflict of Laws (Names) Act still provides that if a person has more than one nationality and one of them is Dutch nationality, Dutch law applies to the determination of the surname. ${ }^{1460}$ If the child or his parents - the possibility only exists for minors - want to have the child's name determined in accordance with the law of the child's other nationality, for example Danish law, he or his parents have to apply to the Dutch Ministry of Justice for a change of surname. ${ }^{1461}$ The narrow approach has been motivated by the uncertainty as to the meaning of Garcia Avello for private international law. ${ }^{1462}$

The guiding principle for the Dutch law on surnames is that the children of the same family bear the same surname. Therefore, it was already possible to apply for a change of surname if the rules of private international law resulted in different surnames for the children of the family. 1463

Pursuant to Garcia Avello, the legislator added that the surname of a child can also be changed in accordance with the law of the child's other nationality, 'taking into account articles 12 and $17 \mathrm{EC}$ and the unity of surnames of minors of the same parents who belong to the same family.' 1464

\footnotetext{
1456 ECJ 20 February 1979, case 120/78 (Rewe-Zentral AG v Bundesmonopolverwaltung für Branntwein (Cassis de Dijon)), Rec 1979, p. 649.

1457 See note 1391.

1458 Opinion 16 December 1999, case C-190/98 (Volker Grafv Filzmoser Machinenbau GmbH), Rec. 2000, p. I-493, par. 18.

1459 Frank 2005b, p. 163.

1460 Article 2 Conflict of Laws (Names) Act (Wet Conflictenrecht Namen).

${ }_{1461}$ Article 3a (1) Besluit geslachtsnaamswijziging (Decree on the change of surnames) inserted by Besluit van 25 mei 2004 tot de wijziging van het Besluit geslachtsnaamswijzigng (Decree of 25 May 2004 on the amendment of the Decree on the change of surnames) (Stb. 2004, 239). See also Belgium: Circulaire van 23 september 2004 betreffende de aspecten van de wet van 16 juli 2004 houdende het Wetboek van internationaal privaatrecht die betrekking hebben op het personeelsstatuut, Belgisch Staatsblad 2004, p. 69594 (nr. 2004009660).

1462 See also Letter of the Staatscommissie voor het internationaal privaatrecht to the Minister of Justice of, 18 juni 2004 (to be consulted at www.justitie.nl $>$ Onderwerpen $>$ wetgeving $>$ wetgeving $>$ privaatrecht $>$ commissies $>$ staatscommissie IPR).

1463 Article 3a (1) under a Besluit geslachtsnaamswijziging.

1464 Article 3a (2) under a Besluit geslachtsnaamswijziging.
} 
According to the explanatory notes to the Decree on the change of surnames the unity of surname within the family implies that if a family consists of more than one child of the same parents and if the children of the family bear the same surname and, next to the Dutch nationality, have the same foreign nationality, a change on the basis of article $3 a,(1)$ under $b$ is only possible if it is applied to all the children of the family. At the same time the legislator recognises that if the children of the same parents do not have the same surname and, next to the Dutch nationality, not the same foreign nationality the change of surname is only possible by infringing upon the unity of the surname in the family. ${ }^{1465}$

The unity of surname for the children of the same family is a guiding principle to determine surnames. Thus if the children in Garcia Avello would have Dutch and Spanish nationality, the Dutch authorities would not have changed the surname of Diego if he wanted a surname in accordance with Spanish law if Esmeralda prefered a surname in accordance with Dutch law (children of 12 years and older have to consent to the change of their surname).

In this case, the question from the perspective of EU law is whether the unity of surnames could be qualified as an objective justification for the restriction of Diego's right to move and reside freely on the territories of the Member States.

In Grunkin and Paul, the German government tried this argument but it was dismissed because Leonard Matthias did not have siblings. ${ }^{1466}$ Advocate General Sharpston suggested that the argument could justify a restriction to free movement if Leonard Matthias would have had siblings and if 'national law totally precludes the possibility of siblings bearing different surnames.' 1467

We have seen above that the Dutch legislator recognises that not in all cases the unity of surnames among the children of the same parents can be guaranteed, especially not if the children have different nationalities. Also, under Dutch private international law on surnames the unity of the family name among the children is not guaranteed. For example, if the first child with Dutch nationality is born in the Netherlands, the Dutch registrar shall determine the name in accordance with Dutch law. If the second child with Dutch nationality is born in the UK, the parents can give the child any name they want, and that name shall be recognised under article 5a Wet Conflictenrecht Namen (Conflict of Laws (Names) Act). It remains to be seen whether this application of the principle of unity of surnames is sufficiently consistent to stand the test of EU law.

\subsection{Choice of law by the parties}

It has also been argued that Garcia Avello obliges civil status registrars to allow the parents of the child a choice of law concerning the law according to which the name of the child must be determined, if the child has more than one nationality. ${ }^{1468}$ After all, it is doubtful whether the costs of the procedure to change a surname in terms of time and money can be justified; for example, in the Netherlands a change of name via the Ministry of Justice costs $€ 487.50 .1469$

Indeed, shortly after the decision in Garcia Avello and before the Decree on the change of surnames had been amended, the Gerechtshof 's-Hertogenbosch held in a case concerning the determination of the surname of a child with Spanish and Dutch nationality that the

\footnotetext{
1465 Besluit van 25 mei 2004 tot de wijziging van het Besluit geslachtsnaamswijzigng, Stb. 2004, 239, p. 4.

1466 Grunkin and Paul (judgment), par. 33.

1467 Grunkin and Paul (opinion AG), par. 33.

1468 De Groot 2004, p. 361; De Groot \& Rutten 2004, p. 275. See also Mansel 2006, p. 693.

${ }^{1469}$ Article 3 (1) Regelen betreffende verzoeken tot naamswijziging en tot naamsvaststelling (Rules for applications on the change or the determination of a surname).
} 
parents could choose for Spanish law. Indirectly, the Dutch court held that article 2 WCN, giving preference to Dutch law for the determination of the surname if the person has, among others, Dutch nationality, violates EU law.

After the amendment of the Decree on the change of surnames, the decision of the Gerechtshof 's-Hertogenbosch was still followed. The district court of Haarlem held in 2008 in a case concerning a child with Dutch and Portuguese nationality that in the light of the decision in Garcia Avello the civil status registrar should allow the parents to choose the law to determine the surname. The court considered that the fact that the procedure to change one's surname imposed an additional hurdle for European citizens to effectuate their rights under EU law could not be justified. It concluded that the rule according to which the name of a person is determined in accordance with Dutch law, if the child has more than one nationality and one of them is the Dutch nationality, ${ }^{1470}$ violates article 12 and $17 \mathrm{EC}$, now article 18 and 20 TFEU. 1471

The question has been raised whether the choice of law to determine the child's surname should also exist if the child has Dutch nationality and the nationality of a third state. De Groot and Rutten argue that although third country nationals cannot invoke EU law, it would be undesirable if in the Netherlands two systems of private international law for surnames exist: a choice of law by the parents for EU citizens and mandatory application of Dutch law (art. $2 \mathrm{WCN}$ ) or the law with which the persons are most closely connected (art. 1 (2) WCN) in case the child has in addition to Dutch nationality, the nationality of a third state or two nationalities of third states. ${ }^{1472}$ In a case concerning a child with Dutch and Russian nationality, the district court of Den Haag did not accept this argumentation. ${ }^{1473}$

Dutch courts did not only apply Garcia Avello to the Dutch conflict rules on surnames, but also to the rules on international jurisdiction to change surnames. The Netherlands is a party to the Convention on changes of surnames and forenames (Istanbul, 1958). Article 2 of the Convention provides that each contracting state shall not authorise changes of surnames or forenames for nationals of other contracting states, unless they are also a national of the first-mentioned state.

The effect of article 2 is that the Dutch courts do not have international jurisdiction to hear an application to change the forename of a national of one of the state parties to the Convention (Belgium, France, Germany, Luxembourg, Switzerland and Turkey). If the applicant is Dutch or if the applicant has any other nationality and resides in the Netherlands, the Dutch courts shall have jurisdiction on the basis of article 3 Dutch Code on Civil Procedure (Wetboek van Burgerlijke Rechtsvordering). The unequal treatment between on the one hand EU citizens from Member States who are also a party to the Convention and on the other hand EU citizens from other Member States has been held to violate EU law. ${ }^{1474}$

If every Member State were to allow parents to choose the applicable law to determine the children's surname thereby privatising, to some extent, the determination of the child's surname, limping surnames would be prevented or at least not imposed by a Member State. The Member States that want to protect the unity of surnames among siblings could restrict the choice of law for the first child and determine the surnames of subsequent children in accordance with the law chosen for the first child.

\footnotetext{
1470 See note 1460.

1471 Rechtbank Haarlem 5 August 2008, LJN BF1973. See also Rechtbank Amsterdam 23 September 2009, LJN BK1836; Rechtbank Haarlem 22 July 2008, LJN BG0882.

1472 De Groot \& Rutten 2004, p. 278.

1473 Rechtbank Den Haag 12 July 2004, LJN AQ7367.

1474 Gerechtshof 's-Gravenhage 18 October 2006, LJN AZ2068; Rechtbank 's-Gravenhage 19 November 2007, LJN BB8201. See also De Groot \& Rutten 2004, p. 277/278.
} 
Choice of law by the parties presents two problems. First of all, it is hard to justify choice of law by the parties in an area such as civil status, which is composed of internally mandatory rules. Why are Dutch rules on the determination of surnames internally mandatory if a person has Dutch nationality only, while if the person also has Spanish nationality the applicability of the Dutch mandatory rules suddenly depends on the will of the persons involved?

The second problem with choice of law by the parties, which is for legal practice more important, arises if the persons involved do not agree. Which law applies in the case of Garcia Avello if Carlos Garcia Avello and his wife Isabelle Weber do not agree on the choice between Spanish and Belgian law? Of course, in case of a happy relationship most people will be able to agree on the law that applies to their children's name. But such common understanding is less obvious if the parents are divorced or have ended their relationship. Outside the area of surnames, for example in the case of parentage the problem is enhanced by the fact that the case can involve more people that need to agree on the applicable law.

If Member States allow the parties to determine the applicable law together, there must always be a default rule for the case when the persons involved do not agree. If the Member States have different default rules it is still possible that limping legal relationships exist. Thus a choice of law by the parties is not in every case the recipe to prevent avoid limping legal relationships.

\subsection{The principle of mutual recognition}

At EU level, the principle of mutual recognition has already been implemented in some areas of civil law, most notably in regulations Brussels I and Ilbis. These instruments implement the principle of mutual recognition of judgments and public and private documents. Although especially under Brussels IIbis, the precise meaning of the application of the principle of mutual recognition to public and private documents remains unclear, these instruments give us some indication of the development of private international law on civil status in general and private international law in particular.

\subsubsection{Mutual recognition of judgments}

The implementation of the principle of mutual recognition with regard to foreign judgments does not constitute a new method of private international law. It has been shown that in each of the legal systems under consideration judgments on parentage are assessed on the basis of a recognition method and not on the basis of a choice of law method. ${ }^{1475}$ Therefore, the implementation of the European principle of mutual recognition with regard to foreign judgments on parentage does not involve a change of method in the legal systems under consideration.

Although the principle of mutual recognition would not change the method of dealing with foreign judgments on parentage, it will affect the requirements for recognition. After all, the principle is not neutral, but it is meant to give effect to the objective of creating a European judicial area. In a European judicial area the ideal is that judgments from courts in the Member States are recognised and enforced in other Member States as if it were national judgments. Thus, the principle of mutual recognition does not only refer to a certain method of private international law (recognition method). It also means that recognition and enforcement of foreign judgments are subject to minimal requirements.

$1475 \S 7.1$. Recognition of legal parentage in foreign judgments. 
This normative aspect of the principle of mutual recognition is apparent from regulations Brussels I and IIbis. Under both regulations judgments are recognised automatically and the grounds for non-recognition are limited.

A judgment from another Member State can only be refused recognition if the judgment violates public policy, if, in case of a default judgment, the document which instituted the proceedings was not served on the defendant in due time or if the judgment is in conflict with another judgment. ${ }^{1476}$

Under Brussels I a limited review of the jurisdiction of the foreign court is still allowed.1477 Under Brussels Ilbis any review of the jurisdiction of the foreign court is prohibited. ${ }^{1478}$ The favourable attitude towards recognition of foreign judgments under Brussels I and IIbis is not yet present in the national requirements for the recognition of foreign judgments on parentage.

\subsubsection{Mutual recognition of public and private documents}

Since the Hague Programme (2004), the European Commission intends to extend the principle of mutual recognition to other documents than judgments. According to the Council the objective of the Hague Programme is to [...] carry further the mutual recognition of judicial decisions and certificates both in civil and criminal matters. ${ }^{\prime 1479}$ In 2005 the Commission even stated that 'another fundamental aspect to be addressed is the enforcement of judicial decisions and mutual recognition of public and private documents.' 1480

The principle of mutual recognition of foreign public and private documents has been worked out in regulations Brussels I and Brussels IIbis. Article 57 of Brussels I provides that a document that has been drawn up or registered as an authentic document in one Member State shall be declared enforceable in another Member State, unless the enforcement is manifestly contrary to public policy. Article 46 Brussels IIbis provides that authentic instruments and agreements between parties that are enforceable in one Member State shall be recognised and declared enforceable under the same conditions as judgments in other Member States.

With regard to matrimonial property, the European Commission raised the question whether article 46 Brussels IIbis should apply to formal documents in that field. ${ }^{1481}$ In the context of succession, the Commission's Proposal for a regulation on jurisdiction, applicable law and enforcement of decisions and authentic instruments in matters of succession also introduces provisions for the recognition of authentic instruments. ${ }^{1482}$

For the purpose of this thesis, it is interesting to examine what mutual recognition of public and private documents means in current EU legislation to determine whether it is possible to apply the provisions on recognition and enforcement of authentic instruments from Brussels I and Brussels IIbis to public documents concerning parentage or civil status in general.

\footnotetext{
1476 Article 34 regulation 44/2001 (Brussels I); articles 22, 23 regulation 2201/2003 (Brussels IIbis).

1477 Article 35 regulation 44/2001 (Brussels I).

1478 Article 24 regulation 2201/2003 (Brussels Ilbis).

1479 Council of the European Union, The Hague Programme: strengthening freedom, security and justice in the European Union, 13 December 2004, 16054/04, JAI 559, p. 3.

${ }^{1480}$ Communication from the Commission to the Council and the European Parliament, The Hague Programme: Ten priorities for the next five years., COM (2005) 184 final, p. 11.

${ }^{1481}$ Green paper on conflict of laws in matters concerning matrimonial property regimes, including the question of jurisdiction and mutual recognition, COM (2006) 400 final.

1482 Proposal for a regulation of the European Parliament and of the Council on jurisdiction, applicable law, recognition and enforcement of decisions and authentic instruments in matters of succession and the creation of a European Certificate of Succession, COM (2009) 154 final. See also Green Paper on succession and wills, COM (2005) 65 final.
} 
In addition to Brussels I and IIbis, also the European Union's approach to the recognition of marriage and partnerships is relevant to find out what mutual recognition means in civil matters in general and civil status matters in particular.

\section{Article 57 Brussels I}

Article 57 Brussels I provides that a document that has been drawn up or registered as an authentic document in one Member State shall be declared enforceable in another Member State, unless the enforcement is manifestly contrary to public policy.

The concept of enforceable authentic instruments does not exist in all Member States. Under Dutch, French and German law it is possible for parties to request a civil law notary to draw up an authentic instrument in which for example A acknowledges that he owns B a certain amount of money. Under Dutch, French and German law the authentic instrument is a title for the enforcement by B of his right to the money. In other words, if A does not pay the amount due, B does not need to go to court but he can enforce his right on the basis of the authentic instrument. ${ }^{1483}$

The concept of authentic instrument within the meaning of article 57 of the Brussels I Regulation and article 50 of the Brussels Convention has been explained by the European Court of Justice in Unibank/Christensen. ${ }^{1484}$ For the definition of the concept of authentic instrument the Court refers to the Jenard-Möller Report. According to this report a document is only an authentic instrument if three requirements have been fulfilled:

the authenticity of the instrument should have been established by a public authority; this authenticity should relate to the content of the instrument and not only, for example, the signature; the instrument has to be enforceable in itself in the State in which it originates. ${ }^{1485}$

The first requirement (involvement of a public authority) in Unibank/Christensen lead to the conclusion that instruments drawn up between private parties do not constitute an authentic instrument within the meaning of Brussels I.

It must be born in mind that unlike a judgment the authentic instrument does not have force of law. ${ }^{1486}$ Thus although the creditor is allowed to execute his right that is described in the authentic instrument, the existence of the right still depends on the applicable law. The authentic instrument is only evidence of the existence of the right; it does not impose the right. The presumption that is raised by the authentic instrument may be rebutted.

For example, A and B conclude a contract whereby A buys from B goods worth 15,000 euros. In the Netherlands, the contract is set out in an authentic instrument and it gives detailed provisions on the payment of the 15,000 euros by A. If A fails to pay, B can enforce the authentic instrument in the Netherlands without interference of a court. However, the authentic instrument does not have force of law; it is only evidence of the contractual obligations. Therefore, A is still entitled to argue, for example, that the contract is invalid. It follows that the title for execution created by an authentic instrument has only a limited value. It does not avoid a judicial procedure, but it merely shifts the initiative. ${ }^{1487}$

Under article 57 Brussels I this is not different: an authentic instrument does not get force of law merely because it is used in an international context. The declaration of enforceability under article 57 does not preclude the debtor from arguing that, according to

\footnotetext{
1483 For a general explanation of enforcement on the basis of an authentic instrument see Fleischhauer 1999.

1484 ECJ 17 June 1999, case C-260/97 (Unibank/Christensen), Rec.1999, p. I-3715.

1485 Jenard-Möller Report, par. 72 (OJ 1990 C 189, p. 57). See also article 4 (3) EC Regulation 805/2004

1486 Fleischhauer 1999, p. 217; Leutner 1997, p. 30; De Bruijn \& Kraan 1992, p. 57 et seq; Droz 1972, nr. 619.

1487 Stein \& Stein 2002, p. 65.
} 
the applicable law, the right of the creditor does not exist. However, this point must be raised in a judicial procedure before a court which has jurisdiction on the matter according to chapter two of the Regulation. This is not necessarily the court of the country where the enforcement of the authentic instrument is sought. It has been suggested that the court that hears the appeal against the declaration of enforceability should be allowed to stay the proceedings in order to allow the defendant to start proceedings to nullify the negotium of the authentic instrument (the juridical act it embodies). ${ }^{1488}$

It follows that the application of the principle of mutual recognition of foreign authentic instruments in article 57 Brussels I refers to the evidential force of the authentic instrument and its enforceability. It does not apply to the rights and obligations which it embodies. The question whether the rights embodied in the authentic instrument exist still depends on the applicable law following the choice of law rules of the court with competent jurisdiction seised with the matter. ${ }^{1489}$

\section{Article 46 Brussels IIbis}

The principle of mutual recognition of documents has also been applied in the field of divorce and parental responsibility. Article 46 Brussels IIbis (EC regulation 2201/2003) provides that documents which have been formally drawn up or registered as authentic instruments and are enforceable in one Member State and also agreements between the parties that are enforceable in the Member State in which they were concluded shall be recognised and declared enforceable under the same conditions as judgments.

Article 46 Brussels IIbis has replaced article 13 (3) Brussels II (EC regulation 1347/2000), which provided that for the purposes of implementing the Regulation, documents which have been formally drawn up or registered as authentic instruments and are enforceable in one Member State and also settlements which have been approved by a court in the course of proceedings and are enforceable in the Member State in which they were concluded shall be recognised and declared enforceable under the same conditions as judgments.

The peculiarity of article 46 Brussels IIbis can only be understood in view of the Regulation's broad definition of 'judgment'. A judgment in the sense of Brussels IIbis is a divorce, legal separation or marriage annulment, as well as a judgment relating to parental responsibility, pronounced by a court of a Member State. 1490

A 'court' is defined as all the authorities in the Member States with jurisdiction in the matters falling within the scope of the Regulation. ${ }^{1491}$ The definitions of court and judgment correspond to articles 1 (2) and 13 (1) Brussels II.1492 Article 1 (2) Brussels II provides that 'other proceedings officially recognised in a Member State shall be regarded as equivalent to judicial proceedings. The term 'court' shall cover all the authorities with jurisdiction in these matters in the Member States'.

It follows that the decisions from non-judicial, administrative authorities relating to matrimonial matters and parental responsibility also fall within the term 'judgment'. Hence, they are recognised directly under article 21 Brussels IIbis and do not fall under article 46. Thus a Danish divorce pursuant to an administrative procedure would be considered a judgment for the purpose of Brussels IIbis if Denmark would be bound by the regulation,

1488 Vlas (Burgerlijke Rechtsvordering), article 57 EEX-Verordening, aant. 6; Hess, Pfeiffer \& Schlosser 2007, nr. 628; Droz 1972, nr. 621.

1489 Gaudemet-Tallon 2002, nr. 468, 470.

1490 Article 2 (4) Brussels IIbis.

${ }^{1491}$ Article 2 (1) Brussels Ilbis.

1492 Proposal for a Council Regulation concerning jurisdiction and the recognition and enforcement of judgments in matrimonial matters and in matters of parental responsibility repealing Regulation (EC) No 1347/2000 and amending Regulation (EC) No 44/2001 in matters relating to maintenance, COM (2002) 222, p. 6. 
just like Finnish agreements on custody, residence and visitation rights that are approved by the kommumal socialnämnd. ${ }^{1493}$

If decisions of administrative authorities are included in the term judgment, the question raises what kind of documents still fall within the scope of article 46. The Borrásreport is confusing on this point. It cites the Finnish and Swedish agreements on custody which are approved by the socialnämnd as examples of documents that fall within the scope of article 46.1494 However, the Finnish agreements (which are similar to the Swedish) are also mentioned as an example of decisions of administrative authorities that fall within the term judgment. ${ }^{1495}$

The Convention on Jurisdiction, Applicable Law, Recognition, Enforcement and Cooperation in Respect of Parental Responsibility and Measures for the Protection of Children (The Hague, 1996) reveals the real issue at stake. The convention distinguishes between nonjudicial authorities that 'effectively take the decision for attribution and extinction of parental responsibility' and non-judicial authorities that only register the declaration of a person 'and does not intervene in order to take any kind of decision.' 1496

Under the Convention, the decision (approval or review) of a non-judicial authority is dealt with under the rules of recognition and enforcement whereas the effects of registration by a non-judicial authority are governed by choice of law rules.

The Swedish agreements on custody and visitation must be approved by the socialnämnd, which has the right to withhold its approval if the agreement is not in the interest of the child. ${ }^{1497}$ Therefore, under the Hague Convention they constitute measures that can be recognised under article 23 of the Convention. Given that an administrative authority has to take an actual decision of approval, the approval of the agreement must probably be characterised as a judgment under the Brussels IIbis regulation.

If only one parent has custody over the child, the other parent can also obtain custody by means of registration with the Swedish tax authority. ${ }^{1498}$ In this case, there is no active intervention (approval or review) of the authority other then whether the forms are filled out correctly. Therefore, under The Hague Convention the effect of the registration has to be determined on the basis of the applicable law. ${ }^{1499}$ Under the Brussels IIbis regulation, the registration cannot be characterised as a judgment, because it is not a judgment relating to parental responsibility (art. 2 (4) Brussels IIbis) by an authority with jurisdiction in matters concerning parental responsibility.

Although the registration of joint custody is not a judgment, it might be recognised as if it were a judgment if it satisfies the requirements of article 46 Brussels IIbis. In that case, the registration must constitute an authentic instrument or an agreement between the parties that is by itself enforceable under Swedish law. 1500

\footnotetext{
${ }^{1493}$ Explanatory report on the Convention drawn up on the basis of Article K.3 of the Treaty on European Union, on Jurisdiction and the Recognition and Enforcement of Judgments in Matrimonial Matters, OJ 1998 C 221/49, nr. 20.

${ }^{1494}$ Explanatory report on the Convention drawn up on the basis of Article K.3 of the Treaty on European Union, on Jurisdiction and the Recognition and Enforcement of Judgments in Matrimonial Matters, OJ 1998 C 221/49, nr. 61. 1495 See note 1493 .

1496 Lagarde 1998, p. 577, 579 and note 54.

${ }^{1497}$ Ch. 6 § 6, 15a Föräldrabalk (1949:381). See also Ryrstedt 2005.

${ }_{1498}$ Ch. 6 § 4 Föräldrabalk (1949:381). See also Ryrstedt 2005. For Dutch law see article 1:252 (1) Burgerlijk Wetboek which provides that parents who never exercised parental responsibility together shall exercise it together if that has been recorded on the appropriate register at their joint request.

${ }^{1499}$ Lagarde 1998, p. 577, 579 and note 54.

${ }^{1500}$ Another example of documents that fall within the scope of article 46 according to the Borrás-report are Scottish documents that are recorded by a public authority and can be recorded in public registers in the Higher Courts in Scotland, which are called the Books of Council and Session and the Books of the Sheriff Court.1500 Unfortunately, Scottish law falls outside the scope of this thesis and I have not been able to find quick access to detailed description of
} 
From the perspective of the method of private international law, the foregoing reveals two questions. The first question is whether the mutual recognition of documents under Brussels IIbis entails a special method of private international law. This question is difficult to answer since it remains unclear which documents and agreements fall within the scope of article 46.

At first sight this does not matter since the requirements for recognition and enforcement are the same for 'judgments' and for documents and agreements. Thus, for the criteria for recognition and enforcement, it does not matter whether the approved agreement on visitation under Swedish law is characterised as a judgment or as an enforceable agreement.

However, if a Swedish approved agreement on custody is not a judgment, it first has to meet the requirements of article 46 Brussels IIbis before it can be recognised. In that case, the question as to the meaning of article 46 Brussels IIbis becomes more relevant.

The second question is whether the recognition and enforcement of decisions of nonjudicial and administrative authorities is a specific method of private international law. This question grasps the problem of international measures on child protection better, because of the involvement of non-judicial authorities in this matter.

The Hague Convention on Child Protection (1996) is clear on the method of private international law that is used to deal with acts of these authorities. If the authority actively takes a decision, the act is characterised as a measure and measures are dealt with by the method of recognition. If the authority is passive, its act is not a measure and the legal effects of the act are determined by the applicable law.

Under The Hague Convention on Child Protection (1996) it would be possible to investigate the extent to which the recognition of measures of non-judicial authorities constitutes a particular method of private international law that can be distinguished from the recognition of judgments and the choice of law methods. For example, if the measures of non-judicial authorities have the same status and effect as judgments it is less likely that the method of recognition of measures of administrative authorities is any different from the method of recognition of judgments.

However, 'measures or decisions of administrative authorities' are not at stake in this thesis. In the first part it has been shown that administrative authorities do not take decisions that create or dissolve legal parenthood, at least not in the legal systems under consideration. They record and sometimes examine the existence of facts to which the applicable law attaches a certain legal effect. An analysis of the method of private international law in case of 'measures or decisions of administrative authorities' within the meaning of The Hague Convention on Child Protection is therefore not directly relevant.

\section{Marriage and partnerships}

Although there is no legislation on the conclusion of a marriage or a partnership under EU law, the existence of a marriage or partnership is relevant under EU law for various purposes.

For example, the Citizen's Rights Directive provides the right of free movement and residence for EU citizens and their family members. ${ }^{1501}$ According to article 2 (2) under a, a family member is amongst others the spouse of the EU citizen. The Family Reunification Directive provides in article 4 (1) under a, that Member States shall under certain conditions authorise the entry and residence of the spouse of a third country national who lawfully

the legal effects of recording documents in the Books of Council and Session and the Books of the Sheriff Court. Therefore I am unable to comment on this example from the Borrás-report.

1501 Directive 2004/38/EC of the European Parliament and the Council of 29 April 2004 on the right of citizens of the Union and their family members to move and reside freely within the territory of the Member States. 
resides in a Member State.1502 Section 1 (2) under a of Annex VII of the Staff Regulations of Officials of the EC provides that the household allowance shall be granted to a married official.

At all these instances, the question arises how it must be determined whether or not the person involved is married. For the purpose of this thesis, the question arises whether there are traces of the principle of mutual recognition in the approach to determine one's marital status under EU law.

When it comes to marriage, EU law neither proffers a definition nor does it provide rules on recognition of a marriage that has been concluded in another Member State or in a non-Member State. The Family Reunification Directive only indicates how the existence of a family relationship must be proven. Article 5 provides that the application shall be accompanied by documentary evidence of the family relationship. If, appropriate and in order to obtain evidence of the existence of the family relationship, Member States may carry out interviews and conduct other investigations that are found to be necessary.

So far, the European Court of Justice has not ruled on the recognition of a marriage in one Member State which has been validly entered into in another Member State. The Court has only ruled to date on the definition of spouse. In Reed, the ECJ held that the term spouse should be given an independent meaning, which takes into account the situation in the whole Community, not merely in one Member State. ${ }^{1503}$ In the case, the question was whether the term spouse in regulation 1612/68 on the freedom of movement for workers within the Community included unmarried partners in a stable relationship. The Court held that in the absence of a general social development to treat spouses and unmarried partners alike, the term spouse refers to a marital relationship only.

The Court's decision in Reed begs the question who can label a relationship as marriage: is it the European Union by means of a European wide definition or is it for the Member States? In $D v$ Council, the Court seems to opt for the first approach. ${ }^{1504} \mathrm{D}$, a man, concluded a registered partnership with another man in Sweden. On the basis of this partnership, D applies for a household allowance on the basis of section 1 (2) under a of Annex VII of the Staff Regulations of Officials of the EC. At the time, the Staff Regulations did not yet contain a provision for registered partners. Thus, the question was whether the Swedish registered partnership could be characterised as a marriage for the purpose of the Staff Regulations.

The Court in $D v$ Council held that according to the definition generally accepted by the Member States, the term marriage means a union between two persons of the opposite sex. The Court followed the method of interpretation which was set in Reed, meaning that terms of Community law should be given an independent interpretation which takes into account the legislation of all the Member States, and not merely in one Member State.

Strictly speaking, Reed and $D v$ Council only deal with the question whether non-marital relationships are included in the term marriage in European law. In its case law the Court has not yet dealt with, for example, the recognition of a Dutch same-sex marriage as a marriage for European Union law purposes or the recognition of a customary marriage in a Member State that has already been recognised in another Member State.

However, in D $v$ Council Advocate General Mischo suggested that the Court's decision in Reed should not be restricted to its context. ${ }^{1505}$ In his view the decision provides us with a general rule of interpretation in terms of EU law. If this is true, the principle of mutual recognition can only play a role with regard to formal relations that fall within the (limited)

\footnotetext{
1502 Council directive 2003/86/EC on the right to family reunification.

1503 ECJ 17 April 1986, case C-59/85 (State of the Netherlands v Reed) Rec. 1986, p. 1283, par. 13.

1504 ECJ 31 May 2001, cases C-122/99 P and C-215/99 P (D and Kingdom of Sweden v Council of the European Union), Rec. 2001, p. I-4319.

${ }_{1505}$ D v Council (opinion AG), par. 41.
} 
Community definition of marriage. In September 2004, the Verwaltungsgericht Karlsruhe held on the basis of Reed that the term spouse in regulation 1612/68 does not include a Chinese spouse of a same-sex Dutch worker who validly concluded a marriage in the Netherlands. 1506

In this regard, it is also interesting to note that the Dutch Raad van State, the highest court in the Netherlands for administrative law, held in July 2009 that within the context of the Citizen's Rights Directive the Dutch authorities have to determine independently of authorities of other Member States whether or not a family relationship, in this case a marriage, exists. ${ }^{1507}$ According to the Raad van State, the existence of the marriage for the purpose of directive 2004/38 has to be determined solely in accordance with Dutch private international law on marriage.

Also with regard to registered partnerships, the scope for the principle of mutual recognition is limited. The Citizen's Rights Directive provides in article 2 (2) under b that a registered partner is a family member of the EU citizen for the purpose of the directive if the legislation of the host Member State treats registered partnerships as equivalent to marriage. Thus there is no mutual recognition of partnerships under the directive. The fact that registered partners are family members in the Netherlands does not mean that they are family members in Italy for the purposes of the directive.

Under the Family Reunification Directive the situation is slightly different. First of all and in contrast to the Citizen's Right Directive, the Family Reunification Directive does not oblige Member States to accept non-marital partners for the purpose of family reunification. Article 4 (3) of the directive merely gives Member States the right to determine for themselves whether or not they should authorise the entry and residence of the non-marital partner of the third country national in accordance with the directive. Hence, the directive does not provide rules for the recognition of non-marital partnerships and certainly does not provide a duty to recognise a partnership that has been validly established outside the European Union. Article 5 (2) only provides that the family relationship with an unmarried partner shall be evidenced by the existence of a common child, previous cohabitation, registration of the partnership and other reliable means of proof.

Under the Staff Regulations the situation is also different. Section 1 (2) under b of Annex VII provides that an official shall get a household allowance if he or she is registered as a stable non-marital partner. The section gives four requirements for the recognition of the partnership. The first three are not particularly surprising: the couple must be able to prove their partnership with an official document, they must not be in a marriage or a partnership with a third person and they must not be close relatives. However, the fourth requirement is questionable: the Community official with a registered partnership is entitled to the household allowance if the couple do not have access to legal marriage in a Member State. According to the provision, a couple shall be considered to have access to legal marriage for the purposes of this point only where the members of the couple meet all the conditions laid down by the legislation of a Member State permitting marriage of such a couple. The fourth requirement would exclude all Commission officials with a registered partnership who work in Brussels from the household allowance, because same-sex couples with habitual residence in Belgium have access to marriage in Belgium. ${ }^{1508}$

Despite the Court's emphasis on the importance of family relations for free movement of persons, 1509 the Community legislator apparently cannot force its Member States to

1506 The case is extensively discussed in Koolhoven 2005.

1507 Raad van State 9 July 2009, LJN BJ3048.

1508 Articles 44 and 45 Belgian Wetboek Internationaal Privaatrecht (Code on private international law).

${ }^{1509}$ Chapter 9. The application of Garcia Avello and Grunkin and Paul to civil status. 
recognise a registered partnership that has been validly entered into in another Member State. Nevertheless, it remains inappropriate if the Community itself does not recognise family relations of its own officials that have been validly established in their home country. ${ }^{1510}$ An international organisation such as the EU should abstain from expressing any preference for one type of relationship over another.

1510 See however also CFI 5 October 2009, case T-58/08 P (Commission of the European Communities $v$ Anton Pieter Roodhuijzen). In that case, the Court of First Instance held that two persons living together under a Dutch notarised cohabitation agreement were partners for the purpose of the health insurance for the Community official and his or her partner. It must be mentioned though that for the partner to be covered by the health insurance the fourth requirement for the household allowance does not apply (art. 72 (1) Staff Regulations). 


\section{Conclusion - Thoughts on a European instrument implementing the principle of mutual recognition in legal parentage}

From the preceding paragraphs it appeared that the role of mutual recognition at the current state of the Court's case law is rather limited. It is unclear whether the principle applies to civil status in general or only to names. Moreover, at the current state of the law it only solves cases which do not involve Member States' public policy or a conflict of interest between private parties. How this case law develops remains to be seen. A more extensive application of the principle of mutual recognition in civil status can also be achieved through legislation. 1511

This paragraph reflects on the idea of creating a European instrument for the recognition of parentage. The objective of such an instrument would be to implement the principle of mutual recognition and to promote a uniform parental status throughout the European Union's area of freedom, security and justice.1512 Experiences with the Dutch and the Swedish private international law systems on parentage, described in the second part, are helpful in thinking of a European instrument of the recognition of civil status.

\subsection{The legal basis for European legislation on private international law on legal parentage}

If the European legislator was to consider the enactment of legislation on the implementation of the principle of mutual recognition in the area of civil status, it would have to be examined whether either article 81 (2) (ex art. 65 (2) EC) or article 21 (2) (ex 18 (2) EC) TFEU provide a sufficient legal basis. According to its wording, article 21 (2) TFEU can only serve as a legal basis if 'the Treaties have not provided the necessary powers'.

Before the Treaty of Nice, there was a discussion whether international family law could fall within the scope of article $65 \mathrm{EC}$ at all. ${ }^{1513}$ However, since the Treaty of Nice, article 67 EC, defining the legislative procedure, explicitly referred to 'aspects relating to family law' in the fifth paragraph, second indent. From that moment, there could be no doubt that the drafters also intended to include family law within the scope of article 65 EC.1514

Still, article 65 EC allowed the Community legislator to act in the field of international family law only 'in so far as necessary for the functioning of the internal market.' It was argued by some that the reference to the internal market limited the legislative power of the Community in international family law. The argument was that free movement of persons in the context of the internal market only refers to workers or at least economically active persons. Therefore, it was argued, the Community legislator only had competence to enact international family law for this category of economic persons. ${ }^{1515}$

The rather unfortunate reference to the internal market in article $65 \mathrm{EC}$ has been nuanced in the new article 81 (2) TFEU which applies since 1 December 2009. Now, article 81 (2) TFEU refers to the first paragraph and provides that measures taken on the basis of this provision must contribute to the development of judicial cooperation in civil matters having cross-border implications, based on the principle of mutual recognition of judgments and of decisions in extrajudicial cases. Measures shall be adopted, according to article 81 (2)

1511 Mansel 2006, p. 691.

1512 See also Mansel 2006, p. 687

1513 Remien 2001, p. 74; Israël 2000, p. 95.

1514 Article 2 (4) Treaty of Nice (OJ 2001/C 80/01). See also Wagner 2004, p. 137; McEleavy 2002, p. 899.

1515 Straetmans 2007, p. 235; Meeusen 2006, p. 17. 
TFEU, particularly when necessary for the proper functioning of the internal market. Thus, unlike under article $65 \mathrm{EC}$, it is no longer required that legislation is only necessary for the functioning of the internal market.

In order to develop the judicial cooperation in civil matters, article 81 (2) TFEU suggests that the European legislator adopts measures to ensure under (a) the mutual recognition and enforcement between the Member States of judgments and of decisions in extrajudicial cases and under (c) the compatibility of the rules applicable in the Member States concerning the conflict of laws and of jurisdiction. A European instrument on the recognition of civil status would fall within the wording of this provision.

However, a legal basis in the Treaty is not sufficient to establish the legislative competence of the European Union. If it has been established that the Community has the competence to enact legislation it has to be determined whether the measure can stand the test of the principles of subsidiarity and proportionality, enshrined in article 5 (3) and(4) EU.1516

According to the principle of subsidiarity, in areas which do not fall within its exclusive competence, the Union shall act only in as far as the objectives of the proposed action cannot be sufficiently achieved by the Member States. Article 4 (2) under a and j TFEU clarifies that the competence of the Union in the area of the internal market and the area of freedom, security and justice, which includes cooperation in civil matters (art. 67 (4) TFEU), is shared with the Member States. Therefore, the principle of subsidiarity applies. According to the principle of proportionality, the content and form of Union action shall not exceed what is necessary to achieve the objectives of the Treaties.

The principles on subsidiarity and proportionality are worked out in the Protocol on the application of the principle of subsidiarity and proportionality. It provides inter alia that the reasons for concluding that a Union objective can be better achieved at Union level shall be substantiated by qualitative and, wherever possible, quantitative indicators. ${ }^{1517}$

In the context of the principles of subsidiarity and proportionality the question would have to be answered whether a European instrument of the recognition of civil status is really necessary. In the light of the Court's case law in Garcia Avello and Grunkin and Paul such a necessity would be established if it is shown that the national legal systems do not establish decisional harmony for civil status. A European instrument only has a true added value if it is better able to provide European citizens with decisional harmony in the area of civil status than the current national systems of private international law. The cases Garcia Avello and Grunkin and Paul show that the recognition of surnames in the European Union is a problem and that legislative action is necessary to solve it. However, the Court has never been confronted with similar problems in the area of parentage.

In the first and the second part of this thesis it has been shown that the great variety of approaches to parentage and private international law in the Member States is a potential source of problems. With regard to England and Wales, there is a problem in understanding English law and applying it in continental legal systems. Serious problems will at a certain moment also come to the surface in the area of assisted reproduction and surrogacy.

National case law also presents some examples of non-recognition in one Member States of a parental status that has been acquired in another Member State. In 2007 the Rechtbank 's-Gravenhage refused to recognise the legal paternity of a Dutch national that had been established in England. 1518 The case has been explained by way of example in the introduction. ${ }^{1519}$ Also in 2009, the Rechtbank 's-Gravenhage refused to recognise the legal

\footnotetext{
1516 Weatherill 2007, p. 637.

1517 Article 5 Protocol 2 to the Treaty of Lisbon, OJ 2008/C 115/206.

1518 Rechtbank 's-Gravenhage, 10 December 2007, LJN BC5651.

$1519 \S 1$ 1.1.2. Private international law on parentage - an example.
} 
paternity of a Dutch national that had been established in France, because the mother of the child gave birth anonymously. 1520

In Germany a decision of the Oberlandesgericht Hamm from 2008 also can have led to a limping parental status, although the case is not conclusive on this point. ${ }^{1521}$ In the case, a British national from Scotland acknowledged his paternity concerning his biological child who was born to a Latvian mother on the 12th of April 2007. The marriage of the mother with her Latvian spouse was dissolved by divorce on the 24th of October 2006 and the child was born on the 27th of February 2007 in Germany. Thus, the child was born within 300 days after the dissolution of the mother's marriage.

On the basis of article 19 EGBGB the choice for the applicable law to the parentage of the child was between German law (habitual residence of the child), Scottish law (personal law of the acknowledger) and Latvian law (nationality of the ex-husband). According to German law, the acknowledger would have been the father, according to Scottish law the court established that there would have been a legal presumption in favour of the exhusband and also under Latvian law the ex-husband would have been the father. On the basis of the Prioritätsprinzip 1522 the court chose for the Latvian law, because it established legal paternity from the moment of birth.

However, it is not clear whether Latvian authorities would have reached the same result. According to Latvian private international personal status is governed by the law of the person's residence. Thus the child's parentage is governed by the law of his residence. Since all the persons involved lived in Germany at the material time, German law applies. However, Latvian law accepts the renvoi which would mean that German private international law is taken into account. How the Latvian registrar would apply German private international law (choice between the connecting factors, renvoi) is not clear. ${ }^{1523}$

\subsection{Working out the principle of mutual recognition in legal parentage}

Ever since the Tampere European Council (1999) the European legislator wants to build cooperation in the area of civil matters on the concept of mutual recognition:

Enhanced mutual recognition of judicial decisions and judgments and the necessary approximation of legislation would facilitate cooperation between authorities and the judicial protection of individual rights. The European Council therefore endorses the principle of mutual recognition which, in its view, should become the cornerstone of juridical cooperation in both civil and criminal matters within the Union. The principle should apply both to judgments and to other decisions of judicial authorities. ${ }^{1524}$

The objective of the principle of mutual recognition in parentage is clear. In an area of freedom, security and justice the child should have one parental status, despite the differences in national laws on parentage.

In the second part of this thesis it has been shown that the national systems of private international law on parentage favour an outcome that is in line with the national policy on parentage. ${ }^{1525}$ Under English law there is hardly any choice of law rule for parentage, the Swedish Act on international paternity questions systematically directs Swedish courts and

\footnotetext{
${ }^{1520}$ Rechtbank's-Gravenhage, 14 September 2009, LJN BK1197. Discussed at note 1238.

1521 OLG Hamm, 7 April 2008, FamRZ 2009, 126. Discussed at notes 905, 909, 990 and 1037.

1522 On the Günstigkeitsprinzip $\S 6.5 .1 .1$. The hierarchy among the connecting factors and conflicting results in German PIL.

1523 On Latvian private international law see Bergmann \& Ferid (1983-), Lettland.

1524 Bulletin EU 199/10, § 33

$1525 \S 6$.8. Conclusion on applicable law.
} 
registrars to the lex fori and also in German private international law the connection to the child's habitual residence (article 19 EGBGB) makes it possible for German authorities to apply German law in most cases.

Dutch conflict rules on parentage are in various instances also directed to the application of Dutch law. For example, with regard to the possibility to contest legal paternity on the basis of marriage, article 2 (2) Conflict of Laws (parentage) Act allows the persons involved to choose for Dutch law if that is in the interest of the child (i.e. when Dutch law makes it possible to contest legal parentage). Another example is article 4 of the Act which determines the law applicable to acknowledgment of paternity. The first paragraph favours the possibility of acknowledgment through four connecting factors (nationality of the man, habitual residence of the child, nationality of the child, habitual residence of the man).

However, for those issues where the application of foreign law would really make a difference (court approval for the acknowledgment of adulterous children and the requirement of the consent of the mother and child) the second and fourth paragraph contain separate conflict rules. Through these separate conflict rules, the Dutch requirements for the court approval and the consent of mother and child can apply even if according to the first paragraph foreign law would govern the acknowledgment of paternity.

Thus, if a national of Thailand wants to acknowledge his paternity in the Netherlands the Dutch registrar first has to find out whether the acknowledgment of paternity is possible according to the law of Thailand, while in fact it does not really matter what Thai law says. After all, if Thai law does not allow the acknowledgment of paternity the registrar has to apply Dutch law as the law of the habitual residence of the child. If Thai law allows the acknowledgment of paternity subject to less restrictive requirements than Dutch law it is uncertain whether this advantage can be taken into account, because for the most important issues a separate conflict rule applies.

The preference for results that are in line with the national law on parentage is also visible in case law. In France, the use of nationality as a connecting factor for parentage forced the courts in various instances to invoke the public policy exception. With regard to the Netherlands also, it has been shown that the public policy has been invoked against foreign law that leads to different results to Dutch law. ${ }^{1526}$ For example, in cases of judicial establishment of paternity, one of the few instances where according to the conflict rule, foreign law could still play a role, Dutch courts invoked the public policy exception if foreign law did not allow the judicial establishment of paternity.

More in general, De Boer showed that Dutch courts in almost all private international law cases apply Dutch law. ${ }^{1527}$ In the few cases where foreign law was applied, it often did not matter for the solution of the case. Given the preference of national authorities for the lex fori or foreign law that provides a similar solution, De Boer argued that European unification of choice of law rules will cause courts to find ways to escape the application of foreign law in those cases where foreign law leads to a different outcome to the lex fori. ${ }^{1528}$

Therefore, despite the unification of choice of law rules, the applicable law to the case is still not the same in all the Member States. Moreover, legal certainty and predictability of the result are reduced, because the outcome of open norms like the public policy exception is difficult to predict.

\footnotetext{
$1526 \S$ 6.7.2. Public policy exception in choice of law on parentage.

1527 Th.M. de Boer 2004, par. 7; Th. M. de Boer 2001, p. 211.

1528 Th.M. de Boer 2008, p. 337.
} 
On the basis of the findings of national private international law on parentage in part two of this thesis, a similar attitude of avoidance can be expected if national authorities are forced to apply foreign law on the basis of European choice of law rules on parentage. ${ }^{1529}$

Also the saga of the Rome III proposal seems to prove De Boer correct. ${ }^{1530}$ The Rome III proposal was a proposal of the European Commission for, amongst others, the unification of choice of law rules for divorce. The proposal was launched in 2006 and withdrawn in 2008, after several Member States threatened to use their veto if the proposal would be brought to a vote in the Council.1531

One of the reasons that caused the failure of the Rome III proposal was that the different private international law methods on divorce in the Member States could not be reconciled in one European instrument. National legal systems do not only differ as to whether they apply the lex fori or conflict rules, but also the different policies underlying (international) divorce law (favor divortii as opposed to favor matrimonii) appeared to be irreconcilable.1532 In the second part of this thesis it has been shown that a similar methodological diversity exists with regard to parentage. Therefore a similar resistance can be expected against the unification of choice of law rules on parentage.

The preference of national legal systems and authorities for solutions that are in line with the national policy on legal parentage requires a system that allows national authorities (courts and registrars) to apply their own law (lex fori) as much as possible.

The first consequence of a preference for the lex fori at national level is that European private international law cannot favour a certain substantive result in matters concerning parentage, such as for example the establishment of legal paternity in conformity with biological reality. After all, that is not a common policy among the legal systems under consideration: Dutch law protects established legal parentage by making it very difficult to contest it, while under Swedish law legal paternity can always be contested if it is not in accordance with biological reality (except in case of assisted reproduction (see § 2.2.5. Grounds for legal parenthood of the second parent under Swedish law).

The second consequence is that nationality is not a suitable connecting factor for parentage in a European instrument of private international law on parentage. Nationality as a connecting factor is likely to lead to the application of foreign law. If the application of foreign law is the starting point one needs all kinds of devices to correct the outcome if it is not in accordance with the national policy on parentage. There is no point in drafting European private international law on parentage that forces (authorities of) Member States to resort to the application of the public policy exception. In that case, the advantage of unified private international law is lost through the back door of the public policy exception.

Nationality as a connecting factor for personal status also does not seem to be in line with the European idea of an area of freedom, security and justice. The European ideal is that European citizens are free to move from Poland to the Netherlands and from Italy to Sweden to enjoy their life in the part of Europe that suits them best. If two men from Poland find it important to create a legal family they can give up their lives in Poland and move to the Netherlands. From that perspective it would be strange if in the Netherlands their personal status would be primarily governed by the law of their nationality. It would not allow them to choose the life they want because for the most personal and intimate parts of their lives (personal status) they remain connected to Polish law.

${ }^{1529}$ Cf Lagarde 2004, p. 239, 240.

1530 Proposal for a Council Regulation amending Regulation (EC) No 2201/2003 as regards jurisdiction and introducing rules concerning applicable law in matrimonial matters, COM (2006) 399. Also sceptical about the possibility to unify choice of law rules in family matters: Mansel 2006, p. 723; Coester-Waltjen 2006, p. 398.

1531 Baarsma 2009, p. 10.

1532 Baarsma 2009, p. 13; Th.M. de Boer 2008, p. 333 et seq. 
In this respect, the opinion of Advocate-General Maduro in Rottmann is revealing. ${ }^{1533}$ In his view, the nationality of a person is only his gateway to European citizenship. Once that status has been acquired, the person is free to enjoy the benefits of free movement. It is incompatible with this view that a person, who acquired the status of European citizen via his nationality, is restricted in his freedom through nationality as a connecting factor for personal status.

Also the practical arguments that are usually submitted in favour of nationality as a connecting factor for personal status, for example by the German government in Grunkin and Paul, are not convincing. It is argued that nationality as a connecting factor is more stable than habitual residence, because a person's nationality changes less easily than his habitual residence. However, if the determination of the habitual residence is fixed in time (for example at the moment of birth or the moment of acknowledgment of parenthood) habitual residence is as stable as nationality.

The argument that nationality is easier to determine is also not necessarily true. Of course, one's nationality is easily proven with a passport, but as soon as the person has more than one nationality that certainty is gone. Another point is that the child's nationality often depends on his legal parentage. Therefore, it is complicated to use the child's nationality to determine parentage, without ending up in a circular reasoning. Moreover, detailed systems of population registration in countries like Germany, the Netherlands and Sweden make it in these countries very easy to establish a person's habitual residence.

If nationality is not the most obvious connecting factor, the alternative is to connect to the law of the habitual residence. It is also possible to push choice of law into the background and to focus on the recognition of legal parentage that has been established abroad, like under Dutch private international law. To highlight the differences and similarities between a choice of law method and a recognition method, both methods will be explored in more detail. In doing so the legal parentage that has been established at birth shall be distinguished from changes of the parental status at a later moment in time.

\subsubsection{Applicable law to legal parentage at the registration of birth}

The first moment to determine a child's parentage is at the registration of his birth. It has been shown in the second part that this is done in any event by the registrar of the place where the child is born. ${ }^{1534}$ Also internationally, there is a consensus that the child's birth should in any event be recorded at the place of birth. 1535 Therefore, it makes sense to take the registration of the child's parentage at birth as the starting point in thinking about a European regulation.

\subsubsection{Lex fori at the registration of birth}

If it is desirable that the registrar applies his own law as much as possible to determine the child's parentage, the choice is between application of the lex fori or the law of the habitual residence of the child at the moment of birth. ${ }^{1536}$

\footnotetext{
1533 Discussed at note 1384 .

$1534 \S 5.1$. International jurisdiction of registrars in matters concerning parentage.

1535 See for example article 7 Convention on the Rights of the Child; Recommendation CM/Rec (2009) 13 of the Committee of Ministers to member states of the Council of Europe on the nationality of children, par. 23: register the birth of all children born on their territory, even if they are born to a foreign parent with an irregular immigration status or if the parents are unknown, in order to safeguard their right to a nationality. The registration of birth should be free of charge and be performed without delay, even if the period within which the birth should have been declared has already expired.

1536 The reason to choose for the habitual residence of the child at the moment of birth and not the habitual residence of the mother or father is because the whole point of the rule is to determine who the child's legal parents are. See also $\S$ 6.8. Conclusion on applicable law.
} 
The advantage of the lex fori is that the registrar is familiar with that law and that citizens know what to expect: if the birth is registered in France, the registrar will apply French law. Also at a later moment in time it is always certain which law has been applied to child's parentage, by checking which authority drew up the birth certificate. Moreover, at the moment of registration there is no longer a problem of applying the public policy exception because the registrar never applies foreign law. Only at the moment of recognition in another Member State can the question of public policy arise.

The first point of attention is that not only the registrar at the place of birth, but also the authorities of the child's nationality have jurisdiction to record the birth of a national of the state they represent. ${ }^{1537}$ In order to avoid conflicting birth registrations, one would have to oblige the authorities of the state of nationality to accept the determination of parentage that has been established by the authorities of the place of birth.

The second point of attention is that in case of application of the lex fori, there is not necessarily a close connection between the persons involved and the law that is applied. After all, the place of birth can be accidental or even deliberately chosen to circumvent the application of the 'otherwise applicable law'. The lack of proximity can be problematic when the legal parentage that has been established at birth and recorded on the birth certificate has to be recognised in another Member State. After all, if there is no proximity between the persons and the law applied, there is no reason for other Member States to replace the application of their own law with the recognition of the parentage that has been established abroad.

For example, if Italian law provides that the ex-husband is the legal father of the child who is born within 300 days after the dissolution of the marriage, the application of the rule in an internal situation is mandatory. The Italian legislator in formulating the rule on legal parentage weighed the different interests involved and came to the conclusion that this particular formulation of the pater is est principle is the best or the fairest formulation. The point of private international law is to find a justification for the Italian authorities to disregard their own law and the underlying ideas and to accept a (different) result on the basis of foreign law.

In general, that justification is proximity. It is believed that persons in an internal case are not in a comparable situation with persons in an international case. Persons in an international case are (also) subject to the laws of another jurisdiction. As a consequence, their legal relations and their living together, have (also) been shaped on the basis of or with a view to foreign law. Therefore, it is generally accepted that the law of the forum, even if it is mandatory in internal cases, does to necessarily apply to persons who are more closely connected with another legal system.

If the place of birth is accidental or deliberately chosen to circumvent the application of the law which would have been applied if the mother would have given birth 'at home', there is no proximity between the persons and the law applied. Hence, there is no justification for the home state to set aside its mandatory law on, for example, legal parentage. After all, the circumvention of mandatory law is per definition difficult to accept. The mandatory character of Dutch law on parentage makes it difficult to accept that the birthmother who lives in the Netherlands goes to France to give birth anonymously and to make it possible for two Dutch men who are also living in the Netherlands to become the legal fathers through acknowledgment of paternity and adoption. ${ }^{1538}$ Thus, if the European legislator would choose for the systematic application of the lex fori at the registration of birth, it would also have to provide for an exception to the recognition of that parental status by other Member States.

$1537 \S 5.1$. International jurisdiction of registrars in matters concerning parentage. 1538 Rechtbank's-Gravenhage, 14 September 2009, LJN BK1197. 


\subsubsection{Habitual residence of the child at the moment of birth}

Conceptually, the problem of the close connection is solved by choosing the child's habitual residence at birth as the connecting factor for the law that applies to his or her parentage. After all, it is fair to say that there is a close connection between the person and law of the place where he lives. ${ }^{1539}$ Although it might be difficult to determine the child's habitual residence at birth, it is already used in the German and Swedish choice of law rules on parentage, so it is not impossible. Usually the habitual residence of a new born child shall be at the place where his birthmother lives.

The effect of the child's habitual residence at the moment of birth as the connecting factor for parentage is that in most cases the registrar will apply his own law. After all, it is assumed that the child usually has his habitual residence at birth at the place where his birthmother lives and it is assumed that a woman usually gives birth in the state where she lives. Therefore, the place of the birth registration and the child's habitual residence at birth usually coincide.

The application of the law of the child's habitual residence at birth does not guarantee that the registrar who records the birth applies his own law; in some cases the registrar at the place of birth would still have to apply foreign law. In that case, the question arises whether the European legislator would have to allow for a public policy exception at the moment of registration.

For example, would it be possible for the French registrar to argue that even though the Dutch woman habitually resides in the Netherlands, she has a right to give birth anonymously in France as a result of which her legal maternity shall not be established? In cases where the woman only wants to give birth anonymously in order to give up the child for adoption, there should not be a problem. In that case the child shall be taken over by the French adoption authority as a result of which the habitual residence of the child is France.

However, it is well-known that the French rules on anonymous birth are also used to execute a surrogacy arrangement. ${ }^{1540}$ If the Dutch woman goes to France to give birth anonymously, in order to hand over the child to commissioning parents from the Netherlands, the habitual residence of the child is probably the Netherlands. In such a case there is no reason for the French registrar to invoke the public policy exception in order to apply French law, because the persons involved use the rule for an unintended purpose.

The idea behind the habitual residence of the child as a connecting factor is that the Member State of the child's habitual residence is responsible for the child's parentage. The system only works if other Member States accept that. Recourse to the public policy exception should therefore be avoided as much as possible.

\subsubsection{Recognition of parentage that has been recorded abroad}

The essence of the principle of mutual recognition is that the legal parentage that has been established at the place of birth shall be recognised throughout the European Union.

It has been argued by some authors that recognition requires a certain connection of proximity between the persons and the registration authority, in this case the registrar recording the child's birth. Mayer states that, in general, recognition as a method of private international law requires that the public authority has 'international jurisdiction' ${ }^{1541}$ In that view the first question is which authority's registration should be recognised by the other Member States. In other words, which Member State is competent to determine a citizen's civil status, or what is the home state of a person's civil status?1542

\footnotetext{
1539 Savigny 1849 , § 359 .

1540 See for example rechtbank's-Gravenhage, 14 September 2009, LJN BK1197.

1541 Mayer 2005, nr. 16. See also Mansel 2006, p. 719, 724; Coester-Waltjen 2006, p. 398; Coester-Waltjen 2004, p. 126.

1542 Mansel 2006, p. 717; Coester-Waltjen 2006, p. 392; Lagarde 2004, p. 231.
} 
According to Mansel, the recognition of the registration of a personal status which is first, is too arbitrary. ${ }^{1543}$ Baratta argues that Member States would be obliged to recognise a person's civil status legally established in the Member State of origin, which is in his view the Member State of the person's nationality. Member States would be under an obligation to recognise legal relationships acquired 'directly ex lege or from an act of the public authorities.' 1544

Although Baratta argues that his version of mutual recognition does not operate as a bilateral conflict rule, the difference is small. The appointment of the state of a person's nationality as 'the competent legal order' to determine a person's civil status is in practice the same as saying that the civil status of a person is governed by the law of his nationality, including the choice of law rules of that legal system. The point is that the authorities of other legal orders have to determine the civil status as the authorities of the competent legal order would do. 1545

However, in case of parentage it is not possible to make the competence to register a birth dependant on proximity between the persons involved and the place of registration. In the second part of this thesis it has been shown that all legal systems require the registration of the birth at the place where the birth takes place, even if the place of birth is merely accidental. 1546

Therefore, if proximity is a necessary concept, its existence in matters concerning parentage has to be guaranteed through the applicable law. Thus a European regulation would have to combine a choice of law rule with a recognition rule: the registrar who records the birth determines the child's parentage in accordance with the law of the child's habitual residence at birth and the other Member States are obliged to recognise the conclusions of that registrar.

The relevance of proximity has been played down by some. From the Court's decision in Grunkin and Paul it follows that Community law does designate any state, be it the state of nationality or the state of residence or any other state, as the competent legal order. After all, in that case, the state of the child's nationality (Germany) had to recognise the name that had been established in the country of residence and birth (Denmark).

Also Lagarde does not seem really concerned with the proximity between the case or the persons involved and the authority whose determination of the civil status is recognised. The system only has to determine which authority is the 'competent authority'. ${ }^{1547}$ As an example he refers to the Convention of 14 March 1978 on Celebration and Recognition of the Validity of Marriages, which provides that the marriage which has been validly entered into at the place of celebration shall be recognised in all the contracting states. ${ }^{1548}$

In cases of marriage, the place of celebration is determined by the persons involved in combination with possible jurisdiction rules of the forum for the authority that celebrates the marriage. For the recognition it is not necessary that the spouses have a certain connection with the state of celebration. The Hague Marriage Convention also regulates choice of law, but it does not guarantee that the law of the marriage is the law with which the spouses are most closely connected. Article 3 obliges the state of celebration to conclude the marriage if the requirements of the lex fori are fulfilled and if one of the spouses is a national or a resident of the forum state or if the spouses fulfil the requirements of the law

\footnotetext{
1543 Mansel 2006, p. 691, 701.

1544 Baratta 2007, p. 9. See also Mansel 2006, p. 687.

1545 Also Mansel 2006, p. 693.

$1546 \S 5$.1. International jurisdiction of registrars in matters concerning parentage.

1547 Lagarde 2004, p. 233.

1548 Article 9 (1) Convention of 14 March 1978 on Celebration and Recognition of the Validity of Marriages.
} 
that applies according to the choice of law rule of the state of celebration. Instead of looking for the closest connection, the rule favours the possibility of the spouses to marry. ${ }^{1549}$

\subsubsection{Applicable law to change the legal parentage that has been established abroad}

So far the recognition of the parentage that has been established at birth has been examined. At a later moment in time it is possible to change the legal parentage that has been established at birth, for example through acknowledgment of parenthood, judicial establishment of parenthood or (judicial) denial of parenthood or adoption. In these instances the question arises which law has to be applied by the authority involved. Those actions that change the legal parentage of a child have to be distinguished from a judicial declaration as to what the legal parentage is.

\subsubsection{Judicial declaration on the child's parentage without status effect}

At birth, the registrar recording the birth determines the child's legal parentage on the basis of the applicable law. Implementing the principle of mutual recognition means that the registrar's conclusion as to the child's parentage must be recognised throughout the EU. However, the conclusion of the registrar does not have force of law. It is possible that the registrar made a mistake or has been misinformed as a result of which the registration of the legal parentage is not in accordance with the applicable law.

The recognition of the parentage that has been established in Member State A in Member State B does not bestow the registration with force of law. If the registration does not have force of law in Member State A it also does not have force of law in Member State B.

Here, the question is which law has to be applied by the courts of Member State B, if the persons involved argue that the legal parentage on the birth certificate is not in accordance with the applicable law. Let us clarify the question with an example. The child is born in Italy and the birth certificate names $\mathrm{Mr} \mathrm{X}$ as the legal father on the basis of his alleged marriage with child's mother at the moment of the child's conception; at the moment of birth the couple had divorced. At a later moment in time, the child moves to Germany where the German court has to determine the child's parentage upon the application of $\mathrm{Mr}$ $\mathrm{X}$. Mr X argues that he is not the legal father because according to German law only the husband at the moment of birth (and not at the moment of conception) is the child's legal father. Therefore, the initial registration of paternity is erroneous.

In this case, the applicant essentially argues that the Italian registrar did not apply the law correctly. Logically, the applicant can only argue that on the basis of the law that should have been applied by the Italian registrar, which is in the proposed system Italian law. Therefore, the argument of the father is bound to fail. Instead contesting the correctness of the registration, he has to contest his legal paternity on the basis of the applicable law in Germany.

The question should be raised whether the German court should have jurisdiction at all to review the correctness of the Italian registration or whether this should be a prerogative of the Italian courts. After all, if a court decides that the registration is not correct, it should not simply lead to non-recognition, but the Italian register of births would have to be changed. On the one hand, it would be very inconvenient if one has to go all the way to Italy to correct the birth certificate, if one lives in Germany. On the other hand, the idea that an Italian registrar would have to defend the Italian registration in a German court goes perhaps too far. Moreover, German courts are not familiar with the technicalities of civil status registration in Italy. Therefore, jurisdiction for German courts is not self-evident.

${ }^{1549}$ Malmström 1978, par. 15. 


\subsubsection{Acknowledgment of parenthood}

In determining the law applicable to the question whether the declaration of a man (or woman) establishes his (or her) legal parenthood, the first issue is that there is not necessarily a lex fori. The acknowledgment of paternity is a declaration to which the applicable law may or may not attach legal consequences. Currently it is not guaranteed in all the legal systems under consideration that some official authority establishes the effectiveness of the acknowledgment. It has been explained elsewhere that unlike the Dutch article 10 WCA assumes, legal parenthood cannot be recognised solely on the basis of an instrument of acknowledgment. 1550

In the most complicated situation, the child is born in Member State A, he lives at the moment of the acknowledgment in Member State B and the acknowledger lives at that time in Member State C. In an internal situation this would not matter: the registrar of municipality $\mathrm{C}$ administers the acknowledgment, sends it to the registrar of municipality $\mathrm{A}$ who checks whether the acknowledgment establishes legal paternity. If it does, he records the acknowledgment on the birth record of the child; if not he informs the registrar of municipality $\mathrm{C}$ of this. However, in an international situation there are no rules that oblige the registrar of country $\mathrm{C}$ to send the instrument of acknowledgment to the registrar of country A.

Mutual recognition of the effectiveness of the acknowledgment is only possible if an authority concluded that the acknowledgement is effective and laid down that conclusion in an official document. However, in the absence of one authority which, in an international case, is responsible for keeping track of the civil status of the child or of persons in general, the effectiveness of the acknowledgment has to be established by every authority individually. This can be the registrar who keeps the original birth record who is requested to record the acknowledgment on the birth certificate. It can also be the registrar of births of the place of the child's habitual residence who records the effective nationality on the transcription of the foreign birth certificate in the local register of births. ${ }^{1551}$ Therefore, the basis to create decisional harmony on the acknowledgment of parenthood is a choice of law rule.

Mutual recognition could play a supplementary role as soon as any official authority in any Member State has determined the effectiveness of the acknowledgment and has laid down its conclusion in an official document. In that case, the rest of Europe knows that the acknowledgment fulfils the requirements of the applicable law and that it does not violate the public policy of the state of the authority that declared the acknowledgment effective. Therefore, the effectiveness of the acknowledgment can be recognised in other Member States, unless it violates the public policy of the state in question.

If the authority which is approached first refuses to recognise the effectiveness of the acknowledgment, the effects for recognition depend on the ground and the nature of the decision. If a registrar refuses to record the acknowledgment on the birth certificate, this is not really a decision that can be recognised if the birth certificate (or any other official document) does not show that the application to record the acknowledgment has been turned down.

However, if a court concludes in a judgment with an erga omnes effect that the acknowledgment is ineffective, it would depend on the reasons for the ineffectiveness whether or not that judgment should be recognised. If the court concludes that the

$1550 \S 7.2 .1 .2 .3$. The legal facts or acts must have been laid down in an instrument.

1551 See for example the Dutch article 1:25 (2) Burgerlijk Wetboek which makes it possible to file a foreign birth certificate in the Dutch register of births if an acknowledgment of paternity has to be mentioned. Article 1:25c Burgerlijk Wetboek is the legal basis to create a birth certificate to mention an acknowledgment if the person cannot submit a foreign birth certificate. 
requirements of the applicable law are not fulfilled, that conclusion should be followed. However, if the court finds that the acknowledgment of paternity violates the public policy of the Member State involved, the decision is not necessarily binding on the other Member States, because the public policy differs from Member State to Member State.

The second issue is the applicable law. According to which law does the registrar in Member State A have to determine whether or not the acknowledgment is valid? If the system in an international case does not guarantee, at least in theory, that one authority determines the effectiveness of the acknowledgment the applicable law cannot be the lex fori of that authority.

At the same time it must be born in mind that in practice the acknowledgment of paternity is often made shortly after the child's birth in the same place where the birth is recorded. In such a case, the internal system of civil status registration of the state makes sure that the acknowledgment is recorded on the child's birth record. For this typical circumstance, it is still convenient if the registrar that has to determine the effectiveness of the acknowledgment can apply its own law. That leads us to the child's habitual residence at the moment of the acknowledgment as the connecting factor for the effectiveness of the acknowledgment, for the same reasons as stated in $\S 11.2 .1 .2$. Habitual residence of the child at the moment of birth.

In cases of acknowledgment of parenthood other considerations also support the choice for the child's habitual residence as a connecting factor. In cases of natural procreation, the most important substantive issue on which legal systems differ is whether or not the child's mother has to consent to the acknowledgment. It has been shown that in the Netherlands the consent of the mother is a means for her to protect her family life with the child. The Dutch legislator argued that this protection should be given to Dutch women and to women who live in the Netherlands and whose national law does not know the concept of acknowledgement. 1552

We hold a different view. If the legislator grants the mother the right to consent in order to protect her family life with the child, the scope of that protection cannot extent beyond the power of the Dutch state; the legislator should only protect the family life of mother and child in situations where that protection can be effective. More concretely, the requirement of the mother's consent does not help the Dutch mother very much, if she and the child live in France and if France recognises the acknowledger as the father without the mother's consent. In that case, the Dutch authorities will not consider the man the child's legal father, but the woman still has to live with the fact that for the French authorities he is the legal father. Since the child lives in France, the French courts can grant the man custody and access rights and the mother will have to comply.

The argument is perhaps less strong in the context of a European regulation, because the European legislator could provide that the French authorities would have to apply the Dutch rules of consent if the mother is Dutch. Still, the question remains why a Dutch national who lives in France should receive protection according to Dutch standards, instead of according to French standards. If the mother and the alleged father are battling over the man's paternity that battle has to be decided by the authorities and their laws that have direct power over the object of the battle, in this case the child.

Therefore, the acknowledgment of paternity should be governed by the law of the child's habitual residence at the moment of the acknowledgment. Another advantage of this connecting factor is that the law of the child's social environment determines issues like whether acknowledgment in case of incest is possible. In France and the Netherlands this is

$1552 \S$ 6.2.4. Applicable law to acknowledgment of paternity under Dutch PIL; § 7.2.1.3.3. Violation of Dutch public policy. 
not possible because it is considered to be against the child's interest to have incest recognised in law. ${ }^{1553}$ If the child lives in England, Germany or Sweden, there is no need to apply Dutch or French standards of child protection.

Thus, the registrar who keeps the birth record would have to determine on the basis of the law of the child's habitual residence at the moment of acknowledgment whether the acknowledgment is effective. Other possible connecting factors for the effectiveness of the acknowledgment are the law of man's nationality or the law of his habitual residence at the moment of the acknowledgment. These connecting factors do not take account of the concern of some states to protect the mother's family life with the child by requiring her consent, thereby provoking recourse to the public policy exception.

Notwithstanding my preference for the child's habitual residence at the moment of acknowledgment, there are some concerns. Firstly, the determination of the child's habitual residence can be problematic. If the man acknowledges his paternity at the registration of birth, there is no problem. However, if he acknowledges his paternity ten years later this can be more problematic. At the same time, it must be realised that Germany and Sweden already use the child's habitual residence in private international law on parentage which has not led to insurmountable problems.

Secondly, the habitual residence of the child as a connecting factor for the validity of the acknowledgment does not help to prevent the circumvention of the law on inter-country adoption, which is one of the concerns in Dutch private international law on parentage. However, above I have already expressed my doubts as to the merits of the idea to use private international law on parentage in the battle against the circumvention of the law on inter-country adoption. ${ }^{1554}$

Thirdly, the habitual residence of the child as a connecting factor is problematic if the law of the child's habitual residence does not allow the establishment of legal parentage out of wedlock. As long as the child lives in a Member State of the Council of Europe this should not be a problem, since the discrimination of illegitimate children is prohibited by the European Court of Human Rights. ${ }^{1555}$ Therefore, Member States of the Council of Europe are supposed to allow the establishment of legal parentage out of wedlock. If the child lives in, for example, Morocco the application of Moroccan law to an acknowledgment of paternity made in the EU is bound to violate public policy to the extent that it does not allow the establishment of legal paternity out of wedlock.

In cases where article $8 \mathrm{ECHR}$ is not at stake, the authorities of the EU should be careful to conclude that the law of the child's habitual residence violates public policy. As has been argued in $\S 11.2 .1 .2$, the choice for the child's habitual residence has been made to avoid forum or law shopping and, in case of acknowledgment, to allow Member States to protect the family life of the mother and the child. In concluding that the law of the child's habitual residence violates public policy, the national authorities should be careful not to overturn these objectives.

The third issue is the law applicable to the form of the acknowledgment. It has been shown that in the legal systems under consideration this issue is often subject to a cascade of connecting factors. ${ }^{1556}$ For the formal validity, it should be sufficient if the acknowledgment fulfils the formal requirements of the law of the place where the acknowledgment is done. Usually, the acknowledger shall make the statement at the place where he or she lives. For

\footnotetext{
$1553 \S 3.2 .2 .5$. The acknowledgment of an incestuous child.

1554 § 6.2.4. Applicable law to acknowledgment of paternity under Dutch PIL; § 7.2.1.3.3. Violation of Dutch public policy.

1555 ECHR 13 June 1979 (Marckx v Belgium), application number 6833/74.

$1556 \S 6.1$. Scope of the applicable law on parentage.
} 
him, it is convenient if it is sufficient if the formal requirements of the place where he lives are fulfille; for the mother and the child it does not really matter which formal requirements have to be fulfilled as long as they are informed of the acknowledgment. Thus, if in jurisdictions such as France, Germany or the Netherlands it is common to go to the civil status registrar to make the declaration, any person should be able to go there irrespective of nationality. The document that is drawn up there should be sufficient when the formal requirements are concerned. If there is no special authority to administer the acknowledgment, as in Sweden, it can hardly be expected that the acknowledger fulfils any requirements in this respect. If the acknowledger who lives in the Netherlands wants to make his acknowledgment in Belgium in accordance with the Belgian formal requirements there is no specific reason why that should not be allowed.

\subsubsection{Judicial establishment of parenthood}

If no legal parenthood exists automatically or on the basis of acknowledgment, the question is whether it can be established by a court. In an action for judicial establishment of parenthood the applicant either has to prove biological affiliation or consent to fertility treatment. ${ }^{1557}$ However, it has been shown that the legal systems under consideration restrict, with different levels of intensity, the possibility to prove the relevant facts. ${ }^{1558} \mathrm{In}$ private international law it is useful to make this distinction, because the restrictions (locus standi, periods of limitation, rules of evidence) on the possibility to prove the ground for legal parenthood (biological affiliation, consent) are not necessarily substantive (as opposed to procedural) issues. ${ }^{1559}$

The starting point in any judicial procedure is the recognition of the legal parentage that has been established abroad. That means that if the registrar at the place of birth established that the ex-husband of the mother is the legal father, the court that hears the application for judicial establishment of paternity has to accept as a fact that the child already has a legal father. If a European instrument provides for a uniform conflict rule, that effect of recognition is not really surprising. After all, in that case, the court that hears the application for judicial establishment of paternity applies the same law as the registrar at the registration of the birth. However, if the legislator opts for the application of the lex fori at the registration of birth, recogntion is more surprising. After all, recognition implies the application of the law of the place of registration.

The next question is which law applies to the judicial establishment of parenthood. Ultimately the objective is that courts apply their own law as much as possible and that decisional harmony on the child's parental status is created. For that, at least three issues have to be taken into account. The first issue is, just as at the registration of birth, the choice is between the lex fori and the child's habitual residence at the moment of the application for judicial establishment of parenthood. That choice is influenced by the second issue, which is the distinction between substantive and procedural issues in an action on judicial establishment of parenthood and the third issue, which is the international jurisdiction of courts to judicially establish parenthood.

In the second part it has been shown that the Member States under consideration have broad grounds for international jurisdiction of courts to establish legal parenthood. The rules focus either on the residence, the domicile or the nationality of one of the persons involved in the action. 1560

\footnotetext{
$1557 \S 3.4 .1$. The ground for judicial establishment of legal parentage.

1558 §3.4. Establishment of parenthood by judicial decision.

$1559 \S 6.1$. Scope of the applicable law on parentage.

$1560 \S 5$.2. International jurisdiction of courts in matters concerning parentage.
} 
It is a given that the more choice there is for the applicant to start an action for the judicial establishment of paternity and the more variety exists between the rules that will be applied, the larger the possibility for the applicant to shop for a convenient forum. Therefore, at first sight either the grounds for jurisdiction have to be restricted or it has to be made sure that every court applies the same rules irrespective of where the applicant sues.

When it comes to international jurisdiction for judicial establishment of paternity there are at least three reasonable grounds for jurisdiction. First of all, the court at the habitual residence of the defendant, usually the putative father, should have jurisdiction. Secondly, , given the fact that it is the child's parentage which is at stake the court at the habitual residence of the child should also have jurisdiction. Thirdly, the state of the nationality of the alleged father can be relevant. This is the case if the child would obtain access to a new nationality as a result of the establishment of paternity. Therefore, the grounds for international jurisdiction to judicially establish parenthood cannot be reduced to one court and some degree of forum shopping must be accepted.

That leaves us with the unification of choice of law rules. However, it is doubtful whether this avoids forum shopping. For example, a key difference among the legal systems under consideration which is relevant in case of judicial establishment of parenthood is the possibility to obtain DNA evidence. In France it is not allowed to make a comparative DNA analysis without the explicit consent of the persons involved; in Sweden the persons can be physically forced to cooperate. One can discuss whether the rules on the admissibility and the means to obtain DNA evidence are substantive or procedural rules. However, even if the issues would be characterised as substantive as a result of which the lex causae decides them, it is hard to imagine that France will apply Swedish rules on DNA evidence or vice versa. Thus if the applicant can choose between suing an uncooperative putative father in Sweden or in France, the applicant is well-advised to sue in Sweden even if the conflict rule for the applicable law in France and Sweden would be the same.

If the putative father lives in France, the next question would be whether the French authorities would recognise the Swedish judgment which is based on a comparative DNA analysis to which the man did not consent. It is not unlikely that the French would not recognise the judgment. In that case, the child obtained a Pyrrhic victory in Sweden. However, this problem would not have been solved with a unified conflict rule for judicial establishment of paternity. Sweden would not have applied the French rules on DNA evidence in any event. Moreover, the example shows that the possibility of forum shopping is limited by practical considerations such as the enforceability of the paternity decision (and perhaps the maintenance assessment based on it) ${ }^{1561}$ in the state where the man lives. If important reasons for forum shopping cannot be eliminated, it is more persuasive to allow courts to apply the lex fori.

There are at least three reasons why the application of the lex fori in case of judicial establishment of paternity seems less problematic than at the registration of the birth.

\footnotetext{
1561 Under Brussels I and the future Maintenance Regulation (Council Regulation (EC) 4/2009 on jurisdiction, applicable law, recognition and enforcement of decisions and cooperation in matters relating to maintenance obligations) the recognition of the judgment on maintenance does not imply the recognition of the parentage underlying the maintenance obligation which gave rise to the decision (art. 22 Maintenance Regulation). However, if the family relationship, on which the maintenance decision is based, does not exist in a Member State, that Member State is not obliged to recognise the maintenance decision. See for example ECJ 4 February 1988, case 145/86 (Hoffmann v. Krieg), Rec. 1988, p. 645. In that case a woman obtained a maintenance decision from a German court on the basis of the existence of a marriage in Germany; in the Netherlands the marriage was already dissolved by divorce. Therefore, since the marriage did not exist anymore in the Netherlands, the Dutch court was allowed not to recognise the German maintenance decision which was based on the existence of that marriage.
} 
First of all, the birthmother ultimately determines the place of birth, while the law determines the grounds for international jurisdiction of courts. Therefore, in case of judicial establishment of parenthood the law, through the grounds of jurisdiction, guarantees a certain degree of proximity between the case and the lex fori. This is not necessarily so if the registrar at birth always applies his own law.

Second and connected with the first submission, if the registrar at birth applies the lex fori, it will be much easier to circumvent mandatory law than when the court in an action for judicial establishment of parenthood applies the lex fori.

For example, a German woman who lives in Germany gives birth in England. She is a registered partnership with another German woman who also lives in Germany. If the registrar applies the lex fori, the English registrar shall mention her partner as the legal parent on the birth certificate on the basis of the Human Fertilisation and Embryology Act 2008. But application of English law here makes no sense. There is no connection whatsoever with England and the application of English law shall only cause problems if the women return to Germany. Application of the child's habitual residence at birth avoids this situation.

At first instance, the application of the law of the child's habitual residence might cause problems. If a German woman who lives in Germany gives birth in England while she is in a registered partnership with an English woman who also lives in Germany, application of the law of the child's habitual residence by the English registrar has as a consequence that the child shall not have British nationality, because the child is not legally affiliated with a British national. That is problematic and from a British perspective perhaps unacceptable. In this proposal, the problem can be solved through judicial establishment of parenthood. Above, it has been proposed to grant the courts of the state of the alleged parent's nationality international jurisdiction to judicially establish parenthood. In this case the child does not have a legal father under German law (mother is not married to a man and no man acknowledged his paternity with her consent). Therefore, the birth mother can sue her partner in England on the basis of her nationality to establish her legal parenthood. That judgment might not be recognised in Germany, but at least the child also has a possibility to obtain British nationality.

The third difference between applicable law at the registration at birth and the applicable law at the moment of judicial establishment of parenthood relates to the number of competent authorities or courts. At the registration of birth there is only one competent authority and that is the registrar at the place of birth. This authority has to record the facts concerning the birth and the child's parental status at birth. Other competent authorities, like the registrar of the child's nationality, usually rely on the facts that are established by the registrar at birth or through legislation they can be easily obliged to do so.

Since at birth the registrar at the place of birth is obliged to record the birth, it is possible to find a compromise between finding proximity, avoiding forum shopping, applying the lex fori and creating decisional harmony on the child's parental status. That compromise is the connection of the child's parentage to the child's habitual residence at birth.

In case of judicial establishment of parenthood there are at least two or three grounds for jurisdiction. Especially the court of the child's habitual residence and the court of the putative father's habitual residence are of equal value: in an uncontroversial case, the child should be able to go to the court of his residence; in a controversial case it is probably more practical to sue the man (or woman) in his residence.

Therefore, it is more difficult to find a compromise between finding proximity, preventing forum shopping, applying the lex fori and creating decisional harmony in cases of judicial establishment of parenthood. If the connecting factor is the law of the child's habitual residence and if the child sues the man in another state than the child's habitual 
residence, uncertainties exist regarding the applicable law and thus the outcome of the case (the distinction between substantive and procedural issues, the public policy exception). After having passed these uncertainties, the judgment perhaps has to be recognised elsewhere where again the public policy exception of the recognising state is lurking. All this uncertainty can be significantly reduced by applying the lex fori to the judicial establishment of parenthood. The only uncertainty left in that case is the public policy in the state where the judicial establishment of parenthood has to be recognised.

\subsubsection{Annulment of legal parenthood}

We have seen that in the legal systems under consideration various persons and authorities have the right to contest legal parentage that has been established either ex lege or through acknowledgment. There are at least four typical circumstances.

First, the child (or his mother) may want to sue the child's legal father/parent to contest his/her legal parenthood. After legal parenthood has been successfully contested, the next step can be to establish the legal parenthood of someone else. Second, the legal father or his heirs (for example the (ex) husband) may want to contest his own legal paternity because he is not the biological father. For the father, the successful annulment of his own paternity is the end of the story. Third, the biological father may want to contest legal parenthood. The objective of the action usually is to establish the legal paternity of the biological father after the successful annulment of existing legal paternity. Fourth, the state through the public prosecutor or, in Germany, the competent authority in some legal systems may want to contest legal parenthood if it violates public policy or if it has been established with the sole objective to create an advantage in the law on nationality or in immigration law. Thus, either the legal family is attacked from the outside (if the applicant is the state, the biological father or the heirs) or the members of the legal family sue each other (the child or the mother contests the paternity of the legal father or the legal father contests his own paternity).

For the international jurisdiction of courts this means the following. The public prosecutor protects the public interest of the state he represents. Therefore his standing before the courts of his own state is determined on the basis of the interest he protects. If the Dutch public policy is at stake or if Dutch nationality law is involved, the Dutch public prosecutor can apply for the annulment of an acknowledgment of paternity. As a defender of the interests of the state, the public prosecutor cannot contest the legal parentage in a foreign court.

For the other potential actors, similar considerations as with judicial establishment of parenthood apply. Decisions about the child eventually need to be enforced at the place where the child lives. Therefore, the courts of the child's habitual residence should in any event have jurisdiction. It can also be necessary to enforce the decision in the place where the respondent is living when the child is the applicant. Therefore, also the courts of this state should have jurisdiction to annul legal parenthood.

The next step is to determine the law that should be applied. If the family does not move after the parentage has been established, the applicable law to contest legal parentage is the same as the law that has been applied to its establishment. However, as soon as the legal parentage has to be recognised abroad, for example because the family moves to another state or because the child claims the nationality of one of his parents, the issue becomes more complicated.

As a preliminary remark, it has been shown that in the private international law systems under consideration there is not a mandatory connection between the law that applies to the establishment of parenthood and the law that applies to the possibility to 
contest it. 1562 Dutch private international law has as a starting point that the law that applies to the establishment of parentage also applies to its annulment. However, in the interest of the child it is possible to depart from this principle when the legal paternity of the (ex) husband is contested. Under German private international law, legal parentage can be contested on the basis of every legal system referred to in article 19 EGBGB that assumes its existence. Under Swedish private international law, the law of the child's habitual residence at the moment of the action applies (which in most cases shall be Swedish law) or Swedish law if it is argued that the acknowledger is not the child's biological father.

If the parentage that has been established in one Member State is invoked in another Member State, the first question is whether it violates public policy. If it does there is no need to contest it because then it does not exist in that Member State anyway. A state authority, like the public prosecutor, that wants to contest legal parentage should do it as soon as the state is involved in the recognition of the legal parentage. This can be, for example, the moment that the family establishes itself in the Member State and has to register in the population register, the moment that the birth certificate is filed in the register of birth of that Member State or the moment that the child applies for a passport of that Member State. For the sake of legal certainty, there should be a period of limitation within which the state can invoke the public policy exception. The ground for the state to act at this moment is that the legal parentage that has been established abroad violates public policy. This ground shall be discussed under the following heading.

If the legal parentage has passed the public policy exception, the next question is which law applies to the possibility to contest legal parentage. At this stage, the arguments in support of the lex fori in case of judicial establishment of parenthood also apply to an action contesting legal parenthood. There are at least two effects that have to be taken into account.

First of all, legal parentage that has been established following assisted reproduction is not necessarily protected in the new state of residence. For example, a child is born in Sweden to a married, heterosexual couple. The conception of the child has been commissioned with donor sperm. According to Swedish law the husband is the legal father and his paternity cannot be contested, even though he is not the biological father. His legal paternity is based on his consent to the treatment of his wife and his responsibility for the conception of the child. Later the family moves to a state which internal law does not recognise consent to fertility treatment as a basis for legal parentage. If the courts simply apply the lex fori, the husband or the child is allowed to contest the legal parentage of the husband in the courts of the new habitual residence of the family. If only the husband moves to that state, in this proposal the courts of that state shall not have jurisdiction to hear the man's application to contest his paternity.

Second of all, in applying the lex fori it could be necessary for the court to take into account the way in which legal parentage has been established abroad. For example, a man acknowledged his paternity in France concerning a child who lived in France at the moment of the acknowledgment. The child's mother with French nationality did not consent to the acknowledgment. Later, the mother and the child move to the Netherlands where the Dutch authorities recognise the legal paternity of the acknowledger. The mother contests his legal paternity in a Dutch court on the basis of the fact that he is not the child's biological father (the Dutch court has jurisdiction on the basis of the child's habitual residence in the Netherlands). According to Dutch law, the mother is only allowed to contest and acknowledgment of paternity if she can prove that she consented to the acknowledgment

$1562 \S$ 6.2.2. Applicable law to annulment of marital paternity under Dutch PIL; § 6.2.5. Applicable law to annulment of acknowledgment of paternity under Dutch PIL. § 6.5.3. Applicable law to contest legal parentage under German PIL. § 6.6.4. Applicable law to contest legal parenthood. 
under the influence of threats, mistake or deceit. However, in this case she never consented to the acknowledgment. Therefore, it would not be self-evident to disallow the woman to contest the acknowledgment, solely on the basis that she cannot prove that she consented under the influence of threats, mistake or deceit.

\subsubsection{Exceptions to recognition - the public policy exception}

The choice of law system has been designed in such a way to avoid as much as possible the application of the public policy exception in the establishment or annulment of legal parentage. It is mainly at the moment of recognition of a foreign birth certificate or judgment that the question arises whether the legal parentage violates the public policy of the recognising state.

Also the European Court of Justice in Grunkin and Paul explicitly recognised the public policy exception. ${ }^{1563}$ Thus, unless the European legislator can convince the Member States to drop this safeguard it shall also exist in a future instrument on the recognition of civil status.

The Court explained the public policy exception in the context of regulation 44/2001 (Brussels I) and its predecessor the Brussels Convention, ${ }^{1564}$ where the ECJ is the ultimate authority to determine whether the courts of a Member State lawfully refused the recognition of a judgment on the basis of the public policy exception (art. 34 (1) Brussels I). ${ }^{1565}$

In the context of Brussels I, the Court repeatedly held that the Member States are in principle free to determine according to their own conceptions, what the public policy requires. Therefore, any influence of European law on the application of the public policy exception does not focus on the contents of the exception, but on its form or, in the words of the Court, on the limits of that concept. 1566 The criterion to be applied is, according to the Court in Krombach, whether the recognition

... would be at variance to an unacceptable degree with the legal order of the State in which enforcement is sought inasmuch as it infringes a fundamental principle. In order for the prohibition of any review of the foreign judgment as to its substance to be observed, the infringement would have to constitute a manifest breach of a rule of law regarded as essential in the legal order of the State in which enforcement is sought or of a right recognised as being fundamental within that legal order. ${ }^{1567}$

Fundamental rights which are derived from the constitutional traditions of the Member States and international instruments such as the European Convention for the Protection of Human Rights and Fundamental Freedoms form an integral part of the general principles of law whose observance will be ensured by the ECJ. ${ }^{1568}$ Therefore, foreign judgments that violate fundamental rights can be refused recognition on the basis of the public policy exception. ${ }^{1569}$ The argument also works the other way around: with regard to parentage the

\footnotetext{
$1563 \S$ 8.2.2.3. Objective justifications for discrimination and hindrances to free movement.

${ }_{1564}$ Convention of 22 September 1968 on Jurisdiction and the Enforcement of Judgments in Civil and Commercial Matters.

1565 E.g. ECJ 2 April 2009, case C-394/07 (Gambazzi v DaimlerChrysler Canada Inc., CIBC Mellon Trust Company); ECJ 11 May 2000, case C-38/98 (Régie Nationale des Usines Renault SA v. Maxicar SpA and Orazio Formento), Rec. 2000, p. I-2973; ECJ 28 March 2000, case C-7/98 (Krombach v Bamberski), Rec. 2000, p. I-1935. The Member States are also obliged to use their public policy exception to enforce European law: ECJ 9 November 2000, case C-381/98 (Ingmar GB Ltd v Eaton Leonard Technologies Inc.), Rec. 2000, p. I-9305; ECJ 1 June 1999, case C-126/97 (Eco Swiss China Time Ltd v Benetton International NV), Rec. 1999, p. I-3055.

1566 Krombach (judgment), par. 22, 23.

1567 Krombach (judgment), par. 37.

1568 Krombach (judgment), par. 25.

1569 Gambazzi (opinion AG), par. 40.
} 
application of the public policy exception may not lead to a violation of fundamental rights that are protected inter alia by article $8 \mathrm{ECHR}$. Thus the refusal to recognise legal parentage that has been established abroad may not lead to an unjustified infringement of existing family life. 1570

For the sake of consistency, a future instrument on the recognition of parentage or civil status on the basis of foreign public document should take the Court's formulation of the public policy exception in Krombach as a starting point. However, in a 'value sensitive' area such as parentage or civil status in general this yardstick still leaves a lot of discretion to the Member States.

Still, the judgment of the Court in Garcia Avello suggests that the Court will not allow the Member States to label rules of national law with a public policy sticker as they see fit. The Court will examine whether the reasoning on the basis of which the national authorities conclude that legal parentage that has been established abroad violates national public policy, can stand the test of rule of reason. ${ }^{1571}$

In Garcia Avello the Belgian government tried to persuade the Court that the principle of immutability of surnames was a 'founding principle of social order', because it is said to avoid confusion with the Belgian administration and the people of Belgium as to the identity and the parentage of the person who changed his name.1572 That argument is too far fetched. Persons are not identified and parentage is not ascertained solely on the basis of his name. The measure (refusal to change the surname) is not necessary to attain the objective (identification of person and determination of parentage) and therefore cannot justify a restriction on free movement. Thus, in more general terms, the authority which invokes the national public policy exception must be able to explain which objective it serves and the non-recognition on the basis of public policy must be a suitable means to attain the objective.

We have seen that especially France, Germany and the Netherlands pursue different objectives with the public policy exception. Let us consider one example to give an idea how the public policy exception in a future European instrument on parentage could work.

In France, the courts have refused to recognise the legal maternity of a commissioning mother that has been established in California in the context of a surrogacy arrangement. ${ }^{1573}$ On the basis of articles 16-7 and 16-9 Code civil the Cour de Cassation developed a prohibition for the commissioning mother to establish her legal maternity concerning a child born to a surrogate mother: she cannot adopt her child and if her maternity has been established abroad it shall not be recognised. ${ }^{1574}$

If EU law is involved, which is not the case if the child moves directly from California to France, it must be observed that France would be free, according to the Court's explanation of public policy in Krombach, to determine what its public policy requires. Given the rigorous ban on surrogacy that has been developed by the Cour de Cassation, it can hardly be argued that the French are not consistent. On the other hand, the right of the birthmother to give birth anonymously is hard to reconcile with the prohibition to establish the legal maternity of the commissioning mother. After all, although the right and the prohibition stem from completely different policies, everyone knows that they can and are combined in order to execute surrogacy arrangements.

Also the Rechtbank 's-Gravenhage in the Netherlands had to rule on the recognition of legal parenthood of commissioning parents. On the first occasion, the legal paternity of the commissioning father had been established in England. The legal maternity of the

\footnotetext{
1570 With regard to the recognition of a foreign adoption degree see ECHR, 28 June 2007 (Wagner and JMWL $v$ Luxemburg), application number 76240/01.

${ }^{1571}$ Kessedjian 2008, p. 35; Basedow 2005, p. 63.

1572 Garcia Avello (judgment), par. 40.

1573 See note 31 .

1574 See note 31.
} 
commissioning mother had not been established in England. The court finds the legal paternity of the man contrary to public policy because his name on the child's birth certificate according to English law only establishes a rebuttable presumption of his legal paternity; under Dutch law it would mean that he is the legal father. Recognising the man as the father, according to the court, would mean that the court recognises more than exists under English law. That is not possible.

It is doubtful whether, what has been called in this thesis, a mere technical difference between English and civil law can justify an infringement on free movement rights. After all, the consequence of the court's view is that paternity from England can never be recognised on the basis of an English birth certificate.

On the second occasion, the Rechtbank 's-Gravenhage refused to recognise two men as the legal parents of a child who had been born to a surrogate mother in California. At the moment of birth, the men were also living in the United States. In essence the court held that the legal parenthood of both the biological father and his male spouse could not be recognised, because the Californian authorities did not establish the legal maternity of the surrogate mother.

If EU law is involved, which is not the case because the family moved straight from California to the Netherlands, the case raises two issues. The first is whether the refusal to recognise the legal parenthood of the two commissioning fathers is consistent with the Dutch policy that legal parenthood of commissioning parents can be established through acknowledgment of paternity and adoption.

The second issue touches upon the concept of the European public policy exception. Does it matter that the commissioning parents and the surrogate mother at the moment of the birth of the child lived in the United States? At the moment of the establishment of legal parentage, their only connection with the Netherlands was rather abstract, namely the Dutch nationality of the child's biological father; when the surrogacy agreement was concluded and when the children were born the men lived in the United States. Would it be consistent to develop a public policy whereby the recognition of the legal parentage of the commissioning parents depends on the degree of proximity between the case and the legal order of the recognising state?

On the one hand, it is almost a universally accepted dogma of private international law that the public policy exception is a relative concept which application depends inter alia on the degree of proximity between the case and the legal order of the forum. On the other hand, in Garcia Avello the fact that in Belgium different systems of naming coexist was a reason for the Court to conclude that the refusal of the Belgian state to recognise the Spanish name of the children could not be justified. Also Advocate General Sharpston in Grunkin and Paul suggests that absolute consistency is required in applying the public policy exception. 


\section{Summary}

This thesis provides a basis for a discussion on European legislation on private international law on legal parentage. Such legislation would be designed to guarantee that legal parentage that has been established in one Member State of the European Union is recognised in another Member State. European legislation on private international law on legal parentage could be a part of the transformation of the European Union into an 'area of freedom, security and justice' (art. 67 TFEU) in which the free movement of persons is guaranteed. After all, the exercise of the right to move and reside freely in the territory of the Member States would be hindered if in crossing the border between, for example France and Italy, the legal parentage of a child that has been established in France is not recognised in Italy. A discussion on European private international law on legal parentage consists of three parts.

\section{Part 1 - Comparative law on parentage}

In the first part of this thesis the differences and similarities of the law on parentage in five legal systems of the European Union are discussed. The legal systems concerned are those of England and Wales, France, Germany, the Netherlands and Sweden. This comparative overview is relevant, because there where legal systems differ the problem can arise that legal parentage that exists in one Member State, is not recognised in another. In the discussion on the national laws on legal parentage the following points have been addressed.

Firstly, the content of the national laws on parentage is discussed. The law on parentage is the part of private law that determines who the legal parents of the child are. The law on parentage has to be distinguished from the law on adoption, on the basis of which it is also possible to become the legal parent of a child.

The difference between the law on parentage and the law on adoption is the ground for legal parenthood, although that difference is not made consistently in all legal systems. Roughly speaking, adoption is a child protection measure, while the law on parentage determines who the original legal parents of the child are. If the original legal parents cannot or do not want to take care of the child, foster parents can take over the legal parenthood through the law on adoption.

It must be realised that in the law on parentage, the biological parents are not necessarily the legal parents. For example, a well known rule is that the husband of the mother is the legal father of the child. For the rule to apply, it does not matter whether the husband is also the biological father. Also in case of artificial reproduction the biological parents (the person whose egg cell or sperm has been used) are not always the legal parents.

Secondly, this thesis presents a basic structure of the law on parentage that is the same in all legal systems. The structure of the law on parentage relates to the rules of the law on parentage as a Christmas tree relates to the decoration: all the legal systems have the same 'Christmas tree', but they decorate it differently. If we know what the Christmas tree (the structure of the law on parentage) looks like, it is then easy to explain at which points the decoration is different or the same.

The common structure of the law on parentage is found through the function of the law on parentage. Every legal system attaches certain legal consequences to the fact that a person is the parent of a child. For example, a child inherits from his parents, parents are obliged to maintain their child financially, the child carries the surname of his parents and 
the child often obtains his nationality through his parents. It is the function of the law on parentage to determine, for this kind of consequence, who the legal parents of the child are.

In drafting the law on parentage, the legislator has to take three steps. These three steps constitute the structure of the law on parentage on the basis of which the law on parentage in England and Wales, France, Germany, the Netherlands and Sweden has been discussed.

The first step is to determine what the ground for legal parentage should be (chapter 2). It has been concluded that in case of natural reproduction the biological affiliation is the ground for legal parentage. In case of artificial reproduction with donor material the ground for legal maternity is the fact that the mother gave birth to the child. This is also true in case of surrogacy.

The ground for the legal parentage of the second parent in England and Wales, France and Sweden is his or her responsibility for the artificial fertilisation. In England and Wales and in Sweden the second parent can be either a man or a woman; in France it can only be a man.

In Dutch and German law the situation is slightly more complicated. In both legal systems, the husband of the mother is automatically the child's legal father in case of artificial reproduction with donor sperm during marriage. His legal paternity cannot be contested by him or the mother if he consented to the artificial fertilisation of the mother. However, the child can contest the legal paternity of the husband on the ground that he is not the biological father. Therefore, the responsibility of the mother's husband for procreation is not the ultimate ground for the law on parentage.

The second step is to determine how the legal parentage has to be established and the exceptions to the ground for legal parentage (chapter 3). In this thesis four means to establish legal parenthood have been distinguished: ex lege (i.e. automatically or by operation of the law), on the basis of an administrative action, on the basis of apparent status or on the basis of a judicial pronunciation. In addition to these four means to establish legal parentage, also the possibility to contest existing legal parentage has been discussed.

It has been concluded that under English law legal parentage always exists automatically. Therefore, there is more attention for evidence of legal parentage under English law (on evidence of legal parentage see chapter 4).

In Dutch, German and Swedish law only legal maternity and the legal paternity of the husband of the mother exists automatically. Under French law legal maternity does not exist automatically, but the legal paternity of the husband of the legal mother does.

In Dutch, French, German and Swedish law there is a lot of attention for other means to establish legal parenthood than by operation of the law. Because of this, in these countries there is the possibility to involve other interests in the establishment of legal parentage than only the ground for legal parentage. Examples of such interests are the intention of the person involved to become the legal parent, the protection of the family life of the mother and her child, the protection of the legal family and legal certainty.

Finally, it has been noted that in Germany, France, the Netherlands and Sweden the state has a role in the establishment and annulment of legal parentage. In France and the Netherlands the role of the state is to guard the 'public order' (ordre public or openbare orde). Guarding the public order means that the state takes action in case of sham acts, evasion of adoption law, acknowledgments of paternity which are evidently untrue and, in France, surrogacy. In Germany, the role is only targeted at avoiding sham acknowledgments to obtain advantages in immigration law or nationality law. In Sweden the role of the state is mainly targeted at the establishment of the legal parenthood of the biological father or, in 
case of artificial reproduction with donor sperm, the parenthood of the consenting partner of the mother.

The third step is to determine how legal parenthood has to be proven (chapter 4). If the law determines that the biological father is automatically the legal father, like under English law in cases of natural reproduction, the final question is how the legal relationship between the child and the biological father has to be proven.

In the context of the main question of this thesis, this third step is very relevant. After all, if the aim is to recognise legal parentage that has been established in one Member State in the other Member State, a system is needed on the basis of which a judge or civil servant in, for example, France can find out whether, and if so which, parentage has been established in, for example, the Netherlands.

All countries whose laws have been discussed in this thesis have a registration system for the legal parentage of persons. In England, France, Germany and the Netherlands this is the register of civil status (register of births and deaths, l'état civil, Standesamt, burgerlijke stand). Before it can be decided to transcribe the legal parentage that has been recorded in England on a German register of civil status, it is relevant to know what the English register describes and proves exactly.

In England the biological parents are the legal parents in cases of natural reproduction. Thus, an English registrar who records a birth has to mention the biological father on the birth certificate of the child. If a father declares the birth of his child while the man is not married to the mother, the English registrar will only mention him as the father of the child if he declares himself to be the child's father and if he can submit a declaration of the mother that supports his declaration. These declarations together are for the registrar sufficient evidence of the biological/legal parentage of the man. The English registrar does not check whether the man is actually the biological father. Therefore, the mention of the man as father on the English birth certificate only constitutes a presumption of his legal paternity. It is always possible to prove that the man is not the biological/legal parent. The effect is a certain level of uncertainty concerning the legal accuracy of the parentage that is mentioned on the English birth certificate.

According to German law, the child who is born out of wedlock does not have a legal father. The legal paternity can be established through an acknowledgment of paternity in an official instrument of acknowledgment. A legally valid acknowledgment creates legal paternity. The effect of this system is that the legal parentage in Germany can be recorded with more certainty. After all, the legal father is the man who acknowledged his paternity and the acknowledgment is laid down in an official instrument of acknowledgment. For the registrar it is relatively easy to check whether this instrument of acknowledgment is valid.

It seems that the transcription of the legal parentage from an English register of births on a German register of births is not possible, because the transcription affects the certainty of the German register of births. This is however not necessarily true. The difference in the legal nature of an acknowledgment of paternity - an avowal under English law or a juridical act under German law - does not alter the fact that in both cases the man is considered the father unless the contrary has been proven. For the recognition of the man as the father, it does not matter whether that is done through disproving the avowal (English law) or through annulling the juridical act (German law).

\section{Part 2 - Private international law}

The second part of the discussion on European private international law on legal parentage is an analysis of the private international law on legal parentage in England and Wales, France, Germany, the Netherlands and Sweden. 
Private international law (pil) intends amongst others to create decisional harmony. In cases of legal parentage that means that the aim of pil is to make sure that the legal parentage of a person is the same in all legal systems.

Thus, the aim of private international law corresponds with what European law wants to achieve, namely that the parentage of a person does not change when he or she crosses the border. The aim of the second part is to examine the extent to which national pil-systems indeed create decisional harmony on legal parentage.

Private international law on legal parentage regulates the international jurisdiction of courts and other authorities, the applicable law (conflict rules) and the recognition of foreign judicial decisions.

In chapter five the international jurisdiction of the civil status registrar or a similar authority and the courts in matters concerning parentage has been analysed. It has been concluded that in any event the registrar at the place of the child's birth determines the child's legal parentage. The reason is that this registrar has to record the birth. However, if the child is born abroad also the registrar of the country of nationality can be competent to record the birth of a child and to determine the parentage. In addition, some countries (Germany, the Netherlands and Sweden) also have a population register in which the parentage is recorded.

Since various authorities can be competent to determine the legal parentage, there is the risk that the child (and his parents) are from the start confronted with a limping legal parental status. That means a situation in which the authorities of two or more countries determine the legal parentage of a person differently.

Concerning the international jurisdiction of courts, it has been concluded that the legal systems involved base this on either the domicile/habitual residence or the nationality of the persons involved. The international jurisdiction of the court is in practice less interesting, because for most people the legal parentage will never be determined by a court.

In chapter 6 the conflict rules on legal parentage in England and Wales, France, Germany, the Netherlands and Sweden have been discussed. The conflict rules determine the law on the basis of which the registrar or the court has to determine the legal parentage. This can be the law of the registrar or the court (lex fori); it can also be foreign law. Parallel to the contents of the conflict rules, also the distinction between substantive and procedural issues in legal parentage, the renvoi and the public policy exception have been discussed.

The examination of the conflict rules is relevant, because the differences in national conflict rules can cause limping legal relations. After all, if the registrar in Germany determines the legal parentage on the basis of the law of the child's habitual residence, while the registrar in the Netherlands takes the law of the mother and her husband as a starting point, both registrars end up applying different laws. If in such a case also the contents of the law is different (see part 1), the registrars shall determine the legal parentage differently and a limping legal relationship has been created.

It has been concluded in the first place that English law does not have conflict rules on legal parentage. In determining the legal parentage, English authorities always apply English law.

Secondly, it appeared that in France and Germany the conflict rules have a universal scope of application. That means that they are applicable to all cases where legal parentage has to be determined, irrespective of whether the relevant facts (birth, acknowledgment) take place inland or abroad.

Thirdly, it appeared that despite the bewildering variety in conflict rules, all systems aim at applying the policy of the national law on parentage to international cases. Thus, a 
neutral system of conflict rules (i.e. a system of conflict rules in which the contents of foreign law is a priori irrelevant) does not exist; choice of law rules aim to reach a result that is in conformity with the starting points of the national law on parentage. This is an important point that has to be involved in the discussion of European private international law on legal parentage.

In chapter 7 it has been discussed to what extent the legal parentage that has been established in one country is recognised in the other country. It has been concluded that in the pil-systems of England and Wales, France and Germany, the Netherlands and Sweden two methods are used. If the legal parentage has been established abroad in a judicial decision, all legal systems apply a recognition method. That means that the decision shall be recognised if certain, mainly procedural requirements, have been met. In any case, it is not relevant whether the foreign court applies the law that would have been applied domestically.

In Dutch pil the recognition method is not only applied to legal parentage that has been laid down in a judicial decision, but also to legal parentage that has been laid down in a foreign instrument like the birth certificate. This is remarkable, because an instrument, in contrast with a judgment, does not have the force of law. It appeared that the recognition of legal parentage that has been laid down in an instrument means that Dutch pil confers evidential value on a foreign instrument regarding the legal parentage (instead of only the facts) that follows from an instrument. It is possible to disprove the legal parentage (after all the instrument does not have the force of law), however this has to be done on the basis of the law of the authority that drew up the instrument.

In the pil of France, German and Sweden the recognition of legal parentage that has been laid down in a foreign instrument depends on the applicable law according to the French, German or Swedish conflict rule. That means that the legal parentage that follows from a foreign instrument shall only be recognised if it is in accordance with the applicable law; if another law has been applied abroad, the legal parentage shall not be recognised.

English law does not have choice of law rules on parentage. That means that the legal parentage that has been established abroad shall not be recognised in England if it is not in conformity with English law.

\section{Part 3 - European law and conclusion}

The third part in the discussion on European legislation on private international law on legal parentage is an analysis of the demands of European law on private international law on legal parentage. Two developments are relevant.

Firstly, the European Court of Justice in its decisions in Garcia Avello and Grunkin and Paul concluded that a limping surname (that means the situation where a person in one country has a different surname than in another country) is in principle irreconcilable with the prohibition of discrimination (art. 18 TFEU) and the right of citizens of the European Union to move and reside freely on the territory of the Member States (art. 21 TFEU).

It has been concluded that the Court, especially in Grunkin and Paul, made an exception to the rule that European law is not concerned with any disparities in treatment for persons and undertakings subject to the jurisdiction of the Union, which may result from divergences existing between the various Member States (chapter 8); in Grunkin and Paul the Court concluded that the disparity in treatment (the limping surname) that was the effect of the differences in the private (international) law on surnames in Denmark and Germany was irreconcilable with European law. With this, the Court made a start with the 
implementation of the principle of mutual recognition in the law on the civil status of EU citizens.

In chapter 9 it has been concluded that the scope of application of the principle of mutual recognition as it has been developed by the Court in Garcia Avello and Grunkin and Paul is limited. The principle only works if there is no conflict of interest of the persons involved and if there is no violation of the public policy in the country of recognition. The effect of these limitations is that the principle can be more easily applied in the law on surnames (like in Garcia Avello and Grunkin and Paul) than in the law on parentage. After all, in the law on parentage a conflict of interest or a violation of public policy is more likely to arise than in the law on surnames. It remains to be seen how the principle of mutual recognition will be developed further by the Court.

Secondly, the European legislator is working at developing a European area of freedom, security and justice in which the free movement of EU citizens is guaranteed (art. 67 TFEU). One of the instruments to create this area of freedom, security and justice is the implementation of the principle of mutual recognition in private (international) law (art. 67 (4); 81 (2) under c TFEU).

In chapter 10 it has been discussed what the implementation of the principle of mutual recognition up until this moment entails. It has been concluded that the implementation is limited to judicial decisions and the evidential value and enforceability of authentic instruments.

Finally, in chapter 11 some thoughts have been formulated on European legislation to implement the principle of mutual recognition in private international law on legal parentage. The essence of the proposal is that judges and registrars who have to determine the legal parentage apply as much as possible their own law and that legal parentage that has been officially established shall be recognised by the authorities of other Member States subject to the public policy exception. 


\section{Résumé}

Dans cette thèse on établit les bases d'une discussion sur la législation européenne concernant le droit international privé de la filiation. Une telle législation devrait garantir que la filiation juridique établie dans un état membre de l'Union européenne soit reconnue dans les autres états membres. La législation européenne concernant le droit international privé de la filiation pourrait être une partie de la transformation de l'Union européenne en un 'espace de liberté, sécurité et justice' (art. 67 TFEU) dans lequel la libre circulation des citoyens européens est garantie. C'est que l'exercice du droit de circuler et de séjourner librement sur le territoire des États membres serait entravé si en passant la frontière entre, par exemple, la France et l'Italie, la filiation d'un enfant qui a été établie en France n'est pas reconnue en Italie. Cette discussion sur le droit international privé européen de la filiation se compose de trois parties.

\section{Première partie - le droit comparé de la filiation}

Cette partie de la thèse traite des différences et similarités entre le droit de la filiation de cinq systèmes juridiques de l'Union européenne, à savoir l'Allemagne, l'Angleterre et le pays de Galles, la France, les Pays-Bas et la Suède. Ce panorama comparatif est pertinent, parce que lorsque les systèmes juridiques diffèrent l'on peut craindre que la filiation juridique qui existe dans l'un état membre, ne soit pas reconnue dans un autre état membre. L'analyse du droit de la filiation national portera sur les points suivants.

En premier lieu, le contenu du droit de la filiation national est discuté. Le droit de la filiation est la partie du droit privé qui prévoit qui sont les parents juridiques d'un enfant. Il faut distinguer le droit de la filiation du droit de l'adoption, qui peut également fournir la base de la maternité et paternité juridique (aussi 'parenté juridique').

La différence entre le droit de la filiation et le droit de l'adoption est le fondement de la parenté juridique, bien que cette différence ne soit pas aussi claire dans tous les systèmes juridiques. En termes généraux, l'adoption est une mesure tendant à la protection de l'enfant tandis que le droit de la filiation prévoit qui sont les parents originaux de l'enfant. Si les parents originaux ne veulent ou ne peuvent plus s'occuper de leur enfant, les parents adoptifs peuvent prendre sur eux la parenté juridique grâce au droit de l'adoption.

Il faut garder à l'esprit que dans le droit de la filiation, les parents biologiques ne sont pas nécessairement les parents juridiques. Par exemple, une règle très connue est que le mari de la mère est le père juridique de l'enfant; peu importe s'il est aussi le père biologique. Aussi en cas de procréation médicalement assistée les parents biologiques (les personnes dont l'ovule ou le sperme a été utilisé) ne sont pas toujours les parents juridiques.

En deuxième lieu, on a cherché une grille de lecture qui permette une analyse comparative $\mathrm{du}$ droit de la filiation des cinq systèmes juridiques. Le lien entre la structure du droit de la filiation et ses règles est similaire à celui qui existe entre l'arbre de Noël et ses décorations: tous les systèmes juridiques ont les mêmes 'arbres de Noël', mais ils sont décorés différemment. Si l'on sait identifier 'l'arbre de Noël' (i.e. la structure du droit de la filiation), il sera facile d'expliquer où les ornements sont différents ou identiques.

On trouve la structure commune de différents droits de la filiation dans la fonction de ce droit. Chaque système juridique attache des conséquences spécifiques au fait que quelqu'un est le parent d'un enfant. A titre d'exemples, un enfant hérite de ses parents, les parents ont une obligation alimentaire à l'égard de l'enfant, l'enfant porte le nom de l'un de 
ses parents et souvent l'enfant obtient la nationalité par ses parents. C'est la fonction du droit de la filiation de définir qui sont les parents juridiques de l'enfant afin d'en tirer les conséquences juridiques.

En rédigeant le droit de la filiation, il faut que le législateur passe par trois étapes. Ces trois étapes constituent la structure du droit de la filiation, elles donnent donc la grille de lecture que l'on a utilisé pour analyser le droit de la filiation en Allemagne, en Angleterre et au pays de Galles, en France, aux Pays-Bas et en Suède.

La première étape est de déterminer les fondements de la filiation juridique (chapitre 2). On a conclu qu'en cas de procréation naturelle, la filiation biologique constitue le fondement de la filiation juridique. En cas de procréation médicalement assistée avec tiers donneur, le fondement de la maternité juridique est le fait que la femme accouche de l'enfant. Cela vaut aussi en cas de maternité pour autrui.

Le fondement de la parenté juridique du deuxième parent est, en Angleterre et au pays de Galles, en France et en Suède, son consentement à la procréation médicalement assistée. En Angleterre, au pays de Galles et en Suède le deuxième parent peut être aussi bien un homme qu'une femme ; en France il peut être uniquement un homme.

En droit allemand et néerlandais la situation est un peu plus compliquée. En cas de procréation médicalement assistée avec tiers donneur, dans un mariage, c'est le mari de la mère qui est automatiquement le père de l'enfant dans ces deux systèmes juridiques. Sa paternité ne peut pas être contestée ni par lui-même ni par la mère s'il a consenti à la procréation médicalement assistée. Cependant, l'enfant a le droit de contester la paternité $\mathrm{du}$ mari en apportant la preuve qu'il n'est pas le père biologique. Cela veut dire que la responsabilité du mari de la mère pour la procréation n'est pas le fondement ultime du droit de la filiation.

La deuxième étape est d'identifier les règles qui permettent d'établir la filiation juridique et leurs exceptions (chapitre 3). Dans cette thèse on distingue quatre façons d'établir la filiation juridique : par l'effet de la loi, par une action administrative comme l'enregistrement ou la reconnaissance, par la possession d'état et par une décision judiciaire. En plus de ces quatre façons d'établir la filiation, on a également abordé la possibilité $\mathrm{d}^{\prime}$ annuler la filiation existante.

On a conclu qu'en droit anglais, la filiation juridique est toujours établie par l'effet de la loi. A cause de cela, en droit anglais, l'attention se porte surtout sur la question de preuve de la filiation juridique (sur ce point voir chapitre 4).

En droit allemand, néerlandais et suédois, seule la maternité juridique et la paternité du mari de la mère juridique existent par l'effet de la loi. En droit français, la maternité juridique n'existe pas par l'effet de la loi, mais la paternité juridique du mari de la mère juridique si.

En droit allemand, français, néerlandais et suédois il existe plusieurs façons d'établir la filiation autres que par l'effet de la loi. De ce fait, il y a la possibilité dans ces pays de prendre en compte, dans l'établissement de la filiation juridique, des intérêts autres que le simple fondement de la filiation juridique. Des exemples de tels intérêts sont la volonté $\mathrm{d}$ 'une personne de devenir le parent juridique, la protection de la vie familiale de la mère et de son enfant ainsi que la protection de la famille juridique et de la sécurité juridique.

Finalement, on s'est aperçu qu'en France, en Allemagne, aux Pays-Bas et en Suède l'état peut intervenir dans l'établissement ou l'annulation de la filiation. En France et aux PaysBas, l'état est responsable de maintenir l'ordre public. Maintenir l'ordre public veut dire que l'état intervient en cas d'une reconnaissance "simulée » (i.e. pour dériver des avantages du droit de la nationalité et de l'immigration), de fraude à la loi, des reconnaissance manifestement invraisemblables et, en France, de la maternité pour autrui. En Allemagne, la 
rôle de l'état vise seulement les reconnaissance simulées. En Suède, le rôle de l'état vise l'établissement de la paternité juridique du père biologique ou, en cas de procréation médicalement assistée avec tiers donneur, la parenté du partenaire de la mère qui a consenti à la procréation.

La troisième étape est de déterminer les modalités de preuve de la filiation juridique (chapitre 4). Si le droit commande que le père biologique est automatiquement le père juridique, comme c'est le cas en Angleterre pour une procréation naturelle, la question porte sur comment prouver l'existence de la relation juridique entre l'enfant et son père biologique.

Dans le cadre de cette thèse, cette troisième étape est très pertinente. En effet, si l'objectif est de reconnaître la filiation juridique qui a été établie dans un certain état membre, on a besoin d'un système par lequel le juge ou le fonctionnaire (par exemple en France) peut rechercher si une filiation a été établie dans un autre état (par exemple aux Pays-Bas).

Tous les pays dont le droit est traité dans cette thèse ont un système d'enregistrement de la filiation juridique des personnes. En Allemagne, en Angleterre, en France et aux PaysBas c'est l'état civil (Standesamt, register of births and deaths, état civil, burgerlijke stand); en Suède c'est l'administration fiscale. Avant que l'on puisse décider de reprendre l'enregistrement de la filiation en Angleterre dans un registre de l'état civil allemand, il faut savoir ce que les registres anglais décrivent et prouvent exactement.

En Angleterre, les parents biologiques sont aussi, en cas de procréation naturelle, les parents juridiques. Donc, un officier de l'état civil qui enregistre une naissance doit mentionner le père biologique dans l'acte de naissance de l'enfant. Si un père déclare la naissance de son enfant, alors qu'il ne s'est pas marié avec la mère, l'officier de l'état civil anglais ne mentionnera le père que s'il déclare lui-même qu'il est le père de l'enfant (i.e. reconnaissance par l'acte de vérité) et s'il produit une déclaration de la mère allant dans le même sens. Ces déclarations ensemble suffissent comme preuve de la paternité biologique/juridique de l'homme. L'officier de l'état civil anglais ne vérifie pas si l'homme est effectivement le père biologique. C'est pourquoi la mention de l'homme comme père dans l'acte de naissance constitue seulement une présomption de sa paternité juridique. Il est toujours possible de prouver que l'homme n'est pas le père biologique/juridique. En conséquence, il existe un certain degré d'incertitude sur l'exactitude de la filiation juridique telle qu'elle est mentionnée dans un registre de naissances anglais.

En droit allemand, l'enfant né hors mariage n'a pas de père juridique. La paternité peut être établie par reconnaissance dans un acte authentique. Une reconnaissance valable crée donc la paternité juridique. La conséquence de ce système est qu'en Allemagne la filiation juridique peut être enregistrée avec plus de certitude. En effet, le père juridique est l'homme qui a reconnu l'enfant dans l'acte authentique. Pour l'officier de l'état civil il est relativement facile de vérifier la validité de l'acte de reconnaissance.

Ainsi, il semble que la transcription de la filiation d'un registre de naissance anglais dans un registre de naissances allemand n'est pas possible, parce que la transcription porte atteinte à la certitude du registre de naissances allemand. Pourtant, ce n'est que de l'apparence. La différence de nature d'une reconnaissance de paternité - l'acte de vérité en droit anglais, l'acte juridique en droit allemand - n'enlève rien au fait que dans les deux cas l'homme est considéré comme père jusqu'à preuve du contraire. Pour la reconnaissance de l'homme comme père, il importe peu si cela se fait en fournissant des preuves contre l'acte de vérité (droit anglais) ou par l'annulation de l'acte juridique (droit allemand). 


\section{Deuxième partie - Droit international privé}

La deuxième partie de la discussion sur la législation européenne concernant le droit international privé de la filiation est une analyse du droit international privé pertinent en Allemagne, en Angleterre et au pays de Galles, en France, aux Pays-Bas et en Suède.

Le droit international privé (dip) vise en particulier à assurer une gestion uniforme d'une même situation d'un pays à l'autre. En cas de filiation juridique cela veut dire que le but à atteindre est que la filiation d'une personne soit la-même dans tous les systèmes juridiques.

Donc, l'objectif du dip correspond finalement à ce que le droit européen vise à achever, $c^{\prime}$ est-à-dire que la filiation d'une personne ne change pas quand elle passe la frontière. Le but de la deuxième partie est d'examiner dans quelle mesure les systèmes nationaux de dip parviennent réellement à gérer de façon uniforme les questions de filiation juridique.

Le droit international privé national de la filiation désigne la compétence internationale du juge et d'autres autorités, la loi applicable (les règles de conflits) et la reconnaissance des décisions judiciaires étrangères.

Dans le chapitre 5 on a analysé la compétence de l'officier de l'état civil ou de l'autorité équivalente et du juge en matière de la filiation. On a conclu que c'est en tous cas l'officier de l'état civil du lieu de naissance de l'enfant qui établit la filiation. La raison est qu'il est obligé d'enregistrer la naissance. Cependant, si l'enfant est né à l'étranger, les autorités du pays dont l'enfant a la nationalité peuvent aussi être habilitées à enregistrer la naissance et établir la filiation. En outre, dans certains pays (l'Allemagne, les Pays-Bas, la Suède) il existe un registre de la population où l'on enregistre la filiation.

Du fait que plusieurs autorités peuvent être compétentes pour établir la filiation, il existe le danger que l'enfant (et ses parents) soient confrontés dès le début à une filiation juridique 'boiteuse'; c'est-à-dire une situation dans laquelle les autorités de deux ou plusieurs pays établissent la filiation d'une personne différemment.

En ce qui concerne la compétence internationale du juge on a conclu que les systèmes juridiques concernés la fondent sur le domicile/la résidence habituel(le) ou la nationalité des personnes concernées. En pratique la compétence internationale du juge est moins intéressante, parce que pour la plupart des gens la filiation ne sera jamais établie par un juge.

Dans le chapitre 6 on s'est penché sur les conflits de lois en matière de la filiation en Allemagne, en Angleterre et au pays de Galles, en France, aux Pays-Bas et en Suède. La règle gouvernant les conflits de lois désigne la loi qui doit être appliquée par une autorité ou un juge pour l'établissement de la filiation. Cela peut être la loi de l'autorité ou du juge (la lex fori) ; cela peut être également une loi étrangère. En plus, on a fait attention à la différence entre des questions substantielles et procédurales dans le droit de la filiation, le renvoi et l'exception d'ordre public.

Il est pertinent de s'intéresser aux conflits de lois, parce que les différences entre les règles nationales de gestion de ces conflits peut produire des situations 'boiteuses'. En effet, si l'officier de l'état civil en Allemagne applique la loi de la résidence habituelle de l'enfant à la filiation, tandis que l'officier de l'état civil aux Pays-Bas applique la loi nationale de la mère et son mari, les deux officiers appliquent des lois différentes. Si, en outre, le contenu des lois est aussi différent (voir première partie), les officiers établiront la filiation différemment et une situation boiteuse émerge.

On a conclu dans un premier temps que le droit anglais n'a pas de règles de gestion des conflits de lois en matière de filiation. En établissant la filiation, les autorités anglaises appliqueront toujours le droit anglais. 
Dans un deuxième temps il s'est avéré qu'en Allemagne et en France les règles sur les conflits de lois ont un champ d'application universel. Cela veut dire qu'elles sont applicables à tous les cas dans lesquels il faut établir la filiation, peu importe que les faits pertinents aient eu lieu à l'intérieur ou à l'extérieur. Dans les règles sur les conflits de lois néerlandaises et suédoises, on distingue selon que les faits pertinents (naissance, reconnaissance) ont eu lieu à l'intérieur ou à l'extérieur.

Dans un troisième temps il s'est avéré que nonobstant la diversité énorme des règles de conflits, tous les systèmes visent à appliquer la politique du droit national de la filiation dans les situations internationales. Il n'est donc pas question de règles de conflits neutres (c'est-à-dire qu'il s'agit d'un système de règles où le contenu de la loi étrangère est a priori non pertinent) ; les règles de conflit visent à un résultat conforme au droit national de la filiation. Cela est un point important qui doit être gardé à l'esprit pour la discussion sur le droit international privé européen en matière de la filiation.

Le chapitre 7 traite de la question de savoir dans quelle mesure la filiation juridique établie dans un certain pays sera reconnue dans un autre pays. On a conclu que les systèmes de dip en Allemagne, en Angleterre et au pays de Galles, en France, aux Pays-Bas et en Suède emploient deux méthodes. Si la filiation a été établie à l'étranger dans une décision judiciaire, tous les systèmes appliquent la méthode de reconnaissance. Cela veut dire que la décision est reconnue si certaines conditions, surtout procédurales, sont remplies. En tout cas, peu importe que le juge étranger ait appliqué la loi qui aurait été appliquée par le juge du for ou non.

En dip néerlandais la méthode de reconnaissance n'est pas appliquée seulement à la filiation juridique contenue dans une décision étrangère, mais également à la filiation juridique contenue dans un acte (de naissance) étranger. C'est remarquable, parce que contrairement aux décisions judiciaires un acte n'a pas force de chose jugée. La reconnaissance de la filiation contenue dans un acte implique donc que le dip néerlandais accorde force probante à un acte étranger ; la filiation juridique (au lieu des faits) peut ainsi être déduite de l'acte. La preuve contraire à l'existence de la filiation juridique est admissible (en effet, l'acte n'a pas force de chose jugée), mais fondée sur la loi de l'autorité qui a établi l'acte.

Dans le dip de l'Allemagne, la France et la Suède, la reconnaissance de la filiation contenue dans un acte étranger dépend de la loi applicable selon le dip allemand, français ou suédois. Cela signifie que la filiation juridique qui a été établie à l'étranger dans ces pays sera reconnue seulement si elle est conforme à la loi applicable; si non, la filiation ne sera pas reconnue.

Le droit anglais ne connait pas de règles permettant de résoudre les conflits de lois en matière de filiation. Cela implique que la filiation juridique qui a été établie à l'étranger ne sera pas reconnue en Angleterre si elle n'est pas conforme au droit anglais.

\section{Troisième partie - Droit européen et conclusion}

La troisième partie de la discussion sur la législation européenne concernant le droit international privé de la filiation est une analyse des exigences imposées par le droit européen sur le droit international privé de la filiation. Ici, deux développements sont pertinents.

Tout d'abord, la Cour de justice européenne dans ses décisions Garcia Avello et Grunkin et Paul a jugé qu'un nom 'boiteux' (c'est-à-dire le phénomène selon lequel une personne porte des noms différents dans des pays différents) est en principe incompatible avec 
l'interdiction de discrimination (art. 18 TFEU) et le droit des citoyens de l'Union européenne de circuler et de séjourner librement sur le territoire des États membres (art. 21 TFEU).

On a conclu que, notamment dans l'arrêt Grunkin et Paul, la Cour a fait une exception à la règle selon laquelle le droit européen ne vise pas l'élimination des éventuelles disparités de traitement qui peuvent résulter, pour les personnes et entreprises soumises à la juridiction de la Communauté, des divergences existant entre les différents États membres (chapitre 8); dans Grunkin et Paul la Cour a jugé que la différence de traitement (le nom boiteux) qui était le résultat de disparités entre les règles de droit (international) privé en matière de noms au Danemark et en Allemagne était en principe incompatible avec le droit européen. Avec cette décision, la Cour a entamé la mise en œuvre du principe de reconnaissance mutuelle dans le droit de l'état civil des citoyens de l'Union européenne.

Dans le chapitre 9, on a conclu que le champ d'application du principe de reconnaissance mutuelle tel que développé par la Cour dans Garcia Avello et Grunkin et Paul est limité. Le principe s'applique seulement lorsqu'il n'y a pas de conflits d'intérêts entre les parties concernées et s'il y a pas de violation de l'ordre public du pays de reconnaissance. Il s'ensuit que le principe s'applique plus facilement dans les états où s'applique le droit du nom (comme dans Garcia Avello et Grunkin et Paul) que dans ceux où le droit de la filiation. En effet, le droit de la filiation soulève davantage de conflits d'intérêts ou de violations de l'ordre public que le droit du nom. Il faut attendre de voir comment le principe de reconnaissance mutuelle sera développé dans la jurisprudence de la Cour.

Ensuite, le législateur européen travaille à 'l'espace de liberté, sécurité et justice' dans lequel la libre circulation des citoyens européens est garantie (art. 67 TFEU). Un des instruments qui sert à la création de cet espace de liberté, sécurité et justice est la mise en œuvre du principe de reconnaissance mutuelle dans le droit (international) privé (art. 67 (4); 81 (2) sous c TFEU).

Dans le chapitre 10 on a discuté de la mise en œuvre du principe de reconnaissance dans le droit international privé jusqu'à maintenant. On a conclu qu'elle se limite aux décisions judiciaires et à la force probante et exécutoire des actes authentiques.

Dans le chapitre 11 on a enfin formulé quelques idées sur la législation européenne donnant effet au principe de reconnaissance mutuelle dans le droit international privé de la filiation. L'essence de la proposition est que les juges et les officiers de l'état civil appliqueront dans la mesure du possible leur propre droit et que la filiation, une fois officiellement établie, sera reconnue par les autorités des autres états membres, sous réserve du respect de l'ordre public. 


\section{Samenvatting}

In dit proefschrift wordt een basis gelegd voor een discussie over Europese wetgeving inzake het internationale afstammingsrecht. Dergelijke wetgeving zou moeten garanderen dat het juridisch ouderschap dat is gevestigd in de ene lidstaat van de Europese Unie, in een andere lidstaat wordt erkend. Europese wetgeving inzake het internationale afstammingsrecht zou een onderdeel kunnen zijn van de transformatie van de Europese Unie in een 'ruimte van vrijheid, veiligheid en rechtvaardigheid' (art. 67 TFEU), waarbinnen het vrij verkeer van EU-burgers is gegarandeerd. De uitoefening van het recht om zich vrij op het grondgebied van de lidstaten te verplaatsen en er te verblijven zou namelijk belemmerd worden, als bij het oversteken van de grens tussen, bijvoorbeeld, Frankrijk en Italië de afstamming van het kind die is gevestigd in Frankrijk niet wordt erkend in Italië. Een discussie over Europees internationaal afstammingsrecht valt uiteen in drie delen.

\section{Deel 1 - Vergelijkend afstammingsrecht}

In het eerste deel van dit proefschrift worden de verschillen en overeenkomsten besproken in het afstammingsrecht van vijf rechtsstelsels van de Europese Unie, te weten Engeland en Wales, Duitsland, Frankrijk, Nederland en Zweden. Dit rechtsvergelijkende overzicht is relevant omdat daar waar de rechtsstelsels verschillen het probleem kan ontstaan dat juridisch ouderschap dat bestaat in de ene lidstaat, in een andere lidstaat niet wordt erkend. Bij de bespreking van het nationale afstammingsrecht is aandacht besteed aan de volgende punten.

In de eerste plaats wordt de inhoud van het nationale afstammingsrecht besproken. Het afstammingsrecht is het onderdeel van het privaatrecht dat bepaalt wie de juridische ouders zijn van een kind. Het afstammingsrecht moet worden onderscheiden van het adoptierecht, op basis waarvan personen ook de juridische ouders van een kind kunnen worden.

Het verschil tussen het afstammings- en adoptierecht zit hem in de grondslag voor het ouderschap, al wordt het verschil niet in alle rechtsstelsels even scherp gemaakt. Grofweg is adoptie een kinderbeschermingsmaatregel, terwijl het afstammingsrecht bepaalt wie de oorspronkelijke juridische ouders van een kind zijn. Als de oorspronkelijke juridische ouders niet meer voor het kind willen of kunnen zorgen, kunnen pleegouders via het adoptierecht het juridisch ouderschap overnemen.

Men moet zich realiseren dat in het afstammingsrecht de biologische ouders niet per se de juridische ouders zijn. Een bekende regel is bijvoorbeeld dat de echtgenoot van de moeder de juridische vader is van het kind. Daarvoor maakt het niet uit of die echtgenoot ook de biologische vader is. Ook in geval van kunstmatige voortplanting zijn de biologische ouders (de personen van wie een eicel of sperma is gebruikt) niet altijd de juridische ouders.

In de tweede plaats is gezocht naar een structuur van afstammingsrecht die alle rechtsstelsels gemeenschappelijk hebben. De structuur van het afstammingsrecht verhoudt zich tot de regels van het afstammingsrecht zoals de kerstboom zich verhoudt tot de versiering: alle rechtsstelsels hebben dezelfde 'kerstboom', maar versieren deze verschillend. Als we weten hoe de kerstboom (lees: de structuur van het afstammingsrecht) eruit ziet, is het vervolgens gemakkelijk om uit te leggen op welke punten de versiering verschilt of hetzelfde is.

De gemeenschappelijke structuur van het afstammingsrecht wordt gevonden in de functie van het afstammingsrecht. Elk rechtsstelsel verbindt bepaalde rechtsgevolgen aan 
het feit dat iemand de ouder is van een kind. Bijvoorbeeld, een kind erft van zijn ouders, ouders zijn verplicht hun kind financieel te onderhouden, het kind draagt de achternaam van één van zijn ouders en het kind verkrijgt vaak zijn nationaliteit via zijn ouders. Het is de functie van het afstammingsrecht om voor dit soort gevolgen te bepalen wie de juridische ouders zijn van een kind.

Bij het formuleren van het afstammingsrecht moet de wetgever drie stappen doorlopen. Deze drie stappen vormen de structuur van het afstammingsrecht op basis waarvan het afstammingsrecht in Engeland en Wales, Frankrijk, Duitsland, Nederland en Zweden is besproken.

De eerste stap is te bepalen wat de grondslag voor het juridisch ouderschap zou moeten zijn (hoofdstuk 2). Geconcludeerd is dat in geval van natuurlijke voortplanting de biologische afstamming de grondslag voor het afstammingsrecht vormt. In geval van kunstmatige voortplanting met donormateriaal is de grondslag voor het juridisch moederschap het feit dat de vrouw het kind ter wereld heeft gebracht. Dit geldt ook in geval van draagmoederschap.

De grondslag voor het juridisch ouderschap van de tweede ouder in Engeland en Wales, Frankrijk en Zweden is zijn of haar verantwoordelijkheid voor de kunstmatige bevruchting. De tweede ouder kan in Engeland en Wales en Zweden zowel een man als een vrouw zijn; in Frankrijk kan het alleen een man zijn.

In het Duitse en Nederlandse recht is de situatie iets ingewikkelder. In geval van kunstmatige bevruchting met donorzaad binnen een huwelijk is in beide rechtsstelsels de echtgenoot van de moeder automatisch de juridische vader. Zijn vaderschap kan niet door hemzelf en de moeder worden ontkend als hij heeft ingestemd met de kunstmatige bevruchting van de moeder. Echter, het kind kan wel het vaderschap van de echtgenoot ontkennen op grond van het feit dat hij niet de biologische vader is. De verantwoordelijkheid van de echtgenoot van de moeder voor de verwekking van het kind is dus niet de ultieme grondslag voor het afstammingsrecht.

De tweede stap is te bepalen hoe het ouderschap gevestigd moet worden en welke uitzonderingen op de grondslag geformuleerd moeten worden (hoofdstuk 3). In dit proefschrift worden vier manieren onderscheiden om ouderschap te vestigen: van rechtswege, op basis van een administratieve handeling zoals registratie of erkenning van het ouderschap, op basis van bezit van staat en op basis van een rechterlijke uitspraak. Naast deze vier manieren om afstamming te vestigen, wordt ook de mogelijkheid besproken om bestaande afstamming teniet te doen.

Geconcludeerd is dat naar Engels recht juridisch ouderschap altijd van rechtswege bestaat. Daardoor is er in het Engelse recht meer aandacht voor het bewijs van juridisch ouderschap (voor bewijs van juridisch ouderschap zie hoofdstuk 4).

In het Duitse, Nederlandse en Zweedse recht bestaat alleen het moederschap en het vaderschap van de echtgenoot van de moeder van rechtswege. In het Franse recht bestaat het juridisch moederschap niet van rechtswege, maar het juridisch vaderschap van de echtgenoot van de juridische moeder wel.

In het Duitse, Franse, Nederlandse en Zweedse recht is er dus veel aandacht voor andere manieren van vestiging van juridisch ouderschap dan van rechtswege. Hierdoor bestaat in deze landen de mogelijkheid om andere belangen in te brengen bij de vaststelling van het ouderschap dan enkel de grondslag voor het afstammingsrecht. Voorbeelden van dergelijke belangen zijn de wil van de betrokkene om de juridische ouder te worden, de bescherming van het gezinsleven van moeder en kind en de bescherming van het juridische gezin en de rechtszekerheid. 
Ten slotte is opgevallen dat in Frankrijk, Duitsland, Nederland en Zweden de staat een rol heeft in de vestiging en het tenietdoen van de afstamming. In Frankrijk en Nederland is het de taak van de staat om de openbare orde te bewaken. Het bewaken van de openbare orde houdt in dat de staat ingrijpt in geval van schijnerkenningen, omzeiling van het adoptierecht, evident onware erkenningen en, in Frankrijk, bij draagmoederschap. In Duitsland is de rol enkel gericht op het voorkomen van schijnerkenningen ten behoeve van het verkrijgen van voordeel in het vreemdelingen- en nationaliteitsrecht. In Zweden is de rol van de staat vooral gericht op de vestiging van het juridisch ouderschap van de biologische vader of, in geval van kunstmatige bevruchting met donorzaad, het ouderschap van de instemmende partner van de moeder.

De derde stap is te bepalen hoe het juridisch ouderschap moet worden bewezen (hoofdstuk 4). Als het recht bepaalt dat de biologische vader van rechtswege de juridische vader is, zoals in het Engelse recht in geval van natuurlijke voortplanting, is de laatste vraag hoe het bestaan van de juridische relatie tussen het kind en zijn biologische vader wordt bewezen.

In het kader van de hoofdvraag in dit proefschrift is deze derde stap zeer relevant. Immers, als het de bedoeling is om de afstamming die in de ene lidstaat is gevestigd te erkennen in de andere lidstaat, dan moet er een systeem zijn op basis waarvan een rechter of ambtenaar in, bijvoorbeeld, Frankrijk kan uitvinden of en zo ja welke afstamming er gevestigd is in, bijvoorbeeld, Nederland.

Alle landen waarvan het recht in dit proefschrift wordt besproken hebben een registratiesysteem voor de juridische afstamming van personen. In Engeland, Duitsland, Frankrijk en Nederland is dit de burgerlijke stand; in Zweden is het de belastingdienst. Alvorens besloten kan worden om een registratie van de afstamming in Engeland over te schrijven in de Duitse registers van de burgerlijke stand, is het van belang te weten wat de Engelse registers precies beschrijven en bewijzen.

In Engeland zijn, in geval van natuurlijke voortplanting, de biologische ouders de juridische ouders. Een Engelse ambtenaar die een geboorte registreert, moet dus de biologische vader als vader op de geboorteakte van het kind vermelden. Als een vader de geboorte van zijn kind aangeeft, terwijl de man niet getrouwd is met de moeder zal de Engelse ambtenaar de man alleen als vader opnemen als hij zelf verklaart de vader van het kind te zijn en als hij ook een verklaring van de moeder kan overleggen die zijn verklaring steunt. Deze verklaringen samen zijn voor de ambtenaar voldoende bewijs van het biologische/juridische vaderschap van de man. De Engelse ambtenaar controleert niet of die man ook daadwerkelijk de biologische vader is. Daarom vormt de vermelding van de man als vader op de Engelse geboorteakte naar Engels recht slechts een vermoeden van zijn juridisch vaderschap. Het is altijd mogelijk om te bewijzen dat de man niet de biologische/juridische vader is. Het gevolg is een bepaalde mate van onzekerheid over de juridische juistheid van de afstamming zoals die is vermeld in een Engels geboorteregister.

Naar Duits recht heeft een kind dat buiten huwelijk wordt geboren geen juridische vader. Het vaderschap kan worden vastgesteld met een erkenning van het vaderschap in een officiële erkenningsakte. De erkenningsakte vestigt het juridisch vaderschap. Het gevolg is dat de juridische afstamming in Duitsland met meer zekerheid kan worden geregistreerd. Immers, de juridische vader is de man die het kind heeft erkend en de erkenning is neergelegd in een akte. Voor de ambtenaar is het relatief eenvoudig te controleren of een geldige erkenningsakte voorligt.

Het lijkt er dus op dat de overschrijving van de afstamming uit een Engels geboorteregister in een Duits geboorteregister niet kan, omdat de overschrijving de zekerheid van het Duitse geboorteregister aantast. Dit is echter schijn. Het verschil in de juridische aard van een erkenning van het vaderschap - waarheidshandeling in het Engelse 
recht of rechtshandeling in het Duitse recht - doet niets af aan het feit dat in beide gevallen de man als vader wordt beschouwd, totdat het tegendeel in rechte is bewezen. Voor de erkenning van de man als vader maakt het niet uit of dat gebeurt door het leveren van tegenbewijs tegen de erkenning als waarheidshandeling (Engels recht) of door de vernietiging van de erkenning als rechtshandeling (Duits recht).

\section{Deel 2 - Internationaal privaatrecht}

Het tweede deel in de discussie over Europese wetgeving inzake het internationale afstammingsrecht is een analyse van het internationaal privaatrecht afstamming in Engeland en Wales, Duitsland, Frankrijk, Nederland en Zweden.

Het internationaal privaatrecht (ipr) beoogt onder andere internationale beslissingsharmonie te creëren. In geval van juridische afstamming wil dat zeggen dat het doel van het ipr is om ervoor te zorgen dat de afstamming van een persoon in alle rechtsstelsels hetzelfde is.

Het doel van het ipr komt dus overeen met wat het Europese recht uiteindelijk verlangt, namelijk dat de afstamming van een persoon niet wijzigt wanneer hij of zij de grens oversteekt. Het doel van het tweede deel is om te kijken in hoeverre de nationale iprsystemen daadwerkelijk internationale beslissingsharmonie inzake de juridische afstamming creëren.

Het nationale internationaal privaatrecht inzake de afstamming regelt de internationale bevoegdheid van de rechter en andere autoriteiten, het toepasselijke recht (de conflictregels) en de erkenning van buitenlandse rechterlijke beslissingen.

In hoofdstuk 5 is de internationale bevoegdheid van de ambtenaar van de burgerlijke stand of een vergelijkbare autoriteit en de rechter in afstammingszaken geanalyseerd. Geconcludeerd is dat in ieder geval de ambtenaar van de burgerlijke stand van de plaats waar het kind geboren wordt de afstamming vaststelt. De reden daarvoor is dat hij de geboorte van het kind moet registeren. Echter, als het kind in het buitenland wordt geboren kan ook de ambtenaar van het land waarvan het kind de nationaliteit heeft, bevoegd zijn om de geboorte van het kind te registeren en de afstamming vast te stellen. Daarnaast bestaat er in sommige landen (Nederland, Duitsland en Zweden) ook een bevolkingsregister, waarin de afstamming wordt vastgelegd.

Doordat meerdere autoriteiten bevoegd kunnen zijn de afstamming vast te stellen, bestaat het gevaar dat het kind (en zijn ouders) van het begin af aan geconfronteerd worden met een hinkende juridische afstamming; dat wil zeggen een situatie waarin de autoriteiten van twee of meer landen de afstamming van een persoon verschillend vaststellen.

Met betrekking tot de internationale bevoegdheid van de rechter is geconcludeerd dat de betrokken rechtsstelsels deze baseren op de woonplaats/gewone verblijfplaats of de nationaliteit van de betrokkenen. De internationale bevoegdheid van de rechter is voor de praktijk minder interessant, omdat voor de meeste mensen de afstamming nooit door een rechter wordt vastgesteld.

In hoofdstuk 6 is het conflictenrecht afstamming in Engeland en Wales, Duitsland, Frankrijk, Nederland en Zweden besproken. Het conflictenrecht bepaalt op basis van welk recht een ambtenaar of de rechter de afstamming moet vaststellen. Dit kan het recht van de ambtenaar of de rechter zelf zijn (de lex fori); het kan ook buitenlands recht zijn. Naast de inhoud van de conflictregel is ook aandacht besteed aan het onderscheid tussen materiële en procedurele kwesties in het afstammingsrecht, de renvoi en de openbare orde.

De bespreking van het conflictenrecht is relevant, omdat de verschillen in het nationale conflictenrecht ervoor zorgen dat hinkende rechtsverhoudingen kunnen ontstaan. Immers, 
als de ambtenaar in Duitsland de afstamming vaststelt op basis van het recht van de gewone verblijfplaats van het kind, terwijl de ambtenaar in Nederland het nationale recht van de moeder en de met haar getrouwde man als uitgangspunt neemt, passen beide ambtenaren verschillend recht toe. Als de inhoud van dat recht ook nog eens verschilt (zie deel 1) dan stellen de ambtenaren dus de afstamming verschillend vast en ontstaat een hinkende rechtsverhouding.

Geconcludeerd is in de eerste plaats dat het Engelse recht geen conflictregels inzake afstamming heeft. Bij het vaststellen van de afstamming passen Engelse autoriteiten altijd Engels recht toe.

In de tweede plaats is gebleken dat in Duitsland en Frankrijk het conflictenrecht een universeel toepassingsgebied heeft. Dat wil zeggen dat het van toepassing is op alle gevallen waarin de afstamming moet worden vastgesteld, ongeacht of de relevante feiten in het binnenland of in het buitenland hebben plaatsgevonden. In het Nederlandse en Zweedse conflictenrecht wordt een onderscheid gemaakt al naar gelang de relevante feiten (geboorte, erkenning) plaatsvinden in het binnenland of in het buitenland.

In de derde plaats is gebleken dat ondanks de enorme verscheidenheid aan conflictregels, alle systemen erop gericht zijn het beleid van het nationale afstammingsrecht in internationale gevallen toe te passen. Er is dus geen sprake van neutrale, regelblinde verwijzingsregels, maar van verwijzingsregels die gericht zijn op het bereiken van een resultaat in overeenstemming met de uitgangspunten van het nationale afstammingsrecht. Dit is een belangrijk punt dat betrokken moet worden in de discussie over Europees internationaal privaatrecht afstamming.

In hoofdstuk 7 is besproken in hoeverre de juridische afstamming die in het ene land is gevestigd in het andere land wordt erkend. Geconcludeerd is dat er in de ipr-sysemen van Engeland en Wales, Duitsland, Frankrijk, Nederland en Zweden twee methoden worden gehanteerd. Indien de afstamming in het buitenland is vastgesteld door een rechterlijke uitspraak, wordt er in alle systemen een erkenningsmethode toegepast. Dat wil zeggen dat het vonnis wordt erkend indien aan bepaalde, vooral procedurele, voorwaarden is voldaan. In ieder geval is niet van belang dat de buitenlandse rechter het recht heeft toegepast dat de eigen rechter zou hebben toegepast.

In het Nederlandse ipr wordt de erkenningsmethode niet alleen toegepast op juridische afstamming die is neergelegd in een buitenlands vonnis, maar ook op juridische afstamming die is neergelegd in een buitenlandse (geboorte)akte. Dit is opmerkelijk, omdat een akte in tegenstelling tot een vonnis geen kracht van gewijsde heeft. Gebleken is dat de erkenning van juridische afstamming die is neergelegd in een akte, betekent dat het Nederlandse ipr bewijskracht verleent aan een buitenlandse akte voor wat betreft de juridische afstamming die uit die akte blijkt. Tegenbewijs omtrent de juridische afstamming is mogelijk (de akte heeft immers geen kracht van gewijsde), zij het op basis van het recht van de autoriteit die de akte heeft opgemaakt.

In het ipr van Duitsland, Frankrijk en Zweden hangt de erkenning van de afstamming die is neergelegd in een buitenlandse akte af van het volgens het Duitse, Franse of Zweedse ipr toepasselijke recht. Dat betekent dat in het buitenland vastgestelde afstamming in de genoemde landen alleen erkend wordt, als het in overeenstemming is met het toepasselijke recht; als in het buitenland een ander recht is toegepast, wordt de afstamming niet erkend.

Het Engelse recht heeft geen conflictregels voor de afstamming. Dat betekent dat de juridische afstamming die in het buitenland is gevestigd niet in Engeland wordt erkend voor zover het niet in overeenstemming is met het Engelse recht. 


\section{Deel 3 - Europees recht en conclusie}

Het derde deel in de discussie over Europese wetgeving inzake het internationale afstammingsrecht is een analyse van de eisen die het Europese recht stelt aan het internationale afstammingsrecht. Daarbij zijn twee ontwikkelingen relevant.

In de eerste plaats heeft het Europees Hof van Justitie in zijn beslissingen in Garcia Avello en Grunkin en Paul geoordeeld dat een 'hinkende' achternaam (dat wil zeggen, het verschijnsel dat een persoon in het ene land een andere achternaam heeft dan in het andere land) in beginsel onverenigbaar is met het discriminatieverbod (art. 18 TFEU) en het recht van burgers van de Europese Unie om zich vrij op het grondgebied van de lidstaten te verplaatsen en er te verblijven (art. 21 TFEU).

Geconcludeerd is dat met zijn rechtspraak in met name Grunkin en Paul het Hof een uitzondering heeft gemaakt op de regel dat dispariteiten die het gevolg zijn van verschillen tussen wetgeving van de lidstaten binnen het Europese recht geaccepteerd moeten worden (hoofdstuk 8); in Grunkin en Paul concludeerde het Hof dat de dispariteit (de hinkende achternaam) die het gevolg was van verschillen in het (internationale) namenrecht in Denemarken en Duitsland onverenigbaar was met het Europese recht. Daarmee heeft het Hof een begin gemaakt met de implementatie van het beginsel van wederzijdse erkenning in het recht inzake de burgerlijke staat van EU-burgers.

In hoofdstuk 9 is geconcludeerd dat het toepassingsgebied van het beginsel van wederzijdse erkenning zoals dat door het Hof is vormgegeven in Garcia Avello en Grunkin en Paul beperkt is. Het beginsel werkt alleen als er geen conflict is tussen de belangen van de betrokken partijen en als er geen strijd is met de openbare orde in het land van erkenning. Het gevolg van deze beperkingen is dat het beginsel gemakkelijker toegepast kan worden in het namenrecht (zoals in Garcia Avello en Grunkin en Paul) dan in het afstammingsrecht. Immers, in het afstammingsrecht is er sneller sprake van een belangenconflict of strijd met de openbare orde dan in het namenrecht. Afgewacht moet worden hoe het beginsel van wederzijdse erkenning door het Hof verder vorm gegeven wordt.

In de tweede plaats werkt de Europese wetgever aan een Europese ruimte van vrijheid, veiligheid en rechtvaardigheid, waarin het vrij verkeer van EU-burgers is gegarandeerd (art. 67 TFEU). Eén van de instrumenten voor het creëren van deze ruimte van vrijheid, veiligheid en rechtvaardigheid is de implementatie van het beginsel van wederzijds erkenning in het (internationaal) privaatrecht (art. 67 (4); 81 (2) onder c TFEU).

In hoofdstuk 10 is besproken hoe de implementatie van het beginsel van wederzijdse erkenning in het internationaal privaatrecht er tot nu toe uit ziet. Geconcludeerd is dat de implementatie zich beperkt tot rechterlijke uitspraken en de bewijskracht en uitvoerbaarheid van authentieke akten.

In hoofdstuk 11 zijn ten slotte enige gedachten geformuleerd over Europese wetgeving waarmee het beginsel van wederzijdse erkenning in het internationale afstammingsrecht geïmplementeerd kan worden. De kern van het voorstel is dat rechters en ambtenaren die de afstamming moeten vaststellen zoveel mogelijk hun eigen recht toepassen en dat eenmaal officieel vastgestelde afstamming door de autoriteiten van de andere lidstaten wordt erkend behoudens strijd met de openbare orde. 


\section{Bibliography}

\section{Ancel \& Lequette 2006}

B. Ancel and Y. Lequette, Les grands arrêts de la jurisprudence française de droit international privé, Paris: Dalloz 2006.

\section{Andrae 2006}

M. Andrae, Internationales Familienrecht, Baden-Baden: Nomos 2006.

\section{Asser/De Boer 2006}

J.d. Boer, Mr. C. Asser's handleiding tot beoefening van het Nederlands burgerlijk recht. Personenen familierecht, Deventer: Kluwer 2006.

\section{Audit 2008}

B. Audit, Droit international privé, Paris: Economica 2008.

\section{Baarsma 2009}

N.A. Baarsma, 'European choice of law on divorce (Rome III): Where did it go wrong?' Nederlands Internationaal Privaatrecht 2009, 27(1), 9-14.

\section{Backmann 2002}

J.L. Backmann, Künstliche Fortpflanzung und Internationales Privatrecht, München: C.H. Beck München 2002.

\section{Baratta 2007}

R. Baratta, 'Problematic elements of an implicit rule providing for mutual recognition of personal and family status in the EC', Praxis des internationalen Privat- und Verfahrensrechts 2007, 27(1), 4-11.

\section{Barnard 2007}

C. Barnard, The substantive law of the EU, Oxford: Oxford University Press 2007.

\section{Barnett 2001}

P.R. Barnett, Res judicata, estoppel, and foreign judgments, Oxford: Oxford University Press 2001.

\section{Basedow 2005}

J. Basedow, 'Recherches sur la formation de l'ordre public européen dans la jurisprudence' in: M.-N. Jobard-Bachellier and P. Mayer eds., Le droit international privé : esprit et méthodes : mélanges en l'honneur de Paul Lagarde Paris: Dalloz 2005, 55-74.

\section{Basedow 2009}

J. Basedow, 'The communitarisation of private international law', Rabels Zeitschrift für ausländisches und internationales Privatrecht 2009, 73(3), 455-460.

\section{Batiffol \& Lagarde 1972}

H. Batiffol and P. Lagarde, 'L'improvisation de nouvelles règles de conflit de lois en matière de filiation', Revue critique de droit international privé 1972, 61(1), 3-26. 


\section{Batiffol \& Lagarde 1993}

H. Batiffol and P. Lagarde, Traité de droit international privé, Paris: Librairie générale de droit et de jurisprudence 1993.

\section{Beaumont 2009}

P. Beaumont, 'International family law in Europe - the Maintenance Project, the Hague Conference and the EC: A triumph of reverse subsidiarity', Rabels Zeitschrift für ausländisches und internationales Privatrecht 2009, 73(3), 509-546.

\section{Bénabent 2003}

A. Bénabent, Droit civil. La famille, Paris: Litec 2003.

\section{Bergen \& Buijssen 2004}

M.v.d. Bergen and C. Buijssen, 'Hoogtechnologisch draagmoederschap. De techniek staat voor niets, nu het recht nog!' Nederlands juristenblad 2004, 79(14), 724-728.

\section{Bergmann \& Ferid (1983-)}

A. Bergmann, M. Ferid, J. Rieck, et al., Internationales Ehe- und Kindschaftsrecht mit Staatsangehörigkeitsrecht, Frankfurt am Main Verlag für Standesamtswesen 1983.

\section{Berthold 2007}

B. Gaaz, 'Scheinvaterschaften. Zum entwurf eines Gesetzes zur Ergänzung des Rechts zur Anfechtung der Vaterschaft', Das Standesamt 2007, 60(3), 75-82.

\section{Bidaud-Garon 2006}

C. Bidaud-Garon, 'La force probante des actes de l'état civil étrangers après la loi du 26 novembre 2003', Revue critique de droit international privé 2006, 95(1), 49-83.

\section{Blauwhoff 2009}

R.J. Blauwhoff, Foundational facts, relative truths. A comparative study on children's right to know their genetic origins, Antwerpen: Intersentia 2009.

\section{Boeles 2003}

P. Boeles, Mensen \& papieren. Legalisatie en verificatie van buitenlandse documenten in probleemlanden, Utrecht: Forum 2003.

\section{Bogdan 2002}

M. Bogdan, 'Internationellt privaträttsliga aspekter av äggdonation och surrogatmoderskap', Svensk jurist tidning 2002, (8), 745-747.

\section{Bogdan 2004}

M. Bogdan, Svensk internationell privat- och processrätt, Stockholm: Norstedts Juridik 2004.

\section{Boiché 2008}

A. Boiché, 'Internationalité du litige familial: la filiation biologique en droit international privé', Actualité juridique famille 2008, 240 et seq.

\section{Braat 2008}

B. Braat, 'Buitenrechterlijke echtscheiding en draagmoederschap. Is Frankrijk er klaar voor?' Tijdschrift voor familie- en jeugdrecht 2008, 30(12), 289-294. 


\section{Broekhuijsen-Molenaar 1991}

A.M.L. Broekhuijsen-Molenaar, Civielrechtelijke aspekten van kunstmatige inseminatie en draagmoederschap, Deventer: Kluwer 1991.

\section{Bylander \& Andersson 2007}

E. Bylander and T. Andersson, Legalisation of public documents within the EU Member States Sweden, 2007.

available at: $\underline{\text { http://ec.europa.eu/civiljustice/news/docs/study_public_docs_sweden.pdf }}$

\section{Cadiet \& Jeuland 2004}

L. Cadiet and E. Jeuland, Droit judiciaire privé, Paris: Litec 2004.

Callé 2004

P. Callé, L'acte public en droit international privé, Paris: Economica 2004.

\section{Carbonnier 2004}

J. Carbonnier, Droit civil. Introduction, les personnes, la famille, l'enfant, le couple, Paris: Presses Universitaires de France 2004.

\section{Carlier 2007}

J.-Y. Carlier, La condition des personnes dans l'Union européenne, Brussels: Larcier 2007.

\section{Clarkson \& Hill 2006}

C.M.V. Clarkson and J. Hill, The conflict of laws, Oxford: Oxford University Press 2006.

\section{Closa 1992}

C. Closa, 'The concept of citizenship in the Treaty on European Union', Common market law review 1992, 29(6), 1137-1169.

\section{Coester-Waltjen 2004}

D. Coester-Waltjen, 'Das Anerkennungsprinzip im Dornröschenschlaf' in: H.-P. Mansel, T. Pfeiffer, H. Kronke, et al. eds., Festschrift für Erik Jayme, München: Sellier. European Law Publishers 2004, 121-129.

\section{Coester-Waltjen 2006}

D. Coester-Waltjen, 'Anerkennung im Internationalen Personen-, Familien- und Erbrecht und das Europäische Kollisionsrecht', Praxis des internationalen Privat- und Verfahrensrechts 2006, 26(4), 392-400.

\section{Collier 2001}

J.G. Collier, Conflict of Laws, Cambridge: Cambridge University Press 2001.

\section{Collins 2006a}

L. Collins ed. Dicey, Morris and Collins on the Conflict of Laws, vol. 1, London: Sweet \& Maxwell 2006.

\section{Collins 2006b}

L. Collins ed. Dicey, Morris and Collins on the Conflict of Laws, vol. 2, London: Sweet \& Maxwell 2006. 
B.F. Verveen, Commissie kunstmatige inseminatie bij de mens, Rapport Den Haag 1965.

Commissie lesbisch ouderschap en interlandelijke adoptie, Report 2007

Commissie lesbisch ouderschap en interlandelijke adoptie, Rapport lesbisch ouderschap, Den Haag 2007.

available at: $\underline{\text { http://www.justitie.nl/images/8332_Bw_Rapport-LO_tcm34-87352.pdf }}$

Commissie regelgeving burgerlijke stand. Report 1988

Commissie regelgeving burgerlijke stand, Rapport aan de staatssecretaris van justitie, Den Haag 1988.

\section{Cullen 2008}

D. Cullen, 'Surrogacy: "commissioning" parents not domiciled in UK - matters to be borne in mind by those contemplating surrogacy arrangements', Adoption and fostering 2008, 32, 75-76.

\section{Cuniberti 2007}

G. Cuniberti, 'The liberalization of the French law of foreign judgments', International and comparative law quarterly 2007, 56(4), 931-939.

\section{De Bruijn \& Kraan 1992}

A.R. de Bruijn and C.A. Kraan, De notariële akte als executoriale titel, Deventer: Kluwer 1992.

\section{De Groot 2000}

G.R. de Groot, 'Wetsvoorstel conflictenrecht afstamming' in: De familie geregeld?, Lelystad: Koninklijke Vermande 2000, 185-228.

\section{De Groot 2004}

G.R. de Groot, 'Op weg naar een Europees IPR op het gebied van het personenrecht', Weekblad voor privaatrecht, notariaat en registratie 2004, 135(6577), 360-363.

\section{De Groot \& Rutten 2004}

G.R. de Groot and S.W.E. Rutten, 'Op weg naar een Europees IPR op het gebied van het personen- en familierecht', Nederlands internationaal privaatrecht 2004, 22(3), 273-282.

\section{De Groot \& Saarloos 2004}

G.R. de Groot and K. Saarloos, 'De valkuil van de Rijkswet op het Nederlanderschap; erkenning en nationaliteit', Migrantenrecht 2004, 19(7), 252-258.

\section{De Meijer 2003}

M.E. de Meijer, Het openbaar ministerie in civiele zaken, Deventer: Kluwer 2003.

De Waele 2009

H.C.F.J.A. de Waele, Rechterlijk activisme en het Europees Hof van Justitie, Den Haag: Boom juridische uitgevers 2009.

\section{De Winter 1969}

L.I. de Winter, 'Nationality or domicile? The present state of affairs', Recueil des cours, Collected courses of The Hague Academy of International Law 1969, 128(3), 347-503. 


\section{Dekeuwer-Defossez 1999}

F. Dekeuwer-Defossez, Rénover le droit de la famille: propositions pour un droit adapté aux réalités et aux aspirations de notre temps: rapport au Garde des sceaux, ministre de la justice Paris 1999.

available at: http://lesrapports.ladocumentationfrancaise.fr/BRP/994001755/0000.pdf

\section{Demay de Goustine 1996}

P.D. de Goustine, 'Procréation médicalement assistée et pouvoir médical', Revue de droit sanitaire et social 1996, 1-15.

\section{Demolombe 1847}

C. Demolombe, Cours de Code Civil, Bruxelles: J. Stienon 1847.

\section{Dörner 2000}

H. Dörner, 'Probleme des neuen internationalen Kindschaftsrechts' in: E. Jayme, D. Schwab and P.Gottwald ed. Festschrift für Dieter Henrich: zum 70. Geburtstag 1. Dezember 2000, Bielefeld: Gieseking 2000, 119-131.

\section{Douglas \& Barton 1995}

G. Douglas and C. Barton, Law and Parenthood, London: Butterworths 1995.

\section{Droz 1972}

G.A.L. Droz, Compétence judiciaire et effets des jugements dans le marché commun, Paris: Dalloz 1972.

\section{Evans 1984}

A.C. Evans, 'European citizenship: a novel concept in EEC law', American journal of comparative law 1984, 32(4), 679-714.

\section{Evers e.a. 2003}

L.J.W. Evers, E.W.M. Gubbels and J.H. Otten, Burgerzaken en de Wet conflictenrecht afstamming, Den Haag: VNG Uitgeverij 2003.

\section{Fallon 2004}

M. Fallon, 'Libertés communautaires et règles de conflit de lois' in: A. Fuchs, H.M. Watt and É. Pataut eds., Les conflits de lois et le système juridique communautaire, Paris: Dalloz 2004, 31-80.

\section{Fallon \& Meeusen 2002}

M. Fallon and J. Meeusen, 'European Union and the exception of mutual recognition', Yearbook of private international law 2002, 4, 37-66.

\section{Ferrand 2006}

F. Ferrand, 'Verwertung heimlich eingeholter DNA-Vaterschaftstests', Zeitschrift für europäisches Privatrecht 2006, 14(2), 436-458.

\section{Fleischhauer 1999}

J. Fleischhauer, 'Reasons to include authentic instruments in a world wide Convention on the Recogntion and Enforcement of Judgments in Civil and Commercial Matters', Praxis des internationalen Privat- und Verfahrensrechts 1999, 19(4), 216-219. 


\section{Forder 2009}

C.J. Forder, Erkenning door de vrouwelijke partner van de moeder. Rapport in opdracht van het Ministerie van Justitie, 2009.

Available at:

http://www.justitie.nl/images/advies\%20van\%20mw.\%20prof.\%20C.J.\%20Forder\%20over \%20lesbisch\%20ouderschap.doc_14556_tcm34-192580.pdf

\section{Foyer 1970}

J. Foyer, 'La réforme du droit de la filiation et le droit international privé', Droit international privé. Travaux du comité français de droit international privé 1969-1971, 105-141.

\section{Foyer 1985}

J. Foyer, 'Problèmes de conlits de lois en matière de filiation', Recueil des cours, Collected courses of The Hague Academy of International Law 1985, 193(4), 9-117.

\section{Foyer 1994}

J. Foyer, 'Vingt ans d'application des articles 311-14 à 311-18 du Code civil' in: Droit des personnes et de la famille. Mélanges à la mémoire de Danièle Huet-Weiller, Strasbourg: Libraire Générale de Droit et de Jurisprudence 1994, 127-140.

\section{Foyer 2002}

J. Foyer, 'Les enfants des concubins. Aspects de droit international privé' in: Des concubinages: droit interne, droit international, droit comparé. Etudes offertes à Jacqueline Rubellin-Devichi, Paris: Litec 2002, 523-538.

\section{Foyer \& Simon-Depitre 1973}

J. Foyer and M. Simon-Depitre, Le nouveau droit international privé de la filiation, Paris: Librairies Techniques 1973.

\section{Frank 2005a}

R. Frank, 'Observations comparatives sur la contestation de paternité', Revue internationale de droit comparé 2005, 57(1), 85-102.

\section{Frank 2005b}

R. Frank, 'Die Entscheidung des EuGH in Sachen Garcia Avello und ihre Auswirkung auf das internationale Namensrecht', Das Standesamt 2005, 58(6), 161-168.

\section{Frank 2009}

R. Frank, 'Die unglückselige Mehrfachanknüpfung in Art. 19 Abs. 1 EGBGB', Das Standesamt 2009, 62(3), 65-70.

\section{Frank \& Helms 2007}

R. Frank and T. Helms, 'Kritische Bemerkungen zum Regierungsentwurf eines 'Gesetzes zur Klärung der Vaterschaft unabhängig vom Anfechtungsverfahren", Zeitschrift für das gesamte Familienrecht 2007, 54(16), 1277-1281.

\section{Frohn 2008}

E.N. Frohn, 'Wijziging geslachtsnaam na huwelijk in het buitenland', Tijdschrift voor familieen jeugdrecht 2008, 30(12), 279-283. 


\section{Funken 2009}

K. Funken, Das Anerkennungsprinzip im internationalen Privatrecht, Tübingen: Mohr Siebeck 2009.

\section{Gamble \& Ghevaert 2009}

N. Gamble and L. Ghevaert, 'The Human Fertilisation and Embryology Act 2008: Revolution or evolution?' Family Law 2009, 39(8), 730-733.

\section{Gaudemet-Tallon 2002}

H. Gaudemet-Tallon, Compétence et exécution des jugements en Europe, Paris: Librairie générale de droit et de jurisprudence 2002.

\section{Gaul 1997}

H.F. Gaul, 'Die Neuregelung des Abstammungsrechts durch das Kindschaftsrechtsreformgesetz', Zeitschrift für das gesamte Familienrecht 1997, 44(23), 14411466.

\section{Gaul 2000}

H.F. Gaul, 'Ausgewählte Probleme des materiellen Rechts und des Verfahrensrechts im neuen Abstammungsrecht', Zeitschrift für das gesamte Familienrecht 2000, 47(23), 1461-1476.

\section{Geimer 2000}

R. Geimer, 'Freizügigkeit vollstreckbarer Urkunden im Europäischen Wirtschaftsraum', Praxis des internationalen Privat- und Verfahrensrechts 2000, 20(5), 366-369.

Geimer 2005

R. Geimer ed. Internationales Zivilprozeßrecht, Köln: Verlag Otto Schmidt 2005.

\section{Gernhuber \& Coester-Waltjen 2006}

J. Gernhuber and D. Coester-Waltjen, Familienrecht, München: Verlag C.H. Beck 2006.

Granet-Lambrechts 2005

F. Granet-Lambrechts, 'Droit de filiation: panorama 2004', Recueil Dalloz 2005, 1748-1754.

\section{Granet-Lambrechts 2006}

F. Granet-Lambrechts, 'Droit de la filiation', Recueil Dalloz 2006, 1139-1148.

\section{Granet-Lambrechts 2007b}

F. Granet-Lambrechts, 'Preuves en droit de la famille: la preuve des liens de filiation', Actualité juridique famille 2007, 459 et seq.

\section{Granet-Lambrechts 2008}

F. Granet-Lambrechts, 'Droit de la filiation (avril 2007-février 2008)', Recueil Dalloz 2008, 1371-1377.

\section{Granet-Lambrechts \& Hauser 2006}

F. Granet-Lambrechts and J. Hauser, 'Le nouveau droit de la filiation', Recueil Dalloz 2006, 17-28. 


\section{Gubbels 2006}

E. Gubbels, Het Nederlands-Antiliaans internationaal privaatrecht. Handleiding voor burgerzakenmedewerkers, Amsterdam: Dienst Persoonsgegevens Amsterdam 2006.

\section{Guiho 1991}

P. Guiho, 'La conception française de l'ordre public international en matière de filiation' in: A. Honorat and P. Julien eds., Mélanges en hommage à André Breton et Fernand Derrida Paris: Dalloz 1991, 145-157.

\section{Guimezanes-Durand 1973}

N. Guimezanes-Durand, La filiation en droit international privé anglais et français comparé, Université de droit, d'économie et de sciences sociales de Paris, 1973.

\section{Guttman 1959}

E. Guttman, 'The status of legitimacy in comparative conflict of laws', International and comparative law quarterly 1959, 8(4), 678-688.

\section{Hailsham of St. Marylebone 1998}

Lord Hailsham of St. Marylebone, Halsbury's Laws of England, Registration Concerning the Individual, London: Butterworths 1998.

\section{Hauser 2008}

J. Hauser, 'Le temps en droit de la filiation' in: T. Helms and J.M. Zeppernick eds., Lebendiges Familienrecht. Festschrift für Rainer Frank zum 70. Geburtstag am 14. Juli 2008, Frankfurt am Main: Verlag für Standesamtswesen 2008.

\section{Hauser \& Huet-Weiler 1993}

J. Hauser and D. Huet-Weiler, Traité de droit civil - La famille, fondation et vie de la famille, Paris: Librairie Générale de Droit et de Jurisprudence 1993.

\section{Heida 2002}

A. Heida, 'Vaderschapsprocedures en DNA-onderzoek', Tijdschrift voor familie- en jeugdrecht 2002, 24(5), 122-129.

\section{Helms 1999}

T. Helms, Die Feststellung der biologischen Abstammung: Eine rechtsvergleichende Untersuchung zum deutschen und französischen Recht, Berlin: Duncker \& Humblot 1999.

\section{Helms 2007}

T. Helms, 'Die missbräuchliche Anerkennung der Vaterschaft', Das Standesamt 2007, 60(3), 69-75.

\section{Helms 2008}

T. Helms, 'Das neue Verfahren zur Klärung der leiblichen Abstammung', Zeitschrift für das gesamte Familienrecht 2008, 55(11), 1033-1037.

\section{Helms 2008a}

T. Helms, 'Entwurf eines Gesetzes zur Klärung der Vaterschaft unabhängig vom Anfechtungsverfahren', Das Standesamt 2008, 61(1), 7-9. 


\section{Helms 2009}

T. Helms, 'Aktuelle Fragen des internationalen Abstammungsrechs', Das Standesamt 2009, 62(10), 293-298.

\section{Henrich 1998a}

D. Henrich, 'Das Kollisionsrecht im Kindschaftsrechtsreformgesetz', Das Standesamt 1998, 51(1), 1-10.

\section{Henrich 2005a}

D. Henrich, 'Das Kind mit zwei Müttern (oder zwei Vätern) im IPR' in: S. Hofer, D. Klippel and U. Walter eds., Perspektiven des Familienrechts: Festschrift für Dieter Schwab, Bielefeld: Gieseking 2005, 1141-1152.

\section{Henrich 2005b}

D. Henrich, 'Anerkennung statt IPR. Eine Grundsatzfrage', Praxis des internationalen Privatund Verfahrensrechts 2005, 25(5), 422-424.

\section{Henrich 2005c}

D. Henrich, 'Das internationalen Namensrecht auf dem Prüfstand des EuGH' in: S. Lorenz, A. Trunk, H. Eidenmüller, et al. eds., Festschrift für Andreas Heldrich, München: Verlag C.H. Beck 2005, 667-677.

\section{Henrich 2006a}

D. Henrich, 'Großbritannien' in: A. Bergmann, M. Ferid, J. Rieck, et al. eds., Internationales Ehe- und Kindschaftsrecht, Frankfurt am Main Verlag für Standesamtswesen 2006.

\section{Henrich 2006b}

D. Henrich, 'Zum Entwurf eines Gesetzes zur Ergänzung des Rechts zur Anfechtung der Vaterschaft', Zeitschrift für das gesamte Familienrecht 2006, 53(14), 977-979.

\section{Hepting 2000}

R. Hepting, 'Konkurrierende Vaterschaften in Auslandsfällen', Das Standesamt 2000, 53(2), $33-42$.

\section{Hepting 2002}

R. Hepting, 'Mehrfachanknüpfung und doppelte Vaterschaft im Abstammungsrecht', Praxis des internationalen Privat- und Verfahrensrechts 2002, 22(5), 388-391.

\section{Hepting \& Gaaz 2006a}

R. Hepting and B. Gaaz, Personenstandsrecht mit Familienrecht und Internationalem Privatrecht. Band 1, Frankfurt am Main - Berlin: Verlag für Standesamtwesen 2006.

\section{Hepting \& Gaaz 2006b}

R. Hepting and B. Gaaz, Personenstandsrecht mit Familienrecht und Internationalem Privatrecht. Band 2, Franfurt am Main - Berlin: Verlag für Standesamtwesen 2006.

\section{Hess, Pfeiffer \& Schlosser 2007}

B. Hess, T. Pfeiffer and P. Schlosser, Ruprecht Karls Universität Heidelberg, Report on the Application of Regulation Brussels I in the Member States (JLS/C4/2005/03), Heidelberg 2007. available at: http://ec.europa.eu/civiljustice/news/docs/study_application_brussels_1_en.pdf 


\section{Höfelmann 2004}

E. Höfelmann, 'Das neue Gesetz zur Änderung der Vorschriften über die Anfechtung der Vaterschaft und das Umgangsrecht von Bezugspersonen des Kindes', Zeitschrift für das gesamte Familienrecht 2004, 51(10), 745 - 751.

\section{Howe 2008}

D. Howe, 'International surrogacy - a cautionary tale', Family law 2008, 38(1), 61-66.

\section{Huet 1973}

A. Huet, 'Les conflits de lois en maitère d'établissement de la filiation depuis la loi du 3 janvier 1972' in: Les conflits de lois en matière de filiation en droit international privé français, allemand et suisses : actes du colloque des 13-14 octobre 1972, Paris: Pichon \& Durand-Auzias 1973.

\section{Ibili 2007}

F. Ibili, Gewogen rechtsmacht in het IPR. Over forum (non) conveniens en forum necessitatis, Deventer: Kluwer 2007.

\section{Israël 2000}

J. Israël, 'Conflicts of law and the EC after Amsterdam. A change for the worse?' Maastricht journal of European and comparative law 2000, 7(1), 81-99.

\section{Israël \& Saarloos 2007}

J. Israël and K. Saarloos, 'Europees internationaal privaat- en procesrecht' in: A.S. Hartkamp, C.H. Sieburgh and L.A.D. Keus eds., De invloed van het Europese recht op het Nederlandse privaatrecht, Deventer: Kluwer 2007, 629-698.

\section{Jacobs 2007}

F.G. Jacobs, 'Citizenship of the Union - A legal analysis', European law journal 2007, 13(5), 591-610.

\section{Jaffey 1982}

A.J.E. Jaffey, 'The foundations of rules for choice of law' in: R. Fentiman ed. Conflict of Laws, Aldershot: Dartmouth 1982, 578-603.

\section{Jänterä-Jareborg 2003}

M. Jänterä-Jareborg, 'Unification of international family law in Europe - a critical perspective' in: K. Boele-Woelki ed. Perspectives for the unification and harmonisation of family law in Europe, Antwerpen: Intersentia 2003, 194-216.

\section{Jänterä-Jareborg 2006a}

M. Jänterä-Jareborg, 'Sweden : Lesbian Couples are entitled to assisted fertilization and to equal rights of parentage', Zeitschrift für das gesamte Familienrecht 2006, 53(18), 1329-1330.

\section{Jänterä-Jareborg 2006b}

M. Jänterä-Jareborg, 'Parenthood for same-sex couples: challenges of private international law form a Scandinavian perspective' in: J. Erauw, V. Tomljenović and P. Volken eds., Liber Memoralis Petar Šarčević. Universalism, tradition and the individual, München: Sellier. European law publishers 2006, 75-91. 


\section{Janzen 2002}

U. Janzen, 'Das Kinderrechteverbesserungsgesetz', Zeitschrift für das gesamte Familienrecht 2002, 49(12), 785-790.

\section{Jessurun d'Oliveira 1985}

H.U. Jessurun d'Oliveira, Krypto-ipr, Kluwer: Deventer 1985.

\section{Jessurun d'Oliveira 2009}

H.U. Jessurun d'Oliveira, 'Hinkende namen', Migrantenrecht 2009, 24(2), 41-46.

\section{Jones 1959}

G.H. Jones, 'The Legitimacy Act 1959', International and comparative law quarterly 1959, 8(4), 722-726.

\section{Joppe 1987}

I.S. Joppe, Overgangsrecht in het internationaal privaatrecht en het fait accompli, Arnhem: Gouda Quint 1987.

\section{Jordens-Cotran 2002a}

L. Jordens-Cotran, 'De Wet conflictenrecht afstamming, deel I', Burgerzaken E Recht 2002, 9(9), 261-303.

\section{Jordens-Cotran 2007}

L. Jordens-Cotran, Nieuw Marokkaans Familierecht en Nederlands IPR, Den Haag: SDU Uitgevers 2007.

\section{Julien \& Fricero 2003}

P. Julien and N. Fricero, Droit judicaire privé, Paris: LGDJ 2003.

\section{Kampers, Evers \& Vat 2008}

J. Kampers, L.J.W. Evers and H. Vat, Inleiding tot de burgerlijke stand, Deventer: Kluwer 2008.

\section{Karnov/Saldeen 2007}

C. Bergman, M. Bogdan, A. Eriksson, et al. eds., Karnov, Svensk lagsamling med kommentarer. Band 1, Stockholm: Thomson Fakta 2007.

\section{Kessedjian 2008}

C. Kessedjian, 'Public order in European law', Erasmus law review 2008, 1(1), 25-36.

\section{Kongstad 2003}

T. Kongstad, Mater semper certa est? En diskussion kring moderskapspresumtionen i svensk rätt och behovet av lagreglering rörande rättsligt moderskap, Lund University, Juridiska Fakultetet vid Lunds universitet, 2003.

available at:

http://www.jur.lu.se/Internet/Biblioteket/Examensarbeten.nsf/0/0A14A71878C95213C12 56FC00048B059/\$File/exam.pdf

\section{Koolhoven 2005}

R. Koolhoven, 'Het Nederlandse opengestelde huwelijk in het Duitse IPR', Nederlands internationaal privaatrecht 2005, 23(2), 138-142. 


\section{Kosters \& Dubbink 1962}

J. Kosters and C.W. Dubbink, Algemeen deel van het Nederlandse internationaal privaatrecht, Haarlem: De erven F. Bohn 1962.

\section{Kronke 2004}

H. Kronke, 'Most significant relationship, governmental interests, culteral identity, integration' in: H.-P. Mansel, T. Pfeiffer, H. Kronke, et al. eds., Festschrift für Erik Jayme München: Sellier European law publishers 2004, 461-470.

\section{Kropholler 2006}

J. Kropholler, Internationales Privatrecht, Tübingen: Mohr Siebeck 2006.

\section{Labbée 2007}

X. Labbée, 'L'enfant de la mère porteuse et la filiation interdite', Recueil Dalloz 2007, 12511255.

\section{Lagarde 1998}

P. Lagarde, Explanatory Report on the 1996 Hague Child Protection Convention 1998.

\section{Lagarde 2004}

P. Lagarde, 'Développements futurs du droit international privé dans une Europe en voie d'unification : quelques conjectures', Rabels Zeitschrift für ausländisches und internationales Privatrecht 2004, 68(2), 225-243.

\section{Laroche-Gisserot 1997}

F. Laroche-Gisserot, Leçons de droit civil - Tome 1, deuxième volume, Les personnes, la personalité, les incapacités, Paris: Montchrestien 1997.

\section{Lasok 1961}

D. Lasok, 'Legitimation, recognition and affiliation proceedings', International and comparative law quarterly 1961, 10(1), 123-142.

\section{Leckey 2009}

R. Leckey, "Where the parents are of the same sex': Quebec's reforms to filiation', International journal of law, policy and the family 2009, 23(1), 62-82.

\section{Lee \& Morgan 2001}

R.G. Lee and D. Morgan, Human Fertilisation and Embryology, Regulating the reproductive revolution, London: Blackstone Press 2001.

\section{LeGac-Pech 2001}

S. LeGac-Pech, 'De Louis XVII à Z ...' Recueil Dalloz 2001, 404407.

\section{Lemaire 1968}

W.L.G. Lemaire, Nederlands internationaal privaatrecht: (hoofdlijnen), Leiden: Sijthoff 1968.

\section{Lennart 1986}

L. Pålsson, 'Rules, problems and trends in family conflict of laws: especially in Sweden', Recueil des cours, Collected courses of The Hague Academy of International Law 1986, 199(4), 317413. 


\section{Leutner 1997}

G. Leutner, Die vollstreckbare Urkunde im europäischen Rechtsverkehr, Berlin: Duncker \& Humblot 1997.

\section{Leveneur 1995}

L. Leveneur, Leçons de droit civil - Tome 1, Troisième volume, La Famille, Paris: Montchrestien 1995.

\section{Lindell 2004}

B. Lindell, 'Evidence in Sweden' in: J.M.L.d. Freitas ed. The law of evidence in the European Union - Das Beweisrecht in der Europäischen Union - Le droit de la preuve dans l'Union européenne, Den Haag: Kluwer Law International 2004, 407-435.

\section{Lipp 2009}

V. Lipp, 'Namensrecht und Europa', Das Standesamt 2009, 62(1), 1-8.

\section{Locré 1807}

J.G. Locré, Esprit du Code Napoléon, Paris: L'imprimerie impériale 1807.

\section{Locré 1836}

M. Locré, Législation civile, commerciale et criminelle ou commentaire et complément des codes français, Bruxelles: Librairie de Jurisprudence de H. Tarlier 1836.

\section{Löhnig 2009}

M. Löhnig, 'Probleme des neuen Verfahrens in Abstammungssachen nach §§ 169 ff. FamFG', Zeitschrift für das gesamte Familienrecht 2009, 56(21), 1798-1800.

\section{Looschelders 1999}

D. Looschelders, 'Alternative und sukzessive Anwendung mehrerer Rechtsordnungen nach dem neuen internationalen Kindschaftsrecht', Praxis des internationalen Privat- und Verfahrensrechts 1999, 19(6), 420-426.

\section{Lowe \& Douglas 2007}

N.V. Lowe and G. Doublas, Bromley's family law, Oxford University Press 2007.

\section{Mackay of Clashfern 2001a}

Lord Mackay of Clashfern, Halsbury's Laws of England, Children and Young Persons, London: Butterworths 2001.

\section{Mackay of Clashfern 2001b}

Lord Mackay of Clashfern, Halsbury's Laws of England, Marriage, London: Butterworths 2001.

\section{Mackay of Clashfern 2003}

Lord Mackay of Clashfern, Halsbury's Laws of England, Conflict of Laws, LexisNexis UK 2003.

\section{Mackay of Clashfern 2008}

Lord Mackay of Clashfern, Halsbury's Laws of England, Children and Young Persons, London: Butterworths 2008. 


\section{Malaurie \& Fulchiron 2006}

P. Malaurie and H. Fulchiron, La famille, Paris: Defrénois 2006.

\section{Malmström 1978}

A. Malmström, Hague Conference on Private International Law, Explanatory report to the Convention on the celebration and recognition of the validity of marriages, The Hague 1978.

\section{Manchini 1851}

P.S. Manchini, Della nazionalità come fondamento del dritto delle genti, Torino: Tipografia eredi botta 1851.

\section{Mansel 2006}

H.P. Mansel, 'Anerkennung als Grundprinzip des Europäischen Rechtsraums', Rabels Zeitschrift für ausländisches und internationales Privatrecht 2006, 70(4), 651-731.

\section{Massip 2006}

J. Massip, Le nouveau droit de la filiation, Paris: Defrénois 2006.

\section{Massip, Morin \& Aubert 1976}

J. Massip, G. Morin and J.-L. Aubert, La réforme de la filiation - Commentaire de la loi nr 72-3 du 3 janvier 1972, Paris: Defrénois 1976.

\section{Masson, Bailey-Harris \& Probert 2008}

J.M. Masson, R. Bailey-Harris and R. Probert, Cretney's Principles of family law, London: Sweet \& Maxwell 2008.

\section{Mayer 1973}

P. Mayer, La distinction entre règles et décisions et le droit international privé, Université de droit, d'économie et des sciences sociales de Paris, 1973.

\section{Mayer 2005}

P. Mayer, 'Les méthodes de la reconnaissance en droit international privé' in: M.-N. JobardBachellier and P. Mayer eds., Le droit international privé: esprit et méthodes, Paris: Dalloz 2005, 547-573.

\section{Mayer \& Heuzé 2007}

P. Mayer and V. Heuzé, Droit international privé, Paris: Montchrestien 2007.

\section{McEleavy 2002}

P. McEleavy, 'The Brussels II regulation: how the European Community has moved into family law', International and comparative law quarterly 2002, 51(4), 883-908.

\section{Meeusen 2006}

J. Meeusen, 'Op weg naar een communautair internationaal familie(vermogens)recht?' Mededelingen van de Nederlandse Vereniging voor Internationaal Recht 2006, 1-70.

\section{Meijers 1938}

E.M. Meijers, 'La question du renvoi', Bulletin de l'Institut juridique international 1938, 191-238. 


\section{Meijers 1955}

E.M. Meijers, 'Het vraagstuk der herverwijzing' in: R.P. Cleveringa ed. Verzamelde privaatrechtelijke opstellen van prof. mr. E.M. Meijers, Leiden: Universitaire Pers Leiden 1955, 366-399.

\section{Michaels 2006}

R. Michaels, 'EU law as private international law? Reconceptualisation the country-of-origin principle as vested-rights theory', Journal of private international law 2006, 2(2), 195-242.

\section{Michaels 2008}

R. Michaels, 'The new European choice-of-law revolution', Tulane law review 2008, 82(5), 1607-1644.

\section{Morgand-Cantegrit 1993}

V. Morgand-Cantegrit, La possession d'état d'enfant, Université de Lille II Droit et Santé, Faculté des sciences juridiques, politiques et sociales, 1993.

\section{Morris, MacClean \& Beevers 2005}

J.H.C. Morris, J.D. MacClean and K.A. Beevers, The conflict of laws, London: Sweet \& Maxwell 2005.

\section{Mosconi 2000}

F. Mosconi, 'A few questions on the matter of international uniformity of solutions and nationality as a connecting factor' in: J. Basedow ed. Private law in the international arena Liber amicorum Kurt Siehr, The Hague: T.M.C. Asser Press 2000, 465-480.

\section{MünchKomm/Klinkhardt 2006}

H.J. Sonnenberger ed. Münchener Kommentar zum Bürgerlichen Gesetzbuch. Band 10 Einführungsgesetz zum Bürgerlichen Gesetzbuch (Art. 1-46) Internationales Privatrecht, München: Verlag C.H. Beck 2006.

\section{MünchKomm/Wellenhofer 2008}

D. Schwab ed. Münchener Kommentar zum Bürgerlichen Gesetzbuch. Band 8 Familienrecht II §§ 1589-1921, München: C.H. Verlag 2008.

\section{Murat 2006}

P. Murat, 'L'action de l'ordonnance du 4 juillet 2005 sur la possession d'état', Droit de la famille 2006, 17-20.

\section{Muschter 2003}

L. Muschter, Statutenwechsel im internationalen Kindschaftsrecht, Hamburg: Verlag Dr. Kovac 2003.

\section{Neirinck 2006}

C. Neirinck, 'La maternité', Droit de la famille 2006, 9-11.

\section{Neuhaus 1963}

P.H. Neuhaus, 'Legal certainty versus equity in the conflict of laws' in: R. Fentiman ed. Conflict of Laws, Aldershot: Dartmouth 1963, 529-541. 


\section{Niboyet \& De Geouffre de la Pradelle 2007}

M.-L. Niboyet and G. de Geouffre de la Pradelle, Droit international privé, Paris: Librairie Générale de Droit en de Jurisprudence 2007.

\section{Norrie 1994}

K.M. Norrie, 'Reproductive technology, transsexualism and homosexuality: new problems for international private law', International and comparative law quarterly 1994, 43(4), 757-775.

\section{North, Fawcett \& Carruthers 2008}

P.M. North, J.J. Fawcett and J.M. Carruthers, Cheshire, North \& Fawcett's Private International Law, Oxford: Oxford University Press 2008.

\section{Oderkerk 2006}

A.E. Oderkerk, 'Tussen formele en materiële rechtvaardigheid. Een analyse van de law in action naar aanleiding van de wijziging van artikel 4 (oud) Rijkswet op het Nederlanderschap', Nederlands internationaal privaatrecht 2006, 23(4), 389-396.

\section{Oprach 2001}

T. Oprach, 'Das Abstammungsstatut nach Art. 19 EGBGB alter und neuer Fassung im deutsch-italienischen Rechtsverkehr', Praxis des internationalen Privat- und Verfahrensrechts 2001, 21(4), 325-328.

\section{Örtenhed 1991}

K. Örtenhed, Hemvistbegreppet, Uppsala: Iustus Förlag 1991.

Otte 1999

K. Otte, 'The new German conflicts law on parents and children', Yearbook of private international law 1999, 1, 189-203.

\section{Pålsson 2006}

L. Pålsson, Svensk rättspraxis i internationell familje- och arvsrätt, Stockholm: Norstedts Juridik 2006.

\section{Parlementaire Geschiedenis/Boek 1 Invoeringswet 1969}

C.J.v. Zeben and O.W.v. Ewijk, Parlementaire geschiedenis van het Nieuwe Burgerlijk Wetboek. Boek 1 Invoeringswet, Deventer: Kluwer 1969.

\section{Parlementaire Geschiedenis/Boek 1 Personen- en Familierecht 1962}

C.J.v. Zeben, W.G. Belinfante and O.W.v. Ewijk, Parlementaire geschiedenis van het nieuwe Burgerlijk Wetboek. Boek 1, Personen- en Familierecht, Deventer: Kluwer 1962.

\section{Pascal \& Trapero 2005}

A. Pascal and M. Trapero, 'Vérité biologique et filiation dans la jurisprudence récente de la Cour de Cassation' in: La vérité. Rapport annuel 2004 de la Cour de Cassation, Paris: La documentation française 2005.

\section{Phipson, Malek \& Auburn 2005}

S.L. Phipson, H.M. Malek and J. Auburn, Phipson on evidence, London: Sweet and Maxwell 2005. 


\section{Plasschaert 2002}

J.N.E. Plasschaert, Burgerlijke Stand, Amsterdam: Register Amsterdam 2002.

\section{Ponsard 1972}

A. Ponsard, 'La loi française du 3 janvier 1972 et les conflits de lois en matière de la filiation', Journal du droit international (Clunet) 1972, 765-796.

\section{Probert 2003}

R. Probert, Cretney's family law, London: Sweet \& Maxwell 2003.

\section{Puljak 2003}

M.-P. Puljak, Le droit international privé à l'épreuve du principe communautaire de nondiscrimination en raison de la nationalité, Aix-Marseille: Presses universitaires d'Aix-Marseille 2003.

\section{Quidelleur 2007}

M. Quidelleur, Guide pratique de l'état civil, Paris: Berger - Levraut 2007.

\section{Ready 2007}

N. Ready, Legalisation of public documents within the EU Member States - United Kingdom, 2007. available at: http://ec.europa.eu/civiljustice/news/docs/study_public_docs_uk.pdf

\section{Remien 2001}

O. Remien, 'European private international law, the European Community and its emerging area of freedom security and justice', Common market law review 2001, 38(1), 53-86.

\section{Rittner \& Rittner 2005}

C. Rittner and N. Rittner, 'Rechtsdogma und Rechtswirklichkeit am Beispiel so genannter heimlicher Vaterschaftstests', Neue juristische Wochenschrift 2005, 58(14), 945-948.

\section{Rutten 2007}

S.W.E. Rutten, 'De bruidsgave: op zoek naar goud', Nederlands internationaal privaatrecht 2007, (2), 101-115.

\section{Ryrstedt 2005}

E. Ryrstedt, 'Custody of Children in Sweden', Family law quarterly 2005, 39(2), 393-404.

\section{Saarloos 2005}

K. Saarloos, 'Erkenning en nationaliteit. De valkuil van de Rijkswet op het Nederlanderschap (2)', Migrantenrecht 2005, 20(5), 157-160.

\section{Saarloos 2006}

K. Saarloos, 'Bezit van staat of het wormvormig aanhangsel van het Nederlandse afstammingsrecht?' Weekblad voor privaatrecht, notariaat en registratie 2006, 137(6654), 123-129.

\section{Saarloos 2008}

K. Saarloos, 'Bezit van staat in het internationaal privaatrecht', Migrantenrecht 2008, 23(5), 165-170. 


\section{Saarloos \& Van Berkel 2008}

K. Saarloos and J.v. Berkel, 'From Russia with Love: ouderschap na draagmoederschap en de Wet conflictenrecht afstamming', Nederlands internationaal privaatrecht 2008, 26(2), 117-124.

\section{Saldeen 1980}

Å. Saldeen, Faststellende av faderskap, Stockholm: Norstedts 1980.

\section{Saldeen 2005}

Å. Saldeen, Barn- och föräldrarätt, Uppsala: Iustus Förlag 2005.

\section{Savigny 1849}

F.C.v. Savigny, System des heutigen römischen Rechts, Band 8, Berlin: Veit 1849.

\section{Schäkel 2004}

I. Schäkel, Die Abstammung im neuen deutschen internationalen Privatrecht, Hamburg: Verlag Dr. Kovac 2004.

\section{Schmidt 2006}

G.E. Schmidt, 'Duidelijkheid en hanteerbaarheid van de Europese wetgeving op het terrein van het internationale familierecht', Mededelingen van de Nederlandse Vereniging voor Internationaal Recht 2006, 133, 71-112.

\section{Schoots, Van Arkel \& Dermout 2004}

M. Schoots, J.v. Arkel and S. Dermout, 'Wetsaanpassing in verband met draagmoederschap', Tijdschrift voor familie- en jeugdrecht 2004, 26(7/8), 189-194.

\section{Schwab 2008}

D. Schwab, 'Abstammungserklärung - leicht gemacht. Oder : Neuer Dialog in der Familie', Zeitschrift für das gesamte Familienrecht 2008, 55(1), 23-27.

\section{Sheldon 2005}

S. Sheldon, 'Fragmenting fatherhood: The regulation of reproductive technologies', Modern law review 2005, 68(4), 523-553.

\section{Singer 2000}

A. Singer, Föräldraskap i rättslig belysning, Uppsala: Iustus Förlag 2000.

\section{Singer 2006}

A. Singer, 'Mater semper certa est?' Juridisk tidskrift vid Stockholms universitet 2006/7, 424-431.

\section{Singer 2007}

A. Singer, 'Between genetic and social parenthood - A legal dilemma. Establishment of legal parenthood in Sweden' in: A. Spickhoff, D. Schwab, D. Henrich, et al. eds., Streit um die Abstammung. Ein europäischer Vergleich, Bielefeld: Verlag Ernst und Werner Gieseking 2007, 139-148.

\section{Socialstyrelsen 2005}

Socialstyrelsen, Att fastställa faderskap, Stockholm: Elanders Gotab 2005. available at: http://www.socialstyrelsen.se/NR/rdonlyres/C0403C8C-DC86-496F-87326834B372B989/3110/20051011.pdf 


\section{Sommer 2009}

E. Sommer, Der Einfluss des Freizügigkeit auf Namen und Status von Unionsbürgern, Sipplingen: Jenaer Wissenschaftliche Verlagsgesellschaft 2009.

\section{Staatscommissie IPR 1995}

'De afstamming en de betrekking tussen ouders en kinderen' in: E.N. Frohn and E. Hennis eds., Staatscommissie IPR Geselecteerde adviezen. Naar een afgewogen IPR, 's-Gravenhage: T.M.C. Asser Instituut 1995, 134-165.

\section{Staatscommissie IPR 2002}

Staatscommissie IPR, Algemene bepalingen Wet internationaal privaatrecht, Den Haag 2002. available at: www.justitie.nl/images/Rapport\%20Algemene \%20bepalingen\%20IPR_tcm 7438129_tcm34-17401.pdf

\section{Staudinger/Henrich 2008}

D. Henrich ed. J. von Staudingers Kommentar zum Bürgerlichen Gesetzbuch, mit Einführungsgesetz und Nebengesetzen. Einführungsgesetz zum Bürgerlichen Gesetzbuche/IPR Art 19-24 EGBGB (Internationales Kindschaftsrecht 3), München: Sellier-de Gruyter 2008.

\section{Staudinger/Rauscher 2004}

H. Engler ed. J. von Staudingers Kommentar zum Bürgerlichen Gesetzbuch mit Einführungsgesetz und Nebengesetzen. 4. Buch §§ 1589-1600e (Abstammung), Berlin: Sellier-de Gruyter 2004.

\section{Stein \& Stein 2002}

H. Stein and H.A. Stein, Goed beslagen. Vormen en aspecten van het Nederlands privaatrechtelijke executie- en beslagrecht, Deventer: Kluwer 2002.

\section{Stößer 2009}

E. Stößer, 'Das neue Verfahren in Abstammungssachen nach dem FamFG', Zeitschrift für das gesamte Familienrecht 2009, 56(11), 923-929.

\section{Straetmans 2007}

G. Straetmans, 'Non-economic free movement of EU citizens and family law matters' in: J. Meeusen, G. Straetmans, M. Pertegás, et al. eds., International family law for the European Union, Antwerpen: Intersentia 2007, 183-238.

\section{Strikwerda 1986}

L. Strikwerda, Naar een gereduceerd conflictenrecht? Iets over bescherming, begunstiging en better law in het internationaal privaatrecht, Groningen: Wolters-Noordhoff 1986.

\section{Strikwerda 2008}

L. Strikwerda, Inleiding tot het Nederlandse internationaal privaatrecht, Deventer: Kluwer 2008.

\section{Struycken 1982}

A.V.M. Struycken, 'Artikel 23 BBS, een netelig element van het takenpakket van de Haagse ambtenaar van de burgerlijke stand', Het personeel statuut 1982, 18-27.

\section{Struycken 2001}

A.V.M. Struycken, 's Lands wijs 's lands eer. Afscheidscollege 31 augustus 2001, Nijmegen: Katholieke Universiteit Nijmegen 2001. 


\section{Struycken 2005}

A.V.M. Struycken, 'Locus regit actum, un nouvel avatar hollandais' in: M.-N. JobardBachellier and P. Mayer eds., Le droit international privé: esprit et méthodes. Mélanges en l'honneur de Paul Lagarde, Paris: Dalloz 2005, 765-779.

\section{Sturm 2001}

F. Sturm, 'Alternatives Abstammungsstatut und Erwerb der deutschen Staatsangehörigkeit' in: G. Hohloch, R. Frank and P. Schlechtriem eds., Festschrift für Hans Stoll, Tübingen: Mohr Siebeck 2001, 451-460.

\section{Sturm 2003}

F. Sturm, 'Das Abstammungsstatut und seine alternative Anknüpfung', Das Standesamt 2003, 56(12), 353-361.

\section{Sutton 1984}

G. Sutton, 'Les articles 311-14 et suivants du Code Civil à l'épreuve de la jurisprudence du Tribunal de Grande Instance de Paris', Droit international privé. Travaux du comité français de droit international privé 1983-1984, 193-223.

T.M.C. Asser Instituut report on non-harmonisation of choice of law rules in divorce matters 2002

T.M.C. Asser Instituut, Practical problems resulting from the non-harmonisation of choice of law rules in divorce matters (JAI/A3/2001/04), Den Haag 2002.

\section{Tapper 2004}

C. Tapper, Cross and Tapper on Evidence, London: LexisNexis 2004.

\section{Terré \& Fenouillet 2005}

F. Terré and D. Fenouillet, Droit Civil. Les personnes, la famille, les incapacités, Paris: Dalloz 2005.

\section{Tetley 1994}

W. Tetley, 'Evasion, fraude à la loi and avoidance of the law', McGill Law Journal 1994, 39(2), 303-332.

\section{Teyssié 2001}

B. Teyssié, Droit civil, Les personnes, Paris: Litec 2001.

\section{Th. M. de Boer 2001}

T.M.d. Boer, 'Prospects for European conflicts law in the twenty-first century' in: P.J. Borchers and J. Zekoll eds., International conflict of laws for the third millennium: essays in honor of Friedrich K. Juenger, Ardsley: Transnational Publishers 2001, 193-213.

\section{Th.M. de Boer 2004}

T.M.d. Boer, 'De fictie van een neutraal conflictenrecht' in: R. Kotting, J.A. Pontier and L. Strikwerda eds., Voorkeur voor de lex fori, Deventer: Kluwer 2004, 199-248.

Th.M. de Boer 2005

T.M.d. Boer, 'Enkele knelpunten bij de toepassing van de Verordening Brussel II-bis', Tijdschrift voor familie- en jeugdrecht 2005, 27(10), 222-230. 
Th.M. de Boer 2008

T.M.d. Boer, 'The second revision of the Brussels II regulation: jurisdiciton and applicable law' in: K. Boele-Woelki and T. Svendrup eds., European Challenges in Contemporary Family Law Antwerp: Intersentia 2008, 321-341.

\section{Th.M. de Boer \& Kotting 1989}

T.M.d. Boer and R. Kotting, 'Het belang van het kind als conflictrechtenlijk keuzemotief: ontkenning van het vaderschap en erkenning van kinderen in het Nederlands internationaal privaatrecht' in: M.d. Langen, J.H.d. Graaf and F.B.M. Kunneman eds., Kinderen en recht, opstellen over de positie van minderjarigen in het recht, Arnhem \& Deventer: Gouda Quint \& Kluwer 1989, 74-84.

\section{Van de Velden 2007}

J.v.d. Velden, British Institute of International and Comparative law, The use of public documents in the EU, London 2007.

available at:

http://ec.europa.eu/civiljustice/news/docs/study_public_docs_synthesis_report.pdf

\section{Van het Kaar 2003}

B.J.v.h. Kaar, 'Bewijskwesties. Enkele kanttekeningen bij art. 15 Algemene Bepalingen Wet Internationaal Privaatrecht zoals opgenomen in het Advies van de Staatscommissie IPR', Weekblad voor privaatrecht, notariaat en registratie 2003, 134(6537), 476-480.

\section{Van het Kaar 2008}

B.J.v.h. Kaar, IPR-bewijsrecht en bewijsverkrijging, Vrije Universiteit Amsterdam, 2008.

\section{Van Iterson 1993}

D.v. Iterson, 'Schijnhandelingen in het familierecht' in: Grensoverschrijdend privaatrecht. Een bundel opstellen over privaatrecht in internationaal verband., Deventer: Kluwer 1993, 119-133.

\section{Vat (Personen- en familierecht)}

H. Vat, Personen- en familierecht. Titel 4 Burgerlijke stand, Deventer: Kluwer (losbl.).

\section{Veit 1999}

B. Veit, 'Verwandtschaftliche Elternstellung und elterliche Sorge bei Scheidungskindern', Zeitschrift für das gesamte Familienrecht 1999, 46(14), 902-908.

\section{Verheul 1989}

J.P. Verheul, Erkenning en tenuitvoerlegging van vreemde vonnissen, Apeldoorn - Antwerpen: Maklu Uitgevers 1989.

\section{Verhoeven 2006}

T. Verhoeven, 'De erkenning naar Brits recht', Burgerzaken \& Recht 2006, 26-29.

\section{Verhoeven 2007}

T. Verhoeven, 'De erkenning naar Brits recht (vervolg)', Burgerzaken \& Recht 2007, 288-289.

\section{Vlaardingerbroek 2003}

P. Vlaardingerbroek, 'Draagmoederschap: een gecompliceerde constructie', Ars Aequi 2003, 52(3), 171-178. 


\section{Vlaardingerbroek (Personen- en familierecht)}

P. Vlaardingerbroek, Personen- en familierecht. Titel 11 Afstamming, Deventer: Kluwer (losbl.).

\section{Vlas (Burgerlijke Rechtsvordering)}

P. Vlas, Burgerlijke Rechtsvordering. EEX Verordening, Deventer: Kluwer (losbl.) 2008.

\section{Vonk 2007}

M. Vonk, Children and their parents. A comparative study of the legal position of children with regard to their intentional and biological parents in English and Dutch law., Antwerpen: Intersentia 2007.

\section{Vonken 1987}

A.P.M.J. Vonken, Het internationale afstammingsrecht in perspectief, Arnhem: Gouda Quint 1987.

\section{Vonken 2000}

A.P.M.J. Vonken, 'Het wetsvoorstel conflictenrecht afstamming', Nederlands tijdschrift voor internationaal privaatrecht 2000, 18(1), 16-25.

\section{Vonken 2006}

A.P.M.J. Vonken, 'De internationale beslissingsharmonie nader beschouwd', Tijdschrift voor privaatrecht 2006, 43(1), 1-111.

\section{Vonken (Personen- en familierecht. Het internationale afstammingsrecht)}

A.P.M.J. Vonken, Personen- en familierecht. Het internationale afstammingsrecht, Deventer: Kluwer (losbl.).

\section{Vonken (Personen- en familierecht. Wet conflicterecht huwelijk)}

A.P.M.J. Vonken, Personen- en familierecht. Wet conflictenrecht huwelijk, Deventer: Kluwer (losbl.).

\section{Wagner 2004}

R. Wagner, 'EG-Kompetenz für das Internationale Privatrecht in Ehesachen?' Rabels Zeitschrift für ausländisches und internationales Privatrecht 2004, 68(1), 119-153.

\section{Wagner 2006}

R. Wagner, 'Anerkennung und Wirksamkeit ausländischer familienrechtlicher Rechtsakte nach autonomem deutschen Recht', Zeitschrift für das gesamte Familienrecht 2006, 53(11), 744753.

\section{Walin \& Vängby vol. I}

G. Walin and S. Vängby, Föräldrabalken och internationell föräldrarätt, vol I, Stockholm: Norstedts Juridik 2001 (with supplements until 2005).

\section{Walin \& Vängby vol. II}

G. Walin and S. Vängby, Föräldrabalken och internationell föräldrarätt, vol II, Stockholm: Norstedts Juridik 2001 (with supplements until 2005).

\section{Weatherill 2007}

S. Weatherill, Cases and materials on EU law, Oxford: Oxford University Press 2007. 


\section{Wedemann 2006}

F. Wedemann, Konkurrierende Vaterschaften und doppelte Mutterschaften im internationalen Abstammungsrecht, Baden-Baden: Nomos 2006.

\section{Wellenhofer-Klein 2003}

M. Wellenhofer-Klein, 'Das Vaterschaftsanfechtungsrecht des leiblichen Vaters - Vorslag zur Änderung von § 1600 BGB', Zeitschrift für das gesamte Familienrecht 2003, 50(24), 1889-1894.

\section{Wellenhofer 2005}

M. Wellenhofer, 'Die prozessuale Verwertbarkeit privater Abstammungsgutachten', Zeitschrift für das gesamte Familienrecht 2005, 52(9), 665-668.

\section{Wolf 2005}

A. Wolf, 'Biologische Abstammung und rechtliche Zuordnung', Neue juristische Wochenschrift 2005, 58(34), 2417-2421.

\section{Zeyringer 1999}

W. Zeyringer, 'Die Überprüfung ausländischer Urkunden durch den Standesbeamten', Das Standesamt 1999, 52(7), 193-200. 


\section{Curriculum vitae}

Kees Jan Saarloos (Nunspeet, 1980) graduated cum laude in 2003 from the faculty of law at Maastricht University, where in September 2004 he became a junior researcher. Additional to his PhD-research, Kees has taught different courses both in Dutch and in English: private international law, comparative law, family law in Europe and introduction to contract and property law (vermogensrecht). Amongst others, he participated twice in the Hague Academy's summer programme on private international law and in the summer programme on Global Arbitration Law and Practice of the Hamline School of Law and Queen Mary University of London. He has also advised lawyers and government authorities on the application of private international law in matters concerning civil status registration, population registration, immigration law and nationality law.

Parallel to his legal work, Kees obtained a bachelor degree in French language and culture in 2007 from the Vrije Universiteit in Amsterdam. In March 2010 he became a lawyer at De Brauw Blackstone Westbroek in Amsterdam. 
